


\section{Library}

\section{Arnold Arboretum}

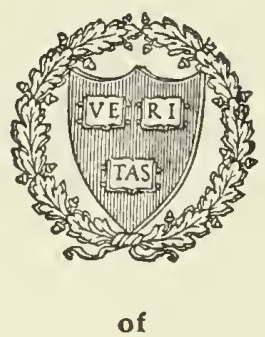

Harvard University 
喜 



\section{Digitized by the Internet Archive}

in 2014 

The Freshwater Swamp-forest of South Johore and Singapore

By E.J.H. Corner, C.B.E. F.R.S.

Emeritus Professor of Tropical Botany

University of Cambridge

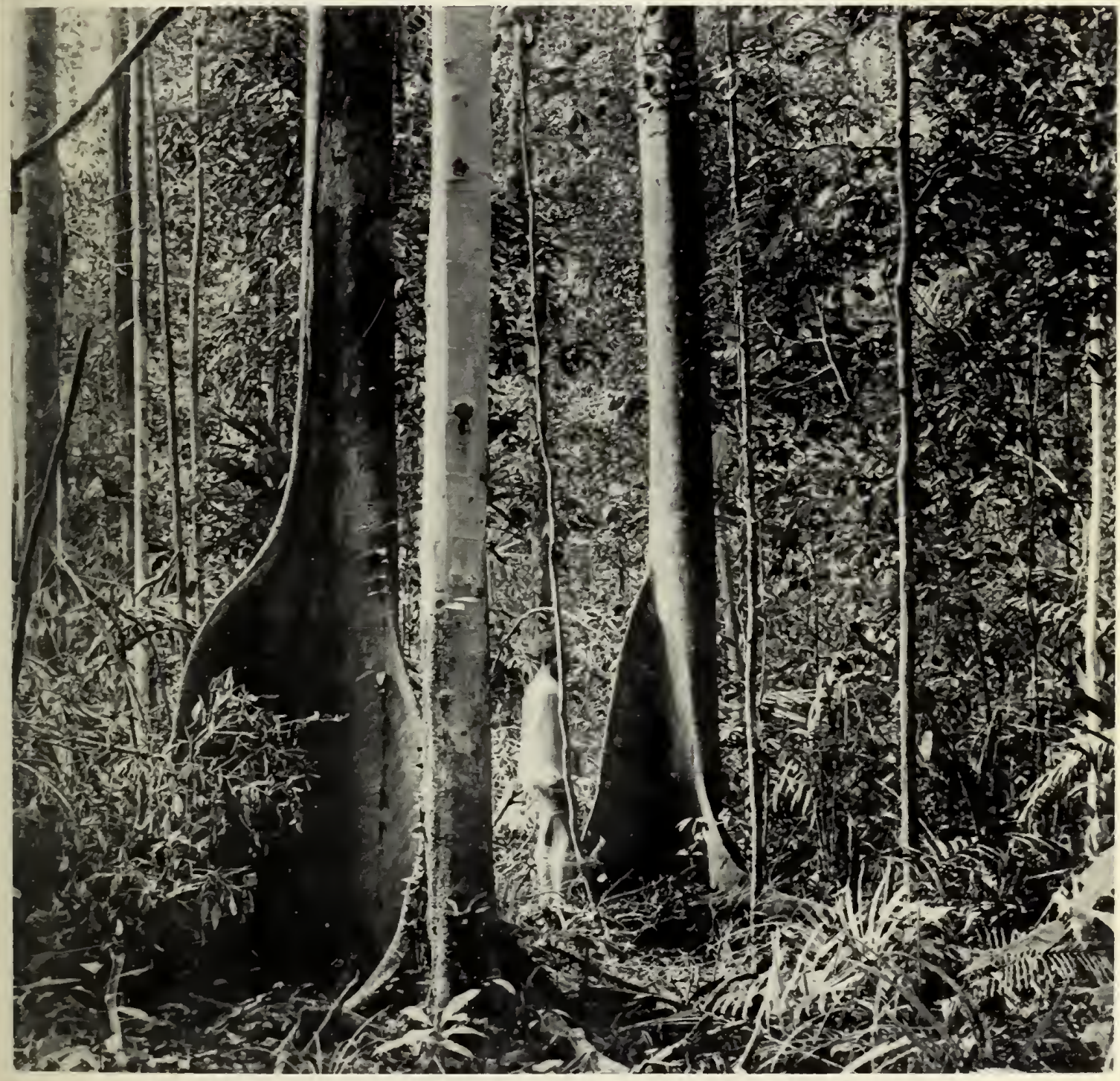


$123^{3}$ 


Gardens' Bulletin Supplement

No. 1

Freshwater Swamp-Forest 
Cover: The buttressed trunks of Pometia pinnata f, alnifolia (Sapindaceae) in the swamp-forest of the Sedili River 


\title{
The Freshwater Swamp-forest of South Johore and Singapore
}

\author{
BY \\ E.J.H. Corner, C.B.E. F.R.S. \\ Emeritus Professor of Tropical Botany \\ University of Cambridge
}

Published by Botanic Gardens

Parks \& Recreation Department

Singapore

1978 
Sold by The Botanic Gardens, Singapore Cluny Road, Singapore 10

For sale only: not for exchange

Price S\$35

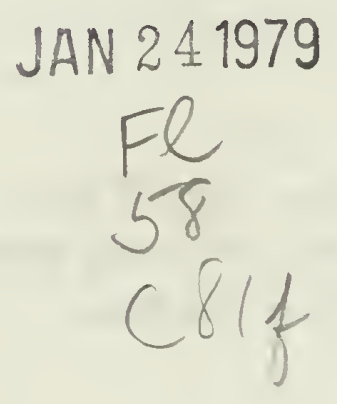

Printed in Singapore at the Singapore National Printers 


\section{CONTENTS}

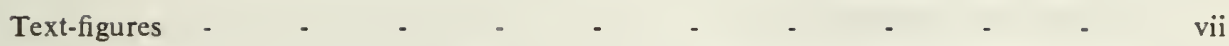

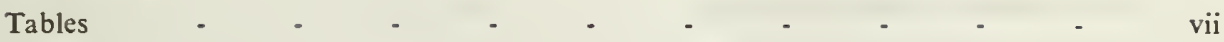

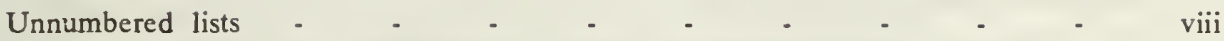

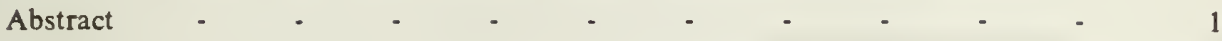

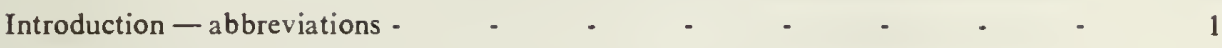

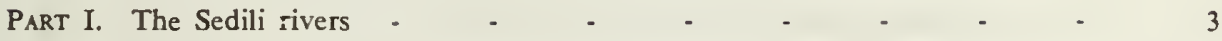

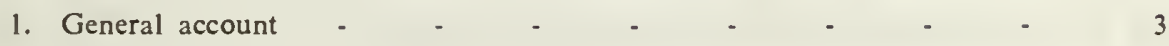

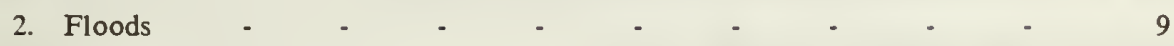

3. Longitudinal succession of riverside vegetation - - _ - 11

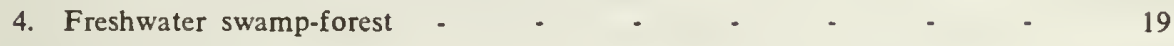

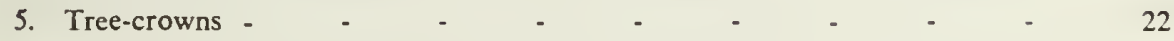

6. Buttresses, still-roots, and pneumatophores in the freshwater swamp-forest 22

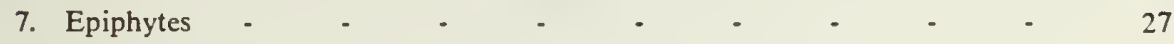

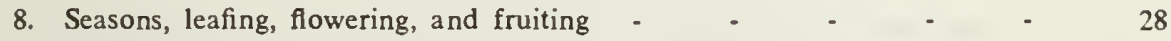

9. Special localities on the Sedili Besar _ - $\quad$ - $\quad$ - $\quad$ - $\quad 31$

10. Flora of the kapur-forests (Dryobalanops aromatica) on the Jemaluang $\mathrm{Rd}$ between S. Berassau and mile 15 - $\quad$ - - $\quad$ - 32

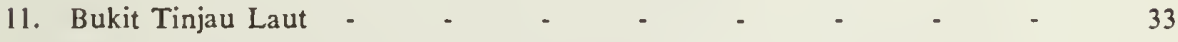

12. Ridge-flora of Gunong Panti, Johore - - - - - - 36

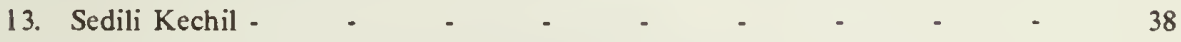

14. Comparison with the Kemaman River, Trengganu - - - - - 40

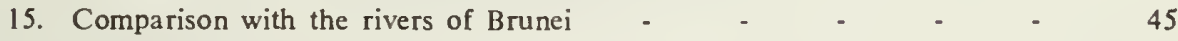

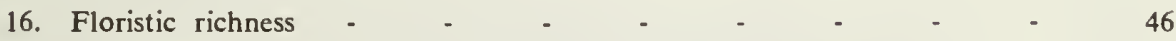

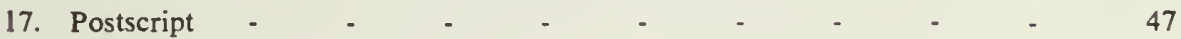

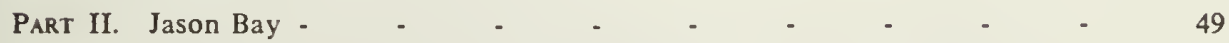

Swamp-forest - Forest-succession on the sand-bank - Sand-dunes - Dry climax-forest - Depressions in the sand-banks - Cultivation - Coastal abrasion - Batu Belayar (K. Sedili Besar) - S. Diman - S. Sebong Coast south of $\mathrm{Tg}$ Sedili Kechil - History of Jason Bay. Herbaceous plants on open sand-dunes, Jason Bay

Seed-plants of Barringtonia-Terminalia rocky shore and Eugenia grandis

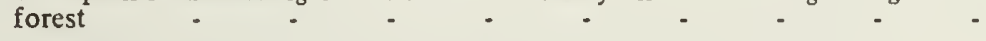

Canopy-trees of the dry climax-forest, Jason Bay - $\quad-\quad+\quad-\quad-\quad 58$ 
(vi)

\section{CONTENTS - continued}

PART III. Swamp-forest at Mandai Rd and Jurong (Singapore) and at Pengkalan Rajah, Pontian (Johore) -

1. Mandai Road, Singapore - _ _ _ _ _ _ _ $\quad$ - 59

2. Jurong Road 15th mile, Singapore - _ _ - _ _ - - 63

3. Pengkalan Rajah, Pontian, Johore - $\quad$ - $\quad$ - $\quad$ - $\quad$ - $\quad 69$

4. List of plants in the swamp-forest of Jurong, Mandai Road, and Pontian 72

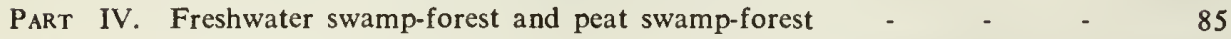

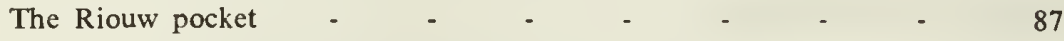

PART V. List of vascular plants of the Sedili region, Johore - $\quad$ - $\quad 91$

PaRT VI. Special notes on plants from Johore and Singapore - $\quad-\quad-\quad 165$

PART VII. Malay names in the Sedili region $\quad \ldots \quad+\quad \ldots$

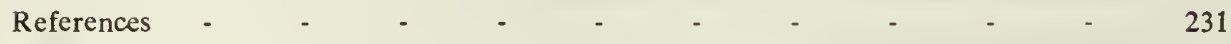

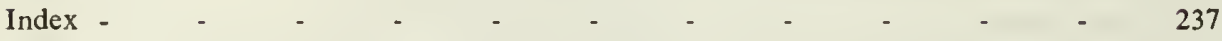

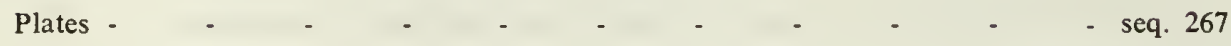




\section{TEXT-FIGURES}

PAGE

Figs. 1, 2. Map of the Sedili Besar - $\quad$ - $\quad$ - $\quad$ - $\quad$ - $\quad$ - 4,5

Fig. 3. Diagram of the longitudinal distribution of characteristic riverside
plants on the Sedili Besar

Figs. 4, 5. Diagrammatic transects of the Sedili Besar at high tide - $\quad$ - 15, 17

Fig. 6. Garcinia ? rostrata, stilt-roots and pneumatophores - $\quad$ - 23

Fig. 7. Xylopia fusca, pneumatophores and loop-roots - $\quad$ - $\quad$ - 25

Fig. 8. Map of lower reaches of the Kemaman River - _ - $\quad$ - 41

Fig. 9. Diagrammatic transects of coastal forest at Jason bay - $\quad$ - 49

Fig. 10. Diagram of the estuary of S. Diman with transect - $\quad$ - 55

Fig. 11. Diagram of the estuary of S. Sebong with transect - $\quad$ - 56

Fig. 12. Diagrammatic transects of coastal vegetation near Jason Bay - - 57

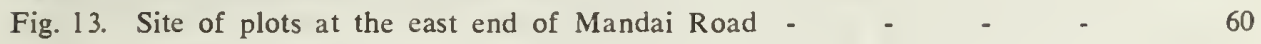

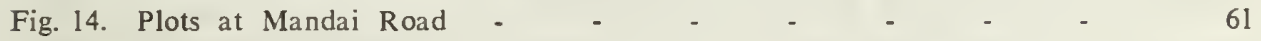

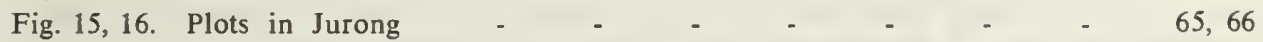

Fig. 17. Plan of Riouw pocket with migration-routes - $\quad$ - $\quad$ - $\quad$ - 90

Fig. 18. Mesua lepidota; diagram of the construction of the terminal
inflorescence

\section{TABLES}

Tb 1. Trees of freshwater swamp-forest with buttresses, stilt-roots and pneumatophores - $\quad-\quad$ - $\quad$ - $\quad$ -

$\begin{array}{llllr}\text { Tb 2. Enumeration of trees at Mandai Road - - } & - & - & 62-63 \\ \text { Tb 3. Enumeration of trees }(>25 \mathrm{~cm} \text { thick) at Jurong Road - } & - & - & 68\end{array}$

Tb 4. Enumeration of trees $(<25 \mathrm{~cm})$ at Jurong Road - $\quad$ - $\quad 69$

Tb 5. Numbers of species at Jurong and Mandai Road and at Pontian - 69

Tb 6. Specific comparison between the swamp-forest of the Scdili region and of Sarawak and Brune

\section{UNNUMBERED LISTS}

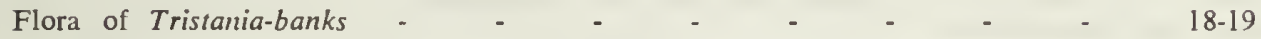

Canopy-trees in the freshwater swamp-forest of the Sedili region - $\quad$ - 20-22

Flora of the kapur-forest (Dryobalanops aromatica) on the Jemaluang Road - 32-33

Plants collected at Bukit Tinjau Laut - $\quad$ - $\quad$ - $\quad$ - $\quad$ - 35

Interesting plants on the ridge of G. Panti - _ _ _ $\quad$ - $\quad$ - $\quad$ - $\quad$ 36-37

Herbaceous plants on open sand-dunes, Jason Bay $\quad-\quad \ldots \quad-\quad 5 \quad 57$

Seed plants of Barringtonia-Terminalia rocky shore and Eugenia grandis forest - 58

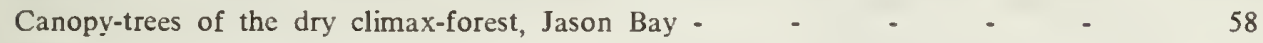

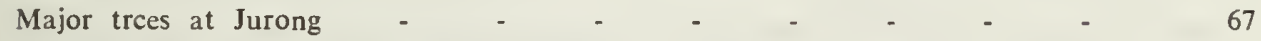

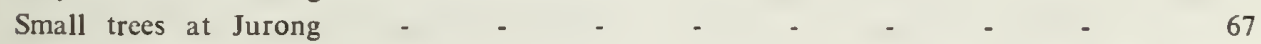

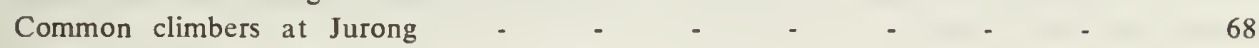

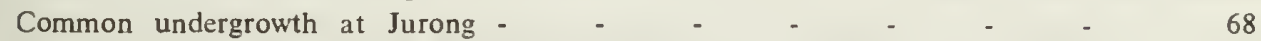

Plants in the swamp-forest of Jurong and Mandai Road and of Pontian - 72-83 


\section{PLATES}

Plate 1. The Sedili Besar near Bagan Kijang, 1932; Tristania-banks with Buchanania sessilifolia and a clump of rassau (Pandanus helicopus).

Plate 2. Sedili Besar, 1932. Between Bt Perah and Bt Tiga with Bt Tinjau Laut in the distance. Tg Rambutan; floating house at Danau.

Plate 3. S. Dohol near the Jemaluang Rd, with Tristania. A Tristania-bank on the Sedili Besar, 3 miles below Mawai.

Plate 4. The Sedili Besar near Bt Perah, 1932. Rassau-belt with putat (Barringtonia conoidea); Pandanus helicopus; rengas (Gluta velutina). Rassau, putat, and rengas, with the mempisang-belt.

Plate 5. The Sedili Besar near Bt Tiga with jejawi (Ficus microcarpa) smothering the belts of putat and rassau. Pandanus kamii in the freshwater swamp-forest.

Plate 6. An old tree of rengas (Gluta velutina) in the slime, at low water below Mawai. Putat (Barringtonia conoidea) at half tide.

Plate 7. Dryobalanops oblongifolia by a wood-cutter's track in freshwater swamp-forest, with several trees of Ganua motleyana and slender trees of Tetractomia, S. Kayu, 1935. Sindora coriacea in the dryer part of the swamp-forest.

Plate 8. Shorea resina-nigra (with Ficus cucurbutina as incipient strangler), by the Jemaluang Rd, mile 13. Kostermansia. The Jemaluang Rd under construction, 1932.

Plate 9. Pometia pinnata f. alnifolia in the freshwater swamp-forest, Sedili Besar 1934, with the buttresses aligned. Aromaderidron nutans in the peat swamp-forest, Pontian 1939.

Plate 10. Cyathocalyx ridleyi with monopodial crown, in hillock-forest, Jemaluang $\mathrm{Rd}$

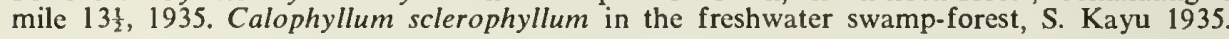

Plate 11. Pneumatophores and trunks of Polyalthia sclerophylla at low tide near Mawai. Still-roots of Ploiarium alternifolium in the mempisang-belt, with Hassan, near Mawai.

Plate 12. Elaeocarpus macrocerus, stilt-roots and pneumatophores in the freshwater swampforest, with Hassan, near Mawai; buttressed trunks arisen from one prostrate trunk.

Plate 13. Mat of aerial roots of Palaquium xanthochymum, with erect pneumatophores of Polyalthia sclerophylla, by the Sedili Besar. Loop-root pneumatophores of Calophyllum sclerophyllum in the freshwater swamp-forest.

Plate 14. A Tristania-bank on the Sedili Besar at low water, with Tristania sumatrana and Lophopetalum multinervium. Myristica elliptica, base of trunk and loop-roots, in the freshwater swamp-forest.

Plate 15. Stilt-roots of Macaranga puncticulata and Endospermum, Mawai 1934. Stilt-roots of Hopea resinosa and Eugenia subhorizontalis with the forest-guard Ibrahim, S. Berassau 1935.

Plate 16. Lophopetalum multinervium with pneumatophores, in the freshwater swampforest near Mawai 1931.

Plate 17. Pneumatophores of Lophopetalum multinervium in the freshwater swamp-forest at Jason Bay. Stilt-roots of Palaquium xanthochymum, with Awan-ti, in the freshwater swamp-forest, S. Kayu.

Plate 18. Stilt-roots of Platea latifolia, with Awan-ti, S. Berassau 1935. Stilt-roots of Platea excelsa var. riedeliana, Pontian 1939.

Plate 19. Stilt-roots of Blumeodendron tokbrai. At S. Berassau 1935, with Awan-ti and in peat swamp-forest at Pontian 1939.

Plate 20. Buttressed trunk of Adinandra sarosanthera, S. Kayu 1935. Stilt-roots of Palaquium sp. 1934, Jemaluang Rd. Stilt-roots of Neoscortechinia nicobarica in freshwater swamp-forest near Mawai.

Plate 21. Stilt-roots, S. Kayu 1935. Notaphoebe coriacea with Awan-ti. Melanochyla bracteata with Mussib. Goniothalamus malayanus with Mussib.

Plate 22. Stilt-roots of Calophyllum sclerophyllum, Mawai 1934, with Hassan. Stilt-roots of Gluta wallichii? 1935, (S. Kayu) with the forest-guard Che' Ali. 
Plate 23. Stilt-roots of Eugenia longiflora (1934, Mawai) with Hassan. Stilt-roots of Garcinia maingayi with the forest-guard Ibrahim, S. Kayu Ara 1935.

Plate 24. Jurong, Singapore, 1932. Xylopia fusca with stilt-roots and loop-roots. Myristica lowiana, sapling. Tristania? merguiensis, blaze at $1.3 \mathrm{~m}$.

Plate 25. Dracaena granulata in freshwater swamp-forest near Mawai. Jemaluang Rd, 1935. Mussaendopsis beccariana, Jurong 1932.

Plate 26. Jason Bay 1934. Coastal abrasion at S. Rhu Reba with the Casuarina-forest cut back to a single file against Eugenia grandis forest; Beilschmiedia tonkinensis between the Casuarina-trees. Pelunga roxburghii in young Casuarina-forest, with Hibiscus and Scaevola, S. Tuenseh.

Plate 27. Jason Bay 1934. Casuarina-forest developing just south of S. Tuenseh. Clearing at S. Rhu Reba with remains of Eugenia grandis forest and Casuarina. Clearing at S. Rhu Reba with intact transect of Eugenia grandis forest, with two old Casuarina-trees embedded in the forest, Beilschmiedia tonkinensis, Casuarina, Erythroxylon cuneatum, Eugenia grandis and Oncosperma filamentosum.

Plate 28. Jason Bay, S. Diman 1934, with young forest of Sonneratia alba. Near the rivermouth with Casuarina, a sward of Paspalum vaginatum, and seedlings of Rhizophora. Further inland with $P$. vaginatum in the foreground and Cyperus malaccensis behind.

Plate 29. Tg Temalak across Telok Temalak. The coast near $\mathrm{Tg}$ Gemoh. The coast between Tg Temalak and $\mathrm{Tg}$ Tebar with Lumnitzera racemosa at the stream-mouth, 1934.

Plate 30. The stream as in Plate 29, with Lumnitzera racemosa on both sides, Pandanus odoratissimus, and a bush of Scyphiphora. The coastal frontage of $L$. racemosa, as in Plate 29.

Plate 31. Jason Bay 1934. Beilschmiedia tonkinensis. Tacca leontopetaloides, the form with purple-streaked stem. Tacca palmata.

Plate 32. Jason Bay 1934, with Haron. Mangifera ? foetida in dry climax-forest. Eugenia syzygioides in E. grandis forest. Ganua motleyana in the freshwater swamp-forest, the blaze at $1.3 \mathrm{~m}$.

Plate 33. The relic of the peat swamp-forest at Pengkalan Rajah, Johore, 1939. Stump of Melanorrhoea wallichii at Jurong, 1933. An uprooted tree of Parartocarpus venenosus ssp. forbesii at Jurong, 1933.

Plate 34. Jurong, Singapore, 1932, the forest profile during felling. Cratoxylon arborescens, with surrounding small trees of Melanorrhoea wallichii, Ganua motleyana Garcinia? rostrata, Koompassia malaccensis, Melanorrhoea sp., Mussaendopsis beccariana, Santiria laevigata with epiphytic Schefflera cephalotes, Santiria rubiginosa, and Tristania? merguiensis.

Plate 35. Mandai Rd, Singapore, the forest in process of felling in 1940 with Melanorrhoea wallichii, Palaquium xanthochymum, Pentace triptera and Xylopia fusca.

Plate 36. Forest of Kostermansia with nine canopy trees, Ulu Tiram, Johore 1932. Peat swamp-forest at Pontian 1939; Amoora rubiginosa with pinnate leaves and Tetractomia tetrandra with small dense crown on the top of the tall slender trunk. Freshwater swampforest, Mandai Rd 1940 with Eugenia sp., Myristica iners, Pometia pinnata f. alnifolia and Xylopia fusca.

Plate 37. Spilanthes urens at S. Tuenseh, Jason Bay 1934. Polyalthia hypoleuca at Pontian, 1939. Schefflera cephalotes, epiphytic on the trunk of Santiria laevigata and supplanting the crown, at Jurong 1932.

Plate 38. Myristica lowiana, with Pandanus atrocarpus, at Jurong 1932.

Plate 39. Garcinia ? rostrata at Pontian 1939. Melanochyla auriculata in freshwater swampforest near Mawai 1934.

Plate 40. Ploiarium alternifolium in incipient peat swamp-forest at Pontian 1939. Podolasia stipitata ncar Mawai 1937, with L. Moysey. 



\begin{abstract}
This account records investigations into the freshwater swamp-forests of the Sedili rivers in east Johore, of Pontian in west Johore, and of Singapore, undertaken 1929-1940. Specieslists are supplied with critical notes. The succession of riparian belts leading to the swampforest is described, also that of the coastal belts leading to the interior swamp-forest, Comparison is made with similar forests in Sumatra and Borneo. Their bearing on the geographical problem of the Riouw pocket is considered.
\end{abstract}

\title{
Introduction
}

At last, in my retirement, the opportunity has come to write about the exploration of the swamp-forest in the south of the Malay Peninsula, conducted from the Singapore Botanic Gardens. When I arrived in Singapore in 1929, an extensive tract of this forest was being felled along the north side of the Mandai Road, at its western end. Ignorant of such vegetation, I marvelled at the strange forms of many trees, on which the 'floras' threw little light. I pursued the subject at the east end of the Mandai Road until this swamp-forest was also felled in 1940-1941 to extend the Seletar* Reservoir. Then, in 1932-1933, I studied the last area of swamp-forest in the west of the island, as it was being felled to the south of mile 15 on the Jurong Road. My main effort became, however, exploration of the coastal plain of the Sedili rivers in scuth east Johore. This a rea, now largely deforested or destructively logged, consisted in those days principally of primary forest. Finally, in 1939-1940, M. R. Henderson and I studied the peat swamp-forest at Pengkalan Rajah, Pontian, in south west Johore, as it was being felled. War, dislocation in the aftermath, and many ensuing duties prevented this account. Actually it could not have been written earlier with satisfaction because so many of the plants could not, until recently, have been identified specifically. Now, with the progress of the Flora Malesiana, edited by my great friend Professor Dr C. G. G. J. van Steenis, most identifications have come to hand. Above all, however, by lucky chance I was able to spend several weeks in Singapore in 1972, when I was able to consult again the majority of my collections, to many of which the all-important field-notes had been attached; and I made a brief return to the Sedili River. My memories were stirred, and I resolved that I must record what has so sadly disappeared.

I begin with the immense vegetation of the two Sedili rivers and Jason Bay (Telok Sebong). I compare the Kemaman River of Trengganu, which I studied in 1932 and 1935, with the Sedili Besar because variations in river-side forest are important in the biogeography of Malaysia. I add notes on the outlying mountains, Gunong Panti and Bukit Tinjau Laut. I never explored the upper waters of the Sedili Besar, to the west, that is, of the road from Kota Tinggi to Jemaluang and Mersing. Then I introduce the comparative account and more detailed ecological studies at Jurong, Mandai Road, and Pontian. Finally I compare these results with the studies of peat swamp-forest in Sarawak, made by J. A. R. Anderson, in central and north Malaya by J. Wyatt-Smith, and in Sumatra by the Dutch botanists. The great beauty and pristine grandeur of lowland Johore has passed; yet pockets of vegetation remain and from these botanists may pick up and extend where I, perforce, have withdrawn.

It is a pleasure to acknowledge the help which I have received from the Singapore Botanic Gardens, particularly from 'Che Md Shah and Dr Chang Kiaw Lan, and from the Rijksherbarium, Leiden, whence Professor van Steenis and his collaborators have led the Flora Malesiana; their contributions to the identifications

* Old spelling: Selitar 
are mentioned in the special notes appended to the flora of the Sedili region. To Dr J. A. R. Anderson, Dr P. S. Ashton, Dr E. F. Brunig, and Mr B. E. Smythies I am indebted for the privilege of their guidance in the forests of Sarawak and Brunei.

\section{Abbreviations}

Bt Bukit (hill)

F.R. Forest Reserve

G. Gunong (mountain)

K. Kuala (estuary, river-junction)
$\mathrm{Kg} \quad$ Kampong (village)

S. Sungei (river)

$\mathrm{Tg}$ Tanjong (cape, point, straight stretch of river)

Ulu river-source, up-river. 


\section{Part I. The Sedili rivers}

\section{General account}

At the beginning of August 1929 it chanced that a German collector of freshwater aquarium-fish visited Singapore. He was taken on the Bank Holiday to Mawai on the Sedili Besar by William Birtwistle, Director of Fisheries S.S. and F.M.S., and I was invited to join. At that time the road from Kota Tinggi led only to Mawai, where it stopped at a small concrete jetty on the south bank of the river. I remember well for the German, with a smattering of Malay, shouted 'tangkap daun' at a floating leaf which he then used to lure his little fish. This day opened my eyes to vegetation that has enthralled me ever since. I had never seen pandans growing in the water or high forest arching over it with limbs heavy with epiphytes. I repeated these visits until 1941. Mawai was the base. I travelled upstream until fallen trunks barred the passage and downstream to Kuala Sedili Besar whence I began to explore the territory round Jason Bay and the Sedili Kechil. Few people lived in those parts; villages were scattered. Chinese wood-cutters had began to log the lower reaches of the Sedili Besar. An occasional tongkang was poled up beyond Mawai and the building of tongkangs was just beginning above K. Dohol. Many stretches of the river, however, passed through virgin forest and, even, the mangrove-trees over $100 \mathrm{ft}$. high were barely cut.

At first I merely collected in order to learn the unfamiliar flora. The place was convenient. A day's trip enabled me to bring back living plants and to make herbarium-specimens on the morrow from what could not be identified. Of these there were too many, and I came to rely on the local names supplied to me by several knowledgeable Malays who became my companions on these river-trips. We hired the motor-boat (or motor sangkut) of Sultan bin Haji Hassan to tow the canoe (or jalu) in which we explored the recesses of the river-banks. Hassan was the treeclimber and the most knowledgeable in the forest; he accompanied me later on my tree-journeys to the north of Malaya; he stands by the tree with Fomes lamaoensis in my Life of Plants (plate 6) and is seated by the tree of Lophopetalum (plate 16 of this account; also plates 12, 22, 23). The place of young Awan-ti was in the bow to direct course from sunken trees, drift-wood, and other hazards that worked a passage downstream; he too was a born naturalist (Life of Plants, plate 13b; plates $17,19,21$ of this account). Mussib (plate 21) carried the axe before the botanical monkeys disposed of this wasteful procedure. Mat Sah carried the heaviest collecting book. Later, when we had created the Botanical Reserve at the wide bend of the river just above Mawai, I was joined by the forest-guards 'Che Ali (plate 22) and Ibrahim (Life of Plants, plate 12a; plates 15, 23 of this account).

The small village of Mawai was on a slight bluff on the south bank of the river. It was, as I discovered, about the mid-point of the tidal reach of the Sedili Besar where nipa had ended, rassau (Pandanus helicopus) had taken over, and Cerbera odollam was still abundant. It suffered less from the floods which so frequently inundated other stretches of the river. The village consisted of a police-station with notice-board for official proclamations, a small mosque, and a football ground on the west side of the road's end and, on the east, a block of a dozen or so Chinese shops set on a concrete apron about fifty paces from the river; the shops tailed off into wooden tenements along the road. Just below the jetty there stood a large jejawitree (Ficus microcarpa) to the descending roots of which small boats were tied; I think that this tree still stands as the last big riverside example when travelling upstream from the kuala. 


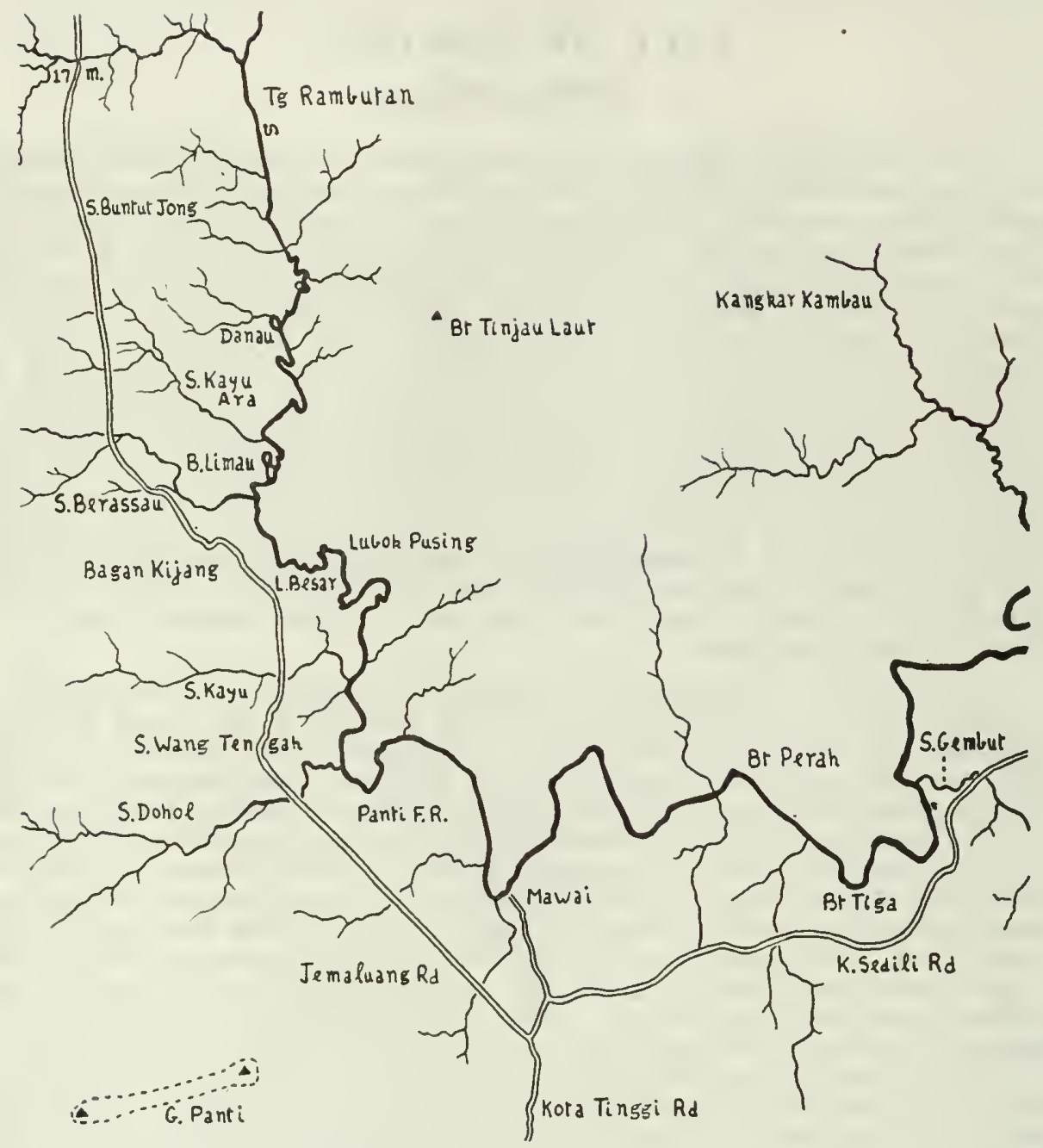

Figure 1. Map of the Sedili Besar from G. Panti and S. Gembut to mile 17 on the Jemaluang Road.

I would arrive soon after sunrise, report to the police-station whence word went round to summon helpers, take kopi-o in a shop and buy bananas while the motor-boats was being got ready. With so many helpers I was at a loss to repay the general kindness until I discovered the football ground. Two or three times a year I would arrive with footballs for Mawai, Kuala Sedili Besar and, K. Sedili Kechil, to be delivered by the police. Awan bin Hassan was then O.C.P.D. of Mawai district. The footballs had a short life because the fields were surrounded by jagged stumps on which they punctured. Later I took inexpensive pipes for headmen at whose houses I stayed up and down the river, and gymn-shoes against thorns in the forest. I have found these gifts acceptable in all parts where I have travelled in South America, Borneo, and the Solomon Islands. Not incidentally, it was on the Sedili Besar that I learned to enjoy Malay, so virile in speech, if torpid in print. 


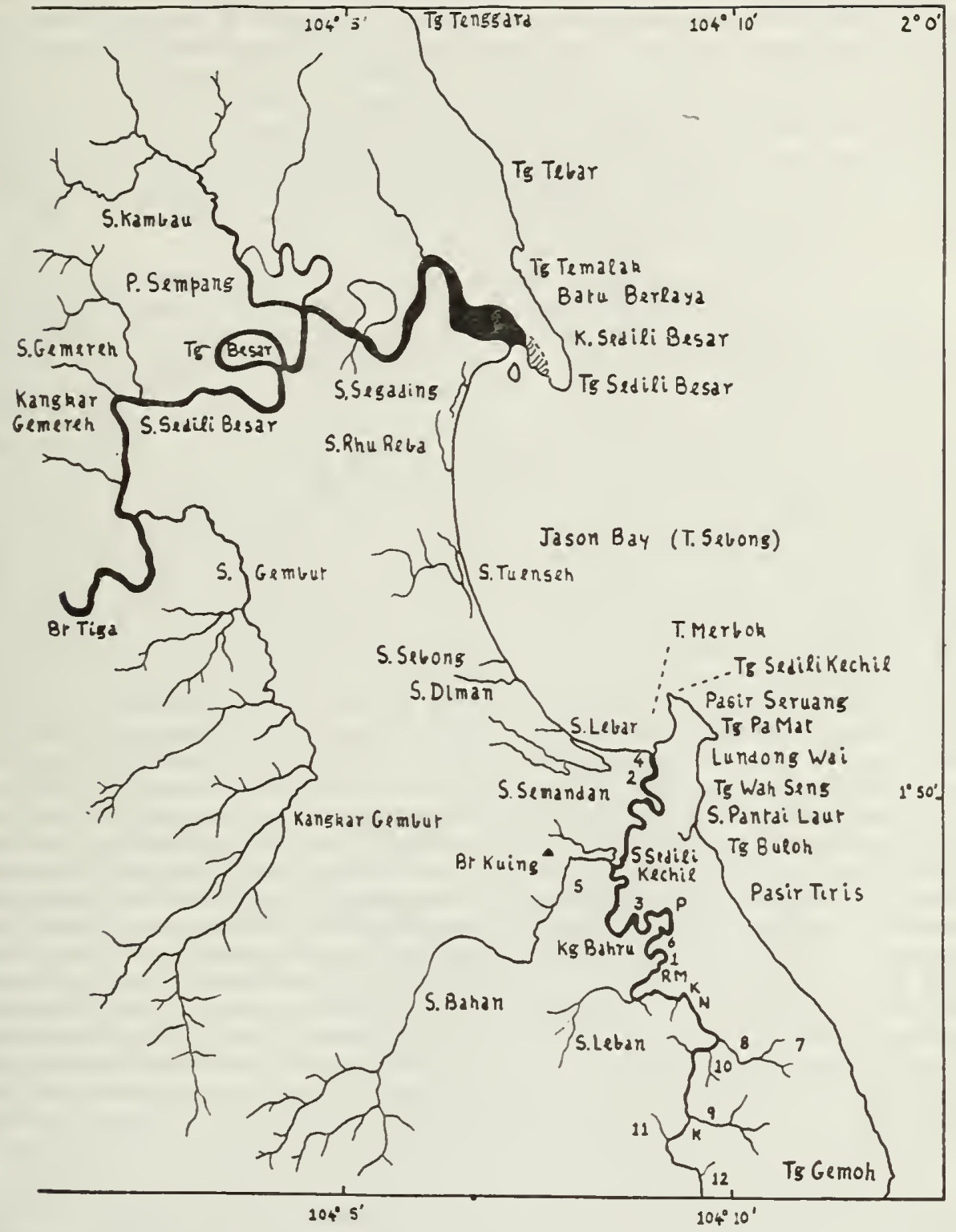

Figure 2. Map of the Sedili Besar from S. Gembut to the kuala, of Jason Bay, and of the Sedili Kechil. Letters and numbers on the Sedili Kechil as follows:-

K - K, Mesua ferruginea very abundant; N, upper limit of nipa. Hibiscus tiliaceus, and Sonneratia; P, lower limit of Barringtonia conoidea; RM, lower limit of Pandanus helicopus and Horsfieldia irya. 1, Tg Bukit; 2, Kg Sedili Kechil; 3, Kg Ladang; 4, Sedili Kechil; 5, S. Jawi; 6, Tg Putus with P. Tembakul; 7, Bt Jeriang; 8, S. Bt Jeriang; 9, S. Lebai Kator; 10, S. Bagan Lanchor; 11, S. Gelenggang Sari; 12, S. Loka.

The road to Mawai persists. It was never more than a lane. It carried sporadic traffic to the shops and, in return, rubber from the Chinese plantations on the hillocks between Mawai and K. Sedili Besar, gambir and pepper as relics of former and more extensive plantations, and such forest-produce as dammar, incense-wood, 
rattans, and attap. The timber went as trunks in the tongkangs to the kuala and round the east coast to the Kallang saw-mills in Singapore. It consisted chiefly of dipterocarps, especially balau, geronggang (Cratoxylon arborescens) in demand for clogs and used to float the heavy balau in the river, jangkang (Xylopia fusca), terentang (Campnosperma) and bintangor (Calophyllum). I found the tracks and fellings of the woodmen helpful in the study of the remaining trees, and the stumps we soon learned to identify. The trunks, cut into lengths of $15-20 \mathrm{ft}$., were levered into the open hold of the tongkang, with little regard for over-loading or rolling, and for many years the tips of the two masts of a tongkang which had rolled and sunk off K. Sedili Besar broke the surface of the sea.

The road to Mawai is now a diverticulum of the highway to K. Sedili Besar. Mawai is dead, levelled to the concrete apron, but the jetty persists. Jason Bay, once so secluded and beautiful with tracts of high forest terminating in the fringe of Casuarina overhanging the waves, has been transformed by logging and reckless deforestation into a hot, fractured, and unattractive landscape. No botanist has recorded this passing, and no one intervened to conserve this wonderful outlet for the people of Johore Bahru and Singapore. During the war an Australian detachment, lodged at Mawai, surrendered there to the Japanese when, doubtless, some damage was done to the village, perhaps also in the ensuing years of occupation when it was a focus of the incessant guerilla warfare maintained in Johore. This chapter in the history of Mawai is unknown but there may be elders in the new village which has sprung up along the highway who can recount those happenings and explain the ill-feeling that has so sadly developed. The levelling of Mawai, however, seems to have occurred during the communist insurgence of the fifties. Thus I learned in August 1972 whell, in the company of Professor Rao, Dr Hsuan Keng, and their research-students from the University of Singapore, we visited Mawai and Jason Bay. We found in the new village my old companion Mat Sah, who came running to the gate as soon as he saw me, to the astonishment of the students for whom the lapse of thirty years was a life-time. $\mathrm{He}$ and his wife lived in a new house where we found old photos that I had given to him and we exchanged many recollections. Awan-ti, unluckily, was in Singapore that day, but Hassan and my other companions were dead. I hope that their families may be traced and told of my appreciation of their companionship which was so disastrously broken. I noticed, however, that in the surrounding deforestation, which had removed so many of my former collecting-sites, there remained good forest to the west of the little road to Mawai. The significance did not occur to me until some time later, for the sight was familiar, but it was the area which in 1935-1936 with the help of the Conservator of Forests of Johore, Mr C. Smith, I had demarcated with notice-boards, nailed at intervals to the trees along the river-front and at certain chain-intervals within the forest, as the Botanical Reserve of the Sedili River. The old boards may still be found, and that area may yet become the place for those ecological studies that it had been my intention to undertake.

As I explored the Sedili Besar, I became aware of the regular change in riverside vegetation on travelling upstream from the mangrove, past the stands of nipa, into the stretches of rassau, with mempisang (Polyalthia sclerophylla), pianggu (Horsfieldia irya), and pelawan (Tristania sumatrana), and finally the territory of keladan (Dryobalanops oblongifolia) and Saraca-streams. Ecology deals with patches of forest and transects, and I could not recall the ecology of a river's length. I fancied the rivers of Europe in their prehistoric splendour and substituted Pandanus for Phragmites, Tristania for Salix, Podocarpus for Pinus, Derris for Lonicera, and many species of Lithocarpus for bog-oak. There were no parallels, however, for mangrove, nipa, putat (Barrington conoidea), mempisang, and the many stiltrooted trees, palms, and gingers in the tropical swamp. I have since travelled the length of the Amazon from Belem-do-Pará and Macapá to Iquitos in boat, in lowflying aeroplane, and in part on foot, and learned that, though immensely vaster, the variety and grandeur of the forest did not equal that along the Sedili. This 
river-side diversification of the forest became a main study. I mapped it carefully and decided, as one would expect from the seaward advance of Jason Bay, that it was progressing down-stream. The critical regions where the vegetation changed may yet be determined. This progress, however, is geologically recent. Into the history of the plain between Mawai and the coast there must be read the transgression of the sea in the interglacial periods, when it may have lapped the foot of G. Panti, and the recession in glacial periods which, in the extreme, united east Johore with west Borneo and led the Sedili rivers past Pulau Aur into the China Sea. The Tristania-banks of the rivers seemed to be relics of this recession which I had hoped to explore across the sand-banks in the swamp-forest round Jason Bay. Misfortune frustrated the intention, but the banks remain, even if largely deforested; Bt Kuing (Quini on the maps) near K. Sedili Kechil appeared to be a place of special interest. An old Malay legend, related to me by one Mat who dwelt in a floating house on the Sedili Besar, tells how a great ship was driven by a storm, long ago, on to the coast, upturned, and became the long ridge of Gunong Panti.

About 1930 the cutting began for the trace which has become the road from Kota Tinggi to Jemaluang. It traverses the hillocks on the east of G. Panti and, thus, transects the main tributaries of the Sedili Besar. When I began the journeys to Mawai, trees were being felled on this trace and I took the advantage to collect from them. At first we walked a mile or two along the clearing, fifty yards wide in this virgin forest. Then, as earth from cuttings was shovelled into swamps and fallen timber made into bridges, we could take the car. The road became the western boundary of my explorations which extended north to the bridge over the main arm of the Sedili, S. Ampang, at mile 17. The cuttings exposed roots and soil; there was yellowish laterite with layers of pebbles and, at intervals, cuttings through stiff white clay. After mile 12 more sandy hillocks appeared and the stately kapur-trees (Dryobalanops aromatica) dominated the forest, as the southernmost occurrence of the species in the Malay Peninsula, Beside the bridge at mile 17 there was a tree on which Pandanus epiphyticus grew, and from which I collected the first fruits of the species in Malaya and, also, the young specimen which I planted on the mango-tree beside the lake in the Singapore Botanic Gardens (Stone 1968). This unmistakable species used to be common in the area between Kluang and Jemaluang where, seated, on the limbs of the great trees that then flanked this road across Johore, it gave a weird and spectacular effect. It occurs along the Endau River and, probably, the Rompin, but it has not been found outside this area in Malaya and I never saw it south of mile 17, to the east of the Jemaluang Road, or on G. Panti. Yet it is common in west Borneo, particularly Sarawak, where it may abound on coastal rocks as well as on trees. It is certainly one of the relics of the former land-connection between the two countries and its exact distribution in Malaya should be ascertained. It made a natural limit to my exploration of the Sedili. Subsequently, when access by car was easy, I explored the Jemaluang Road with the help of the plantcollectors, Kiah and Ngadiman, of the Singapore Botanic Gardens. We stayed at the country house of $\mathrm{Mr} \mathrm{Ah}$ Lec (of Borneo Motors in Singapore). He was starting an orchard at mile 6 on the road from Kota Tinggi to Mawai, and we were greatly indebted to him for this hospitality. The swamp-forest opposite to the orchard, where we collected intensively, persists, but the rest of the forest that we explored along the Jemaluang Road has been cut down. The late Mr J. Sinclair tried to find our localities for rare Annonaceae and Myristicaceae, but where there was high forest along the road, there is now lalang.

I note here that, at the foot of G. Panti West, in Ulu Segun, there was in the forest a deposit of quartz gravel washed from the weathered granite, or washed down in storms from the weathered sandstone ridge, which was tending to compact into the white clay which puzzled me on the Jemaluang Road. How thick the deposit was I did not discover because the terrain was treacherous and on the two occasions when I visited the place there were heavy thunderstorms. This end 
of the mountain is collapsing into a débris of enormous boulders covered by a precarious tangle of tree-roots below which one may hear in the gaps between the boulders streams gurgling, and catch an occasional glimpse of water; it is easy to fall into these chasms. There was a tale of a Chinese collector of the Taiping Museum who never returned from just such terrain on Pulau Tioman.

Collecting from trees is slow and arduous, cven with an expert tree-climber or, as I later perfected, with a berok monkey. The botanist must adopt the forester's method with bark and fallen leaf for subgeneric, if not specific, recognition. I made a practice of noting vegetative characters for nearly every collection. With the sharp eyes of my companions we learned to identify most trees of the swamp-forest from such characters; then a new bark became a signal. Because little attention is paid to these points in most floras, I have given my observations on various species in the section headed Special Notes; many, however, were incorporated in the descriptions drawn up for Wayside Trees of Malaya. Stilt-roots intrigued me with their bizarre effect; I photographed them whenever possible and made collections of large specimens, but nearly all have been destroyed; they stood outside the Herbarium of the Botanic Gardens and became riddled with beetles. Mangroves-stilts are, of course, well known but even now few botanists realise that stilt-rooted trees of many genera of other families abound in the freshwater swamp-forest. I took up the study of pandans, which Dr Stone has mastered, then palms with the help of Dr Furtado, Zingiberaceae which Professor Holttum has described, and orchids with the help of my lamented friend C. E. Carr. Lastly I strove to deal with the big climbers, which are the most difficult and intractable, though with leafy spray in the hand among the easier to recognise. One day, when examining trees on the Jemaluang Road through binoculars, I learned the importance of the colour of withering leaves as a field-character; thus, from the red old leaves, I could identify Uncaria in the canopy (Corner 1938). As my own speciality, I took up the study of Ficus, especially the vast strangling figs which were so common in the freshwater swamp.

By 1934 I had acquired sufficient knowledge of the Sedili flora to begin the more difficult work of ascertaining the boundary between the swamp-forest and that of dry land, the series or belts of vegetation along the river, the peculiarities of the hillocks in the swamp-forest, the seasons of flowering and leafing, and the development of the swainp-forest on and between the succession of sand-banks at Jason Bay. Three events cut short these expectations. An almost fatal expedition to Jason Bay in June 1934 led to an attack of scrub-typhus, or Japanese river-fever, from which many months of convalescence were needed, and I was advised to give up further visits to the district. There was a record of fatality among the inhabitants of Kuala Sedili Besar and K. Sedili Kechil; around the bay there were several deserted villages where so many inhabitants had died of a mysterious sickness that cultivation had been given up; lalang invaded and it became an even better medium for the spread of scrub-typhus. The eyelids of my botanical monkeys, as they walked through this lalang, used to collect the mites which convey scrub-typhus; the monkeys did not suffer, but two Malays who were with me were striken and I never discovered what became of them; one was the delightful character Haron bin Awang Kechil of Kampong Ladang on the Sedili Kechil. Then, of course, the war stopped all exploration and, at its end, I was at loggerheads with the Colonial Office and dismissed. My last recollection of Jason Bay, until I saw it again in 1972, was a cold and choppy passage across the rising waves of the afternoon swell, against the advice of Malays who feared lest the small boat would overturn, but I lay careless in the bottom while Ngadiman bailed and, besides the yawing and soaking, I can still see the ikan parang that leapt from a crest and shot over the top of us. With Ngadiman's assistance I got to Mawai and by taxi to Singapore where I entered the General Hospital clad in sweater, overcoat, scarf, and hat, and soon became insensible from the cold. So my researches are incomplete, though I continued to frequent Mawai and the Jemaluang Road, and I explored Bt Tinjau 
Laut. I record them as a beginning for others. The Endau and Rompin will provide bigger instances, and there must be even larger rivers in west Borneo as yet not wholly deforested; their importance is emphasized by Hsuan Keng (1970).

\section{Floods}

The plain of the Sedili rivers, lying east of the Jemaluang Road, is flooded habitually in two ways. There is the daily tidal flooding the effect of which on the Sedili Besar extends c. 35 mile from the kuala to Tanjong Rambutan, well above Mawai (Figures 1,2); its extent on the Sedili Kechil was not known to me. Salt water from the estuary banks up the brackish water to a depth of several feet and the effect is carried upstream until there is a rise of merely an inch or so, but even this can affect the vegetation, especially the forest herbs which seem the least tolerant of flooding. The water would rise in the creeks and spill over into the swamp-forest with a slight gurgling and hissing, as air was driven out, and a rush, here and there, where temporarily impeded by a fallen trunk; leaves and logs were floated; pneumatophores were covered, and a thin film of mud was deposited on them as the water retreated. Equally important is the recession of the tide, which increases at the spring tides as they approach the equinoxes when, as in other parts of Malaya at the change in tidal cycle, there may be only one extensive tide in the twenty four hours. On such an occasion at Kuala Pahang, I watched the river bed dry out into pools, exposing all the low mud-banks which were normally under water. These excessive tides, which I failed to study on the Sedili, must provide the rare opportunities for the establishment of seedlings of putat and rassau, after which they become bushy and spread with suckers from the base of the immersed stem.

The other way, of course, is freshwater flooding from rain. It is much less frequent but can be more drastic both for the vegetation and the river when banks are washed away. Much débris is carried down by the larger rain-floods; some is caught up in branches along the river, and a thicker film of mud is deposited as the water recedes; lenticels on roots and trunks then burst forth with renewed vigour. Thus I estimated that above Mawai floods might reach a height of $15-20 \mathrm{ft}$. I was anxious to witness a big flood, such as the inhabitants of Mawai had narrated to me, but there was no means of prediction and, as I discovered, it would have been impossible to ascend the torrent and see the effects, had one been prepared. Indeed, on such occasions, access to Mawai was impossible, even to Kota Tinggi for the water would be racing over the main road on both sides of the town and even the bridge across the Johore River might be submerged.

It happened, nevertheless, that I had planned to spend Easter week-end, 25-29 March 1932, on the Sedili Besar. It began to rain when I arrived at Mawai at 8 a.m. on Good Friday, but we took Sultan's motor-boat up to the floating house at Danau where we lodged for the next four nights. It poured incessantly until 3 p.m. when the skies cleared. Such bad luck for collecting had happened before and I gave little thought to it, but Hasan with long experience tied the motor-boat with two ropes to the upper part of the trunk of a little tree some fifty feet high, which stood on the bank beside the floating house. There were two or three of these rafts up river from Mawai, though none below. Big trunks were nailed and lashed together with poles to make a platform on which an attap hut was built, and the trunks were moored by stout rotans to two large trees on the bank. A Malay family lived in each on river-fish, fowls that ran about the platform, forest-produce, and such rice and other commodities that barter could obtain from Mawai. Each house had a dog to warn against the tiger, a kerah monkey whose screeching warned against the snake that might swim aboard, and a quantity of fish-traps. coiled rotans, fire-wood, and spare oars piled on the narrow platform (Plate 2). What with the unending 
gossip of adults on this occasion, the scrambling of the children, the snarling of the dog, the chattering of the kerah, the smoke, and the smell of dried fish, I decided to sleep in the motor-boat. It bumped all night against the raft. The rain recommenced, beat upon the awning, and splashed into the straining and jolting boat. At length, near dawn, I snatched some sleep of exhaustion, to be awoken by a strange and loud hissing that filled the ears and all around; the rain had stopped. I looked out on an unfamiliar expanse of water. Logs were swirling past half-submerged trees; their branches were swaying, tugging, and bobbing all around, and their leaves were jerking and swishing in the turmoil and eddies. The opposite bank with its small clearing was not there. I thought we had broken loose and were travelling down river, when a trunk rolled into view. I looked for the ropes, and they were not there. I could not recognise the scene of yesterday. Then I saw that the prow of the motor-boat was almost submerged and that the ends of the ropes passed vertically into the water. In fact the river had risen over twenty feet in the night and I was level with the crown of the little tree to which the ropes had been attached. We were in situ and, thankfully, just in time to avoid a sinking. A coil of rotan was produced; the boat was lashed to the raft, and the ropes untied from the prow; Sultan recovered them on his next journey up the river. The water stayed at this height during Saturday and Sunday but fell about two feet on Monday. It rained that night and was still raining when we left on Tuesday, but the river was falling. We reached Mawai after dodging many floating trunks and found the jetty still awash; it had been completely submerged and the ground-floors of the shops had been flooded, but my car had been parked, luckily, on high ground behind the village.

During the three days at Danau we paddled in a canoe through the flooded forest. The force of the flood was lost among the trees, though impossible to stem on the main river. I could stand up at a height of twenty feet above the floor of the forest and collect from the tops of the undergrowth trees, though the collections could only be bundled up in the hope that they would last until I returned to Singapore and could have them dried. Wherever we touched leaf, twig, trunk, or floating log, showers of insects tumbled into the canoe. Everything that could had climbed above the water. Ants ran over everything. I bailed insects and spiders instead of water, even scorpions, centipedes, and frogs. All around there was the incessant swishing of the half-submerged leaves, the oblong lanceolate form of which was eminently successful for the occasion, and the incessant honking of frogs and toads. Lizards clung to the trunks; earthworms wriggled in the water, with snapping fish. I found in those short trees many birds' nests, one of which was a reductio ad absurdum for it consisted of two pairs of twigs crossed and entwined at right angles with one small egg perched over the central gap. As the water receded, there was the tell-tale smear of mud, and stranded trunks and branches were jammed into the small crowns suspended with débris of everything that could float. The subsiding waters revealed the tops of stilt-roots and I came, thus, to understand that the maximum height of these roots, which I had measured near Mawai as c. $30 \mathrm{ft}$. on trees of Calophyllum and Palaquium, was that of the rain-floods to which the trees were subjected. I realised the importance of the hillocks in and around the swampforest to animal life, for anything that could escape the flood must have fled there. We met no corpses. Pig, deer, tapir, rat, porcupine, leopard, tiger, monitor lizard, and snakes must have congregated on those hillocks in disquieting proximity. I saw, later, the trampling of elcphants round the foot of $\mathrm{Bt}$ Kuing and $\mathrm{Bt}$ Tinjau Laut. The commotion of flood and feet must have churned up the statistical regularity of sediment beloved of numerical ecologists. Fallen trunks were shifted long distances by the floods; old trunks, buried in humus, were floated out and stranded upright in the crowns of small trees; all the upper soil-strata had been deranged. Bracket-fungi that had withstood the rush had a layer of débris deposited on them into which their hyphae would then grow as knobs, spikes and clavarioid branches 
among seedlings of epiphytes. Loose pioneer vegetation along the river was washed away; new débris accumulated in creeks to supply new niches for fortuitous seedlings. As for the trees themselves, none that could not survive the drowning of roots and bole for several days would survive; perhaps the pneumatophores had a store of oxygen that supplied the roots. How often big floods occurred I could not find out but, certainly, two or three times a year. They are the great test of fitness which rules the life of the swamp-forest; they are ecological experiments of a surpassing magnitude that need to be witnessed. For a dramatic account of the greater flood of the Pahang River in 1926-1927, I refer to that by "Cactus" (1954).

\section{Longitudinal succession of riverside vegetation}

The plants that habitually occur on the riverside, either on firm banks or on the shifting mud, can be grouped into eight categories for which I have used mostly vernacular names. There are, of course, bridging species but it is necessary, at first, to get a concise view. These categories, or belts of vegetation, have the following succession from the estuary inland:-

1. Mangrove (Rhizophoraceae, Avicennia, Carapa, Lumnitzera) in the seawater estuary.

2. Nipa-belt on the mud in brackish water and quieter parts of the estuary.

3. Putat-belt (Barringtonia conoidea) pioneering submerged mud-banks in flowing water, mainly in the tidal freshwater region.

4. Rassau-belt (Pandanus helicopus) with rengas (Gluta velutina) following closely behind the putat-belt as the mud bank widens.

5. Mempisang-belt (Polyalthia sclerophylla) with medang jankang (Elaeocarpus inacrocerus) and pianggu (Horsfieldia irya), following behind the rassau-belt, as the first forest-formation on the stabilised mud-bank, limited to the freshwater tidal region.

6. Jejawi-belt (Ficus microcarpa) growing over rassau and mempisang, chiefly in the lower and variably brackish region.

7. Tristania-banks ( $T$. sumatrana, or pelawan) on the firm raised river-banks, especially in the freshwater tidal zone, either fronting the river or behind the inernpisang-belt. The Tristania-banks, however, extended far above the tidal region and were still evident at mile 17 on the Jemaluang Road.

8. Saraca-streams (S. bijuga) with pelong (Pentaspadon officinalis) and various dipterocarps, along the banks of the tributaries under the forest-canopy, at the periphery of the swamp-forest and leading from the Saraca-streams of the interior. Schoutenia glomerata accompanied Saraca and, by swift streams flowing through rocky foothills, Ficus lepicarpa.

These belts, or strips of vegetation along the river, are shown diagrammatically in Figure 3, as I had determined them by 1934. The environmental factors which control them are, evidently, salinity, silting, illumination, tides, freshwater floods, and the course of the river. The factors grade from a maximum to a minimum value and the belts have, in consequences, a maximal representation where conditions are optimal, whence the representation decreases upstream and downstream, and the belts variously overlap. Their state appeared to be steady but, over a long period with slow advance of the estuary, they must be moving gradually downstreams; that is, the upstream end of the belt should have moribund plants. This was obvious in the case of jejawi, the scraggy and scattered bushes of which above Mawai were 
old, long-established, and unsuccessful plants compared with the vigorous growth in the upper part of the nipa-belt. Likewise in the rassau-thickets above Mawai there were dead and dying bushes of rengas and putat, between which the rassau was invading with new suckers.

The jejawi-belt illustrates the difficulty in giving precise measure to the environmental factors. Judged by abundance and vigour of growth, jejawi prefers the somewhat brackish tidal zone. It may require a certain degree of salinity or it may require the daily flushing with salt-water at high tide and freshwater at low tide. Then seasonal effects may bring severe conditions which the plants cannot tolerate, especially in youth. Dry weather in Ulu Sedili lowers the river and permits brackish water to ascend above Mawai where, on such occasions, even well-water became undrinkable. The effect is greatest if the drought coincides with the tides of the equinox. Clearly one needs a monthly, even weekly, assessment of these factors over a period of several years as part of the rive-regime. The critical region for the change from fresh to salt-water on the Sedili Besar was the stretch of the river between $\mathrm{Bt}$ Tiga and $\mathrm{Bt}$ Prah.

All the riverside belts are lightloving except that of Saraca. Putat seemed to establish itself with fruits stranded on the outermost mud-banks at exceptionally low water. Rassau, on less deeply submerged banks, was taller than putat and, as the bank silted up, so the rassau encroached and established a river-front where dead putat and rengas could be found. The mud-banks of rassau were probably uncovered at spring tides; those of the mempisang-belt were uncovered at most low tides. The trees of the mempisang-belt, being taller than rassau, came similarly to

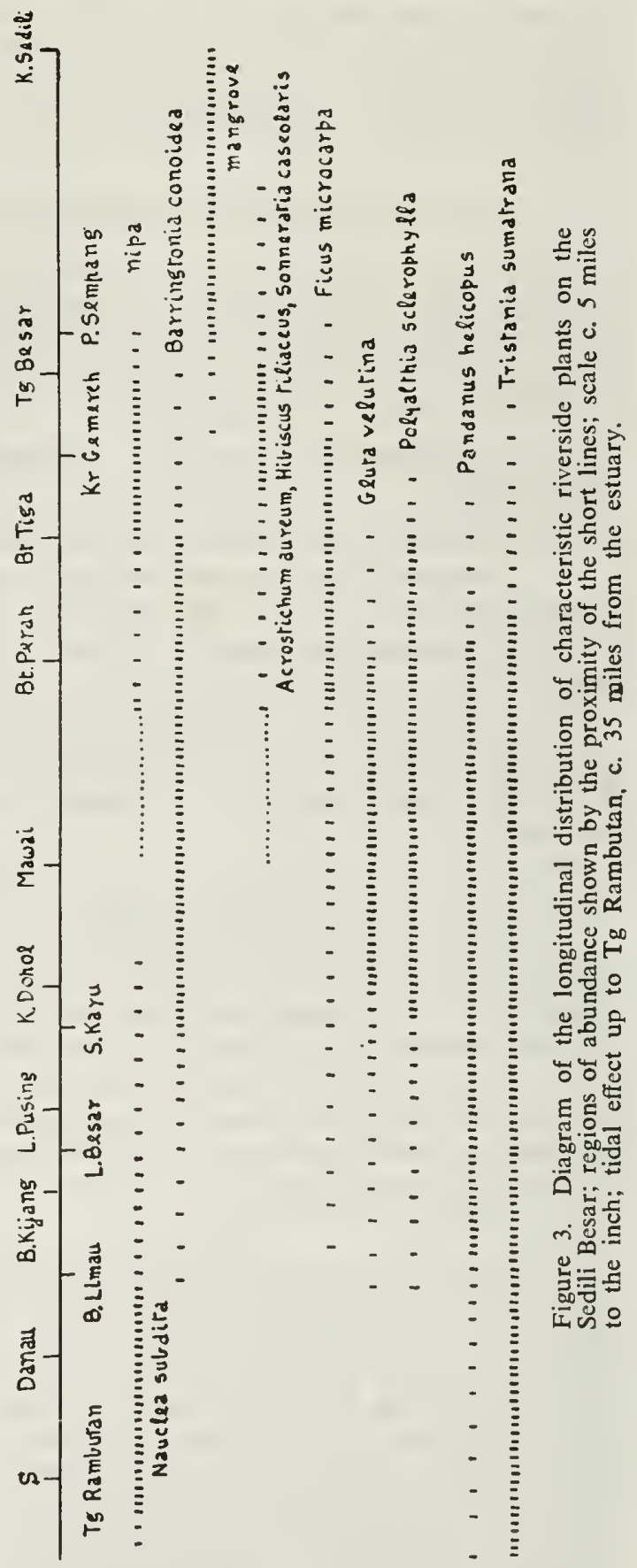


invade it. Behind the mempisang-belt there was either freshwater swamp-forest or a Tristania-bank; in either case the taller trees overshadowed the mempisang-belt. Thus the forest closed on the river and began to undo its establishment. With dead and dying roots the mud of the mempisang-belt washed away. The taller trees of the swamp-forest grew out over the river, leant in the soft ground, and fell under their own weight or in storms or in floods. Gaps gradually appeared on the river-front and they were variously patched. If the fallen tree was not washed away, it entangled the flotsam of the river and started a new mud-bank; it probably deflected the current and so led to the undermining and destruction of other banks. The river front was, therefore, extremely complicated in detail and every place carried its own history. The wreckage of both Sedili rivers was stranded at Jason Bay.

The Saraca-streams belong to the forest shade. Above the tidal reaches, the small Saraca-streams debouched here and there through Tristania-banks with or without an element of rassau; in such places it seemed that the smaller pandans, $P$. malayanus and $P$. yvanii, might substitute $P$. helicopus. In the tidal parts, the Saraca-streams were peripheral and commonly lost themselves in beds of Salacca, smaller pandans, and the water-lily Barclaya. They marked roughly the boundary of the swamp-forest.

Ox-bows, or cut-off river bends, were few. I note the large bow at Tanjong Besar towards the kuala; it had been formed but not yet eliminated as late as 1940. Another at Lobok Pusing above Mawai still retained in 1934 an isthmus of forest which the Malays were considering as narrow enough to sever.

The belts of putat, rassau and mempisang were best developed at the wide river-bends where, with reduced current on the inside, the mud-shelf extended. Behind the mempisang-belt there would be swamp-forest or a Tristania-bank and on the undercut outer side of the bend there was commonly a Tristania-bank. These banks, as I have mentioned, appeared to be relics of a former course of the river when it extended further into the China Sea. In places along the river below Mawai there were a few islets of Tristania-banks where the current had cut behind them. Such islets slumped eventually into the river and most of the trees, unable to withstand so much immersion, would die. An exception appeared to be mensirau (Ilex cymosa), a common tree of the Tristania-bank, which occurred in clumps at various places on the river-front, as if it were the last remains of a Tristania-bank. Possibly dendulang (Eugenia cerina) and resak (Vatica wallichii) had the same faculty. Shortly above Lubok Besar there was a low bench covered with mensirau along with Cryptocarya kurzii, Elaeocarpus robustus. and Helicia robusta, immediately in front of a Tristania-bank, as though part of it had slipped into the river and these were the survivors. I encountered many other unsolved problems as I explored the Sedili rivers more closely, and among them I mention the occurrence of Mesua (Kayea) ferruginea.

Mangrove-belt. I did not study this in detail. On travelling downstream from Mawai, the mangrove began about S. Gembut and Kangka Gemcreh. From Tanjong Besar down to the kuala there was typical mangrove-forest with trees of Rhizophora up to $40 \mathrm{~m}$ high.

Nipa-belt. The distribution of this belt, coincident with tidal brackish water, is shown in Figure 3. There was a small clump of nipa, apparently sterile, on the north bank of the river shortly below Mawai; whether it had been planted or was a relic of the original nipa-belt as it moved downstream, I do not know. The first big and fertile clumps were further down river about half a mile below $\mathrm{Bt}$ Prah. From there on, it formed an almost continuous front to the river until Tanjong Besar where the mangrove took over. The reason is not clear; perhaps the estuary was too rough for nipa. The rhizomes and leaf-bases, with large airspaces, float on extremely treacherous mud. I have plunged sticks into the mud to depths of 2 and $3 \mathrm{~m}$ without reaching firm ground. Usually one had to walk 
along fallen trunks, on the rhizomes, or on a plank, to venture on foot into the nipa-belt. Plants commonly occurring in the belt were the following:-

Acrostichum aureum, Aglaodorum griffithii (the aroid forming carpets under nipa), Brownlowia argentata, Carapa moluccensis, Cerbera odollam, Hibiscus tiliaceus, Oncosperma filamentosum, Pandanus affinis ( $P$. aurantiacus), Scirpodendron, Sonneratia caseolaris, Vitex clarkeana, and the climbers Derris uliginosa, Randia longiflora, and Sarcolobus globosus.

Photographs of nipa generally show it in open and deforested sites. The natural nipa-belt on the Sedili Kechil is shown in my Life of Plants (plate 36b). The time may not be distant when we shall lose track of the original surroundings of this plant.

Putat-belt. This was the pioneer belt that formed on the incipient mud-banks in the tidal freshwater zone. It consisted of the shrub Barringtonia conoidea, which seems to be the most remarkable species of the genus. It formed dwarf thickets, $1-1 \frac{1}{2} \mathrm{~m}$ high, composed of tufted stems in the manner of $B$. racemosa and $B$. acutangula, but never so robust (Plates 4, 6). At normal high tides all but the tops of the bushes were submerged; at spring tides they were completely submerged, at least in the lower course of the river. I never saw the stems exposed to the base, which may happen only at the equinoctial tides when, presumably, seedlings could establish themselves. The belt was narrow and as discontinuous as the mud-shelves appeared to be. The species, described in Wayside Trees of Malaya, is distributed from Lower Burma round the Malay peninsula to south west Sumatra and Borneo with, apparently, the same habitat. It certainly needs investigation.

Putat appeared to be more tolerant of variations in salinity than rassau or rengas. It overlapped with nipa and extended as far up the river as the tidal effect but, as the river-banks became more abrupt, the mud-shelf narrowed or disappeared and there was no foot-hold for putat. It did not occur above Bagan Limau on the Sedili Besar. It was abundant from S. Dohol past Mawai down to Bt Prah below which it was less frequent, and at $\mathrm{Bt}$ Tiga it had dwindled to scattered clumps among the nipa; at Tanjong Besar it had disappeared. At low water one could see the grass Sphaerocaryum malaccense in masses near the bases of the stems, as it clustered also round the stems of rassau.

Rengas (Gluta velutina). Whether this typical riverside shrub or small tree formed a belt distinct from those of putat and rassau, I could not determine. It grew between them. Its fruits float and the seedlings establish themselves on mud-banks which are probably less deep than those of putat. It grew up to $7 \mathrm{~m}$ high and, leaning towards the river, the thick and grotesque trunk inclined and was supported by many adventitious roots entering the mud (Plates 4, 6); it had no special pneumatophores. The thickets which it formed overshadowed putat and were in turn ousted by rassau. It had the same distribution as putat along the river but seemed less tolerant of salinity; thus it did not extend below Bt Tiga on the Sedili Besar. Mawai was at the centre of its abundance where, at night, it was conspicuous with fireflies (Buck 1966, 1968; Haneda 1966). This abundance might have been caused by the reluctance to clear the poisonous bushes. The large riverside rengas tree, Gluta rengas, did not occur on the Sedili rivers and, perhaps, may not occur south of the Pahang river; it seems, however, to occupy a similar habitat. Thus, there appear to be two kinds of rivers on the east coast of Malaya; the neram-rivers with Dipterocarpus oblongifolius in the upper parts and both $G$. rengas and $G$. velutina in the tidal parts occur from the Pahang river northwards, and to the south there is the Sedili kind with Shorea lepidota and $S$. singkawang, but only $G$. velutina. The neram-rivers, certainly, are mirrored along the north coast of Borneo as part of the China Sea enclave. 


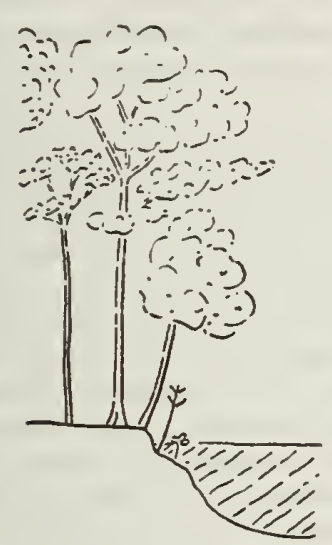

$T P B$

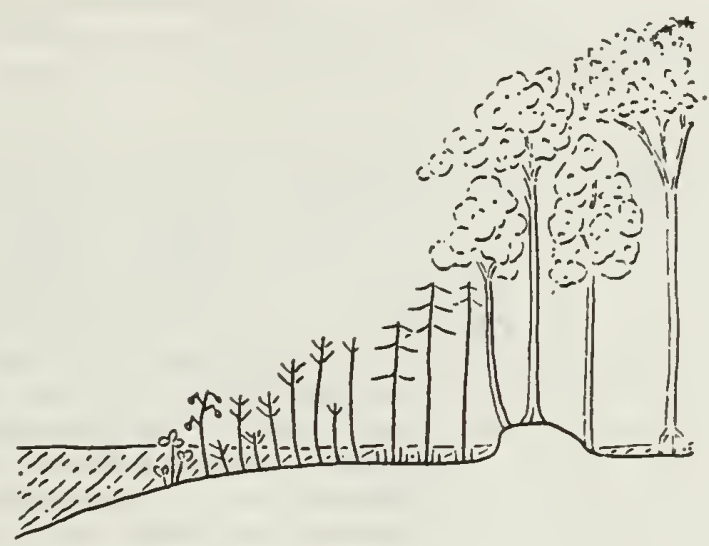

B C
$P$

M

T
$S$

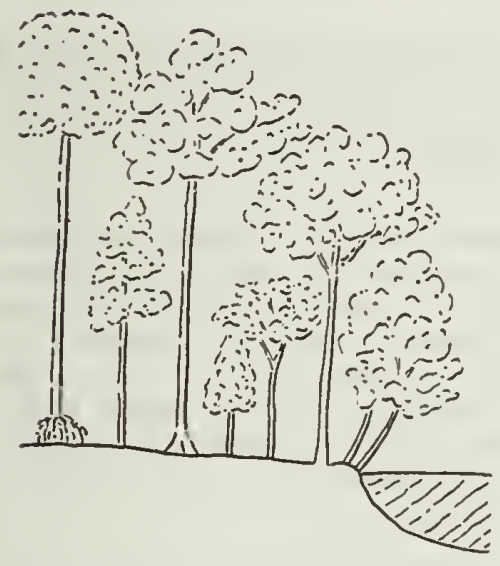

F

$T$

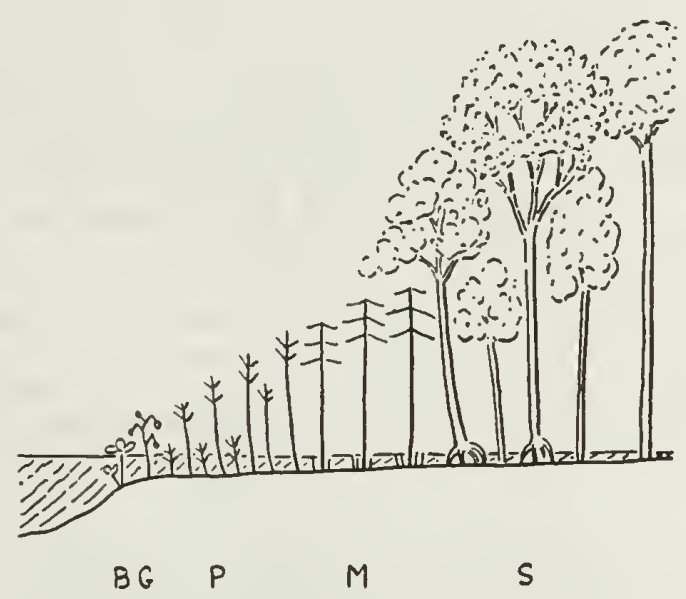

Figure 4. Diagrammatic transects of the Sedili Besar at high tide, showing the occurrence of putat (Barringtonia conoidea, B), rengas (Gluta velutina, G), rassau (Pandanus helicopus, P), mempisang (Polyalthia sclerophylla, M), Tristania-banks (T), freshwater swamp-forest (S), and flood-forest $(\mathrm{F})$.

Rassau-belt. Pandanus helicopus grew taller, $-12 \mathrm{~m}$ high, than rengas and, being soboliferous, formed thicker belts which were the chief invaders of the riverside (Plates 1, 4). On the Sedili Besar between K. Dohol and Lubok Besar, there were thickets advanced almost to one-third across the river, and the Sedili Kechil was in places almost blocked by rassau. Where it extended in this way, dead and dying stems of rassau were often seen along the advancing edge where the current had worn away the bank. So much of the river-front was infested with rassau that I saw no clear case of a young bank with colonising seedlings. Though some parts of the rhizomes were exposed at most low tides, the suckers grew up more or less under water and the young shoots jumped and bobbed in the flow; I used to say that 
the emblem of the swamp-forest biologist should have been the sign of the sunken pandan. In floods only the tops of the rassau would be visible. Flowering occurred mainly from March to June, but could be prolonged by sporadic stems even till October.

On the Sedili Besar rassau occurred in the freshwater tidal parts. It overlapped with nipa and above Danau, where the river was steepened into predominant Tristania-banks, rassau was limited to rather small clumps, not more than $50 \mathrm{~m}$ long, and much less extensive than the main rassau-belts from Lubok Besar to Bt Prah. The last clump that I observed upstream was at the junction of $S$. Ampang with the Sedili Besar. The mud-spits that developed between the main river and the tributaries were favourite spots for rassau which had in many cases almost concealed the egress, especially at the junction of $\mathrm{S}$. Berassau. Being a light-loving plant, rassau did not endure the forest and, by shady Saraca-streams, its place was taken in the muddy hollows by the smaller Pandanus malayanus and $P$. yvanii. Here and there, however. in the swamp-forest near to the river, I found thin sterile patches of a pandan which I took to be another species, but Dr Stone has identified it with $P$. helicopus; thus, they were evidently remnants of the former river-front, but I refer also to the record from the Pontian forest where there was no such river (see p. 80). Nevertheless, $P$. helicopus occurs far inland at Tasek Berah where, perhaps, variable flooding takes the place of the tidal effect though the locality may be the relic of a former tidal river. By the rivers of Sarawak I got the impression that $P$. helicopus grew taller, $-17 \mathrm{~m}$ high, and that the stems branched more frequently. At Lubok Besar on the Sedili Besar, there were two islands of rassau containing moribund putat and rengas.

Trees of Cerbera odollam were frequent in the rassau-belt, as they were behind the nipa-belt, and the slender grass Sphaerocaryum malaccense often formed clumps at the bases of the stems of rassau, as they did with putat, but the remaining vegetation of the rassau-belt took the form of climbers, established in the belt or invading from the mempisang-belt. I noted the following:-

Dalbergia beccarii with delicate light green leaves, the very thorny $D$. parviflora (akar laka), Derris heptaphylla, Ficus globosa, Loeseneriella macrantha, Premna trichostoma, Rourea mimosoides, Uncaria attenuata, U. scleroptera, and Zizyphus calophylla. The orchid, Thrixsperinum amplexicaule, commonly scrambled on rassau, rengas, and putat, and the aroid, Raphidophora minor, often covered old stems of rassau. Between Bagan Limau and Lubok Pusing on the Sedili Besar, Eugenia spicata grew in the rassau-belt though normally it belonged to the mempisang-belt; with scraggy scrambling branches and leaning trunk it resembled stunted specimens of jejawi. E. spicata was also a firefly bush.

Mempisang-belt. This belt of incipient forest, distinguished by its most characteristic species Polyalthia sclerophylla (though I am not satisfied with the identification), took the place of brackish water Sonneratia caseolaris. It occurred behind the rassau-belt in the freshwater tidal stretch from Bt Tiga, on the Sedili Besar, upstream to Bagan Limau. It seemed intolerant of much brackish influence but one member of the association, Horsfieldia irya, was less subject and occurred in the mangrove-belt from Kangka Gemereh to Tanjong Besar. The mempisang-belt was distinguished by the variety of trees and shrubs and by the prevalence of erect pneumatophores which, in places, were so dense that passage was impossible (Plates $11,12)$. It formed on the older parts of the mud-banks where they were exposed at most low tides, and it was commonly backed by a Tristania-bank though it could lead directly into the low-lying swamp-forest of Palaquium xanthochymum. That it established itself on old rassau-banks and invaded them was clear from the common occurrence of dead rassau in the mempisang-belt, but I never saw an instance of the initiation of the mempisang-belt. Roots were so numerous that the mud-bank was no longer dangerous for walking. Stilt-roots occurred in Elaeocarpus 
macrocerus, Knema, and Ploiarium. Pneumatophores were characteristic of Polyalthia sclerophylla (unbranched pegs as in Sonneratia) and as loops, knee-roots or $\lambda$-roots in Elaeocarpus macrocerus and Myristica elliptica. That this belt was invaded by the tall freshwater swamp-forest was clear from the occurrence of saplings of Palaquium xanthochymum and from the fact that E. macrocerus, Knema, Ixonanthes, and Myristica elliptica persisted in the freshwater swamp-forest; other trees and shrubs seemed to die out as the shade increased. Nothing is known, however, of the requirements of the seedlings. None of the trees or shrubs had the faculty of vegetative spreading except, perhaps, $E$. macrocerus fallen trees of which could send up new shoots to grow into tall trees (p. 20, Plate 12).

Habitual members of the mernpisang-belt were the following:- trees, Cerbera odollam, Chisocheton amabilis, Dysoxylon costulatum, Elaeocarpus macrocerus, Eugenia muelleri, Garcinia bancana, G. nervosa, Helicia robusta, Horsfieldia irya, Ixonanthes reticulata, Ixora grandifolia, Knema glaucescens, $K$. intermedia, Lithocarpus elegans, Myristica elliptica, Notaphoebe coriacea, Ploiarium alternifolium, Polyalthia sclerophylla, Pongamia pinnata var. xerocarpa, and Vitex clarkeana:shrubs, Ardisia tuberculata, Barringtonia racemosa, Ochthocharis borneensis:epiphytes, Schefflera subulata:- climbers, Dalbergia parviflora, Derris uliginosa, Ficus globosa, Rolirea mimosoides, Uncaria spp., and Zizyphus calophylla:palms, Licuala spinosa:- sedges, Hypolytrum nemorum, Rhynchospora corymbosa, and Scirpodendron.

Jejawi-belt. The small-leafed strangling fig, $F$. microcarpa, did not form a separate belt of vegetation but it transformed the nipa-, rassau-, and mempisangbelts, especially at the change from brackish to fresh water (Plate 5). Beginning as an epiphyte of Sonneratia, Cerbera, Hibiscus, rassau, or trees of the mempisang-belt, it grew long spreading branches from which copious aerial roots descended into the mud and from which side-roots clasped round neighbouring supports; it did not form a massive trunk. At its best along the Sedili Besar, between Bt Prah and Kangka Gemereh, the branches were more or less erect up to $10 \mathrm{~m}$ high, smothering

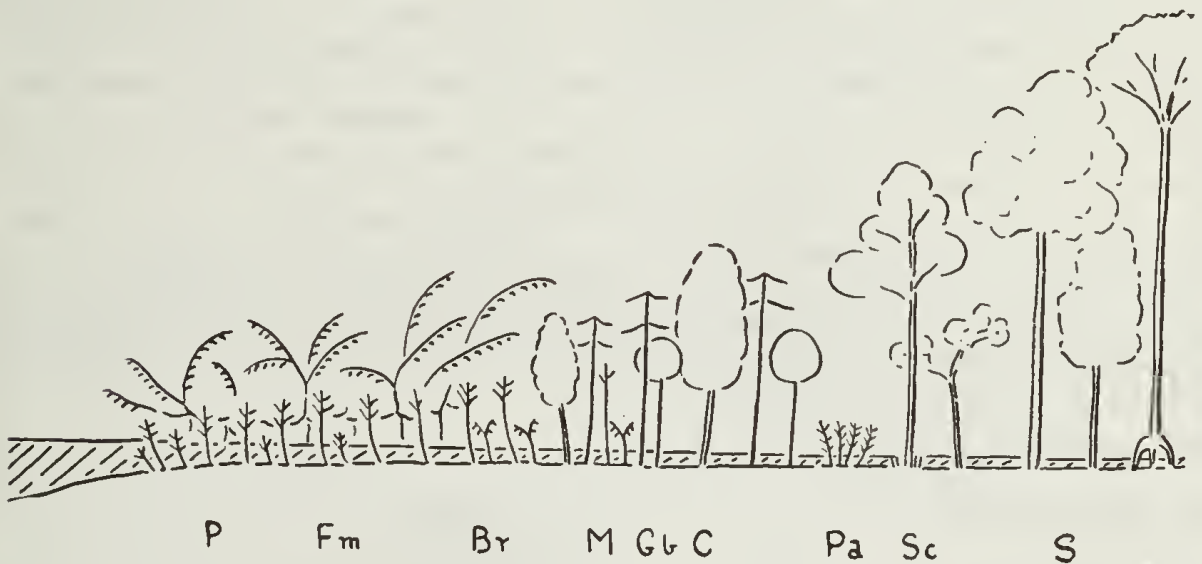

Figure 5. Diagrammatic transect of the bank of the Sedili Besar at high tide, c. 1 mile above Bt Tiga, Pa, Pandanus affinis; P. Pandanus helicorpus; Fm. Ficus microcarpa; Br, Barringtonia racemosa; M, Polyalthia sclerophylla; Gb, Garcinia bancana; C, Carapa moluccensis and Cerbera odollam; Sc, Sonneratia caseolaris; S, freshwater swamp-forest.

rassau and nipa, and the aerial roots were so abundant as to form impenetrable thickets. Here it was accompanied by the woody climber Combretum tetralophum which grew over it. The most luxuriant stands of jejawi were on the south bank from a mile above $\mathrm{Bt}$ Tiga down to the second bend of the river below this 
point. Towards its upper and lower limits, at Bagan Limau and Tanjong Besar, jejawi took the form of a small woody climber insinuating into the thickets of rassau or nipa, without overwhelming them. Except for that at Mawai, no large tree of jejawi occurred along the riverside, which was remarkable because ten or more other species of strangling fig developed to a large size by or near the river's edge. Along the brackish tributaries, however, such as S. Gembut and the small rivers leading into Jason Bay, there were quite a number of large trees of jejawi among which was the largest that I have even seen; it was described in Wayside Trees of Malaya under the mistaken name of $F$. retusa. Many of these jejawi-trees still stood in the region in 1972 though the rest of the forest had been more or less cleared; the large number of pillar-roots make felling difficult and dangerous, and jejawi is one of the strangling figs venerated by Chinese wood-cutters. These relics of the forest showed the normal habitat of $F$. microcarpa by tidal creeks.

Whether the small riverside trees of jejawi were an ecological form or a special variety is not clear. $F$. microcarpa is a wide-spread species that can be found in Malaya in such different habitats as limestone hills, rocky sea-coasts and islands, and infesting trees in towns. It does not occur in the lowland forest except by the tidal creeks, though in Ceylon it is a forest species ascending to $2000 \mathrm{~m}$ alt. On rocks and cliffs it has a low carpeting form with decumbent branches. The tall treeform with massive trunk and many pillar-roots seems to develop only when seedlings have become established high up on host-trees. The riverside form may, therefore, be only an ecological variant.

Tristania-banks. These banks, with more or less vertical front, were raised $\frac{1}{2}-2 \mathrm{~m}$ above the general level of the river or, in the tidal part, that of the usual high tides (Plates 1, 3). Above Bagan Limau, Tristania-banks lined long stretches of the Sedili Besar up to the Jemaluang Road and, probably, beyond until the tall forest overshadowed this light-loving community. Down the river, mempisang- and rassaubelts commonly fronted the banks. The last Tristania-bank downstream was on the north side of the river just below Kangka Gemereh. The banks would be covered in rain-floods but seemed independent of the tidal effect. I never saw one in the process of making. They appeared to have been formed long ago when the river cut into the alluvial plain and before the river-silt had accumulated into mud-banks; they were not a continuation of this process. The vegetation of the banks was complicated through such accidents as undercutting, slumping, and gaps caused by falling trees. I list the following plants which occurred normally on these banks where $T$. sumatrana was predominant. There are c. 110 species of which twenty are climbers. Shrubs were few, namely Gardenia tentaculata, Ixora javanica, Prismatomeris, and the palm Licuala spinosa. The only herb was the sedge Hypolytrum nemorum. I remark that four species of Connarus grew commonly on the banks without obvious ecological preference, and there were three other species of Connaraceae (Rourea, Roureopsis). Similarly the five species of strangling fig revealed no difference in habitat.

\section{Flora of Tristania-banks.}

\author{
Adinandra sarosanthera \\ Barringtonia filirachis \\ $B$. racemosa \\ Bauhinia bidentata \\ Beilschmiedia glabra \\ B. kunstleri \\ Buchanania lucida \\ $B$. sessilifolia \\ Calophyllum macrocarpum \\ C. pulcherrimum \\ C. rupicolum \\ Carallia brachiata \\ Cerbera odollam \\ Connarus grandis
}

\author{
C. monocarpus \\ C. paniculatus \\ C. semidecandrus \\ Cratoxylon formosum \\ Cryptocarya kurzii \\ Daemonorops angustifolius \\ Dalbergia parviflora \\ Derris malaccensis \\ Dillenia excelsa \\ D. suffruticosa \\ Dryobalanops oblongifolia \\ Dysoxylon costulatum \\ Elaeocarpus griffithii \\ E. paniculatus
}


E. petiolatus

E. robustus

Embelia coriacea

Entada phaseoloides

Eugenia cerina

E. fastigiata

E. longiflora

E. muelleri

E. scortechinii

E. spicata

Fagraea racemosa

Ficus binnendijkii

$F$. bracteata

F. calophylla

$F$. consociata

$F$. crassiramea

F. globosa

F. obpyramidata

$F$. obscura var. borneensis

$F$. pisocarpa

F. relusa

$F$. sundaica

(the three enormous flat-crowned

stranglers of the river-banks were

$F$. calonhylla, $F$. crassiramea, and

$F$. sundaica)

Garcinia bancana

$G$. nervosa

Gardenia tentaculata

G. Iubifera

Gnetum gnemonoides

Gomphia serrata

Grewia antidesmifolia

Gynotroches axillaris

Helicia petiolaris

Hypolytrum nemorum

llex cymosa

Ixora javanica

Lepionurus sylvestris

Licuala spinosa

Lishocarpus elegans

L. sundaicus

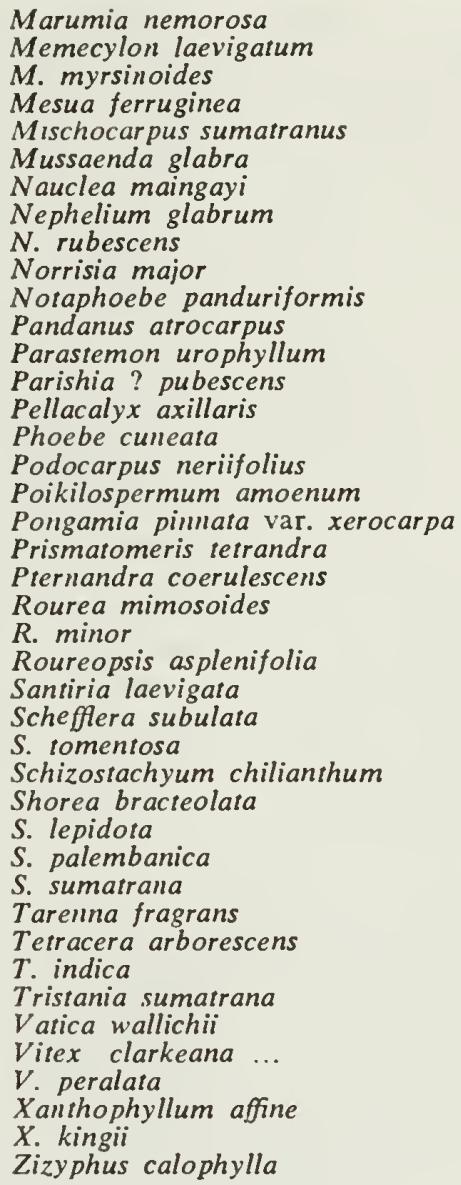

\section{Freshwater swamp-forest}

This was the forest of the alluvial plain round the Sedili rivers and Jason Bay, more or less subject to tides and floods. I distinguished it from the belts of vegetation along the riverside because it was not exposed to the force of the current and its trees did not usually occur in those belts. It pressed upon them, as it were, through the taller stature of its trees, and overshadowed them where trees leant or thrust boughs over the river. It was a climax forest though, presumably, in years beyond the span of human life it would have been displaced by lowland dipterocarp forest of dry land at the periphery, as it was displacing the brackish swamp-forest of nipa and Sonneratia.

This swamp-forest contained many peculiar trees with prominent buttresses (banir), stilt-roots (akar jangkang), and pneumatophores (akar tunjang). Yet, many of the trees lacked these peculiarities, such as Cratoxylon. Mangifera, Sindora, Tristania, and most Lauraceae and Annonaceae. The herbaceous flora was poor and consisted mainly of monocotyledons, ferns, and the water-lily Barclaya. Palms, especially rotans, and pandans were abundant. There were many kinds of liane none of which had pneumatophores, so far as I observed, and epiphytes, some of which I never managed to identify. 
I did not enumerate in detail any part of this swamp-forest, as I had done in Singapore (p. 59) and I was unable to analyse it in ecological detail because too many factors were involved. Thus, daily tidal flooding in varying depths and with high tides varying from morning to evening in different halves of the year, seasonal rain-flooding, extent of brackish water, and proximity to the main river or to sluggish muddy streams. were prime factors with endless interaction. Many events had to be seen in order to be realised. The fallen fruits of Terminalia phellocarpa float with the rising tide and are deposited mbstly round the periphery of its influence; seedlings and saplings tended, therefore, to be separated from the river. I have stood knee-deep in the rising water as thousands of the fruits, like small mangos, drifted past. When a tree was uprooted, much soil was heaved up; in time, trunk and roots decayed and a mound of soil up to $1 \frac{1}{2} \mathrm{~m}$ high was left beside a hollow or pool where the roots had been pulled out. This effect puzzled me for a long time until I saw many intermediate stages in the coastal forest where strong winds and sandy ground caused many trees to be uprooted. Salacca throve in the hollows and many seedlings sprouted on the mounds the tops of which might exceed normal high tide levels. Some trees, when prostrated, threw up from the trunk along its whole length new shoots which rooted adventiously and established a short row of new trees. I saw such files of 3-8 trees of Elaeocarpus macrocerus which had grown to $20 \mathrm{~m}$ high with normal stilt-roots and formed colonies, or clones, in the swamp-forest. The old leaves of the massive palms such as Livistona, Oncosperma, and Pholidocarpus often created more or less barren patches by smothering or smashing the undergrowth. Along with rotans, their strong roots created special surroundings in the soil. Floods swept fallen trunks and limbs into heaps, padded with drifted humus, to create barriers, mounds, and pools where water was trapped, and this diversified the apparently uniform habitat. Pigs rooted up the soil in search of worms and edible rhizomes. Elephants, entering the swamp in the dryer periods, smashed pathways and pulled up seedlings, saplings, and many kind of monocotyledon. The result was the chaos of mounds, pools, muddy creeks, small clearings, and multifarious débris among dense stands of trees with stilt-roots and pneumatophores, often so closely set as to obstruct passage. In places I was unable to pass, even sideways, through the plank-like pneumatophores of Lophopetalum multinervium (Plates 16, 17). Hence I have limited my account to a list of species, their habitats, and such special notes as needed fuller explanation.

The average height of the freshwater swamp-forest was c. $35 \mathrm{~m}$. Larger trees occurred, e.g. Cratoxylon arborescens $(-45 \mathrm{~m}, 20-28 \mathrm{~m}$ to the first branch, bole $70-80 \mathrm{~cm}$ thick), Ganua motleyana $(-50 \mathrm{~m})$, Koompassia malaccensis $(-50 \mathrm{~m}, 27 \mathrm{~m}$ to the first branch); the measurements were taken from trees felled by the woodcutters. In places both Cratoxylon arborescens and Palaquium xanthochymum were so abundant as practically to be dominants. Seedlings and saplings of the large trees abounded in the loose humus, many growing from the sides of fallen trunks, and not a few lost the leading shoot broken by falling limbs or palm-leaves, or browsed by tapir. The following is a list of the canopy-trees of this forest.

Canopy-trees in the freshwater swamp-forest of the Sedili region (*recorded from Sarawak and Brunei peat swamp-forest).

ANACARDIACEAE

Buchanania lucida

B. sessilifolia

Campnosperma squamala*

Gluta malayana

Melanorrhoea wallichii

Pentaspadon officinalis

ANNONACEAE

Mezzellia leplopoda*

Polyalthia hypoleuca*

Xylopia fusco*
APOCYNAECEAE

Alstonia spalhulala*

BOMBACACEAE

Coelostegia griffithii

Koslermansia malayana

Neesia malayana*

BURSERACEAE

Canarium litlorale

Dacryodes macrocarpa*

D. rostrala 
BLRSERACEAE - continued

Santiria laevigata*

S. rubiginosa*

S. tomentosa*

\section{CELASTRACEAE}

Lophopetalum multinervium *

\section{CLUSIACEAE}

Calophyllum incrassatum

C. inophylloide var. singapurense

C. macrocarpum

C. relusum*

C. sclerophyllum*

C. soulatri

C. wallichianum

COMBRETACEAE

Terminalia phellocarpa

DILLENIACEAE

Dillenia excelsa

D. grandifolia

D. pulchella*

D. reticulata

DIPTEROCARPACEAE

Dryobalanops oblongifolia

Dipterocarpus lowii

Dipterocarpus $s p$.

Hopea mengarawan

Shorea bracteolata

$S$. exelliptica

S. lepidota

$S$. palembanica

S. platycarpa*

S. singkawang

$S$. sumatrana

Vatica wallichii

\section{ELAEOCARPACEAE}

Elaeocarpus macrocerus

E. sphaericus

ERYTHROXYLACEAE

Ixonanthes reticulata

EUPHORBIACEAE

Blumeodendron tokbrai*

Macaranga griffithiana

FAGACEAE

Lithocarpus bennettii

L. leplogyne

L. urceolaris

HYPERICACEAE

Cratoxylon arborescens*

C. formosum

ICACINACEAE

Platea latifolia*

Stemonurus scorpioides*

$S$. secundiflorus

LEGUMINOSAE

Dialium patens

D. playtyse palum

D. wallichii

Intsia palembanica

Koompassia malaccensis*

Parkia speciosa

Sindora coriacea

S. wallichii

\section{LYTHRACEAE}

Lagerstroemia ovalifolia

MELIACEAE

Amoora rubiginosa*

Dysoxylon macrothyrsum

\section{MORACEAE}

Artocarpus elasticus

A. kemando

Ficus calophylla

F. crassiramea*

$F$. consociata*

$F$. delosyce

$F$. sumatrana*

$F$. sundaica*

Parartocarpus venenosus ssp. forbesii*

\section{MYRISTICACEAE}

Gymnacranthera eugeniifolia var. griffithii

G. forbesii

Myristica crassa

M. iners

M. lowiana*

\section{MYRTACEAE}

Eugenia cerina*

E. leptostemon

E. nigricans

E. papillosa

E. pseudosubtilis

OLACACEAE

Ochanostachys amentacea

Scorodocarpus borneensis

Strombosia maingayi

ROSACEAE

Parinari costata

$P$. nannodes

$P$. oblongifolia

\section{RUBIACEAE}

Mussaendopsis beccariana*

Nauclea maingayi

SAPINDACEAE

Nephelium glabrum

N. rubescens

Pometia pinnata f. alnifolia*

Xerospermum muricatum*

SAPOTACEAE

Ganua motleyana*

Palaquium confertum

$P$. macrocarpum

$P$. obovatum

$P$. semaram

$P$. xanthochymum

Planchonella maingayi*

STERCULIACEAE

Heritiera elata

H. simplicifolia

Pterospermum javanicum

Scaphium macropodum*

Sterculia macrophylla*

THEACEAE

Adinandra sarosanthera

Gordonia singapureana 
THYMELAEACEAE

Aquilaria malaccensis

TILIACEAE

Pentace triptera
GYMNOSPERMAE

Podocarpus motleyi

$P$. neriifolius

$P$. wallichianus

\section{Tree-crowns}

I distinguished four kinds between which, however, there seemed to be all intermediates though species and, even, some genera and families were characteristic. Firstly, there were persistently monopodial trees, such as Annonaceae and Myristicaceae, Calophyllum and Garcinia, among which some species of Calophyllum and Myristica built large crowns in the canopy. Secondly, there were those like Shorea, Koompassia, Cratoxylon, and Parartocarpus which had a long phase of monopodial growth that gave place eventually to the dense sympodial crown. Thirdly, there were those with a shorter phase of monopodial growth, and their trunks divided at $\mathrm{c}$. $17 \mathrm{~m}$ high into $2-3(-4)$ main ascending limbs which continued the sympodial growth. Such were Melanorrhoea wallichii (rather narrow, even subcylindric, crown), Amoora rubiginosa (lax, incomplete crown), Mussaendopsis (rather lax crown), Pometia (dense crown), Ganua motleyana (as $M$. wallichii but with rather lax crown), Palaquium xanthochymum (large rounded, fairly dense crown with small spires of foliage), and T'ristania ? merguiensis (Jurong, Singapore, with thin, almost flat-topped crown with repeatedly forking branches); possibly Terminalia phello. carpa and Pentace triptera belong in this category. Fourthly, there were the small crowns on monopodial trunks which just inserted themselves into gaps in the canopy. The smallest of these was the crown of Tetractomia, frequently with but. two or three short branches (Plates 7, 36). The better crowns of Cyathocalyx ridleyi and Aromadendron nutans (Pontian, Johore) had more or less unramified limbs (Plates 9, 10).

Thus it became possible to recognise many trees from their crowns and leaves, as well as from trunk and bark. The study of the mature crown, however, requires to be followed from the sapling into the flowering stage, which may set the limit to monopodial growth. Old moribund trees, of which there are few records in botany, also lose their shape in a characteristic manner of dying back, e.g. Koompassia malaccensis. I know of no case in the study of tropical trees which is complete from seedling to dead trunk. Once, as a novice in the Mandai Road forest in Singapore, I struck a tree with a parang and received almost instantly a tremendous blow on the strong topi that I was fortunately wearing, and the next moment I was showered with sawdust which filled my shirt until it ballooned from the belt. The upper piece of a dead trunk had toppled off and was so rotten that the merest shell had struck me. Later, on Mount Kinabalu, I was constantly aware of these dangerous trunks, and every camp required inspection. So I recommend not only the study of saplings but of the moribund which restore detritus to the soil. Probably wind-damage, permitting the entry of fungus and insect, kills the big tropical trees before they succumb naturally. Of the life and death of undergrowth trees I think we know nothing. The hard wood and thin bark of Memecylon and several Rubiaceae suggest slow growth and long life, c.f. Buxus sempervirens in temperate woodland.

\section{Buttresses, stilt-roots, and pneumatophores in the freshwater swamp-forest}

Stilt-roots are familiar among species of Pandanus. They occur also among some palms, sedges, and gingers, but neither stilts, buttresses, nor pneumatophores occur in shrubs, climbers, or, generally, small trees; the stilted Goniothalamus malayanus 
is an exception (Plate 21). They develop, however, sooner or later in the saplings of certain tall trees, though the time of inception has not been studied in any detail. In the Sedili region about 150 species in 34 families had these features, as listed in Table 1. Inspection of this list reveals that the features occur in one or a few species of a genus and that they are rarely a generic character; yet the ability to produce them is a specific property and not, as often assumed, a general faculty in response to flooding. Many typical trees of the swamp-forest had cylindric boles without any buttresses or stilts, e.g. most Annonaceae and Lauraceae, Calophyllum. Dipterocarpus, and Elaeocarpus and, perhaps, all species of Cratoxylon, Mangifera, Sindora, Stemonurus, and Strombosia.

Table 1 gives c. 75 species with strong buttresses and $9-10$ with slight buttressing. Species with stilt-roots number 75 , and two others have slight stilting. Those with pneumatophores number 36, and there are two uncertainties. Nearly all the species were common and, hence, the striking appearance of the swamp-forest. Six species could develop both buttresses and stilt-roots (Dryobalanops oblongifolia, Eugenia nigricans, E. oleina, Lithocarpus urceolaris, Myristica iners, and $M$. lowiana). Two species had both buttresses and pneumatophores (Alstonia spathulata, Ctenolophon), and Horsfieldia irya, sometimes with slight buttresses, had pneumatophores. Palaquium xanthochymum and Eugenia oleina could develop all three features. In contrast, 18 species had both stilt-roots and pneumatophores, but 14 species with pneumatophores lacked stilt-roots and, of these, 11 species lacked also buttresses. There was a tendency for stilt-roots and pneumatophores to be associated. Stilt-roots involve the breaking out and downgrowth of aerial roots, which is the manner of branching of the $\lambda$-shaped pneumatophores which first grow upwards and then branch downwards to form the loops. Stilt-roots generally become flattened sideways and are composed, evidently, of tension-wood in the same way as the buttresses. When buttresses begin to develop in saplings, they thicken outwards over the main lateral roots and inhibit the thickening of the main stem in the intervals; the process continues up the trunk but the outgrowth and inhibition diminish and, in consequence the trunk comes to taper from its greatest diameter above the buttresses down to its insertion into the soil. Stilt-roots have the same effect and the tapering trunk can often be seen very clearly (Figure 6); indeed, the tapering base may rot away and leave the trunk supported only by the stilt-roots. In a few species, however, the stilts remained cylindrical and served as props on the leaning side of the tree; both methods of props and stays were illustrated in my Life of Plants (plate 12). The wood of pneumatophores, in contrast, was soft, aerenchymatous, and spongy.

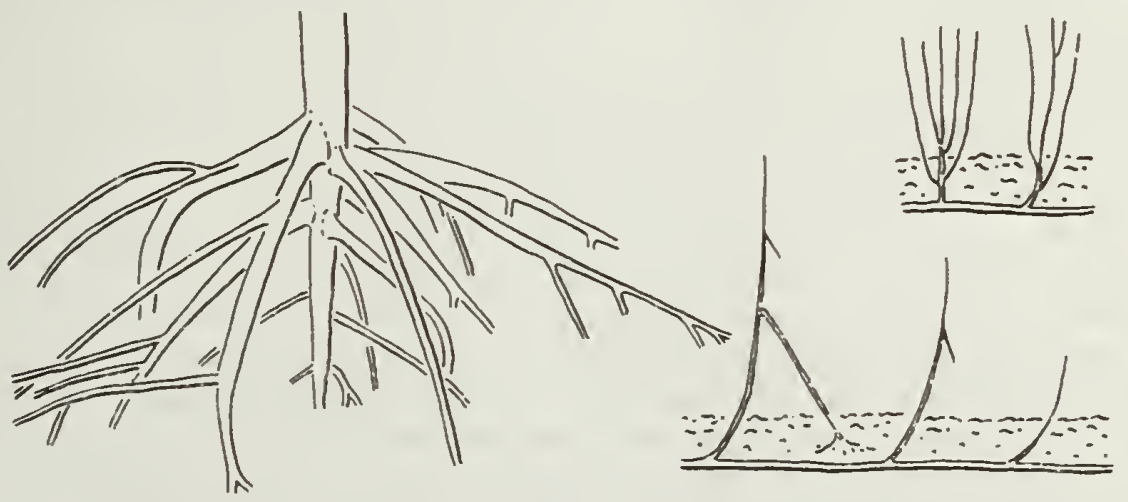

Figure 6. Garcinia? rostrata; stilt-roots of a small trunk c. $13 \mathrm{~cm}$ thick (from a photograph); pneumatophores developing as $\lambda$-roots or as clusters of erect roots. 
Pneumatophores were best developed under strong tidal influence. The greatest variety occurred in the mempisang-belt, which corresponded with that of Avicennia, Bruguiera, and Sonneratia in salt water. This was true to some extent for stilt-roots and buttresses, but they were subject to other influences. Stilt-roots were connected with rain-flooding and, as already mentioned, the height at which they emerged from the trunk was that of average flooding. Buttresses were prevalent in the interior of the swamp-forest and were connected with tensions on main lateral roots in the soft soil. Koompassia malaccensis had shorter buttresses as the soil became firmer and dryer, but Kostermansia was an exception and had its biggest buttresses (up to $7 \mathrm{~m}$ high) in the hill-side forest of Gunong Panti. Dillenia grandiflora, Xylopia ferruginea, and some species of Garcinia and Pandanus were habitually stilted whether in hill-side or swamp-forest.

Five forms of pneumatophore could be distinguished by their shapes and direction of growth, but I failed to investigate them in detail. That they were aerenchymatous was tested simply by blowing through the cut ends and observing the bubbles that emerged from the lenticels when held under water. The five kinds were as follows:-

1. Erect conical pegs, as in Polyalthia sclerophylla and Sonneratia.

2. Erect planks in Lophopetalum multinervium, but degenerating into short thick knee-roots in places with shallow tidal flooding.

3. Slender loop-roots growing up, then curving down into the soil, as in Xylopia fusca (Figure 7) and species of Calophyllum (Plate 13).

4. As 3, but forming thick knee-roots, as in Alstonia spathulata, Ganua motleyana, Horsfieldia irya, Myristica elliptica, and Tetractomia.

5. $\lambda$-roots formed by more or less erect growth followed by a downgrowing lateral into the soil, the distal part often drying up; probably the most usual way of forming loop-roots, e.g. Elaeocarpus macrocerus (Plate 12).

The peat-swamp forests of Sarawak and Brunei add the following species, described by Anderson (1963):-

with stilt-roots; Alangium havilandii, Calophyllum fragrans, Eugenia nemestrina (see Ashton 1964b, plate 32), Garcinia havilandii, Lithocarpus andersonii (as $L$. wenzigianus), Xylopia cerïfolia.

with pneumatophores; Copaifera palustris, Dyera lowii, Dactylocladus stenostachys.

Trees with cylindrical boles in the swamp-forest had stout lateral roots from which descended many smaller tapering roots perpendicularly into the peat or swamp ground, even to depths of $3 \mathrm{~m}$ as with Parartocarpus (Plate 33). This was also the habit of most buttressed trees. I studied the roots in the deforested area round the swamp-forest of Jurong in Singapore, and photographed various upheaved stumps and those from which the peat had shrunk as it had dried. It seemed to me that, in spite of the obviously shallow or superficial main lateral roots, these trees were firmly anchored and well supplied with water even in the dry season. In this connection, I refer to the special notes under Eugenia grandis, Kostermansia, Mussaendopsis, Parartocarpus, Scaphium macropodum, and Shorea collina.

For comparative accounts of buttresses, stilt-roots, and pneumatophores from West Africa there are the recent articles by Jenik (1967), Kunkel (1965), and Lowe (1963). The African Xylopia staudtii resembles the Malaysian X. fusca; Anthocleistus (Loganiaceae) resembles Polyalthia sclerophylla; and Mitragyna (Rubiaceae) resembles Ganua motleyana. Oldeman (1970) has analysed the forms of the riverside trees in French Guiana. 


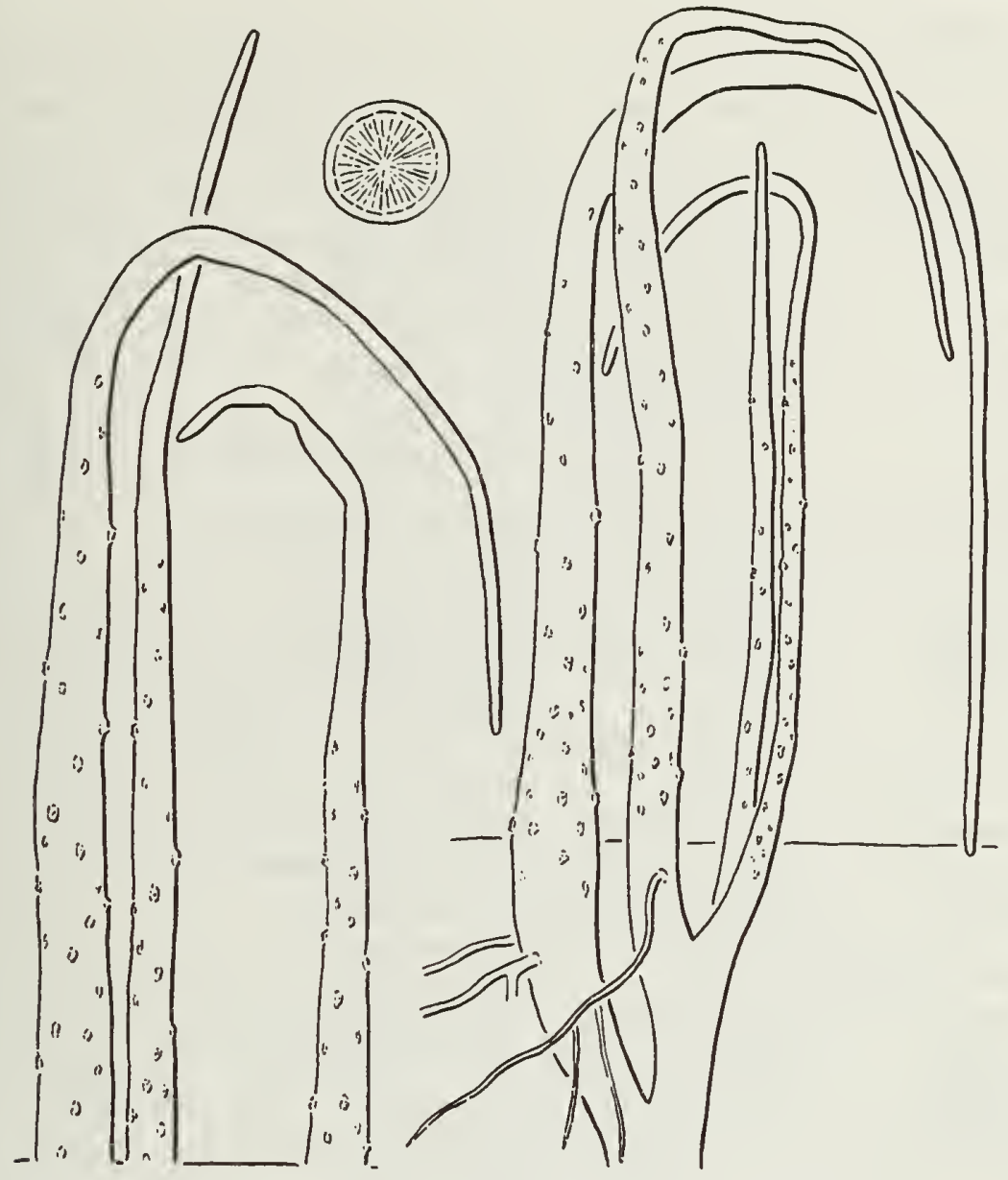

Figure 7. Xylopia fusca; small lenticellate pneumatophores as loop-roots, $\times \frac{1}{4}$; t.s., $\times \frac{1}{2}$.

Table 1. Trees of freshwater swamp-forest with buttresses (B), stilt-roots (SR), and pneumatophores (P).

\begin{tabular}{|c|c|c|c|c|c|c|c|}
\hline & B & SR & P & & B & SR & $\mathrm{P}$ \\
\hline $\begin{array}{l}\text { ANACARDIACEAE } \\
\text { Campnosperma } \\
\text { macrophylla } \\
\text { Melanochyla sp. } \\
\text { (Pontian) } \\
\text { Melanorrhoea aptera } \\
\text { Gluta malayana } \\
\text { Parishia spp. } \\
\text { Pentaspadon officinalis } \\
\text { ANNONACEAE } \\
\text { Goniothalamus } \\
\text { malayanus } \\
\text { Polyalthia sclerophylla } \\
\text { Xylopia ferruginea }\end{array}$ & 二 & - & - & \begin{tabular}{||}
$X$. fusca \\
$X$. malayana \\
APOCYNACEAE \\
Alstonia spathulata \\
BOMBACACEAE \\
Coelostegia griffithii \\
Kostermansia malayana \\
BURSERACEAE \\
Dacryodes macrocarpa \\
Santiria laevigata \\
S. rubiginosa \\
S. tomentosa
\end{tabular} & $\underset{(一)}{(-}$ & $(\overline{(-)}$ & 二 \\
\hline
\end{tabular}


Table 1 cont.

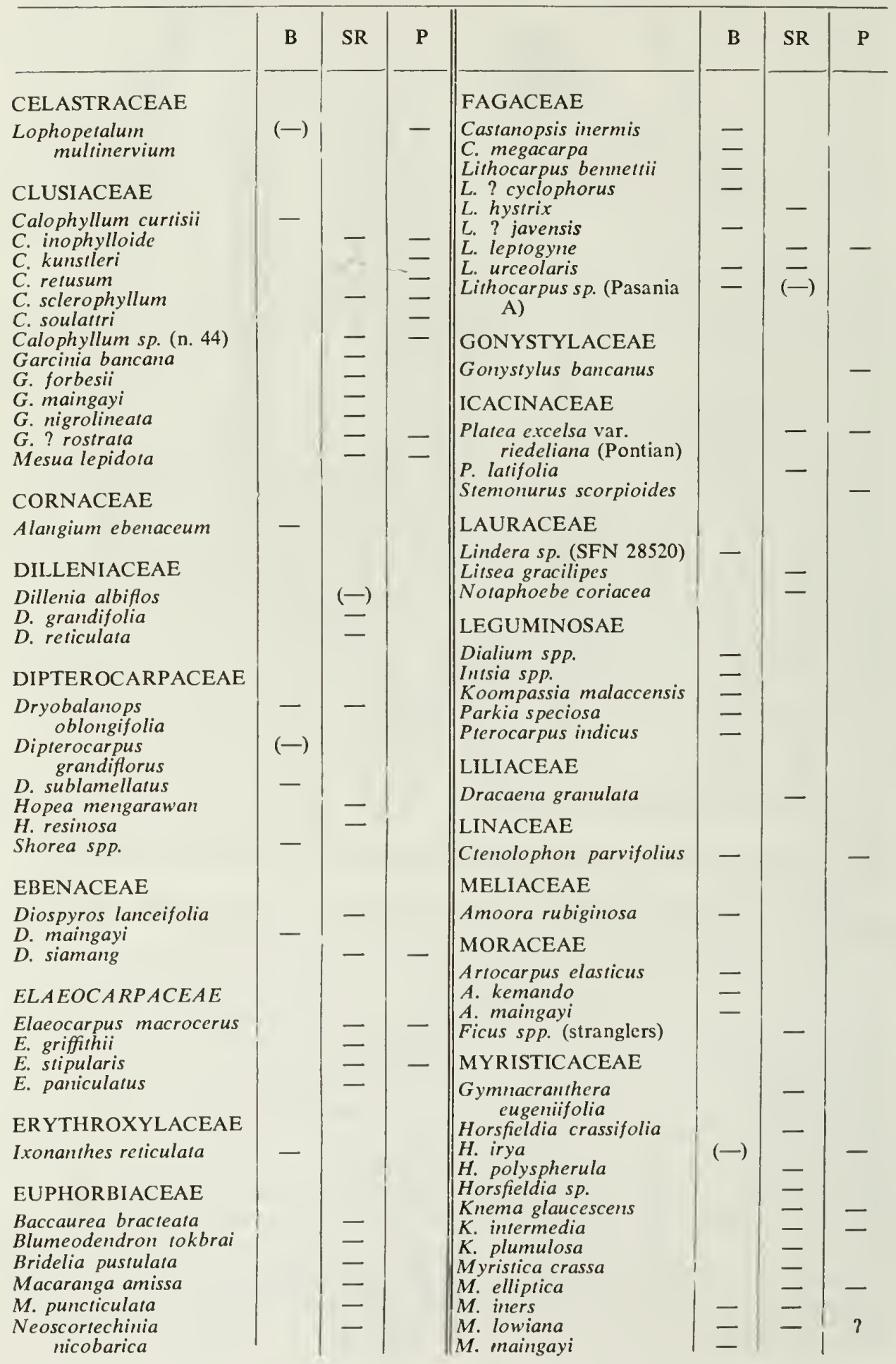


Table 1 cont.

\begin{tabular}{|c|c|c|c|c|c|c|c|}
\hline & B & SR & $P$ & & B & SR & $P$ \\
\hline $\begin{array}{l}\text { MYRTACEAE } \\
\text { Eugenia atronervia } \\
\text { E. cerina } \\
\text { E. conglomerata } \\
\text { E. cumingiana } \\
\text { E. garciniifolia } \\
\text { E. grata } \\
\text { E. leptostemon } \\
\text { E. longiflora } \\
\text { E. muelleri } \\
\text { E. nigricans } \\
\text { E. oblata } \\
\text { E. oleina } \\
\text { E. papillosa } \\
\text { E. pseudor } \\
\text { E. subhorizonulata } \\
\text { E. tumida } \\
\text { Eugenia sp. (SFN } 37730) \\
\text { Pseudoeugenia } \\
\text { singapurensis } \\
\text { PANDANACEAE } \\
\text { Pandanus atrocarpus } \\
\text { P. helicopus } \\
\text { P. malay:anus } \\
\text { P. yvanii } \\
\text { POLYGALACEAE } \\
\text { Xanthophyllum ? } \\
\text { pulchrum } \\
\text { RHIZOPHORACEAE } \\
\text { Pellacalyx axillaris } \\
\text { RUBIACEAE } \\
\text { Anthocephalus cadamba } \\
\text { Mussaendopsis beccariana } \\
\text { RUTACEAE } \\
\text { Tetractomia tetrandra }\end{array}$ & $\begin{array}{l}- \\
- \\
-\end{array}$ & $\begin{array}{l}- \\
- \\
= \\
= \\
= \\
= \\
= \\
- \\
- \\
-\end{array}$ & - & $\begin{array}{l}\text { SAPINDACEAE } \\
\text { Pometia pinnata f. } \\
\quad \text { alnifolia } \\
\text { SAPOTACEAE } \\
\text { Ganua motleyana } \\
\text { Palaquium confertum } \\
\text { P. hexandrum } \\
\text { P. macrocarpum } \\
\text { P. rostratum } \\
\text { P. semaram } \\
\text { P. xanthochymum } \\
\text { Palaquium sp. } \\
\text { Planchonella maingayi } \\
\text { Pouteria malaccensis } \\
\text { STAPHYLEACEAE } \\
\text { Turpinia sphaerocarpa } \\
\text { STERCULIACEAE } \\
\text { Heritiera elata } \\
\text { H. simplicifolia } \\
\text { H. sumatrana } \\
\text { Pterospermum javanicum } \\
\text { Scaphium linearicarpum } \\
\text { S. macropodum } \\
\text { Sterculia macrophylla } \\
\text { THEACEAE } \\
\text { Adinandra sarosanthera } \\
\text { Ploiarium alternifolium } \\
\text { Tetramerista glabra } \\
\text { TILIACEAE } \\
\text { Pentace triptera } \\
\text { VERBENACEAE } \\
\text { Vitex peralata } \\
\text { V. pubescens }\end{array}$ & $\begin{array}{l}= \\
= \\
= \\
(-)\end{array}$ & $\begin{array}{l}- \\
(-)\end{array}$ & - \\
\hline
\end{tabular}

\section{Epiphytes}

I made no special study of epiphytes but collected from fallen trees as the opportunity arose. Two interesting species, concerning the distribution of which more should be discovered, were Solanum parasiticum and the fern Platycerium ridleyi. In June 1937, in company with the late F. Kingdon-Ward, I enumerated the species of epiphyte (36) which grew on an old tree of Norrisia major ( $20 \mathrm{~m}$ high) on the bank of the Sedili Besar shortly below Mawai; the tree was festooned with the root-climber Ficus recurva, and the trunk and branches were thickly covered with these epiphytes:-

Asclepiadacede, Dischidia nummularia:- Gesneriaceae, Aeschynanthus parvifolius: - Melastomataceae, Medinilla hasseltii, $M$. maingayi, Pachycentria tuberosa:-Moraceae, $F$. deltoidea var. deltoidea:- Orchidaceae, Bulbophyllum 
pulchellum, B. purpurascens, B. sessile, B. vaginatum, Cymbidium finlaysonianum, Dendrobium acerosum, D. aloifolium, D. spurium, Eria pudica, E. vestita, Sarcostoma javanicum, Taeniophyllum sp.:-Rubiaceae, Hydnophytum, Myrmecodia:Pteridophyta, Asplenium nidus, Cyclophorus acrostichoides, Davallia solida, Drymoglossum piloselloides, Drynaria quercifolia, Hunzata repens, Hymenophyllum neesii, $H$. polyanthos, $H$. serrulatum, Lycopodium laxum, Microsorum punctatum, Ophioglossum pendulum, Phymatodes sinuosum, Platyceriun coronarium, Pyrrosia longifolia, Selliguea heterocarpa, Thelypteris crassifolia, Vittaria ensiformis.

This diversity on one tree raised the question whether there were 36 physiological ways of extracting a livelihood from this species of Norrisia, and the immense problem why the tropical forest was so rich.

\section{Seasons, leafing, flowering, and fruiting}

A wet season from October to December or January, with the river more or less in flood, was followed by less rainy weather and fine periods from February to September with the river at its lowest about July and August. This was my general conclusion without exact meteorological observations; there were no meteorological stations at Mawai or Kuala Sedili. It was the climate of the east coast, but it was modified in two ways. The dual regime of south Johore and Singapore, with dry weather in February-March and again in July-August, had some effect in the Sedili region, which was also influenced by the proximity of Gunong Panti and the range of small mountains leading north to $G$. Belumut, as the main watershed. Floods from heavy rain in the ulu happened in any month of the year, and there were othcr vagaries. In 1935, January was exceptionally dry, February exceptionally wet, and March exceptionally dry. In other years heavy rain would begin in August and, then, October or November would be fairly dry. Yet, there was an annual succession of leafing flowering and fruiting which occurred once a year, as on the east coast, or for some trees and shrubs twice a year as in Singapore. Whether the stimulus lay in the dryness of the air, the lowering of the water-table, the rise in insolation and temperature, or the opposite effects in rainy weather, it was impossible to decide. Perhaps the bright and dry days of January made the biggest contrast and, then, the gradual, if intermittent, lowering of the water-table. Nevertheless, a field-note of mine for 3 Feb. 1934 says 'I went along the Mawai-Jemaluang road about 7 a.m. and was so cold in the back-seat of the open car that my teeth chattercd and I had to clutch myself to keep warm'. The behaviour of trees which I record is based mainly on observations during the years 1934-1940, when I was sufficiently acquainted with the flora to be able to identify leafing and flowering on the spot.

The following information on rainfall, extracted from the tables compiled by Wycherley (1967), confirm the conclusion that the climate was partly that of the east coast and partly that of Singapore:-

Mersing: $2616 \mathrm{~mm}$ per ann. (average of 25 years), with the dryer season Feb.-Oct.

Kahang: $2718 \mathrm{~mm}$ per ann. (average of 14 years), with the dryer season Feb.-Oct.

Kota Tinggi: $2946 \mathrm{~mm}$ per ann. (average of 27 years), with dryer periods Feb.-March and June-Sept., and generally wet March-April and Oct.-Jan.

Firstly I note that by the Sedili Besar and on the slopes of Gunong Panti, there were always two seasons for the fruiting of fungi, March-May and Aug-Oct. (Corner 1935). The fruiting was the result of $2-4$ weeks of fine weather, sufficient to dry the humus and halt mycelial growth, followed by heavy rain which induced fructification. It was the consequence of the double monsoon. On the ridge of G. Panti, however, I never observed a fungus season, though I visited the ridge 
many times, covering most months, from 1929-1940. The ridge. athwart the monsoons, is exceptionally wet and probably accounts for the higher rainfall of Kota Tinggi. January was the only month when dry weather could be expected; otherwise, on most days, heavy rain would begin about 11 a.m. and last well into the afternoon. I noted, nevertheless, dry weather on the ridge in March-April 1931. To this abundant rain and cloud-cover the ridge owes its peculiarity of lowland swamp-forest and mountain Leptospermum-forest (p. 36).

With the opening of the new year, various trees in the swamp-forest began to change leaves and to flower. From January on there was a succession of flowering cven into the wet weather of November and December when some species of Calophyllum and of rengas flowered. The canopy was never wholly in flower and, thus, individual trees could be picked out and their specific abundance recognised. The period of flowering for any one species was 3-5 weeks, after which fruits ripened in 3-6 months. January to May was the best flowering season, and May to October the fruiting. Double flowering ocurred with Tristania sumatrana, the two species of Buchanania, and Ixora grandifolia in Jan.-Feb. and in July-Aug. The shrub Kopsia singapurensis and the shrubby species of Ixora flowered copiously in the forest-undergrowth in Jan.-Feb. and Sept.-Oct. Pentaspadon officinalis, Pterospermum javanicum, and, perhaps, Mesua rosea flowered about April and October. Since these double flowerings were so general, I assumed without proof that the individual plants flowered twice a year. When Kopsia and Ixora flowered, the undergrowth became a mixture of white and orange-red, which seemed to me as good a mark as any of the double climate. Perhaps the species of Nephelium and Xerospermum flowered twice. In contrast, the single annual rhythm was shown by thc undergrowth tree Macaranga baccaureifolia which shed its leaves in February (p. 187).

Exceptions to the annual rhythm were few, though outstanding, and I think that many more remain to be discovered. As is well known, a general flowcring of dipterocarps occurs at intervals of 3-4 years, especially when prcceded by a very dry spell. Medway (1972) records the flowering of various dipterocarps in Selangor on 1-3 occasions during the seven years 1963-1969. Burgess (1969 records the fruiting of Shorea curtisii every 7-10 years after severe drought. I noted a general flowering of dipterocarps in the Sedili region only in May 1935 when January had been exceptionally dry. I collected the first fruiting specimens of Kostermansia in Sept. 1932, when there was a general fruiting of this fairly common and immense tree in south east Johore, but I never saw flowers or fruits again until the end of March 1940 when there was a general flowering. I am certain of this because I inspected regularly a group of trees that stood near the beginning of the Jemaluang road. It appears that Kostermansia flowers about March, once in eight years. This appears to be the rate of flowering of lanjut (Mangifera lagenifera), a few trees of which occurred by the Sedili Besar, but I did not observe them in flower. Medway (1972) records the flowering of Gluta renghas in two consecutive years over the period 1963-1969, and three annual flowerings of Swintonia schenkii in the samc period. My impression was that several kinds of Anacardiaceae in the swamp-forest seldom flowered. Then I note that fertile material of the large tree Pentace corneri has not been collected, though it is known from Borneo and east Johore. Pentace triptera seemed to flower as seldom as Kostermansia. Medway (1972) recorded two annual flowerings of Pentace strychnoidea in the years 1963-1969.

January. The year began with the conspicuous white flowering of Buchanaria sessilifolia. As it was finishing in the sccond half of the month, the crowns of Melanorrhoea wallichii were converted into white mounds of fragrance. The abundance of both species became obvious, though the trees were not gregarious. Towards the end of the month Tristania sumatrana began to flower and the Tristania-banks were whitened for 3-4 weeks. Leaf-fall and the development of inflorescences began in the mempisang-belt. 
February. The following events might overlap into March.

Gregarious flowering: - Buchanania lucida (see also August), Campnosperma, Croton laevifolius (small undergrowth tree, fruiting in May), Eugenia spp., Lithocarpus spp., various Lauraceae and Myristicaceae, Macaranga baccaureifolia (small undergrowth tree, fruiting in June), Neesia, Pometia, Kopsia singapurensis, shrubby species of Ixora.

Fruiting:- Calophyllum spp. (evidently from flowering in Oct.-Nov.), Connarus grandis.

New leaves: - Shorea spp., Sindora coriacea (deciduous), Macaranga baccallreifolia (deciduous).

March. The main flowering of trees began in this month of uncertain rain. Most striking was the leaf-fall and flowering of Cratoxylon fornosum; the bare crowns flushed with reddish pink from the flowers and opening buds, revealed the great abundance of this tree (up to $30 \mathrm{~m}$ high) in the swamp-forest. Not being a timber-tree sought by Chinese wood-cutters, it flourished after their selective logging.

Gregarious flowerings:- Castanopsis spp., Cerbera odollam, Crateva religiosa, Elaeocarpus spp., Entada phaseoloides, Eugenia spicata, Flagellaria, Gardenia tubifera, Gluta velutina (with flowering prolonged into June or July), Goniothalamus spp., Horsfieldia irya, Poikilospermum spp., Vitex clarkeana.

Fruiting:- Mesua ferruginea, Myristica elliptica, Neoscortechinia forbesii, Nephelium glabrum, Vatica wallichii.

New leaves:- Dalbergia beccarii (riverside climber), Koompassia malaccensis, Pongamia pinnata var. xerocarpa, Polyalthia sclerophylla (beginning to shed all its old leaves, developing olive-buff new leaves), Calophyllum sclerophyllum (complete leaf-change but no inflorescences; see July).

These events might begin in February or be prolonged into April. Regarding Koompassia malaccensis, Medway (1972) recorded the development of new leaves about every six months but flowering was uncertain; only one general flowering was observed in the years 1963-1969.

April, May. Gregarious flowering:- Barringtonia filirachis, Chisocheton amabilis, Cratoxylon arborescens, Dillenia excelsa, Elaeocarpus macrocerus, Eugenia spicata, Garcinia bancana, Gardenia tubifera, Horsfieldia irya, Jackia, Lophopetalum multinervium, Mussaendopsis, Myristica elliptica, Palaquitum xanthochymum, Pandanus helicopus (prolonged into August or September), Pentaspadon officinalis (see also October), Polyalthia sclerophylla, Premna trichostoma (riverside climber), Pterospermum javanicum, Shorea spp., Sterculia bicolor, Vitex peralata, Ixora congesta and 1. lobbii (continuing to flower in the undergrowth).

Aquatic plants flowering:- Barclaya, Cryptocoryne spp.

Fruiting:- Bhesa paniculata, Connarus grandis, Gnetum gnemon, var. brunonianum.

New leaf: - Podocarpus neriifolius.

In May 1935, when there was the heavy flowering of dipterocarps, many trees of Scaphium macropodum became completely deciduous and flowered on the new shoots. I recorded also that this species changed its leaves in Singapore in November 1935 , then flowered for three weeks on the bare twigs, and developed new leaves in January 1936. Medway (1972) records two flowerings of $S$. macropodum (as $S$. affine) during the years 1963-1969. Sterculia bicolor seemed to ripen its fruits and shed it leaves in March-April along the Sedili Besar before it flowered in May.

June, July. Gregarious flowering:- Connarus grandis, Elaeocarpus spp., Eugenia cerina, Fagraea racemosa, Nephelium rubescens, Tristania sumatrana (second flowering), Vitex clarkeana (see March). 
Fruiting:- Buchanania, Dillenia excelsa, Elaeocarpus macrocerus, Gardenia tubifera, Grewia antidesmaefolia, Pentaspadon officinalis, Pentace triptera (1939, 1940, as in Singapore), Rinorea anguifera, Schoutenia accrescens, Sterculia macrophylla, Vitex clarkeana, Xanthophyllum affine, and Pandanus helicopus (continuing to fruit until October or November).

New leaves:- many kinds of tree; some, as Calophyllum sclerophyllım (see March) changed leaves in July.

August. A general fruiting, and a second flowering of Buchanania lucida.

September. General flowering of Dysoxylon macrothyrsum and second flowering of Kopsia singapurensis and the shrubby species of Ixora (both delayed in some years until October).

October. Gregarious flowering:- Dacryodes macrocarpa, Dryobalanops oblongifolia (in 1936), Pentaspadon officinale (second flowering), Pterospermum javanicum (second flowering, see April), Xanthophyllum affine.

Fruiting:- Garcinia ? penangiana.

New leaves:- Melanorrhoea aptera (more or less deciduous, ? flowering in November, with or before the new leaves).

November. Many trees in fruit.

December. Several species of Calophyllum flowered in this month, or in November. As the wettest time of year, collecting was often impossible.

Deciduous trees. The following were noteworthy as deciduous even in the conditions of the swamp-forest and its tidal effect:-

Cratoxylon formosum, Dillenia grandifolia, D. reticulata, Heritiera simplicifolia, Macaranga baccaureifolia, Melanorrhoea pubescens, Parkia speciosa, (? Pentace triptera), Pentaspadon officinalis, (? Pterospermum javanicum), Polyalthia sclerophylla, Scaphium macropodum, Sterculia bicolor, S. macrophylla, Sindora coriacea.

Ever-flowering trees. I noted merely Dillenia suffruticosa and Hibiscus tiliaceus, but Barringtonia racemosa may be such.

\section{Special localities on the Sedili Besar}

S. Berassau. The Jemaluang Road crossed two branches of this stream, the southern being more swampy and lying lower. Both were restricted in places by banks 2-3 m high or there were merely slight banks leading into muddy backwaters. After heavy rain the streams overflowed into the surrounding swamp-forest with Elaeocarpus macrocerus, Notaphoebe coriacea, Palaquium xanthochymum, Cratoxylon arborescens, Dryobalanops oblongifolia, and Xylopia fusca. This forest merged gradually into that of the hillocks. I never followed the stream to its junction with the main river. From mile 8 to mile 13, the Jemaluang Road cut through white clay soil on the hillocks.

S. Kayu Ara. Where the Jemaluang Road crossed this stream, it was like S. Berassau but with steeper banks clad with hillock-forest. Here Areca montana was common on the west side of the road. Cuttings through hillocks in this part had a layer of sharp broken stones, $8-60 \mathrm{~mm}$ wide, situated about $70-100 \mathrm{~cm}$ below the surface.

S. Buntut Jong. I visited this place above Danau in July 1940 and found that fallen trees had caused a sand-bank to form across much of the main river. It appeared to have been about two years old. On it grew Mapania sp., Cyperus 
haspan, Cryptocoryne sp., and seedlings of Gardenia tentaculata. It would be interesting to know if and how this bank may have developed.

S. Kayu. At this part of the Jemaluang Road the Hock Moh saw-mill started in January 1934. A rail-track was laid eventually into the kapur-forest north of $\mathrm{G}$. Panti East. The site for logging and for building tongkangs on the Sedili Besar about 200 yards above its junction with S. Kayu was started in April in 1934. These were the timber tongkangs described by Gibson Hill (1952).

Mile 17, Jemaluang Road. Here the main branch of the Sedili Besar would, in flood, cover the long bridge. At the beginning of February 1934 the river was low, c. $2 \mathrm{~m}$ deep, but flood-marks on the banks showed that it had recently flowed about $6 \mathrm{~m}$ higher.

Riverside from Bt Tiga to K. Sedili Besar. Downstream from Bt Tiga there were long stretches of nipa with jejawi, and where jejawi ended, there the mangrove began. Aglaodorum griffithii and Herpestis monniera were common on the nipamud. The first riverside mangrove tree was Kandelia, a few bushes of which occurred above Kangka Gemereh. A mile or so below the Kangka, Bruguiera, Rhizophora mucronata, and Carapa moluccensis began; mixed with Kandelia, they were very abundant at $\mathrm{Tg}$ Besar. From this island down to the Kuala there was continuous mangrove forest consisting mainly of Kandelia and $R$. mucronata, without nipa though it occurred in patches throughout the interior of the mangrove forest. In gaps in the nipa-front, below Bt Tiga to the start of the mangrove, there were stands of Hibiscus tiliaceus, Sonneratia caseolaris, and Acrostichum aureum; they were especially abundant between the end of jejawi and the start of the mangrove, but in the upper part of the mangrove reaches they became sporadic. Actually these three plants extended up stream beyond $\mathrm{Bt}$ Tiga to about three miles below Mawai where they were small and scattered in the mud in front of the Tristaniabanks; whether they were unsuccessful establishments above their normal occurrence or relics of a former nipa-belt, I did not ascertain. I have noted the clump of nipa just below Mawai; near to it was a fruiting tree of $S$. caseolaris about $7 \mathrm{~m}$ high. The patches of nipa in the mangrove forest near the estuary may have been relics of former open creeks for, presumably the sun-loving nipa is shaded out by the mangrove in its local advance and becomes sterile, but I made no observation on the death of nipa.

Behind the nipa-belt in the reaches of the river below $\mathrm{Bt}$ Tiga there were belts of rassau and mempisang, as well as Tristania-banks, and there was an occasional frontage of Barringtonia conoidea. Thus, this part of the river had the most complicated riverside vegetation. I fear that it may now have been much disturbed.

\section{Flora of the kapur-forest (Dryobalanops aromatica) on the Jemaluang Road between S. Berassau and mile 15}

I give a bare list of the plants that I found in this magnificent forest. I think it has been entirely exploited.

\author{
Adinandra acuminata \\ A. corneriana \\ Alphonsea johorensis \\ Alseodaphne obovata \\ Anisophyllea corneri \\ A porosa lunata \\ Aralidium pinnatifidum \\ Ardisia pachysandra \\ A. ? solanacea \\ Areca montana \\ Artocarpus elasticus \\ Baccaurea parviflora
}

Balanocarpus heimii

Calophyllum incrassatum
C. wallichianum
Canarium littorale
Chrysophyllum lanceolatum
Cinnamomum mollissimum
Cleistanthus praetermissus
Cnestis palala
Cryptocarya griffithiana
Cyathocalyx pahangensis
C. ridleyi


Dialium ? kingii

Dillenia albiflos

Diospyros confertiflora

D. lanceifolia

D. nutans

Dissochaeta punctulata

Dryobalanops aromatica

Durio singapurensis

Dysoxylon cauliflorum

Elateriospermum tapos

Electtrarricpsis curtisii

Endospermum diadenum

Enicosanthum praestigiosum

Erycibe maingayi

Eugeissona tristis

Eugenia conglomerata

E. cf. duthieana

E. dyeriana

E. pseudosubtilis

Eugenia sp. (SFN 29319)

Fagraea ceilanica

Gaertnera obesa

Garcinia? penangiana

Gardeniopsis longifolia

Gironniera nervosa

Gluta tavoyana

Gomphandra quadrifida var. ovalifolia

Goniothalamus tapis

Gymnacranthera bancana

Hopea mengarawan

$H$. polyalthoides

Horsficldia polyspherula

Hydnocarpus castanea

Ixora javanica var. retinervia

J. Teysmannia altifrons

Koompassia malaccensis

Lasianthus ellipticus

Lepisanthes tetraphylla

Leptonychia glabra

Lindera malaccensis

Madhuca sessiliflora

Mangifera cf. quadrifida

Mapania kurzii
M. lorea

M. micropandanus

Melanochyla aff. auriculata

Meliosma pinnata ssp. ridleyi

Memecylon maingayi

Mesua ferrea

$M$. kochummeniana

Nenga macrocarpa

Osbeckia sp. ? (s.n. 11.5.35)

Palaquium clarkeanum

P. sukoei

Parinari nannodes

Phyllanthus gomphocarpus

$P$. oxyphyllus

Polyalthia brunneifolia

$P$. sumatrana

Pouteria malaccensis

Pseuduvaria galeata

$P$. macrophylla

Ptychoraphis singaporensis

Randia penangiana

Raphidophora sylvestris

Rennellia elongata

Sandoricum sp. (SFN 29363)

Saprosma glomerulatum

S. quadrifidum var. ?

Scorodocarpus borneensis

Shorea acuminata

S. exelliptica

S. foxworthyi

S. palembanica

Stephania ? (s.n. 11.5.35)

Sterculia coccinea

S. rubiginosa

S. cf. scortechinii

Streblus taxoides

Strychnos ignatii

Swintonia penangiana

Symplocos barringtoniifolia

Ternstroemia elongata

Timonius wrayi

Trigonostemon longifolius

$T$. rufescens

T. villosus

Tristania? pontianensis

\section{Bukit Tinjau Laut}

This hill, $400 \mathrm{~m}$ high, is isolated on the northern limit of the Sedili region. As its name implies, it is a look-out to the sea. I had often seen it from the long tanjong of the Sedili Besar one or two miles above Bt Prah, and I wished to compare it with Gunong Panti $(500 \mathrm{~m})$, the long ridge of which contrasted with the apparently simple hump of Bt Tinjau Laut. The opportunity came in August 1939, and the approach was made from Lubok Pusing on the Sedili Besar.

I left Singapore at 5.30 a.m. on 5 August and did not reach Mawai until 7.45 a.m. on account of heavy rain. The river was in flood, but Sultan and his companions were ready with the motor-boat. We left Mawai at 8 a.m., reached Lubok Pusing 
at 9.30 a.m., and had set up camp at the foot of Bt Tinjau Laut by 2 p.m. There was a track from Lubok Pusing for about a mile through secondary forest and derelict primary forest. As we approached the hill, signs of elephant increased, and we camped on flat ground in secondary forest by a little stream crossed by a wide elephant track with fresh dung. We kept a fire and two hurricane lamps burning on the three nights of our visit, lest the elephants returned. The stream was meagre; the water was clear but there were horse-leeches and, for bathing, we had to scoop water with a frying pan.

On 6 August we set out at 7.30 a.m. and went up a ridge to the summit. It was a granite hill covered, to my surprise, with virgin kapur-forest. The trees, along with chengal and several kinds of Dipterocarpus and Shorea, stood c. $50 \mathrm{~m}$ high. Millettia atropurpurea, which I had not seen elsewhere in the Sedili region, was frequent. The ascent was moderately steep, though not as steep as on G. Panti, and there were no rocky cliffs. On the summit a survey-beacon was overgrown with secondary forest $6-7 \mathrm{~m}$ high, and no clear view was obtainable. In this secondary forest Cratoxylon ligustrinum was abundant, though I had seen it but rarely in the rest of the Sedili region. I saw no difference in the forest from foot to summit except for the commoner occurrence of Pandanus recurvatus in the upper part above $250 \mathrm{~m}$. The undergrowth consisted mainly of saplings, Licuala, Nenga, Arenga westerhoutii, and the abundant Fordia johorensis; neither of these last two had been found elsewhere in the Sedili region. I noted the absence of Eugeissona, J. Teysmannia, and the Euphorbiaceous Trigonostemon, typical of the kapur-forest on the Jemaluang road. There were many kinds of Eugenia, but most were sterile; I noted particularly the abundance of E. rugosa and Eugenia spp. (A and B, 6.8.39, and A, 7.8.39). Later identification of my collections revealed the following peculiarities. Sapium baccatum, Beilschmiedia lumutensis, and the two large Sapotaceous trees, Ganua kingiana and Palaquium hexandrum, were common in the kapur-forest, but I had not found them on the Jemaluang road. The Anacardiaceous Swintonia penangiana, with orange bark like Pometia, and Melanochyla sp. were common on the ridges. Antidesma pahangense was frequent, though it has been known otherwise only from the mountains of north Malaya and from G. Panti. I collected, also, Cyathea obscura and Zingiber wrayi, otherwise from the main range of Malaya, Vatica stipularis (otherwise known from Mt. Ophir), and the ferns Asplenium borneense and Thelypteris motleyana.

That afternoon it rained hard until sunset and drizzled all night. I suspect that, like other hills of the east coast, it had its local climate. On 7 August the day was fine, though cloudy in the afternoon. We explored the second top of the hill, which is not discernible from a distance, and ascended and descended by valleys. The upper valleys were very steep and filled with big granite boulders (much as Fern Valley on Bt Timah). The second top was rounded and almost flat, just as the main summit. Scattered boulders occurred on the slopes but mostly near the top. The valley-bottoms were filled with Phacelophrynium maximum which, in the Sedili region, occurred also by $S$. Kayu on the Jemaluang road, yet did not occur round G. Panti. This day we suffered from the little ticks and had to spend an hour smoking them off our bodies and out of our clothing.

On 8 August we left camp, met Sultan with his motor-boat at Lubok Pusing, and were in Singapore by sunset. Ngadiman of the Singapore Botanic Gardens and four local Malays accompanied me on this trip; they were well satisfied with \$1 per day along with the food of their choice, namely rice, dried fish, salt, condensed milk, tea, and bananas. I have recorded details because it would be interesting to note how a visit to Bt Tinjau Laut would now be undertaken. 
If it has not been too drastically deforested, the hill needs much further exploration, earlier in the year when more trees could be expected in flower. Phacelophrynium indicates floristic connection with Trengganu. The abundance of Eugenia rugosa indicates connection with coastal dry-climax forest. The dominance of kapur, which is absent from G. Panti, is curious for it represents the southerly limit of the species in the peninsula. The hill seems to be a relic of the complex of G. Muntahak and G. Belumut, or the southernmost of a coastal range from Trengganu. There may be traces of marine transgression round the foot.

Plants collected on Bt Tinjau Laut (August 1939)

Achasma macrocheilos

Aglaia cf. trichostemon

A glaia sp. (SFN 36939)

Aglaonema simplex

Antidesma pahangense

Antidesma sp. (SFN 37080)

Aquilaria malaccensis

Ardisia ? wrayi (SFN 36949)

Ardisia sp. (SFN 36929)

Arenga westerhoutii

Aromadendron elegans

Artocarpus elasticus

A. integer var. silvestris

Asplenium borneense

Balanocarpus heimii

Bauhinia integrifolia

Beilschmiedia lumutensis

Boesenbergia praineana

Canarium littorale

Combretum sundaicum

Cratoxylon ligustrinum

Croton laevifolius

Cyathea obscura

Dapania racemosa

Dillenia albiflos

Diospyros? graciliflora (SFN 36936)

Diospyros sp. (s.n. 6-8-39)

Dipterocarpus spp. (abundant)

Donax grandis

Dryobalanops aromatica

Dryopteris crassifolia

Durio singapurensis

Ellipanthus tomentosus var. gibbosus

Eugenia rugosa

Eugenia tumida

Eugenia sp. (A, 6.8.39; B, 6.8.39)

Eugenia sp. (B, 7.8.39)

Fordia johorensis

Ganua kingiana

Globba variabilis

Gluta ? malayana (tree B, C, 6.8.39)

Gluta tavoyana

Gordonia ? multinervia

Habenaria sumatrana

Justicia sp. (SFN 37051)

Knema glaucescens var. patentinervia Knema laurina
Kopsia singapurensis

Licuala lanuginosa

L. Iriphylla

Madhuca tomentosa

Mapania lorea

$M$. palustris

Melanochyla sp. (A, 6.8.39)

Melanorrhoea woodsiana (rengas A, 6.8.39: tree $-40 \mathrm{~m}$, common up to the summit)

Memecylon maingayi

Millettia atropurpurea

Nenga macrocarpa

Ochthocharis sylvestris

Palaquium hexandrum

Parkia speciosa

Phacelophrynium maximum

Phrynium capitatum

Pithecellobium bubalinum

Piptospatha ridleyi

Plagiostachys albiflora

Plocoglotis gigantea

Polyalthia cauliftora var. beccarii

Psychotria helferiana

Randia scortechinii

Renuellia elongata

Sapium baccatum

Saurauia tristyla

Scaphium linearicarpum

S. macropodum

Scaphochlamys klossii var. minor

Schismatoglottis brevicuspis

Schoutenia accrescens

Shorea foxworthyi

Shorea spp.

Sonerila costulata

Staurogyne griffithiana

Stichoneuron caudatum

Streblus taxoides

Styrax crotonoides

Swintonia penangiana

Trivalvaria nervosa

Urophyllum streptopodium

Vatica stipulata

Zingiber wrayi

Unidentified:- s.n. 6.8.39, as Tree A; see special notes. 


\section{Ridge-flora of Gunong Panti, Johore}

The long ridge of $\mathrm{G}$. Panti (c. $500 \mathrm{~m}$ ) tops the granite mass of the mountain as a sandstone crest (c. $50 \mathrm{~m}$ high) from north west to south east. The highest point at the west end drops precipitously into lowland dipterocarp forest. There is a survey-beacon in a small clearing whence, on a fine day, G. Belumut may be seen and, formerly, the incursions of kapur-forest in the lowland leading to Muntahak, but they have largely been destroyed. The flanks of the ridge are precipitous and, apart from the ascent-route at the west end, they have not been explored botanically.

It has been known since Ridley's ascent in 1892 (Burkill 1927) that the flora of the ridge is peculiar and distinct from the dipterocarp forest on the granite slopes. The ridge-forest is a mixture of montane, lowland, and freshwater swamp forest. Probably there is nowhere else where Leptospermum, Cibotium barometz, and Cyrtostachys grow together. When, to these, there are added Ficus pendens, Cheiropleuria, Parartocarpus, Myristica lowiana, Lithocarpus wrayi, Illicium, and Sympetalandra, it can be seen that the ridge is a relic of a high mountain with upland swamps comparable, perhaps, with some range in west Borneo. It may be that $\mathrm{Bt}$ Tinjau Laut, P. Tinggi, and P. Tioman have lost the sandstone cap which lingers on the islet P. Berhala to the north of P. Tioman. According to Gobbett and Hutchison (1973), the sandstone is upper Jurassic to lower Cretaceous and situated unconformably on palaeozoic granite; it suffers very slow vertical weathering and is destroyed by scarp-retreat. Similar instances of mountain flora on lowland summits are given by Ashton (1964b, p. 51).

In 1935 a proposal was put to the Johore Government by the surveyor, F. B. Sewell, for a hill-station at the east end of the ridge. Aware of the damage that an ascent road might cause, as well as irreparable damage to the ridge itself through deforestation, a counter proposal for the conservation of the whole ridge with its unique flora was made by the Singapore Botanic Gardens. The original plan fell through for various reasons, as I was informed by the Conservator of Forests, C. Smith, but the danger is ever present even though the ridge has been scheduled as part of the Panti Reserve.

I have made the following list of c. 75 remarkable species known to occur on the ridge, but it must be emphasized that it has not been thoroughly explored. Perusal of collections in the Singapore Herbarium will add many more species but, too often, the brief locality ' $G$. Panti' gives no indication whether the collection came from the ridge or the lower slopes. Indeed the ridge needs exploration over a period of years in all months, as it were de novo, by the botanists of Singapore. Ahmat, Ridley's plant-collector, used to tell me how they were nearly frustrated on their first attempt to ascend the mountain by a tiger, until Ridley shouted at it and it went off.

Interesting plants known to occur on the ridge of G. Panti (*, species of lowland swamp-forest)

ANNONACEAE

Disepalum anomalum Hook.f. (also Perak, Sarawak, Sabah)

* Polyalihia macropoda King

ARACEAE

Homalomena delroidea Hook.f.

BIGNONIACEAE

*Deplanchea bancana

\section{CLUSIACEAE}

Calophyllum austrocoriaceum Whitmore; several other species.

Garcinia sp. A3 (Tree Flora of Malaya vol. 2 ); on the slopes of the mountain and on the ridge; also several other species of Garcinia.

CONNARACEAE

*Ellipanthus tomentosus 


\section{CYPERACEAE}

* Mapania palustris

Paramapania parvibracteata (Clarke) Uitt. (also from Kelantan)

\section{DILLENIACEAE}

${ }^{*} D$. grandifolia $($ ? D. reticulata $) ; D$. albiflos unrecorded.

\section{EBENACEAE}

*Diospyros maingayi

*D. siamang

\section{ERICACEAE}

Vaccinium bracteatum Thunb. (sea-shore species)

\section{EUPHORBIACEAE}

Antidesma pahangense (also Bt Tinjau Laut, G. Bubu, G. Tahan, Penang)

Blumeodendron calophyllum Airy Shaw frequent tree, $-20 \mathrm{~m}$ high)

\section{FAGACEAE}

Lithocarpus wrayi (King) A. Cam. (north Malaya)

\section{GESNERIACEAE}

Loxocarpus holltumii

\section{ILLICIACEAE}

Illicium peninsulare A.C. Smith (frequent on the rocky sides of the ridge; also on the main range and $\mathrm{G}$. Benom).

\section{LEGUMINOSAE}

Sympetalandra hildebrandii v. St. (at the foot of the ridge)

\section{LILIACEAE}

Smilax calophylla Wall.

\section{MARANTACEAE}

*Phrynium hirtum

\section{MELASTOMATACEAE}

*Medinilla rubicunda var. hasseltii

* Pachycentria tuberosa

\section{MELIACEAE}

Aglaia angustifolia

\section{MORACEAE}

Ficus pendens Corner (also the mountains of Pahang, Perak, Penang)

* Parartocarpus venenosus ssp. forbesii

\section{MYRISTICACEAE}

* Gymnacranthera eugeniifolia var. griffithii

* Knema laurina

*Myristica lowiana

\section{MYRTACEAE}

${ }^{*}$ Eugenia cerina

* E. papillosa

*E. spicata

Leptospermum flavescens (common along the edges of the ridge)

*Tristania sumatrana (but ? T. spathulata)

\section{NEPENTHACEAE}

*Nepenthes ampullaria, N. gracilis, N. rafflesiana

\section{ORCHIDACEAE}

Bulbophyllum cuspidipetalum J.J.Sm.

B. membranifolium Hook.f.

Calanthe johorensis Holtt.

Corybas mucronatus (Bl.) Schltr

Dipodium pictuin (Lindl.) Rehb.f.

Liparis tricallosa Rchb.f.

Paphiopedilum bullenianum (Rehb.f.) Pfitz.

Phaius tankervillae (Ait.) Bl.

*Plocoglottis sp.

Sarcochilus berkeleyi Rchb.f.

Thecostele secunda Ridl.

Trichoglottis lanceolaria $\mathrm{Bl}$.

\section{PALMAE}

Calamus holttumii Furt.

${ }^{*}$ Cyrlostachys lakka

\section{PANDANACEAE}

*Freycinetia corneri

* Pandanus kamii

(several spp. of Pandanus, ? P. atrocarpus, $P$. recurvatus).

\section{PIPERACEAE}

Piper stylosum Miq. (growing on rocks)

\section{ROSACEAE}

Pygaeum griffithii (Prunus arborea)

\section{RUBIACEAE}

*Timonius flavescens (very common, nearly all the trees infested by a form of Fomes pectinatus)

\section{SAPOTACEAE}

Ganua kingiana (also G. Belumut, Bt Tinjau Laut)

\section{PTERIDOPHYTA}

Belvisia callifolia (Chr.) Copel.

Cheiropleuria bicuspis (BI.) Presl (lowest altitudinal record in Malaya)

Cibotium barometz (L.) J.Sm. (lowest altitudinal record in Malaya)

Ctenopteris moultoni (Copel.) Holtt. ?

Dipteris conjugata Reinw.

Hymenophyllum penangianum Matt. et Chr. Isoloma divergens (Hook. et Grev.) J. Sm.

I. ovatum (J.Sm.) Presl

Lindsaea borneensis Hook.

Ophioglossum simplex Ridl. (at the n.w. end of the ridge, as the only locality in Malaya)

Polystichopsis hasseltii (B1.) Holtt.

Pteris asperula J.Sm.

Pteridium aquilinum (L) Kuhn

Scleroglossum debile (Kuhn) v.A.v.R.

Syngramma alismifolium (Pr.) J.Sm.

S. borneensis (Hook.) J.Sm.

S. minima Holtt.

Tectaria grandidentata (Ces.) Holtt.

Trichomanes aphlebioides C. Chr. 


\section{Sedili Kechil}

The river descends gradually from the low hills that confine the southern end of the vast swamp of Jason Bay. Like S. Gembut to the Sedili Besar, it flows north but enters Jason Bay at the opposite end from K. Sedili Besar. It drains part of the swamp with its main tributaries S. Bahan and S. Leban, and short tributaries drain the west side of the strip of coastal hills which separate the river by 1-3 miles from the sea. There is no mountainous source to direct massive floods into the narrow Sedili Kechil, as happens on the Sedili Besar. Its flat terrain is mostly swamp-forest, and it seemed to me that here lay the best possibility of probing into the history of Jason Bay by means of pits and borings. When I visited the region in April and June 1934, the forest had not been exploited except for the extraction of mangrove at the kuala and for old clearings on some hillocks for plantations of pepper, gambir, and, more recently, rubber. The river was navigable at high tide by small motor-boat up to the derelict Chinese village of Kangkar Sedili Kechil, where I stayed in June. The village is about ten miles in a straight line from the kuala. Higher up fallen trees obstructed passage. The places which I visited are shown in Figure 2. Local names were verified from several sources; firstly from my guide Haron bin Awang Kechil, then from the inhabitants of Kampong Ladang and Kangkar Sedili Kechil, and finally from the records in the police-station at Kuala Sedili Besar.

Access in those days was either by foot along the coast of Jason Bay from K. Sedili Besar or across the bay, but these crossings were restricted by the rough weather that blew up in the afternoon. My visits were limited to five days (30 March-3 April) as a reconnaissance for the main visit of two weeks in the following June, though this visit should have been longer because I intended to explore the Sedili Kechil and S. Banum, as well as the coast, with some thoroughness. Along the coast I succeeded eventually in traversing the whole distance from $\mathrm{Tg}$ Tebar, north of K. Sedili Besar, to Tg Gemoh, south of K. Sedili Kechil. A few notes from my diary of April will convey some of the circumstances. The diary of June was unfinished but, fortunately, I have the accounts of most of my botanical studies.

30 March 1934. Went down to K. Sedili Besar. Stayed in an empty room at the Police Station. Walked round to Batu Belayer in the evening.

31 March. Too rough to cross the bay. The masts of a sunken tongkang project from the sea between Pulau Tagal and Tg Sedili Besar. Walked along Jason Bay (Telok Sebong) from Tg Lembu to S. Tuenseh.

1 April. Left K. Sedili Besar in a small motor-boat about 7.45 a.m., reached K. Sedili in an hour after a rough passage, then up the Sedili Kechil with a few stops to collect plants, and reached Kangkar Sedili Kechil about noon. Returned to Sedili Besar as darkness fell after a rougher crossing with much bailing.

2 April. Went similarly to K. Sedili Kechil, stopped at the kuala, and walked east through the forest to Pasir Seruang, then for two miles down the coast. Had to wait two hours for the wind to drop before we could return to K. Sedili Besar, so walked along the beach north of the kuala for two miles. Drinking water at K. Sedili Besar from a Government well at 10 cts for two kerosene tins, but good water; a well of rather dirty water at K. Sedili Kechil, but a good clear stream at Kangkar Sedili Kechil. Pasir Seruang and Lundong Wai (where I had hoped to camp) had several good clear streams said not to fail in dry weather; tiger-marks along the sand.

3 April. Returned to Mawai via a trip up S. Kambau to Tan Chin Tuan Estate, reached after walking for half a mile across the swamp along pairs of planks raised on wooden stakes. The estate employed the most enormous Chinese labourer, like a Japanese wrestler, who carried two pikuls of rubber-sheet across these planks 
daily, ate a prodigious amount of rice, had a very red face, and was most cheerful and foolish.

The officer in charge of the Police District at K. Sedili Besar was Awan bin Hassan. The headmaster of the Malay School at the Kuala was away and the second master Masbut introduced me to the school. Abdul Rani bin Halifin, of Kangkar Sedili Kechil, was the local guide.

Riverside vegetation. This was essentially the same as on the Sedili Besar but with sharper transitions between the characteristic belts or formations. The more remarkable differences were the following:-

1. The mangrove from the kuala to $\mathrm{Kg}$ Landang had been drastically cut. Carapa molvccensis was common by the river in the upper mangrove reaches.

2. The nipa-belt was short but extremely beautiful from the narrowness of the river and the high forest which rose behind it (see my Life Of Plants, plate 36c, of the east bank of the Sedili Kechil).

3. Rassau encroached so as almost to obstruct the river which in places flowed in lanes $2-3 \mathrm{~m}$ wide through serried ranks of rassau. Above S. Lebai Kator the whole river narrowed to $7-10 \mathrm{~m}$ wide, almost as a tunnel through the swampforest, and there the light-loving rassau stopped.

4. Rengas (Gluta velutina) was scarce. There were few large bushes and no sign that it was ousting putat. The narrow passage of the river appeared to have been stabilised.

5. Jejawi formed no continuous banks. I saw no large trees but Haron told me that S. Jawi (or Jejawi), as a tributary of S. Banum, was indeed blocked by the trees from which it had got its name.

6. The following trees were largely absent or scarce:-Buchanania sessiliflora, balau (Shorea spp., hence little or no logging along the river), Dryobalanops oblongifolia, Nauclea subdita, Polyalthia sclerophylla, Shorea sumatrana, sengkawang (Shorea spp.) and Tristania sumatrana. Elaeocarpus macrocerus was scarce by the river. In fact, there was neither mempisang-belt nor Tristania-bank. The river was a ditch with slight and continually inundated banks, winding through flat swamp-forest, as if its valley had been an arm of Jason Bay that had silted up.

7. Pianggu (Horsfieldia irya) was common, as big trees up to $27 \mathrm{~m}$ high, much larger than had been usual on the Sedili Besar, where the straight trunks might have been felled for poles, masts, or spars.

8. Pandanus affinis was very abundant in the upper reaches of the mangrove and nipa where, on going upstream, the first plants of putat appeared.

9. Pandanus malayanus formed small thickets in the water among the taller rassau and was especially abundant in all the darker or tunnel-like tributaries without rassau.

10. Mesua ferruginea was exceedingly abundant, much more than on the Sedili Besar. It grew from the edge of the rassau in thickets up to $5 \mathrm{~m} \mathrm{high,} \mathrm{stand-}$ ing in the water at high tide, spreading over the river, and smothering both putat and rengas but, eventually, smothered by rassau.

11. Despite the absence of Tristania-banks, Elaeocarpus griffithii and Trigonachras acuta were more abundant than on the Sedili Besar.

12. In the swamp-forest off the river's edge, Lophopetalum multinervium and Palaquium xanthochymım were exceptionally abundant; indeed, their aerial roots blocked one's passage. Xylopia fusca was scarce.

13. Upstream beyond the rassalı, which ended at S. Lebai Kator, there seemed to be no distinct river-side vegetation but continuous swamp-forest, just as along the tributaries of the Sedili Besar. I noted the following as common:-Anaxagorea, 
Aporosa frutescens, Artocarpus kemando, Barringtonia reticulata. Calophyllum spp., Campnosperma auriculata, Crudia havilandii, stilted Dillenia, Elaeocarpus griffithii, Eugenia cerina, E. pseudosubtilis, Ganua motleyana, Garcinia nigrolineata, Goniothalamus malayanus, Grewia antidesinaefolia, G. fibrocarpa, Ilex cymosa, Koompassia malaccensis, Lithocarpus bennettii, Melanorrhoea wallichii, Mernecylon paniculatum, Morinda ? rigida (commonly climbing Ilex cymosa), Pternandra coerulescens, Shorea platycarpa, Strombosia, Symplocos celastrifolia, and Vitex peralata. Strangely my notes have no reference to Cratoxylon. The big spiny aroid, Podolasia stipitata, (Plate 40), was common in the swamp-forest, in the water by streams and in shallow parts by the river's edge. I found also in the shady streams a species of Batrachospermum (SFN 28445) which I had not met by the Sedili Besar.

There were immense stranglers of Ficus calophylla, $F$. crassirarnea, $F$. sundaica, and $F$. virens var. glabella. by the main river.

\section{Comparison with the Kemaman River, Trengganu}

In June 1932 I paid my first visit to Bt Kajang Tin Mine, which lay inland from Chukai. I took the opportunity of comparing the riverside vegetation of the Kemaman with that of the Sedili, and spent four days in the undertaking (Figure 8). On 26 June I went in an open prahu from S. Ayam near the mine, to S. Nipa and thence to the Kemaman river as far as S. Pinang Hilir. There I took an old car to Chukai and spent the night at the house of E. T. Swan, manager of the mine. Next day I drove back to S. Pinang Hilir and took the prahu down to the kuala, returning that evening to $\mathrm{Bt}$ Kajang. On 29 June I went down to $\mathrm{Kg}$ Ayer Puteh, where I spent the night, and next day I took a motor-boat to the kuala in order to check my first observations. I repeated most of the journey in 1935 and find, now, in my

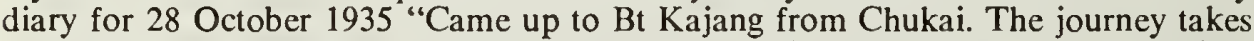
6 hours under favourable conditions, and has scarcely altered since 1932. The river looks just the same and the road to S. Pinang Hilir is no better. I was poled up the river by the same Malays, and the same persons met me at the mine". That road was fearful and the car had broken springs. On 26 June, when it was raining hard and the hood was up and I was wearing a rubber topi to keep the drips off, the driver was bent on getting the journey over. The car thumped into a pot-hole, jerked up, and rammed my topi through the hood. After several minutes of agony, I straightened my neck, and I have never worn a topi in a closed car again. Yet it was the guard against bumps and thorns in the forest, and the place for matches in the rain.

In contrast with the Sedili, the banks of this lower part of the Kemaman river were under cultivation with rice-fields and orchards, or had been deforested and returned to belukar. There were, nevertheless, patches of original vegetation sufficient to reconstruct the sequence. In broad outline it resembled that of the Sedili. The succession from the estuary, as shown in Figure 8, was mangrove, nipa, Sonneratia caseolaris, putat, and rassau leading to Tristania-banks, and finally neram (Dipterocarpus oblongifolius) and Saraca-streams. The failure of the original vegetation to regenerate was striking. The reason lay, evidently, in the deforestation of the river, the death of the protective layer of tree-roots along the banks, and the removal of fallen trees which stemmed the current. Torrential rains streamed into the river, instead of percolating through the forest, and eroded new channels. The swifter current eroded the banks and carried away the soft mud of the putat-rassau belts. At river-bends there were spits and bars of coarse sand, unsuited to the regeneration of putat or rassau, while the opposite bank was severely undercut. Everywhere along the river, banks were slipping. There was denudation on a scale not seen on the Sedili; yet, this may be its fate. 

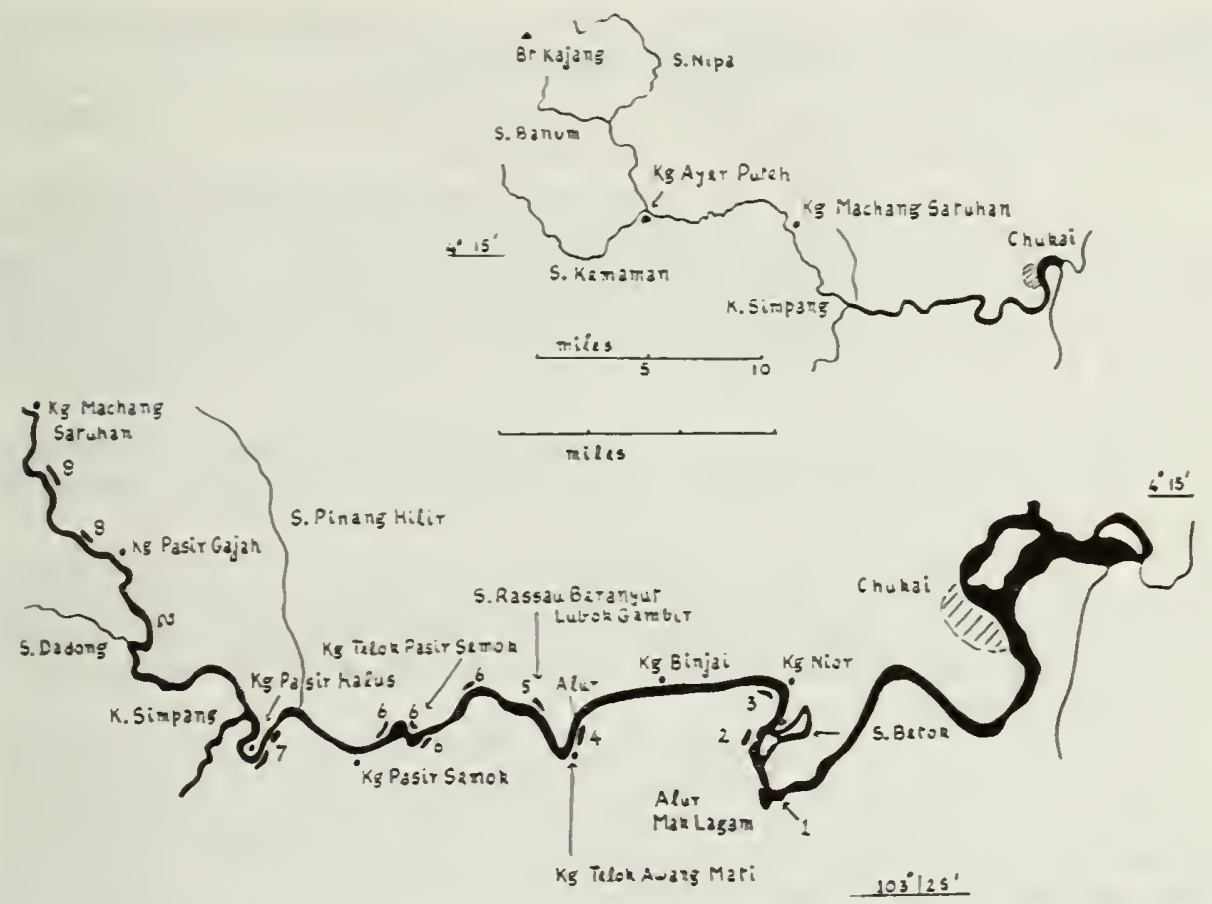

Figure 8. The lower reaches of the Kemaman river. with that from Kg Machang Satuhan downstream enlarged to show the following details as observed in June 1932:- 1, the upper limit of nipa: 2, Licuala spinosa and Sonneratia caseolaris abundant: 3. Eugenia densiflora. Milletria hemsleyana, Hibiscus tiliaceus, and Acrostichum aureum abundant: 4, Sonneratia caseolaris; 5, Millentia hemsleyana. Hibiscus tiliaceous, and I.rora javanica abundant; 6 , Barringlonia conoidea, Gluta velutina, and Pandanus helicopus abundant; 7, Pandanus helicopus, Dipterocarpus oblongifolius, Millentia hemsleyana, and Tristania sumatrana; 8, Saccharum arundinaceum in big stands.

The river was tidal up to the region just above the entry of $S$. Dadong from the west. It was brackish up to the vicinity of S. Rassau Beranyut and Lubok Gambir. Below this bend, the river broadened and mangrove had some stabilising effect on its course. Upstream there were patches of putat, rassau, pelawan (Tristania), and neram. The long stretch from K. Simpang to Kg Machang Satuhan was entirely kampong and belukar. Above this village neram became more abundant, but without pelawan.

In the following notes I give some precise details of the river as it was in 1932 and 1935. It would be interesting to know how the relics of the original vegetation may have survived.

Transition between neram and pelawan. The only indication of this was at $\mathrm{Kg}$ Pasir Halus, shortly below K. Simpang. Here the river made a wide bend. On its south side there was a small backwater, or sluggish stream, which had on its low west bank fairly large clumps of rassau in mud that had not been scoured away. and on its abrupt east bank a well-grown original stand of neram, jada (Millettia hernsleyana), and pelawan intermixed. The trees stood about 20-25 m high, as the critical forest relic. Above this bend there was no pelawan. Below the bend pelawan and jada occurred in patches down stream to $\mathrm{Kg} \mathrm{Nior,} \mathrm{but} \mathrm{no} \mathrm{neram.} \mathrm{Below} \mathrm{this}$ village there were no abrupt banks to sustain pelawan. Thus pelawan indicated the original steep banks of the river in its tidal freshwater stretch; neram indicated the upper non-tidal reaches; but jada infiltrated both. I note here the absence of Gluta renghas from the Kemaman river, in contrast with the Pahang, Trengganu, and 
Kelantan rivers where its large trees marked, also, the tidal freshwater stretch. Possibly they had been felled or carried away by floods.

Floristic comparison with the Sedili. In the few days available to me I concentrated on the more conspicuous members of the vegetation.

a. Species common on the Kemaman river, absent from the Sedili:Barringtonia spicata (putat ulu, B. acutangula ssp. spicata), Derris heptaphylla (rare on the Sedili), Eugenia densiflora (jambu ayer), Dipterocarpus oblongifolius (and its associated flora, p. 44), Grewia tomentosa (common in belukar on the Kemaman, coastal in the Sedili region), Lagerstroemia speciosa (bungor raya), Mallotus floribundus (taping), Millettia hernsleyana (jada), and Securinega virosa (bebeti).

Lagerstroemia ovalifolia (bungor menuku), was fairly common, but scarce on the Sedili. Two species of Tetracera ( $T$. akara, $T$. indica, akar pelah or mempelas) were abundant up stream from the nipa-zone.

b. Species common on the Sedili river, absent from the Kemaman:Buchanania, Ceratopteris, Elaeocarpus macrocerus, Eugenia cerina, E. fastigiata, E. muelleri, E. pseudosubtilis, E. spicata, E. valdevenosa. Ficus calophylla, Gardenia tubifera, Limnophila, Mesua ferruginea, Polyalthia sclerophylla, Pongainia pinnata, and Vatica wallichii.

There was, in fact, no vestige of the mernpisang-belt of the Sedili river. The common large strangling figs of the Kemaman were $F$. crassiramea and $F$. sundaica. $F$. microcarpa was very scarce on the Kemaman; I saw only one fairly well-grown specimen on the river-bank at S. Rassau Beranyut where, as might be expected, the fresh and brackish water interchanged.

\section{Notes on the river-side vegetation of the Kemaman river.}

Acrostichum aureum extended from the mangrove abundantly to $\mathrm{Kg} \mathrm{Nior}$; not seen above $\mathrm{Kg}$ Binjai.

Barringtonia conoidea (putat) apeared in the upper part of the nipa-zone and continued in more or less scattered clumps up to $\mathrm{Kg}$ Pasir Halus where the last upstream stand of rassau was situated. Putat was most abundant between $\mathrm{Kg}$ Nior and S. Rassau Beranyut. It soon disappeared where, on going downstream, nipa began.

Barringtonia spicata (putat ulu) occurred in fair abundance from $\mathrm{Kg}$ Nior upstream to K. Simpang. It was evidently restricted to the freshwater tidal stretch of the river.

Derris heptaphylla occurred chiefly between the upper limit of nipa and K. Simpang, but scattered plants were climbing in flood-damaged parts of the nerain-banks on S. Ayam and S. Nipa.

Dipterocarpus oblongifolius (nerain) was first encountered, going upstream, at $\mathrm{Kg}$ Pasir Halus, where tidal effect in the freshwater part of the river was becoming slight. Probably, in its original state, the Kemaman was a nerain-river from S. Pinang Hilir up to the Saraca-streams of the ulu.

Eugenia densiflora (jarnou ayer) was in full flower at the end of June 1932 and, therefore, easy to distinguish. It occurred from $\mathrm{Kg}$ Binjai upstream to S. Ayam and was abundant as far up as $\mathrm{Kg}$ Pasir Gajah, well above K. Simpang. Between $\mathrm{Kg}$ Binjai and S. Pinang Hilir it formed in many places almost pure stands for up to $100 \mathrm{~m}$ along the river's edge. Here it was entwined with the two species of Tetracera, the red fruits of which among the posses of fragrant white flowers of the Eugenia made striking and beautiful pictures but the Malays with me were, as usual, indifferent to such sights. Upstream with neram this Eugenia was very scattered, but prospered in open flood-damaged places. It had become, indeed. a plant of river-side belukar. 
Eugenia oblata (kelat) was co-extensive with Hibiscus tiliaceus but extended about two miles further upstream to $\mathrm{Kg}$ Telok Pasir, above which no examples were seen. This species was rare on the Sedili, where it occurred in freshwater tidal swamp-forest.

Ficus microcarpa (jejawi) was very scare in the neighbourhood of S. Rassau Beranyut where one fairly large tree occurred.

Ficus obpyramidata was much commoner than on the Sedili, doubtless because it succeeded with deforestation and flood-damage. It first appeared going upstream, about S. Pinang Hilir and continued thence in flood-damaged places up to the beginning of the Saraca-streams.

Gluta velutina (rengas, $r$. ayer) was co-extensive with rassau. The last stand, upstream, of rassau, rengas, and putat had exactly the same construction as on the Sedili, but this stand was being sanded up in places and becoming moribund. At Kg Telok Pasir Semoh there were similar stands.

Hibiscus tiliaceus (baru baru, bebaru) became conspicuous from Alur Mak Lagam, where the nipa ended, upstream to S. Rassau Beranyut; that is in the brackish tidal stretch. Between S. Alur and Alur Mak Lagam, H. tiliaceus and Eugenia oblata were the commonest shrubs or small trees along the river.

llex cymosa (mensirau) appeared to have the same distribution as Eugenia densiflora, but it was much less abundant. It occurred chiefly between $\mathrm{Kg}$ Binjai and K. Simpang.

Ixora javanica and 1 . lobbii var. stenophylla together made a more or less continuous undergrowth along the river-side from the neram-river down to $\mathrm{Kg}$ Nior. They were bushes of steep banks, growing $\frac{1}{2}-1 \mathrm{~m}$ above the ordinary floodlevel. All the bushes were flowering at the end of June 1932 but, unfortunately, my notes do not distinguish their exact distribution, Var. stenophylla was upstream in forested places while $I$. javanica was downstream in the belukar.

Lagerstroemia ovalifolia (bungor menuku) occurred on the banks of S. Nipa behind, or above, the neram-trees, and a few individuals were seen in such places between $\mathrm{S}$. Ayam and $\mathrm{Kg}$ Machang Satuhan.

Lagerstroemia speciosa (bungor raya) also had the same distribution along the river as Eugenia densiflora, but was much less common. It was more abundant, in fact, in belukar far removed from the river.

Mallotus floribundus (taping) was roughly co-extensive with $F$. obpyramidata.

Millettia hemsleyana (jada) occurred throughout the lower neram-reaches of S. Nipa (from Jeram Gajah downstream) and S. Ayam, and throughout the pelawanreach of the Kemaman. It seemed to prefer the flood-damaged parts of the neramrivers and, evidently as a more light-demanding species than sapling neram, prospered in the forest-relics along the Kemaman. No trees were seen below $\mathrm{Kg}$ Nior.

Nipa occurred in the long stretches of the river-bank from Chukai up to Alur Mak Lagam where it disappeared quite abruptly.

Pandanus helicopus (rassau) occurred from Kg Binjai upstream to $\mathrm{Kg}$ Pasir Halus. It formed small clumps where streams entered the river, but it was very scattered and several clumps were being covered with river-sand and were clearly moribund. Thus it showed the automatic destruction of the primeval vegetation as deforestation changed the character of the river.

Saccharum arundinaceurn (tebrau) occurred only between K. Simpang and $\mathrm{Kg}$ Machang Satuhan where, in several places, it formed massive stands.

Securinega virosa (bebeti) and Nauclea subdita (gedembak) occurred abundantly on flood-damaged river-banks from $\mathrm{Kg}$ Binjai upstream to $\mathrm{S}$. Ayam. Both seemed intolerant of brackish water. 
Sonneratia caseolaris (berembang) occurred in the estuarine mangrove, behind the nipa-belt. At S. Betok and $\mathrm{Kg}$ Nior it was still abundant, but the last groups upstream at $\mathrm{Kg}$ Telok Awang Mati consisted of small stunted trees. Here Hibiscus tiliaceus disappeared also on journeying upstream. Licuala spinosa appeared to be co-extensive with $S$. caseolaris.

Tetracera akara and $T$. indica occurred from the upper limit of nipa right up the main river and its tributaries, and on S. Nipa up to Jeram Gajah, but they were especially abundant with Eugenia densiflora.

Tristania sumatrana (pelawan) required raised river-banks and occurred from $\mathrm{Kg}$ Nior up to $\mathrm{Kg}$ Pasir Halus. The trees were very scattered and stumps showed that many had been cut down, probably for firewood. Pelawan did not occur where neram had established its hold on the river-banks, except in the overlap at $\mathrm{Kg}$ Pasir Halus.

Neram-rivers. By this name I indicated, in Wayside Trees of Malaya, the swift rivers with firm banks along which there grow in great abundance trees of neram (Dipterocarpus oblongifolius). They occur in Pahang, Trengganu, and Kelantan but whether they have always the same characteristic river-bank flora as in Kemaman has yet to be recorded.

Neram-trees on S. Nipa grew on the very edge of the river-bank, just above normal flood-level. The banks varied $2-7 \mathrm{~m}$ high and were steep and earthy with boulders here and there and a fair amount of humus, but the lower half metre or so in the flood-zone was swept bare. The neram-trees leant over the water and their branches arched into a canopy at a height of some $25 \mathrm{~m}$. They were heavily laden with epiphytes among which Ficus deltoidea var. kunstleri was characteristic. In flower, neram scented the river with orange-blossom. The trunks rose from a twisted buttressed base, generally with a buttress up the bank, away from the direction of leaning and the main roots were more or less superficial and spread horizontally.

The banks of the Kemaman river and the lower part of S. Nipa had been badly flood-damaged. Many neram-trees had fallen into the water. In the gaps there grew up thickets of Nauclea subdita, Ficus obpyramidata, and Securinega virosa. Where no such damage had occurred, big neram-trees stood about $20 \mathrm{~m}$ apart with smaller neram-trees at irregular intervals so that young and old occurred almost every $2 \mathrm{~m}$; in one place on S. Nipa I counted ten well-grown trees along $40 \mathrm{~m}$ of the bank. Associated with them were trees of jada which, however, seemed not to extend so far into the ulu as nerain; on S. Nipa I saw none beyond Jeram Gajah.

Under the neram-trees there was a characteristic flora of the following herbs, shrubs, and small trees, which became more or less submerged in floods:-

Grasses:- Coelorachis glandulosa (Trin.) Stapf, Eragrostis unioloides (Retz.) Nees, Lophatherum gracile Brong., Panicum brevifolium L., Paspalum conjugatum Berg, Pogonatherum paniceum (Lamk) Hack., Vetiveria neinoralis (Bal.) A. Cam.

Cyperaceae:- Fimbristylis dura (Zoll. et Mor) Merr., Scleria ? purpurascens Steud. (SFN 25908, as S. multifoliata Boeck.)

Araceae:- Homalomena confusa Furt. (collected as $H$. angustifolia), $H$. griffithii (Schott) Hook.f.

Acanthaceae:- Hygrophila saxatilis Ridley.

Clusiaceae:- Garcinia cataractalis Whitmore.

Euphorbiaceae:- Antidesma salicinum Ridley (mempenai ayer, chapok), Drypetes riparia Ridley (bebull, bebulus), Homonoia riparia Lour. (kayu suarah).

Meliaceae:- Aglaia salicifolia Ridley, Dysoxylon angustifolium King (jemart).

Rubiaceae: - Gardenia tentaculata Hook.f., Hedyotis auricularia L., Ixora lobbii var. stenophylla Corner. 
Scrophulariaceae:-Vandellia crustacea Benth.

Vitaceae:- Leea gigantea Griff.

Pteridophyta:- Blechnum orientale L., Lindsaea lucida Bl., (? Dipteris lobbiana, though I made no record of this).

Of these species, the Aglaia, Blechnum, Drypetes, Garcinia, Homalomena Dysoxylon, Leea, and Ixora grew on the earthy banks just above the usual floodzone. The Antidesina, Gardenia, and Lindsaea grew on the rocky banks and among the large boulders by the river's edge. Homonoia and Hygrophila stood the full force of the current in rock-clefts and on the rocks in mid-stream. The grasses and sedges developed mainly on the sand-spits which formed in the quieter stretches and in the backwaters. Here Paspalum conjugatum formed swards up to $60 \mathrm{~cm}$ high. Panicum brevifolium and Scleria? purpurascens occurred also at the normal flood-level of the earthy banks. At Jeram Gajah, on S. Nipa, Begonia sinuata occurred on the rocks where a small stream entered, and the little herb Salomonia cantoniensis Lour. was abundant. A noteworthy absentee was Ficus ischnopoda Miq., which is common in the swift forest rivers from Selangor and Pahang northwards, but has not been recorded for Trengganu.

All these riparian plants, as well as neram and jada, have oblong, lanceolate, willow-like leaves or leaflets, and this form is typical of these swift rivers. In the case of Ixora it seems to be an adaptation to the swift current (Corner 1941), but there was no clear evidence of this for the others. It would be interesting to raise plants from seeds under various conditions to discover any possible variability in leafform. The Garcinia, when I first met it in abundance on S. Nipa, did not seem to be a plant distinctive of cataracts, if such small broken falls can be called such, but a very twiggy bush $-2.7 \mathrm{~m}$ high of the river-banks with Aglaia and Dysoxylon; the specimens had been filed provisionally under $G$. uniflora. Had I known that it was to be described, I could have corrected the impression.

As the neran-rivers narrowed upstream, the neram disappeared and they became Saraca-streams with Pometia pinnata, Meliosma sumatrana, Pternandra capitellata, Saraca bijuga, and Schoutenia glomerata. Conditions were, presumably, too shady for the growth of neram, as they had become too shady for jada, or the waters of the Saraca-streams may be too cold. Practically nothing is known in detail of the manner in which the seedlings of these riparian plants establish themselves, the nature and construction of the roots which hold them so firmly against the current, or, indeed, of their stems; they are, still mainly herbarium-specimens.

\section{Comparison with the rivers of Brunei}

In February 1959, in company with Dr P. S. Ashton, I studied the more obvious features of riverside succession on S. Damit, S. Belait, and S. Temburong. There was a general agreement with the Sedili Besar, but some floristic differences.

Mangrove gave place to the nipa-belt with Pandanus affinis and $P$. corneri. Then, upstream, there came thickets of Barringtonia conoidea, $B$. racemosa, Gluta velutina (mostly old specimens with thick gnarled trunks), and Notaphoebe coriacea. On the muddy flats behind these pioneers there were in abundance Horsfieldia irya and Sapium indicum. I saw neither Pandanus helicopus nor Polyalthia sclerophylla; where they would have been expected, there was Dyera lowii, which is absent from Malaya. In the freshwater tidal reach Metroxylon, with spiny trunk, was common on the river-bank, and Hanguana anthelminthica floated into the water along with a grass. In the nipa-belt there were scattered plants of a stout spiny pandan recalling $P$. odoratissimus. Most timber had been removed from the lower stretches of the rivers. Above the tidal reach on $S$. Temburong the abundance of Duabanga moluccana showed that this river lay in a different phytogeographical region. The 
continental $D$. grandiflora (D. sonneratioides) does not occur in the south of the Malay Peninsula, Sumatra, or Riouw; in fact Duabanga is absent from the Riouw pocket in its widest extent.

\section{Floristic richness}

The richness of the tropical flora is well known. The problem is what all these different plants are doing side by side in the same forest. In the long list of seedplants from the Sedili region, it is easy to pick out a few which, with special requirements, have special habitats, e.g. Barringtonia conoidea, Ficus microcarpa, nipa, Pandanus helicopus, or Tristania sumatrana. The more particular the habitat, the fewer are the species which it holds. Presumably, for it has not been ascertained, their seeds may sprout anywhere and in the general competition die, unless under those particular circumstances. With the trees of the high forest, however, the climbers that ascend them, and their epiphytes, the numbers mount and it is impossible to say at once which factors govern the establishment of seedlings, the survival of saplings, and the success of flowering, fruiting, and seeding; in these steps there enter successively the characters of species, genus, family, and, even, order. The idea behind the systematic categories is that the individuals of a species are working together in a certain way that differs from the ways of other species; there must be, for instance, some fifty ways of Annonaceous, Lauraceous, Leguminous, or Myrtaceous existence in the Sedili region. The tropical flora shows that the more favourable the environment for plant-growth, so the number of different ways of plant-life increases. As in a prosperous city, trade and occupations multiply; they build establishments and, in so doing, create new occupations, trades, and services; their complexity is evolving. Thus it is in the tropics that uniform habitats such as freshwater swamps or copiously watered plains develop such complex forests. They are communities in that they are the outcome of this symbiotic evolution; and the scope for ecological research is titanic.

In this respect I draw attention to roots. Commonly hidden, even from our thoughts, in the swamp-forest they obstruct, trip, and force themselves to the front. They are anchoring, breathing, and absorbing of water, mineral salts, and the products of decomposition from the litter of the forest. This litter is, perhaps, the most complicated organic mixture in the world. It cannot be processed into simple substances for root-absorption in any single manner. Inspection of the occurrence of such obvious products of decomposition as the fruit-bodies of fungi shows that they occupy many more or less restricted habitats, not the whole litter of a species of tree, for instance, but parts of this litter; petioles may be distinguished from blades, veins even from mesophyll, and all these from twigs, branches, flowers, fruits, seeds, and roots. An underground city of micro-organisms is required for the sewerage of the forest. The micro-organisms around and within the rootlets are part of this processing and they pass on to the green plant some of the simplified organic substances. It cannot be supposed that one species of green plant is fitted with a 'rhizosphere' competent to reduce all the litter. It follows, therefore, that the more varied the forest, the more varied become the opportunities for root-growth. Stems largely compete, but the roots, as shown by the relays of micro-organisms required for decomposition of the litter, may also act in relay. Hence $I$ consider that different species of root may be in symbiosis, as well as their micro-organisms, and that this is part of the answer to the question why tropical forest is so rich in species. Every new product of photosynthesis that gets into the litter needs a new micro-organism, or a new process, for its decomposition, and this provides a niche for another species of green plant. The formative action of roots on stems has 
been recognised (Torrey and Clarkson 1975); its extent needs investigation in the diversity of the tropical forest.*

\section{Postscript}

Since completing this account, I have been able to study aerial photographs of the Sedili rivers taken by the Royal Air Force in 1957 and 1958. They show the whole region heavily forested as I knew it in the years before the war. Such photographs, of course, were not available in my day; indeed, it was not possible even to fly over the region. If, however, the botany of the rivers is to be pursued, it will be essential to compare these aerial photographs with the modern environment as it has been opened up in order to detect the relics of forest and the remaining places of particular ecological interest; recent aerial photographs may be available for comparison. The photographs reveal much of the detail that I have described and, I think, the various riverside belts, freshwater swamp-forest as opposed to hillock forest, and mangrove could be distinguished when they have been correlated on the ground with the pattern and tint in the aerial photograph. Three points strike me as having special interest: 1 , the pools of standing water in the swampforest about $\frac{1}{2} \cdot \frac{3}{4}$ mile to the east and west of the large bend of the Sedili Besar at $\mathrm{Bt}$ Tiga, for I did not encounter such pools in my explorations; 2 , similar pools on the north side of the river about midway between Bt Perah and K. Gembut; 3, the large swamps of nipa, apparently pure stands, in the mangrove east of S. Kambau.

- See the recent publication by Dr. P. J. Grubb. The maintenance of species richness in plant communities, Biological Reviews vol 52, 1977, pp. 107-145. The author emphasizes the importance of spccific differences in matters of dispersal, seedling-establishment, and regeneration. 



\section{Part II. Jason Bay}

This shallow bay, about six miles across, was known locally as Telok Sebong; the cartographic name was unfamiliar. The coast between the two headlands was sandy, but rocky immediately to the north and south. The coastal dune was raised $1.2 \mathrm{~m}$ above high tide level, in places even to $3 \mathrm{~m}$, and consisted of white coral sand with, here and there, the tops of buried rocks; there was no alluvial layer on the sand-bank. It varied in width from 50 yards to a third of a mile, but on the west side of K. Sedili Kechil it was nearly a mile. A succession of forest developed on the bank. Casuarina-forest fronted the sea and was overtaken by that of Eugenia grandis which, in turn, became what I called in my notes dry climax-forest because it was raised above the level of the swamp-forest to the interior. The sand became greyer from the addition of humus and on the inland side of the broad dune it was discoloured to a depth of $30 \mathrm{~cm}$ or more. There was no extensive system of dunes along the coast, but short series of wide sand-spits developed at the mouths of the rivers.

Swamp-forest. For 2-3 miles inland from the coast there was a confusion of brackish and freshwater swamp-forest and remains of former coastal dunes. It was drained on its western boundary by S. Gembut, flowing north by the hillocks leading to Bt Tiga on the Sedili Besar. I travelled up this river, when it was a tunnel through the forest, as far as Kangkar Gembut, but made little investigation. I note that Swan (1967) in his map of east Johore shows a north-south line of

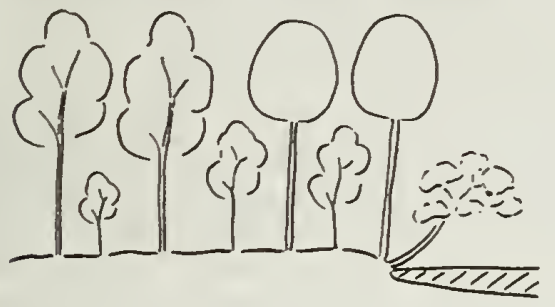

3

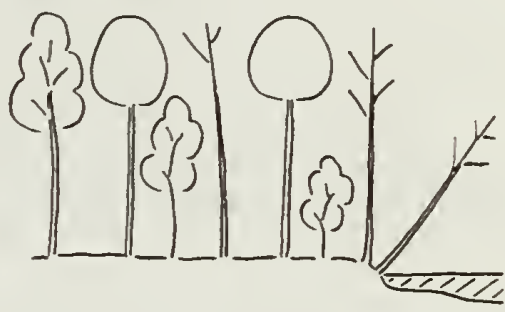

2

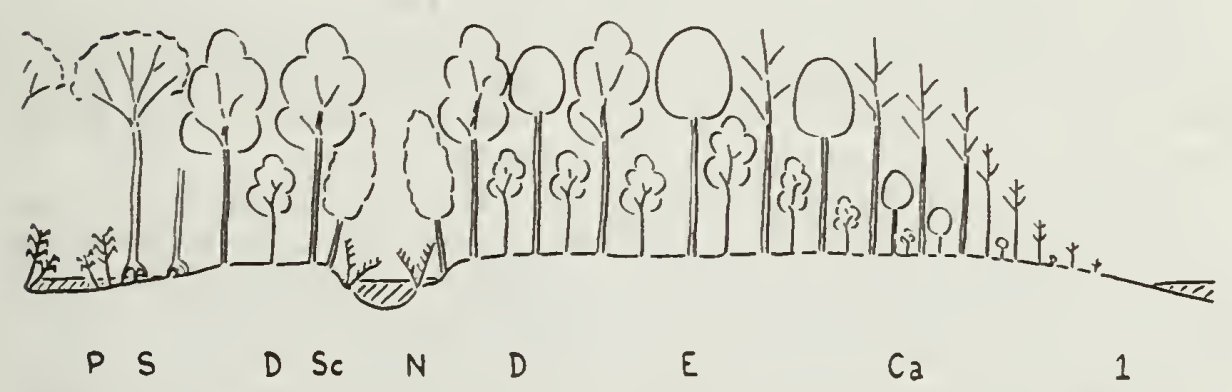

Figure 9. Diagrammatic transects of coastal forest at Jason Bay. 1. the sandy shore advancing seawards to the right. 2, the shore receding with Casuarina undercut. 3 , The shorc abraded to Eugenia grandis forest with a coastal strip of Barringtonia asiatica, Calophyllum inophyllum, and Terminalia catappa. - Ba, Barringtonia asiatica: Ca, Casuarina equisetifolia; D, dry climax-forest; E, Eugenia grandis forest; N, nipa; P, Pandanus; S, freshwater swamp-forest; Sc, Somneratia caseolaris. 
gabbroic intrusion along the course of S. Gembut. I explored more fully the seven short rivers which flowed directly into Jason Bay. I intended to traverse the whole area from east to west at several places, but illness overcame me. I wanted to discover if any coastal plants, such as Cycas rurrphii, Pandanus dubius, $P$. odoratissimus, or Eugenia grandis survived on the old sand-banks from the time when they had been on the earlier sea-coast. Though much of this area has now been logged and cleared, enough bits of forest remain to piece together the botanical history of the bay; it seemed to have been seaward advance with short periods of retreat, as shown by the erosion of the coast in 1934. It was in this swamp-forest that kerepit or kopit (Inocarpus fagiferus) was so abundant, being apparently its only place of occurrence in the Malay Peninsula and the western limit of its wide Pacific distribution.

Forest-succession on the sand-bank. This was the main botanical problem at Jason Bay. The natural succession from bare sand-dune to dry climax-forest could be seen at the mouths of S. Tuenseh, S. Sebong, S. Diman, S. Lebai, and S. Semandan, which I describe later in some detail. The open dune was colonised by the usual grasses, sedges, Canavalia, and Ipornoea but, at the same time, there sprouted among them seedlings of Casuarina equisetifolia and those of the fruits of coastal trees thrown up by the waves. In these hot places young Casuarina grew fast and built a forest-belt, $10-50 \mathrm{~m}$ wide, of small trees which developed into an apparently pure stand of tall trees but, in fact, there were growing up beneath them the more shade-tolerant saplings which, with slower growth, would form the Eugenia grandis forest. Seeds of Casuarina sprouted nowhere but on the open dunes, never in the shade or under old trees of Casuarina. Thus the presence of a file of old trees along the sea-front meant that the sand-bank had not extended or, if so, it had been eroded. S. Rhu Reba was, indeed, the place where the coast was being eroded and the old Casuarina-trees were falling into the sea (Plate 26).

The plants of Eugenia grandis forest are listed on p. 58. Their seedlings may also require open places for establishment, but those of the dry climax-forest, brought by flood and animal from the interior, established themselves in the shade of Eugenia grandis forest. Old, lofty, and stag-headed crowns of Casuarina could be seen embedded even in the dry climax-forest, as much as $300 \mathrm{~m}$ from the sea (Plate 27). The old trees appeared to die, eventually, from attack by the polypore Phellinus (Fomes) rimosus. Eugenia grandis and Beilschmiedia tonkinensis persisted in the dry climax-forest up to $400 \mathrm{~m}$ from the coast.

The purple-brown and clavaria-like fungus Thelephora ramarioides was invariably associated with the roots of Casuarina, possibly mycorrhizal, and in season the fruit-bodies developed in myriads along the lines of the roots (Corner 1968). On the open dunes a species of the agaric Naucoria and one of Inocybe developed in great numbers from the buried remains of grasses.

This Casuarina-forest seems to be the only formation in Malaya that is dominated by a single species of tree. Under it there persisted for varying lengths of time the grasses, sedges, and herbs of the open dune and, as mentioned, there were growing up in it the plants of the Eugenia grandis forest. The one other species at Jason Bay that seemed peculiar to the Casuarina-forest was the small, shrubby, Sapindaceous Dodonaea viscosa; I found no evidence that it persisted in the Eugenia grandis forest.

Eugenia grandis, though commonly planted inland, occurs wild only on rocky and sandy shores in the Malay Peninsula. It did not occur along the Sedili rivers or in their interior forests, but there were some old trees at Bt Kuing (Bt Quini on the map) which lay two miles inland from K. Sedili Kechil, clearly as relics of coastal forest. 
Whether the old sand-banks with dry climax-forest persisted as long islands in the swamp-forest, far removed from the coast, seemed doubtful because with falling trees and erosion by floods they were worn away. I traversed the forest for a mile inland from S. Semandan and found that, while the dry climax-forest persisted, it was being invaded by such swamp-forest trees as Ilex cymosa, Eugenia cerina, Myristica lowiana, Campnosperma squamata, Shorea platycarpa, Koompassia malaccensis, Coelostegia, Parartocarpus, Dialium patens, Nephelium glabrum, Crudia wrayi, and Timonius flavescens; floods would carry their seeds into this swamp.

Sand-dunes. These formed at the mouths of the rivers; they were not piled up by wind. Spits of sand grew across the river-mouth from a northerly direction, probably owing to the prevailing wind and current, and the spits deflected the mouth southwards. The spits varied from 50 yards to a quarter of a mile wide and extended even for a mile. It was evident that this long deflection caused the rivers, when in flood and re-inforced perhaps by an exceptional high tide, to break through the sand-bank at some flexure distant from the mouth; possibly abrasion helped the siting of the new mouth. The result was the formation of a new sand-spit and dune roughly parallel with the first, and the development of brackish swamp-forest in the estuarine part of the river as it became cut off by deposition of silt. There were no extensive dunes along the coast to suggest a general build-up into the bay. If, as seems, this had been the manner of advance of the coast, then the swamp-forest to the interior should have consisted of a succession of sand-banks of varying length, intersected with freshwater swamp-forest away from the coast, and brackish swampforest near to it. Probably these ancient dunes have become blurred as floods wore them away and in the older parts, just east of S. Gembut, they may have disappeared under the extension of the swamp-forest. For comparison, I refer to the account by Fitch (1949) on the sand-dunes formed in the bay between the Kuantan and Kemaman rivers, but I observe that Gobbett and Hutchison (1973) record a northward current along the east coast of Johore and imply a northward deflection of the river-mouths; there are, also, the accounts of Mersing beaches by Hill (1966) and Tjia (1970 a).

I was informed by Haron bin Awang Kechil, who had lived at Jason Bay for 34 years and was thoroughly acquainted with it, that some twenty years ago $\mathrm{S}$. Tuenseh had opened into the sea a mile or so south of its present mouth, probably at the mouth of S. Sebong. The new opening had been forced by the river but it was also cut in part by an old Malay called Tuenseh, who had since died. The bed of the short river S. Sebong was dry when I visited it and was being filled with swamp-forest. It appeared to me that, formerly, S. Diman had opened at the mouth of S. Lebai.

The sand-spit, just north of the mouth of S. Semandan, carried a dense stand of Casuarina 10-15 m high, up to $25 \mathrm{~m}$ in the older part that was furthest north, but in this forest there were seedlings and saplings (up to $7 \mathrm{~m}$ high) of Barringtoria asiatica, Cerbera manghas, Calophyllum inophyllum, Eugenia grandis, Hibiscus tiliaceus, Terininalia catappa, Ardisia elliptica, Guettarda, Scaevola, and Dillenia suffruticosa with abundance of the creeping Wedelia biflora. I think that this site has been felled.

The most interesting plant on the sand-dunes was the small creeping Composite Spilanthes which occurred, apparently as a relic, only between the mouths of $\mathrm{S}$. Tuenseh and S. Semandan (Plate 37). I note the absence of Spinifex, Cyperus pedunculatus (Remirea maritima), and Sesuvium portulacastrum, the rarity of Fimbristylis sericea, and the occurrence of Paspalum vaginatum where Sesuvium would have been expected. 
Dry climax-forest. As Casuarina gave place to Eugenia grandis forest, so this was overcome by taller trees $30-50 \mathrm{~m}$ high, the seedlings of which had grown up in the deeper shade. I list below the canopy-trees of this forest. It became infiltrated, however, by so many seeds of the freshwater swamp-forest and the low sand-bank on which it grew was so apt to be flooded with freshwater, that this climax-forest changed into a mixture of climax and swamp-forest. As the inland sand-bank deteriorated, typical freshwater swamp-forest took over and had the complex and various character of that seen round Mawai. Very few of these swamp-forest trees, small or large, established themselves in the Casuarina-forest as those of the Eugenia grandis forest generally did. Hence there was the continuous succession from open dune through forest of Casuarina. Eugenia grandis, and dry climax to the freshwater swamp; and this, presumably, would have been gradually overcome by lowland dipterocarp forest as the swamp filled in at its boundary. The whole may be a sere prolonged over many centuries but every stage has its edaphic situation where it is an extensive climax.

The herb Tacca palmata and the small Rubiaceous tree Petunga roxburghii were common in Eugenia grandis forest and persisted well into the shade of the dry climax-forest (Plates 26, 31). Then, as mentioned, E. grandis and Beilschmiedia tonkinensis persisted as canopy trees in this forest as far as $400 \mathrm{~m}$ from the coast, but what was the end of these old trees I did not discover. It was possible that a species of Dipterocarpus $(D$. ? hasseltii) also entered the $E$. grandis forest; at $S$. Sebong some canopy trees of this species, $25-30 \mathrm{~m}$ high, stood in this forest merely $60 \mathrm{~m}$. from the shore.

In several parts of the dry climax-forest, I found that the large trees were gregarious, e.g. Cratoxylon, Pterospermum, and the three species of Eugenia. In one patch, c. $50 \times 30 \mathrm{~m}$, there were seven large trees of Cratoxylon formosum, 25-35 m high and $30-50 \mathrm{~cm}$ thick at breast-height. They appeared to be the second generation around the parent tree which had been the pioneer seedling in the upgrowth of $E$. grandis forest. Cratoxylon and Pterospermum were common in the swamp-forest, but the three species of Eugenia (list on p. 58) appeared, like $E$. grandis, to be strictly coastal.

Depressions in the sand-banks. A fairly thick layer of humus formed in the climax forest. Pushing through the dense undergrowth, one would come suddenly upon a ditch or hollow. Some of these were old stream-beds, tributary to the main rivers but filling up witlı debris and saplings. Others seemed to be irregular backwaters which the river might have scoured previously into the sand-bank; and yet others of greater extent were bits of old river-courses filled up with nipa, Acrostichum, Avicennia, Sonneratia, Scirpodendron, and rotans. Generally the main dune-troughs were recognisable in the Casuarina-forest and that of E. grandis; they collected the same brackish swamp-plants as the bits of old river-bed. One kind of hollow, however, puzzled me until I came upon its cause and, then, discovered the process which led to subcircular depressions $2-4 \mathrm{~m}$ across and about $\frac{1}{2}-1 \mathrm{~m}$ deep. They were the places where large trees had been uprooted and fallen over. The prostrate trunk with smashed crown had pulled the large roots out of the sandy soil, where they had been interlaced in the tangle of other roots, and they projected several metres vertically upward with a great deal of soil, rootlets, and humus entangled in them. Where the roots had been pulled out, there was the hollow and, generally, it became half full of water. In course of time rain washed, and gravity pulled, the soil about the upstanding roots into a heap round the base of the trunk. Root and trunk then mouldered away until there was left a heap of soil covered with young ferns and seedlings, and on one side of it the depression which filled with debris and was colonised by Salacca, Scirpodendron, and rotans. 
The heap subsided into a slight mound with ferns, Agrostistachys, Mapania, and saplings. Having searched for these stages, I was astonished at their abundance and concluded that the strong north east winds eventually blew down most of the canopytrees, one by one, as they aged, to churn up the soil and start in little patches a new generation of trees. Thus, too, the general outline of the old forested sand-bank was obliterated and merged into the hollows of the swamps-forest. Then I learnt round Bt Kuing, where there were many traces of elephants, that they pushed over not only the smaller trees to create many small hollows, but the dead boles of big rotting trees to create large hollows. The elephants evidently put their trunks into the hollow trees and mopped up the soft, mouldering, and cheesy wood until the interior was smooth; and the hollow trunks were often smashed with trampling. The final result of all these excavations must have been the levelling of the old sand-bank into swamp-forest.

Cultivation. Primeval forest, rising intact from the sandy shore, occurred between S. Tuenseh and S. Semandan, and for some distance south of S. Rhu Reba. The rest had been variously felled. Casuarina provided good firewood. The mature trees were felled except, usually, for a single file as a wind-break along the shore. The dune-grasses, which were being shaded out, then flourished again and built a sward for goats and cattle. This was fired once a year, at least, and lalang entered to form the vast wastes on white sand from which the humus had been burnt; indeed, patches of white sand were in places all that remained of the forest. These lalang wastes harboured the rats which carried the Japanese river-fever that had decimated the Malay villages round the bay and which ended our expedition in June 1934. After the Casuarina had been felled, then followed the forest of $E$. grandis and that of the dry climax. In their place coconuts were planted. Lalang fires extended into the plantations and burnt off the scrub. The neighbouring swamp-forest never burnt.

The padang at K. Sedili Kechil, just north west of the village, consisted of shining white sand without a trace of old tree-stumps. The vegetation consisted chiefly of Adinandra dumosa, Rhodomyrtus, Eugenia palembanica and, in damper parts, Dillenia suffruticosa. In the dryest part near the cemetery there was only Rhodornyrtus. I do not doubt that it was once covered by high climax-forest.

Coastal abrasion. Between the mouths of the small rivers the coast was being abraded. Sand-banks with Casuarina were undercut; the exposed roots trailed over the sand and were awash at high tide; many trees were slowly falling into the sea. Where cultivation had substituted coconut palms, they too were inclining into the sea. Yet, there were three exceptions. For a mile north of the mouth of S. Rhu Reba the coast was sanding up; there was a rather narrow bank with Casuarina-seedlings among the runners of Ischaemum and Ipomoea, but the bank did not appear to be growing rapidly, and the coast was being abraded half a mile north of it. Then a stretch of a few hundred yards immediately west of K. Sedili Kechil was sanding up. About S. Lebai the situation appeared to be stabilised. The sand washed away must have contributed to the building of the sand-spits at the river-mouths.

Abrasion leads naturally to the disappearance of the Casuarina-fringe and to the appearance of Eugenia grandis forest on the sea-front, as if it had been the pioneer. This was the case at Pasir Seruang and Lundong Wai, south of Tg Sedili Kechil, where the steep shore lead directly to $E$. grandis forest backed by dry climax-forest (Figures 9, 12).

Batu Belayer (K. Sedili Besar). Northwards from the kuala the steep rocky coast, c. $100 \mathrm{~m}$ high, led to Batu Belayar and $\mathrm{Tg}$ Temalak. Then came Telok Temalak, which was a delightful sandy bay with primeval forest along its shore (Plates 29, 30); I had intended to study this had not the bigger Jason Bay commanded my 
attention. The forest on the rocky coast up to Batu Belayer had been more or less felled. Further north it was intact with a typical sea-front of Barringtonia-Terminalia (as listed on p. 58); yet it had interest. At the foot of the cliff, more or less embedded in the forest, there were old trees of Casuarina to show that, formerly, there had been a sandy shore where, now, shelving rocks led into the sea. On these rocks, low and wind-swept bushes of Pernphis acidula grew just above high tide with branches spread away from the sea. In ravines in the cliff there grew Crytostachys lakka, Pandanus recurvatus, Caryota mitis, and Scirpodendron. The first and last bespoke swamp-forest, as if in creeks where $P$. recurvatus had grown on the sloping sides. Where small streams emptied on to the rocks, there grew Lumnitzera littorea, Sonneratia alba, and Rhizophora mucronata to show the relics of mangrove which had led from the swampy creeks on to the Casuarina-foreshore. In muddy crevices on the rocks, there survived the dune-plants Ischaemum inuticum, Fimbristylis ferruginea, and $F$. polytrichoides. It might be supposed that these small plants were recent and haphazard arrivals, but tell-tale Casuarina, Cyrtostachys, and Scirpodendron revealed the disappearance of a bay, such as Jason, of which Telok Temalak was the relic. If the sea washed four miles inland to the hillocks separating the Sedili Besar from the coastal swamp of Jason Bay, there would be such a rocky coast as at Batu Belayar. If the sea receded, there would be a vast sandy plain along the east coast of Johore, as there is in Pahang.

S. Diman. This small river turned north for a short distance before debouching on to the sandy shore with a typical sand-spit developed on its north side (Figure 10). At this estuarine part three sand-banks were evident, which I have numbered from the sea inland as banks 1-3 (Figure 10). The first was submerged at high tide and carried no vegetation. The second was raised about $1 \mathrm{~m}$ above high tide and carried a close stand of Casuarina with saplings of Eugenia grandis forest. On its seaward side there was a rather narrow stretch of sand with Ischaemum, Canavalia, Ipomoea, etc., with seedlings of Casuarina in transition to the forest on the bank. At low tide there remained a few inches of sea-water between the first and second banks. On the landward side the second bank was separated from the third and oldest by the river itself. The third bank was about $1 \mathrm{~m}$ high and, to north and south of the estuary of the river, it was united with the second. The third bank carried $E$. grandis forest and, further inland, dry climax-forest. Both second and third banks dipped rather steeply into the river and carried on this slope a narrow belt of Sonneratia alba. In the estuarine region (marked F in Figure 10), there was a dense sward of Paspalum vaginatum, up to $45 \mathrm{~cm}$ high, under the trees and inundated at high tide (Plate 28). Then, higher up in the region marked G (Figure 10), Sonneratia was joined by nipa, Cyperus malaccensis (in place of Paspalum) in thickets nearly $2 \mathrm{~m}$ high, Bruguiera sexangula, and Rhizophora apiculata. But, between the Sonneratia and the E. grandis forest on the third bank, there was a narrow belt of old Casuarina-trees (marked D, Figure 10); some of them grew even among the Sonneratia.

It would seem that three sand-banks had developed here and that, in making the second with Casuarina-forest, the river had been deflected northwards, contrary to the usual trend on this coast. I think, however, that there had been but two sand-banks, the first and the older combining the second and third, and that the river had flowed south, even to S. Lebai, and had then broken through the older bank and made the new estuary by cutting through the Casuarina-forest.

The river had at its mouth four zones of vegetation, thus: - 1, the sand-spit with Paspalum vaginatum and seedlings of Sonneratia and Rhizophora; it was the zone where Sesuviurn would have been expected if it occurred at Jason Bay.- 2 , the zone of Sonneratia alba and $P$. vaginatum. - 3, the zone of $S$. alba with nipa, 

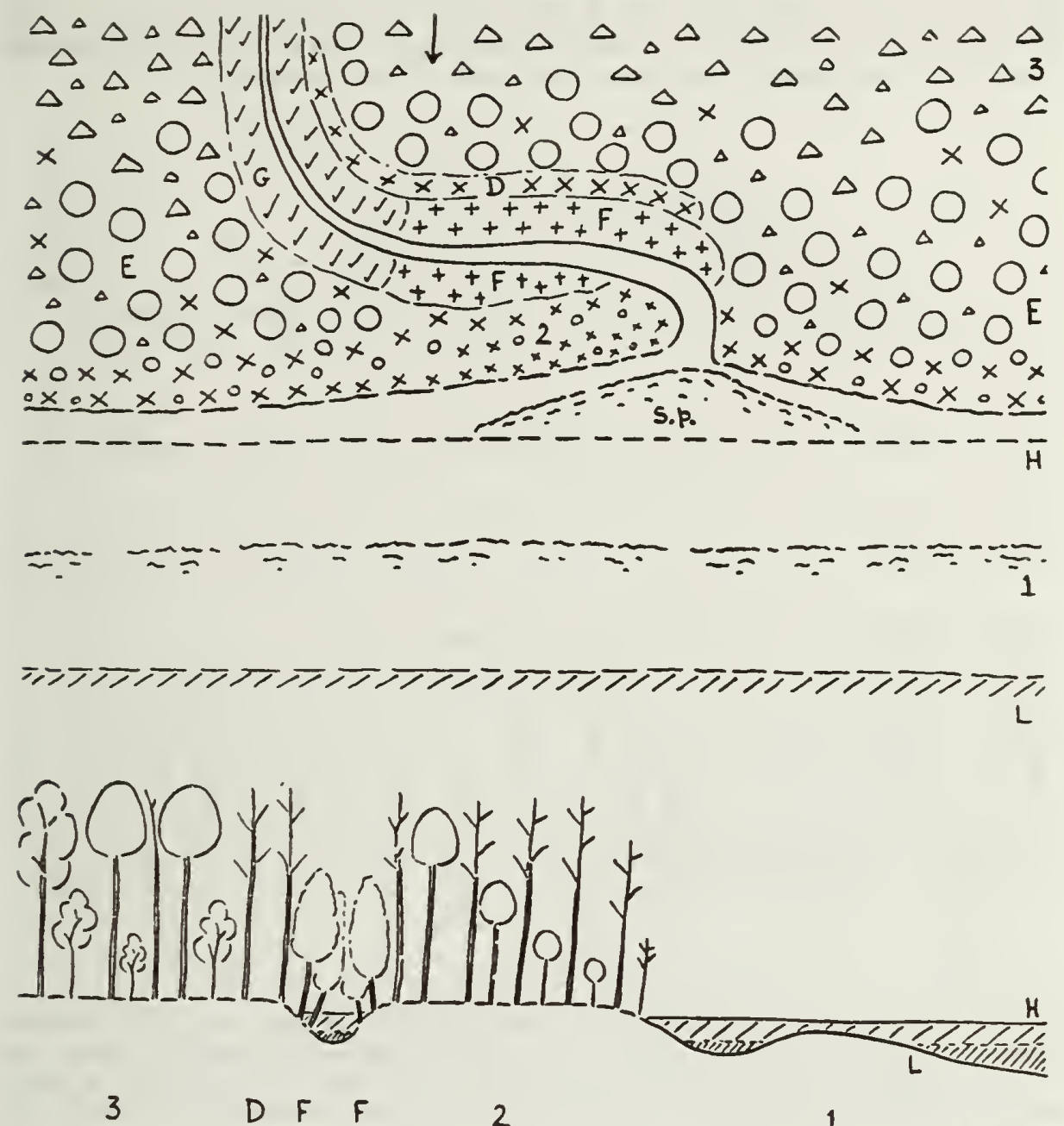

Figure 10. Diagram of the estuary of S. Diman (Jason Bay) in June 1934, with a transect in the direction of the arrow. $1,2,3$, successive sand-banks; $\mathrm{H}$, high tide; $\mathrm{L}$, low tids; S.p., sand-spit at the river-mouth; D, row of Casuarina equisetifolia (X) along the left bank of S. Diman; E, Eugenia grandis forest (O); F, Sonneratia alba (+) with Paspalum vaginatum; G, S. alba with Rhizophora (V), Bruguiera, Cyperus malaccensis, and nipa; dry climaxforest $(\Delta)$.

Bruguiera, etc. - 4, typical freshwater swamp. I note that $P$. vaginatum occupied similar places at S. Tuenseh and S. Semandan where I observed it to be awash on the sand-spit at high tide.

S. Sebong. The structure of the river-mouth, as it was in 1934, is shown in Figure 11. It seemed to be a derelict river-mouth, following the diversion of S. Tuenseh some twenty years previously. The bed dried up at low tide; yet the estuary retained in minature the typical vegetation as on the Sedili Besar. There was mangrove (A, Figure 11) leading to freshwater swamp, a strip of mature Casuarina along the abraded coast, $E$. grandis forest (E) behind this strip, and freshwater swamp-forest behind the $E$. grandis, as though this swamp were the remains of an old river-bed 
that had led south to S. Diman. Trees of Sonneratia caseolaris (B, Figure 11) in this freshwater swamp were nearly $30 \mathrm{~m}$ high and surrounded with pneumatophores $.50 \mathrm{~cm}$ high, often with capitate or knobbed apices. Between them and the $E$. grandis forest there was almost a single file of tall trees of Pterocarpus indicus $(\mathrm{Pt})$.
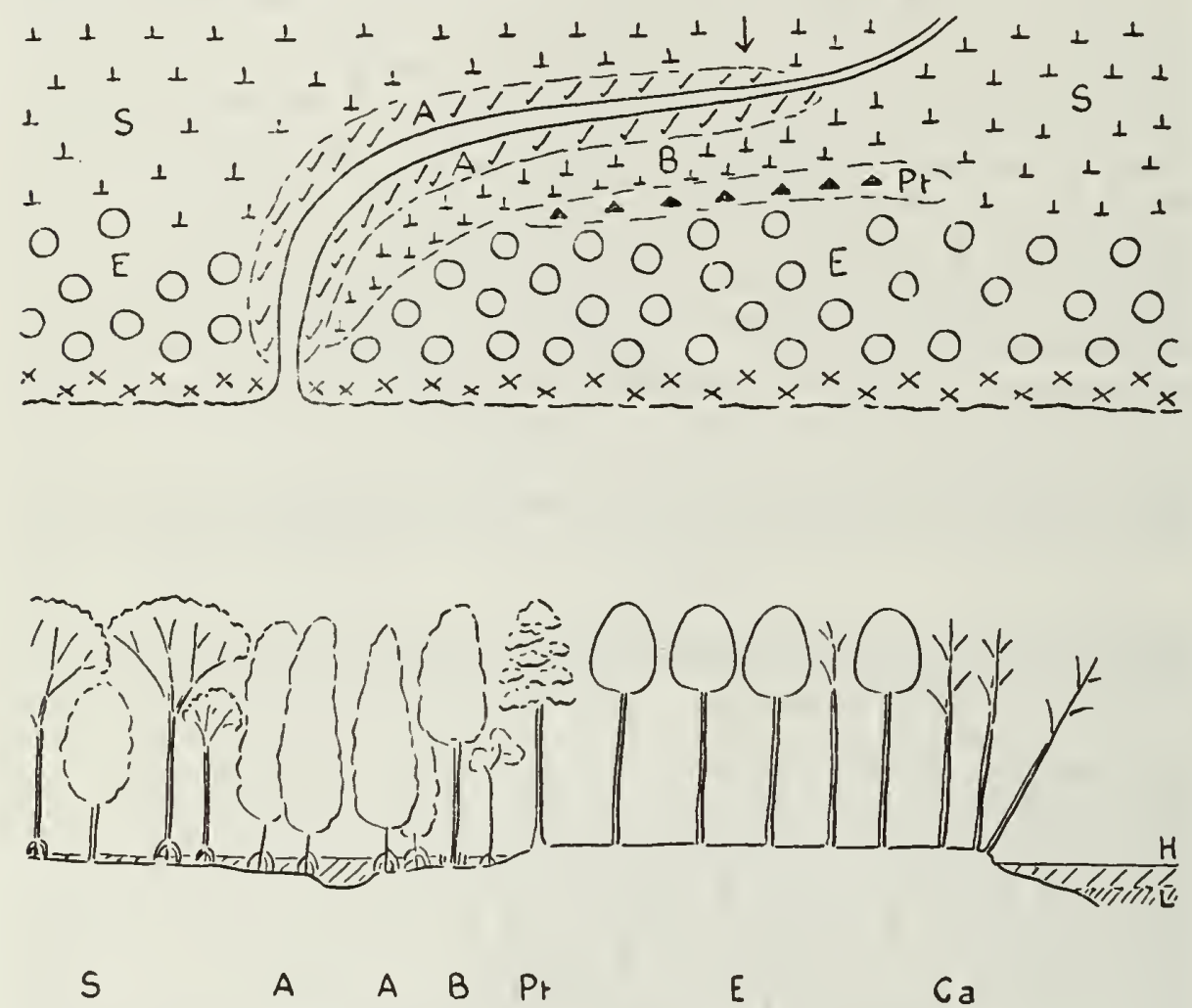

Figure 11. Diagram of the estuary of S. Sebong (Jason Bay) in June 1934, with a transect in the direction of the arrow. A, Rhizophora apiculata, Bruguiera sexangula, Sonneratia alba (near the estuary), S. caseolaris, nipa, Scirpodendron, and Hibiscus tiliaceus ( V); B, freshwater swamp-forest; Ca, Casuarina (X); E, Eugenia grandis forest (O); Pt, Pterocarpus indicus ( $\Delta)$; $\mathrm{S}$, freshwater swamp-forest $(\perp) ; \mathrm{H}$, high tide; $\mathrm{L}$, low tide.

Coast south of $\mathbf{T g}$ Sedili Kechil. At Pasir Seruang and Lundong Wai a narrow sandy beach rose steeply from the sea, but not undercut, and a flat sandy padang $100-200 \mathrm{~m}$ wide led inland to the dry forest on the hillside (Figure 12). The padang, or deforested sward, was a terrace separated from the coastal bank by a small cliff 1-3 $\mathrm{m}$ high. Rocks were scattered in the littoral and sublittoral zone. There was no Casuarina along the sea-front. All the forest, presumably dry climax-forest, on the padang had been felled. The coastal sand-bank was covered for the most part with Eugenia grandis forest, in which I met no old Casuarina-trees. The padang-terrace with its low seaward cliff indicated extensive abrasion long ago. The $E$. grandis forest indicated a later seaward growth followed by recent abrasion.

I studied the coast as far as a mile or two south of Tg Gemoh which I reached by cutting east through the forest from Kangkar Sedili Kechil along a track known to Haron bin Awang Kechil. Unfortunately the Japanese fever was coming on us. Haron, his companion, and I were feeling hot, dry, sick, and oppressed by headache. I failed to write up notes in the evening but, by a great effort, I managed to develop 
the photographic plates that I exposed, and I have this record (Plate 29; Life of Plants pl. $35 \mathrm{~b})$.

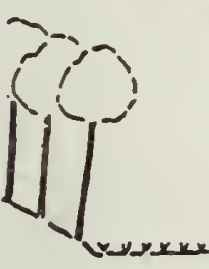

HF $P_{S}$

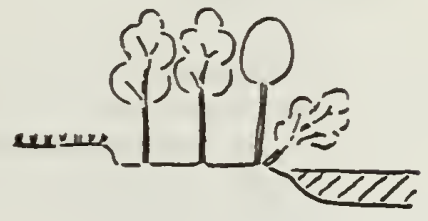

Ps
D E

2

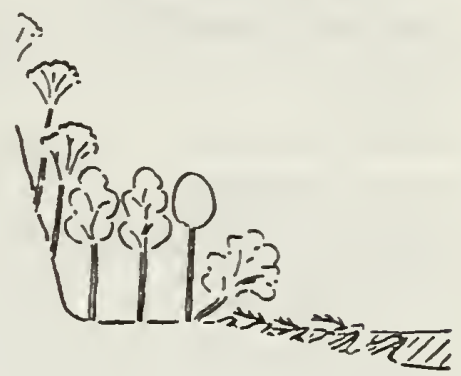

$C D E$ Pe

1

Figure 12. Diagrammatic transects of coastal vegetation near Jason Bay. 1, near Tg Tebar; rocks with Pemphis $(\mathrm{Pe})$ leading into the sea, backed with the Barringtonia-Terminalia belt (E), with a strip of dry climax-forest (D) in front of the cliff-forest (C); $\mathrm{H}$, high tide. 2, at Lundong Wai, as in 1 , but with a cliff $2-3 \mathrm{~m}$ high behind the dry climax-forest, a deforested padang ( $\mathrm{Pg}, 100-200 \mathrm{~m}$ wide) and hill-side forest (Hf).

I note that the name Pasir Seruang, given on the map, was unknown locally, and this long stretch of sandy coast was called Pasir Tiris.

History of Jason Bay. It appeared in 1934 that most of the coast of Jason Bay and of the headlands to the north and south was being abraded. The evidence from Batu Belayar and Pasir Seruang indicated a much longer period of abrasion than in the bay itself. In contrast, the extent of swamp-forest and old sand-banks inland from the coast of Jason Bay, without alluvial soil or firm Tristania-banks, the occurrence of Casuarina deeply embedded in the coastal forest, and the manner of formation of sand-dunes at the river-mouths indicated a long period of seaward extension. These facts must somehow be connected with the recession of the sea in glacial times and its subsequent advance. At maximum advance, Jason Bay would have extended to the hillocks west of S. Gembut and the Sedili Kechil. At maximum retreat, the rivers of east Johore would have drained into, or along with, the proto-Kampar river that flowed from south Sumatra between Borneo and Malaya into the China Sea. At some intermediate period, Pulau Aor and P. Tinggi would have been headlands of the great bay that has dwindled into Telok Sebong.

\section{Herbaceous plants on open sand-dunes, Jason Bay}

\section{Borreria hispida Bulbostylis barbata \\ Canavalia rosea \\ Cyanotis vaga \\ Cyperus javanicus \\ C. polystachyos \\ C. radians \\ C. stoloniferus}

Dactyloctaenium aegyptiacum

Digitaria dispar

D. ? longifora

Eragrostis atrovirens

Evolvulus alsinoides

Eulophia graminea

Euphorbia atoto

Fimbristylis cymosa

$F$. dicholoma

$F$. polytrichoides

$F$. sericea (scarce)
Ipomoea gracilis

I. pescaprae

I. stolonifera

Ischaemum muticum

Panicum repens

Paspalum cartilagineum

$P$. orbiculare

$P$. vaginatum

Sebastiana chamaelea

Spilanthes urens

Sporobolus virginicus

Synostemon bacciformis

Thuarea involuta

Vigna marina

Vitex ovala (scarce)

Wedelia biflora 
Seed plants of Barringtonia-Terminalia rocky shore and Eugenia grandis forest; (large trees marked $t$ ).

Adenanthera pavonina $(\mathrm{t})$

Allophylus cobbe

Ardisia crispa

A. elliptica

Atalantia monophylla

Barringtonia asiatica (t)

Beilschmiedia tonkinensis (t)

Calophyllum inophyllum (t)

Canthium confertum

Cerbera manghas (t)

Cycas rumphii

Cynometra ramiflora

Dalbergia ferruginea

Dendrobium crumenatum

$D$. secundum

Desmodium umbellatum

Dios pyros ferrea (?)

Dischidia rafflesiana

Dracaena maingayi (t)

Erythroxylon cuneatum (t)

Eugenia densiflora

E. grandis (t)

E. palembanica (t)

Eugenia sp. (25.11.34)

Ficus microcarpa

F. xylophylla

Garcinia hombroniana

Garcinia sp. (25.11.34)

Guettarda speciosa

Guioa pleuropteris
Heritiera littoralis (t)

Hernandia nymphaeifolia (t)

Hibiscus tiliaceus (t)

Hoya spp.

Intsia bijuga (t)

Lumnitzera littorea $(\mathrm{t})$

L. racemosa

Mallotus tiliifolius

Myristica guattariifolia (t)

Ochrosia borbonica (t)

Pandanus dubius (t)

$P$. odoratissimus

Peltophorum pterocarpum (t)

Pemphis acidula

Petunga roxburghii

Pittosporum ferrugineum

Planchonella obovata (t)

Podocarpus polystachyus (t)

Pongamia pinnata (t)

Scaevola taccada

Serianthes dilmyi (t)

Suregada glomerulata

Terminalia catappa (t)

Thespesia populnea $(\mathrm{t})$

Thrixspermum arachnites

Vaccinium bracteatum

Vanilla griffithii

Canopy-trees of the dry climax-forest, Jason Bay

Artocarpus elasticus

A. gomezianus

A. kemando

Buchanania lucida

Chisocheton pentandrus

Cratoxylon arborescens

C. formosum

Dipterocarpus grandiflorus

D. ? hasseltii

Eugenia nigricans

E. rugosa

E. syzygioides
Ficus callophylla

$F$. consociata

$F$. crassiramea

$F$. delosyce

F. dubia

$F$. stricta

F. sundaica

F. xylophylla

Mangifera ? foetida

Palaquium semaram

Parinarium corymbosum

Podocarpus neriifolius

Pterospermum javanicum 


\section{Part III. Swamp-forest at Mandai Road and Jurong (Singapore) and at Pengkalan Rajah, Pontian (Johore).}

\section{Mandai Road, Singapore}

Between the Seletar Reservoir and the Mandai Road there used to be a tract of original swamp-forest large enough for one to get lost, if it had not been for the occasional passage of a car along the road. It became a favourite haunt of mine morning, afternoon, and evening at week-ends, until it was felled for the extension of the reservoir in 1940. There I began the study of tropical trees as I followed up my first impressions when the swamp-forest was being cleared at the west end of the road on my arrival in Singapore. Now a highway has removed all trace of the narrow road that wound under the trees by the edge of the swamp.

On many visits I had the privilege of the companionship of Ahmad bin Hassan, storekeeper of the Botanic Gardens, who had begun his career as Ridley's plantcollector and with his brothers Sappi and Sappan had served the Gardens so truly; I am grateful for the enthusiasm which he imparted to the recruit. Together we established a look-out in the canopy of the forest by driving iron-pegs into the trunk of a big Meliaceous tree (never identified) which served as a ladder, and I began to record leafing and flowering of surrounding trees and lianes until one day an incursion of minute ants bit me so insidiously that I cannot recall how I descended, got home, or retained sanity during hours of scalding irritation. After this I carried in my haversack a small bottle of Scrubb's Ammonia which, by counter-irritation at least, rendered such bites tolerable. Lotong, kerah and a troop of berok monkeys would pass by in the canopy, though the authorities at Raffles Museum denied the existence of wild berok on the island. When this forest was cleared, I photographed the large trees which I had known from root and bole before they fell (Plate 35). Some forest of this kind persists to the south of the reservoir. I visited it in 1944 with Professor Kwan Koriba during the Japanese occupation and it was there that we found the fruits of Sloanea javanica, and the durian-theory began.

By April 1933 I had decided to follow up at the Mandai Road the detailed work that I had begun at Jurong. With the help of Ahmad three plots were marked out at a bend of the old Mandai Road where it passed through the swamp-forest (Figure 13). We enumerated the trees in two plots, A and B, but merely inspected plot $\mathrm{C}$ for comparison. The results are given in Table 2 , and the actual occurrence of trees in plot $\mathrm{A}$ is shown in Figure 14.

\section{Plot A}

Size; c. 1 acre ( $80 \times 60$ yards), rectangular.

Canopy-height; c. $32 \mathrm{~m}$, the biggest tree being Palaquium xanthochymum.

Situation; low, level, between two streams, with an ill-defined streamlet through the middle; no raised ground; water-table generally c. $30 \mathrm{~cm}$ below the surface of the loose humus, the whole area liable to flood and, possibly, somewhat tidal before the construction of the reservoir.

Ground; no solid earth, merely humus or peat built up by ants, termites, and decay of vegetable remains, over a complex of wide-spreading roots, those of $P$. xanthochymum being conspicuous; roots making a trellice on which to step, with 


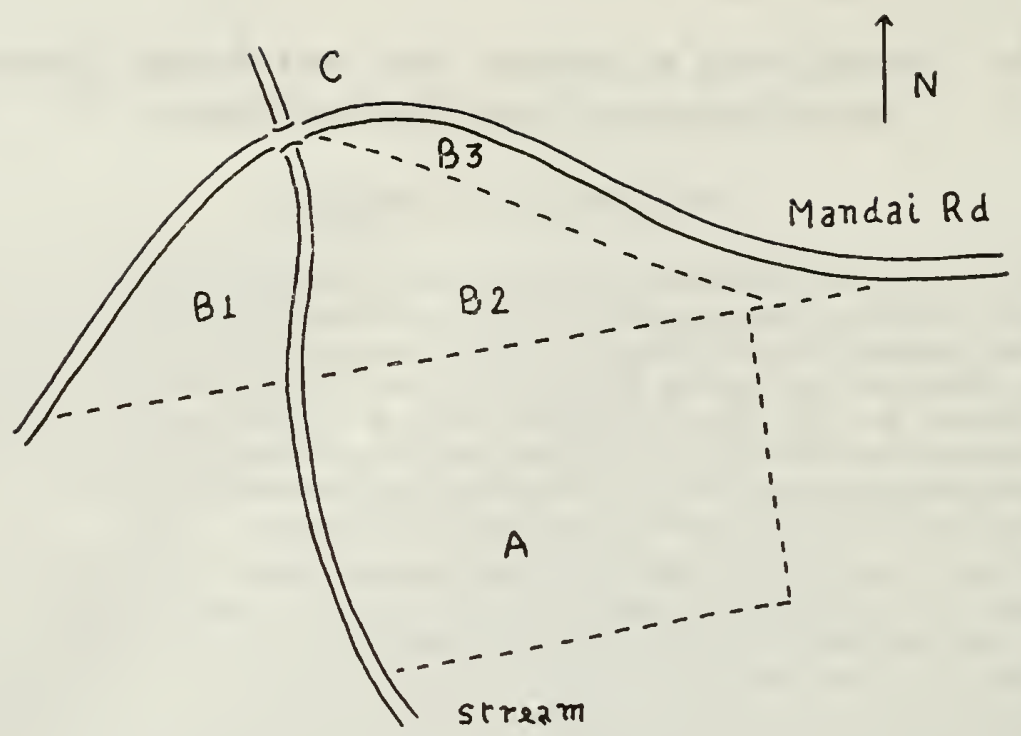

Figure 13. The sites of plots $\mathrm{A}, \mathrm{B} 1, \mathrm{~B} 2, \mathrm{~B} 3$, and $\mathrm{C}$ at the east end of the Mandai Road, Singapore, April 1933.

the water showing through the irregular meshes; humus collecting round tree-trunks and building slight mounds (? the action of flood), but the mounds soft and often giving under foot.

Undergrowth; nainly Pandanus atrocarpus (to $20 \mathrm{~m}$ high). P. kamii, Nenga, Oncosperma horridum, Salacca, and rotans, and the aroids Aglaonema and Homalomena, with seedling and saplings; few fallen trees.

Small trees; Talauma singapurensis very abundant, with Timonius, Urophyllum, Garcinia, and saplings.

In this plot $P$. xanthochymum was dominant. It composed nearly half of the canopy. The trunks were massive with copious stilt-roots branching extensively into the humus and forming bundles and fans of thin subaerial roots which accumulated the humus and provided in many parts the only means of walking. The second abundant tree was Xylopia fusca which, instead of providing pathways, tripped one with its copious loop-roots. These extended up to $18 \mathrm{~m}$ from the trunk and often followed hidden streamlets. Thirdly Pometia with its orange-brown bark and sharp buttresses guided one to firmer mounds of humus where it was possible to stand at ease. Lophopetalum multinervium and Alstonia spathulata occurred along the streams with pneumatophores not exceeding $50 \mathrm{~cm}$ high. $P$. xanthochymum tended to be gregarious, though not by coppicing from fallen trunks.

The Myristica-Horsfieldia group (n. 22 in Table 2) consisted of species which, at that time, were much confused. They were mostly trees up to $20 \mathrm{~m}$ high with trunks c. $30 \mathrm{~cm}$ thick at $1.7 \mathrm{~m}$.

I listed as unknown about 7 species of tree which it was then impossible to identify. Some have turned out to be Strombosia maingayi. I have been unable to trace the other records in modern revisions because unnumbered specimens are seldom listed. 


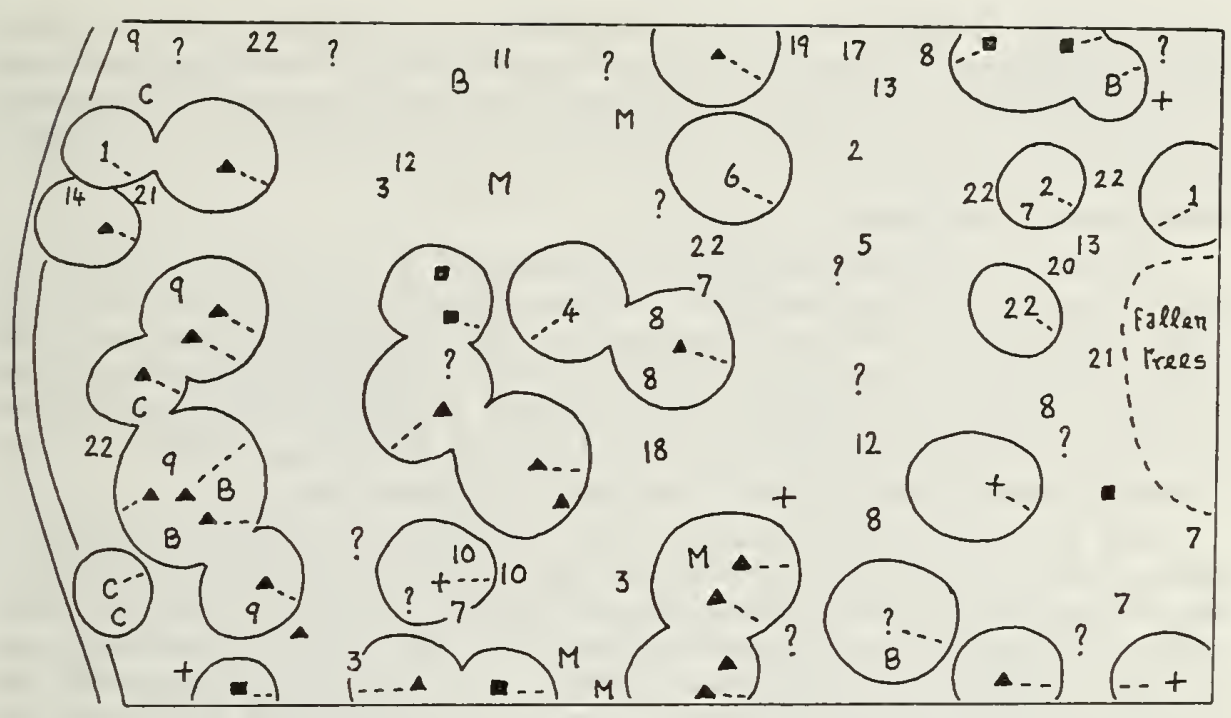

Figure 14. Plot A, Mandai Road; the trees numbered or marked as in Table 2; the crowns of the larger trees outlined; the larger gaps between the crowns filled mainly by Oncosperma horridum and Pandanus atrocarpus.

\section{Plot B}

Size; c. $1 \frac{3}{4}$ acres, divided into plots B1 ( $\frac{1}{2}$ acre), B2 ( $\frac{3}{4}$ acre) and B3 ( $\frac{1}{2}$ acre).Canopy height as in plot $\mathrm{A}$.

Situation; B1 and B2 roughly level with plot A; B3 on slightly raised ground, c. $50-70 \mathrm{~cm}$ higher than $\mathrm{B} 1$ and $\mathrm{B} 2$, but sufficient to affect the vegetation (see below); ground similar to plot A, but in B3 without standing water under the tangle of roots and humus.

In $\mathrm{B} 1$ the dominant tree was Xylopia fusca with Cratoxylon arborescens as the second most abundant; $P$. xanthochymum was curiously scarce. B2 had essentially the same construction as plot A, with $P$. xanthochymum as the dominant. In B3 the dominant trees were Melanorrhoea wailichii, Shorea macroptera and S. platycarpa, indicative of the dryer part of the swamp less prone to flooding. The area of B3 was barely one third of the whole plot B, yet it contained half the trees of $M$. wallichii, most of those of S. platycarpa, Lithocarpus bennettii, Ganna motleyana, C. arborescens, and Xylopia malayana, and all those of $S$. macroptera. Unrepresented in B3 were P. xanthochymum, Pometia, Lophopetalum multinervium, and $X$. fusca. The old road along the edge of plot B evidently followed the slightly raised ground; yet in floods this part of it soon became impassable.

\section{Plot C}

Inspection of this plot showed that it had the same swamp-forest on level ground as in plots $\mathrm{A}, \mathrm{B} 1$, and B2. Therefore I did not trouble to enumerate it in detail.

\section{Comparison of the plots}

In spite of their small size these plots revealed differences in tree-composition that appeared to indicate differences in habitat. Plots A and B2 were very similar, though Pometia and Alstonia were absent from B2. The presence of many saplings 
and specimens of medium-size of the dominant trees showed that, after the death of the canopy-trees, the plots would retain their character. $P$. xanthochymum forest was the swampiest in the sense of that mosi prone to flooding, and it might have been within the tidal reach before construction of the reservoir. In this connection I note that only one specimen of Polyalthia sclerophylla, as a $17 \mathrm{~m}$ tree, was found in the Mandai Road forest.

Plot B1 was distinguished by the abundance of $X$. fusca and $C$. arborescens and the scarcity of $P$. xanthochymum. Such an association occurred near the stream in the west of plot $\mathrm{A}$, and plot B1 appeared to be a continuation of the association on the other side of the stream above the main swamp of $P$. xanthochymum. Possibly $X$. fusca is less suited to tidal fluctuation. I noticed that both here and on the Sedili Besar $X$. fusca tended to occur higher up the swampy streams than did $P$. xanthochymum. Thus $X$. fusca forest may be distinguished.

Plot B3 on the slightly raised ground typified the freshwater swamp-forest which occurred at some distance from the tidal influence in the Sedili region. There was no sharp demarcation between plots B2 and B3; yet the four trees so characteristic of the more swampy forest were absent from B3, namely $P$. xanthochymum, $X$. fusca, Pometia, and Lophopetalum. There were many more canopy-trees per unit area in B3 than in B2 and plot A because the crowns of many, especially $M$. wallichii, were narrower. Hencc I would describe this slightly raised forest as $M$. wallichii forest. It is that which leads from the swamp to the Shorea forest of dry ground.

With regard to the species represented by one or two individuals, I think that their occurrence was fortuitous. Larger plots might well have shown their general, if sparse, distribution, and they would have introduced other such species which were notably absent, e.g. Koompassia malaccensis, Eugenia spp., Pentace triptera, Myristica lowiana, and Cratoxylon formosum. Larger plots in this restricted a rea, however, would have introduced different situations. Transects would have lead only to secondary forest on the rising ground, for which reason I did not employ them.

On comparison with the Jurong Forest (described later). plot B3 had most similarity. At Jurong, Alseodaphne? penduliflora, Mangifera aff. parvifolia, and Tristania? merguiensis were common, but the first was scarce at Mandai Road and the other two were absent, Oncosperma horridum and Talauma singapurensis were common at Mandai Road but absent from Jurong. The thickets of Pandanus atrocarpus and Salacca were much denser at Jurong. I think that these differences were phytogeographical and ecological.

Table 2. Mandai Road, Singapore. Enumeration of trees with trunks $25 \mathrm{~cm}$ thick and more at $1.7 \mathrm{~m}$. ( $\mathrm{Ca}=$ canopy-trees).

\begin{tabular}{|c|c|c|c|c|c|}
\hline \multicolumn{2}{|c|}{$\begin{array}{l}\text { Symbol in } \\
\text { Fig. } 14\end{array}$} & \multicolumn{2}{|c|}{$\begin{array}{l}\text { Plot A } \\
1 \text { acre }\end{array}$} & \multicolumn{2}{|c|}{$\begin{array}{l}\text { Plot B } \\
1 \frac{3}{4} \text { acre }\end{array}$} \\
\hline & & $\mathrm{Ca}$ & Total & Ca & Total \\
\hline$\Delta$ & Palaquium xanthochymum & 18 & 26 & 20 & 26 \\
\hline $\mathbf{a}$ & Xylopia fusca & 5 & 7 & 18 & 24 \\
\hline+ & Pometia pinnata f. alnifolia & 3 & 6 & 0 & 0 \\
\hline B & Blumeodendron tokbrai & 2 & 4 & 2 & 12 \\
\hline 1 & Alstonia spathulata & 2 & 2 & 0 & 0 \\
\hline C & Cratoxylon arborescens & 1 & 4 & 4 & 15 \\
\hline
\end{tabular}


Table $2-$ continued

\begin{tabular}{|c|c|c|c|c|c|}
\hline \multirow{2}{*}{$\begin{array}{l}\text { Symbol in } \\
\text { Fig. } 14\end{array}$} & & \multicolumn{2}{|c|}{$\begin{array}{l}\text { Plot } A \\
1 \text { acre }\end{array}$} & \multicolumn{2}{|c|}{$\begin{array}{l}\text { Plot B } \\
1 \frac{3}{4} \text { acre }\end{array}$} \\
\hline & & $\mathrm{Ca}$ & Total & $\mathrm{Ca}$ & Total \\
\hline 2 & Campnosperma auriculata & 1 & 2 & 0 & 6 \\
\hline 3 & Campnosperma squamata & 1 & 3 & 3 & 10 \\
\hline 4 & Santiria rubiginosa & 1 & 2 & 2 & 2 \\
\hline 5 & Coelostegia griffithii & 1 & 1 & 1 & 1 \\
\hline 6 & Parishia sp. & 1 & 1 & 0 & 0 \\
\hline$M$ & Melanorrhoea wallichii & 0 & 6 & 10 & 26 \\
\hline 7 & Horsfieldia polyspherula & 0 & 5 & 2 & 12 \\
\hline 8 & Canarium pilosum & 0 & 5 & 0 & 0 \\
\hline 9 & Lophopetalum multinervium & 0 & 4 & 1 & 2 \\
\hline 10 & Ganua motleyana & 0 & 2 & 2 & 4 \\
\hline 11 & Polyalthia glauca & 0 & 2 & 0 & 0 \\
\hline 12 & Artocarpus kemando & 0 & 2 & 1 & 5 \\
\hline 13 & Shorea platycarpa & 0 & 2 & 3 & 4 \\
\hline 14 & Xylopia malayana & 0 & 1 & 2 & 6 \\
\hline 15 & Calophyllum floribundum & 0 & 1 & 0 & 2 \\
\hline 16 & Macaranga puncticulata & 0 & 1 & 0 & 5 \\
\hline 17 & Mussaendopsis beccariana & 0 & 1 & 0 & 1 \\
\hline 18 & Artocarpus scortechinii & 0 & 1 & 0 & 1 \\
\hline 19 & Amoora rubiginosa & 0 & 1 & 0 & 0 \\
\hline 20 & Knema intermedia & 0 & 1 & 0 & 0 \\
\hline 21 & Eugenia spp. & 0 & 2 & 1 & 5 \\
\hline 22 & Myristica-Horsfieldia spp. & 1 & 7 & 2 & 14 \\
\hline \multirow[t]{12}{*}{$?$} & $\begin{array}{l}\text { Unidentified (plot A } 7 \text { spp., plot B c. } \\
12 \text { spp.) }\end{array}$ & 1 & 14 & 14 & 32 \\
\hline & Shorea macroptera (plot B3) & 0 & 0 & 5 & 6 \\
\hline & Lithocarpus bennettii & 0 & 0 & 3 & 5 \\
\hline & Myristica iners & 0 & 0 & 2 & 4 \\
\hline & Calophyllum retusum & 0 & 0 & 2 & 3 \\
\hline & Sterculia macrophylla & 0 & 0 & 1 & 1 \\
\hline & Calophyllum incrassatum & 0 & 0 & 0 & 2 \\
\hline & Vatica wallichii & 0 & 0 & 0 & 2 \\
\hline & Artocarpus elasticus & 0 & 0 & 0 & 1 \\
\hline & Diospyros siamang & 0 & 0 & 0 & 1 \\
\hline & Jackia ornata & 0 & 0 & 0 & 1 \\
\hline & Totals & 38 & 116 & 103 & 241 \\
\hline
\end{tabular}

\section{Jurong Road 15th mile, Singapore}

Tree-trunks piled by the road to Jurong in 1932 indicated the felling of high forest the existence of which was not known at the Botanic Gardens. I was always on the look-out for fellings as a means of learning about trees, climbers, and epiphytes, and my attempts to learn from official sources wherc they would occur met no success. By chance I found that half a mile south of mile 15 on this road 
there remained some 15-20 acres of original swamp-forest where felling had just begun. I explained my interest to the Chinese lieadman and his wood-cutters, and I was indeed grateful to them for their full co-operation. I was allowed to select two representative acres which they left untouched for several months until I had enumerated the trees. When fine specimens of trees became revealed by the felling, they would leave them standing until there was sufficient clearance around for photography (Plate 34). Thus, gradually, I recorded with photograph, specimens, and notes the disappearance of the last tract of swamp-forest in the west of the island. Felling began, as usual, with clearance of the undergrowth; what might remain was smashed by falling trees, and my presence was not welcome on these dangerous occasions. I discovered that after the logs had been removed and the slash burnt, it was still possible to identify the large stumps and, so, to obtain in the cleared parts an idea of specific abundance. In felling, many trees were knocked over and uprooted; then, as the peaty soil contracted from burning and exposure, the root-sytems became apparent. There was, indeed, a battlefield where I studied and counted corpses and skeletons. My friend C. E. Carr came with me on several occasions and to him I owe the fairly complete list of orchids. (c. 45 species).

The Jurong district had been a collecting ground for H. N. Ridley and I. H. Burkill (Burkill 1927). I have not recorded their collections in this account because the exact locality was too often uncertain. As proof of the virgin nature of the forest which I studied, I found no old cut stumps, no Gleichenia, Lycopodium cernuum, Lygodium, Adinandra, Eurya, or Dillenia suffruticosa, such as were abundant along the Jurong Road itself. By June 1933 the whole forest had been transformed into a pine-apple estate.

I selected for enumeration two plots $\mathrm{A}$ and $\mathrm{B}$, about 1 acre each, in the distant south-west part of this uniform forest on flat land. With compass and string, boundaries were delimited and, when I had become familiar with the trees which were being felled, I enumerated the contents of the plots in the last week of February 1933 and the first week of March. The wood-cutters were waiting to come in, fell, and burn in the dry weather of May and June. Five trees in the plots have remained unidentified, and I cannot trace the leaf-specimens which were put in the Singapore Herbarium; they were not dominant trees. What puzzles me now is that I recorded no Aglaia, Baccaurea, Barringtonia, Chisocheton, Coelostegia, Memecylon, Neesia, Calamus, Caryota, Livistona, or Pinanga, and few species of Ardisia, Calophyllum, Eugenia, Lithocarpus, Macaranga, and Pandanus.

In comparison with the swamp-forest at Mandai Road and at Pontian (described later), that at Jurong was distinguished by 15 species which did not occur in the other two and by the great abundance of Tristania ? merguiensis, which might have occurred at Pontian, thus:-

Alseodaphne ? penduliflora (common), Anisoptera marginata (scarce), Cantleya corriculata (frequent), Dischidia aff. complex (frequent), Eugenia muelleri (common), Ficus albipila (rare), Hexapora ? curtisii (scattered), Hopea mengarawan (scattered), Horsfieldia macrocoma (scarce), Hymenocardia sp. ? (common), Mangifera aff. parvifolia (common), Melanorrhoea sp. (rare), Ormosia macrodisca (rare), Schefflera cephalotes (frequent), Sterculia coccinea (very abundant), and Tristania ? merguiensis (common).

I note the absence, too, from Jurong of Campnosperma squamata, Carallia brachiata, Elaeocarpus griffithii, Fagraea racemosa, Gymmacranthera, Ilex, Litsea gracilipes, and Talauma. I conclude that the Jurong forest in the west of Singapore was phytogeographically distinct from that at Mandai, Pontian, and the Sedili region. 
I intended also to enumerate small trees in restricted plots, but I managed to do this in the time available only for one part of plot B, which I have called plot C (Table 4). It showed the density of saplings in this forest and the lack of other undergrowth except where there were thickets of Pandanus atrocarpus, Cyrtostachys, Daemonorops, and Salacca. There were few places in this original forest where it was possible to walk without hacking a passage.

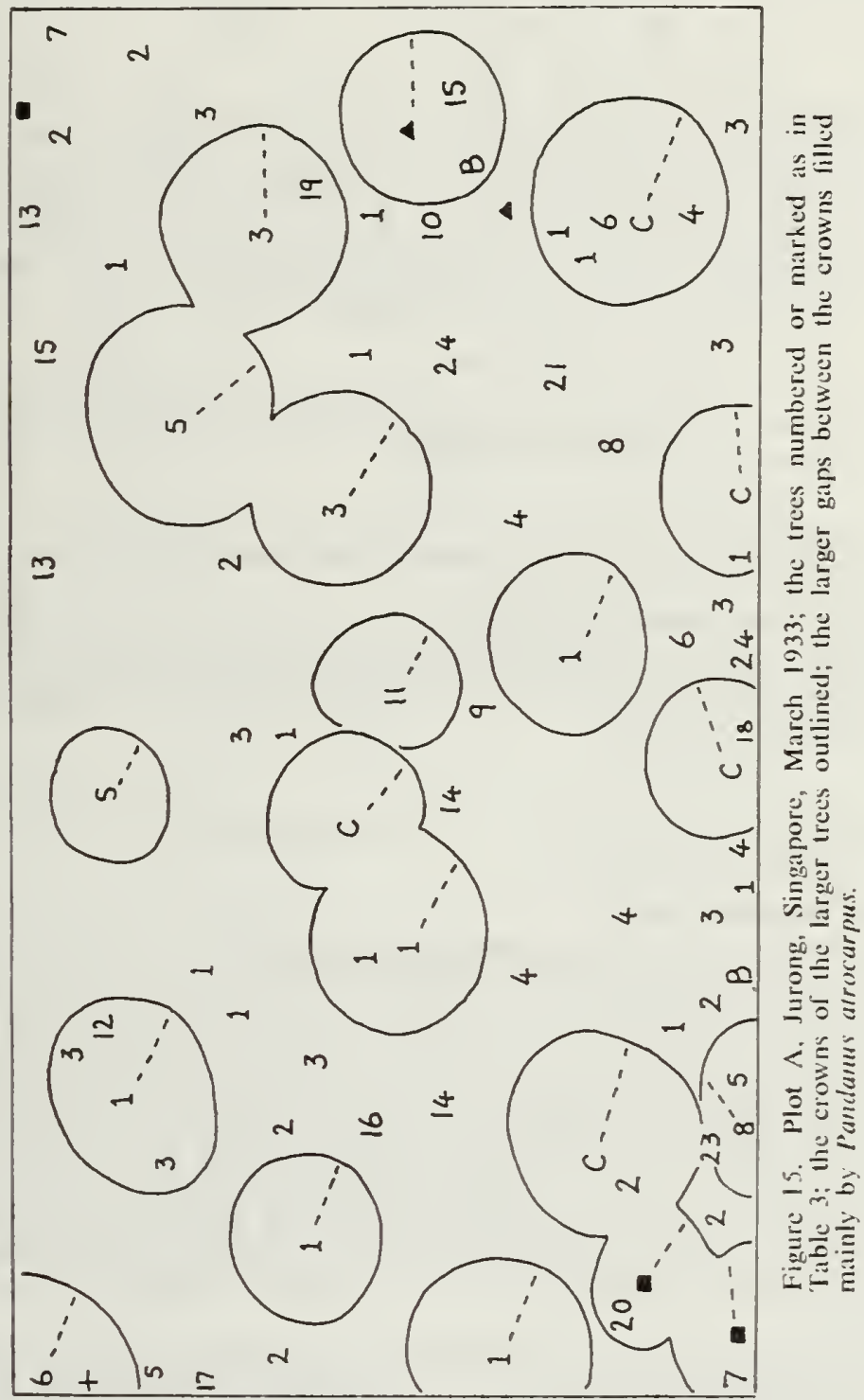




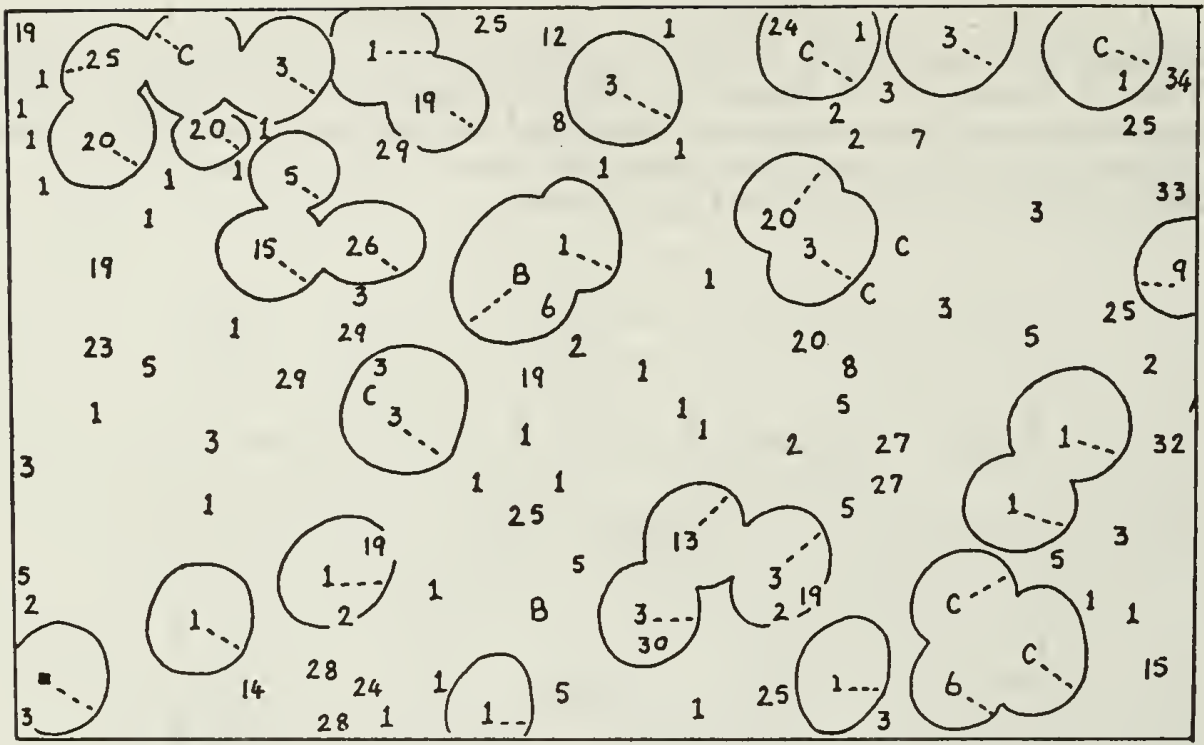

Figure 16. Plot B, Jurong, Singapore, March 1933; the trees numbered or marked as in Table 3: the crowns of the larger trees outlined.

\section{Plot A}

Size; c. 1 acre. Canopy-height not above $32 \mathrm{~m}$, the highest tree being Cratoxylon arborescens (bole $70 \mathrm{~cm}$ thick at $2 \mathrm{~m}$ ).

Situation; more or less level but with loose mounds of humus built up round the big trunks, swampy and easily flooded, not or scarcely tidal; bounded on one side by a stream deepened artificially into a straight ditch for drainage; water-table c. $30-40 \mathrm{~cm}$ below the humus.

\section{Plot B}

As plot A but further east of the steam and, probably, less flooded. Canopy height c. $30 \mathrm{~m}$ (C. arborescens).

\section{Comparison of plots $A$ and $B$}

The plots appeared identical until enumeration showed a denser stand in plot $\mathrm{B}$ (Table 3). The rather narrow crowns of the two predominant trees in plot B, namely Ganua motleyana and Melanorrhoea wallichii, seemed to permit this increase in both canopy and undergrowth. The interest of both plots lay in the greater resolution that they gave to the forest-types condensed at the Mandai Road. They represented $M$. wallichii forest adjoining the more regularly and deeply flooded $P$. xanthochymum forest and its riverine continuation into $X$. fusca forest, but the greater extent of the level, or slightly shelving, land spread out this transition in plot A to plot B. P. xanthochymum, X. fusca, and Pometia were represented in plot A, but only $X$. fusca was present, if thinly, in plot B. The transition between the $P$. xanthochymum forest and that of $M$. wallichii appeared to be filled by $G$. motleyana.

The succession, then, from tidal freshwater swamp-forest to dry land appeared to follow the loss of tidal effect and the gradual rise, or build-up, of the ground in this sequence:- from mempisang-belt through $P$. xanthochymum and $X$. fusca forests to $G$. motleyana forest, $M$. wallichii forest, and finally lowland dipterocarp forest. In this sequence many other species come and go; their ecological preferences are not known; the plots which I studied were too small to recognise peculiarities in their scattered or locally gregarious occurrence. It would seem that Mussaendopsis 
beccariana and Diospyros siamang went with G. motleyana, and that Eugenia, Horsfieldia, Knema, and Lithocarpus bennettii went with $M$. wailichii forest. C. arborescens, however, went with both. It is noteworthy that $L$. bennettii had practically the same representation in plot B of Mandai Road and plot B of Jurong. The scattered trees of Koompassia malaccensis escaped both plots.

While, therefore, the swamp-forests at Jurong and Mandai showed the same general ecological structure as in the Sedili region, the species peculiar to Jurong showed the floristic difference which did not occur in so striking a manner between the Mandai Road and the Sedili.

\section{Plot C}

This small plot, $10 \mathrm{ft}$. square. was a minuscule part of the forest, and many such plots would be needed to obtain a fair picture of the undergrowth. Using the figure of 46 small trees per 100 sq. ft. (as in Table 4), then an acre (as plots A or B), would have above 20,000 small trees. Fair sampling on this scale with such a mixed flora appeared impossible. Another such small plot might have contained only Pandanus atrocarpus, Cyrtostchys, or Salacca. Transects might have been more useful. Plot $\mathrm{C}$, however, indicates regeneration of plot $\mathrm{B}$.

\section{Major trees at Jurong}

Amoora rubiginosa-1 large tree per 3-4 acres.

Artocarpus kemando - scattered, ? not a canopy-tree.

Blumeodendron tokbrai-scattered.

Calophyllum retusum - frequent, some very big trees, with loop-roots.

C. wallichianum, C. floribundum - scattered.

Campnosperma auriculata - frequent, not secondary forest.

Canariuni pilosum - scattered.

Cantleya corniculara - 1 large tree per 1-3 acres, rarely in the canopy.

Cratoxylon arborescens - frequent big trees, ? little regeneration.

Dialium patens - c. 1 large tree per 2-3 acres.

Dillenia pulchella - rare, but in the canopy.

Diospyros siamang - c. 1 large tree per acre.

Ganua motleyana - most abundant, regenerating.

Hopea mengarawan - scattered.

Koompassia malaccensis - scattered.

Lithocarpus bennettii - rather scattered.

Lophopetalum multinervium - scarce.

Mangifera aff. parvifolia - common.

Melanorrhoea wallichii - frequent to locally abundant.

Mussaendopsis beccariana - 1-2 large trees per acre, rarcly 5; saplings common.

Myristica lowiana - scattcred.

Polyalthia glauca - frequent, rarely in the canopy.

Palaquium xanthochymum - scarce.

Pometia pinnata f. alnifolia - c. I large tree pcr acre; mostly as slender trecs or saplings.

Santiria laevigata - abundant, with many saplings, but not in the canopy.

Santiria rubiginosa - 1-2 large trees per 2-3 acres.

Shorea platycarpa - 1 large tree per acre.

Strombosia maingayi - rather common, rarely $23 \mathrm{~m}$ high.

Tristania? merguiensis - locally common, in places scattered.

$X y l o p i a$ fusca - locally frcquent.

Xylopia malayana - scattered.

\section{Small trees at Jurong}

Alseodaphne? penduliflora-common.

Cyathocaly $x$ ramuliflorus - tree $-17 \mathrm{~m}$, frequent.

Eugenia cerina var. turbinata - frequent, often shortly buttressed, but here without stilt-roots.

Eugenia muelleri - tree $-11 \mathrm{~m}$, frequent, occasionally with short stilt-roots.

Garcinia forbesii - common, flowering at $3 \mathrm{~m}$ high.

G. gaudichaudii - common.

G. ? rostrata - locally frequent. 
Horsfieldia polyspherula - scattered.

Jackia ornata - common, occasional large trees in the canopy at 1 per 1-2 acres.

Knema curtisii - scattered.

$K$. intermedia - frequent, with or without stilt-roots.

Macaranga puncticulata - common, occasionally as a canopy-tree at c. 1 per 1-2 acres.

Polyalthia hypoleuca - frequent.

Timonius flavescens - common.

Xylopia caudata - frequent, not in the canopy.

Pandanus atrocarpus - very abundant.

\section{Common climbers at Jurong}

Dapania (large), Embelia, Mitrella kentii (often large), Morinda rigida (often large), Uncaria; Daemonorops leptopus, Flagellaria indica, Pothos latifolia; Gnetum.

\section{Common umdergrowth at Jurong}

Ardisia tuberculata, Labisia, Sterculia coccinea; Cyrtostachys, Hanguana, Nenga. Salacca.

Table 3. Jurong Road, Singapore. Enumeration of trees with trunks $25 \mathrm{~cm}$ thick and more at $1.7 \mathrm{~m}(\mathrm{Ca}=$ canopy-trees $)$.

\begin{tabular}{|c|c|c|c|c|c|}
\hline \multirow{2}{*}{$\begin{array}{l}\text { Symbol in } \\
\text { Fig. } 15,16\end{array}$} & & \multicolumn{2}{|c|}{ Plot A } & \multicolumn{2}{|c|}{ Plot B } \\
\hline & & $\mathrm{Ca}$ & Total & $\mathrm{Ca}$ & Total \\
\hline 1 & Ganua motleyana & 5 & 17 & 10 & 40 \\
\hline 2 & Mangifera aff. parvifolia & 5 & 10 & 3 & 8 \\
\hline $\mathrm{C}$ & Cratoxylon arborescens & 5 & 5 & 3 & 8 \\
\hline 3 & Melanorrhoea wallichii & 2 & 11 & 6 & 16 \\
\hline 4 & Mussaendopsis beccariana & 3 & 5 & 0 & 0 \\
\hline a & Xylopia fusca & 2 & 3 & 0 & 1 \\
\hline$\overline{5}$ & Campnosperma auriculata & 1 & 4 & 1 & 10 \\
\hline 6 & Shorea platycarpa & 1 & 3 & 1 & 2 \\
\hline 7 & Diospyros siamallg & 1 & 2 & 0 & $\overline{1}$ \\
\hline$\Delta$ & Palaquium xanthochymum & 1 & 2 & 0 & 0 \\
\hline$\overline{8}$ & Parartocarpus venmenosus ssp. forbesii & 1 & 2 & 1 & 3 \\
\hline 9 & Canarium pilosum & i & 1 & i & $i$ \\
\hline 10 & Hexapora? curtisii & i & i & 0 & 0 \\
\hline 11 & Polyalthia glauca & 1 & 1 & 0 & 0 \\
\hline B & Blumeodendron tokbrai & 0 & 2 & 0 & 1 \\
\hline 12 & Jackia ornata & 0 & 2 & 0 & 1 \\
\hline 13 & Myristica lowiana & 0 & 2 & 1 & i \\
\hline 14 & Santiria laevigata & 0 & 2 & 0 & $\mathrm{i}$ \\
\hline 15 & Xylopia malayana & 0 & 2 & 1 & 2 \\
\hline 16 & Austrobuxus nitidus & 0 & $i$ & 0 & 0 \\
\hline 17 & Cantleya corniculata & 0 & i & 0 & 1 \\
\hline 18 & Garcinia? rostrata & 0 & l & 0 & 0 \\
\hline 19 & Horsfieldia, Knema & 0 & i & 1 & 6 \\
\hline 20 & Lithocarpus bermettii & 0 & i & 3 & 4 \\
\hline 21 & Macaranga puncticulata & 0 & $\mathrm{i}$ & 0 & 0 \\
\hline+ & Pometia pinnata f. alnifolia & 0 & i & 0 & 0 \\
\hline 22 & Vatica wallichii & 0 & i & 0 & 0 \\
\hline 23 & $X y l o p i a$ caudata & 0 & i & 0 & l \\
\hline 24 & Unidentified (A, 4 spp.; B, I sp.) & 0 & 4 & 0 & 1 \\
\hline 25 & Calophyllum retusuin & 0 & 0 & 1 & 6 \\
\hline 26 & Dialium patens & 0 & 0 & 1 & 2 \\
\hline 27 & Tristania? merguiensis & 0 & 0 & 1 & 2 \\
\hline 28 & Alstonia angustifolia & 0 & 0 & 0 & 4 \\
\hline 29 & Alseodaphme? penduliflora & 0 & 0 & 0 & 1 \\
\hline 30 & Artocarpus kemando & 0 & 0 & 0 & i \\
\hline 31 & Calophyllum wallichianum & 0 & 0 & 0 & i \\
\hline 32 & Eugenia cerina & 0 & 0 & 0 & 1 \\
\hline $3 \overline{3}$ & Garcinia bancana & 0 & 0 & 0 & $\mathrm{i}$ \\
\hline 34 & Santiria rubiginosa & 0 & 0 & 0 & $\mathrm{i}$ \\
\hline \multicolumn{2}{|c|}{ Plot A c. 33 spp., plot B c. 31 spp. Totals } & 30 & 90 & 35 & 129 \\
\hline
\end{tabular}


Table 4. Jurong Road, Singapore. Enumeration of trees with trunks $5-24 \mathrm{~cm}$ thick at $1.7 \mathrm{~m}$ (mostly $5.18 \mathrm{~m}$ high), in Plot C.

\begin{tabular}{|c|c|}
\hline & Number of trees or trunks \\
\hline Pandanus atrocarpus & 7 \\
\hline Knema intermedia, Melanorrhoea wallichii & 5 each \\
\hline $\begin{array}{l}\text { Ganua motleyana, Horsfieldia polyspherula, Mangifera aff. } \\
\text { parvifolia, Mussaendopsis beccariana, rotans (large stems) }\end{array}$ & 3 each \\
\hline Alseodaphne? penduliflora, Hymenocaria?, Santiria laevigata & 2 each \\
\hline $\begin{array}{l}\text { Alstonia angustifolia, Diospyros siamang, Jackia ornata, } \\
\text { Myristica lowiana, Parartocarpus, Polyalthia glauca, } \\
\text { Vatica wallichii, unidentified sp. }\end{array}$ & 1 each \\
\hline Plot C, 19 spp. & 46 \\
\hline
\end{tabular}

\section{Pengkalan Rajah, Pontian, Johore}

This small area of sivamp-forest, about the size of that at Jurong, had persisted in south west Johore, though all the surrounding forest had been converted into pine-apple estates (Plate 33), until 1939 when the District Officer informed M. R. Henderson, Curator of the Herbarium, that it was about to be felled. Henderson and $I$ arrived as the felling began in July. We collected all that could not be identified on the spot and all flowering and fruiting material, but any opportunity to enumerate intact plots had been lost. The situation was flat land, as at Jurong, even flatter, and my first impression was that the forest was similar, but in spite of general agreement with swamp-forest in Singapore and the Sedili region it proved to be distinct. The species which occurred at Pontian, Jurong, and the Mandai Road are give on pp. 72-83.

The forest at Pontian did not seem to have been tidal; it was certainly not brackish. From the abundance of stilt-rooted trees throughout, it was clearly a uniform stand of freshwater swamp. As at Jurong, the soil was peaty humus collected round the big trees and over the roots with many hollows to the watertable which, in the dry month of July, stood about $30-40 \mathrm{~cm}$ below the uneven surface of the humus.

The poverty of the Pontian flora is shown in the following Table 5.

Table 5. Numbers of species at Jurong (J), Mandai Road (M), and at Pontian (P); species not in the Sedili region in brackets.

\begin{tabular}{|c|c|c|c|}
\hline & $\mathbf{J}$ & $\mathbf{M}$ & $\mathrm{P}$ \\
\hline $\begin{array}{l}\text { Angiosperms (excl. orchids) } \\
\text { Orchidaceae } \\
\text { Gymnosperms } \\
\text { Ptcridophyta }\end{array}$ & $\begin{aligned} 158(28) \\
41(1) \\
3(0) \\
18(0)\end{aligned}$ & $\begin{array}{c}313(55) \\
13^{*}(?) \\
1 *(0) \\
15^{*}(2)\end{array}$ & $\begin{array}{r}123(20) \\
16(5) \\
2(0) \\
7(3)\end{array}$ \\
\hline & 220 & 342 & 148 \\
\hline
\end{tabular}

* not fully collccted. 
This poverty was revealed by the absence from Pontian of the following genera and species:-

Aglaia, Chisocheton, Dysoxylon, Artocarpus, Baccaurea, Barringtonia (absent from all three localities). Calophyllum floribundum, C. wallichianum, Canarium pilosum, Coelostegia, Dilienia (stilt-rooted), Euonymus javanicus, Ganua, Gynotroches, Horsfieldia, Knema, Lithocarpus, Lophopetalum, Melanochyla, Melanorrhoea, Mernecylon, Mussaendopsis, Neesia, Nenga, Oncosperma, Palaquium xanthochymum, Pseudoeugenia, Salacca, Santiria rubiginosa, Strombosia, Vatica, Xylopia, Apocynaceae, Connaraceae, and most woody climbers. It was shown by Ficus which had at Pontian but three species of large strangler, namely $F$. callophylia, $F$. stricta, and the rare $F$. tristaniifolia which has been found elsewhere in the Malay peninsula only at S. Udang in Malacca. The poverty was more striking because formerly the forest must have been surrounded by the rich dipterocarp forest of south Johore; it could not be ascribed to the isolation in which we found it. The forest at Mandai Road owed its richness to this proximity.

The following 14 species, which distinguish also the swamp-forest of Singapore and the Sedili, were frequent to abundant at Pontian:- Amoora rubiginosa, Blumeodendron tokbrai, Calophyllum retusum, Campnosperma squainata, Cratoxylon arborescens, Eugenia cerina, Garcinia nigrolineata, Jackia ornata, Koompassia malaccensis, Macaranga puncticulata, Myristica lowiana, Pometia pinnata f. alnifolia, Santiria apiculata, Shorea platycarpa.

Amoora and Koompassia were unusually abundant. In addition, there was the usual sprinkling of Austrobuxus, Campnosperma auriculata, Dialium patens, Diospyros siamang, and Podocarpus wallichianus. Pandanus atrocarpus (-20 m high), Cyrtostachys lakka, and Timonius flavescens were common in the undergrowth which, as at Jurong, consisted mainly of saplings. At Jurong Cyrtostachys was often tufted but at Pontian the palms were nearly all solitary.

Then the Pontian forest had the following 24 species which did not occur at Jurong or the Mandai Road, though 13 or 14 (marked S) occurred in the Sedili region:- Aromadendron nutans, Campnosperma macrophylla (common) Ctenolophon parvifolius (abundant; S), Dialium platysepalum (S), D. wallichii (S), Diospyros sp. A (see special notes), Engelhardtia serrata (scattered as a big tree), Eugenia kiahii (S), F. callophylla (S), F. stricta (S), F. tristaniifolia, Gonystylus bancanus (common; S), Macaranga pruinosa (common; S), Palaquium burckii, $P$. ridleyi, $P$. semaram (S), Platea excelsa, Ploiarium (f requent big trees $20-30 \mathrm{~m}$, stilt-roots $-2.5 \mathrm{~m}$ high: S), Santiria tomentosa (S), Stemonurus secundiflorus (S), Tetractomia major (S), T. tetrandra (common; (S), Tetramerista (common), Tristania pontianensis (perhaps the commonest tree as saplings and up to $30 \mathrm{~m}$ high: ?S).

This contingent is the Malayan element, as opposed to that of Singapore or the Riouw pocket, and it has sufficient character with 9 or 10 particular species to distinguish it as the swamp-forest of west Johore from that of east Johore.

In common with the forest at Mandai Road, there were Carallia brachiata, Elaeocarpus griffithii, Gymnacranthera eugeniifolia (common), Litsea gracilipes, and Parastemon urophyllum. In common with the forest at Jurong, there were Dillenia pulchella, Eugenia rugosa, Garcinia bancana, G. ? rostrata, Parartocarpus, Polyalthia hypoleuca (very abundant, $-30 \mathrm{~m}$ high), Santiria laevigata, Cyrtostachys lakka, and possibly Tristania? merguiensis (which needs comparison with $T$. pontianensis). Absent from the Sedili region were $18 \%$ of the species at Jurong and at the Mandai Road, and $16 \%$ of those at Pontian. For the orchids and ferns at Pontian the values rise to $31 \%$ and $43 \%$ respectively.

So far as I could judge there was little difference in the habitat of the freshwater swamp-forest at Jurong, Mandai, Pontian, or the Sedili. Certainly the proximity of the Sedili rivers led to more frequent and, possibly, deeper flooding but, if 
the height of stilt-roots is a measure of the height of flooding, there was little to choose between the four localities. I came to the conclusion in 1940 that the four represented different phytogeographical regions, namely the south Sumatran for Jurong, the Riouw archipelago for Mandai, the mid-Sumatran for Pontian, and the west Bornean for the Sedili. They must date from the geography of the protoKampar river, which defines the Riouw pocket. Thus I have long realised that the phytogeography of Singapore and south Johore was far from simple. Most of the forest has been irredeemably exploited or entirely destroyed but, through the exertions of a few botanists, there are the past collections to be collated and it should still be possible to compare the forests of G. Pulai, G. Panti, and Bt Timah, perhaps Bt Tinjau Laut.

Now, long after my explorations, Anderson (1963) and Wyatt Smith (1959) have described the peat-swamp forests of Borneo and Malaya as distinct from the freshwater which is subject to inundation and does not form a raised bog. I had concluded that the Pontian forest, composed so largely of Cratoxylon, Gonystylus, and Tristania, without Melanorrhoea and Mussaendopsis, was a phase leading from Melanorrhoea forest to lowland dipterocarp forest, such as had surrounded it. Now it seems that the Pontian forest was freshwater swamp-forest on the way to becoming peat-forest. I take this up later in the section dealing with the Sarawak forest, though I fear it may never be solved. I give, therefore, the following scheme for the sequence of the swamp-forests.

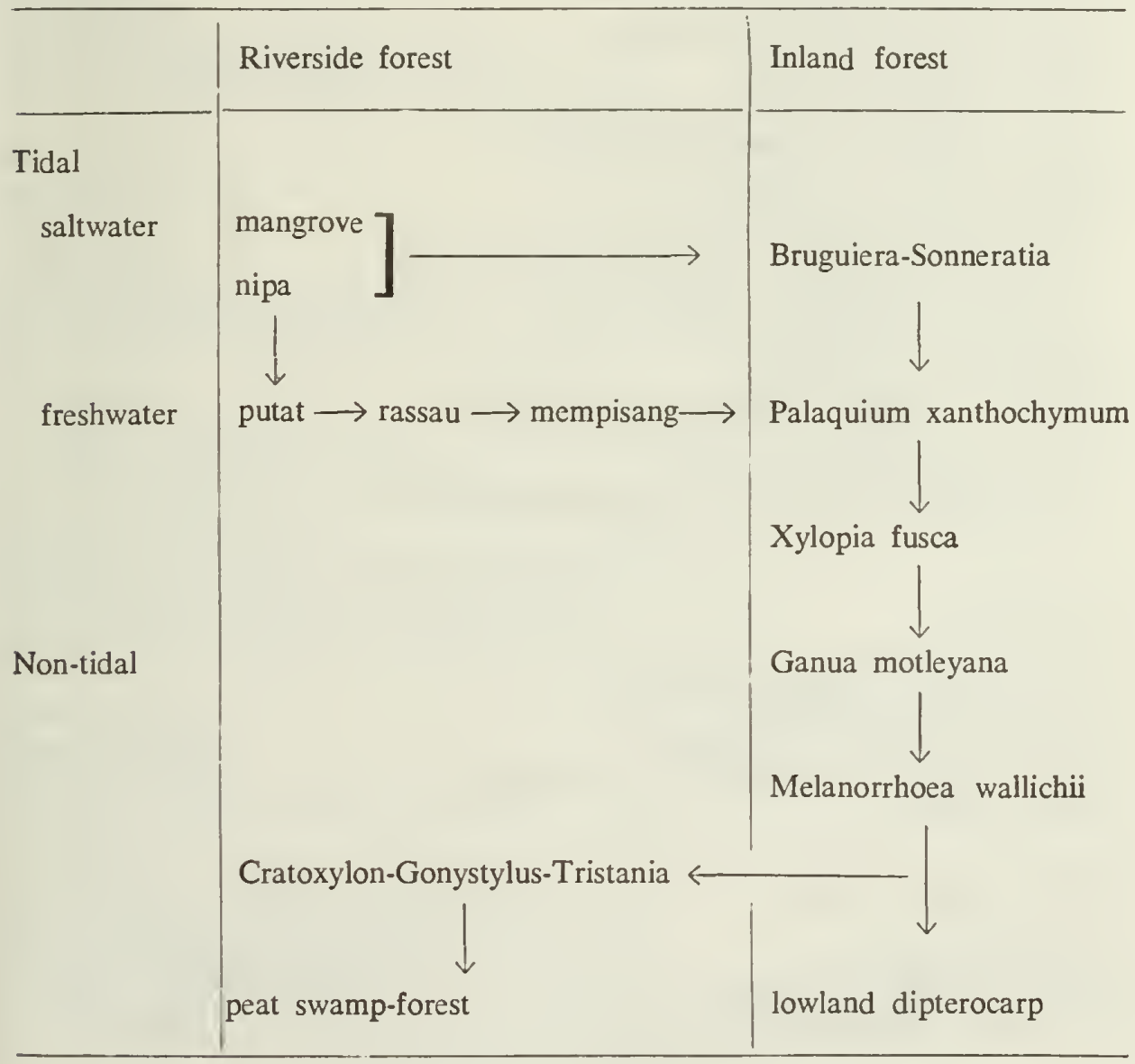


List of plants in the swamp-forest of Jurong (J) and Mandai Road (M) in Singapore and of Pontian $(\mathrm{P})$ in Johore.

(present marked as -; species not in the Sedili region marked *)

\section{ANACARDIACEAE}

Campnosperma auriculata; 26021 (J)

*C. macrophylla (Bl.) Hook. f.; 36625 (P), see special notes

C. squamata; 36757 (P)

* Mangifera aff. parvifolia; 26193 (J), see special notes

M. quadrifida; s.n. 1940 (M)

Mangifera sp.; s.n. 1940 (M)

Melanochyla auriculata

*M. kunstleri King; 37128 (M)

Melanorrhoea wallichii; 26095 (J), 37116 (M)

* Melanorrhoea sp.; s.n. 1933 (J)

Parishia sp.; s.n. (M)

\section{ANNONACEAE}

*Cyathocalyx ramuliflorus (Maing.) Scheff.; 26162 (J)

Cyathostemma viridiflorum; 39246( (M)

Desmos dumosa; s.n. 19.10.32 (J), big climber

Goniothalamus malayanus; 36775 (P)

G. ridleyi King; s.n. 26.1 .30 (M), 14.9.30 (M)

Mezzettia leptopoda; 33147 (M)

Mitrella kentii; 26157 (J), s.n. 28.11.34 (M)

* Oxymitra biglandulosa (Bl.) Scheff.; 38870 (M)

*O. borneensis Miq. var. sumatrana Miq.; 40004 (M)

O. glauca; 26151 (J)

Polyalthia angustissima; 40028 (M)

P. glauca; 26099 (J); 34448, 37120, 37706 (M)

$P$. hypoleuca; 26163 (J); 36644, 36689, 36697 (P); tepis; see special notes. Plate 37

P. lateriflora; 33141,40375 , s.n. 12.8 .40 (M); 33141 as a $13 \mathrm{~m}$ tree with c. 100 fruiting carpels per branch

$P$. sclerophylla; s.n. 1940 (M)

* Popowia hirta Miq.; 39540 (M)

* Pyramidanthe prismatica (Hook.f.) J. Sinclair; 26152 (J)

Uvaria leptopoda; 26153, s.n. 3.11 .32 (J)

Xylopia caudata; 26030 (J)

X. fusca; $26096(\mathrm{~J}) ; 34531,37115(\mathrm{M})$

X. malayana; 26098 ; s.n. 4.2 .33 (J); $37140,37147,37744$, s.n. 26.7.40, Nov. 1940 (M)

\section{APOCYNACEAE}

Alstonia angustifolia

A. spaihulata

Anodendron candolleanum

Kopsia singapurensis; 37714 (M), abundant

Parameria polyneura; 37733 (M)

Tabernaemontana corymbosa; 30668 (M)

* Urceola torulosa Hook. f.; 34529 (M)

*Urnularia flavescens (Dyer) Staff; 26161 (J), 37135 (M)

Willughbeia coriacea

\section{A POSTASIACEAE}

Nieuwiedia griffithii; 36758 (P)

\section{AQUifoliaCEAE}

Ilex cymosa; 37726 (M)

*I. macrophylla Wall.; 36620 (P)

Ilex sp.; 36633, 36673, 36691 (P)

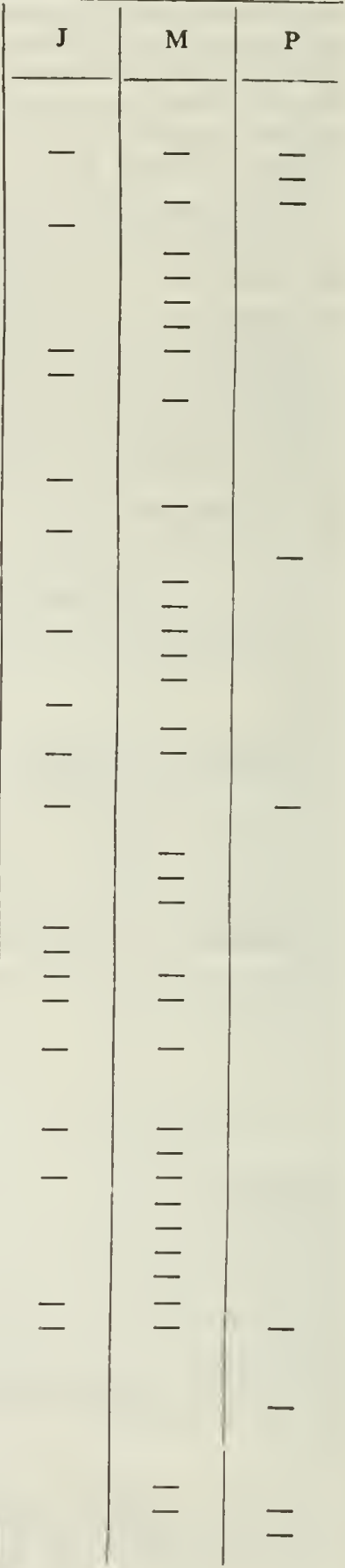




\section{ARACEAE}

Aglaonema nitidum

* A. pictum Kunth; s.n. 18.6 .39 (P)

Alocasia denudata

Anadendrum montanum

Homalomena sagittifolia

H. sagittifolia var. angustifolia; 36652 (P)

Pothos latifolia Hook.f.; 26102 (J)

Raphidophora sylvestris: 36774 (P)

\section{ARAliaceae}

Arthrophyllum ovalifolium

* Schefflera cephalotes (C.B.Clarke) Harms; 28142 (J). Plate 37

S. subulata; 36653 (P)

\section{ASClepIADACEAE}

Dischidia coccinea; 36772 (P)

D. collyris

$D$. aff. complex; see special notes

D. hirsuta

D. nummularia

D. rafflesiana

Hoya lacunosa

Hoya sp.; (P)

* Physostelma wallichii Wight; s.n. 25.6 .39 (P)

Toxocarpus glabrescens; (J), frequent slender climber

* $T$. griffithii Dene

\section{BIGNONIACEAE}

Deplanchea bancana

BOMBACACEAE

\section{Coelostegia griffithii}

Durio graveolens; s.n. 1940 (M)

D. singapurensis; 26060,37046 (M)

Neesia malayana; 37138 (M)

\section{Burseraceae}

*Canarium pilosum Benn.; 26197, s.n. April 1933 (J); 26135, 33142, $37130(\mathrm{M})$

C. odontophyllum; s.n. 25.4.34 (M)

* Dacryodes incurvata (Engl.) H.J. Lam; s.n. 29.7 .40 (M)

D. rostrata; $37743(\mathrm{M})$

Santiria apiculata; 26046 (J); s.n. 25.7 .40 (M) 36648, 36753 (P)

*S. griffithii (Hook.f.) Engl.; 34904 (M), $20 \mathrm{~m}$ tree

S. laevigata; $26039,26046(\mathrm{~J}) ; 36648,36753(\mathrm{P})$

S. rubiginosa; s.n. 26.2 .33 (J); 34903, 37118, s.n. 25.7 .40 (M)

S. tomentosa; $36755(\mathrm{P})$

\section{Celastraceae}

Bhesa paniculata

Euonymus javanicus

Lophopetalum multinervium; 28092 (M)

\section{Clusiacene}

Calophyllum floribundum; s.n. 14.1 .33 (J); 33143, s.n. 12.9.36, $26.7 .40,1.8 .40(\mathrm{M})$; no special roots

C. incrassatum; s.n. 12.11.36 (M), flowering Oct.-Nov.

C. inophylloides var. singapurense

*C. molle King; 37715 (M)

C. retusum; 26047, 26159, s.n. 13.12.32, 25.12 .32 (J); 36637 (P); common tree $-35 \mathrm{~m}$, no special roots, at Jurong

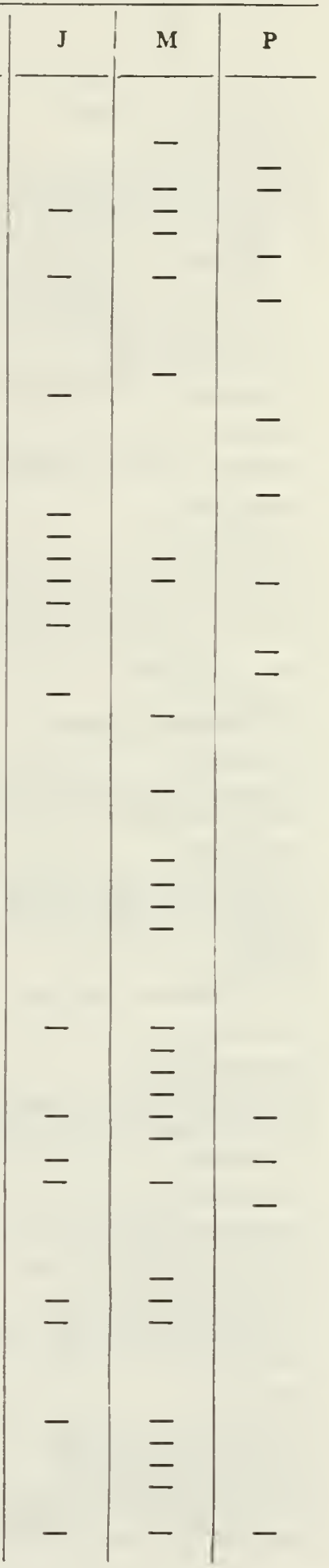


Clusiaceae - continued

C. wallichianum

Garcinia bancana; 36618, 36666, 36755 (P)

G. forbesii; 34625,34626 (M)

G. gaudichaudii; 26038 (J)

G. ? hombroniana; s.n. 20.8 .40 (M)

G. nigrolineata: 26198 (J); 28098, s.n. 15.4 .34 (M); 36614, 36617 (P); see special notes

G. parvifolia; s.n. 19.10.32 (J); fissured grey bark, yellow latex

G. ? rostrata; 26097 (J); 36613, 36615, 36629, 36687 (P); see special notes

${ }^{*} G$. scortechinii King; s.n. 7.9 .40 (M)

Garcinia sp.; 28087, 28094 (M); see special notes

COMBRETACEAE

Terminalia phellocarpa; 36987, s.n. 5.9.40 (M)

CONNARACEAE

Agelaea borneensis

Cnestis palala

Connarus monocarpus ssp. malayanus

C. semidecandrus; s.n. 25.7 .40 (M)

Rourea minor; 37124,37139 (M)

Convolvulaceae

Argyreia ridleyi

* Erycibe griffithii Clarke

CORNACEAE

Alangium ebenaceum var. tutela; 37708 (M)

Mastixia trichotoma; 37746 (M)

\section{CYPERACEAE}

*Cyperus sphacelatus Rottb.; 36776 (P), forest edge

Fimbristylis pauciflora, 36784 (P), forest edge

Mapania enodis

$M$. lorea

Mapania sp.

Thoracostachyum bancanum

Dilleniaceae

Acrotrema costata

Dillenia grandifolia

D. pulchella; 26041 (J); 36640 (P); $33 \mathrm{~m}$ at Jurong

* Tetracera akara (Burm.f.) Merr. (T. sylvestris)

T. arborescens s.n. 25.11 .40 (M) (T. lucida)

DipTEROCARPACEAE

*Anisoptera marginata Korth.; (J), 20 m tree, scarce

Hopea mengarawan

Shorea ? eximia; 37719 (M)

*S. gratissima Ridley

S. macroptera; $37125(\mathrm{M})$

S. platycarpa; 37720, s.n. April-May 1933 (M); 36680 (P)

Vatica wallichii; 26184 (J)

Ebenaceae

*Diospyros coriacea Hiern; 37150 (M)

D. lanceifolia; 37145 (M)

D. maingayi; 37711 (M)

D. oblonga; 37728,37749 (M)

D. siamang; $26167(\mathrm{~J}) ; 36623(\mathrm{P})$; see special notes

Diospyros sp. A; s.n, 1.7.39 (P); see special notes

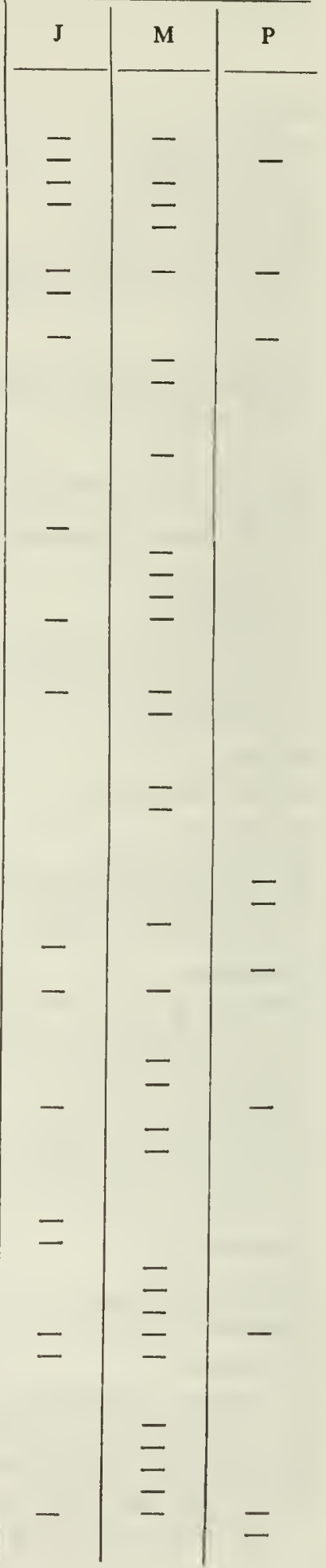




\section{Elaeocarpaceae}

Elaeocarpus griffithii; $32522,34530(\mathrm{M})$, with stilt-roots $-45 \mathrm{~cm}$ high; 36649 (P)

-E. mastersii King

E. polystachyus

Elaeocarpus sp.; s.n. 1.7.39 (P), sapling with few stilt-roots $.1 \mathrm{~m}$ high, buds resinous

\section{EUPHORBIACEAE}

Agrostistachys sessilifolia

- Alchornea villosa (Benth.) M.A.

- Antidesma? montanum B1.; 36602, 36630 (P)

Austrobuxus nitidus; 28143 (J); 36619 (P)

Baccaurea? bracteata

B. kunstleri King

Baccaurea sp.; 37713 (M); tree $-23 \mathrm{~m}$, fruit yellow-ochre with pale orange translucent seed-pulp

Blumeodendron tokbrai; s.n. 19.10.32 (J); 30665, 32515, 37113 (M); 36766 (P)

Bridelia cinnamomea

B. griffithii Hook.f.

Croton laevifolius

-Drypetes pendula Ridley; 33148 (M)

Endospermum diadenum

Galearia fulva; 34450 (M)

Glochidion lutescens; 32525, 32526 (M)

G. leiostylum; 32527, 32533, s.n. 25.11.36 (M)

G. sericeum

- Hymenocardia sp.; 26100, 28146 (J); see special notes

- Macaranga conifera (Zoll.) M.A.; 34543 (M)

M. gigantea

M. griffithiana

$M$. hypoleuca

M. pruinosa

M. puncticulata; 26033 , s.n. 19.10 .32 (J); 36636, 36688 (P)

M. recurvata; 34528,37709 (M)

M. trichocarpa

M. triloba

Pimeleodendron griffithianum; 37717 (M)

- Sapium discolor (Champ.) M.A.

\section{Fagaceae}

Castanopsis inermis

Lithocarpus bennettii; 26192 (J); 37149 (M)

L. elegans; 36545 (M)

L. encleisacarpus

\section{Flacourtiaceae}

- Casearia lobbiana Turcz; (J), common; 32532 (M)

Casearia sp.; 32517 (M); see special notes

Flacourtia rukam

- Osmelia maingayi King; 28096 (M)

Flagellariacene

Flagellaria indica

Hanguana malayana; 36651 (M)

\section{GESNERIACEAE}

Aeschynanthus parvifolius; 36612 (P)

A. wallichii; 26034 (J); 36656 (P)

\section{GONYSTYLACEAE}

Gonystylus bancanus; 36657 (P); see special notes

G. confusus; s.n. $7,9.40$ (M)

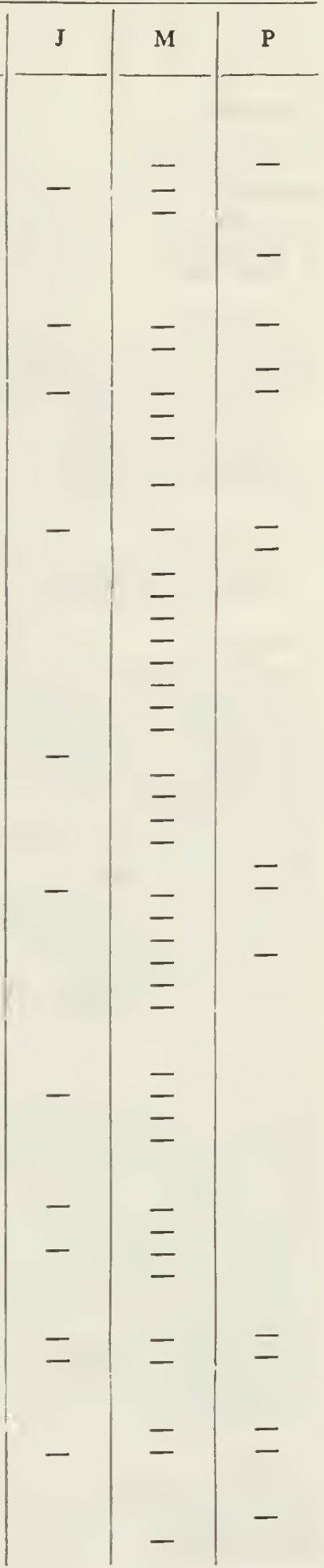




\section{GRAMINEAE
Leptaspis urceolata
HYPERICACEAE
Cratoxylon arborescens; 36665,36754 (P)
C. formosum \\ C. formosum}

\section{ICACINACEAE}

Cantleya corniculata; 26182 (J)

* Phytocrene bracteata Wall.;

- Platea excelsa Bl. var. riedeliana Sleumer; 36686 (P); see special notes. Plate 18.

P. latifolia; 37723 (M)

Stemonurus scorpioides

S. secundiflorus; $36761(\mathrm{P})$

\section{JUGLANDACEAE}

- Engelhardtia serrata Bl.; 36658, 36677 (P); tree to $33 \mathrm{~m}$ high, kedi; ( $E$. nudiflora)

\section{LAURACEAE}

Actinodaphne maingayi; s.n. 29.7.40 (M)

A. sesquipedalis var. venosa; $36766(\mathrm{P})$

Actinodaphne sp.; 36765 (P); tree $-5 \mathrm{~m}$

* Alseodaphne ? penduliflora

Beilschmiedia kunstleri; (M) frequent

Cryptocarya griffithiana

Cryptocarya sp.

* Hexapora ? curtisii; 26196, s.n. 4.3 .33 (J); see special notes Lindera lucida

L. malaccensis; 28091 (M)

*Litsea ferruginea Bl.; 28093, 37132 (M)

L. firma; s.n. 3.1.37 (M), common

L. gracilipes; s.n. $3.7 .39(\mathrm{P})$

L. grandis; 34449 (M)

"L. machilifolia Gamble; s.n. 3.8.39 (P)

Litsea sp.; s.n. 1.8.40 (M)

\section{LEGUMINOSAE}

-Adinobotrys erianthus Dunn; s.n. 12.8.40 (M)

Crudia caudata; 24985 (M)

* Dalbergia havilandii Prain; s.n. 17.3.32 (J); climber

Dialium patens; 37721 (M); 36759 (P)

D. platysepalum; 36764 (P)

D. wallichii; s.n. 4.7 .39 (P)

Koompassia malaccensis; 37745 (M); 36764 (P)

* Kunstleria curtisii Prain

* K. ridleyi Prain; 37735 (M)

* Ormosia macrodisca Baker; (J); see special notes

Parkia speciosa

* Pithecellobium confertum Benth.

-P. ellipticum (Bl.) Hassk.

Sindora wallichii

Spatholobus sp.

\section{LiLiaceae}

Dianella ensifolia

Dracaena sp.

Peliosanthes sp. 


\section{LiNACEAE}

Ctenolophon parvifolius; 36607, 36647, 36672 (P); see special notes

Roucheria griffithiana; (J), common

\section{LOGANiACEAE}

*Fagraea auriculata Jack; 37739 (M); 36752 (P)

F. ceilanica; $36671(\mathrm{P})$

$F$. racemosa

\section{Magnoliaceae}

*Armomadendron nutans Dandy; 36626 (P); see special notes. Plate 9.

* Talauma lanuginosa Hook.f.; 37272 (M)

T. singapurensis; $37126(\mathrm{M})$, frequent

\section{MARANTACEAE ?}

\section{Melastomataceae}

* Anplectrum viminale (Jack) Triana; 30666 (M)

* Marumia rhodocarpa Cogn.; 26035 (J)

Medinilla rubicunda var. hasseltii; (J), common; 36642 (P)

Memecylon sp.; 37742 (M)

Pternandra coerulescens; 37737 (M)

* $P$. echinata Jack

\section{Meliaceae}

Amoora rubiginosa; 26020 (J); 36601, 36641 (P)

Aphanamixis rohituka: 26036 (J)

"Sandoricum $?$ emarginatum; 33146 (M)

\section{MoraceaE}

Artocarpus elasticus

A. kemando; 37716 (M)

A. nitidus ssp. griffithii; 32545 (M)

* A. scortechinii King;

*Ficus albipila Miq.; s.n. 1932 (J), one tree (? the last in Singapore)

F. apiocarpa; (J), common

F. binnendijkii; 36543 (M)

F. bracteata; 24797, s.n. 1940 (M)

F. callophylla; 36955 (P)

$F$. consociata

F. excavata; s.n. 18.11 .32 (J)

$F$. fistulosa

F. globosa; $37738(\mathrm{M})$

F. grossularioides; 36777 (P)

$F$. microcarpa

F. microsyce; s.n. $25.7 .40(\mathrm{M})$

F. obscura var. borneensis; 24798 (M); 36692, 36773 (P)

F. pellucido-punctata; 37127 (M)

$F$. recurva var. ribesioides; s.n. 22.1 .33 (J)

F. retusa;

$F$. ruginervia

F. sagittata var. minor; $39992(\mathrm{M})$

F. stricta; $36693(\mathrm{P})$

F. sundaica; 37137,37143 (M)

F. trichocarpa; s.n. 3.11 .32 (J); 25.11 .40 (M)

* F. tristaniifolia Corner; 36606,36698 (P)

F. villosa

*F. xylophylla Wall.; 37136 (M); 36694 (P)

Parartocarpus venenosus ssp. forbesii; 26194, 28145, 28147 (J); $36661,36682(\mathrm{P})$

*Streblus elongatus (Miq.) Corner

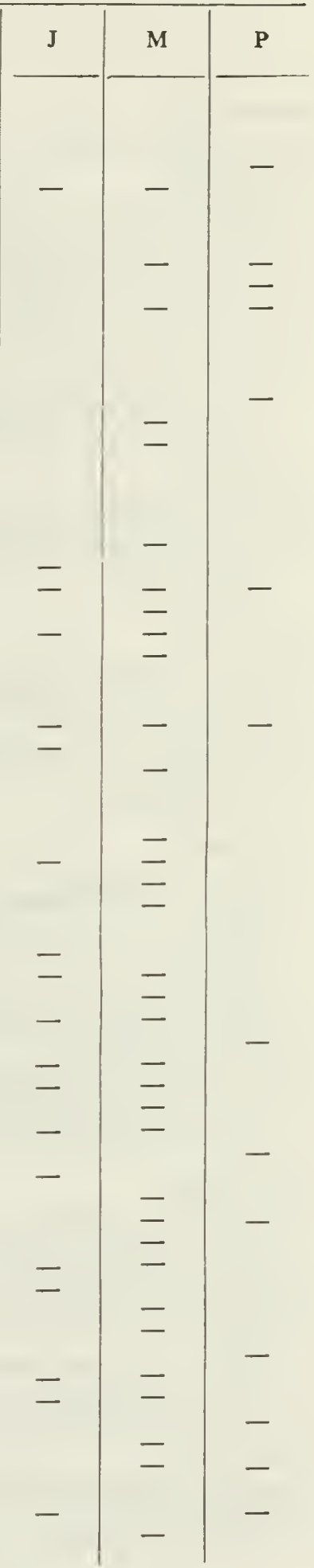




\section{MYRISTICACEAE}

Gymnacranthera bancana

G. eugeniifolia var. griffithii; 37718 , s.n. 26.7 .40 (M); s.n. 2.7.39 (P)

Horsfieldia bracteosa; s.n. 26.7 .40 (M)

H. crassifolia; $34542,34905,37710,37258$ (M)

$H$. grandis; see Sinclair (1975, p. 48)

H. macrocoma var. canarioides;

H. polyspherula; s.n. 5.3 .33 (J); 37144, s.n. 24.7 .40 (M)

*H. subglobosa (Miq.) Warb.

H. superba;

Knema conferta; $33145,37129,37254$ (M)

* K. curtisii (King) Warb, var. paludosa J.Sinclair 26155 (J); 37123, 37148, s.n. 15.4.34 (M)

K. glaucescens var. patentinervia; s.n. 24.7 .40 , s.n. 7.8 .40 (M)

$K$. intermedia; 34544 (M)

$K$. malayana

Myristica cinnamomea; see Sinclair (1958a, p. 360)

M. elliptica; 37275 , s.n. 24.7 .40 (M)

$M$. iners; $28097,36282,37134(\mathrm{M})$

M. lowiana; 28131 , s.n. 19.10 .32 (J); 36603,36623 (P), flowering July 1939

\section{MYRSINACEAE}

Ardisia tuberculata; 36605 (P)

Ardisia sp.; 36609 (P); see special notes

Embelia ? amentacea; 26185 (J)

$E$. coriacea

Labisia punctata; (J), common; 36643 (P)

Maesa ramentacea

Pachycentria tuberosa

\section{MYRTACEAE}

Decaspermum fruticosum

* Eugenia brantiana Henders.; 36574, 36956, riverside, Pontian Besar

E. cerina; s.n. 15.10.32, 15.4 .33 (J); s.n. 26.7.40, $12.8 .40(\mathrm{M})$; 36639 (P)

E. cumingiana; 37727 , s.n. 1.8 .40 (M)

E. kiahii var. angustifolia; 36668 (P), tree $-17 \mathrm{~m}$

E. kunstleri; 37725 , s.n. $1.8 .40(\mathrm{M})$, tree $-10 \mathrm{~m}$

E. longiflora; 36767 (P)

* E. microcalyx Duthie; 39603 (M)

E. muelleri; 26042, 29966, s.n. $18.12 .32(\mathrm{~J})$, common

*E. nemestrina Henders.; 28095, 37252, 37396, 37736, s.n. $25.7 .40,12.8 .40(\mathrm{M})$, tree $-33 \mathrm{~m}$, frequent

E. oleina

E. pachyphylla

E. papillosa; 37259 (M)

*E. pseudocrenulata Henders.; 28090 (M)

E. ? rugosa; 26190 (J); 36612, s.n. 25.6.39 (P)

E. tumida; s.n. $15.1 .33(\mathrm{~J})$

Eugenia spp.; 37133 (M), 37730 (M), 37741 (M)

Pseudoeugenia singaporensis; 26029 (J), frequent; 37141, 37712 (M)

Tristania ? merguiensis; 26049, s.n. 5.12 .32 (J); see special notes. Plates 24, 34

T. pontianensis Henders.; 36659, 36695 (P); see special notes

NEPENTHACEAE

Nepenthes ampullaria; 36624 (P)

N. gracilis

N. rafflesiana; 36631 (P)

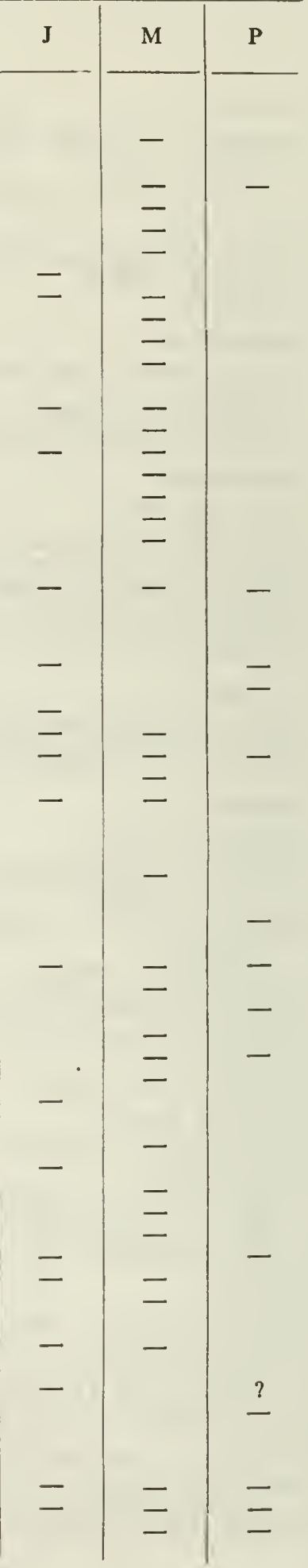


NYMPHAEACEAE

Barclaya motleyana

OCHNACEAE

Brackenridgea hookeri

*Euthemis leucocarpa Jack; 36635 (P)

\section{OLACACEAE}

Strombosia maingayi; 26160 , s.n. 17.4 .32 (J); 37257, 37707, $37740(\mathrm{M})$; tree $-23 \mathrm{~m}$, in swamp-forest

\section{Oleaceae}

Linociera ? insignis; 36664,36670 (P); tree $-13 \mathrm{~m}$ L. pauciflora

\section{ORCHIDACEAE}

*Adenoncos sumatrana J.J. Sm; 36676 (P)

Agrostophyllum bicuspidatum

Anaectochilus geniculatus

Appendicula lucida

Appendicula sp.

* Bromheadia finlaysoniana (Lindl.) Rchb. f.; 36685 (P)

Bulbophyllum acuminatum

B. apodum; 28132 (J)

$B$. botryophorum

B. pileatum; 26181 (J)

B. pulchellum

B. purpurascens

$B$. resirepia

B. sessile

B. vaginatum

Bulbophyllum sp. (sect. Aphanobulbum)

Calanthe pulchra

Camarotis adnata

Chamaeanthus laciniatus

Cheirorchis filiformis

Claderia viridiflora

* Coelogyne rochussenii de Vr.

Dendrobium aloifolium

*D. bifarium Lindl.

*D. calycopsis Ridley

D. carnosum

D. comatum

D. crumenatum

D. leonis

D. lonchophyllum

D. plicatile

D. prostratum

D. spurium

Dendrochilum longifolium

Eria floribunda

E. neglecta

E. nutans

E. pannea; $36762(\mathrm{P})$

*E pulchella Lindl.; 36770 (P)

E. velutina

Eulophia gramines; 36769 (P)

E. squalida:

Galeola kuhlii

Hylophila mollis

Lepidogyne longifolic

Liparis gibbosa

L. wrayi

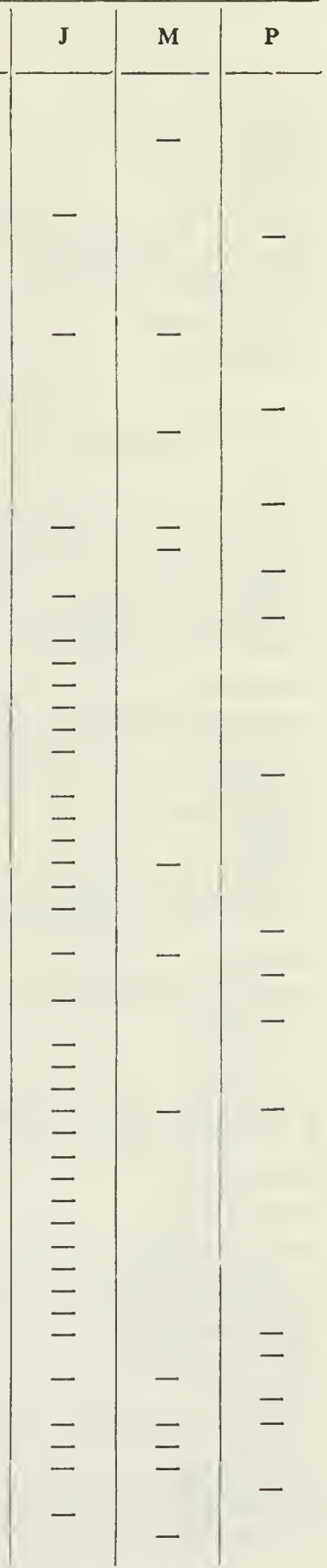


ORCHIDACEAE - continued

Malaxis micrantha

Nervilia punctata

Oberonia sp.

Plocoglottis javanica

Sarcostoma javanicum; 36763 (P)

Schoenorchis secundiflora

Taeniophyllum filiforme

T. obtusum

Thelasis micrantha

$T$. triptera

Vanilla griffithii

\section{Oxalidaceae}

Dapania racemosa; 36751 (P)

Palmae

Calamus spp.

Cyrtostachys lakka; (J), commonly tufted; (P), solitary

Daemonorops leptopus; s.n. Nov. 1932, March 1933 (J)

Daemonorops spp.

*Nenga pumila (Mart.) Wendl.; 26101 (J)

Oncosperma horridum

Salacca conferta; 26200 (J)

\section{PANDANACEAE}

Freycinetia angustifolia; s.n. 28.2 .42 (M)

F. confusa

F. corneri; 26481, s.n. 22.2 .43 (M)

F. javanica

Pandanus atrocarpus

P. alticola

P. kamii

$P$. odoratissimus; 37386 (P)

Pandanus sp:?P. helicopus, forest-form, as on the Sedili River)

Piperaceae

*Piper flavimarginatum C.DC.

$P$. miniatum

*P. nigrum $\mathrm{L}_{2}$

POLyGalacEAe

Xanthophyllum affine; 36542 (M)

$X$. ? ellipticum; (J)

RHAMnaCEAE

Zizyphus elegans

\section{RHIZOPHORACEAE}

Anisophyllea disticha

Carallia brachiata; 36546, 37273, 37281 (M); 36604 (P)

Gynotroches axillaris

Pellacalyx axillaris

\section{ROSACEAE}

Parastemon urophyllum; 37724 (M); ? 36663 (P), tree $-30 \mathrm{~m}$ high

Parinari costata

$P$. oblongifolia

*Pygeum griffithii Hook.f.; [Prunus arborea (B1.) Kalkm.]

*P. lanceolatum Hook.f.; [Prunus grisea (C.Muell.) Kalkm.]

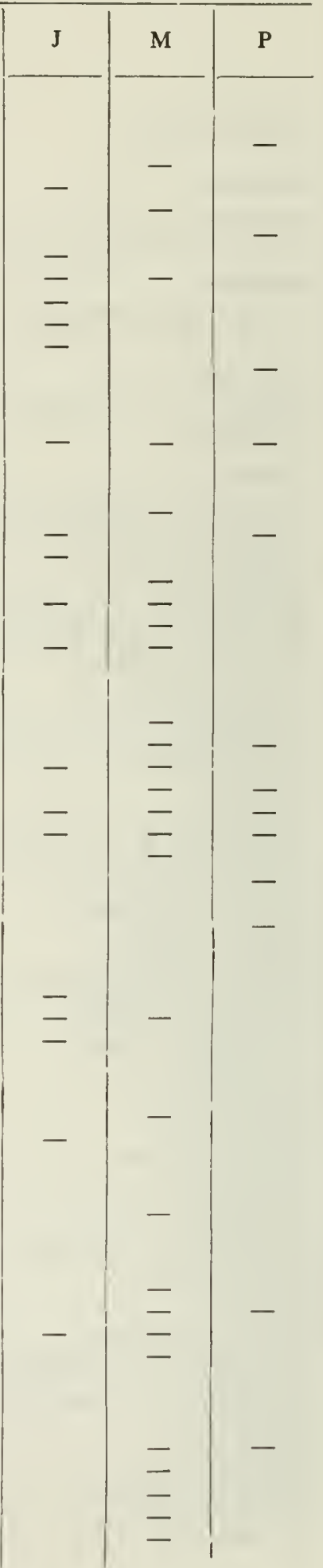




\section{RUBIACEAE}

* Coelospermum scandens $\mathrm{Bl}$.

Gaertnera sp.

Gynochthodes lanceolata: 36632, 36782 (P)

Ixora congesta

Hydnophytum formicarum

Jackia ornata; 26183 (J); 36638 (P)

Lasianthus griffithii

Lecananthus erubescens; 36654 (P)

Lucinaea morinda; 36681 (P)

Morinda ridleyi

*M. rigida Miq.; 26111 (J); see special notes

Mussaendopsis beccariana

Myrmecodia tuberosa

Pavetta indica

Psychotria maingayi

P. obovata; ? 36669 (P)

Randia auriculata; (J), common; 37750 (M)

* $R$. clarkei King; 26180 (J), scarce

* $R$. macrophylla Hook.f.

Tarenna appressa; 36645, 36778 (P)

T. longifolia

Timonius flavescens; 32524 (M); 36621 (P)

T. wallichianus

Uncaria ovalifolia; (J), common; 37146 (M); 36781 (P)

Urophyllum glabrum

U. streptopodium; s.n. 22.4 .34 (M)

RUTACEAE

Tetractomia major; 36674 (P), tree $-26 \mathrm{~m}$

T. tetrandra; $36634,36684,36690(\mathrm{P})$; see special notes

SANTALACEAE

*Dendrotrophe buxifolia (Bl.) Miq.; 36616 (P)

SaPINDACEAE

"Lepisanthes fruticosa (Roxb.) Leenh.; s.n. 20.8.40 (M)

Nephelium glabrum; 37131 (M)

N. rubescens

Pometia pinnata f. alnifolia; 37114 (M)

\section{SAPOTACEAE}

Ganua motleyana; 26158 (J)

Ganua sp.

"Palaquim burckii H.J.Lam; 36678, 36683 (P)

$P$. hexandrum; 37720 (M); buttressed steeply $.70 \mathrm{~cm}$

* P. leiocar pum Boerl.; 36679, 36646 (P)

${ }^{*} P$. ridleyi King et Gamble; 36699 (P); see special notes

*P. rostratum Burck; 37117,37720 (M), buttressed -2 m

P. semaram; 36298 (P)

P. xanthochymum; 37122 , s.n. $25.7 .40,1.8 .40$ (M)

Planchonella maingayi; 37734 (M)

\section{Simaroubaceae}

*Irvingia malayana Oliver; s.n. 12.8 .40 (M), on slightly raised bank at edge of swamp, with new leaves

STERCULIACEAE

Heritiera elata; 37731 (M); tree $-23 \mathrm{~m}$, fluted-buttressed $-3.5 \mathrm{~m}$ high

Sterculia bicolor; 37732 (M)

S. coccinea; (J), very common; (S. laevis)

S. macrophylla

S. rubiginosa

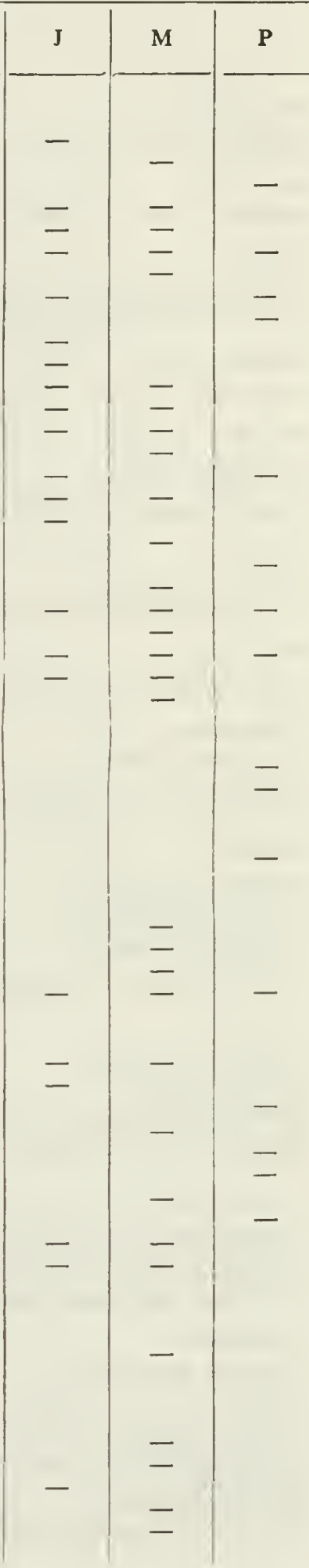




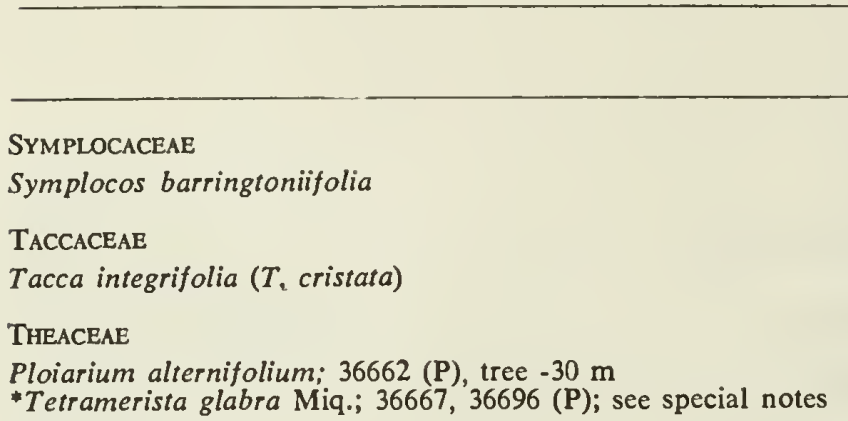

\section{Thymelaeaceae}

Aquilaria malaccensis; 37142 (M); see special notes

Tiliaceae

Grewia blattaefolia

G. umbellata

Pentace triptera; 37119 (M), fruiting 27.7 .40

\section{UlMaCEAE}

Gironniera parvifolia

Trema tomentosa; 36785 (P); (T. amboinensis)

\section{URTICACEAE}

Poikilospermum scortechinii; 36700 (P)

VERBENACEAE

Clerodendron deflexum

C. villosum

Callicarpa farinosa; 36783 (P)

\section{VITACEAE}

Pterisanthes coriacea

* Vitis glaberrima Wall.

-V. hastata Miq.

V. japonica; 36780 (P)

$V$. mollissima

*V. novemfolia Wall.; 36650 (P)

\section{ZiNGIBERACEAE}

Amomum hastilabium

A. xanthophlebium

Hornstedtia leonurus

${ }^{*}$ H. scyphiphora (Koen.) Steud.

Zingiber puberulum; 36608 (P)

\section{GYMNOSPERMAE}

Gnetum gnemonoides: 26191 (J), frequent

G. latifolium var. funiculare; 36660 (P)

G. microcarpum f. silvestre; (J), frequent

Podocarpus wallichianus; scattered

\section{PTERIDOPHYTA}

Asplenium glaucophyllum

A. nidus

*A. tenerum Forst.; 36655 (P)

Blechnum orientale

*Cyathea glabra (B1.) Copel.; 36610 (P)

C. latebrosa

Drynaria quercifolia

* Histiopteris incisa (Thunb.) J.Sm.; 36675 (P)

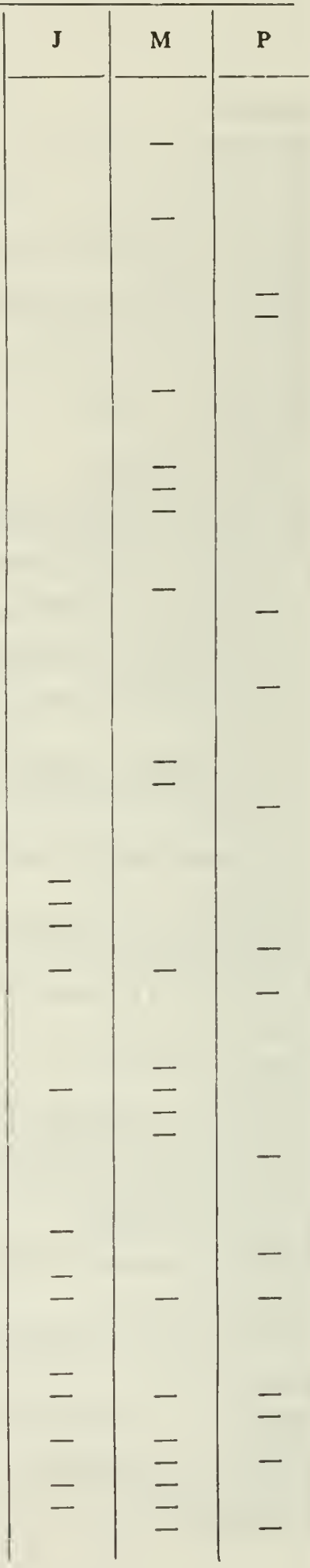




\begin{tabular}{|c|c|c|c|}
\hline & $\mathbf{J}$ & $\mathbf{M}$ & $\mathbf{P}$ \\
\hline $\begin{array}{l}\text { PTERIDOPHYTA - continued } \\
\text { Lindsaea scandens } \\
\text { Lycopodium phlegmaria } \\
\text { L. scabrum } \\
\text { L. squarrosum } \\
\text { Nephrolepis biserrata; } 36627 \text { (P) } \\
\text { Phymatodes sinuata } \\
\text { Platycerium coronarium } \\
\text { "Pteris tripartita Sw.; } 36760 \text { (P) } \\
\text { Pyrrosia angustata } \\
\text { Stenochlaena palustris } \\
\text { Taenitis blechnoides } \\
\text { Teratophyllum ludens } \\
\text { Thelypteris chlamydophora; (J), abundant } \\
\text { *Trichomanes motleyi v.d.Bosch } \\
\text { T. obscurum } \\
\text { Vittaria ensiformis }\end{array}$ & $\begin{array}{l}= \\
= \\
= \\
= \\
= \\
= \\
=\end{array}$ & $\begin{array}{l}- \\
- \\
- \\
- \\
= \\
-\end{array}$ & $\begin{array}{l}- \\
- \\
-\end{array}$ \\
\hline
\end{tabular}





\section{Part IV. Freshwater swamp-forest and peat swamp-forest.}

At the U.N.E.S.C.O. symposium in 1958 at Tjiawi, Java, interest in lowland tropical peat swamp-forest was re-awakened by Anderson's account of his thorough investigations in Sarawak and Brunei. The discussion which ensued, and is printed with the record of Anderson's paper, revealed almost as many points of view as there were speakers with different territories in mind. Since then Anderson (1963, 1964) has published his fuller accounts and Wyatt-Smith $(1959,1961,1964)$ has published his account of peat swamp-forest in Malaya; his work has been followed up by Hewitt (1967) and Tay (1969).

Peat swamp-forest is considered to be an outcome of freshwater swamp-forest, behind the mangrove and nipa, where for some reason the water-logged soil is no longer subject to tidal inundation or disturbed by the passage of streams. The forest débris accumulates into peat which raises the soil into a convex mound or dome, even up to $16 \mathrm{~m}$ in depth in Sarawak and Brunei, and becomes eventually so poor for plant-growth that a rather low forest of small trees, like crowded poles, survives along with a little undergrowth and Sphagnum. Regeneration is mainly vegetative through suckers or coppice-shoots from trunks broken by wind or blown down (Ashton 1964, plate 12; see also plate 12 in this paper).

Anderson distinguished six phasic communities in the development of the peat swamp-forest of Sarawak and Brunei. They are largely peculiar to these countries because many of the dominant or participant trees are endemic, e.g. Shorea albida and species of Casuarina, Dacrydium, and Dactylocladus. The first phasic community, with abundance of Gonystylus bancanus and Neoscortechinia (as well as Dactylocladus), has its analogy in Malaya and Sumatra, and so has the final phase of pole-forest though worked out with different species. Thus, if the Menchali F.R. in south Pahang (without Gonystylus and Tetramerista) is peat swamp-forest, then Vatica wallichii forms the pole-forest (Beveridge 1953). Ecologically the sequence has similarities in all the countries but floristically there are differences between Borneo, on the one hand, and Malaya and Sumatra on the other hand; they should not be under-rated. The litter of Malayan peat swamp-forest may not be so resistant to decay and, therefore, such strongly domed peat swamps as in Borneo may not develop. In other words, the peat swamp-forests of Malaya appear to represent Anderson's first phasic community more or less integrated, at least peripherally, with freshwater swamp-forest.

In his map of the peat swamp-forests of the Malay Peninsula Wyatt-Smith excludes the swamp-forests of the Johore and Sedili rivers, but includes that of Pengkalan Rajah at Pontian. Certainly at Pontian Gonystylus bancanus, Gymnacranthera eugeniifolia, and Tetramerista were abundant, as in Anderson's first phasic community. Yet, floristically, the Sedili region was closer to Wyatt-Smith's circumscription of peat swamp-forest. He gives 36 species as characteristic, to which I add Polyalthia hypoleuca because it is probably confused with $P$. glauca. Of these 37 species, 9 are not recorded from the Sedili region; 10 are not recorded by Anderson for Borneo; 16 are not recorded from Pengkalan Rajah; 18 are not from Jurong and 20 not from the Mandai Road. Some of these differences may be omissions of collecting or faults in identification of sterile specimens, but on the whole they are ecological or phytogeographical. The nine species of Malayan peat swamp-forest missing from the Sedili region are:-

Anisoptera marginata (J), Calophyllum scriblifolium, (local in north Johore and in Perak), Campnosperma macrophylla (P), Durio carinatus, Palaquium ridleyi (P), Phoebe declinata, Shorea rugosa var. uliginosa, S. teysmanniana, and Tetrainerista glabra (P); note occurrence in Jurong (J) and Pontian (P). 
The three of these nine species which occurred at Pontian seem to indicate progress from freshwater swamp-forest, for the region was certainly inundated at times, towards peat swamp-forest, but there was no pole-forest at the site.

The species of Tristania are puzzling and in need of taxonomic revision. It is a peat-forming genus in that the vegetative parts are slow to decay. It is not in Wyatt-Smith's list of peat-swamp species, but Anderson records $T$. grandifolia, $T$. aff. maingayi, and $T$. obovata for the Bornean peat-swamps. T. ? merguiensis was characteristic of the Jurong swamp-forest and the allied $T$. pontianensis of that at Pontian. Sewandono (1938) recorded Tristania sp. for the Sumatran swamps, but Polak (1933) made no mention of it. In the Sedili region, apart from the riverside $T$. sumatrana, $T$. ? merguiensis was curiously rare and $T$. pontianensis, or an ally, occurred with another species in the hillock-forest.

The following 16 species are excluded from the definition of peat swamp-forest by Wyatt-Smith and referred to freshwater swamp-forest:-

Campnosperma auriculata, C. squamata (C. minor), Coelostegia griffithii, Dryobalanops oblongifolia. Engelhardtia serrata (E. nudiflora), Hopea mengarawan, Macaranga triloba, Melanorrhoea wallichi, Mezzettia leptopoda, Nauclea maingayi, Neesia, Palaquium xanthochymum, Parishia insignis, Pometia pinnata, Shorea platycarpa, and Vatica wallichii.

Except Engelhardtia, which was common at Pontian, the fifteen other species were common in the Sedili region and, mostly, at Jurong and the Mandai Road. Anderson, however, records many of them in his first phasic community which, evidently, makes the transition from freshwater to peat swamp-forest and for which there can be no exact limits. With increasing stagnation and peat-development, the

Table 6. Specifie comparison between the swamp-forest of the Sedili region and that of Sarawak and Brunei (S.B.).

\begin{tabular}{|c|c|c|c|c|c|}
\hline Category & S.B. & Sedili & $\begin{array}{l}\text { Species } \\
\text { in } \\
\text { common }\end{array}$ & $\begin{array}{l}\text { Sedili secies } \\
\text { in common } \\
\text { as \% of S.B. }\end{array}$ & $\begin{array}{l}\text { Species at Pontian (P), } \\
\text { Mandai Road (M), or } \\
\text { Jurong (J), not in the } \\
\text { Sedili region }\end{array}$ \\
\hline Upper storey & 38 & 92 & 13 & $34 \%$ & $1(\mathrm{~J}), 1(\mathrm{P})$, see note 1 \\
\hline Middle storey & 65 & 142 & 24 & $37 \%$ & $1(\mathrm{M}), 3(\mathrm{P})$, see note 2 \\
\hline Lower storey & 38 & 170 & 15 & $39 \%$ & \\
\hline Under storey & 11 & 168 & 2 & $18 \%$ & 1 (G. Panti), see note 3 \\
\hline Shrubs & 20 & 71 & 9 & $45 \%$ & $1(P)$, see note 4 \\
\hline Herbs & 14 & 78 & 6 & $43 \%$ & $1(P)$, see note 5 \\
\hline Sun-epiphytes & 14 & 93 & 9 & $40 \%$ & $2(\mathrm{P})$, see note 6 \\
\hline Shade-epiphytes & 9 & 38 & 3 & $33 \%$ & \\
\hline Large elimbers & 19 & 94 & 7 & $37 \%$ & $\begin{array}{l}1 \text { (Selangor), } \\
1 \text { (Endau), see note } 7\end{array}$ \\
\hline Small elimbers & 17 & 82 & 9 & $53 \%$ & \\
\hline Pteridophyta & 30 & 52 & 12 & $40 \%$ & 1 (M.P), see note 8 \\
\hline Totals & 387 & 1080 & 138 & $36 \%$ & $\begin{array}{l}2(\mathrm{~J}), 4(\mathrm{M}), 10(\mathrm{P}) \\
2(\mathrm{G} . \text { Panti), see note } 9\end{array}$ \\
\hline
\end{tabular}

Note 1: Anisoptera marginata (J), Tetramerista glabra $(\mathrm{P}),-$ Note 2: Eugenia nemestrina (M), Aromadendron nutans (P), Palaquium ridleyi (P), Platea excelsa (P).-Note 3: Disepalum anomalum. - Note 4: Euthemis leucocarpa (P).-Note 5: Aglaonema pictum (P).-Note 6: Adenoncos sumatrana (P), Eria pulchella (P).-Note 7: Ficus spathulifolia (Sclangor), Willoughbeia grandiflora (W. glaucina; Endau).-Note 8: Cyathea glabra (M.P.),-Note 9: Ficus tristaniifolia (P). Elaeocarpus mastersii (J,M), Sandoricum? emarginatum (M), Pygeum griffithii (M), Dipodium pictum (G. Panti). 
flora begins to be impoverished. To obtain a fuller idea of this depletion I have compared in Table 6 the two kinds of swamp-forest according to the ecological categories used by Anderson (1963); the riparian species and those of brackish swamp have been omitted.

The incessant tidal seepage in and out of the Sedili swamp-forest, the frequence of rain-floods, and the devious passage of streams prevented the accumulation of peat and permitted the continued enrichment of the soil with silt. Yet, in nearly all the ecological categories, the percentage of species in common with Anderson's list for Sarawak and Brunei was roughly the same, about $36 \%$. Possibly in the interior of the swamp inland from Jason Bay there was some deterioration into peat swampforest. At the Mandai Road the forest partook of the richness of the Sedili region. With Jurong and Pontian it was different.

About $50 \%$ of the species in the relatively poor flora of Pengkalan Rajah are recorded by Anderson for Bornean peat-swamps. The resemblance is heightened by the abundance of Gonystylus, Gymnacranthera, Ctenolophon, Tetramerista, and large trees of Parastemon urophyllum, which was nowhere conspicuous in the Sedili region. Then, the ten species which Pengkalan Rajah had in common with Borneo, but did not occur in the Sedili region (Table 6, notes), emphasize the resemblance, especially the rare Aromadendron nutans and Ficus tristaniifolia. Further, the following trees (c. 36 species) of freshwater swamp-forest were not recorded either for Pengkalan Rajah or by Anderson for Sarawak and Brunei:-

Melanorrhoea wallichii, Pentaspadon, Coelostegia, Kostermansia, Terminalia phellocarpa, Dillenia grandifolia, D. reticulata, Dryobalanops oblongifolia, Dipterocarpus lowii, D. sublamellatus, Hopea mengarawan, Shorea bracteolata, S. exelliptica, S. palembanica, S. singkawang, S. sumatrana, Vatica wallichii, Elaeocarpus macrocerus, Ixonanthes reticulata, Lithocarpus bennettii, L. leptogyne, L. urceolaris, Cratoxylon formosum, Artocarpus elasticus, A. kemando, Myristica crassa, $M$. iners, Eugenia papillosa, Parinari, Strombosia, Palaquium xanthochymum, Heritiera elata, Pterospermum, Adinandra, Gordonia, Pentace triptera, and the water-lily Barclaya.

The felling which took place at Pengkalan Rajah at the time of our investigation prevented careful ecological analysis. I have no record of a raised bog, of Sphagnum, or of pole-forest. The Jurong forest seemed to be freshwater swampforest moving towards the first phase of peat swamp-forest, as it was represented at Pengkalan Rajah. Clearly, this had led through freshwater swamp-forest to the mangrove on the west coast of Johore. Topography and phytogeographical position must effect these initial stages of peat swamp-forest. Thus, even Tristania-banks on the Sedili Besar could subside into freshwater swamp-forest and, if isolated topographically, could initiate a minor peat swamp-forest. Such transitions evidently occurred, as one would expect, on a vaster scale in south Sumatra (Polak 1933, Sewandono 1938). The phytogeographical aspect involves the historic or geological. It is important because it is not clear that the peat of one floristic region is identical or ecologically equivalent with that of another. Every area of swamp-forest, therefore, needs its particular investigation. With the rapid destruction of lowland forest, many areas of original swamp-forest will have been annihilated without record. Hence I have put on record the few and imperfect observations that I was able to make.

\section{The Riouw pocket}

The centre of the peat swamp-forests of Sarawak is the mouth of the Rejang river. About 460 miles to the west, across the China Sea and roughly in the same latitude, there is the mouth of the comparatively tiny Sedili river. In the glacial period, as we are given to understand (Haile 1971), the sea receded to its present $100 \mathrm{~m}$ contour. A vast plain connected the Malay peninsula and Borneo. It was 
broken by the mountains of the east coast islands of Malaya and of the Anamba and Natuna islands. Great rivers traversed this plain in a north easterly direction from the mountains of the Malayan mainland, Sumatra, Java, the Riouw Archipelago, and west Borneo. The plain must have been filled in great part with swamps of mangrove, nipa, and freshwater swamp-forest, possibly several hundred miles in extent and far greater than at present. This aggregate of swamp and river was, surely, a formidable barrier to the migration of plants and animals from the dry land on one side to the other. Thus these countries retain their floristic and faunistic peculiarities but enjoy a common heritage of such plants and animals that dwelt in the swamps or negotiated the peripheral uplands. With the return of the sea, making islands of the former mountains, the vegetation receded until present geography shows the narrowed swamp-lands of south Malaya, east Sumatra, and west Borneo. At its maximum return, about $40 \mathrm{~m}$ above its present level, the sea must have driven the swamp-forest even further inland. Now this basin is the region to which I have referred in my accounts of the geography of Ficus as the Riouw pocket (Corner 1958, 1969). I have sought to investigate it from the point of view of the swamp-forest, especially the dipterocarps (Symington 1943; Ashton 1964a, 1968) and Ficus (Corner 1965).

Firstly I note that, so far as is known, the Sedili region is a critical southernmost limit in Malaya for species which occur commonly or mainly on the east side of the peninsula. Thus:-

i. Absent apparently from the Sedili region:- Anisoptera marginata, Cotylelobium malayanum, Dipterocarpus coriaceus, Hopea nutans, and Shorea macrantha. All these occur in Borneo but only A. marginata is also in Sumatra, as it is in Singapore. Fagraea fragrans, common on the coast of Pahang, offers a similar problem. Thus, the flora of the Menchali F.R., just north of the Rompin river, is already different from that of the Sedili (Beveridge 1953).

ii. With the Sedili region as the southernmost Malayan limit:-Dipterocarpus lowii, Dryobalanops aromatica, Shorea collina, S. exelliptica, S. foxworthyi, S. materialis, S. resina-nigra, S. singkawang, S. sumatrana; Ficus beccarii, $F$. obpyramidata, $F$. stupenda, $F$. uncinata, $F$. uncinulata, Artocarpus gornezianus. All these occur in Borneo except $S$. collina, $S$. sumatrana (which has there a close ally in $S$. seminis), and $A$. gomeziants.

Secondly I note that, for the peat swamp-forest of Sarawak and Brunei, 9 of the 15 species of dipterocarp are endemic to Borneo and that the others occur in Malaya though only $S$. platycarpa is in the Sedili region. Of the 26 species of Artocarpus and Ficus recorded by Anderson, there are five endemic species or varieties of Ficus, and the others are wide-spread on the Sunda shelf except $F$. spathulifolia, $F$. tristaniifolia, and $F$. sundaica var. beccariana; of these 26 species, 15 occur in the Sedili region.

Thirdly I note that 5 of the 22 species of dipterocarps in the Sedili region are Malayan endemics and that 15 occur in Borneo, though not in the peat swampforest. Of the 32 species of Moraceae in the Sedili region, 24 are widely distributed on the Sunda shelf; 3 occur only in Malaya and Borneo; 3 do not occur in Borneo but extend variously to the Philippines. Thailand, and Sumatra; F. cucurbitina occurs in the Sedili region, Borneo, and the Philippines; and $F$. uncinulata occurs in the Sedili region, Borneo, and the Natuna Isl.

This complexity has led me to the following analysis of the geographical routes by which the species arrived at the Riouw pocket.

i. Species of northerly distribution:- Dipterocarpus grandiflorus, Vatica mengachapoi; Artocarpus gomezianus, $F$. spathulifolia (cf. $F$. depressa and $F$. glaberrima, which avoid the Riouw pocket). 
ii. Species of north easterly distribution, including the Anamba and Natuna islands and the Philippines:- Dipterocarpus apterus; Ficus cucurbitina, F. stricta, F. uncinulata; (cf. Chisocheton pentandrus, Inocarpus, Myristica guattariifolia, Pandanus dubius, ? Quassia indica).

iii. Species of Malaya and Borneo:- Cotylelobium malayanum, Dipterocarpus coriaceus, D. sublamellatus, Shorea exelliptica, S. foxworthyi, S. macrantha, $S$. materialis, $S$. resina-nigra; Ficus delosyce, $F$. obpyramidata, $F$. subgelderi.

Ashton (1972) observes that 57 species of dipterocarp reach their eastward limit at the Lupar river in west Borneo, and that the proto-Lupar of the glacial period seems to have been one of the formidable barriers to migration.

iv. Species of southerly distribution (Malaya, Sumatra, Riouw, Borneo):Anisoptera marginata, Dipterocarpus lowii, Dryobalanops oblongifolia, Hopea mengarawan, Shorea bracteolata, S. leprosula, S. macroptera, S. ovalis, S. platycarpa, $S$. singkawang, $S$. teysmanniana, Vatica inaingayi, Ficus apiocarpa, $F$. bracteata, $F$. calophylla, $F$. deltoidea var. deltoidea, $F$. dubia, $F$. excavata, $F$. retusa (not $F$. microcarpa), $F$. ruginervia, $F$. stupenda, $F$. tristaniifolia, and ? $F$. acamptophylla (Bangka, Borneo).

In this category I add the following list of freshwater swamp-forest trees:-

Artocarpus kemando
Blumeodendron tokbrai
Cantleya corniculata
Cratoxylon arborescens
Dacryodes macrocarpa
Dialium patens,
D. playtyse palum
Durio carinatus
Gymnacranthera eugeniifolia
Koompassia malaccensis
Mezzettia leptopoda
Musssaendopsis beccariana
Myristica lowiana
Parartocarpus venenosus ssp. forbesii
Parastemon urophyllum

Artocarpus kemando

Blumeodendron tokbrai

Dialium patens,

D. playtyse palum

Durio carinatus

Mezzettia le ptopoda

Musssaendopsis beccariana

Parartocarpus venenosus ssp. forbesii

Parastemon urophyllum

\author{
Polyalthia hypoleuca \\ Sandoricum emarginatum \\ Santiria laevigata \\ S. rubiginosa \\ Sindora coriacea \\ S. wallichii \\ Stemonurus scorpioides \\ $S$. secundiflorus \\ Xylopia caudata \\ $X$. fusca (? Sumatra) \\ $X$. maingayi \\ Cyrtostachys lakka \\ Salacca conferta \\ Pandanus helicopus \\ P. corneri (?)
}

v. Species of westerly distribution (Malaya, Sumatra):- Shorea acuminata, $S$. lepidota, S. palembanica, S. sumatrana, Vatica stapfiana, V. wallichii; Ficus microsyce.

vi. Bornean endemics:- Cotylelobium burckii, Dryobalanops rappa, Hopea pentanervia, Shorea albida, $S$. inaequilateralis, $S$. longiflora, $S$. pachyphylla, $S$. rugosa, S. scabrida; Ficus callicarpides, $F$. deltoidea var. borneensis and var. motleyana, $F$. heteropleura var. hirta, $F$. supperforata.

vii. Malayan endemics:- Balanocarpus heimii (apparently related to the two following species of Hopea), Dipterocarpus cornutus, Hopea polyalthioides, $H$. resinosa, Shorea collina, Vatica stipulata (Mt Ophir and Bt Tinjau Laut; cf. Cratoxylon glaucum from Mt Ophir, G. Arong near Mersing, Riouw Archipelago, Natuna Isl. and Borneo).

The occurrence of $B$. heimii in the Kota Tinggi Sedili region and in Singapore (Bt Timah) seems to have been overlooked by Symington.

viii. Dryobalanops aromatica. The distribution of this famous tree bears on the whole problem. It occurs on the east side of Malaya with its southern limit just north of G. Panti, in Selangor, Sumatra, Riouw Archipelago, and east Sarawak to south west Sabah. It impinges on the Sedili region on the hillocks along the Jemaluang Road and on Bt Tinjau Laut. It surrounds and crosses the Riouw pocket except for the region of Singapore and south Johore. It has been considered to indicate early erosion surfaces, preceding the swamp-basin of the Riouw pocket, 


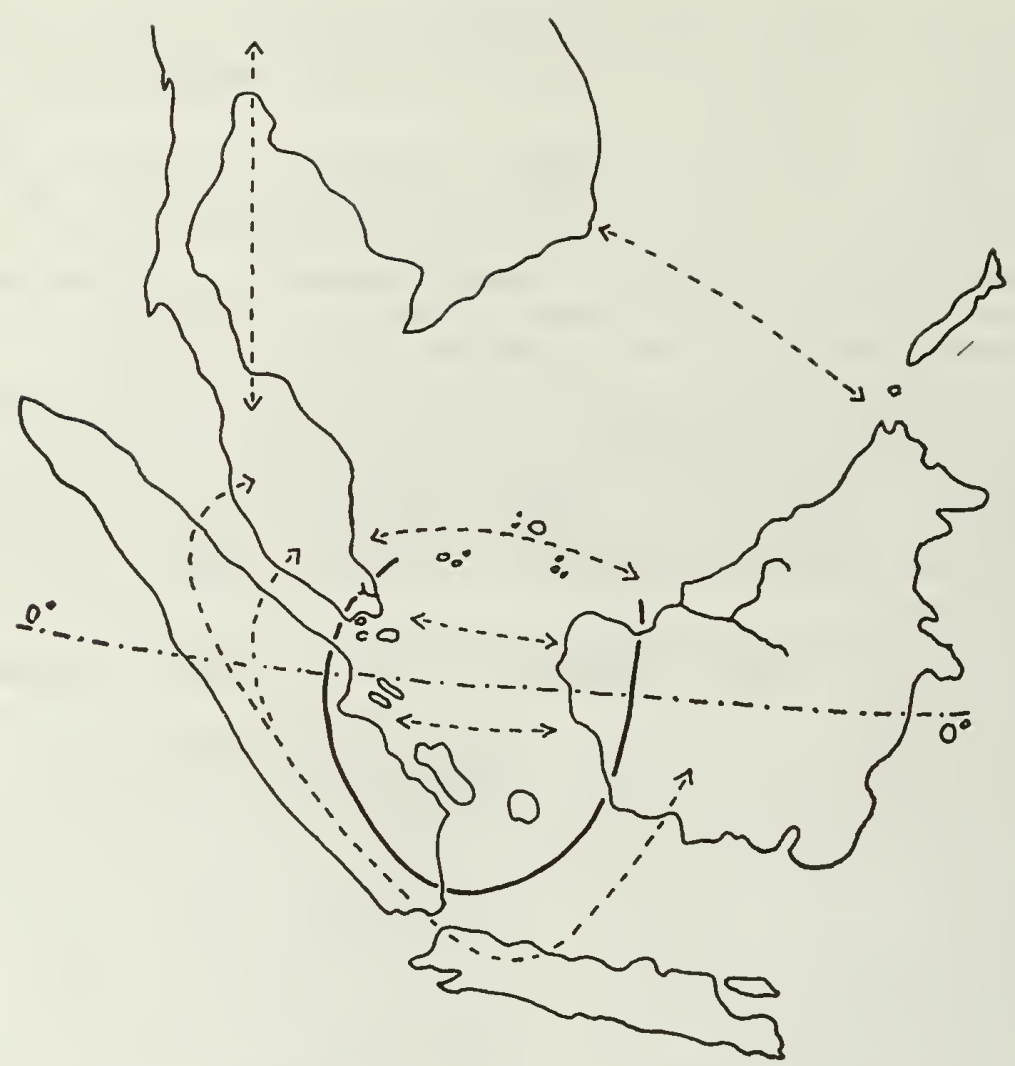

Figure 17. Plan of the Riouw pocket (heavy line) with migration-routes (broken lines) in glacial periods; the Rejang and Sedili rivers shown at the northern extremities of the pocket.

but this is doubted by Ashton (1972); possibly the vegetation of the raised beach at Kahang in Johore may be relevant (Swan 1974). Dryobalanops oblongifolia has much the same distribution and, except that they do not occur in Sumatra or the Riouw Archipelago, the same holds for Shorea foxworthyi, S. macrantha, Dipterocarpus coriaceus, and Cotylelobium malayanum. S. teysmanniana occurs in Bangka, west and north Borneo, and only Selangor in Malaya. All these accompany geographically, if not ecologically, $D$. aromatica. The lofty Koompassia excelsa may be another instance.

ix. Ten of the dipterocarps in the Sedili region (eleven if Anisoptera marginata is added) occupy the arc of Malaya. Sumatra, and Borneo. This arc is the limit of the swamp-forest which drained the Riouw pocket. I note that the endemic $S$. albida of the peat swamp-forests of Sarawak and Brunei is allied with the more wide-spread $S$. bracteolata and that the Bornean $S$. seminis is the ally or S. sumatrana to complete this representation along the arc. Indeed. the arc seems to indicate the peripheral occurrence of the peat swamp-forest.

These ideas are conveyed roughly in Figure 17. For recent papers on quaternary shore-lines of west Malaysia I refer to Aleva (1973), Biswas (1973), Haile (1971), and Tjia (1970b). 


\section{Part V. List of vascular plants of the Sedili-region, Johore}

The list is alphabetical for the families of flowering plants, with genera and species in the same order. Gymnosperms and ferns follow. The nomenclature of the Flora Malesiana has been followed and, where families have not yet been revised, names have been taken from standard Malayan works. For many specimens which have not been critically studied I have had to retain the names under which the specimens have been filed in the Singapore Herbarium. Thus sterile and unnumbered specimens, collected for ecological record, are often not included in lists of identification.

The revival of taxonomy after the Second World War has been part of the growth of internationalism. Money has been forthcoming to visit important and distant herbaria. Postal services have been so improved that types are readily lent. There is a much greater number of specimens for collation. The outcome is an almost new language for Malesian botany. Lack of these facilities in the past, coupled with the imperfect description of many species, led to a superfluity of names as the same species or genus was described again and again, almost country by country. The common merambong (Scaevola) has changed its name twice in the last twenty years, and the medang (Elaeocarpus macrocerus) twice in the last forty years. Finality is not in sight. Many genera will be reduced as breadth of mind increases in botanical wisdom, and many species need further assessment. Hence I have made a list of Malay names, as used on the Sedili rivers; many are specific and all are useful in the forest.

The main localities where I collected are numbered 1-10, as listed below. The numbers are given in the species-list after the number or date of collection, preserved in the Singapore Herbarium. The chief locality for riverside- and swampforest is the Sedili Besar (7) and the adjoining parts of its tributaries. Nos. 2-4 refer to these tributaries where they were crossed by the Jemaluang Road and where the swamp-forest adjoined the hillock-forest; this is represented mostly by nos. 4 and 5 and by Bt Tinjau Laut (10). S. Segun (6) was a Saraca-stream leading into swampforest with Shorea lepidota and S. singkawang.

1. Kota Tinggi-Mawai Road, mile 5-6, swamp-forest.

2. S. Kayu, Jemaluang Road.

3. S. Berassau, Jemaluang Road.

4. S. Kayu Ara, Jemaluang Road.

5. Jemaluang Road, mile 13-14, (partly kapur-forest).

6. S. Segun.

7. S. Sedili Besar.

8. S. Sedili Kechil.

9. Jason Bay (shore and forest).

10. Bt Tinjau Laut (kapur-forest).

The total number of species recorded for the Sedili-region is c. 1710, of which 1082 occurred in the swamp-forest (fresh - and saltwater). The proportion of monocotyledons to dicotyledons is low at $21-22 \%$. 


\section{Specific representation of angiosperm families}

\begin{tabular}{|c|c|}
\hline Species & Specific number in brackets \\
\hline 100 or more & Orchidaceae (115), Euphorbiaceae (110), Rubiaceae (110). \\
\hline $50-99$ & $\begin{array}{l}\text { Myrtaceae (65), Lauraceae (60), Annonaceae (58), Moraceae } \\
\text { (57), Leguminosae (54), Palmae (50). }\end{array}$ \\
\hline $30-49$ & $\begin{array}{l}\text { Clusiaceae (40), Meliaceae (c. 40), Melastomataceae (35), Dip- } \\
\text { terocarpaceae (34), Cyperaceae (31), Myristicaceae (30), } \\
\text { Gramineae (30), Zingiberaceae (30). }\end{array}$ \\
\hline $20-29$ & $\begin{array}{l}\text { Myrsinaceae (28), Anacardiaceae (27), Caesalpinioideae (24), } \\
\text { Apocynaceae (23), Araceae (23), Sapotaceae (23), Pandanaceae } \\
\text { (22). Fagaceae (20), Papilionatae (20). }\end{array}$ \\
\hline $10-19$ & $\begin{array}{l}\text { Sapindaceae (18), Sterculiaceae (18), Verbenaceae (18), Flacour- } \\
\text { tiaceae (15), Gesneriaceae (15), Tiliaceae (15), Liliaceae (14), } \\
\text { Rhizophoraceae (13), Rutaceae (13), Acanthaceae (12), Bur- } \\
\text { seraceae (12), Celastraceae (12), Dilleniaceae (12), Theaceae } \\
\text { (12), Connaraceae (11), Elaeocarpaceae (11), Icacinaceae (11), } \\
\text { Polygalaceae (11), Convolvulaceae (10), Mimosoideae (10), } \\
\text { Piperaceae (10). }\end{array}$ \\
\hline $4-9$ & $\begin{array}{l}\text { Combretaceae (9), Loranthaceae (9), Vitaceae (9), Lecythidaceae } \\
\text { (8), Marantaceae (7), Urticaceae (7), Bombacaceae (6), Com- } \\
\text { positae (6), Loganiaceae (6), Menispermaceae (6), Rosaceae } \\
\text { (6), Oleaceae (5), Proteaceae (5), Commelinaceae (4), Lythra- } \\
\text { ceae (4), Symplocaceae (4), Taccaceae (4), Violaceae (4). }\end{array}$ \\
\hline $1-3$ & 50 families. \\
\hline
\end{tabular}

\section{Large genera (species-number in brackets)}

Eugenia (c. 57), Ficus (46), Bulbophyllum (23), Calophyllum (19), Dendrobium (19), Ardisia (c. 18), Shorea (17), Diospyros (? 17), Garcinia (16), Pandanus (16), Lithocarpus (15), Macaranga (15), Lindera (13), Baccaurea (12), Memecylon (12), Elaeocarpus (11), Polyalthia (11), Calarnus (10), Daemonorops (10), Horsfieldia (10), Psychotria (10), Xanthophyllum (10).

To these must be added Aglaia and Dysoxylon in the range of Calophyllum.

List of families in the Sedili-region with total number of species and those of fresh-water swamp-forest

\begin{tabular}{|c|c|c|c|c|}
\hline & \multicolumn{2}{|c|}{ Total } & \multicolumn{2}{|c|}{ Swamp-forest } \\
\hline & Dicot. & Monocot. & Dicot. & Monocot. \\
\hline $\begin{array}{l}\text { Acanthaceae } \\
\text { Aizoaceae } \\
\text { Amaranthaceae } \\
\text { Amarullidaceae }\end{array}$ & $\begin{array}{r}12 \\
1 \\
1\end{array}$ & 2 & $\begin{array}{l}2 \\
0 \\
0\end{array}$ & 0 \\
\hline Anacardiaceae & 27 & & 16 & \\
\hline
\end{tabular}




\begin{tabular}{|c|c|c|c|c|}
\hline & \multicolumn{2}{|c|}{ Total } & \multicolumn{2}{|c|}{ Swamp-forest } \\
\hline & Dicot. & Monocot. & Dicot. & Monocot. \\
\hline Annonaceae & 58 & & 49 & \\
\hline Apocynaceae & 23 & & 15 & \\
\hline $\begin{array}{l}\text { Apostasiaceae } \\
\text { Aquifoliaceae }\end{array}$ & & 2 & & 2 \\
\hline $\begin{array}{l}\text { Aquicoliaceae } \\
\text { Araceae }\end{array}$ & 3 & 23 & 3 & 16 \\
\hline Araliaçeae & 5 & & 4 & \\
\hline Asclepiadaceae & 21 & & 12 & \\
\hline $\begin{array}{l}\text { Bignoniaceae } \\
\text { Bombacaceae }\end{array}$ & $\begin{array}{l}2 \\
6\end{array}$ & & $\begin{array}{l}2 \\
4\end{array}$ & \\
\hline Boraginaceae & 3 & & 1 & \\
\hline Burseraceae & 12 & & 11 & \\
\hline Capparidaceae & 1 & & 1 & \\
\hline $\begin{array}{l}\text { Casuarinaceae } \\
\text { Celastraceae }\end{array}$ & $\begin{array}{r}1 \\
12\end{array}$ & & $\begin{array}{l}0 \\
7\end{array}$ & \\
\hline $\begin{array}{l}\text { Celastraceae } \\
\text { Clusiaceae }\end{array}$ & c. 40 & & 25 & \\
\hline $\begin{array}{l}\text { Combretaceae } \\
\text { Commelinaceae }\end{array}$ & 9 & 5 & 3 & 2 \\
\hline $\begin{array}{l}\text { Commelinaceae } \\
\text { Compositae }\end{array}$ & 6 & & 0 & 2 \\
\hline Connaraceae & 11 & & 8 & \\
\hline Convolvulaceae & 10 & & 5 & \\
\hline $\begin{array}{l}\text { Cornaceae } \\
\text { Crassulaceae }\end{array}$ & $\begin{array}{l}3 \\
1\end{array}$ & & $\begin{array}{l}3 \\
0\end{array}$ & \\
\hline $\begin{array}{l}\text { Crassulaceae } \\
\text { Cucurbitaceae }\end{array}$ & 4 & & 3 & \\
\hline Cyperaceae & & 31 & & 7 \\
\hline $\begin{array}{l}\text { Dichapetalaceae } \\
\text { Dilleniaceae }\end{array}$ & $\frac{2}{12}$ & & $\begin{array}{l}1 \\
8\end{array}$ & \\
\hline Dioscoreaceae & 12 & 3 & & 3 \\
\hline Dipterocarpaceae & $\begin{array}{r}34 \\
218\end{array}$ & & 22 & \\
\hline $\begin{array}{l}\text { Ebenaceae } \\
\text { Elaeocarpaceae }\end{array}$ & $\begin{array}{l}? 18 \\
11\end{array}$ & & 5 & \\
\hline Ericaceae & 2 & & $i$ & \\
\hline Erythroxylaceae & 2 & & i & \\
\hline Euphorbiaceae & $\begin{array}{r}110 \\
20\end{array}$ & & 71 & \\
\hline $\begin{array}{l}\text { Fagaceae } \\
\text { Flacourtiaceae }\end{array}$ & $\begin{array}{l}20 \\
15\end{array}$ & & 12 & \\
\hline Flagellariaceae & & 2 & & 2 \\
\hline Gesneriaceae & c. 15 & & 10 & \\
\hline $\begin{array}{l}\text { Gonystylaceae } \\
\text { Goodeniaceae }\end{array}$ & 3 & & 3 & \\
\hline $\begin{array}{l}\text { Goodeniaceae } \\
\text { Gramineae }\end{array}$ & & 30 & & 3 \\
\hline Hernandiaceac & 1 & & $?$ & \\
\hline $\begin{array}{l}\text { Hypericaceae } \\
\text { Hypoxidaceae }\end{array}$ & 3 & 2 & 2 & 1 \\
\hline Icacinaceae & 11 & & 7 & \\
\hline $\begin{array}{l}\text { Labiatae } \\
\text { Lauraceae }\end{array}$ & $\begin{array}{r}1 \\
\text { c. } 60\end{array}$ & & $\begin{array}{r}0 \\
37\end{array}$ & \\
\hline $\begin{array}{l}\text { Lauraceae } \\
\text { Lecythidaceae }\end{array}$ & $\begin{array}{r}\text { c. } 60 \\
8\end{array}$ & & 5 & \\
\hline Leguminosae & & & & \\
\hline $\begin{array}{l}\text { Caesalpinioidcae } \\
\text { Mimosoideae }\end{array}$ & 24 & & 12 & \\
\hline $\begin{array}{l}\text { Mimosoideae } \\
\text { Papilionatae }\end{array}$ & $\begin{array}{l}10 \\
20\end{array}$ & & $\frac{2}{2}$ & \\
\hline Lentibulariaceac & 1 & 14 & 0 & \\
\hline $\begin{array}{l}\text { Liliaceae } \\
\text { Linaceae }\end{array}$ & 2 & 14 & 2 & 12 \\
\hline $\begin{array}{l}\text { Linaceae } \\
\text { Loganiaceae }\end{array}$ & 6 & & 4 & \\
\hline $\begin{array}{l}\text { Loranthaceae } \\
\text { Lowiaceae }\end{array}$ & 9 & 1 & 7 & 1 \\
\hline $\begin{array}{l}\text { Lowiaceae } \\
\text { Lvthraceae }\end{array}$ & 4 & & 1 & \\
\hline $\begin{array}{l}\text { Lvthraceae } \\
\text { Magnoliaceae }\end{array}$ & 3 & & 1 & \\
\hline Malpighiaceae & 2 & & 1 & \\
\hline Malvaceae & 3 & 7 & 0 & 2 \\
\hline $\begin{array}{l}\text { Marantaceae } \\
\text { Melastomataceac }\end{array}$ & c 35 & & 25 & \\
\hline
\end{tabular}




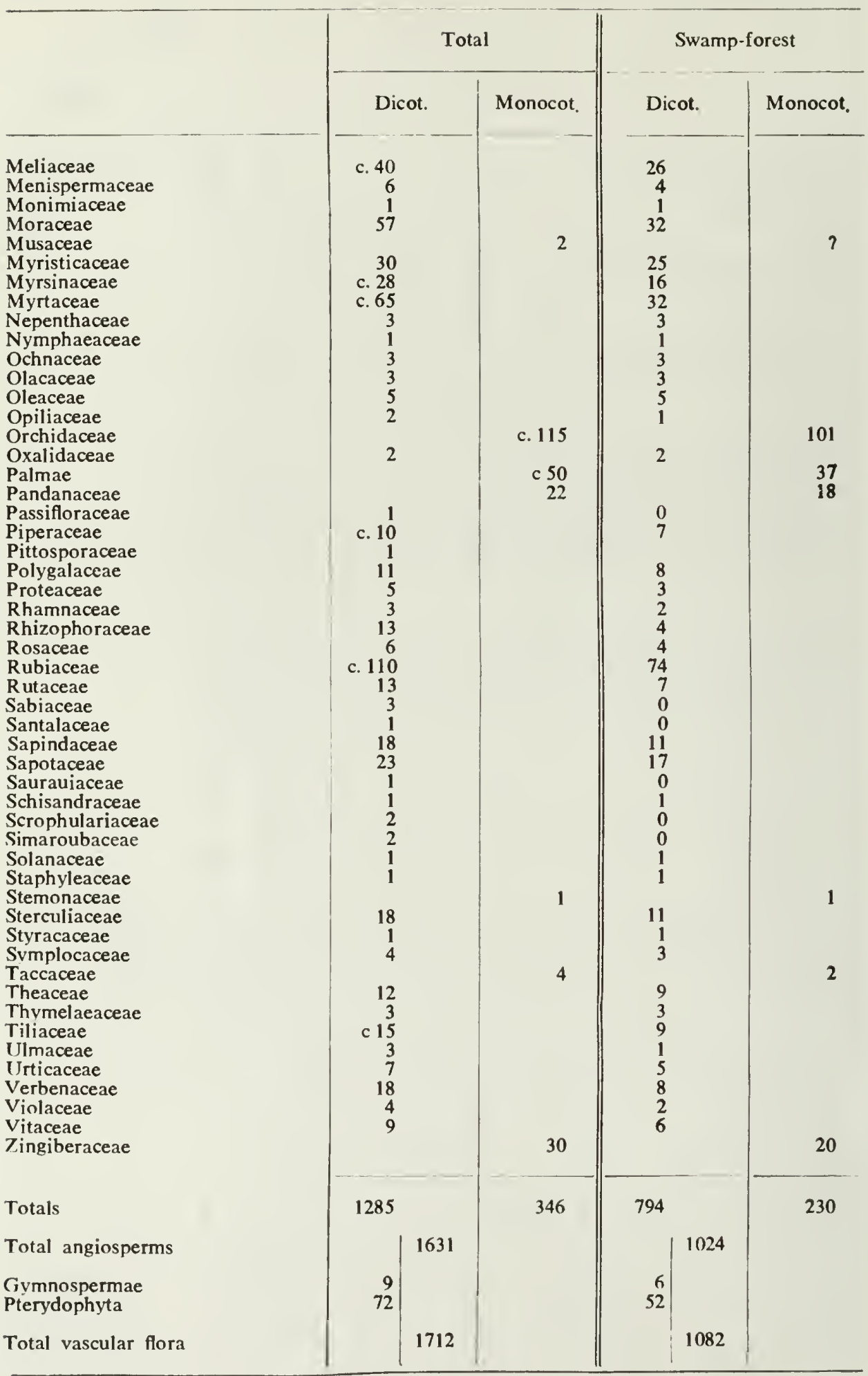




\section{Acanthaceae}

Acanthus ilicifolius L.: mangrove; jerujoh.

Gymnostachyurn ? : 29472, 29497 (2); herb in swamp-forest. See special notes.

Justicia johorensis J. Sinclair; s.n. 5.1.36 (5). Gdns’ Bull. Singapore 15 (1956) 18.

J. uber Clarke: 30653 (6).

Justicia sp.: 32083 (2), 32501 (2).

Justicia sp.: 37051 (10).

Lepidagathis longifolia Wight: s.n. (4).

Peristrophe sp.: s.n. 28.4 .35 (3).

Pseuderanthernum crenulatum Radlk.: 30782 (1).

Pseuderanthemum sp.: 30785 (1).

Staurogyne griffithiana Ktze: 36945 (10), (6).

S. kingiana Clarke: 28652 (8); herb, frequent in sandy coastal forest.

\section{Aizoaceae}

Sesuvium portulacastrum L.: coastal herb in mangrove; beremi laut, geylang. See special notes.

\section{Amarantaceae}

Achyranthes aspera $L . .:(9)$; coastal herb.

\section{Amaryllidaceae}

Crinum asiaticum L.: (9); in mangrove. See Corner, Life of Plants pl. 36a.

Pancratium maritimum L.: (9); coastal; bakong.

\section{Anacardiaceae}

Buchanania lucida B1.: 23898 (7), 28460 (9), 36856 (7); ketah udang.

B. sessilifolia B1.: 28981 (3), 29410 (5), 32428 (6); in swamp-forest and kapur-forest; ketah udang.

Campnosperma auriculata Hook. f.: terentang, teruntang.

C. squamata Ridl. in swamp-forest: teruntang jantan; $(C$. minus in Wayside Trees of Malaya).

Gluta malayana (Corner) Ding Hou: s.n. 9.6 .34 (as rengas A), 7.2.35 (as rengas 1 and 2), 28.6.36 (3); in swamp-forest.

G. tavoyana Wall.: 37063 (10).

G. velutina B1.: 24631 (7), 31448 (7); small tree $-7 \mathrm{~m}$, common along riverside; rengas, $r$. ayer. See special notes. Plates $4,6$.

G. wallichii (Hook. f.) Ding Hou: s.n. 3.2 .35 (2) (as rengas 2, det. Melanochyla nitida, Plate 22); in swamp-forest. See Melanorrhoea wallichii. 
Mangifera foetida Lour.: 34909 (4); tree $-33 \mathrm{~m}$, in hillock-forest; machang utan. See special notes. Plate 32.

M. griffithii Hook. f.: 34756 (7), 34756A (7), 34948 (1); in swamp-forest; lekub. See special notes. (M. microphylla in Wayside Trees of Malaya).

M. lagenifera Griff.: 34701, 34705 (7).

M. quadrifida Jack: 32203 (2), 32436 (7), 34946 (1), 34947 (1), 34970; tree -33 m, on Tristania-banks and in swamp-forest; kolah. See special notes. ( $M$. longipetiolata in Wayside Trees of Malaya).

$M$. cf. quadrifida: s.n. 8.2.35 (5), 5.5 .35 (4); repat.

Mangifera sp.: s.n. 31.12 .34 (5); in kapur-forest.

Melanochyla auriculata Hook. f.: frequent in swamp-forest; rengas. See special notes. Plate 39.

M. aff. auriculata: 29364 (4).

M. bracteata King: 21340 (2), 32445 (7); in swamp-forest. Plate 21.

$M$. densiflora King: 31468 (3); in swamp-forest.

Melanochyla sp.: s.n. 6.8 .39 (10). See special notes.

Melanochyla sp.: s.n. 3.10 .34 (5), 7.10 .34 (5).

Melanorrhoea pubescens Ridley s.n. (5); tree with scaly bark imbricating downwards, deciduous (Oct. 1936, April-May 1940); in dryer parts of the swampforest and in hillock-forest; kerbau jalang. (Melanorrhoea sp. of Wayside Trees Malaya).

M. wallichii Hook. f.; common in swamp-forest; rengas. See special notes. Plates 33-35.

M. woodsiana Scort.: 32187 (2), (4), (10); tree of hillock-forest; rengas. See special notes.

Melanorrhoea sp.: s.n. 5.2.35 (2); rengas ayam.

Parishia ? insignis: s.n. 16.6 .34 (9, as Meliaceae A); in swamp-forest, very strongly buttressed; bengong.

P. ? pubescens: s.n. (7); on Tristania-bank; bunot.

Pentaspadon motleyi Hook. f.: s.n. 28.8 .32 (7, as Microsternon curtisii); tree -25 m, without buttresses; bark reddish grey, flaky; frequent in swamp-forest.

P. officinalis Homes: 36844 (7), 36963 (7), s.n. 21.5 .34 (4); large buttressed tree in swamp-forest, often by streams. See special notes.

Semecarpus velutina King: 32399 (2).

Swintonia penangiana King: 29365 (4), s.n. 6.8 .39 (10); in kapur-forest. See special notes.

\section{Annonaceae}

Alphonsea elliptica Ridl.: 32312 (2), s.n. 10.6 .34 (9, S. Tuenseh); tree $-25 \mathrm{~m}$, in hillock-forest and in sandy Eugenia grandis forest; segun.

A. johorensis J. Sinclair: 29934 (3), 29375 (4), 30864 (2), 32139 (2); tree -20 m; bark dark grey, finely rugulose and fissured; leaves with rank smell when crushed; in dryer part of swamp, in hillock- and in kapur-forest; segun. Apparently endemic to this region.

Anaxagorea javanica Bl. var. javanica: 29469 (4).

A. javanica var. dipetala Corner: 28972 (3), 29464 (4), $31932(4,5)$; shrub or small tree $-5 \mathrm{~m}$, flowering at $2 \mathrm{~m}$; frequent to abundant in the dryer part of the swamp-forest; dedahruang. Apparently endemic to south Johore. 
Artabotrys suaveolens Bl.: 31969 (2), 32497 (2); climber in swamp-forest.

A. venustus King: s.n. 24.6 .35 (4); climber in swamp-forest, with rose-red fruits.

A. wrayi King: 32301 (2); climber in swamp-forest.

Cyathocalyx pahangensis (Henders.) J. Sinclair: 29014 (5), 29198 (4), 29432 (5), 29982 (7), 32080 (2), 36855 (7); tree $-8 \mathrm{~m}$; bark pale greyish, slightly lenticellate; inner bark yellowish, sweetly aromatic; flowers very fragrant; frequent in dryer parts of the swamp-forest and in kapur-forest; bunga antoi.

C. ridleyi (King) J. Sinclair: 21317 (2); common tree in dryer parts of the swampforest and in hillock-forest; antoi. Plate 10.

Cyathostemma viridiflorum Griff.: 29460 (4); climber in swamp-forest; cauliflorous almost from the ground.

Desmos dasymaschala (B1.) Saff.: 28184 (4), 28499 (9), 28518 (9); small spreading tree $-8 \mathrm{~m}$, with flopping branches, not climbing, often gregarious or tufted; leaves generally with very glaucous undersides (not in 28499); common in dryer parts of the swamp-forest, by streams, and in Eugenia grandis forest; lidah katak.

D. dasymaschala var. wallichii (Hook. f.) Ridley; 28682 (4); as var. dasymaschala.

D. dumosa Saff.: 32145 (2); in dryer parts of the swamp-forest.

Enicosanthum praestigiosum J. Sinclair: 28449 (4, 5), 32017 (2), 32237 (2), 32765 (2), 36393 (2); tree in dryer parts of the swamp-forest and in kapur-forest. Apparently endemic in this region.

Fissistigma fulgens (Hook. f. et Th.) Merr.: s.n. 21.5 .34 (7).

F. kingii (Boerl.) Burkill; 32197 (2), Sinclair 10674 (2); in dryer parts of the swampforest.

F. lanuginosum (Hook. f. et Th.) Merr.: 32199 (7); in dryer parts of the swampforest.

F. latifolium (Dunal) Merr.: s.n. 15.5 .34 (4); streamside.

F. manubriatum (Hook. f. et Th.) Merr.: 28500 (9, S. Rhu Reba), 28646 (8, Kg Ladang); common in mangrove and in Eugenia grandis forest.

Goniothalamus macrophyllus (Bl.) Hook. f. et Th.: 28490 (9), 28554 (9), 28720 (1), (4), s.n. $10.10 .36(2)$; shrub or small tree $-4 \mathrm{~m}$; common in dryer parts of the swamp-forest.

G. malayanus Hook. f. et Th.: 28604 (9), 28739 (3), 29307 (1), 32156 (2), s.n. $27.3 .32(7), 1.4 .34(8)$; common in dryer parts of the swamp-forest and in Eugenia grandis forest; jelunut, kenanga utan. See special notes. Plate 21.

$G$. ridleyi King: 30869 (6), 32345 (2); tree $-13 \mathrm{~m}$; in swamp-forest.

G. tapis Miq.: s.n. 11.5.35 (4), $15.4 .36(1)$; treelet $-4 \mathrm{~m}$; in dryer parts of the swampforest and in kapur-forest; jelunut.

Marsypopetalum pallidum (B1.) Kurz: 30729 (6), 32469 (2), 40350 (3, leg. Sinclair); treelet $-3 \mathrm{~m}$; common in swamp-forest.

Meiogyne virgata (Bl.) Miq.: s.n. 7.10 .37 (2); treelet -3 m, by stream.

Mezzettia leptopoda (Hook. f. et Th.) Oliver: 29417 (5), 32073 (2), 32986 (7), s.n. 12.6.34 (9); tree $-40 \mathrm{~m}, 75 \mathrm{~cm}$ thick at $2 \mathrm{~m}$, often fluted at the base, not buttressed; frequent in swamp-forest and in Eugenia grandis forest.

Mitrella kentii (Bl.) Miq.: 32005 (2), 36820 (7), 36893 (7); big climber, the old branches becoming striate with tumid elongate brown lenticels more or less in longitudinal rows; in swamp-forest.

Mitrephora maingayi Hook. f. et Th.: Kostermans s.n. Aug. 1938; tree -15 m, in swamp-forest. 
Monocarpia marginalis (Scheff.) J. Sinclair: 32320 (2); tree $-25 \mathrm{~m}$, frequent in swamp-forest.

Oncodistigma monosperma (Hook. f. et Th.) J. Sinclair: 32133 (2), 32160 (2); tree $-10 \mathrm{~m}$, in hillock-forest.

Orophaea enterocarpa Maingay: 32058 (2); tree -5 m, in swamp-forest.

Oxymitra affinis Hook. f. et Th.: 32494 (2); shrub becoming a climber; frequent in swamp-forest.

O. filipes Hook. f. et Th.: 29435 (5), 30692 (6), 31962 (2), s.n. 27.10 .36 (2), 13.4.35

(7); treelet $-5 \mathrm{~m}$, becoming a small climber $-10 \mathrm{~m}$; in swamp-forest.

O. glauca Hook. f. et Th.: 32044 (2); in dryer parts of the swamp-forest.

O. latifolia Hook. f. et Th.: 29434 (5), s.11. 14.4 .35 (2); climber in swamp-forest.

Phaeanthus ophthalmicus (Roxb.) J. Sinclair: s.n. 16.6 .34 (9, S. Semandan); common treelet $\mathbf{- 3} \mathrm{m}$ in sandy Eugenia grandis forest.

Polyalthia angustissima Ridley: s.n. 16.6.34 (9. S. Semandan); tree $-20 \mathrm{~m}$, trunk $20 \mathrm{~cm}$ thick; bark fuscous, rough with a thin blackish superficial layer; frequent in sandy coastal forest.

P. brunneifolia J. Sinclair: s.n. 10.2 .35 (4), 13.5 .35 (5), Sinclair 10160 (2); treelet $-4 \mathrm{~m}$, becoming cauliflorous; in swamp- and kapur-forest.

P. bullata King: s.n. 30.9 .36 (7); treelet $-3.5 \mathrm{~m}$, occasional in the swamp-forest.

P. cauliflora Hook. f. var. beccarii (King) J. Sinclair: 29026 (5), 32069 (2), 36941 (10), 37069 (10); small tree, bark with transversely elongate tumid lenticels; scattered in hillock-forest. See special notes.

P. cauliflora var. desmantha (Hook. f. et Th.) J. Sinclair: 25978 (7), 28503 (9), 28600, 28601 (8), 28684 (4), 32101 (2), 32125 (2), 34739 (7), Sinclair 10597 (S. Dohol); tree $-10 \mathrm{~m}$; bark fuscous grey, with transversely elongate lenticels; crushed leaves with sour resinous smell; frequent in dryer parts of the swamp-forest and in Eugenia grandis forest.

P. glauca (Hook. f.) Boerl.: 29274 (7), s.n. 14.4 .35 (2); tree -20 m; bark pale grey, smooth; fruits pinkish purple; frequent in swamp-forest. See special notes.

P. hookeriana King: 36859 (7), s.n. 7.6 .37 (5); small tree -12 m; bark dark grey; in swamp-forest.

P. hypoleuca Hook f. et Th.: 32189 (2); tree $-20 \mathrm{~m}$; in hillock-forest. See special notes. Plate 37.

P. lateriflora (Bl.) King: 32033 (2), 32169 (2), s.n. 28.8 .32 (3); tree -20 m; common in swamp-forest.

P. macropoda King: 32067 (2); in swamp-forest, also on the ridge of G. Panti.

P. sclerophylla Hook. f. et Th.: 23894 (7), 25862 (7), 32799 (5); riverside tree; mempisang. See special notes. Plate 11.

P. sumtatrana (Miq.) King: 28070 (8), 29330 (4), 36979 (7), s.n. 8.2 .35 (5); tree $-20 \mathrm{~m}$; bark dull greyish, pallid, pustulate with tiny lenticels; fruits redstriped; frequent in swamp-, hillock-, and kapur-forest.

Popowia pisocarpa (Bl.) Endl.: 32446 (2); tree -8 m; frequent in swamp-forest.

Pseuduvaria galeata J. Sinclair: 29022 (5), 29194 (4), 29937 (3); small tree -8 m; bark fuscous grey with a thin hard black outer layer; frequent in dryer parts of the swamp-forest and in kapur-forest; segun. ? endemic in this region.

P. macrophylla (Oliver) Merr.: 21316 (1), 29438 (5), s.n. 5.1 .36 (2), 11.10 .36 (2); treelet $-4 \mathrm{~m}$; twigs blackish, stems whippy and used as fishing rods; in swamp-forest; segun. 
Trivalvaria nervosa (Hook. f. et Th.) J. Sinclair: 29032 (5), 37070 (10), s.n. 3.8 .39 (10); small bushy tree $-13 \mathrm{~m}$; bark dark grey; frequent in hillock-forest; segun.

Uvaria cordata (Dunal) Alst.: 31971 (2), s.n. 1.9.35, (1), 8.1 .38 (7); low climber in swamp-forest.

U. leptopoda (King) J. Sinclair: 28443 (9, 7), 28580 (9), Kostermans s.n. Aug. 1938 (7); common climber in swamp-forest.

$U$. pauciovulata Hook. f. et Th.: 32128 (2); large climber in hillock-forest.

Xylopia caudata Hook. f.: 28729 (2), 29413 (5), 36881 (7), s.n. 13.6 .34 (9); graceful tree $-20 \mathrm{~m}$; frequent to very abundant in swamp-, hillock-, and Eugenia grandis forest, saplings common; tempunai. See special notes.

X. elliptica Maingay: 32403 (2); tree $-17 \mathrm{~m}$, in hillock-forest.

$X$. ferruginea Hook. f. et Th.: 31985 (2); tree $-20 \mathrm{~m}$, always stilted; bark ferruginous; scattered in swamp-forest, frequent in hillock-forest.

$X$. ferruginea var. oxyantha (Hook. f. et Th.) J. Sinclair; 36853 (7).

$X$. fusca Maingay: 36868 (7); tree $-30 \mathrm{~m}$, with stilts and loop-roots; frequent in swamp-forest; jangkang. See special notes. Plates 24, 35, 36; Figure 7.

$X$. malayana Hook. f. et Th.: 32403 (2); tree $-27 \mathrm{~m}$; scattered in dryer parts of the swamp-forest. See special notes.

$X$. subdehiscens (King) J. Sinclair: s.n. 23.6 .34 (8); shrub -2 m; fruits with blood-red interior and grey-blue seeds; in swamp-forest. (I took this to be sapling $X$. malayana).

Xylopia sp. ?: s.n. 13.4 .35 (7); tree $-20 \mathrm{~m}$; in swamp-forest. See special notes.

\section{Apocynaceae}

Alstonia angustifolia DC: 21307 (1), 25855 (7), 31452 (7), 36897 (7); tree -23 m, without latex in the trunk; locally abundant in swamp-forest; inggi burong.

A. angustiloba Miq.: in swamp-forest.

A. spathulata $\mathrm{Bl}$.: tree $-30 \mathrm{~m}$ or more, buttressed, with knee-roots as in Bruguiera; frequent by streams in the swamp-forest; pulai.

Anodendron candolleanum Wight: lofty climber with rather slender stem; common in the swamp-forest.

Cerbera manghas L.: tree $-20 \mathrm{~m}$, common on rocky and sandy coasts; buta-buta, pong-pong. See special notes.

C. odollain Gaertn.: tree $-20 \mathrm{~m}$, common in mempisang- and nipa-belts and on Tristania-banks from K. Dohol to the estuary of the Sedili Besar, most abundant at the back of the mangrove; buta-buta.

Chilocarpus cantleyi King: 32060 (3).

C. costatus Miq.: 29950 (2); low climber in swamp-forest.

C. decipiens Hook. f.: 30726 (3), 31930 (5), 32093 (2).

C. obtusifolius Merr.: Kadim and Nur 501934 (Kuala Sedili).

Dyera costulata (Miq.) Hook. f.: (2), (3); scattered in dryer parts of the swampforest, frequent in hillock-forest; jelutong.

Epigynum ridleyi King et Gamble: 32141 (2); slender climber, ? rare.

Kopsia singapurensis Ridley: 21339 (2), 25999 (7), 28680 (4), 28730 (2), 28731 (2), 31959 (2), 32039 (2), 37067 (10); shrub or small tree $-7 \mathrm{~m}$, common in swampforest; medang. See special notes.

Melodinus orientalis $\mathrm{Bl} .: 31958$ (2); large climber. 
Ochrosia oppositifolia (Lamk) K. Schum.: $28611(8,9)$; frequent tree in coastal forest.

Parameria polyneura Hook. f.: 28967 (3); fairly large climber with pink flowers, in swamp-forest.

Tabernaemontana corymbosa Roxb.: 32333 (2); frequent small tree in swamp-forest.

T. corymbosa var. kelsalli King et Gamble: 32276 (5). See special notes.

T. ? cylindrica King et Gamble: (4); shrub $-1.7 \mathrm{~m}$, in hillock-forest.

T. ? malaccensis Hook. f.: (4); shrub $-1 \mathrm{~m}$.

T. ? pauciflora Ridley: 32468 (2).

T. sphaerocarpa B1.: 30696 (6), 34741 (7).

Urceola brachysepala Hook. f.: 21310 (1), 30894 (1), 34744 (1); large climber in swamp-forest.

Willughbeia coriacea Wall.: 32000 (2); large climber, common in the swamp-forest.

\section{Apostasiaceae}

Apostasia nuda R. Br.: $(2,3)$.

Nieuwiedia griffithii Rchb. f.: 30721 (1), 32463 (2).

\section{Aquifoliaceae}

Ilex cymosa B1.: tree $-23 \mathrm{~m}$; common on Tristania-banks and in Eugenia grandis forest; mensirau. See special notes.

I. maingayi Hook. f.: 30861 (2).

I. malaccensis Loessn.: 29992 (1).

\section{Araceae}

Aglaodorum griffithii Schott: common on mud under nipa.

Aglaonema nebulosum N.E. Br.: 32462 (2); frequent in swanı-forest.

A. nitidum (Jack) Kunth: 36967 (2); common in the swamp-forest.

A. simplex Bl.: 36947 (10), 37088 (10). (3); (these collections det. Schismatoglottis brevicuspis Hook. f.).

Alocasia denudata Engl.: common in the swamp-forest and in coastal forest; kernuyang.

Amorphophallus bufo Ridley: 30738 (6), (9); frequent in coastal forest with Tacca leontopetaloides.

Anadendrum microstachyum (Miq.) Bakh. f.: (7); frequent small climber in swampforest.

A. ? latifolium: (3).

Cryptocoryne cordata Griff.: 28633 (8), 32111 (2); common in mud along the riverside and by streams. See special notes.

C. griffithii Schott: (3), (7): common in shallow stream-beds of the swamp-forest; spathe bright yellow, the pallid white tube with faint pink stripes.

Cryptocoryne sp.: 32349 (2).

Epipremnopsis media (Zoll. et Mor.) Engl.: ? this record. 
Homalomena griffithii (Schott) Hook. f. forma kingiana Furtado: 32056 (2).

H. kiahii Furtado: 32358 (2); forma maculata Furtado, 32146 (2).

H. pendula (Bl.) Bakh. f.: 36813 (7); (det. H. rubra Hassk.).

H. rostrata Griff.: 28612 (8), 36965 (7), (9); common in swamp and coastal forest.

H. sagittifolia Jungh. var. angustifolia Furtado: 29360 (3), (9).

Homalomena sp.: 30691 (6).

Piptospathe ridleyi N.E. Br.: 36932, 36933 (10), s.n. 12.4 .36 (6); common small aroid on rocks by Saraca-streams.

Podolasia stipitata N.E. Br.: 29443 (1), 36966 (7), (8); thorny aroid with large hastate leaves, purple-brown spathes, cream-white spadix, red berries; in swamp-forest. Plate 40.

Pothos macrocephalus Scort.: 32104 (2).

P. scandens L.: 29247 (2), 32284 (2); common climber in swamp-forest.

Raphidophora beccarii Engl.: (3), (4).

R. minor Hook. f.: 24628 (7); commonly climbing on rassau (Pandanus helicopus); pokok gegli.

R. sylvestris (Bl.) Engl. forma crassifolia: 29318 (5), (4): climber in kapur-forest.

Schismatoglottis wallichii Hook. f. var, oblongata : 29987 (2).

\section{Araliaceae}

Arthrophyllum ovalifolium Miq.: common in secondary forest of swamp and dry land.

Arthrophyllum sp.: s.n. 24.6 .35 (4); treelet -2 m , in swamp-forest.

Schefflera lanceolata Ridley: (7); common epiphyte of Tristania-banks.

S. subulata (Seem.) Vig.: common epiphyte of Tristania-banks and mempisang-belt.

S. tomentosa (Hassk.) Vig.: common epiphyte of Tristania-banks and swamp-forest; (S. farinosa (Bl.) Merr.).

S. venulosa (Seem.) Harms: 28556 (8); epiphyte in mangrove and nibong-swamps; kuku bujang.

\section{Asclepiadaceae}

Asclepias curassavica L.: (9), coastal weed; bunga ekor mera.

Dischidia R. Br.: creeping and hanging epiphytes on trees, mostly widely occurring.

D. benghalensis Colebr.

D. coccinea Griff.

D. collyris Wall.

D. aff. complexa Griff.: R.E. Holttum s.n. 10.2 .48 (2); as at Jurong, Singapore. See special notes.

D. hirsuta (Bl.) Dene.

D. nummularia R. Br. (D. gaudichaudii).

D. rafflesiana Wall.: very common in coastal forest.

Dischidia sp.: s.n. 11.4.36 (2); epiphyte in swamp-forest; corolla pale green with dark longitudinal stripes.

Finlaysonia obovata Wall.: 28647 (8); common creeper and scrambler over mud in mangrove: buah pelir kambing (? in mistake for Sarcolobus). 
Hoya R. Br.: epiphytic climbers.

$H$. coronaria Bl.: common in coastal and mangrove forest.

H. diversifolia $\mathrm{Bl}$.

H. ? diversifolia: s.n. 2.2 .36 (6). See special notes.

H. lacunosa Bl.

H. latifolia $\mathrm{G}$. Don.

$H$. parasitica Wall.

$H$. ? ridleyi King et Gamble: s.n. June 1934 (9). See special notes.

Hoya sp.: s.n. 27.7 .39 (7); on riverside trees. See special notes.

Sarcolobus globosus Wall.: 23824 (7), (8), (9); frequent slender climber in freshwater and brackish tidal reaches; pelir kambing.

Toxocarpus glabrescens Henders.: (7); climber.

Tylophora asthmatica W. et A.: 28528 (9); climber in secondary forest behind coastal Casuarina.

\section{Bignoniaceae}

Deplanchea bancana Scheff.: 29412 (5); in swampy ground by stream leading from kapur-forest.

Radermachera lobbii Miq.: 32385 (2): common locally.

\section{Bombacaceae}

Coelostegia griffithii Benth.: canopy tree $-45 \mathrm{~m}$, steeply and strongly buttressed; locally frequent in swamp-forest, readily identified from the long persistent fallen fruits; punggai. See special notes.

Durio griffithii (Mast.) Bakh.: 29004 (5); streamside in hillock-forest.

D. ? graveolens Becc.: s.n. 7.2 .35 (3), (5); sterile specimens from hillock-forest, det. Kostermans; tree $-35 \mathrm{~m}$, buttressed $-2 \mathrm{~m}$ high; bark fuscous rufous with lenticels 3-5 mm wide.

D. singapurensis Ridley: 29350 (6), 29572 (2), 36974 (7), s.n. 11.5 .35 (5), (10); tree $-25 \mathrm{~m}$, not or scarcely buttressed; frequent in swamp-forest; durian daun. See special notes.

Kostermansia malayana Soegeng: 34673 (1), 36998 (7), 37100,37111 (7), s.n. 11.5 .35 (5), (2); big canopy tree, very strongly buttressed; bark fuscous rufous, fissuredflaky; leaves pale brownish beneath; frequent in swamp- and hillside-forest, in places locally dominant; krepal, krepau. See special notes. Plates 8, 36.

Neesia malayana Bakh.: tree $-33 \mathrm{~m}$, scattered in the swamp-forest, locally frequent, and in Eugenia grandis forest, easily recognised from the fallen fruits with irritant hairs; apa apa, ha ha. See special notes.

\section{Boraginaceae}

Ehretia sp.: 28713 (1).

Heliotropium indicum L. : 28529 (9); herb scattered in the grass-sward under Casuarina; selaseh pasir.

Ptelaeocarpa malaccensis Oliver: 36803 (7), 36916 (7), 36973 (7); slender climber in swamp-forest. 


\section{Burseraceae}

Canarium apertum H. J. Lam: 28437 (7); tree, scattered in swamp-forest. See special notes.

C. littorale Bl.: 28501 (9), 28555 (9), 29011 (5), 29028 (5), 29327 (4), 36827 (7), 37071 (10), s.n. $13.5 .34(7), 15.4 .36(1)$; tree $-20 \mathrm{~m}$, frequent in swamp- and Eugenia grundis forest; kedongdong.

C. patentinervium Miq.: 32140 (2), 36906 (7); tree $-17 \mathrm{~m}$, scarce in swamp-forest.

C. pilosum Benn.: ? in the Sediii-region, frequent in the swamp-forest of Singapore with leaflets withering red. See special notes.

Dacryodes laxa (Benn.) H. J. Lam: s.n. 16.7 .39 (7); in swamp-forest below Mawai.

D. macrocarpa H. J. Lam: 31949 (5), 34910 (5); tree -35 m, scarce in swamp-forest. See special notes.

D. rostrata (Bl.) H. J. Lam: 36858 (7), 36867 (7), 36970 (7); tree -27 m, in swampforest.

Santiria apiculata (Benn.) H. J. Lam: 29029 (5), 29031 (5), 29440 (5); generally a small tree frequent in swamp- and hillock-forest. See special notes.

S. conferta Benn.: 28708 (1), 32133 (2), 34703 (7); tree $-20 \mathrm{~m}$, in dryer parts of the swamp-forest. See special notes.

S. laevigata Bl.: 32398 (2), 36798 (7), 36804 (7), 36864 (7), 36895 (7), 36960 (7), s.n. 13.4.36 (2), 15.4.36 (2); tree $-40 \mathrm{~m}$, frequent in swamp-forest and on Tristaniabanks. See special notes.

S. rubiginosa BI.: 25993 (3), 30983 (2), 32307 (2), s.n. 7.10 .34 (7), 31.12 .34 (4), 18.2.37 (2), 3.7 .38 (7); tree $-40 \mathrm{~m}$, fluted or with low buttresses, with loop-roots; common in swamp-forest, often as a canopy tree with Cratoxylon arborescens; pasah. See special notes.

S. tomentosa Bl.: 32377 (2), 34753 (7), 34913 (5); tree $-25 \mathrm{~m}$, frequent in swampforest.

\section{Capparidaceae}

Crateva religiosa Forest. f.; lax straggling tree $-10 \mathrm{~m}$, frequent along streamsides in swamp-forest; kepayang ayer. (Crateva membranifolia of Wayside Trees of Malaya).

\section{Casuarinaceae}

Casuarina equisetifolia L.: (9), coastal forest; rhu. Plates 26, 27.

\section{Celastraceae}

Bhesa paniculata Arn.: 28697 (1), 28742 (3), 29271 (7), 38697 (1); tree -20 m, with poor irregular crown; common in swamp-forest. (Kurrimia paniculata in Wayside Trees of Malaya).

Euonymus javanicus Bl.: 28480 (9), 29040 (5), 32322 (2); small tree -13 m, or shrub 1-2 $\mathrm{m}$; abundant in dryer parts of the swamp-forest, in hillock-forest, and in Eugenia grandis forest. See special notes.

Glyptopetalum quadrangulare Prain: s.n. 9.2.35 (5); shrub -2 m, roots with yellow underbark (as in Euonymus javanicus); fruits depressed- globose, rose-pink; in hillock-forest. 
Kokoona ochracea (Elm.) Merr.: 37249 (4).

Loeseneriella macrantha (Korth.) A. C. Smith: 21197 (7), 25951 (7), 28066 (8); frequent rivcrside climber on putat, rassau, and jejawi from Lubok Pusing to Bt Tiga; follicles flat, 2-3 together; akar china.

Lophopetaium javanicum (Zoll.) Turcz.: 37022 (1); tree -35 m, riverside, infrequent but striking in fruit.

L. multinerviurn Ridley: 28092 (7), no fertile collections made; tree $-27 \mathrm{~m}$, with plank-like pneumatophorcs; frequent in freshwater tidal swamp-forest; buah ulat, perupoh. See special notes. Plates 14, 16, 17.

Microtropis valida Ridley: 32087 (2); shrub or small tree.

Salacia chinensis L.: s.n. 12.6 .34 (9); big climber, stems $-15 \mathrm{~cm}$ thick; in Eugenia grandis forest.

S. korthalsiana Miq.: 36817 (7); big climber in swamp-forest.

S. macrophylia Bl.: 28966 (3), 30690 (6); shrub $1 \mathrm{~m}$ high (? becoming a climber), with pink flowers; in swamp-forest.

S. oblongifolia $\mathrm{Bl}$.: 36548 (2); big climber in swamp-forest.

\section{Clusiaceae}

Calophyllurn L. See special notes.

Calophyllum canum Hook. f.: 36891 (7); tree -30 m, no buttresses.

C. curtisii King: 30865 (2), 32324 (2); tree $-50 \mathrm{~m}$, with steep blunt buttresses $-5 \mathrm{~m}$ high; in dryer parts of the swamp-forest, locally frequent.

C. depressinervium Henders, et Wyatt-Smith: s.n. 7.10 .34 (7); tree $-20 \mathrm{~m}$, without stilts or buttresses; scattered in swamp-forest with Cratoxylon arborescens.

C. floribundum Hook. f.: 28599 (8), 34748 (7), 34751 (7), 37387 (7); tree -17 m, without stilts and buttrcsses, flowcring in Dccember; frequent in swamp-forest.

C. graciliinum Henders. et Wyatt-Smith: 28998 (5); tree $-13 \mathrm{~m}$, without stilts and buttresses; fruiting in February; in hillock-forest.

C. incrassatum Henders. et Wyatt-Smith: 30977 (1), 34911 (5), s.n. 8.2 .35 (5), 10.2.35 (5), 15.2.35 (2); trce $-33 \mathrm{~m}$, without stilts and buttresses; fruiting March-April; frequent in swamp-forest and kapur-forest.

C. inophylloide King var. singapurense Henders. et Wyatt-Smith: s.n. 28.8.32 (3), 8.2.35 (5), $14.5 .35(5), 21.5 .35$ (7); tree $-40 \mathrm{~m}$, with congested stilt-roots $-2 \mathrm{~m}$ high, and loop-roots; wood hard, heavy; not infrequent in swamp-forest.

C. inophyllum L.: (9); common coastal tree; bintalgor, penaga laut.

C. kunstleri King: 30877 (7), 34719 (7), 34752 (7); tree -20 m, without buttresses, but with loop-roots $-45 \mathrm{~cm}$ high; frequent in swamp-forest.

C. macrocarpum Hook. f.: 32240 (2), 37108 (7), s.n. 19.6 .34 (7), (8); tree $-37 \mathrm{~m}$, without stilts and buttresses; not infrequent in swamp-forest; bintangor bumut.

C. pulcherrimum Wall.: 31990 (2), s.n. 9.2 .35 (4), (7); tree -9 m, without stilts and buttresses; riversidc and swamp-forest, frequent.

C. retusum Wall.: 29050 (1), (7), Sinclair s.n. (9); trcc $-40 \mathrm{~m}$, without buttresses or stilts, but with loop-roots; in swamp-forest (formerly common in Singapore). See special notes.

C. rubiginosum Henders. et Wyatt-Smith: s.n. 28.10 .32 (2); in hillock-forest.

C. rupicolum Ridley var. elatum Whitmore: 34706 (7), 34747 (7), s.n. 17.6 .34 (8); small tree $-10 \mathrm{~m}$; riverside in mempisang-belt and on Tristania-banks, locally frequent. See special notes. 
C. sclerophyllum Vesque: 34728 (7), s.n. 27.6 .32 (7), 37.7 .32 (7), 15.3 .34 (7), 16.3.34 (9), 21.5.34 (7), 7.10.34 (7), 2.2.35 (1); tree .40 m, stilt-roots up to $4 \mathrm{~m}$ high on the trunk, copious; roots with $\lambda$-shaped pneumatophores $-45 \mathrm{~cm}$ high; wood hard, heavy (sinking); abundant in the swamp-forest, often very large; bintangor $b a t u, b$. jangkang, penaga darat. Plates 10, 13, 22.

C. soulattri Burm.: 36806 (7, S. Gembut), s.n. 10.6 .34 (9, S. Tuenseh); tree $-30 \mathrm{~m}$, without stilts and buttresses, but in swamp-forest with $\lambda$-shaped pneumatophores $-30 \mathrm{~cm}$ high; riverside and frequent in Eugenia grandis forest; bintangor sempang.

C. tenuivenium Henders. et Wyatt-Smith: 32274 (1); in swamp-forest, ? endemic in this region.

C. wallichianum Planch. et Tr.: 30987 (1), s.n. 5.5 .35 (4); tree $-53 \mathrm{~m}$ in kapurforest, $-40 \mathrm{~m}$ in swamp-forest, without stilts and buttresses; in dryer parts of the swamp-forest and in kapur-forest. (C. rufigemmatum Henders. et WyattSmith).

Calophyllum sp.: s.n. $30.4 .34,16.6 .34$ (9, S. Semandan); tree -15 m, with congested stilt-roots and loop-roots (30.4.34); frequent in sandy coastal forest and adjacent swamp-forest. (Henderson and Wyatt-Smith 1956, p. 350, n. 44).

Garcinia L. See special notes.

G. atroviridis Griff.: 36902 (7); in swamp-forest; asam gelugor.

G. bancana Miq.: 24627 (7), 29262 (2), 29406 (6), 34730 (7), s.n. 10.1 .38 (7), 2.2.38

(7); tree-15 (-20) $\mathrm{m}$, with few short stilt-roots or none; common in the mempisang-belt, rarely on Tristania-banks; chepurah, cheret budak.

G. bancana var. curtisii (Ridley) Whitmore: 25854 (7).

G. ? eugeniaefolia Wall.: s.n. 11.6 .34 (9, S. Rhu Reba); tree -13 m, without stiltroots; frequent in Eugenia grandis forest; tulang dain. See special notes.

G. forbesii King: 29291 (3), 36856 (7), 36964 (7); small tree, often with a few short stilt-roots; in swamp-forest, common; kandis.

G. griffithii T. And.: 32195 (2); frequent in the dryer parts of the swamp-forest and in hillock-forest; kandis gajah.

G. hombroniana Pierre: (9); in coastal forest, frequent; bruas.

G. maingayi Hook. f.: 21331 (2), ? 28667 (5), 31993 (2), ? 36829 (7), s.n. 20.1.35 (4); tree $-20 \mathrm{~m}$, stilted or not; frequent in dryer parts of the swamp-forest and in hillock-forest. See special notes. Plate 23.

G. nervosa Miq.: 25966 (7); tree $-17 \mathrm{~m}$, conspicuous from the long hanging leaves; scattered in rassau- and mempisang-belts, especially near K. Dohol; asam garam.

G. nigrolineata Planch.: 28072 (7, 8), 28498 (9), s.n. 13.5 .34 (7); frequent in swamp forest and sandy coastal forest; kandis. See special notes.

G. opaca King var. dumosa Whitmore: 28653 (8), s.n. 18.4 .32 (3), 7.2.35 (3); straggling treelet $-3.5 \mathrm{~m}$ high, fruit cherry red: frequent in swamp-forest and in sandy coastal forest. (Gdns' Bull. Singapore 26, 1973, 277).

G. parvifolia Miq.: 28564 (8), 28577 (8), 32381 (2), 34716 (7), 34735 (7), 36878 (7); common small tree in swamp-forest.

G. ? penangiana: 31499 (5), 34940 (5), s.n. 9.9 .34 (4), 31.12 .34 (5), 8.2.35 (5), $30.5 .37(5)$; tree $-23 \mathrm{~m}$; frequent in dryer parts of the swamp-forest, in hillockforest, and in kapur-forest. See special notes.

G. ? rostrata: 26198 (5), 28541 (9), 28665 (5), 30971 (1), 32020 (2), 34766 (7), s.n. 31.12.34 (5); tree $-17 \mathrm{~m}$, with stilt-roots; frequent in swamp-forest and in sandy coastal forest; tulang dain. See special notes. Plates 34, 39: Figure 6. 
G. urophylla Scort.: 29204 (4); treelet $-3 \mathrm{~m}$, in dryer part of the swamp-forest. Garcinia sp.: s.n. 25.11 .34 (7, Tg Tebar). See special notes.

Mesua L. See special notes.

$M$. ferrea L.: $(4,5)$; tall tree in kapur-forest; penaga.

M. ferruginea Pierre: 23900 (7), 25973 (7), 26140 (7), 29272 (2), 31450 (7), 34733 (7), $36802(7)$; shrub or small tree $-7 \mathrm{~m}$; common in rassau- and mempisangbelts. See special notes.

M. kochummeniana Whitmore: 29430 (5), (7), s.n. 31.12 .34 (5); tree $-36 \mathrm{~m}$; in swamp- and kapur-forest. See special notes.

M. lepidota Anderson: 32243 (2), s.n. 20.1 .35 (4); tree $-20 \mathrm{~m}$, sometimes with stilts and loop-roots; common in swamp-forest. See special notes.

M. rosea (Ridley) Kosterm.: 29273 (7), 32122 (2); small tree $-13 \mathrm{~m}$; common in swamp-forest. See special notes.

\section{Combretaceae}

Combretum squamosum Roxb.: 31968 (2); climber in swamp-forest.

C. sundaicum Miq.: 37062 (10), (6); climber.

C. tetralophum Clarke: 25859 (7); common climber on jejawi by riverside.

Lumnitzera littorea (Jack) Voigt; mangrove and coastal creeks, common; susop, teruntum.

L. racemosa Willd.: as $L$. littorea but a smaller tree; infrequent by coastal creeks. Plates 29, 30.

Quisqualis indica L.: s.n. 12.5 .35 (6); not in the swamp-forest.

Terminalia catappa L.: common in coastal forest; ketapang, lingtak.

T. citrina (Gaertn.) Roxb.: 31471 (2); tree -25 m, in swamp-forest.

T. phellocarpa King: 34743 (7), s.n. 13.5 .35 (2), 24.6 .35 (1); tree -30 m, not buttressed; crown rather flat-topped, with small leaves; fruits like small tough mangoes; flowering Nov.-Jan., fruiting May-Sept.; common in swamp-forest; jelawai, mempelam babi, pelawai, telisai.

\section{Commelinaceae}

Aneilema vaginatum R. Br.: 28457 (9); tufted herb, common in the sward under Casuarina.

Cyanotis vaga (Lour.) J. A. et J. K. Schultes: (9), coastal herb. See special notes.

Forrestia gracilis Ridley: s.n. 13.6.34 (9); common in Eugenia grandis forest.

$F$. marginata Hassk. and/or F. mollis Hassk.; (7), in dryer parts of the swampforest.

\section{Compositae}

Erechtites hieracifolia (L.) Raf.: (9), common in coastal scrub and under Casuarina. E. valerianifolia (Wolf) DC.: (9), coastal; sawi nggang.

Pluchea indica (L.) Less.: shrub or small tree of mangrove; beluntas. 
Spilanthes urens Jacq.: 28061, 28459 (9); rhizomatous herb of sand-dunes. See special notes. Plate 37.

Tridax procumbens L.: (9), coastal herb.

Wedelia biflora (L.) DC.: coastal herb; serunai laut.

\section{Connaraceae}

Agelaea borneensis (Hook. f.) Merr.: 29266 (7); climber in swamp-forest.

A. macrophylla (Zoll.) Leenh.: s.n. 18.6 .34 (8); riverside climber.

Cnestis palala (Lour.) Merr. ssp. diffusa (Blco) Andreas; 29332 (4); big climber, fruit rose-red, seed black with bright pale yellow aril; in swamp-, hillock-, and kapur-forest.

Connarus grandis Jack: 25861 (7), 28488 (9), 32182 (2). s.n. 28.5 .36 (7); large climber, fruit scarlet, seed black with orange-yellow aril; frequent in swampforest and on Tristania-banks from S. Kayu to Bt Tiga, and in coastal forest.

C. monocarpus L. ssp. malayensis Leenh.: 26138 (7), s.n. 1.5 .32 (7); climber, fruit yellow, seed brown with orange-yellow aril; frequent on Tristania-banks.

C. paniculatus Roxb.: 25853 (7), 25895 (7); climber on Tristania-banks.

C. semidecandrus Jack: 31453 (7), 34755 (7); climber, scattered on Tristania-banks.

Ellipanthus tomentosus Kurz var. gibbosus (King) Leenh.: 28180 (7), 29199 (4), 32320 (2), 37072 (10); lax treelet -5 m high; frequent in swamp- and hillockforest.

Rourea mimosoides (Vahl) Planch.: 25888 (7), 26059 (7), 32383 (2); climber in swamp-forest, on Tristania-banks, and growing over putat and rassau; liujan panas.

R. minor (Gaertn.) Leenh.: 25969 (7), 31459 (7), 32196 (2); big climber in swampforest and on Tristania-banks.

Roureopsis asplenifolia Schellenb.: 31978 (2), s.n. 16.5 .32 (7); climber in swampforest and on Tristania-banks.

\section{Convolvulaceae}

Argyreia ridleyi Prain: 32457 (2), s.n. Feb. 1935 (1); common climber in swampforest.

Erycibe aenea Prain: 29308 (1), 37362 (5); climber in swamp-forest.

E. albida Prain: 28717 (1), (4); shrub -1 m, flowers fragrant, petals white and 2-lobed; in swamp-forest.

E. maingayi Clarke: 21332 (2), 29334 (4); climber in swamp-and kapur-forest. (E. princei Wall.).

E. tomentosa Bl. var. hirsuta (Hall. f.) Hoogl.: 32367 (2).

Evolvulus alsinoides L.: (9), common coastal herb.

Merremia tridentata (L.) Hall. f. ssp. hastata (Desr.) Ootstr.: 28656 (9), s.n. 12.6 .34 (9); common in clearings behind Casuarina-forest.

Ipomoea gracilis R. Br.: (9); coastal dunes; kangkong pasir. (I. littoralis Bl.).

I. pes-caprae L.: (9); coastal dunes; daun tapah kudah.

I. stolonifera (Cyrill) J. F. Gmel.: (9), coastal dunes. (I. carnosa R. Br.). 


\section{Cornaceae}

Alangium ebenaceum (Clarke) Harms var. tutela (Ridley) Kochumm.: 28980 (3), 36925 (7); tree -20 m, buttressed; scattered in swamp-forest. See special notes.

Aralidium pinnatifidum Miq.: 21325 (5), 28629 (8), 29256 (2), 29441 (5); frequent in dryer parts of the swamp-forest, in hillock- and kapur-forest, and in nibongforest; chengpok.

Mastixia ? trichotome Bl.: 28696 (1), 28974 (3), 29299 (3), 32204 (2), 32417 (2); tree $-14 \mathrm{~m}$;frequent in swamp-forest. See special notes.

\section{Crassulaceae}

Bryophyllum calycinum Salisb.; (9), coastal; setabal. (Kalanchoe pinnata).

\section{Cucurbitaceae}

Alsomitra sp.: s.n. 15.5 .35 (7, S. Dohol); riverside climber, bare of leaves when fruiting; fruits like cartridge-cases, fuscous when ripe, dehiscing apically, not fleshy.

Hodgsonia capniocarpa Bl.: 29407 (1); frequent climber in dryer parts of the swamp-forest and in hillock-forest.

Trichosanthes ? tricuspidata Lour.: 32108 (2).

T. wallichiana Wight: very common climber in swamp-forest, especially in small clearings.

\section{Cyperaceae}

Bulbostylis barbata (Rottb.) Clarke: coastal on open dunes and in dune-hollows.

Cyperus cyperoides (L.) O.K.: in coastal scrub. (Mariscus sieberianus).

C. cyperinus (Retz.) Valck Sur.: in coastal scrub. ( $M$. cyperinus).

C. javanicus Houtt.: coastal, dune-hollows and muddy creeks. (M. albescens).

C. malaccensis Lamk: 28526 (9, S. Diman); common sedge $-1.7 \mathrm{~m}$ high, along the riverside in the tidal region between brackish and fresh water, occasionally in dune-hollows; selimbu. Plate 28.

[C. pedunculatus (R. Br.) Kern: not seen at Jason Bay. (Remirea maritime)].

C. polystachyos Rottb.: coastal dune-hollows, tufted. (Pycreus polystachyos).

C. radians Nees et Mey.: coastal, on open dunes and in dune-hollows, tufted.

C. stoloniferus Retz.: 28079 (9); coastal, on open dunes, also in muddy or sandy places in advancing mangrove, very abundant; rhizomes subterranean with black corms.

C. tenuiculmis Boeck: s.n. 15.6.34 (9); forming swards under Casuarina, and in wet hollows in Eugenia grandis forest.

Fimbristylis cymosa R. Br. 28076 (9); coastal dune-hollows, often with seedling Avicennia.

$F$. dichotoma (L.) Vahl; coastal dune-hollows and muddy creeks. 
F. ferruginea (L.) Vahl: 28075, 28077 (9); coastal, in wet brackish hollows and creeks.

F. pauciflora R. Br.: coastal dune-hollows, by streams in Eugenia grondis forest, and in swamp-forest.

F. polytrichoides (Retz.) $\mathrm{R}$. Br.: coastal dune-hollows and muddy creeks.

F. sericea $\mathrm{R}$. Br.: coastal, forming flat tussocks on open dunes; scarce at Jason Bay.

Fuirena umbellata Rottb.: coastal, in swampy places.

Gahnia tristis Nees: in secondary forest and waste land.

Hypolytrum nemorum (Vahl) Spreng.: sedge $-1 \mathrm{~m}$ high, common on flood-banks of the river just above normal high tides.

$H$. nemorum var. proliferum (Boeck) Kern: sedge $-45 \mathrm{~cm}$ high; common in swampforest.

Mapania cuspidata (Miq.) Uitt.: 29476 (7), 29985 (4); gregarious or solitary sedge; abundant in swamp-forest. See special notes.

M. cuspidata var. petiolata (Clarke) Uitt.: 30742 (6), 31945 (7), 32514 (2), s.n. $11.4 .36(2)$.

M. enodis (Miq.) Clarke: 29736 (2). 37106 (7); tufted sedge: common in swampforest.

M. kurzii Clarke: s.n. 9.9.34, 5.5.34; in hillock- and kapur-forest, not in the swamp.

M. lorea Uitt.: 28594 (8), 30683 (6), 30884 (7), 37074 (10), s.n. 3.8 .31 (7), 5.5 .35 (4); common in swamp-, hillock-. and kapur-forest, generally in dryer places than Scirpodendron.

M. micropandanus Holtt.: 29362 (4), 29989 (4), 32336 (2); in dryer parts of the swamp-forest, in hillock- and kapur-forest, locally common. See special notes.

M. palustris (Hassk.) F.-Vill.: 37057 (1); in hillock-forest.

M. squarnata (Kurz) Clarke: s n. 10.4 .36 (6).

Rhynchospora corymbosa (L.) Britt.: erect and Scleria-like; frequent in the mempisang-belt.

Scirpodendron ghaeri (Gaertn.) Merr.: forming thickets, common in the tidal parts of the river from the nipa-belt to the mempisang, also by streams in the swampforest (? as relics); selengsen.

Scleria lithosperma (L.) Sw.: 28157 (9); coastal.

S. poaeformis Retz.: 28507 (9); coastal in wet places behind Casuarina, like stands of Iris; purun tikus.

(Other species of Scleria came into clearings in the swamp-forest, but I failed to note them).

Thoracostachyum bancanum (Miq.) Kurz: common in the swamp-forest, easily mistaken for Hypolytrum.

T. sumatranum (Miq.) Kurz: (2), (7); frequent in the swamp-forest.

\section{Dichapetalaceae}

Dichapetalurn griffithii (Hook. f.) Engl.: 30734 (6), (4); small shrub becoming a climber; in dryer parts of the swamp-forest.

Dichapetalum sp.: 31979 (2); (? identity; not listed by Leenhouts 1956). 


\section{Dilleniaceae}

Acrotrema costatum Jack: 32144 (2); frequent suffrutescent herb, in dryer parts of the swamp-forest.

Dillenia albiflos Ridley: 26850 (7), 29300 (1), 29369 (4), 32016 (2), 36850 (7), 37059 (10), s.n. $31.12 .34(4)$, (5); small tree $-17 \mathrm{~m}$, rarely with a few stilt-roots; frequent in dryer parts of the swamp-forest and on hillocks; endemic to south east, or east, Johore.

D. excelsa (Jack) Gilg: 29335 (1), s.n. 27.3 .32 (7); tree -27 m, without buttresses or stilts; flowering March-May (? not every year); frequent in swamp-forest.

D. excelsa var. tomentella (Mart.) Corner: 32190 (1); flowering in October: frequent in swamp-forest.

D. grandifolia Wall.: 26854 (7), s.n. 10.4 .36 (6); tree $-40 \mathrm{~m}$, with prominent stiltroots $-3 \mathrm{~m}$ high; deciduous; flowers without petals: scattered in swamp-forest; simpoh jangkang. (D. eximia Miq.).

$D$. indica L.: frequent small tree on the banks of Saraca-streams and in the dryer parts of the swamp-forest; peradun.

D. pulchella (Jack) Gilg: tree $-30 \mathrm{~m}$, without buttresses or stilts, evergreen; frequent in the swamp-forest.

D. reticulata King: 30678 (6), (7); stilted tree as D. grandifolia, apparently impossible to distinguish when sterile; deciduous; flowers with yellow petals; scattered in swamp-forest; simpoh jangkang.

D. suffruticosa (Griff.) Martelli: 21189 (7), 32984 (7), 33546, 33547 (7); shrub or small tree, evergreen, often with some aerial roots from the branches; common on Tristania-banks between Mawai and Bt Tiga; simpoh ayer.

Dillenia sp.: s.n. 11.6.34 (9,-S. Rhu Reba). See special notes.

Tetracera arborescens Jack: s.n. 29.11 .32 (7); frequent climber on Tristania-banks; mempelas asah.

T. fagifolia Bl.: (8).

T. indica (Houtt.) Merr.: 28631 (8): conmon riverside climber on Tristania-banks and in the swamp-forest; mempelas.

T. sarmentosa (L.) Vahl (9); coastal climber, common; mempelas gajah.

\section{Dioscoreaceae}

Dioscorea lamprocaula Prain et Burkill: s.n. (7).

D. pyrifolia Kunth: 28735 (3); climber with ovate-cordate leaf, 5-7 basal veins; in swamp-forest.

Dioscorea sp.: 32120 (2), 32499 (2).

\section{Dipterocarpaceae}

Balanocarpus heimii King: 30863 (2), 30867 (2), 32025 (2), (4), (10); tree -55 m, frequent in hillock-forest and in the dryer parts of the swamp-forest, among the first to be felled; chengal, penah.

Dryobalanops aromatica Gaertn. f.: (4), (5), (10); tree $-60 \mathrm{~m}, 34 \mathrm{~m}$ to the first branch, dominant on some hillocks and in the adjacent parts of the swampforest, at its southernmost occurrence in Malaya; kapur. 
D. oblongifolia Dyer: 21181 (7), 32194 (2); tree $-40 \mathrm{~m}$, sharply buttressed, sometimcs with a few arcuate stilt-roots; common in swamp-forest, and on Tristania-banks from Lubok Pusing upstream; general flowering in October 1936; keladan, kuras. Plate 7.

Dipterocarpus apterus Foxw.: s.n. 4.2 .35 (2); tree $-30 \mathrm{~m}$, not buttressed; in dryer parts of the swamp-forcst; kruing gombang.

D. cornutus Dyer: frcquent in dryer parts of the swamp-forest.

D. grandiflorus Blanco: s.n. 2.4.34 (9), 23.6 .34 (8); tree $-40 \mathrm{~m}$, without buttresses but the iree of 23.6 .34 with large buttresses $-2 \mathrm{~m}$ high; common in coastal climax-forest; kuing.

D. ? hasseltii Bl. (? D. sublamellatus): s.n. 2.6 .34 (9), 2.6 .34 (9); tree -35 m, not buttressed; frequent in Ellgenia grandis forest; kuing. See special notes.

D. lowii Hook. f.: 37030 (5), s.n. 30.12 .34 (5), 14.5 .35 (5); tree $-47 \mathrm{~m}$, slightly buttressed; frequent canopy-tree with Dryobalanops oblongifolia in the swampforest, not seen south of mile 13 on the Jcmaluang Road, not along the Sedili rivers; kruin sol.

D. sublamellatus Foxw.: s.n. 9.235 (4); tree -45 m. buttressed -1.7 m; bark greyish fawn, irregularly flaky with oblong angular scales; frequent in dryer parts of the swamp-forest; kruin so! (erroneously according to Symington).

Dipterocarpus sp.: s.n. 9.9 .34 (3); on stream-banks in swamp-forest. See special notes.

Hopea mengarawan Miq.: s.n. 27.5 .34 (7); scattered in the swamp-forest; merawan. See special notes.

H. ? mengarawan: 30988 (1); locally frcquent and gregarious in dryer parts of the swamp-forest; (dct. H. ? dyeriana). See spccial notes.

H. polyalthioides Symington: 21342 (5); small tree $-5 \mathrm{~m}$; common in kapur-forest on the Jemaluang Road; resak rambai. See special notes.

H. resinosa Symington: 28478 (9). 28514 (9), 32323 (2), 36879 (7). 36911 (7), s.n. 9.9 .34 (7), ? 31.12 .34 (5), 6.2 .35 (3); small tree $8-20 \mathrm{~m}$; scattered or locally gregarious in swamp-forest and Engenia grandis forest; mengkedi; endemic in east Pahang and east Johore. See special notes. Plate 15. See also p. 163.

Shorea acuminata Dyer: 29372 (4), s.n. 15.5 .35 (4); tree $-47 \mathrm{~m}$ : frequent in kapurforest; meranti rambai dalı. See special notes.

S. bracteolata Dyer: 29261 (2), s.n. 6.2.35 (3), (7): tree $-30 \mathrm{~m}$ : frequent in swampforest, on Tristania-banks, and in hillock-forest: meranti pa'ang. See special notes.

S. collina Ridley: 30857 (2); tree $-47 \mathrm{~m}$, scarcely buttressed. with a very deep taproot $(-3.5 \mathrm{~m}$ long. $45 \mathrm{~cm}$ thick at $1 \mathrm{~m}$ from the trunk-base, as seen in an uprooted tree); in dryer parts of the swamp-forest.

S. exelliptica Meijer: 30853 (2), 33559 (4), (7); tree -57 m; frequent in the swampforest, especially the dryer parts, and in kapur-forest; belatl. Sec special notes.

S. foxworthyi Symington: 33558 (4), (10); tree $-47 \mathrm{~m}$; frequent in kapur-forest; balau. See special notes.

S. lepidota (Korth.) Bl.: 21184 (7), s.n. 10.2 .35 (4); tree $-40 \mathrm{~m}$; frequent in dryer parts of the swamp-forest, and on Tristania-banks from Lubok Pusing upstream: meranti rambai daun, usually sengkawang (but these names, though used locally, erroneous according to Symington; see S. singkawang). See special notes. 
S. leprosula Miq.: s.n. 2.2 .35 (1), 7.2 .35 (3); tree $-50 \mathrm{~m}$; frequent in hillock-forest and the dryer part of the swamp-forest behind Tristania-banks, then arching over the river, buttressed up the bank, the rather flat-topped crown laden with epiphytes; meranti tembaga. See special notes.

S. macroptera Dyer: 30985 (1); tree $-40 \mathrm{~m}$, slightly buttressed; in swamp-forest.

S. materialis Ridley: 21182 (7); frequent large tree in the swamp-forest, among the first to be felled; balau.

S. ovalis (Korth.) Bl.: s.n. 2.2 .35 (1), 10.5 .35 (1); tree $-47 \mathrm{~m}$; frequent in the dryer part of the swamp-forest and in hillock-forest; meranti kepong. See special notes.

S. palembanica Miq.: 29331 (4), 29382 (4), s.n. 4.2 .35 (1), 6.2 .35 (3); tree -35 m; frequent in swamp-forest, especially the dryer parts, also in kapur-forest; meranti gajah, $m$. pinang baik. See special notes.

S. parvifolia Dyer: s.n. 2.2 .35 (1); tree $-35 \mathrm{~m}$; frequent in hillock-forest; meranti sarang punai. See special notes.

S. pauciflora King: s.n. 2.2 .35 (1); tree $-20 \mathrm{~m}$; in hillock-forest; meranti samak. See special notes.

S. platycarpa Heim: tree $-35 \mathrm{~m}$; common in the swamp-forest; meranti paya. See special notes.

S. resina-nigra Foxw.: s.n. 2.2 .35 (1), $31.12 .34(3),(7)$; tree $-55 \mathrm{~m}$; occasional in dryer parts of the swamp-forest and in hillock-forest; damar hitam. See special notes. Plate 8. See also p. 163.

S. singkawang (Miq.) Burck: 21343 (5). 25996 (7), s.n. 31.12.34, (2), 2.2 .35 (1), 1.9 .35 (3); tree $-40 \mathrm{~m}$; frequent in swamp-forest, especially by streamsides, and in hillock-forest, as a dominant by the Sedili Besar above Bagan Limau; meranti gajah, sengkawang, tengkawang. See special notes.

S. sumatrana (v. Sl.) Symington: 21183 (7); tree $-25 \mathrm{~m}$, often with short buttresses; bark smooth; inner bark brownish; common in swamp-forest and on Tristaniabanks; damar mata kuching (this name consistent, not sengkawang as given by Symington).

Vatica maingayi Dyer: 32418 (2), 37098 (5); in swamp-forest.

V. stapfiana (King) v. Sl.: 32063 (2); tree $-15 \mathrm{~m}$, in swamp-forest.

V. stipulata Ridley: 36928 (10). See p. 163.

V. wallichii Dyer: 21185 (7), 21189 (7), ? 28982 (3). 32438 (7), (8); tree -23 m, often short and crooked; common in the mempisang-belt with Mesua ferruginea, especially between Mawai and Bt Tiga, in swamp-forest, and on Tristaniabanks; resak, r. laru (28928). See special notes. Sce also p. 163.

\section{Ebenaceae}

Diospyros apiculata Hiern: 29359 (3); tree- 10 m, in swamp-forest. See special notes.

D. argentea Griff.: 21322 (1), 28491 (9), s.n. 10.6 .34 (9); treelet 3-5 m; common in dryer parts of the swamp-forest, in hillock-forest, and in Eugenia grandis forest; segun. See special notes.

D. confertiflora (Hiern); Bakh.: 28701 (1), 29254 (2); treelet -4 m; frequent in swamp- hillock-, and kapur-forest. See special notes. 
[D. ferrea (Willd.) Bakh. on rocky coasts, but ? not in the Sedili region].

D. ? graciliflora Hiern: 36936 (10).

D. lanceifolia Roxb.: 29373 (3), 34749 (7), (4), ? s.n. 10.6 .34 (9); tree -17 m, with stilt-roots; in swamp-forest, ? in Eugenia grandis forest; segun.

D. latisepala Ridley: 37029 (5).

D. maingayi (Hiern) Bakh : 28438 (7), 28666 (5); tree $-20 \mathrm{~m}$; frequent in swampforest. See special notes.

D. ? malayana Bakh.: 32396 (2), 32470 (2).

D. nutans King: 21312 (1), 29339 (4), 29442 (5), 32304 (2), 32365 (2); small tree $-10 \mathrm{~m}$, slender; bark black; twigs becoming corky-angular; frequent in swampand kapur-forest.

D. oblonga Wall.: 30883 (7).

D. ? pahangensis Bakh.: 32303 (2).

D. styraciformis King et Gamble: 30989 (1).

D. sumatrana Miq. var. decipiens: 32149 (2).

Diospyros sp.: 36926 (7).

Diospyros sp. s.n. 7.10.34; tree $-13 \mathrm{~m}$, in dryer part of the swamp-forest, with Cratoxylon. See special notes.

Diospyros sp.: s.n. 6.8 .39 (10); tree $-25 \mathrm{~m}$, in kapur-forest. See special notes.

\section{Elaeocarpaceae}

Elaeocarpus floribundus Bl.: 32290 (2); tree $-30 \mathrm{~m}$, developing flowering coppiceshoots from the cut stump.: this collection referred by Weibel to $E$. acmossepalus Ridley.

E. griffithii Masters: 28563 (9), 28602 (8), 32800 (7), 32987 (7); tree -20 m; very abundant on Tristania-banks; jiremong.

E. macrocerus (Turcz.) Merr.: 21192 (7), 25976 (7), 28164 (7), 31449 (7), 34724 (7), s.n. 30.5 .37 (7); common tree with stilt-roots and pneumatophores in the mempisang-belt and swamp-forest; medang jangkang. See special notes. Plate 12.

E. nitidus Jack: 36834 (7), 36904 (7); in swamp-forest.

E. paniculatus Wall.: 24981 (7), 25957 (7), s.n. 1.7.39; common tree of Tristarilabanks, occasionally with stilt-roots $-45 \mathrm{~cm}$ high; pinang punai. (Treated as a form of $E$. griffithii by Weibel).

E. petiolatus Wall.: 36876 (7); common tree on Tristania-banks.

E. polystachyus Wall.: 32414 (2); in dryer parts of the swamp-forest.

E. robustus Roxb.: 25977 (7), 34726 (7), s.n. 10.11 .40 (7); tree -13 m, abundant on Tristania-banks from Lubok Pusing upstream; medang.

E. salicifolius King: 36909 (7).

E. sphaericus (Gaertn.) K. Schum.: s.n. 10.4 .36 (6), 8.1 .38 (7), (9); tree -30 m, scattered in the swamp-forest. especially in Salacca-swamps.

E. stipularis Bl.: 29048 (1), 32024 (2), 36847 (7); in swamp-forest with low flattened and scarcely spreading stilt-roots $-80 \mathrm{~cm}$ high and resembling Macaranga puncticulata; common in swamp- and hillock-forest. 


\section{Ericaceae}

Vaccinium acuminatissimum Miq.: 25998 (7), 32045 (2), 32062 (2); common epiphytic shrub, sometimes rooting to the ground; in swamp-forest.

V. bracteatum Thunb.: coastal small tree with Eugenia grandis and Terminalia catappa. ( $V$. malaccense of Wayside Trees of Malaya).

\section{Erythroxylaceae}

Erythroxylon cuneatum (Miq.) Kurz: 28476 (9); tree -23 m, characteristic of the Eugenia grandis forest; inai inai.

Ixonanthes reticulata Jack: 25898 (7), 28623 (8), s n. 5.2 .35 (2), (7); tree -33 m, buttressed; frequent in the mempisang-belt and in the swamp-forest; inggi burong. See special notes.

\section{Euphorbiaceae}

Acalypha siamensis Oliver: (9); coastal shrub; pokok teh.

Agrostistachys gaudichauddi M.A.: 32070 (2), 32318 (2), s.n. 14.6 .34 (9); tree -13 m, often densely gregarious, in swamp-forest and Eugenia grandis forest.

A. sessilifolia Pax et Hoffm.: 32001 (2); shrub -3 m, seldom branched; common in swamp-forest.

Alchomea rugosa (Lour.) M.A. : 30973 (1), 32031 (2): in swamp-forest. (A. javensis M.A.).

Antidesma brachybotrys Airy Shaw: 28984 (3), 29433 (5); shrub or treelet -5 m, in swamp- and hillock-forest; (det. A. stipulare Bl.).

A. cuspidatum M.A.: 29424 (5), 36849 (7); tree -10 m; in the dryer parts of the swamp-forest.

A. leucopodum Miq.: 29347 (6), also CWL 288 (Kuala Sedili); a small riverside tree.

A. neurocarpum Miq.: 21314 (1), 28071 (8), 32361 (2), (7); small tree -6 m; common in swamp-forest. (A. alatum of Wayside Trees of Malaya).

A. pachystachys Hook. f. var. palustre Airy Shaw: 29043 (5), 29232 (5), 32155 (2); shrub or treclet $-4 \mathrm{~m}$; frequent in swamp-forest; (det. A. tomentosum).

A. pahangense Airy Shaw: 37080 (10); in kapur-forest.

Antidesma sp.: 30689 (6), 30872 (6).

A porosa falcifera Hook. f.: 28694 (1); treclet -5 m, in swamp-forest.

A. frutescens Bl.: 28065 (8), ? 28723 (2), 31456 (7); tree -7 m, frequent in swampforest.

A. lunata (Miq.) Kurz: 21313 (1), s.n. 11.5 .35 (4); tree -7 m; frequent in swampand kapur-forest. See special notes.

A. nigricans Hook. f.: s.n. 9.2 .35 (5); tree $-10 \mathrm{~m}$; in hillock-forest. Sce special notes.

A. prainiana King: 29469 (1); tree $-5 \mathrm{~m}$; in the dryer part of the swamp-forest.

A. pseudoficifolia Pax: 29425 (5) 31999 (2); trcelet -5 m, in swamp-forest. Sec special notes.

A. symplocoides (Hook. f.) Gage: 32351 (2), 37024 (5), s.n. 9.9 .37 (7). 
Aporosa spp.: 36843 (7) and 36848 (7).

Austrobuxus nitidus Miq. : 21348 (1); tree $-10 \mathrm{~m}$, in the dryer part of the swampforest. (Longetia malayana in Wayside Trees of Malaya).

Baccaurea bracteata M.A.: 28575 (8), 34745 (7). 37033 (5); tree -8 m, often with arcuate stilt-roots $-1.7 \mathrm{~m}$ high; scattered in swamp-forest.

B. brevipes Hook. f.: 29017 (5), 29461 (4), 37023 (2); tree -6 m, frequent in hillockforest; rambai tikus.

B. hookeri Gage: 32997 (7); tree $-13 \mathrm{~m}$, in swamp-forest. See special notes.

B. ? javanica (Bl.) M.A.: 29456 (7); tree $-13 \mathrm{~m}$, in swamp-forest. See special notes.

B. lanceolata (Miq.) M.A.: 36976 (7); in swamp-forest. See special notes.

B. macrophylla M.A.: 28172 (7), 36861 (7); in swamp-forest.

B. motleyana M.A.: s.n. 7.10.34; in swamp-forest with Cratoxylon arborescens, wild; tampoi, tampal.

B. parviflora M.A.: 28997 (5); common in hillock- and kapur-forcst: setambun.

B. racernosa (Reinw.) M.A.: 28747 (3), 28750 (3), 34732 (7), 36977 (7), s.n. 15.7.40 (7); tree $-13 \mathrm{~m}$; common in the swamp-forest. See special notes.

B. scortechinii Hook f.: 29408 (6); treelet -5 m, ramiflorous; common by Saracastreams; rambai tikus. See special notes.

B. sumatrana (Miq.) M.A.: 36840 (7); trce -15 m, in swamp-forest. See spccial notes.

B. ? velutina Ridley: 32178 (2).

Blumeodendron kurzii (Hook. f.) J. J. Sm.: 28734 (2); small tree -13 m, without stilt-roots; leaves in false whorls of 5 at the ends of long twigs; ramiflorous; frequent in swamp-forest.

B. tokbrai (Bl.) Kurz: 31986 (2), 36787 (7), 36819 (7), 36877 (7); large tree, often stilted; frequent in swamp-forest. See special notes. Plate 19.

Botryophora geniculata (Miq.) Beumée: 32032 (2); swamp-forest.

Breynia coronata Hook. f.: (9); coastal shrub; hujan panas.

B. vitis-idaea (Burm.) C. E. C. Fischer: (9); coastal climber; hujan panas. (B. rhamnoides in Wayside Trees of Malaya).

Bridelia ? cinnamomea Hook. f.: 28983 (3); tree -17 m, in swamp-forest. See special notes.

B. pustulata Bl.: 21306 (1), 31445 (1); spiny treelet -5 m, in swamp-forest. See special notes.

B. stipularis (L.) Bl.: (4), (5); in secondary forest.

Cephalomappa lepidotula Airy Shaw: 28173 (7), 28951 (3); tree -20 m; locally common in swamp-forest, especially by streams. See special notes.

Claoxylon indicum (Reinw.) Hassk.: 28466 (9); shrub or small tree $-5 \mathrm{~m}$; frequent with Guettarda at the edge of Eugenia grandis forest behind Casuarina.

Cleistanthus ? contractus Airy Shaw: 32078 (2); (det. C. aff. glaber Airy Shaw).

C. hirsutipetalus Gage: 36828 (7).

C. marcrophyllus Hook. f.: 29346 (6), 36826 (7); treelet -5 m; very. abundant by streams in the forest.

C. maingayi Hook. f.: 29034 (5), 29042 (5), 32088 (2), 37031 (5); tree -8 m, frequent in hillock-forest. Sec special notes.

C. myrianthus (Hassk.) Kurz: 37109 (7); small tree, common in swamp-forest; fruiting gregariously in July 1940.

C. podocarpus Hook. f.: 29437 (5); treelet in swamp-forest. 
C. praetermissus Gage: 29371 (4); tree $-10 \mathrm{~m}$, in kapur-forest.

C. pseudopodocarpus Jabl.: 28741 (3); shrub or treelet $-5 \mathrm{~m}$; twigs brown hairy; frequent in swamp-forest.

Croton ? erythrostachys Hook. f.: (5).

C. heterocarpus M.A.: 28190 (7), 36812 (7); treelet $-6 \mathrm{~m}$; common in tidal creeks behind the mangrove.

C. laevifolius B.: 21323 (1), 28695 (1), 29298 (3), 29343 (1), 29385 (4), 34737 (7), 37082 (10); shrub or small tree; very common in swamp-forest, especially by streams. See special notes.

Dimorphocalyx murinus Elm.: 29295 (3), 29296 (3), 37247 (5), 37248 (5); tree -13 m, frequent in swamp-forest. See special notes.

Drypetes curtisii (Hook. f.) Pax et Hoffm.: 29446 (5); treelet -3 m, in swamp-forest. Drypetes sp.: (5); shrub $2 \mathrm{~m}$.

Elateriospermum tapos $\mathrm{Bl}$.: s.n. 5.5.35 (5), (4); tree $-47 \mathrm{~m}$, in kapur-forest, frequent; prah.

Endospermum diadenum (Miq.) Airy Shaw: 28670 (5), 29938 (3), (4), (5); in swamp-, hillock-, and kapur-forest, frequent; membulan: E. malaccense of Wayside Trees of Malaya. See special notes. Plate 15.

Euphorbia atoto Forst. f.: (9); coastal herb.

Excoecaria agallocha L.: common mangrove tree; buta buta, bebuta.

Galearia fulva (Tul.) Miq.: 28591, 28592 (8); frequent small tree in swamp-forest. See special notes.

Galearia sp.: s.n. 10.6.34, 12.6.34, 13-6.34 (9); small tree in Eugenia grandis forest at S. Rhu Reba.

Glochidion glomerulatum (Miq.) Boerl.: 30895 (1), 32773 (1); common at the edge of the swamp-forest.

G. leiostylum Kurz: 28588 (8), 28679 (7), 32754 (2), 34675 (7), 36809 (7); rather common in swamp-forest; senkam, tetimah.

G. lutescens Bl.: 21309 (1); common in hillock-forest; senkam. (G. laevigatum of Wayside Trees of Malaya).

G. littorale $\mathrm{Bl}$. : (9); coastal shrub; selengsar.

G. rubrum Bl.: 32488 (6); by Saraca-streams.

G. sericeum (Bl.) Zoll. et Mor.: 29946 (5), 32505 (2); common in dryer parts of the swamp-forest, in hillock-forest, and in secondary forest.

G. superbum Baill.: only in secondary forest by roads.

Macaranga amissa Airy Shaw: 32774 (2), s.n. 21.5 .34 (7), 28.3 .37 (7); common tree in swamp-forest, often with a few congested stilt-roots $-1.7 \mathrm{~m}$ high. (M. aff. populifolia in Wayside Trees of Malaya).

M. baccaureifolia Airy Shaw: 29287 (3), 36997 (2), 37107 (7), s.n. April 1932 (3); tree $-17 \mathrm{~m}$, without stilts, deciduous in March, flowering with male catkins on the bare twigs; young fruits in April; common undergrowth tree in swampforest, often gregarious; keropoh. See special notes.

M. gigantea (Rchb. f. et Zoll.) M.A.: 36899 (7); frequent in openings in the swampforest.

M. griffithiana M.A.: 28567 (8), s.n. 17.8-32 (7), 30.5 .37 (7); tree -25 m, fluted over the lateral roots; common in swamp-forest and re-growth; kobing, mahang. See special notes.

M. hosei King: 32294 (2), s.n. 6.2 .37 (2); locally common in swamp-forest. 
M. hypoleuca (Rchb. f. et Zoll.) M.A. : s.n. 16.1 .38 (7); common in swamp-forest, especially in re-growth.

$M$. javanica Hook. f.; in secondary forest; mesepat. See special notes.

$M$. kingii Hook. f.: 32275 (2); rather scarce in the swamp-forest.

M. pruinosa (Miq.) M.A.: s.n. (7); tree $-27 \mathrm{~m}$, in swamp-forest. ( $M$. maingayi in Wayside Trees of Malaya).

M. puncticulata Gage: tree $-20 \mathrm{~m}$, sometimes with stilt-roots; common in sivampforest; kobing, setudong. (? M. caladiifolia). Plate 15.

M. quadricornis Ridley: 28689 (7), 32271 (2), 32388 (2), 32762 (2), 32797, 32780, 32781 (2), s.n. 11.4.37; shrub or tree $-8 \mathrm{~m}$, common in swamp-forest; kobing. (M. ? terluifolia of Wayside Trees of Malaya). See special notes.

$M$. recurvata Gage: 29449 (5): tree $-20 \mathrm{~m}$, common in sivamp-forest.

M. tanarius (L.) M.A. : 28472 (9); very common in the coastal zone between Eugenia grandis forest and Casuarina, not in old forest.

M. trichocarpa (Rchb. f. et Zoll.) M.A.: 32289 (2), 32510 (2), (7); common straggling climber in re-growth of swamp-forest.

M. triloba (B1.) M.A.: common in openings in the swamp-forest and along the riverside; flowering as a shrub at $2 \mathrm{~m}$; kobing.

Mallotus dispar (B1.) M.A.: 29041 (5); shrub -2 m; leaves brownish beneath; fruit pale rusty brown with yellowish spines; scattered in hillock-forest; (det. Coelodiscus subcuneatus).

M. ? korthalsii M.A.: 31934 (5).

M. oblongifolius (Miq.) M.A.: 21327 (5), 29255 (2), 31992 (2), 32757 (2); common shrub or small tree in the dryer parts of the swamp-forest. ( $M$. porterianus of Wayside Trees of Malaya).

M. tiliifolius (Bl.) M.A.: 28467 (9); common small tree in the coastal zone between Eugenia grandis forest and Casuarina.

Mallotus sp.; 32002 (2).

Micrococca johorica Airy Shaw: 36981 (7); treelet -3 m, frequent in the swampforest.

Neoscortechinia forbesii (Hook f.) C. T. White: 29250 (7); tree -7 m, in swampforest; beki. See special notes.

N. nicobarica (Hook f.) Pax et Hoffm.: 32341 (2), s.n. 5.2 .35 (2); in swamp-forest. (N. paniculata Ridley). Plate 20.

N. sumatrensis S. Moore: 29283 (7), 29297 (3); tree $-20 \mathrm{~m}$, frequent in swampforest. See special notes.

Omphalea bracteata (Blco) Merr.: s.n. (1), (4), (5); climber in hillock-forest, rarely in the swamp-forest.

Ostodes pendula (Hassk.) A. Meeuse: 28616 (8), 32308 (2); tree -17 m, in hillockforest. See special notes.

[Ostodes ? : s.n. 9.2.35 (5); shrub -2 m, in hillock-forest.]

Phyllanthus gomphocarpus Hook f.: 29203 (4), 29467 (4), 30724 (3); shrub 1-3 m in the dryer parts of the swamp-forest and in kapur-forest.

P. oxyphyllus Miq.: 29415 (5), 29991 (4), 31935 (5); shrub 1-3 m, or a crooked treelet; in kapur-forest. ( $P$. frondosus of Wayside Trees of Malaya).

Phyllanthus sp.: 32272 (1); climber with short leafy sprays; fruits red; in swampforest.

Pimeleodendron griffithianum (M.A.) Benth.: s.n. (4), (5); scattered tree in hillockforest. 
P. macrocarpum J. J. Sm.: s.n. 10.5.25 (1); large tree, very scattered in the swampforest; prah. See special notes.

Ptychopyxis kingii Ridley: 34710 (7); tree $-8 \mathrm{~m}$.

Sapium baccatum Roxb.: 36942 (10); in kapur-forest.

S. indicum Willd.: (7); small tree on frcshwater and brackish tidal river-banks; buah saminyak. See special notes.

Sebastiana chamaelea (L.) M.A.: (9); coastal herb.

Suregada glomerulata (Bl.) Baill.: 32028 (2), (9); tree -13 m, generally coastal. See special notes.

S. multiflora (Juss.) Baill. : 28650 (8), 29384 (4); shrub -2 m; fruits rose-pink; in swamp-forest and in sandy swamp-forest by the coast, frequent.

Synostemon bacciformis (L.) G. L. Webster: 28456 (9); common coastal herb. (Agyneia bacciformis).

Trigonostemon aff. borneensis Merr.: s.n. 14.5 .35 (5), 12-4.36 (6); shrub -2 m, unbranched; in swamp-forest; (det. Ostodes).

T. longifolius Baill.: (5); in kapur-forest.

T. rufescens Jabl.: 28999 (5), 29196 (4), 29428 (5); shrub or treelet with red sap; scattered in dryer parts of the swamp-forest, in hillock-and kapur-forcst, from mile 11 northwards on the Jemaluang Road. See special notes.

T. sumatranus Pax et Hoffm.: 28713 (4), 30700 (2), 31953 (2), 32453 (2), 37032 (5); tree in swamp-forest. Sec special notes.

T. villosus Hook .f : 28664 (5), (4); common treelet in kapur-forest and the dryer parts of the swamp-forest. See special notes.

\section{Fagaceae}

Castanopsis fulva Gamble: 37363 (5); trec $-20 \mathrm{~m}$, in hillock-forest.

C. inermis (Lindl.) B. et H.: 28709 (1), s.n. 12.5 .35 (1), (2), (7); trec -27 m, often buttressed $-1 \mathrm{~m}$ high; frcquent in dryer parts of the swamp-forest, locally gregarious; berangan.

C. johorensis Soepadmo: 36869 (7); tree $-10 \mathrm{~m}$, in swamp-forest.

C. malaccensis Gamblc: s.n. (7); serta tangga.

C. megacarpa Gamble: (7), (8); tree $-30 \mathrm{~m}$, buttressed; occasional in swamp-forest and Eugenia grandis forest; seranta tangga.

Lithocarpus bennettii (Miq.) Rehd.: 34746 (7), s.n. 11.2 .35 (1), 15.7 .40 (7); in swamp- and hillock-forest, not infrequent; bereh. See special notes.

L. eichleri (Wenzig) A. Cam.: 21328 (5), 28990 (4); tree $-17 \mathrm{~m}$, frequent in dryer parts of the swamp-forest. Sce special notes.

L. elegans (Bl.) Hatus.: 25893 (7); tree -7 m high; in rassau- and mempisang-belts, and on Tristania-banks; beri. (Quercus spicata in Wayside Trees of Malaya).

L. encleisacarpus (Korth.) A . Cam.: 32201 (2); in hillock-forest.

L. ewyckii (Korth.) Rehd.: 36885 (2).

L. hystrix (Korth.) Rehd.: 21329 (at mile 17, Jcmaluang Road., Sedili Bridge), (2); tree $-20 \mathrm{~m}$ with low stilt-roots; frequent in dryer parts of the swamp-forest. Sce special notes. 
L. kingianus (Gamble) A. Cam.: s.n. leg. Ngadiman (7).

L. kunstleri (King) A. Cam.: 29035 (2), 32411 (2), (4); tree -13 m, with poor crown; uncommon in swamp-forest. See special notes.

L. leptogyne (Korth.) Soepadmo: 28959 (3), 28968 (3), 28986 (3); tree -23 m, with copious stilt-roots; common in swamp-forest along S. Berassau east of the Jemaluang Road, not seen elsewhere. See special notes.

L. lucidus (Roxb.) Rehd.: s.n. 10.2.35 (2), 18-2-37 (2); occasional in the dryer parts of the swamp forest.

L. maingayi Benth.) Rehd.: 32993: tree $-20 \mathrm{~m}$, in hillock-forest at mile 19 on the Jemaluang Road; ? the only collection from lowland forest.

L. perakensis Soepadmo: 32348 (2), s.n. 10.1 .38 (7); tree $-8 \mathrm{~m}$; in dryer parts of the swamp-forest, not common.

L. sundaicus (Bl.) Rehd.: 25958 (3), 29457 (4), 29751 (7), s.n. 28.3 .32 (7); frequent in the swamp-forest; beri.

L. urceolaris (Jack) Merr.: 28170, 28737, 28738 (3), 32279 (1); tree -25 m, sharply buttressed and somewhat stilted; frequent in swamp-forest. See special notes. (Quercus craterophora of Wayside Trees of Malaya).

Lithocarpus incertae sedis: see special notes.

\section{Flacourtiaceae}

Casearia grewiaefolia Vent. var deglabrata K. et V.: 28519 (9), 28524 (9); tree $-23 \mathrm{~m}$, in sandy coastal forest by streams. See special notes.

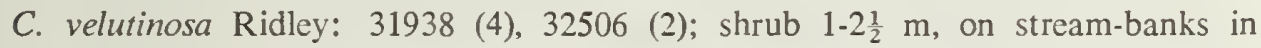
swamp forest.

Flacourtia rukam Zoll.: 32347 (2).

Homalium dasyanthum (Turcz.) Warb.: 29458 (4); tree $-13 \mathrm{~m}$, not infrequent in swamp-forest. See special notes.

H. longifolium Benth.: 32364 (2), 34727 (7); tree $-10 \mathrm{~m}$, in swamp-forest.

Hydnocarpus castanea Hook. f. et Th.: 29338 (4), 30974 (1), 32415 (2); tree -20 m, in the dryer part of the swamp-forest and in kapur-forest.

H. curtisii King: 29036 (5), 29202 (4); small tree -7 m, in swamp-forest. See special notes.

H. filipes Selum.: 37105 (7); tree in swamp-forest.

H. kunstleri (King) Warb. var. tomentosa (King) Sleumer: 36837 (7); tree in swamp-forest.

H. nana King: 29206 (5); shrub $-2 \mathrm{~m}$, in hillock-forest.

H. scortechinii King: 32134 (2), 32364 (2).

Ryparosa hulletti King: 32171 (2), 32455 (2), 32756 (2), (6); small tree 6 m, streamside.

R. scortechinii King: 21344 (5), 29007 (4); tree $-13 \mathrm{~m}$, common in the dryer parts of the swamp-forest and in hillock-forest. See special notes.

Scaphocalyx spathacea Ridley: 32332 (2); treelet $-8 \mathrm{~m}$, in swamp-forest.

Scolopia spinosa (Roxb.) Warb.: 29279 (7), 36901 (7); tree -13 m, with thorny twigs and sapling-stems; in swamp-forest. 


\section{Flagellariaceae}

Flagellaria indica L.: in open places on the river-bank from $\mathrm{Bt}$ Tiga upstream on the Sedili Besar; rotan dini.

Hanguana malayana (Jack) Merr.: abundant in swamp-forest; bakong ulu, keladi utan. See special notes.

\section{Gesneriaceae}

Aeschynantluts obconica Clarke, A. parvifolia R. Br., A. purpurascens Hassk., $A$. radicans Jack, $A$. wallichii $\mathrm{R}$. Br.; all these recorded from the Sedili Besar, but without special notes.

Cyrtandra lanceolata Ridley; 30651 (1), (6); among rocks by Saraca-streams.

C. pilosa Bl.: 32181 (2), s.n. 10.4 .36 (6); shrub -1 m.

C. suffruticosa Ridley: 28961 (3), 29267 (7); epiphyte on low branches, common in the swamp-forest. See special notes.

Cyrtandra spp.: 28162 and 28416; in swamp-forest along the Jemaluang Road.

Cyrtandromoea grandis Ridley: 31937 (4); shrub 1-2 m high, by the road. See special notes.

Didissandra johorica Ridley: s.n. 12.1 .36 (3), 28.6 .36 (5), 23.4 .38 (5); herb $-75 \mathrm{~cm}$ high, in dryer parts of the swamp-forest and in hillock-forest. See special notes.

Didymocarpus platypus Clarke: common in hillock-forest; sembong.

Paraboea densifolia (Ridl.) Henders. : 30654 (6), 32540 (6), 30870 (6); herb -45 cm high, on rocks by Saraca-streams. See special notes.

P. pyrrhaeflora Ridley: 32360 (2); by streams in hillock-forest.

Paraboea sp.: 32486 (1).

\section{Gonystylaceae}

Gonystylus bancanus (Miq.) Kurz: s.n. 27.7 .39 (7). See special notes.

G. confusus Airy Shaw: 36830 (7); tree $-10 \mathrm{~m}$, in swamp-forest.

G. macroplyyllus (Miq.) Airy Shaw: 34722 (7); tree $-17 \mathrm{~m}$, in swamp-forest.

\section{Goodeniaceae}

Scaevola taccada (Gaertn.) Roxb.: common coastal shrub; merambong. (S. frutescens in Wayside Trees of Malaya; S. sericea of others).

\section{Gramineae}

(I have followed the nomenclature of Gilliland 1971)

Centotheca lappacea (L.) Desv.: forest-paths.

Chrysopogon aciculatıs (Retz.) Trin.: coastal.

C. orientalis (Desv.) A. Cam.: coastal.

Coelorachis glandulosa (Trin.) Stapf: 28527 (9); tall grass scattered in scrub behind Casuarina along the coast. 
Dactyloctaenium aegyptiacum (L.) P. Beauv.: coastal dunes, creeping.

Digitaria heteranthera (Hook. f.) Merr.: coastal dunes, with more or less superficial rhizome. (D. dispar Henn.).

D. ? longiflora (Retz.) Pers. : coastal dunes, with superficial rhizome.

Eragrostis atrovirens (Desf.) Trin.: coastal dunes, tufted.

Heteropogon contortus (L.) P. Beauv.: coastal.

Imperata cylindrica (L.) P. Beauv.: in vast wastes in old pepper and gambir land round the Sedili Kechil, also at Jason Bay; lalang.

Isachne globosa (Thunb.) O.K.: coastal, in wet hollows.

Ischaemum muticum L.: coastal dune-pioneer.

Leersia hexandra Sw.: in swampy places near the coast.

Leptaspis urceolata (Roxb.) R. Br.: leaves broad, 'seeds' hispid; in swamp-forest and Eugenia grandis forest, common; rumput tai babi.

Lepturus repens (G. Forst.) $\mathrm{R}$. Br.: in mangrove.

Oplismenus compositus (L.) P. Beauv.: on forest-paths.

Oryza minuta J. S. Presl: occasional in swamp-forest.

O. ridleyi Hook. f.: occasional in tufts by pools, with Barclaya and Salacca, in the forest.

Panicum repens L.: 28062 (9); coastal dune-pioneer, with underground rhizome; rumput dawai. See special notes.

Paspalum cartilagineum J. S. Presl: coastal, forming rank tufts of yellow-green leaves in old dune-sivards.

$P$. orbiculare Forst.: coastal, more or less tufted.

P. vaginatum Sw.: 28530 (9); coastal in wet dune-hollows, with underground rhizome; rumput dawai. See special notes. Plate 28.

Perotis indica (L.) O.K. : coastal, creeping in old dune-swards.

Saccharum arundinaceum Retz.: tall grass like sugar-cane, in dense tufts along deforested parts of the riverside; tebrau.

Schizostachyum gracile (Munro) Holtt.: s.n. 28.3 .32 (7); bamboo -4 m long, stems $2 \mathrm{~cm}$ thick, often sprawling; common on Tristania-banks; buloh.

S. zollingeri Steud.: 30679 (6); bamboo $-15 \mathrm{~m}$ tall, stem $-10 \mathrm{~cm}$ thick; by Saracastreams; buloh.

Sphaerocaryum malaccense (Trin.) Pilger: 28635 (8); riverside in putat- and rassaubelts, often submerged. See special notes.

[Spinifex littoreus (Burm. f.) Merr.; coastal dune-pioneer, with underground rhizome, building large tussocks; not seen at Jason Bay].

Sporobolus virginicus (L.) Kunth: coastal dune-pioneer, with underground rhizome, building small tufts.

Thuarea involuta (Forst.) R. Br.: coastal dune-pionecr, with superficial light yellow stems and small light green leaves; fruit-head buried in the sand.

Zoysia matrella (L.) Merr.: coastal dune-pioneer, with underground rhizome, building up close swards persistent under Casuarina.

\section{Hernandiaceae}

Hernandia nymphaeifolia (Presl) Kubitzki (9); tree $-20 \mathrm{~m}$, common on rocky and sandy coasts without Casuarina, and in Eugenia grandis forest. (H. ovigera in Wayside Trees of Malaya). 


\section{Hypericaceae}

Cratoxylon arborescens (Vahl) Bl.: 32162 (2), 34759 (7); large canopy tree without buttresses; common in the swamp-forest, in places more or less dominant; geronggang.

C. formosum (Jack) Dyer: tree $-33 \mathrm{~m}$, never as big as $C$. arborescens; common in swamp-forest and on Tristania-banks; mampat.

C. ligustrinum (Spach) Bl.: s.n. Aug. 1939 (10), (7); occasional on Tristania-banks, at the summit of Bt Tinjau Laut. See special notes.

\section{Hypoxidaceae}

Curculigo latifolia Dryand.: (2), (3); lembah. See special notes.

C. villosa (Kurz) Ridley: 32500 (2); common in coastal forest; lembah.

\section{Icacinaceae}

Cantleya corniculata (Becc.) Howard: CF 5826 (7. S. Gembut, 3.7.21); not collected by me in the Sedili region. See special notes.

Gomphandra quadrifida (Bl.) Sleum.: 29386 (4), s.n. 9.2 .35 (4); shrub or treelet 1-4 m; cymes small, scorpioid, leaf-opposed, with white flowers; frequent in swamp-forest.

G. quadrifida var. ovalifolia (Ridley) Sleum.: 29322 (4); treelet $-3 \mathrm{~m}$, in kapurforest; buah sa-puteh.

Gomphandra sp.: 31470 (4).

Gonocaryum gracile Miq. : 32393 (2), s.n. 24.6 .35 (5); treelet -5 m, in swamp-forest.

Iodes ovalis $\mathrm{Bl}$.: 28570 (8); small riverside climber; tendrils nodal, extra-axillary; fruit rose-pink, translucent; ? scarce.

Medusanthera gracilis (King) Sleum.: 32337 (2); shrub in hillock-forest.

Phytocrene oblonga Wall.: (1); climber at the edge of swamp-forest.

Platea latifolia Bl.: s.n. 15.5 .35 (3); tree $-30 \mathrm{~m}$, stilted; scarce in swamp-forest; medang. See special notes. Plate 18.

Stemonurus malaccensis (Mast.) Sleum. : 28985 (3); trec -17 m, scattered in swampforest; medang. See special notes.

S. scorpioides Becc.: 29288 (3), 29475 (1), 31952 (2), 32374 (2), 34764 (7), s.n. 14.6.34 (9), Kostermans s.n. 1967 (7); tree -27 m, with peg-like pneumatophores; abundant in swamp-forest; cheret budah. See special notes.

S. secundiflorus Bl.: Sinclair 10569, Kadim and Noor 139 and 220, CWL 225; frequent in swamp-forest and on the new road to Kuala Sedili Besar.

\section{Labiatae}

Leucas zeylanica $\mathrm{R}$. Br.: 28531 (9); herb, common under Casuarina and in coastal scrub; ketumbit. 


\section{Lauraceae}

Actinodaphne corneri Furtado (? ined.): s.n. 9.2.35 (5), 13.4.35 (7), 28.4 .35 (3), 9.7.39 (7), Sinclair 10846 (4); shrub or treelet 3-5 m, in swamp- and hillock-forest.

A. glomerata (Bl.) Nees: (5); shrub $3 \mathrm{~m}$; twigs, petioles fulvous hairy; lamina subglaucous beneath; Kadim and Noor 190 (5), tree $-20 \mathrm{~m}$.

A. maingayi Hook. f.: s.n. 28.2 .39 (7).

A. malaccensis Hook. f.: 21345 (6), 29270 (7); common in swamp-forest; (29270 also det. A. areolata Bl.).

A. sesquipedalis Hook f. et Th.: (3), (7); shrub or small tree with large subverticillate leaves and ant-inhabited buds; frequent in swamp-forest.

Actinodaphne sp.: 32386 (2).

Alseodaphne bancana (Miq.) Kosterm.: 21326 (5), 28748 (3), 29947 (5); common in dryer parts of the swamp-forest.

A. coriacea Kosterm.: 30981 (2); (det. Dehaasia).

A. obovata Kosterm.: 29370 (4); in kapur-forest.

A. paludosa Gamble: 28991 (5), 29444 (5); also det. A. corneri Kosterm., Reinwardtia 5 (1960) 343.

Alseodaphne sp. : 31982 (2); tree -17 m, in hillock-forest; (det. Dehaasia).

Beilschmiedia glabra Kosterm.: 28550 (9), 28551 (9, S. Semandan), 32424 (2), s.n. 26.3.32 (7); small riverside tree.

B. kunstleri Gamble: 28321 (9), (7); tree $-13 \mathrm{~m}$, on Tristania-banks, with the habit of Notaphoebe panduriformis.

B. lumutensis Gamble: 37081 (10); tree $-7 \mathrm{~m}$, in hill-forest.

B. tonkinensis Ridley: 28060 (9); common tree in coastal forest, generally inland from Eugenia grandis; urat kurus. Plates 26, 27, 31.

Beilschmiedia spp.: 29035 (5, as Nothaphoebe); 29423 (5, as Cryptocarya); 32066 (2, as Cryptocarya).

Cassytha filiformis L.; (9); common in coastal scrub; chenkri.

Cinnamomum iners Reinw.: 28957 (3), (2); tree $-13 \mathrm{~m}$; common in the dryer parts of the swamp-forest, also as a small tree in the dense swamp-forest.

C. mollissimum Hook f.: 29325 (4), 30885 (7); frequent small tree in swamp-forest.

C. rhynchophyllum Miq.: 36896 (7); frequent small tree in swamp-forest.

Cryptocarya cinnamornifolia Merr.: 28958 (3).

C. crassinervia Miq.: 32107 (2), 32356 (2).

C. ferrea Bl.: 34754 (7), Kadim and Noor 161 (3); tree $-7 \mathrm{~m}$.

C. griffithiana Wight: 29018 (5), 29416 (5), (3); scattered in kapur-forest.

C. impressa Miq.: 36835 (7), 36978 (7).

C. kurzii Hook. f.: 25972 (7); small tree; frequent on Tristania-banks, mostly upstream from Lubok Besar; jiremong babi.

C. nitens Bl.: 32397 (2).

Cryptocarya sp.: 28971 (3), 29289 (2), 32407 (2); (det. Alseodaphne and Endiandra). Cryptocarya spp.: 32010 (2); 32161 (2, tree $-20 \mathrm{~m}$ in swamp-forest); 32782 (7, in swamp-forest). 
Endiandra holttumii Henders. : 28721 (7).

E. ? macrophylla (B1.) Boerl. : 26052 (7), 28700 (1), 28718 (1), Sinclair 10592 (2); small tree in swamp-forest; see also Notaphoebe reticulata.

E. maingayi Hook. f.: Sinclair 10857 (9); tree $-27 \mathrm{~m}$, in sandy coastal forest.

Lindera lucida (Bl.) Boerl. : 28669 (5), (7); tree -13 m, in dryer parts of the swampforest and in hillock-forest.

Linderc sp. : 28520 (9); tree $-25 \mathrm{~m}$; buttresses sharp, spreading; trunk often swollen $-1 \mathrm{~m}$ thick in the lower $2 \mathrm{~m}$; common canopy-tree in Eugenia grandis forest; (det. L. malaccensis).

Litsea costalis (Nees) Kosterm.: 28715 (1); tree -17 m, in swamp-forest. (L. megacarpa in Wayside Trees of Malaya).

L. ? costata (Bl.) Boerl.: 32085 (2); see L. sessilis.

L. firma Hook. f.: 30788 (1); in the dryer part of the swamp-forest.

L. gracilipes Hook. f.: 28451, 28452 (7), (9); tree 7-20 m; stilt-roots in swamp-forest few, low, cylindric, $-1 \mathrm{~cm}$ thick, up to $30 \mathrm{~cm}$ high; smoke of burning wood irritating; in swamp-forest.

L. grandis Hook. f.: 32177 (2) ;tree $-17 \mathrm{~m}$, in hillock-forest.

L. johorensis Gamble: 29282 (7), Sinclair 10552 (7); small tree -5 m, cauliflorous; in swamp-forest.

L. ? kunstleri Gamble; 29479 (4); treelet $3 \mathrm{~m}$, in swamp-forest.

L. lanceifolia (Roxb.) Hook. f.: 32394 (2); treelet -5 m, in swamp-forest.

L. lanceolata (B1.) Kosterm.: 30855 (2); treelet -5 m, in dryer part of the swampforest. (L. sarawakensis).

L. maingayi Hook. f.: 32164 (2); tree $-20 \mathrm{~m}$, in hillock-forest.

L. perakensis Gamble: 34709 (7); tree $-10 \mathrm{~m}$, in swamp-forest.

L. sessilis (B1.) Boerl.: 28973 (3), 29233 (3), 29292, 29293 (3), 32085 (2), 32286 (2), s.n. 14.5.35 (5); treelet $3-5 \mathrm{~m}$, very conspicuous in new leaf with tassels of limp, brownish ochre new leaves; frequent in swamp-forest. (L. ellipticibacca Merr.; see L. ? costata).

L. teysmarmii Gamble; 30880 (7); tree $-13 \mathrm{~m}$, in swamp-forest.

L. umbellata (Iour.) Merr.: 32430 (2); in swamp-forest.

Neolitsea cf. dealbata (R. Br.) Merr.; s.n. 9.7 .39 (7); tree -5 m (? sapling), in swampforest.

Notaphoebe coriacea Kosterm.: 25953 (7), 28175 (7), 28582 (9), 28590 (8), 28676 (7), 28722 (2), 28745 (3), 32431 (2), 36822 (7); tree 3-10 m; in the mempisangbelt, common. See special notes. Plate 21.

N. nitidissima Kosterm. : 32346 (2) ;tree $-10 \mathrm{~m}$, in swamp-forest.

N. pandurifornits Gamble: s.n. 27.3 .32 (7); small tree; leaves large, subsessile, auricled; panicles orange; conspicuous, but scattered, on Tristania-banks from Bagan Limau upstream; medang.

N. reticulata Gamble: 26052 (7), (2); frequent by muddy streams in the swampforest. See also Endiandra? macrophylla.

Phoebe cuneata Bl.: 28159 (7), 28189 (7), 28589 (8); tree on Tristania-banks, scattered; medang ketanah.

Phoebe spp.: 30982 (2); 32372 (2). 


\section{Lecythidaceae}

Barringtonia asiatica (L.) Kurz: common in coastal forest; butun, putat laut.

B. conoidea Griff.: 23895 (7), s.n. 25.1 .31 (7); small riverside shrub -4 m, standing in the water as the putat-belt; putat, p. ayer. Plates 4,6.

B. filirachis Payens: 21334 (2), 25890 (7), 28326 (9), 35560 (7); small tree -13 m; abundant in swamp-forest and on Tristania-banks. See special notes.

B. Inacrocarpa Hassk.: s.n. 5.5 .35 (4); treelet $-5 \mathrm{~m}$, the hanging racemes with red rachis and pedicels; in swamp-forest; (also by streams round G. Panti).

B. macrostachya (Jack) Kurz: 29027 (5), s.n. 12.3 .37 (2); tree -7 m, sparingly branched; frequent in hillock-forest, occasional in the swamp. See special notes.

B. racemosa (L.) Spreng. : 21194 (7), 31455 (7); shrub or small tree $-10 \mathrm{~m}$; common on Tristania-banks in the tidal reaches, and at the back of the mempisang-belt, often with Cerbera odollarn, not in the swamp-forest; putat ayam. See special notes.

B. reticulata (Bl.) Miq.: s.n. 1.4.34, 2.4 .34 (8); tree $-7 \mathrm{~m}$; in swamp-forest, ? rare. (B. sumatrana in Wayside Trees of Malaya).

B. scortechinii King: 29491 (4), 36888 (7), s.n. 1.9 .40 (2); tree -15 m, in swampforest, not abundant.

\section{Leguminosae - Caesalpinioideae}

Bauhinia audax de Wit; 32192 (2); climber in swamp-forest.

B. bidentata Jack: 25967 (7): climber, scattered on Tristania-banks.

B. finlaysoniana Benth.: 37021 (5).

B. integrifolia Roxb.: 37089 (10); big climber in hillock-forest. (B. flammifera Ridley).

B. kockiana Korth.: 28692 (1), 32050 (2); short climber, common in swamp-forest.

Caesalpinia bonduc L.: coastal climber, with hard grey seeds; gorek, kelubu.

C. crista L.; thorny climber, common in mangrove. (C. muga Ait.)

C. tortuosa Roxb.: (6).

Crudia caudata Prain: 28606 (8); tree $-8 \mathrm{~m}$, scattered along the riverside; kranji papan. See special notes.

C. wrayi Prain: 28088 (8), 29280 (7), 29471 (3), 31955 (2), 36821 (7); small spreading tree $3.7 \mathrm{~m}$ high; racemes hanging; flowers white, common in swamp-forest, especially by streams; katong.

Cynometra ramiflora L.: 28614 (8), 36811 (7); mostly in or just behind mangrove, also riverside near Mawai, and on rocky and sandy coasts; katong laut.

Dialium ? kingii Prain: s.n. 5.5.34 (4); tree -33 m, kapur-forest; kranji. See special notes.

D. Inaingayi Baker: 36833 (7); tree $-30 \mathrm{~m}$.

D. patens Baker: 28724 (2), s.n. 21.5 .34 (7); tree $-27 \mathrm{~m}$, buttressed; frequent in swamp-forest; kuran. Special notes.

D. platysepalum Baker: 36823 (7).

D. wallichi (Baker) Prain: 36908 (7), s.n. 27.5 .35 (7), Sinclair 10559; tree -20 m, buttressed, with bark as in $D$. patens; frequent in swamp-forest. 
Intsia bijuga (Colebr.) O.K.: large buttressed tree of sea-coast, mangrove, and riverside in the brackish reaches, nearly all cut down as one of the first trees to be felled, but frequent on the Sedili Kechil; ipil.

1. palembanica Miq.: 30858 (2), (5); large buttressed tree $-45 \mathrm{~m}$, in dryer parts of the swamp-forest and in hillock-forest; merbau.

Koompassia malaccensis Maing.: tree $-50 \mathrm{~m}$, strongly buttressed; common, if scattered, in the swamp- and hillock-forest; kempas.

Peltophormm pterocarpum (DC) Baker: frequent in coastal forest; batai.

Saraca bijuga Prain: 29409 (6), 29942 (1), 32124 (2); common along streams entering the sivamp-forest; [referred to S. indica by Zuijderhoudt (1967), but all the trees of the Sedili region with typically 1-2 pairs of leaflets].

Sindora coriacea Maing.: (4); frequent large tree in dryer parts of the swamp-forest; sepetir. Plate 7.

S. wallichii Graham: frequent large tree in dryer parts of the swamp-forest; sepetir. Sympetalandra hildebrandii v. Steenis: 31984 (2), s.n. 18.10 .36 (2); tree -15 m; apparently rare. See special notes.

\section{Leguminosae - Mimosoideae}

Entada phaseoloides Merr.: large climber with enormous long flat pods; common on Tristania-banks; kachang belurok.

E. spiralis Ridley: 32150 (2); large climber with massive coiled pods; in dryer parts of the swamp-forest.

Adenanthera pavonina L.: on the rocky headlands of Jason Bay.

Parkia speciosa Hassk.: (7), (10); scattered in swamp-forest, more frequent in hillock- and kapur-forest; petai.

Pithecellobium bubalinum (Jack) Benth.: 37073 (10); in hill-forest.

P. clypearia (Benth.) Merr.: frequent in secondary forest; petai belalang.

$P$. contortım Mart.: frequent in coastal scrub.

$P$. jiringa (Jack) Prain: in dryer parts of the swamp-forest.

$P$. kunstleri Prain: in sivamp-forest.

Serianthes dilmyi Fosberg: 28089 (8), (9); tree like the rain-tree, coastal, scarce. (S. grandiflorum Benth.)

\section{Leguminosae - Papilionatae}

Canavalia rosea (Sw.) DC: (9); coastal dune-pioneer; kachang laut. (C. maritima, C. obtusifolia).

Dalbergia beccarii Prain: 28655 (9), s.n. 16.5 .32 (7); common small riverside creeper witl delicate light green foilage, from Bt Tiga to Danau on the Sedili Besar, in putat-and rassau-belts; hujan panas.

D. fermginea Roxb.: 28160 (9); straggling bushy creeper on rocks facing the sea; guri.

[D. forbesii Prain: Teruya 395, 1181, 1192, as a climber in swamp-forest near Kota Tinggi; not found by me in the Sedili region.]

D. parviflora Roxb.: 28523 (9), 36875 (7), s.n. 27.3 .32 (7), 29.7 .32 (7); big climber with spiky stem; common in mempisang-belt and on Tristania-banks, but also in sandy forest near the sea. See special notes. 
D. stercoracea Maingay; (9), coastal.

Dalbergia sp.: 25887 (7).

Derris amoena Ridley: 36841 (7).

D. heptaphylla (L.) Merr.: (7); selunjut. (D. sinuata Thw.)

D. malaccensis Prain: 28638 (9, S. Bahau), s.n. 17.7 .32 (7); big riverside climber on freshwater and slightly brackish tidal banks; $t u b a$, but the roots said to be of no use.

D. uliginosa Benth.: s.n. 31.7 .32 (9), MS 829 (7); slender climber, common in mangrove and near the sea.

Desmodium umbellatumn (Lour.) DC: common along the coast; lemak ketam.

Fordia johorensis Whitmore: 37065 (10), s.n. 3.8 .39 (10); small tree -6 m, in hillforest; racemes from small burrs on the trunk; flowers very fragrant of lily-ofthe-valley.

F. ngii Whitmore: 32042 (2); small tree $-7 \mathrm{~m}$.

Fordia sp.: 37025 (5); (det. Kunstleria corneri Furtado, ? ined.).

Inocarpus fagiferus (Parkinson) Fosberg: 28640 (9, S. Bahau), 34704 (7, S. Gembut), s.n. 19.10 .37 (7, S. Gembut); bush or small tree $-8 \mathrm{~m}$, often tufted; common in slightly brackish tidal swamp behind nipa and under Bruguiera; kerepit, kopit. See special notes.

Kunstleria (see under Fordia sp. 37025).

Millettia atropurpurea Benth.: (10); in kapur-forest.

Pongamia pinnata (L.) Pierre: (9); in coastal forest, occasional; mempari.

P. pinnata var. xerocarpa Merr.; 25988 (7), 29453 (7); common tree in mempisangbelt and on Tristania-banks from S. Gembut upstream on the Sedili Besar to shortly above Danau, in the freshwater tidal zone; conspicuous in new leaf from the bright yellow-green foliage; mempari.

Pterocarpus indicus Willd.: large buttressed tree of brackish tidal creeks round Jason Bay, formerly frequent; sena. See special notes.

Sophora tomentosa L.: occasional in coastal forest of Jason Bay; longgundi.

Vigna marina Merr.: (9); kachang laut.

\section{Lentibulariaceae}

Utricularia flexuosa Vahl: $(8,9)$; in side-streams of the Sedili Kechil and in S. Diman at Jason Bay.

\section{Liliaceae}

Dianella ensifolia Red.: common in swamp-forest; chekri.

Dracaena congesta ?: s.n. 11.5 .35 (4).

D. elliptica Thunb.; 32421 (2), 32758 (2), (7).

D. graminifolia Wall.: 28511 (9); herb -1.7 m high; fruit ochre-brown; more or less gregarious and common in Eugenia grandis forest.

D. granulata Hook. f.: 28719 (1), 32432 (7), (2); tree -13 m, scattered in the swampforest; linjuang utan, setawar. See special notes. Plate 25.

D. maingayi Hook. f.: tree of rocky coastal forest.

D. porteri Bak.: s.n. 15.6 .34 (9); herb $-1.7 \mathrm{~m}$, in coastal forest. 
D. paludosa Holtt.: 32306 (2).

D. singapurensis Ridley: (4); herb $-45 \mathrm{~cm}$ high; frequent by streams.

Peliosanthes violacea Wall. (7).

P. viridis Ridley: (7).

Smilax calophylla Wall.: 28543 (9); small shrub $-50 \mathrm{~cm}$ high; common in dryer parts of the swamp-forest and in Eugenia grandis forest.

S. leucophylla $\mathrm{Bl}$.: frequent in swamp-forest, seldom flowering.

S. inyosotiflora A.DC: (5); small twining climber.

S. setosa Miq.: scattered in swamp-forest, seldom flowering. (S. barbata).

\section{Linaceae}

Ctenolophon parvifolius Oliver: 36839 (7); tree $-18 \mathrm{~m}$, in swamp-forest.

Roucheria griffithiana Planch.: big climber, common in swamp-forest; akar kekait.

\section{Loganiaceae}

Fagraea ceilanica Thunb.: s.n. 16.6 .34 (9), (4); common epiphyte in swamp-forest; sepungga.

F. racemosa Jack: 25949 (7), 32055 (2), 36874 (7); tree -13 m, common on Tristaniabanks; flowering in July; kopi utan, tengkok biawak.

[Gaertnera: see Rubiaceae].

Norrisia major Soler.: 33545 (7); tree -17 m, scattered on Tristania-banks, usually leaning over the water, See special notes.

Strychnos axillaris Colebr.: 29451 (5); hook-climber in swamp-forest.

S. ignatii Berg. : 29321 (4); large hook-climber in kapur-forest.

S. villosa Hill: 37110 (7); hook-climber in swamp-forest.

\section{Loranthaceae}

Anyema beccarii Dans.: 28510 (9); mistletoe in coastal forest.

Barathranthus axanthus Miq.: 29500 (2).

Dendrophthoe lanosa Danser; common in hillock-forest.

D. pentandra Miq.: 29414 (5): mistletoe on Xylopia caudata.

Elytranthe albida Bl.: 34725 (7).

Helixanthera cylindrica (Jack) Dans.: 30980 (1).

Macrosolen formosus (Bl.) Miq.: 26057 (7), 28953 (3), 32084 (2); scattered in swamp-forest.

Viscum orientale Willd.: frequent in swamp- and hillock-forest.

V. wrayi Gamble: 28992 (5), 30984 (1); mistletoe, common on Calophyllum, Garcinia, and Mesua.

\section{Lowiaceae}

Orchidantha fimbriata Holtt.: occasional in swamp-forest; crushed tissue smelling of banana. 


\section{Lythraceae}

Lagerstroemia ovalifolia T. et B. var exapiculata Furtado et Montien: 34738 (7), s.n. 10.5.35 (1); scattered in swamp-forest; bungor. See special notes.

Pemphis acidula Forst.: (9), coastal forest and rocks; mentigi.

Sonneratia alba J. Smith: mangrove pioneer; perepat (S. griffithii).

S. caseolaris (L.) Engl. : nipa- and mangrove-swamps; berembang. (S. acida).

\section{Magnoliaceae}

Aromadendron elegans B1.: 36940 (10) ;large tree in hill-forest.

Magnolia maingayi King: 31997 (2); treelet -5 m, in hillock-forest.

Talauma singapurensis Ridley: s.n. 8.2.35 (5); small tree -5 m; twigs softly greyfawn hairy; in swamp-forest.

\section{Malpighiaceae}

Brachylophon curtisii Oliver: 32302 (2); shrub in swamp-forest.

Tristellateia australasiae A. Rich.: climber in coastal forest.

\section{Malvaceae}

Hibiscus tiliaceus L.: common in nipa-belt; baru baru, bebaru, b. sungei.

Sida cordifolia L.: (9); coastal herb.

Thespesia populnea L.: coastal tree; baru baru laut.

\section{Marantaceae}

Donax grandis (Miq.) Ridley: common in Eugenia grandis forest; bemban.

Phacelophrynium maximum (B1.) K. Schum.: 37084 (10), s.n. 13.3 .37 (2); in streambeds in the forest; the most southerly records in Malaya.

Phryniurn basiflorum Ridley: 30680 (6); by Saraca-streams.

P. capitatum Willd.: 30677 (6), 32291 (2), 37090 (10).

P. gracile Holtt.: 29981 (7), s.n. 28.6 .36 (4); apparently endemic in the Sedili region.

P. hirturn Ridley: s.n. 10.4 .36 (6); by Saraca-strearns. See special notes.

Stachyphrynium griffithi (Bak.) K. Schum.: frequent in dryer parts of the swampforest and in hillock-forest.

\section{Melastomataceae}

Anplectrella anomala (Stapf et King) Furtado: 30876 (7), 32061 (2); large climber, frequent in swamp-forest.

Blastus caudatus G. H. Spare: 29304 (1); shrub or treelet $-3.5 \mathrm{~m}$, frequent in swamp-forest, often by streams.

Dissochaeta gracilis (Jack) Bl.: s.n. 12.5 .35 (6); climber, white petals. 
D. johorensis Furtado: 32357 (2).

D. punctulata Hook. f.: 29377 (4); big climber in kapur-forest; petals white.

Marumia nemorosa (Jack) Bl.: 28571 (7); frequent on Tristania-banks; kemunting akar, k. semut. (Macrolenes nemorosa).

Medinilla rubicunda Jack var. hasseltii (Bl.) Bakh. f.: 26054 (7), 31980 (2); common epiphyte in the swamp-forest. ( $M$. hasseltii).

$M$. maingayi Clarke: common epiphyte in the swamp-forest.

[M. pendens Ridley: - ? in the Sedili region.]

M. scandens King; 32048 (2), 32456 (2), 32755 (2); root-climber; locally frequent in swamp-forest.

Medinilla sp.: 32791 (7); epiphyte; leaves for a long time purple beneath in swampforest.

Melastoma molle (Wall.) Ridley: s.n. 12.5.35 (6); shrub with red seeds; streamside in the forest.

Mentecylon amplexicaule Roxb.: 30781 (1); tree -13 m, in swamp-forest.

M. campanulatum Clarke: 29021 (5), 29044 (5), 31942 (7), 32057 (2); in swampand hillock-forest.

M. garcinioides Bl.: 28733 (2), 29450 (5), 36980 (7); tree -17 m, frequent in swampforest; delek. See special notes.

M. hepaticuin Bl.: 29251 (2), 29481 (4), 30882 (7), 30976 (1), 31961 (2), 32467 (2), s.n. 4.2.35 (4), 9.2.35 (5), ? $10.2 .35(5)$; shrub or treelet $-7 \mathrm{~m}$, laxly branched; bark greyish white; common in the swamp-forest; delek.

M. heteropleurum Bl.: 28683 (4), 29016 (5); tree -13 m, in swamp- and hillockforest; delek.

M. hullettii King: 29243 (4), 29984 (7); treelet -5 m, branches drooping; fruit white then purplish blue; irs swamp-forest.

M. laevigatum $\mathrm{Bl}$.: (7); small tree on Tristania-banks and on stream-banks in the swamp-forest; mangas.

M. maingayi Clarke: 28702 (1), 29245 (2), 31981 (2), 32246 (2), 32311 (2), 32504 (2), 32759 (2), 36931 (10), (7); tree $-7 \mathrm{~m}$, often infested with keringa-ants; common in swamp-and hillock-forest; delek. (M. wallichii in Wayside Trees of Malaya).

M. myrsinoides $\mathrm{Bl}$. : 25896 (7), 28562 (5), 28565 (5); tree $-10 \mathrm{~m}$, common by streams in the swamp-forest and on Tristania-banks; nipis kulit.

M. paniculatum Jack: 28603 (8), 32188 (2), 34734 (7); tree $-10 \mathrm{~m}$, frequent in swamp-forest; mangas. See special notes.

M. subtrinervium Miq.: 29459 (4), 31994 (2), 32079 (2), 34657 (4); treelet -5 m.

Memecylon sp.: 32170 (2).

Ochthocharis borneensis $\mathrm{Bl}$.: 21195 (7); small shrub -1.5 m; petioles and young stems purple; common in the mempisang-belt especially from Lubok Pusing to K. Labek and below Mawai, sendudok ayer.

O. sylvestris Ridley: 30859 (2), 32116 (2), 37085 (10).

Osbeckia ? ; s.n. 11.5 .35 (4); big climber in kapur-forest.

Pachycentria tuberosa Bl.: common epiphyte in swamp-forest.

Plethiandra sessiliflora Ridley: 29988 (3), 32395 (2).

Pogonanthera pulverulenta (Jack) Bl.: 30790 (1), 32142 (2), 32316 (2). 
Pternandra coeruiescens Jack: 32119 (2), 32429 (2); small tree, scattered on Tristania-banks and by streams in the swamp-forest; lidah katak, sial menaung.

Sonerila caesia Stapf et King: 32509 (2).

S. picta Korth.: (6); by Saraca-streams, occasionally in the swamp-forest.

Sonerila sp.: 32053 (2).

\section{Meliaceae}

Aglaia angustifolia Miq.: s.n. 15.4 .36 (1); treelet -3.2 n, in swamp-forest.

A. argentea Bl.: 29492 (4); in hillock-forest.

A. hiernii King: 32041 (2), 32089 (2).

A. lanuginosa King: 29326 (5), 34939 (5); scattered in hillock-forest.

A. melios!noides Craib: 28553 (9, S. Semandan).

A. odoratissima Bl.: 21319 (1), 29342 (1), 30687 (6), 32012 (2), 32081 (2), 32176 (2); small tree, frequent in dryer parts of the swamp-forest.

A. palembanica Miq.: 28517 (9).

A. cf. trichostemon C. DC: 32090 (2), 36883 (7), 36938 (10); tree -12 m, in swamp-and hillock-forest.

Aglaia spp.; 29243 (2), (4); 29235 (4); 29303 (1), 29401 (6); 29452 (5), in kapurforest; 32062 (2); 32184 (2); 34731 (7); 36939 (10); s.n. 15.10 .35 (leg. Kiah), shrub.

Amoora rubiginosa Hiern: 32798 (7), 36818 (7); frequent tree of swamp-forest. See special notes. Plate 36.

Anoora spp.: 21347 (1); 32202 (2); 32283 (2).

Aphanamixis rohituka Pierre: 36884 (7).

Carapa granatum Koen.: in mangrove; nyireh.

C. moluccensis Lamk: 28067 (8), 32441 (7); common by the Sedili rivers in the upper part of the mangrove, in the nipa-belt, and on the banks behind the lower reaches of jejawi above and below Bt Tiga on the Sedili Besar; nyireh batu.

Chisocheton amabilis (Miq.) C. DC: 21199,21199 A (7), 28568 (9), 28595 (8), 28674 , 28675 (7), 32434 (7); small riverside tree of the mempisang-belt, perhaps also of Tristania-banks, between Mawai and Bt Tiga on the Sedili Besar; flowering March-April; tangisong burong. See special notes.

C. erythrocarpus Hiern: 32402 (2); in swamp-forest.

C. pauciflorus King: 28714 (1); in swamp-forest.

C. paucijugus (Miq.) B. D. Jackson: 29445 (5), 32071 (2); in swamp-forest.

C. patens Bl.: 36986 (1); in swamp-forest.

C. penduliflorus Planch.: 32400 (2), s.n. 23.6 .34 (8); in swamp-forest.

C. pentandrus (Blco) Merr. 28496 (9); common large tree in Eugenia grandis forest, and coastal climax forest.

C. princeps Hemsl.: 29285 (2), (7); in swamp-forest.

C. sarawakensis (C. DC) Harms: 21350 (1), 29311 (1), 29465 (4); in swamp-forest.

Chisocheton spp.: 29404 (6); 30698 (6).

Dysoxylon cauliflorum Heirn: 25857 (7), 28685 (4), 29478 (4), 36889 (7), (5); common in swamp-forest. [These specimens have recently been identified by D. J. Mabberley as D. sericeum (BI.) Adelb.] 
D. costulatum Miq.: 29427 (5), 29462 (4); tree -13 m, scattered in the mempisangbelt and on Tristania-banks.

D. dumosum King: 29019 (5), 29241, 29242 (2), 30733 (6), 31987 (2), 32138 (2),

32465 (2); treelet $3-5 \mathrm{~m}$; frequent in swamp- and hillock-forest.

D. euphlebium Merr.: 28960 (3).

D. flavescens Hiern: 29306 (1).

D. macrothyrsum Miq.: 24630 (7), 26058 (7), 28952 (3), 34715 (3), 34723 (7), s.n. 29.1.33 (7), 3.10.34 (7), 2.2.38 (7). (? D. excelsum Bl.).

Dysoxylon spp.: 28706 (1); 28969 (3); 28989 (5), in dryer parts of the swamp-forest and in kapur-forest; 32127 (2); 32352 (2); 32772 (1); 36842 (7); 37099 (7), 30561 ; s.n. 18.10 .36 (2, leg. Kiah).

Sandoricuin sp.: 29363 (4) in kapur-forest.

\section{Menispermaceae}

Cocculus ovalifolius DC: 28468 (9); slender climber, common at the seaward edge of Eugenia grandis forest, on Guettarda etc.

Fibraurea ochroleuca Miers: 28566 (8); common riverside climber; sekunyit.

Hypserpa cuspidata Miers: 28573 (8); riverside creeper; leaves yellow-green; fruit yellow then red.

Limacia velutina Miers: in dryer parts of the swamp-forest.

Pericampylus incanus Miers: 29746 (mile 1, Jemaluang Road); climber, leaves glaucous beneath; common in dryer parts of the swamp-forest and in hillockforest; akar mempening.

Stephania ? : s.n. 11.5 .35 (5); small climber in kapur-forest.

\section{Monimiaceae}

Kibara chartacea B1.: 29286 (7); treelet -4 m, in swamp-forest. See special notes.

\section{Moraceae}

Artocarpus anisophyllus Miq.: (6); scattered in dryer parts of the swamp-forest and in hillock-forest.

A. dadah Miq.: 32185 (2), s.n. Jan. 1936 (3); tree $-25 \mathrm{~m}$, scattered in dryer parts of the swamp-forest and in hillock-forest; chempedak ayer, tampang.

A. elasticus Reinw.: tree $-40 \mathrm{~m}$, strongly buttressed; frequent in coastal forest, occasional in dryer parts of the swamp-forest and in kapur-forest; terap.

A. gomezianus Wall.: s.n. $12.6 .34,13.6 .34$ (9, S. Rhu Reba); tree $-20 \mathrm{~m}$, not or slightly buttressed; scarce in coastal forest; tempulut. See special notes.

A. integer (Thunb.) Merr. var. silvestris Corner: 32988 (5), s.n. Oct. 1936 (2), (10); tree $-50 \mathrm{~m}$, not buttressed; bark brown; inner bark pale ochraceous; in hillockforest, scattered.

A. kemando Miq.: s.n. 3.2 .35 (2), 7.2 .35 (3), 18.6 .34 (8); tree - $30 \mathrm{~m}$, not infrequent in swamp-forest and coastal forest; chempedak ayer, pudu. See special notes.

A. maingayi King: s.n. 5.5.35 (4); in kapur-forest. 
A. nitidus Trec. ssp. griffithii (King) Jarrett: 21349 (1); tree $-20 \mathrm{~m}$, frequent in swamp-forest; tampang. See special notes.

A. rigidus $\mathrm{Bl}$.: (6); not in the swamp-forest.

FICUS subgen. Urostigma (Gasp.) Miq.

F. annulata Bl.: 32008 (2), s.n. 2.2 .35 (1); scarce in swamp-forest; ara jantong.

$F$. benjamina L.: s.n. 10.4 .36 (6); very large strangling fig in dry forest, roots descending for $25 \mathrm{~m}$.

F. binnendykii Miq.: 28641 (7); scarce in swamp-forest; beringin.

F. binnendykii var. coriacea Corner: s.n. 11.3 .37 (2), 31.2 .34 (7); occasional in dryer parts of the swamp-forest and in hillock-forest.

$F$. bracieata Wall.: 24626 (7), 28619 (8); frequent epiphyte rooting to the ground, not strangling, in swamp-forest and on Tristania-banks, especially between Lubok Pusing and L. Besar.

F. calophylla Bl. var. malavana Corner: 21190 (7), 28634, 28657 (9), s.n. 26.3 .32 (7); common large strangling fig of the riverside in freshwater zones, in swampforest, and coastal.

F. consociata Bl. var. murtoni King: 28540 (9), 28632 (8), 31970 (2), s.n. 2.4 .34 (8), 7.2 .35 (7); common large strangling fig, distributed as $F$. calophylla; young leaves pinkish to purplish brown hairy.

F. crassiramea Miq. : 21188 (7); common large strangling fig, riverside and swampforest, from Danau downstream to Bt Tiga on the Sedili Besar, the main roottrunk developing strong buttress-roots parallel with the river, without stilt-roots.

F. cucurbitina King: 29473 (2), s.11. 31.12 .34 (3); large strangling fig with irritant hairs; in swamp-forest, rare; (elsewhere in Malaya, only from Kuantan).

F. delosyce Corner : 21337 (2), 28178 (7), 28607 (8), 36800 (7), s.n. 9.6 .34 (7); very large strangling fig, common in swamp-forest.

F. dubia Wall.: (9), in coastal forest.

F. elastica Roxb.: Tg. Besar, Sedili Besar, two very large trees, possibly planted, but the fruits ripening reddish orange and, perhaps, with insects.

F. globosa Bl.: 31954 (2), 36873 (7), s.n. 27.7 .32 (7); common slender climber in rassau- and meinpisang-belts.

F. kerkhovenii Val.: 28673 (7), 32074 (2), 32779 (7), s.n. 17.6 .34 (8); very large strangling fig, frequent in swamp- and hillock-forest, seldom fruiting. (Johore Fig of Wayside Trees of Malaya).

F. microcarpa Linn. f.: forming the jejawi-belt connecting the rassau- and nipabelts, as scattered big strangling fig-trees in the sivamp round Jason Bay, and on the rocky coast. ( $F$. retusa in Wayside Trees of Malaya). Plate 5.

F. microsyce Ridley: 28544 (9), 32247 (2), s.n. 31.7 .32 (7); small climber in swampforest and mangrove, often with galled buds.

F. pisocarpa Bl.: 28319 (7): riverside strangling fig, rather small, infrequent.

F. retusa L.: 28626 (8), 36872 (7), s.n. 28.3 .32 (7), 21.5 .34 (7), 19.6 .34 (8), 13.4 .36 (7); epiphytic, rooting $20 \mathrm{~m}$ to the ground, not strangling, crown small, fairly abundant in the swamp-forest, often rooted into tidal freshwater. ( $F$. truncata Miq., not $F$. retusa auctt. $=F$. microcarpa Linn. f.).

F. stricta Miq.: 32297 (9, S. Rhu Reba), Sept. 1972; fairly large strangling fig, the strangling roots flattened and shell-like round the host-trunk; in swamp-forest round Jason Bay.

F. stupenda Miq. var. minor Corner: 37027 (5). 
F. subgelderi Corner var. rigida Corner: 23899 (7), 30791 (2); strangling fig in swamp-forest.

F. sundaica $\mathrm{Bl}$ : : 28537, 36799 (7); large strangling fig with many stilt-roots, common in mangrove and freshwater tidal zone. $(F$. indica of Wayside Trees of Malaya).

F. sumatrana Miq. var. circumscissa Corner: 29937 (7).

F. sumatrana Miq. var. microsyce Corner: 32241 (2).

F. virens Ait. var. glabella (Bl.) Corner: s.n. 13.6 .39 (7), (8); scarce on the Sedili Besar (at Mawai), frequent on the Sedili Kechil.

F. xylophylla Wall.: 28658 (9); large epiphyte, not strangling, coastal.

FICUS subgen. Pharmacosycea Miq.

F. vasculosa Wall. var acuminata Miq.: s.n. 11.3 .37 (2). a single sapling; (the typical form of this common species not found in the Sedili region, but var. acuminata also on G. Panti).

FICUS subgen. Ficus sect. Ficus

F. aurata Miq. var. longipilosa Corner: 29387, 32313 (2); in hillock-forest. (F. chrysocarpa of Wayside Trees of Malaya).

F. deltoidea Jack var. deltoidea: 32147 (7), 32250 (2), s.n. 22.6 .34 (8), H. M. Burkill 1846 (7); common bushy epiphyte on high trees in swamp-forest; limited in Malaya to the east from Rompin to Singapore (Corner 1969). ( $F$. diversifolia in Wayside Trees of Malaya).

F. glandulifera Wall.: 33000 (7); sapling only.

$F$. grossularioides Reinw.: (6); not in the swamp-forest. ( $F$. alba of Wayside Trees of Malaya).

FICUS subgen. Ficus sect. Kalosyce (Miq.) Corner

F. apiocarpa Miq.: 21186, 31463 (1), 31957 (7); frequent climber in swamp-forest, locally abundant.

F. ruginervia Corner: 28446 (9), 32796 (7); common climber in dryer parts of the swamp-forest and in hillock-forest.

FICUS subgen. Ficus sect. Rhizocladus Endl.

F. excavata King: 29990 (1), Sinclair 9978 (1); slender inconspicuous climber of swamp-forest, curiously rare in the Sedili region.

F. recurva Bl. var. bridelioides Corner : s.n. 13.4 .36 (7); riverside climber, scattered.

F. recurva var. ribesioides (Wall.) King: 28605 (8).

F. sagittata Vahl: 28487 (9); common root-climber of dry coastal forest, possibly overlooked in the swamp-forest.

F. trichocarpa $\mathrm{Bl}$.: 32006 (2); frequent climber in hillock-forest, scarce in the Sedili region.

F. uncinulata Corner: 30699 (2), 32007 (2); slender climber; no other records from Malaya but frequent in Borneo.

F. urnigera Miq.: 25948 (7, Bagan Limau); root-climber, rare in the Sedili region.

FICUS subgen. Ficus sect. Sycidium Miq.

F. obscura Bl. var. borneensis (Miq.) Corner: 28084, 28086 (7), 28587 (8), 28618 (8), 28906 (3); epiphytic shrub, rooting to the ground; common in swamp-forest and on Tristania-banks. 
F. parietalis $\mathrm{Bl}$ : 32007 (2), 32433 (7), 36985 (7); frequent climber in swamp-forest, often epiphytic.

F. sinuata Thunb.: 28085 (7), 28512 (9), 28515 (9), 29045 (5), 29389 (5), 29735 (2), 31928 (3), 32458 (2), s.n. 3.4 .34 (7), 13.4 .34 (7); shrub or treelet in swamp- and hillock-forest, frequent.

F. sinuata var. oblonga Corner: 21338, 29023, 32502 (2).

F. uniglandulosa Wall: 29447 (5); epiphytic shrub in hillock-forest.

FICUS subgen. Ficus sect. Sycocarpus Miq.

$F$. beccarii King: (1); geocarpic fig of hillock-forest.

$F$. fistulosa Reinw.: small cauliflorous tree by streams in the dryer part of the swamp-forest and in hillock-forest.

F. fistulosa var, angustifolia Corner: 25983 (7).

F. lepicarpa Bl.: 29349 (6); small tree of Saraca-streams, not in the swamp-forest.

F. obpyramidata King: 29997 (7), (2, 6); small caulifforous tree $-5 \mathrm{~m}$, on Tristaniabanks beween Danau and Bagan Limau on the Sedili Besar; scarce.

F. schwarzii Koord.: (6), (10); cauliflorous tree of Saraca-streams. (F. miquelii of Wayside Trees of Malaya).

F. scortechinii King: 29258 (2); small tree of streams and hillsides in hillock-forest.

F. uncinata Becc. var. strigosa Corner : Sinclair 9980 (4), (6); geocarpic fig in hillockforest. ( $F$. geocarpa of Wayside Trees of Malaya).

Parartocarpus venenosus (Zoll. et Mor.) Becc. ssp. forbesii (King) Jarrett: 32185 (2), s.n. Feb. 1935 (1), (4); canopy tree in swamp- and coastal forest, tengayun. See special notes. Plate 33.

Streblus taxoides (Heyne) Kurz: 28668 (5), (10); small thorny tree $-5 \mathrm{~m}$, often bushy; common in hillock-forest, entering the periphery of the swamp-forest; merlimau. (Phyllochlamys wallichii of Wayside Trees of Malaya).

\section{Musaceae}

Musa gracilis Holtt.: frequent swampy ground at the edge of the forest and by open streams, (? not in the swamp-forest).

$M$. violascens Ridley: at forest-edges and by open streams.

\section{Myristicaceae}

Gymnacranthera bancana (Miq.) J. Sinclair: 29945 (5), 32193 (2); in kapur-forest.

G. eugeniifolia (A.DC) J. Sinclair: 29955 (2), 36909 (7); in swamp-forest.

G. eugeniifolia var. griffithii (Warb.) J. Sinclair: 29499 (2), 32157 (2); often with stilt-roots.

G. forbesii (King) Warb.: 28712 (1), (2), 28970 (3), 36866 (7), 36918 (7), 36961 (7); common in the swamp-forest.

Horsfieldia brachiata (King) Warb.: 25991 (7), 28707 (1), 28963 (3), 29466 (7), 32281 (2), 34708 (7), 36791 (7), s.n. 28.3 .32 (3), 7.10 .34 (7); common in the swamp-forest.

H. brachiata var. sumatrana (Miq.) J. Sinclair: 32064 (2).

H. bracteosa Henders.: 29310 (1), 36789 (7), s.n. 1.9 .35 (1), 16.7 .39 (7). 
H. crassifolia (Hook. f. et Th.) Warb.: 32105 (2), s.n. 12.4 .36 (7); with short-stiltroots; in swamp-forest.

H. flocculosa (King) Warb.: 32314 (2); apparently rare.

H. grandis (Hook. f.) Warb.: 36831 (7).

H. irya (Gaertn.) Warb.: 25856 (7), 25964 (7), 28493 (9); common in the mermpisangbelt; pianggu. See special notes.

H. macrocoma Warb. var. canarioides (King) J. Sinclair; 34742, 36924 (7).

H. polysphaerula (Hook. f.) J. Sinclair: 29366 (4), 31976 (2), 32109 (2); often with cylindric stilt-roots $-2 \mathrm{~m}$ high; frequent in the swamp-forest, also in kapurforest.

H. superba (Hook f. et Th.) Warb.: 28703 (1), s.n. 23.6 .34 (8), (7): in the dryer parts of the swamp-forest.

H. wallichii (Hook f. et Th.) Warb.: s.n. 30.12 .34 (4).

Horsfieldia sp.: s.n. 28.4 .35 (3); tree $-13 \mathrm{~m}$, with stilt-roots. See special notes.

Knema conferta (King) Warb.: 28505 (9), 32034 (2), 34714 (7).

$K$. furfuracea (Hook. f. et Th.) Warb.: s.n. 28.8 .32 (7), (4).

K. glaucescens Jack: 28176 (7), 28962 (3), 29275 (7), 31951 (2), 32384 (2); common in the mempisang-belt, often with stilt-roots.

K. glaucescens f. rubens J. Sinclair: 29403 (6).

K. glaucescens var. cordata J. Sinclair : 29015 (5), 29419 (5), 29436 (5), 29477 (4); in hillock-forest.

K. glaucescens var. patentinervia J. Sinclair : 28649 (8), 31951 (2), 36935 (10), s.n. 16.7.39 (7).

K. intermedia (B1.) Warb.: 21333 (2), 28453 (9), 29252 (7), 29268 (7), 36392 (2); with stilt-roots; common in the mempisang-belt and in swamp-forest. See special notes.

K. latericia Elm.: 28711 (1), 28975 (3), 29277 (7), 29290 (3), 29420 (5).

K. laurina (Bl.) Warb.: 28615 (8), 32334 (2), 32379 (2), 36927 (10), 37078 (10).

K. malayana Warb.: 28440 (9), 28504 (9), s.n. 14.4 .35 (3).

K. mandaharan (Miq.) Warb.: s.n. 28.8 .32 (7).

K. plurnulosa J. Sinclair : 29367 (4), 29944 (1), 30972 (1), 31473 (5), 32130 (2), Kep. F.n. 53930 (7); often with stilt-roots; common in the swamp-forest. (K. cantleyi of Wayside Trees of Malaya).

Myristica cinnamomea King: 28671 (4), s.n. 16.7 .39 (7); common in hillock-forest.

$M$. crassa King: 34912 (5), 36919 (7); with stilt-roots.

M. elliptica Wall. : 25954 (7), 26055 (7), 28322 (9), 28584 (8), 29402 (6), 32004 (2), 34729 (7), s.n. 10.5 .35 (1); very common in swamp-forest, especially in the mempisang-belt; tabah, tajam penggali. See special notes. Plate 14.

M. guattariifolia DC: 28512 (9), s.n. 20.6 .34 (9); coastal.

M. iners Bl.: 28186 (7), 36863 (7), s.n. 2.3 .38 (7); with stilt-roots; frequent in swamp-forest. Plate 36.

M. lowiana King: 36880 (7); with stilt-roots; scattered in swamp-forest. See special notes. Plates $24,38$.

M. maingayi Hook. f.: 36900 (7).

M. maxima Warb.: 34740 (7). 


\section{Myrsinaceae}

Aegiceras corniculatum (L.) Bloc: 28648 (8); in mangrove; lemak ketam.

Ardisia andamanica Kurz; 28620 (8); tree $-10 \mathrm{~m}$; common on the riverside. See special notes.

A. colorata Roxb.: 28323 (9), 32373 (2); shrub in swamp-forest.

A. crispa (Thunb.) DC: small coastal shrub, common: mata ayam.

A. elliptica Thunb.: (9); common shrub or tree $-10 \mathrm{~m}$; on the sandy coast, in Eugenia grandis forest, and in swampy scrub near the coast; mata pelandok, mempenai.

A. foliosa Furtado: 32330 (2).

A. lanceolata Roxb.: 21321 (1), (7); tree $-13 \mathrm{~m}$, flowering as a shrub; common locally in swamp-forest.

A. miqueliana Scheff.: 32076 (2), 32236 (2).

A. ngadimanii Furtado: 32092 (2).

A. odontophylla King et Gamble: 31943 (4), s.n. 28.4 .35 (3).

A. pachysandra Mez.: 29197 (4), s.n. 5.5 .35 (4); treelet -4 m; branches slightly dilated at the base; in dryer parts of the swamp-forest, in hillock- and kapurforest.

A. ? solanacea Roxb.: 29000 (5); tree $-7 \mathrm{~m}$; branches dilated at the base; in dryer parts of the swamp-forest and in kapur-forest.

A. teysmanniana Scheff.: 36894 (7).

A. tuberculata Wall.: 28174 (7), 29276 (7), 36810 (7): shrub $-3 \mathrm{~m}$; common in the mempisang belt.

A. ? wrayi King: 29422 (5), 36949 (10); herb or shrub -2 m high; frequent in swamp- and hillock-forest. See special notes.

Ardisia sp.: 29012 (5), tree $-13 \mathrm{~m}$, in hillock-forest. See special notes.

Ardisia spp.: 30871, (6), 36929 (10); 32165 (2); 32410 (2).

Embelia amentacea Wall.: 31991 (2).

E. canescens Jack: 28613 (8); climber in scrub on hillock.

E. coriacea Wall.: 25894 (7), 32151 (2); big climber, frequent on Tristania-banks.

E. dasythyrsa Miq.: 30893 (1).

E. garciniaefolia Wall.: 32014 (2).

Labisia punctata (Reinw.) Airy Shaw: 32172 (2); herb, frequent in swamp-forest. (L. pothoina).

Maesa ramentacea Wall.: 28558 (8), 32021 (2); sprawling bushy climber in swampforest, often in clearings.

Tetrardisia corneri Furtado: s.n. (3), (7). (Gdns' Bull. Singapore 17, 1958, 306).

\section{Myrtaceae}

Decaspermum fruticosum Forst.: 28691 (1), 36394 (7); common in dryer parts of the swamp-forest.

Eugenia anisosepala Duthie: 36917 (7).

E. atronervia Henders. : 29328 (4), s.n. 2.2 .35 (1), 1.9 .40 (2); tree $-12 \mathrm{~m}$, with low flattened stilt-roots; in the dryer parts of the swamp-forest and in kapur-forest. 
E. castanea Merr.: 28977 (3), 29249 (4); treelet -5 m, in swamp-forest.

E. cerina Henders.: 28546 (9), 29049 (1), 36790 (7), 36962 (7), s.n. 4.2 .35 (1); tree $-23 \mathrm{~m}$, common in swamp-forest, on Tristania-banks, and in coastal forest; dendulang, dulang dulang, nenulang. See special notes.

E. cerina var. turbinata Henders.: 23897 (7), s.n. 27.3 .32 (7).

E. chlorantha Duthie: 32484 (1); tree $-17 \mathrm{~m}$, by Saraca-streams.

E. chloroleuca King: s.n. 24.6 .34 (4) ;treelet $-2 \mathrm{~m}$ (fertile) in the dryer part of the swamp-forest.

E. claviflora Roxb. var. Inaingayi King: 31940 (4); treelet -5 m.

$E$. conglonerata Duthie var. paniculata Henders.: 29368 (4); large tree with steep narrow buttresses; in kapur-forest.

E. cumingiana Vidal : 36824 (7), s.n. 10.6 .34 (9), 12.6 .34 (9), 19.6 .34 (8); tree $-17 \mathrm{~m}$, sometimes with stilt-roots; in swamp-forest and commonly in Eugenia grandis forest. See special notes.

E. curtisii King: 28622 (8), s.n. 18.6 .34 (8); tree $-17 \mathrm{~m}$; frequent riverside tree on the Sedili Kechil. See special notes.

E. densiflora Duthie: 28073 (9), 28465 (9); tree -13 m; flowers white or pink; flowering gregariously in June; common in Eugenia grandis forest; jambu ayer.

E. cf. duthieana: s.n. 15.5 .35 (5); in kapur-forest.

E. dyeriana King: 37096 (2); in hillock- and kapur-forest.

E. fastigiata Koord. et Val.: 32342 (2), s.n. 29.1 .33 (7), 28.3 .33 (7); tree -17 m, on river-bank and in swamp-forest, distributed as $E$. cerina.

[E.. filiformis Duthie ?].

E. garcinifolia King: 31469 (2), s.n. 10.2 .35 (4); tree -34 m, buttressed; in swampforest. See special notes.

E. grandis Wight: common in the sandy coastal belt, replacing Casuarina and building its own coastal belt; jambu laut, ubah. See special notes. Plate 27.

$E$. grata Wight: 32409 (2), s.n. 13.5 .34 (7), 9.7 .39 (7); tree $-17 \mathrm{~m}$, often with a few arcuate stilt-roots $-75 \mathrm{~cm}$ high; frequent in swamp-forest.

E. griffithii Duthie: 29970 (mile 17, Jemaluang Road); on the Tristania-bank.

E. kiahii Henders.: 29400 (2), 32036 (2); tree -12 m, with stilt roots; in swampforest.

E. kiahii var. angustifolia Henders.: 36921 (7); tree $-30 \mathrm{~m}$, with stilt-roots.

E. kunstleri King: 29301 (1), 36920 (7); tree $-20 \mathrm{~m}$, in dryer parts of the swampforest and in hillock-forest. See special notes.

E. leptostemon (Korth.) Miq.: 28979 (3), s.n. 28.5 .39 (7); tree -20 m, common by streams in the swamp-forest. See special notes.

E. leucoxylon Miq.: 28557 (8); tree $-17 \mathrm{~m}$, in the upper reaches of the mangrove; kelat puteh. See special notes.

E. longiflora (Presl) F.-Vill.: 21311 (1), 28637 (9), 29312 (7), s.n. 21.5 .34 (7); tree $-23 \mathrm{~m}$, often strongly stilted; frequent on Tristania-banks, in swamp- and hillock-forest. See special notes. Plate 23.

E. muelleri Miq.: 21196 (7), 28325 (9), 32444 (7); tree of low straggling habit, not or slightly stilted; in the mempisang-belt, more or less submerged at high tides, and in the swamp-forest behind the mangrove. (E. venulosa in Wayside Trees of Malaya). 
E. napiformis Koord. et Val.: 32132 (2); tree $-12 \mathrm{~m}$ in swamp-forest, $-30 \mathrm{~m}$ with fluted base in hill-side forest; bark dull warm brown, fissured and flaky.

E. ngadimaniana Henders.: 32152 (2); tree $-20 \mathrm{~m}$, in hillock-forest.

E. nigricans King: 28497 (9), 28522 (9); tree $-23 \mathrm{~m}$, sometimes with stilt-roots; common in sandy coastal forest; kelat samak. See special notes.

E. oblata Roxb.: 36805 (7); tree $-13 \mathrm{~m}$, stilt-roots $-1 \mathrm{~m}$ high; in swamp-forest.

E. oleina Wight: 28081 (7, S. Kambau), 28513 (9), s.n. 14.6 .34 (9); tree -13 m, often with stilt-roots or shortly buttressed, with loop-roots; on stream-banks and in Eugenia grandis forest.

E. pachyphylla Kurz: 28078 (8); tree in sandy coastal forest.

E. palembanica (Miq.) Merr.: 28549 (9), s.n. 16.6 .34 (9); tree -13 m, common in coastal forest, especially in scrub (? conserved for use of the bark in tanning); kelat samak.

E. papillosa Duthie: 21315 (1), 32328 (2), s.n. 9.7 .39 (7); tree -23 m, with stilt-roots and loop-roots; common in swamp-forest. See special notes.

E. pauper Ridley: 28978 (3), 30697 (6); tree $-7 \mathrm{~m}$; stilt-roots $-50 \mathrm{~cm}$ high, few, slender, spreading; in swamp-forest and by Saraca-streams.

E. polyantha Wight: 32392 (2); tree $-20 \mathrm{~m}$, in swamp-forest.

E. polyantha var. sessilis Henders. : 32413 (2); tree -12 m, in swamp-forest.

E. ? pseudoformosa King: s.n. 9.9 .34 (5); common small tree of Saraca-streams round G. Panti. See special notes.

E. pseudosubtilis King: 21336 (2), 28583 (8), 28609 (8), 28746 (3), 29935 (3), 32096 (2), s.n. 3.2 .35 (5); tree $-23 \mathrm{~m}$, in swamp-, hillock-, and kapur-forest; flowering Feb. and Sept.; old leaves turning dull orange-yellow; kelat.

E. quadribracteata Henders.: 30986 (1); tree $-20 \mathrm{~m}$, in dryer parts of the swampforest.

E. ridleyi King: 29047 (1), 29200 (4); tree with dark blue young leaves; in dryer parts of the swamp-forest.

E. rugosa (Korth.) Merr.: 26190 (7), 28521 (9), s.n. 6.8 .39 (10); big tree, very abundant and subdominant in coastal sandy forest at Jason Bay.

E. scortechinii King: s.n. 26.3 .32 (7), 17.7 .40 (7); riverside tree $-17 \mathrm{~m}$, frequent upstream from Danau on the Sedili Besar; jambu.

E. spicata Lamk: 28561 (8), s.n. 1.5 .32 (7), 15.6 .34 (9); common small tree of rassau- and mempisang-belts and of Tristania-banks; kelat gelam, $k$. nasi nasi, k. nenasi. See special notes.

E. subdecussata Duthie: 29941 (1), 36836 (7); tree $-25 \mathrm{~m}$, in dryer parts of the swamp-forest.

E. subhorizontalis King: s.n. 18.4 .32 (3), 6.2.35 (4), May 1935 (3); tree -14 m; stilt-roots $-1.2 \mathrm{~m}$; bark rufous orange, papery flaky; frequent in swamp-forest; ? seldom flowering kelat gelam. Plate 15.

E. syzygioides (Miq.) Henders.: 28525 (9), s.n. 12.6 .34 (9); large tree of Eugenia grandis forest. (E. cymosa in Wayside Trees of Malaya). Plate 32.

E. tetraptera (Miq.) Henders. var. pseudotetraptera (King) Henders.: 32018 (2), 30.9 .36 (7); tree $-10 \mathrm{~m}$, in swamp- and hillock-forest.

E. tumida Duthie: 34707 (7), 37086 (10); tree $-8 \mathrm{~m}$, stilted as E. longiflora in the swamp-forest but not so strongly. 
E. valdevenosa Duthie: 28327 (7), 31474 (1), 32369 (2), 36882 (7); tree -13 m, frequent in swamp-forest; kelat jambu. See special notes.

Eugenia sp.: 32282, s.n. 18.2 .37 (as Eugenia A), (1); tree -20 m, slightly buttressed, without stilt-roots, in dryer parts of the swamp-forest.

Eugenia sp. : 28995 (5), 29319 (4), s.n. 5.5 .35 (4).

Eugenia spp.: s.n. 7.10 .34 (7); s.n. 25.11 .34 (Tg. Temelak); s.n. 15.5 .35 (4).Eugenia A, 6.8 .39 (10); Eugenia A, 7.8 .39 (10); Eugenia B, 6.8 .39 (10); see special notes.

Pseudoeugenia perakensis Scort.: 32106 (2); slender tree $-7 \mathrm{~m}$, in swamp-forest.

P. singapurensis King : 21346 (1) 28179 (7), 28548 (9), 29248 (2); slender tree -13 m, sometimes with short stilt-roots; frequent in swamp-forest and in the wetter parts of sandy coastal forest. See special notes.

Rhodaminia cinerea Jack: 28585 (8); scattered on river-banks and by streams in swamp-forest; mempoyan. (R. trinervia in Wayside Trees of Malaya).

Rhodomyrtus tomentosa Wight; occasional in secondary scrub at Jason Bay; kernunting.

Tristania ? merguensis Griff.: s.n. 13.4 .36 (9); sapling $7 \mathrm{~m}$; in swamp-forest; curiously absent from most of the Sedili region. Plates 24, 34.

[T. obovata King; ? on rocky headlands of Jason Bay.]

T. ? pontianensis Henders.: 31939 (4); tree $-35 \mathrm{~m}$, scattered in hillock- and kapurforest. See special notes.

T. sumatrana Miq.; 24629 (7), 31451 (7), 34717 (7), (3); tree -23 m; common on raised river-banks in the tidal region and up to the Saraca-streams; pelawan. See special notes. Plates 1, 3, 14.

Tristania sp.: s.n. 31.12 .34 (5); tree $-40 \mathrm{~m}$, in hillock-forest. See special notes.

\section{Nepenthaceae}

Nepenthes ampullaria Jack, $N$. gracilis Korth., $N$. rafflesiana Jack : in swamp-forest, more often in the dryer parts and in regrowth.

\section{Nymphaeaceae}

Barclaya motleyi Hook. f.: 32049 (2), (3), (7); common in muddy places by streams in the swamp-forest, often submerged; hati hati.

\section{Ochnaceae}

Brackenridgea hookeri (Planch.) A. Gray: 28993 (5); tree $-20 \mathrm{~m}=$ petals white; scattered in dryer parts of the swamp-forest and in kapur-forest. See special notes.

[Euthemis leucocarpa Jack; ? (I have not record.)]

Gomphia serrata (Gaertn.) Kanis: 25974 (7), 32991 (5); common shrub or small tree on Tristania-banks, especially above Bagan Limau on the Sedili Besar; flowers yellow, young leaves pink.

Neckia serrata Korth.: herb, common in hillock-forest. 


\section{Olacaceae}

Ochanostachys amentacea Mast.: not infrequent in the swamp-forest but big trees scarce.

Scorodocarpus borneensis Becc.: 29388 (7), 32038 (2), 34945 (5), (4); large tree, all parts smelling of garlic when bruised; frequent in dryer parts of the swampforest; kulim.

Strombosia maingayi (Mast.) Whitmore: 28404 (4), 29264 (7), 29496 (2); tree -23 m, common in the swamp-forest and in Eugenia grandis forest; ketaling. See special notes.

\section{Oleaceae}

Jasminum ? maingayi: s.n. 11.10 .36 (2); slender twiner in undergrowth by streams. Linociera insignis Clarke: 34702 (7), 36922 (7).

L. peludosa King et Gamble: 32325 (2).

L. pauciflora Clarke: 28083 (7), 29281 (7); tree $-20 \mathrm{~m}$, rather common in the swamp-forest.

Myxopyrum nervosum B1.: 32382 (2)

\section{Opiliaceae}

Champereia manillana (Bl.) Merr.: occasional in-swamp-forest.

Lepionurus sylvestris Bl.: 32406 (2), s.n. 11.6.34 (9); shrub on Tristania-banks above Lubok Besar on the Sedili Besar; common in Eugenia grandis forest.

\section{Orchidaceae}

(see special notes)

Acriopsis javanica Reinw.: (7).

Aerides odoratum Lour:: (7), (9).

Agrostophylluin bicuspidatum J. J. Sm.: 30727 (3).

Anaectochilus geniculatus Ridley: (2), (3).

Appendicula cornuta Ridley, A. densifolia Ridley (7), A. lucida Ridley (7), A. pendula $\mathrm{Bl}$. (6).

Bromheadia alticola Ridley (7), B. aporoides Rchb. f.

Bulbophyllum acuminatum Ridley, B. adenopetalum Lindl. 30792 (1), B. alcicorne Par. et Rchb. f. 26137 (7), B. apodum Hook. f. 29994 (3) and 31956 (2), B. botryophorum Ridley, B. carunculaelabrum Carr. (7), B. cleistogamum Ridley, B. concinnum Hook. f., B. epicrianthes Hook. f. 28163 (7), B. lasianthum Lindl. 28169 (7), B. limbatum Lindl., B. macranthum Lindl., B. pileatum Lindl., B. pulchellum Ridley, $B$. purpurascens Teysm. et Binn., $B$. restrepia Ridley, $B$. rugosum Ridley, B. sessile (Koen.) J. J. Sm., B. singaporeanum Schltr, B. stella Ridley, $B$. subumbellatum Ridley, B. tenuifolium (Bl.) Lindl., B. vaginatum (Lindl.) Rchb. f.

Calanthe pulchra (Bl.) Lindl.: common in swamp-forest; lembah.

C. veratrifolia $\mathrm{R}$. Br.: common in coastal forest.

Camarotis adnata (Ridley) Holtt. 
Ceratostylis subulata $\mathrm{Bl}$.

Chamaeanthus laciniatus Carr: (7).

Cheirorchis major Carr: 9.3 .36 (1).

Claderia viridiflora Hook. f.: (7), in swamp-forest, frequent.

Coelogyne cumingii Lindl.: 30783 (1).

C. testacea Lindl.: (7).

Cymbidium finlaysonianum Lindl.: chiefly coastal.

Dendrobium acerosum Lindl., D. aloifolium (BI.) Rchb. f., D. callibotrys Ridley, D. carnosum (Bl.) Rchb. f., D. comatum (Bl.) Lindl., D. crocatum Hook. f., D. crumenatum Sw., D. fugax Schltr, D. indivisum (Bl.) Miq., D. indragiriense Schltr, D. kelsallii Ridley, D. leonis (Lindl.) Rchb. f., D. lonchophyllum Hook. f., $D$. pandaneti Ridley, $D$. plicatile Lindl., $D$. prostratum Ridley, $D$. salaccense (Bl.) Lindl. s.n. 11.10.36 (2), D. secundum (Bl.) Lindl. common on rocky coast, $D$. spurium (B1.) J. J. Sm.

Dendrochilum album Ridley 32098 and 32476 (2), D. longifolium Rchb. f. (7), D. spathulatum Ridley 25899 (7).

Didymoplexis ornata (Ridley) J. J. Sm.: 30660 (6).

Eria floribunda Lindl., E. gracilis Hook. f. 30728 (3), E. neglecta Ridley common on sengkawang trees (Shorea), E. nutans Lindl., E. pannea Lindl., E. pudica Ridley, E. teysmannii J. J. Sm., E. velutina Lindl. 29995 (3), E. vestita Lindl. 31464 (3) and 36928 (7).

Eulophia graininea Lindl.: (9); in coastal sand-dunes.

E. squalida Lindl.: s.n. 12.1.36 (3); frequent in swamp-forest.

Galeola kuhlii Rchb. f., 32191 (2).

Gastrodia javanica (B1.) Endl.: s.n. 12.4 .36 (9).

Geodorum citrinum Jacks.: (7).

Grammatophyllum speciosum Bl.: common throughout the Sedili region; ekor gajah, nibong palai.

Habenaria singapurensis Ridley $(2,7)$, H. surnatrana Schltr 37087 (10).

Hylophila mollis Lindl.: $(2,3,7)$; in swamp-forest.

Liparis gibbosa Finet $(7,8)$, L. wrayi Hook. f. (7).

Nervilia punctata (B1.) Schltr: $(2,3)$.

Oberonia flabellata Holtt. 28162 (7), O. miniata Lindl. 25989 (7), O. rhizophoreti J. J. Sm. (7).

Phalaenopsis fuscata Rchb. f.

Phreatia secunda (B1.) Lindl.

Plocoglottis gigantea (Hook. f.) J. J. Sm. : in dryer parts of the swamp-forest and in kapur-forest, frequent.

P. javanica B1.: 12.5 .35 (6).

Podochilus lucescens Bl., P. microphyllus Lindl.

Pornatocalpa latifolium (Lindl.) J. J. Sm.

Robiquetia spathulata (B1.) J. J. Sm.

Sarcanthus halophilus (Ridley) J. J. Sm., S. machadonis (Ridley) J. J. Sm.

Sarcochilus johorensis Holtt.: C. E. Carr s.n. Oct. 1932 (7).

Sarcostoma javanicum Bl.

Schoenorchis secundiflora (Ridley) J. J. Sm. 
Taeniophyllum culiciferum Ridley, $T$. filiformie J. J. Sm., T. obtusum Bl.

Thelasis carinata Bl. 32464 (2), T. micrantha (Brongn.) J. J. Sm., T. triptera Rchb. f. s.n. $5.1 .36(3)$.

Thrixspermum acuminatissimum (Bl.) Rchb. f.

T. amplexicaule (Bl.) Rchb. f.: 28461 (9), (7); scrambling over putat and rassau along the rivers, and on coastal bushes, common.

$T$. arachnites (Bl.) Rchb. f.: frequent on rocky coasts.

$T$. carinatifolium (Ridley) Schltr, $T$. corneri Holtt. (7), $T$. recurvatum (Hook. f.) Car 30656 (6).

Vanilla griffthii Rchb. f.: (9), common along the rocky coast.

\section{Oxalidaceae}

Dapania racemosa Korth.: 25995 (7), 31965 (2), (10); large climber, common in swamp-forest, also hillock- and kapur-forest.

Sarcotheca laxa (Ridley) Knuth var. hirsuta Veldk.: 29009 (4), 29025 (5), 29380 (4), 31922 (5); shrub or spindly tree $-5 \mathrm{~m}$; frequent in dryer parts of the swampforest, often on stream-banks, also in hillock-forest; apparently endemic in this region. See special notes.

\section{Palmae}

Areca latiloba Ridley: 28987 (4).

A. montana Ridley: 28687 (4), 28988 (4), (2); frequent at these parts of the Jemaluang Road.

Arenga hastata (Becc.) Whitmore: 25867 (7).

A. westerhoutii Griff.: s.n. Aug. 1939 (10); langkap.

Calamus exilis Griff.: 29999 (2), 31446 (7); rotan lilin.

C. flabellatus Becc.: 32475 (2), 32768 (2).

C. flabelloides Furtado: 29284 (2); in hillock-forest; ? endemic.

C. giganteus Becc.: 29474 (4), (2), (3); frequent in dryer parts of the swamp-forest.

C. javensis Bl. var. peninsularis Becc.: s.n. 17.3 .37 (2).

C. mawaiensis Furtado s.n. 12.3 .37 (2); ? endemic.

C. paspalanthus Becc.: 30875 (6), 32387 (2); rotan batu.

C. ranosissimus Griff.: 28539 (9); in coastal forest.

C. riparius Furtado: 32310 (2); ? endemic.

C. tumidus Furtado: 294747 (4); rotan manau lilin.

Caryota mitis Lour.: in dryer parts of the swamp-forest, common; tukas.

Cornera lobbiana (Becc.) Furtado: 29493 (4), s.n. 1.11 .40 (4); stem short. -1.5 m high. See special notes.

Cyrtostachys lakka Becc.: frequent in swamp-forest; linau.

Daemonorops ungustifolius (Griff.) Mart.: 29550 (7), 29749 (1), 32173 (2), s.n. 27.3.32 (7); common on Tristania-banks; rotan manall, r. tawar.

D. geniculatus (Griff.) Mart.: 29283 (4).

D. kunstleri Becc.: 29748 (7). 
D. lasiospathus Furtado: 29482 (4), 29494 (4); solitary, erect. stem -2 m.

D. leptopus (Griff.) Mart.: 32412 (2).

D. longipes (Griff.) Mart.: 28598 (8); common in swamp-forest.

D. periacanthus Miq.: 29317 (1), 32280 (2).

D. periacanthus var. macrocarpus Furtado: 28645 (8).

D. sabut Becc.: 29485, 29486 (2); locally frequent.

D. verticillaris (Griff.) Mart.: 29484 (4), 29748 (7), 30780 (1), 32174 (2); common in swamp-forest.

Eugeissona tristis Griff.: $(4,5)$; common in hillock- and kapur-forest, but not seen at Bt. Tinjau Laut; bertam.

Iguanura geonomaeformis Mart. 28743 (3), 29001 (7), 32167 (2).

I. polymorpha Becc.: common in swamp-forest.

I. wallichiana (Mart.) Hook. f.: very common in swamp-forest, especially with Cratoxylon arborescens; stems used as sticks for nipa-attap, at 5 cts. per 100 stems.

J. Teysmannia altifrons (Rchb. f. et Zoll.) H. Moore: $(3,4,5$,); abundant in dryer parts of the swamp-forest, in hillock- and kapur-forest, from S. Berassau northwards along the Jemaluang Road, not south of this, not in the main Sedili region, not on Bt. Tinjau Laut; daun payong.

Korthalsia paludosa Furtado: 32344 (2).

Licuala ferruginea Becc.: 28688 (4).

L. kiahii Furtado: 32137 (2); in hillock-forest.

L. lanuginosa Ridley: 30739 (6), 37068 (10).

L. longecalycata Furtado: 32401 (2); in swamp-forest.

L. spinosa Wurmb.: 28485 (9), s.n. 16.5 .32 (7); in low breaks in Tristania-banks from Mawai down to Bt. Tiga, common in Eugenia grandis forest.

L. triphylla Griff. : 37079 (10), s.n. 5.1 .36 (7).

Livistona kingiana Becc.: in swamp-forest; kapau, kepau.

L. saribus (Lour.) Chev.: in swamp-forest, frequent; serdang.

Nenga macrocarpa Scort.: 29482B (4), 37060 (10); in hillock- and kapur-forest: muring.

Nipa fruticans Wurmb.: nipa.

Oncosperma filarnentosum Bl.: nibong. See special notes.

O. horridum (Griff.) Scheff.: bayas.

Pholidocarpus macrocarpus Becc.: 32371 (2); kapau, serdang (? by mistake).

Pinanga disticha (Roxb.) Bl.: 29314 (1); common in the swamp-forest.

P. limosa Ridley: 29316 (1); solitary, -1 m high.

P. malaiana (Griff.) Mart. : 29219 (4), 29240 (2), 32423 (2); tufted, stems -4 m high; muring (as Pinanga and Nenga).

P. pectinata Becc.: 29313 (1), 29239 (7), (6); tufted or solitary, stems -8 m high; common in the swamp-forest.

P. simplicifrons (Miq.) Becc.: 29315 (1), 32166 (2); common in the swamp-forest.

Pinanga sp.: 30659 (6).

Plectocomia griffithii Becc.: (1).

Ptychoraphis singaporensis Becc.: $(3,4,5$.); frequent in hillock-forest.

Salacca conferta Griff.: common in the swamp-forest; asam paya, a. kelugi. 


\section{Pandanaceae}

(see special notes)

Freycinetia angustifolia Bl.: 28074 (8), 28617 (8), 30784 (1), 32354 (2), 32435 (7), s.n. 23.3.40 (7); common riverside climber; selengsen akar. See special notes.

F. confusa Ridley: 30886 (7); common in the swamp-forest; leaf narrow, glaucous beneath.

F. corneri B. C. Stone: 34672 (1), 34938 (5); stout climber, leaves 2-3.5 cm wide; common in the dryer parts of the swamp-forest (also on G. Panti); ? endemic in s.e. Johore and Singapore.

F. imbricata B1.: 28181 (5), 32380 (2), s.n. 13.4 .36 (2).

F. javanica Bl.: s.n. 17.3 .34 (7), 2.2 .38 (7); common in swamp-forest.

F. rigidifolia Hemsl.: 29738 (5); leaves subglaucous beneath.

Pandanus affinis Kurz: slender pandan with orange-red syncarps; common in nipabelt and mangrove, below Bt. Tiga on the Sedili Besar; rassau tikus. ( $P$. aurantiacus).

$P$. alticola Holtt. et St. John: common epiphytic pandan with narrow grassy leaves, in swamp- and hillock forest.

P. atrocarpus Griff.: 32238 (2), 32273 (2); common large pandan - $35 \mathrm{~m}$ high, with abundant short loop-roots as pneumatophores; syncarps blackish brown; in freshwater swamp and on Tristania-banks; mengkuang.

$P$. corneri Kanehira: by streams in nipa and mangrove swamps; easily known from the almost stemless habit with unbroken, shortly acute leaves like swords: (now called $P$. rostratus Martelli).

$P$. dubius Spreng.: 28463 (8); pandan -13 m high, much branched, with broad leaves, solitary; occasional on the coast. See special notes.

P. echinodermops Holtt. et St. John: 28483 (9), 28579 (8), 31948 (7), 33694 (7); short, more or less decumbent, pandan in thickets in stream-beds and hollows behind the nipa-belt and in Eugenia grandis forest, common; selengsen, siakum. See special notes.

P. epiphyticus Martelli: 29979 (mile 17, Jemaluang Road); not in the swamp or coastal forest of the main Sedili region? southernmost record in Malaya. See special notes.

P. helicopus Kurz: 28161 (7), 29238 (2), s.n. 25.1 .31 (7), 13.5 .34 (7), 30.5 .37 (7), 16.7 .40 (7); the common rassau on the freshwater tidal river-banks. See special notes. Plates $1,4,5$.

P. kamii B. C. Stone: 28482 (9), 29490 (1), 29737 (2); apparently stemless pandan forming large dense thickets; common in the swamp-forest and in Eugenia grandis forest; pandan. See special notes. Plate 5.

P. malayanus B. C. Stone: 28627 (8), 31203 (2), 32512 (2); slender pandan, stems $.5 \mathrm{~m}$ high; by sluggish streams and ponds in the swamp-forest. usually standing in the water, common; rassau tikus. See special notes.

P. odoratissirnus Linn. f.: 32763 (2), s.n. 5.6 .34 (9); the common and very spinous sea-shore pandan, with large heads of compound fruits ripening red. See special notes.

P. parvus Ridley: 29996 (7), 32477 (2), s.n. 30.9 .36 (7); dwarf pandan with short broad leaves; locally abundant in swamp-forest. See special notes.

P. pentadon Ridley: 29391 (4), 29998 (2), 32168 (2), 32482 (1); low prostrate pandan in dense thickets along the swifter streams in the swamp-forest, often immersed in the water; rassau tikus. See special notes. 
P. recurvatus St. John: s.n. 16.6 .34 (9), 8.4 .36 (7), (10); slender pandan $-5 \mathrm{~m}$ tall, branched, often in thickets, the narrow leaves glaucous beneath; syncarps solitary, pendent, bluish grey; in dryer parts of the swamp-forest and in hillockforest. (P. ornatus).

P. scortechinii Martelli: 28744 (3), 29237 (1), ? 29238 (2), 29361 (3), 29997 (3), 32102 (2), 32460 (2), 36923 (7), s.n. 7.2 .35 (3); small pandan with stilt-roots, gregarious but not forming thickets by streams in the swamp-forest, common. See special notes.

P. yvanii Solms: 28576 (8), 29390 (4), 32278 (2), 32513 (2), s.n. 2.4 .34 (8); rather slender pandan $-5 \mathrm{~m}$ tall, in loose thickets in the swamp-forest and with $P$. helicopus, common, especially on the Sedili Kechil; rassau tikus. See special notes.

\section{Passifloraceae}

Adenia singaporeana Wall.: common in hillock-forest. [A. macrophylla (Bl.) Koord. var. singaporeana (Wall.) de Wilde, in Flora Malesiana ser. 1, 7. 1972, 429.]

\section{Piperaceae}

Piper ? boehmeriaefolium Wall.: 32121 (2), (1).

P. caninum Bl.: 28492 (9), 31977 (2), 32471 (2); common small epiphytic climber in swamp-forest and Eugenia grandis forest.

P. miniatum Bl.: 28165 (7); common epiphyte in the swamp-forest; kadoh.

P. ? muricatum: s.n. 28.4 .35 (7), (3); frequent epiphyte in swamp-forest.

$P$. pedicellosum Wall.: 28536 (9); big climber, stem $-12 \mathrm{~cm}$ thick; in Eugenia grandis forest: sireh murai.

$P$. porphyrophyllum N. E. Br.: frequent small climber in swamp-forest.

P. ramipilum DC: 32335 (2).

P. stylosum Miq.: 30731 (6).

Piper spp.: 32023 (2); 32136 (2).

\section{Pittosporaceae}

Pittosporum ferrugineum Ait.: (9), scattered in coastal forest.

\section{Polygalaceae}

Trigoniastrum hypoleucum Miq.: 34713 (7).

Xanthophyllum affine Korth.: 28188 (7), 28610 (8), 29341 (1), 32099 (2), 32100 (2), $32996(7), 36794(7)$; tree $-13 \mathrm{~m}$, common in swamp-forest and on the riverside; lemak berok. See special notes.

$X$. bullatum King: $(4,5)$; treelet $-3 \mathrm{~m}$.

X. curtisii Ridley: 36832 (7).

X. ellipticum Korth.: 25963 (7); small tree; leaves small, dark glossy green; fruit bright orange; on Tristania-banks, scarce: lemak berok.

X. maingayi Benn.: 36852 (7).

X. malayanum Meijden: 32094 (2), 32419 (2), 33137 (2); tree $4-10 \mathrm{~m}$ with pinkish or purplish flowers; in swamp- and hillock-forest. 
$X$. obscurum Benn.: 32205 (2); tree $-18 \mathrm{~m}$, in swamp-forest.

X. pulchrum King: 29321 (5), 37246 (4); treelet -4 m, with stilt-roots. See special notes.

X. stipitatum Benn.: 36907 (7).

X. wrayi King: 29205 (3), s.n. 7.2 .35 (3); treelet -4 m, in swamp-forest; lemak berok. See special notes.

\section{Proteaceae}

Helicia attenuata (Jack) Bl.: Sinclair 40294 (Sedili bridge, Jemaluang Road); riverside.

H. petiolaris Benn.: 25965 (7); frequent on Tristania-banks at Bagan Limau, Sedili Besar; fruits blue.

H. robusta (Roxb.) R. Br.: s.n. 27.3 .32 (7); shrub or small tree; riverside, common in the freshwater tidal region; putat ulu.

H. rufescens Prain: 30856 (2), 32065 (2), 32327 (2); tree -20 m, in dryer parts of the swamp-forest.

Heliciopsis velutina (Prain) Sleumer : 37097 (2); tree -13 m, in swamp-forest.

\section{Rhamnaceae}

Colubrina asiatica Brongn.: coastal.

Ventilago malaccensis Ridley: frequent climber on Tristania-banks.

Zizyphus calophylla Wall.: 25851 (7): common climber on rassau and on Tristaniabanks; kuku lang.

\section{Rhizophoraceae}

(see special notes)

Anisophyllea corneri Ding Hou: 29324 (4), 36999 (7); tree -10 m; frequent in hillock- and kapur-forest. See special notes.

$A$. disticha (Jack) Baillon: frequent treelet in dryer parts of the swamp-forest.

Bruguiera cylindrica (L.) Bl.: mangrove. (B. caryophylloides $\mathrm{Bl}$.)

$B$. parviflora (Roxb.) W. et A.: mangrove; lenggadai.

B. gymnorrhiza (L.) Lamk: mangrove; tumu.

$B$. sexangula (Lour.) Poir.: mangrove; busing. (B. eriopetala W. et A.)

Carallia brachiata (Lour.) Merr.: 28677 (7), 28678 (7), 29418 (5), 30889 (7), 32760

(2), 36795 (7), 36857 (7); tree $-17 \mathrm{~m}$, frequent in swamp-forest and on Tristaniabanks. See special notes.

Ceriops tagal (Perr.) C. B. Robinson: mangrove; tengar. (C. candolleana Arn.)

Gynotroches axillaris Bl.: 25889 (7), 32163 (2); tree -15 m, scattered on Tristaniabanks, as the slender form (Ridley, Fl. Mal. Pen. I); mata keli.

Kandelia candel (L.) Druce: mangrove; menkadai. ( $K$. rheedii W. et A.)

Pellacalyx axillaris Korth.: 32035 (2); tree -20 m, scattered in swamp-forest; buloh buloh, membuloh. See special notes.

Rhizophora apiculata $\mathrm{Bl}$. : mangrove; akit, bakau. (R. conjugata Arn.)

$R$ mucronata Lamk: mangrove; bakau laut, belukap. 


\section{Rosaceae}

Parastemon urophyllum A.DC: 25952 (7), 25970 (7); small tree on Tristania-banks, above Lubok Besar on the Sedili Besar.

Parinari corymbosa (BI.) Miq.: 28495 (9); tree -33 m, in Eugenia grandis forest; batu, membatu, m. laut.

P. costata (Korth.) Bl.: 34674 (7), 34765) (7), 36915 (7), s.n. 8.9 .35 (5); tree -30 m, in swamp-forest, not common.

P. nannodes Kosterm.: 29329 (4), 31466 (3), 34712 (7), 36898 (7), 37245 (4), s.n. 4.2 .35 (1); tree $-20 \mathrm{~m}$; common in swamp-forest and in kapur-forest.

P. oblongifolia Hook. f.: 36910 (7); in swamp-forest.

Pygeum lampongum Miq.: 21308 (2); tree -10 m, in swamp-forest. See special notes.

\section{Rubiaceae}

Anthocephalus cadamba (Roxb.) Miq.: frequent in re-growth in dryer parts of the swamp-forest.

Argostermma johorensis Ridley; s.n. 28.4 .35 (3); herb; peduncle and corolla pinkish white; in swamp-forest.

Aulacodiscus preminoides Hook f.: 29443 (5), 30695 (6), 32285 (2), 32408 (2); tree $-8 \mathrm{~m}$, frequent in swamp-forest. See special notes.

Borreria hispida Hook. f.: (9); coastal herb. [B. articularis (Linn. f.) F. N. Williams].

Canthium confertum Korth.: 28542 (9), 32426 (2), 32485 (1); tree -10 m, frequent in swamp-forest and on the rocky coast.

C. didymum Gaertn.: 25852 (7), 32340 (2). See special notes.

C. glabrum Bl.: 28532 (9), 34763 (7).

C. hirtellurn Ridley: 32047 (2).

C. horridum Bl.: 29752 (5), 32422 (2); low spreading climber with paired hooks; in swamp-forest.

Canthium sp.: 32378 (2).

Cephaelis griffithii Hook. f.: (4); shrub $-1 \mathrm{~m}$, in dryer parts of the swamp-forest.

C. singapurensis Ridley: s.n. 14.5 .35 (4).

Chasalia curviflora Ridley: 28955 (3), 31989 (2), 32114 (2); common shrub -3 m in swamp-forest.

Coptophyllum capitatum Miq. (6); by Saraca-streams.

Diplospora malaccensis Hook. f.: 28168 (7), 28533 (9), 31458 (7); common in swamp-forest; kayu baki, kopi utan.

Gaertnera obesa Hook. f. : 32110 (2), (7); treelet -7 m, common in the swamp-forest. G. schizocalyx Bremek.: 32015, 32507 (2); shrub in swamp-forest.

Gardenia griffithii Hook. f.: (3).

G. tentaculata Hook. f.: 25959 (7); small shrub, common on Tristania-banks.

G. tubifera Wall.: 24625 (7), 25971 (7), 28736 (3), 32368 (2), 32440 (7); tree -13 m, common on Tristania-banks, mostly above K. Dohol on the Sedili Besar and disappearing 1-2 miles above Mawai, none downstream; pakan heran.

Gardeniopsis longifolia Miq.: 28686 (4), 32029 (2), 32315 (2); shrub or treelet -4 m; corolla pale pinkish white; common in dryer parts of the swamp-forest and in hillock-forest. 
Guettarda speciosa L.: coastal; kampar.

Gynochthodes sublanceolata Miq.: common small climber in swamp-forest.

Hedyotis capitellata Wall.: 28693 (1); common in openings in the dryer parts of the swamp-forest and in hillock-forest.

H. pinifolia Wall. : coastal herb.

Hydnophytum formicarum Jack: common epiphyte; kepala berok.

Ixora concinna Hook. f.: 32043 (2), 32143 (2); tree -12 m, frequent in the swampforest. See special notes.

1. congesta Roxb.: 25968 (7), 32226 (1), 32326 (2), s.n. 1.9 .35 (1); shrub or small tree 1-6 $\mathrm{m}$; common in swamp-forest.

1. grandifolia Zoll. et Mor.: 25892 (7), 28578 (8), 28628 (8), 31944 (4), 32052 (2), 32277 (2), 32498 (2), 35559 (7), s.n. 3.4 .37 (7), 11.4 .36 (2), 6.10.36 (2), 11.10 .36 (2); bushy tree $-10(-20) \mathrm{m}$, common in the mempisang-belt and in swampforest. See special notes.

1. grandifolia var. lancifolia Corner: s.n. 9.3 .36 (6), 10.4 .36 (6); tree of Saracastreams.

I. javanica (B1.) DC: 25960, 25961 (7); on Tristania-banks.

1. javanica var. retinervia Corner: 29020 (5), 29939 (3), 32359 (2); occasional in hillock- and kapur-forest.

1. lobbii King et Gamble: 28166 (7), 30787 (1), 32292 (2), 32293 (2), 32495 (2); shrub or spindly tree $-7 \mathrm{~m}$; common locally in swamp-forest and by streams in hillock-forest. See special notes.

I. pendula Jack: 32317 (2); tree $-7 \mathrm{~m}$, in hillock-forest.

I. umbellata Koord. et Val.: 28489 (9), 30685 (6); shrub or small tree 3-8 m; flowers white, very fragrant; common in Eugenia grandis forest and along Saraca-streams.

Jackia ornata Wall.: 32305 (2), (7); tree $-27 \mathrm{~m}, 30-38 \mathrm{~cm}$ thick at $2 \mathrm{~m}$, often fluted at the base; frequent in swamp-forest.

Lasianthus chryseus Ridley: 32487 (1).

L. ellipticus Wight: 29936 (3); treelet $-5 \mathrm{~m}$; in kapur-forest.

L. griffithii Wight: 32481 (1).

L. maingayi Hook. f.: 32338 (2).

L. stipularis Bl. 29986 (2), (3); shrub -2 m.

Lasianthus sp.: 32244 (2).

Lecananthus erubescens Jack : 28454 (9), 30860 (2), 31966 (2), (7); slender epiphyte or creeper, common in swamp-forest.

Lucinaea membranacea King: 32030 (2), (4).

L. morinda DC: 28068 (8), 28596 (8); root-climber on riverside trees, with pendent flowering sprays $-30 \mathrm{~cm}$ long, frequent; akar subong 'che minah.

Morinda citrifolia L.: coastal.

$M$. ridleyi King: climber in swamp-forest.

M. umbellata L.: ?

Mussaenda glabra Vahl: 32200 (2), 36912 (7); scrambler in open places along the river, from Bt Tiga upstream on the Sedili Besar; balek adap.

M. mutabilis Hook. f.: 29340 (1); frequent climber in dryer parts of the swampforest. 
Mussaendopsis beccariana Baill.: 35562 (7), s.n. 12.3 .37 (2); tree -27 m, common in swamp-forest; malbera. See special notes. Plates $25,34$.

Myrmecodia armata DC: common epiphyte.

Nauclea maingayi Hook. f.: 25900 (7), 28621 (8), 32183 (2), 36816 (7), s.n. 19.6.34

(8); tree $-20 \mathrm{~m}$, common on Tristania-banks and in the swamp-forest; bengkai, bengkal. See special notes.

N. subdita (Miq.) Merr.: 31465 (3); bush or small tree $-7 \mathrm{~m}$, very common along the banks of the Sedili Besar above Bagan Limau; gedembah. See special notes.

Neonauclea sp. : 32985 (7); shrub or treelet $-5 \mathrm{~m}$, riverside. See special notes.

Ophiorrhiza singapurensis Ridley: 29294 (3), (7); herb, abundant in swamp-forest.

Paederia verticillata Bl.: 30772 (3), 36914 (7).

Pavetta indica L.: 34602,34603 (2); frequent in dryer parts of the swamp-forest.

P. naucleiflora Don: s.n. 23.6 .34 (8); shrub $2 \mathrm{~m}$, in sandy coastal forest.

P. tomentosa Roxb.: 28597 (8), 29448 (5), (2); frequent in swamp-forest. (See Corner, Gdns' Bull. Singapore 10, 1939, 48).

Pavetta spp.: (4): (specimens in the Singapore Herbarium).

Petunga roxburghii DC: 28477 (9), 32366 (2); tree -20 m, occasional in swampforest, common in Eugenia grandis forest; Inembras. See special notes. Plate 26.

P. venulosa Hook. f.: 28450 (9), 29201 (4); bush or tree -7 m, in the dryer part of the swamp-forest. See special notes.

Prismatomeris tetrandra K. Schum.: 25858 (7); tree -7 m, on Tristania-banks, scattered.

Prismatomeris sp.: s.n. 14.4 .35 (2).

Psychotria angulata Korth.: 28509 (9); shrub 2 m, Eugenia grandis forest.

$P$. griffithii Hook. f.: (4).

P. helferiana Hook. f.: 36950 (10).

P. maingayi Hook. f.: 32115 (2).

P. obovata Wall.: 28608 (8), (9); common small root-climber, riverside; flowering in June.

$P$. ridleyi King et Gamble: 25994 (7); common epiphyte in swamp-forest.

P. rostrata $\mathrm{Bl}$.: (3).

P. sarmentosa Bl.: 32474 (2).

P. ? stipulacea Wall.: (3).

Psychotria sp.: 29940 (3), epiphytic bush at c. $20 \mathrm{~m}$ on a tree in swamp-forest; stem-base and roots grey-green, swollen, fleshy, tuberous; not climbing; ? rare (found only once).

Psychotria sp.: 32295 (2).

Randia auriculata K. Schum.: 28158 (7), 32376 (2), 36886 (7); root-climber, scattered in swamp-forest.

R. binata King et Gamble: 32037 (2), ? 32459 (2); climber.

$R$. fragrantissina Ridley: frequent small tree in swamp-forest.

R. kuchingensis Wyatt-Smith: 32153 (2); tree $-10 \mathrm{~m}$, in hillock-forest.

$R$. longiflora Lamk: common climber with hooked thorns, mangrove; kuku lang.

R. ? oppositifolia (Roxb.) Koord.: 28954 (3); epiphytic bush in swamp-forest. See special notes.

R. ? penangiana King: 29333 (4); large climber with hooks, in kapur-forest. 
R. scortechinii King et Gamble: 32131 (2), 36930 (10); small tree in hillock- and kapur-forest.

Rennellia elongata Ridley: 37053 (10); in kapur-forest.

R. speciosa (Wall.) Hook f.: 29030 (5), 32309 (2), (4); in hillock-forest; mengkudu rimba.

Saprosina glomerulatum King et Gamble: 29269 (7), 29439 (5), 32072 (2), 32159 (2), s.n. 30.12 .34 (4); shrub or small tree $-13 \mathrm{~m}$, twigs foul-smelling when broken; common in swamp-forest and kapur-forest; kentut kentut, sekentut.

Scyphiphora hydrophyllacea Gaertn.: $(8,9)$; mangrove: chingam.

Streblosa pubescens Ridley: 32355 (2).

Tarenna appressa (King) Corner: 30878 (7); shrub or treelet in swamp-forest.

$T$. costata Miq.: 32425 (2); tree $-12 \mathrm{~m}$, in swamp-forest.

T. fragrans Bl.: 24624 (7), 25962 (7), 28569 (8), 36814 (7); shrub or treelet, scattered on Tristania-banks below Mawai on the Sedili Besar, common on the Sedili Kechil.

T. longifolia (Don) Ridley: 28732 (2), 32248 (2), s.n. 18.6.34 (8), 28.6 .36 (3): treelet 2-4 $\mathrm{m}$, with deflexed panicle; frequent in swamp-forest.

T. mollis Wall.: 28705 (1), 29383 (4), 31998 (2), (7); tree -10 m, common in swampforest. See special notes.

$T$. stellulata Ridley: (5); treelet $-4 \mathrm{~m}$, frequent in swamp-forest.

Timonius flavescens (Jack) Baker: 32148 (2); frequent small tree by streams in the swamp-forest.

T. wrayi King et Gamble: 29326 (4); tree $-17 \mathrm{~m}$, in kapur-forest. See special notes.

Uncaria Schreb.: climbers with flattened sprays of opposite leaves, with axillary hooks not developed on the uppersides; leaves withering red; akar kait kait, a. kekait.

$U$. attenuata Korth.: common in rassau- and jejawi-belts along the river.

U. glabrata (BP.) D.C.: ?

U. ovalifolia Roxb.: 34762 (7).

U. pedicellata Roxb.: s.n. 21.6 .34 (8); very abundant on the banks of the Sedili Kechil.

U. pteropoda Miq.: frequent in swamp-forest.

$U$. scleroptera Roxb.: frequent in rassau- and jejawi-belts along the river.

Urophyllum corymbosum Korth.: 28976 (3), 30681 (6); shrub in swamp-forest.

U. glabrum Jack: 28651 (8), 29498 (2), 32242 (2), 32473 (2); shrub -4 m, abundant in the sivamp-forest.

U. hirsutum Hook. f.: 30786 (1), 32075 (2).

U. ? macrophyllum Korth.: 29948 (4); treelet -4 m, sparingly branched; in swampforest.

U. streptopodium Wall. : 28699 (1), 29480 (4), 36943 (10), (7); treelet -5 m; stem $2-5 \mathrm{~cm}$ thick, monopodial; common in swamp-forest.

U. trifurcum Pears.: 36870 (7).

Urophyllum sp.: 28964 (3); shrub or treelet $-5 \mathrm{~m}$, frequent in swamp-forest.

Urophyllum sp.: 32113 (2).

"Rubiaceae s.n. 7.7.35 (4)"; (specimen put at the end of Rubiaceae in the Singapore Herbarium). 


\section{Rutaceae}

Acronychia porteri Hook. f.: 32375 (2), 32420 (2).

Atalantia monophylla DC: $28458(9),,(8)$; tree $-14 \mathrm{~m}$, with thorny twigs; common in Eugenia grandis forest; merlimau. (A. spinosa of Wayside Trees of Malaya).

Clausena excavata Burm.: 28473 (9); tree $-10 \mathrm{~m}$, with nauseous smell from the crushed twigs and leaves; common in young Eugenia grandis forest.

Evodia glabra Bl.: 31927 (5); tree $-20 \mathrm{~m}$; bark pinkish grey, creviced; inner bark pale pinkish orange; wood yellowish white; in hillock-forest.

E. roxburghiana (Champ.) Benth.: 21200 (7), 28508 (9); tree $-13 \mathrm{~m}$; bark as $E$. glabra: in swamp-forest and in wet hollows or water-courses in Eugenia grandis forest; inggi burong.

Glycosmis chlorosperma (Spreng.) Tanaka: 29038 (4), 30975 (1), 31975 (2), 32239 (2), s.n. 11.6.34 (9); shrub or treelet $3-10 \mathrm{~m}$, frequent in swamp-forest and in Eugenia grandis forest. ( $G$. pentaphylla in Wayside Trees of Malaya).

G. decipiens B. C. Stone: s.n. 10.2.35 (5); shrub -1.7 m. (Phoenicimon rubiginosum Ridley).

Luvunga scandens B. Ham.: 32439 (2), s.n. 19.10 .37 (7); big climber with spiny stem, in swamp-forest.

Merope angulata (Willd.) Swingle: thorny bush in mangrove; limau lilang. (Paramignya angulata in Wayside Trees of Malaya).

Paramignya lobata Burkill: s.n. 13.4.36 (7); climber with thorny stems and orangeyellow petioles; fruit tomato-red; not infrequent in swamp-forest.

P. scandens (Griff.) Craib: s.n. 17.3 .34 (7); scrambler low down in the forest, not infrequent in swamp-forest; juice of root said by Malays to be an infallible cure for sore nose and throat and 'ulat dalam kepala'; sakit rastong.

Tetractomia major Hook. f.: 35561 (7); tree -20 m, with narrow monopodial crown; in swamp-forest (Botanical Reserve, Sedili Besar, upper boundary, chain 15).

T. tetrandra (Roxb.) Craib: 28725, 28726, 28727 (2), 36797 (7); tree -23 m, with pneumatophores; frequent in swamp-forest; medang. See special notes. Plates 7,36 .

\section{Sabiaceae}

Meliosina lanceolata Bl.: 32086 (2).

M. pinnata (Roxb.) Walp. ssp. ridleyi (King) Beus.: 29411 (5); tree $-17 \mathrm{~m}$, in kapurforest. See special notes.

M. sumatrana (Jack) Walp.: s.n. 14.4 .35 (2); treelet $-5 \mathrm{~m}$, common in hillock-forest. See special notes.

\section{Santalaceae}

Scleropyrum ridleyi Gamble: 29348 (6); treelet $-5 \mathrm{~m}$, cauliflorous; by Saracastreams.

\section{Sapindaceae}

Allophylus cobbe L. var. velutina Corner; 28470 (9); tree -7 m, in young Eugenia grandis forest, frequent. See special notes.

Dimocarpus longan Lour. ssp. malesianus Leenh.: 32405 (2); tree -10 m, in hillockforest; mata kuching, pedaru. See special notes. 
Dodonaea viscosa Jacq. : 28455 (9); shrub or small tree $-7 \mathrm{~m}$; common in coastal forest of Casuarina and secondary forest with Hibiscus tiliaceus.

Guioa bijuga (Hiern) Radlk.: 32249 (1); tree $-13 \mathrm{~m}$, at the edge of the swampforest; several trees in fruit in Feb. 1937.

G. pleuropteris (Bl.) Radlk. : 28082 (7), (9); in secondary forest and on rocky coasts.

Lepisanthes $\mathrm{Bl}$.: see special notes.

L. rubiginosa (Roxb.) Leenh.: 28486 (9), (7); in swamp-forest and commonly in Eugenia grandis forest; mertajam. (Erioglossum rubiginosum of Wayside Trees of Malaya).

L. senegalensis (Poir.) Leenh.: 32350 (2); tree $-17 \mathrm{~m}$, in hillock-forest.

L. tetraphylla (Vahl) Radlk. : 28494 (9), 28593 (8), 28996 (5), 32496 (2), s.n. 11.6 .34 (9), 9.2.35 (5); treelet $-5 \mathrm{~m}$, cauliflorous; young leaves white, drooping; common in swamp-forest by riversides, in hillock-forest, and in Eugenia grandis forest.

Mischocarpus sumatranus Bl.: 25975 (7), 28320 (9); tree $-11 \mathrm{~m}$, scattered on Tristania-banks upstream from Bagan Limau on the Sedili Besar.

Nephelium eriopetalum Miq. : 36845 (7).

N. glabrum Noronh.: 25980 (7), 32442 (7); tree $-25 \mathrm{~m}$; inner bark green just below the surface even in old trees; frequent on Tristania-banks and in dryer parts of the swamp-forest; general fruiting in March 1937; redan.

$N$. cf. herveyi Ridley: 32118 (2), 36838 (7).

N. rubescens Hiern: 26136 (7), 28572 (8), 28574 (8), 28625 (8); tree -20 m; scattered on Tristania-banks on the Sedili Besar, common on the Sedili Kechil; general flowering in June 1934.

Pometia pinnata Forst f. alnifolia (Bl.) Jacobs: 29302 (1); tree $-30 \mathrm{~m}$, strongly and sharply buttressed $-4 \mathrm{~m}$ high; common in swamp-forest; kasai. See special notes. Plates 9, 36.

Trigonachras acuta Radlk.: 28630 (8); tree $-23 \mathrm{~m}$, common along the Sedili Kechil from Kg Ladang upstream to S. Lebai Kator; general flowering at the end of June 1934; tangisong burong.

Xerospermum muricatum Radlk.: 29260 (2), 32186 (2), 32339 (2); tree -20 m, frequent in the swamp-forest; kikir buntal.

Xerosperinum sp.: s.n. 12.6.34, 14.6 .34 (9); tree $-20 \mathrm{~m}$; fruits ripening yellow; common in wet hollows and by water-courses in Eugenia grandis forest; geringgong.

Xerospermum sp.: s.n. 13.4 .35 (7); tree $-20 \mathrm{~m}$; fruits ripening yellow with yellow pulp; common in swamp-forest; kikir buntal. See special notes.

\section{Sapotaceae}

Chrysophyllum lanceolatum (B1.) DC: 34943 (5); tree -20 m, monopodial; in kapur-forest.

Ganua kingiana (Brace) w.d. Assem: s.n. 6.8 .39 (10); tree $-25 \mathrm{~m}$, common on Bt. Tinjau Laut.

G. motleyana (de Vr.) Pierre: 28442 (9), 32154 (2), (7); tree -47m, with knee-roots; common in swamp-forest; bengku. See special notes. Plates 7, 34.

Madhuca hirtiflora H. J. Lam: 29037 (5), (4); scattered in dryer parts of the swamp-forest and in hillock-forest; nyatoh. See special notes.

M. sericea (Miq.) H. J. Lam var. ridleyi $\mathrm{Ng}$ : s.n. 10.2 .35 (1). 
M. sessiliflora v. Royen: 28994 (5), 29024 (5), 29429 (5), s.n. 24.6 .35 (4); small tree $2-7 \mathrm{~m}$; common locally in swamp-, hillock-, and kapur-forest about mile 13-14 Jemaluang Road; apparently endemic in this region. See special notes.

M. tomentosa H. J. Lam: 21330 (5), 31996 (2), 32129 (2), 32390 (2), 36934 (10); small trec 3-12 m; frequent in sivamp-, hillock-, and kapur-forest; nyatoh. See special notes.

M. tubulosa H. J. Lam : 29039 (4); in the dryer part of the swamp-forest; nyatoh.

M. utilis H. J. Lam: 32019 (2), 32992 (5).

Madhuca sp.: 29305 (1); tree -20 m, in swamp-forest; nyatoh. See special notes.

Palaquium clarkeanum King et Gamble: (5); in kapur-forest.

P. confertum H. J. Lam: 30789 (1); tree $-33 \mathrm{~m}$, sharply and steeply buttressed -2 m; in the drycr part of the swamp-forest.

P. gutta (Hook.f.) Baill.: (5); scattered in dryer parts of the swamp-forest; taban, getah taban.

P. hexandrum (Griff.) Engl.: 37076 (10); tree -50 m, in kapur-forest. See special notes.

P. macrocarpum Burck: 29305 (1); tree $-20 \mathrm{~m}$, in the dryer parts of the swampforest; also det. P. leiocarplm Boerl.

P. obovatum (Griff.) Engl.: 21324 (1), 28639 (8); tree -30m; not infrequent in dryer parts of the swamp-forest and in nibong-forest at the back of the mangrove; nyatoh.

P. semaram H. J. Lam: 28516 (9), 36793 (7), s.n. 18.2.37 (2); tree -50m, steeply buttressed $-3 \mathrm{~m}$ high; scattered in swamp-forest and as a canopy-tree in Eugenia grandis forest; semaram, sundek.

P. sukoei Fischer: 29320 (4), 29379 (4), 31995 (2), 32990 (5), s.n. 15.5 .35 (4); tree $-27 \mathrm{~m}$, frequent in hillock- and kapur-forest.

P. xanthochymum Pierre: 25891 (7), 25990 (7), 29265 (7), 34718 (7), 34758 (7), 36796 (7); tree $-35 \mathrm{~m}$, with strong stilt-roots; common in swamp-forest and in the mempisang-belt; bengka, bengku, jangka tinggi, suntai. See special notes. Plates 13, 17, 35.

Palaquium sp.: s.n. 9.9.34 (4) as Sapotaceae A. See special notes. Plate 20.

Planchonella maingayi (Clarke) v. Royen: 21318 (1), 28624 (8); tree -23 m, fluted at the base; frcquent in swamp-forest. (Lucuma maingayi).

P. obovata (R. Br.) Pierre; common on the sandy and rocky coast of Jason Bay; misi.

Pouteria malaccensis (Clarke) Baehni: 29468 (4); tree $-33 \mathrm{~m}$, sharply and steeply buttressed $-3.3 \mathrm{~m}$ high, the buttresses often forked; in kapur-forest, occasional in the swamp-forest and with a few stilt-roots $-2 \mathrm{~m}$ high. (Lucuma malaccensis).

P. paucinervia Erlee: 34721 (7); trec $-17 \mathrm{~m}$, frequent in swamp-forest.

\section{Saurauiaceae}

Saurauia tristyla DC: 32027 (2), 37077 (10), (6); small tree -7 m; flowers pink, mostly ramiflorous; common by Saraca-streams.

\section{Schisandraceae}

Kadsura cauliflora Bl.: s.n. 13.6 .34 (9), 27.3 .39 (7); cauliflorous climber with pinkish purple fruits; in swamp-forest and in Ellgenia grandis forest. 


\section{Scrophulariaceae}

Cyrtandromoea: see under Gesneriaceae.

Herpestis monniera HBK : on mud under nipa; beremi, beremilu.

Limhophila erecta Benth.: 32051 (2); common aquatic herb, more or less submcrged, by the edge of the Sedili Bssar from K. Dohol downstream to a short way below Bt. Tiga: rumput ekor kuching. (See Sinclair, Gdns' Bull. Singapore 22, 1967, 229).

\section{Simaroubaceae}

Brucea javanica (L.) Merr.: s.n. 10.7.36. (B. amarissima in Wayside Trees of Malaya).

Eurycoma longifolia Jack: (8); in hillock-forest; penawa pahit.

Quassia indica (Gaertn.) Noteboom: 28547 (9); trcelet -5 m; common in wetter parts of the sandy coastal forest, especially by streams, often tufted; piandong. See special notes.

\section{Solanaceae}

Solanum parasiticum Bl.: 32503 (2), (7); compact little epiphyte with white flowers, in deeper parts of the swamp-forest, frequent.

\section{Staphyleaceae}

Turpinia sphaerocarpa Hassk.: 28690 (1), 28710 (1); tree -20 m, frequent in swamp-forest. See special notes.

\section{Stemonaceae}

Stichoneuron caudatum Ridley: 28716 (1), 30684 (6), 32761 (2), 37056 (10); herb $-70 \mathrm{~cm}$; leaves silvery beneath; inflorescence pale grcenish white; flowers opening one at a time; filaments purple, anthers yellow; locally frequent in the swamp-forest.

\section{Sterculiaceae}

Byttneria brevipes Ridley: s.n. 14.5 .35 (5); treelet $3 \mathrm{~m}$, in swamp-forest.

B. maingayi Mast.: 32443 (2).

Commersonia bartramia (L.) Merr.: in secondary forest; menkirai.

Heritiera elata Ridley: (7); large buttressed tree, rather frequent in swamp-forest by the Sedili Besar.

H. littoralis Ait.: (9); mangrove and sca-coast, frequent; dungun.

H. simplicifolia (Mast.) Kostcrm.: 37026 (5), s.n. 30.12 .34 (5), 2.2 .35 (1); tree $-30 \mathrm{~m}$, buttressed; in dryer parts of the swamp-forest, in hillock- and in kapurforest: bengkulang. See special notes.

H. sumatrana (Miq.) Kosterm.: s.n. 7.2 .35 (3), 16.7 .39 (7); buttressed tree of swamp-forest; bengkulang daun tujoh. 
Leptonychia glabra Turcz.: 29259 (2), 29336 (4), 32082 (7); shrub -3 m; fruiting April 1935; flowering May 1935; in hillock- and kapur-forest; See special notes. (? L. heteroclita Sch.)

Pterospermum javanicum Jungh.: s.n. 11.6.34, 12.6 .34 (9), 2.2.35 (1), (7); tree -30 m, buttressed; frequent in swamp-forest, common in Eugenia grandis forest; letop letop. See special notes.

Scaphium macropodum (Miq.) Beumée: 36860 (7), 36862 (7), s.n. 5.5 .35 (1), 13.5 .35

(5), 2.5 .37 (7), (10); tree $-40 \mathrm{~m}$, buttressed; frequent in the swamp-forest; kembang samangkok. See special notes. (S. affine in Wayside Trees of Malaya).

S. linearicarpum (Mast.) Pierre: s.n. 10.2 .35 (2), (4), (10); tree as S. macropodum; in the dryer parts of the swamp-forest (? only as saplings), and in hillock-forest; kembang samangkok.

Sterculia bicolor Mast.: 32437 (2), 36801 (7), 36808 (7), s.n. 28.3 .37 (7); tree -27 m, frequent in swamp-forest. See special notes.

S. brachycarpa Ridley: 36905 (7).

$S$. coccinea Jack: frequent shrub or treelet in swamp-forest. ( $S$. laevis in Wayside Trees of Malaya).

S. macrophylla Vent.: 28471 (9), 36892 (7); tree $-20 \mathrm{~m}$, frequent in swamp-forest and in Eugenia grandis forest; fruiting in June 1934. See special notes.

$S$. cf. rostrata Ridley: 34658 (4).

S. rubiginosa Vent.: 28663 (5); in hillock- and kapur-forest.

S. cf. scortechinii King: 29323 (4), 29378 (4); tree $-13 \mathrm{~m}$, frequent in kapur-forest. See special notes.

\section{Styracaceae}

Styrax crotonoides Clarke: 28704 (1), 29246 (1), 30688 (6), 32095 (2), 36937 (10); tree - $13 \mathrm{~m}$, in dryer parts of the swamp-forest, in hillock- and kapur-forest; medang. See special notes.

\section{Symplocaceae}

Symplocos barringtoniifolia Brand : 29013 (5), 29374 (4); tree -17 m, in hillock- and kapur-forest. See special notes.

S. celastrifolia Griff. : 28069 (8), 28080 (7), 28636 (8), 36807 (7); tree -17 m, common in riverside forest with Ilex cymosa; flowers white, very fragrant; no Malay name.

S. odoratissima (BI.) Choisy var. odoratissima: 32404 (2).

S. rubiginosa Wall. : 29263 (7); tree $-10 \mathrm{~m}$, in swamp-forest. See special notes. Symplocos sp. ?: s.n. 3.2 .35 (2); tree $-23 \mathrm{~m}$, in swamp-forest. See special notes.

\section{Taccaceae}

Tacca chantrieri André: frequent in swamp-forest; pelali urat. ( $T$. verspertilio).

$T$. integrifolia Ker-Gawl: common in swamp- and hillock-forest; pelali urat. ( $T$. cristata).

T. leontopetaloides (L.) O.K.: 28462 (9); solitary plant scattered along the seafront beneath Casuarina, rather scarce; toyok. See special notes. Plate 31.

T. palmata Bl.: 28474 (9); flowers dull purple; frequent in Eugenia grandis forest. Plate 31. 


\section{Theaceae}

Adinandra acuminata Korth.: 30979 (1), 32040 (2), 32391 (2); tree -10 m, in swamp-forest; tiup tiup, tetiup.

A. corneriana Kob.: 29010 (5), 29376 (4), 29426 (5), 30854 (2), 32011 (2); tree $-10 \mathrm{~m}$, frequent in dryer parts of the swamp-forest, in hillock-and kapur-forest. See special notes.

A. sarosanthera Miq.: 23896 (7), 25992 (7), 28581 (8), 28728 (2), 29977 (5), 30881 (7), 34720 (7), 36788 (7); buttressed tree in swamp-forest and on Tristaniabanks, rather scattered. See special notes. (A. lamponga in Wayside Trees of Malaya). Plate 20.

Adinandra sp.: 28559 (8); tree $-17 \mathrm{~m}$, in mangrove (Kg Ladang, Sedili Kechil).

Adinandra sp.: 36786 (7).

Eurya acuminata DC: 29309 (1), 32003 (2); tree -13 m, in high swamp-forest; mempadi.

Gordonia ? multinervia King: 37064 (10).

G. singapureana Wall.: 29253 (2), 34757 (7); tree - $27 \mathrm{~m}$, fairly abundant in swamp-forest; tiup tiup. See special notes.

Ploiarium alternifolium (Vahl) Melchior: small stilted tree frequent in the mempisang-belt; riang riang, reriang. See special notes. Plates 11, 40.

Pyrenaria acuminata Planch.: 31964 (2); tree -13 m, occasional in swamp-forest.

$P$. kunstleri King: 32077 (2); small tree as $P$. acuminata.

Ternstroemia bancana Miq. : 28740 (3), 30888 (7), 32158 (2), 32245 (2), 34736 (7), 36815 (7), s.n. 27.3 .32 (7); common tree in swamp-forest. See special notes.

T. elongata (Korth.) Koord.: 29244 (2), 32416 (2), (4); in swamp-forest.

\section{Thymelaeaceae}

Aquilaria beccariana van Tiegh.: 29008 (4), 29195 (4), 29381 (4), 29470 (3); small spindly tree $-7 \mathrm{~m}$, scattered in the swamp-forest and on the riverside. See special notes.

A. malaccensis Lamk: 37083 (10), (9); tree -30m, in hillock- and kapur-forest, scattered in Eugenia Grandis forest; kayu gaharu. See special notes.

Phaleria capitata Jack: 28481 (9), 32776 (2), Sinclair 10851 (9), Kadim and Noor 196 (?9); small cauliflorous treelet $-5 \mathrm{~m}$; in swamp-forest and common in Eugenia grandis forest. See special notes.

\section{Tiliaceae}

Brownlowia argentata Kurz: 28643 (8), (9); shrub or small tree $-10 \mathrm{~m}$, in the nipa-belt and in the upper part of the mangrove, common; flowering JuneJuly; dungun.

B. tersa (L.) Kosterm. : 28644 (8); bush -2 m high, spreading under mangrove trees in their upper reaches along the Sedili Kechil; dungun. (B. lanceolata in Wayside Trees of Malaya).

Grewia antidesmaefolia King: 28064 (8), 28586 (8), 32775 (4), 36972 (7); tree -13 m, frequent in swamp-forest and on Tristania-banks.

G. blattaefolia Corner: 28545 (9), 31500 (1), 32059 (2), 32480 (1); tree -13 m, frequent in swamp-forest and coastal forest. See special notes. 
G. fibrocarpa Mast.: 28063 (8), 29278 (7), 31472 (4), 32508 (2); shrub or treelet $-5 \mathrm{~m}$, frequent in swamp-forest; asam damat, kelentek nyamok.

G. hirsuta (Korth.) Kochummen: 30670 (7), 32009 (2), 34760 (7); tree -17 m. See special notes. (G. omphocarpa Miq.)

$G$. tornentosa Juss.: in coastal forest; chenderai.

G. umbellata Roxb.: 28475 (9), 31960 (2); climber with rather spiky stem; in the dryer parts of the swamp-forest and in secondary forest; akar letop. (G. acuminata Juss.)

Grewia sp.: 36913 (7).

Pentace corneri Kosterm.: s.n. 5.5 .35 (5); tree -57 m, in kapur-forest. See special notes.

P. triptera Mast.: 36968 (7), 37104 (7); tree $-47 \mathrm{~m}$, scattered in the swamp-forest. See special notes. Plate 35.

Pentace sp.: s.n. 8.2 .35 (5); tree -17 m, by stream in hillock-forest; medang.

Schoutenia accrescens Mast.: 36846 (7), 36975 (7), 37250 (4), (10); tree -20 m, frequent in dryer parts of the swamp-forest and in hillock- and kapur-forest.

S. accrescens var.: 28681 (4), 29006 (4); tree $-17 \mathrm{~m}$, common on stream-banks in the dryer parts of the swamp-forest and along Saraca-streams in hillock-forest. See special notes.

S. corneri Roekmowarti-Hartono: 29978 (5), 37361 (5); small stream-side tree.

S. glomerata King: 29463 (4), s.n. 12.5 .35 (6); tree -13 m, common along Saracam streams. See special notes.

Triumfetta repens (B1.) Merr. et Rolfe: (9); coastal herb, forming mats with the branches rooting as short runners.

\section{Ulmaceae}

Gironniera nervosa Planch.: 28672 (4); common in hillock- and kapur-forest.

G. parvifolia Planch.: 31983 (2).

Trema orientalis (L.) Bl.: 28698 (1); shrub or small tree, common in hillockforest; mendarong.

\section{Urticaceae}

Elatostema sp.: 30694 (6). (This genus not in the swamp-forest).

Poikilospermum cordifolium (Barg. Petr.) Merr.: s.n. 26.3 .32 (7); frequent big climber with large leaf, in swamp-forest and on Tristania-banks.

P. microstachys (Barg. Petr.) Merr.: 30723 (3), 31967 (2); common small climber in the swamp-forest.

P. scortechinii (King) Merr.: 28484 (9); common small climber with aerial roots, in the undergrowth of the swamp-forest and in Eugenia grandis forest.

P. suaveolens (Bl.) Merr.: 28506 (9); common large climber along the rivers and in Eugenia grandis forest; akar lundong. a. setahun. See special notes.

Pouzolzia indica Gaud.: 28502 (9); herb $-60 \mathrm{~cm}$ high, very common in scrub behind Casuarina.

Procris sp.: 30675 (6), 32112 (2), 32461 (2), s.n. 12.5 .35 (6); epiphytic, with fleshy green stem; not infrequent in the swamp-forest. 


\section{Verbenaceae}

Avicennia: see special notes.

Callicarpa farinosa Bl.; 30730 (6), (7); tree $-17 \mathrm{~m}$, frequent in swamp-forest.

Clerodendron? brevifolium Ridley: s.n. 9.6 .34 (7); in swamp-forest. See special notes.

C. buchanani Roxb.: 30000 (3); shrub -2 m, locally frequent in the swamp-forest. See special notes.

C. deflexum Wall.: (4); in dryer parts of the swamp-forest.

C. inerme (L.) Gaertn.: mangrove, frequent.

C. myrmecophilum Ridley: (4), in the dryer part of the swamp-forest.

C. ? paniculatum L.: s.n. 28.4 .35 (3).

C. villosum Bl.: frequent at the edge of the forest: pakai panggil.

Peronema canescens Jack: 36890 (7).

Premna divaricata Wall.: 32999 (7).

P. obtusifolia R. Br.: (9); coastal shrub; buas buas, bebuas. (P. corymbosa of Wayside Trees of Malaya).

P. trichostoma Miq.: 21193 (7); common riverside creeper over putat, rassau, rengas, and jejawi, from Lubok Pusing down to $\mathrm{Bt}$ Tiga on the Sedili Besar; ara lumut.

Vitex clarkeana Gamble: 28187 (7), 28642 (8), 33693 (7), 34711 (7); riverside shrub or small tree in freshwater and brackish tidal zones. See special notes.

V. ovata Thunb.: (9), creeper on sand-dunes, scarce at Jason Bay; demundi, lenggadi. See special notes.

$V$. pubescens Vahl: in dryer parts pf the swamp-forest and in coastal scrub, frequent; leban.

V. peralata King: 32771 (1); tree $-23 \mathrm{~m}$, in the swamp-forest and on Tristaniabanks from Bt. Tiga upstream to Saraca-streams, common; flowering April 1937; kayu gah.

\section{Violaceae}

Rinorea anguifera (Lour.) O.K.: 31931 (5), 31936 (5), 36871 (7); shrub or small tree $2-5 \mathrm{~m}$, common in swamp- and hillock-forest.

R. horneri (Korth.) O.K.: 32046 (2), 32362 (2), s.n. 15.4 .36 (1), 11.10 .36 (2); shrub $-2 \mathrm{~m}$ high, frequent in swamp- and hillock-forest.

$R$. javanica (Bl.) O.K.: 37028 (5); tree $-5 \mathrm{~m}$, in hillock-forest.

R. lanceolata (Wall.) O.K.: 32135 (2); shrub $-5 \mathrm{~m}$ high, in hillock-forest.

\section{Vitaceae}

Leea indica L.: in secondary forest in swampy ground; mali mali, memali.

Pterisanthes coriacea Korth.: common climber in swamp-forest.

Vitis furcata Lamk. 28469 (9), 28560 (8); climber with small fleshy coriaceous leaves; in mangrove and Eugenia grandis forest.

V. gracilis Wall.: 28552 (9); small climber, common in swamp-forest; nyaru.

V. japonica Thunb.: 29949 (2), 31974 (2); common climber in dryer parts of the swamp-forest. 
V.? lawsonii: s.n. 12.6 .34 (9); climber with flat ribbon-like stems; common in Eugenia grandis forest.

V. mollissima Wall.: 28479 (9), s.n. 13.5 .35 (5); common climber in swamp- and hillock-forest; fruits clear pink, distinctly irritant on eating.

V. pyrrhodasys Miq.: 29455 (7); frequent climber in swamp-forest.

V. ? trifolia L.: (8).

\section{Zingiberaceae}

(see special notes)

Achasma macrocheilos Griff.: 29993 (5), 31476 (4), 37061 (10); common in dryer parts of the swamp-forest and in coastal forest; tepus.

A. megalocheilos Griff.: 30891, 30892 (6); tepus.

A. pauciflorum (Ridl.) Holtt.: 30890 (6).

A. sphaerocephalum (Bak.) Holtt. var. petiolatum Holtt.: 30745 (6).

Alpinia javanica Bl.: (1); in swamp-forest.

Amornum hastilabium Ridley: 30744 (6).

A. uliginosum Koen.: s.n. 15.6.34 (9); in coastal forest.

A. xanthophlebium Bak.: 32180 (2).

Boesenbergia plicata Holtt.: (1); in swamp-forest.

B. prainiana (Bak.) Scheff.: 32389 (2), 37052 (10), s.n. 5.1 .36 (5).

Camptandra parvula (King) Ridley var.: 30874 (6), (4); frequent in dryer parts of the swamp-forest and on rocks in Saraca-streams.

Costus speciosus (Koen.) Sm.: in open swampy places.

Elettariopsis curtisii Bak.: s.n. 8.9.35 (5); in kapur-forest, generally gregarious, common.

Geocharis aurantiaca Ridley: 32446 (2), 32454 (2), 32777 (mile 2, Jemaluang Road); apparently endemic in Johore.

Globba leucantha Miq. : 32097 (2), s.n. 10.4 .36 (6); common in swamp-forest.

G. marantina L.: 28538 (9); coastal forest, frequent.

G. patens Miq.: 30693 (6). (G. aurantiaca Miq.).

G. pendula Roxb.: s.n. 11.10 .36 (2); occasional in swamp-forest.

G. variabilis Ridley: 37055 (10), (1).

G. variabilis ssp. pusilla Lim: 32013 (2).

Hedychium longicornutum Bak.: frequent epiphyte, usually low down, in the swamp-forest, with fleshy roots; lempoyang utan.

Hornstedtia leonurus (Koen.) Retz.: 30746 (6).

H. phaeochoana K. Schum.: 31946 (4); apparently the only collection of this Bornean species from Malaya.

Languas melanocarpa (T. et B.) Burk: (9); common in Eugenia grandis forest.

Phaeomeria maingayi (Bak.) K. Schum.: 36969 (7).

$P$. venusta Ridley: 32778 (mile 2, Jemaluang Road).

Plagiostachys albiflora Ridley: 30657 (6), 37091 (10).

Scaphochlamys erecta Holtt.: 31941 (4). 
S. klossii (Ridley) Holtt. : 28965 (3), 29983 (3), 30743 (6), 31963 (2), s.n. 14.5.35 (5); gregarious in damp hollows in the swamp-forest, common; apparently endemic to G. Panti and the Sedili region.

S. klossii var. minor Holtt.: 30743 (6), s.n. 5.8 .37 (10).

Zingiber puberulum Ridley: 31477 (4).

Z. puberulum var. chryseum Ridley: 30658 (6).

Z. wrayi Prain: 37054 (10).

\section{Unidentified Trees}

(see special notes)

\section{Gymnospermae}

Cycas rumphii Miq.: coastal, chiefly in the Terminalia-zone; paku laut.

Gnetum gnernon L.: 32331 (2).

G. gnemon var. brunonianum (Griff.) Mgf: 28654 (8), s.n. 24.6.34, 28.6.34 (8); shrub or treelet $-1.5 \mathrm{~m}$, frequent in sandy coastal forest; cheperai.

G. gnemonoides Brongn.: 29431 (5), 30879 (7), 31972 (2), 36792 (7); climber in swamp-forest.

G. latifolium Bl. var. funiculare (B1.) Mgf: 28177 (7), 28535 (9), 32427 (2); big cauliflorous climber with fragrant 'flowers'; common in swamp-forest and Eugenia grandis forest.

G. microcarpurn Bl.: 29454 (7), 31454 (2), 32998 (7); big climber on Tristaniabanks and in hillock-forest.

Podocarpus motleyi (Parl.) Dumm.: 21341 (2); tree -27 m, in swamp-forest. See special notes.

P. neriifolius D. Don: 32288 (2), 34750 (7), s.n. 12.6 .34 (9); tree $-25 \mathrm{~m}$, frequent in swamp-forest, on Tristania-banks, and in Elıgenia grandis forest; getting new leaves May-June; setada.

P. polystachyus R.Br.: (2), (9); tree $-20 \mathrm{~m}$, chiefly coastal and in mangrove; setada.

$P$. wallichianus Presl: 30877 (7); tree of swamp-forest, scattered. ( $P$. blumei in Wayside Trees of Malaya).

\section{Pteridophyta}

Abacopteris triphylla (Sw.) Ching: 36395 (1). [Pronephrium triphyllum (Sw.) Holtt., 1972].

Acrostichum aureum L.; with nipa and mangrove; piai raya.

Angiopteris evecta (Forst.) Hoffm.: in stream-valleys in the dryer parts of the swamp-forest and in hillock-forest.

Antrophyum callifolium Bl.: (2), (3).

Asplenium borneense Hook. 36948 (10). - A. glaucophyllum v.A.v.R.- A. macrophyllum Sw. $(3,8)$, chiefly on the rocky coast. $-A$. nidus L., abundant in all parts.

Athyrium esculentum (Retz.) Copel.

Belvisia callifolia (Chr.) Copel.: (2).

Blechnum finlaysonianum Hook. et Grev. - B. orientale L. 
Ceratopteris thalictroides (L.) Brongn.: common by the riverside in open muddy places in the freshwater tidal reach of the Sedili Besar from K. Dohol down to the beginning of the nipa-belt.

Cyathea latebrosa (Wall.) Copel.: 32198 (2), frequent in swamp-forest.

C. obscura (Scort.) Copel.: 36946 (10).

C. squamulata (Bl.) Copel.: 32179 (2).

Davallia denticulata (Burm.) Mett.-D. solida (Forst.) Sw., coastal.

Drymoglossum piloselloides (L.) Presl.

Drynaria quercifolia (L.) J. Sm.

Gleichenia laevigata (Willd.) Hook., forest edges.- G. linearis (Burm.) Clarke, forest-edges and riverside.- $G$. linearis var. altissima Holtt.: 31447 (7), in swamp-forest.

Humata heterophylla (Sm.) Desv.: 30862 (2), 31988 (2).-H. repens (Linn.f.) Diels. Hymenophyllum denticulatum Sw.- H. polyanthos Sw.- H. serrulatum (Presl)

C. Chr., low down on tree-trunks, buttresses and pneumatophores; common.

Isoloma divergens (Hook et Grev.) J.Sm.: in swamp-forest.

Lindsaea scandens Hook.: 31933 (5). [L. parasitica (Roxb.) Hieron, f. Kramer 1967].

Lomariopsis cochinchinensis Fée: common in freshwater swamp-forest, especially in clearings.

Lycopodium cernutum L.: $(2,3,7)$; in clearings; rumput sesuroh, suroh suroh.

L. laxum C. Presl, L. nummularifolium Bl.; frequent epiphytes.

L. phlegmaria L., L. squarrosum Forst.; frequent epiphytes; ekor tikus.

Lygodium borneense v.A.v.R.: 26053 (7), (2, 3); frequent in swamp-forest; apparently the only localities in Malaya.

L. circinnatum (Burm.) Sw., L. flexuosum (L.) Sw., in clearings.

Microsorium punctatum (L.) Copel.: 30740 (6).

Nephrolepis biserrata (Sw.) Schott; coastal, abundant.

Ophioglossum pendulum L.: epiphytic with Asplenium nidus.

Photinopteris speciosa (Bl.) Presl: (6).

Phymatodes crustacea (Copel.) Holtt.; common on high branches in the swampforest.- P. scolopendria (Burm.) Ching.- P. sinuosa (Wall.) J.Sm.

Platycerium coronarium (Koen.) Desv.: common; passu petri.

$P$. ridleyi Christ: frequent on high branches in the swamp-forest, often on dead limbs.

Psilotum sp.: epiphytic, not infrequent.

Pteris ensiformis Burm.: coastal, abundant.

Pyrrosia adnascens (Forst.) Ching, (9), coastal. $-P$. angustata (Sw.) Ching. $-P$. longifolia (Burm.) Morton.-P. nummularifolia (Sw.) Ching.

Schizaea dichotoma L.: frequent in dryer parts of the swamp-forest.

S. digitata (L.) Sw.: frequent in hillock-forest.

Schizoloma ensifolium (Sw.) J.Sm.: [Lindsaea ensifolia Sw. f. Kramer 1967].

Selliguea heterocarpa $\mathrm{Bl}$.

Stenochlaena palustris (Burm.) Bedd.: common in the swamp-forest and in clearings.

Syngramma alismifolium (Pr.) J.Sm.

Taenitis blechnoides (Willd.) Sw.- T. interrupta Hook. et Grev. 
Tectaria barberi (Hook.) Copel.- T . semibipinnata (Wall.) C.Chr.- T. singaporeana (Wall.) Ching, 32068 (2).

Teratophyllum aculeatum (B1.) Mett.: in hillock-forest.

$T$. ludens (Fée) Holtt.; common in freshwater swamp-forest.

T. rotundifoliatum (R. Bonap.) Holtt.: 28141 (8).

Thelypteris chlamydophora (Rosenst.) Ching: 32117 (2). [Mesophlebion chlamydophorum (Rosenst.) Holtt, 1975].

T. crassifolia (Bl.) Ching: (7).

T. motleyana (Hook.) Holtt.: 37075 (10). [Mesophlebion motleyanum (Hook.) Holtt., 1975].

Trichomanes aphlebioides Chr.: 30652 (6).-T. obscurun Bl.

Vittaria ensiformis Sw.

\section{Postscript}

In an article which is in press, Ashton reduces four species of dipterocarp, given in the List of Vascular Plants of the Sedili-region (p. 111 and 112) to synonymy. Thus Hopea resinosa Sym. becomes $H$. pachycarpa (Heim) Sym.; Shorea resina-nigra Foxw. becomes S. longisperma Roxb.; Vatica stipulata Ridl. becomes $V$. hullettii Ridl; and $V$. wallichii Dyer becomes $V$. pauciflora (Korth.) Bl. See P.S. Ashton 1978, Flora Malesiana Precursores: Dipterocarpaceae, Gdns' Bull. Singapore vol. 31, part 1. 



\section{Part VI. Special notes on plants from Johore and Singapore}

Struck with the paucity of information on living plants in Malaysia, I made field-notes on nearly every collection. Included here are such notes as have not been incorporated in Wayside Trees of Malaya or in the post-war accounts of Annonaceae and Myristicaceae (Sinclair), Calophyllum (Henderson and WyattSmith), and Eugenia (Henderson). Some of these notes were attached to the herbarium-specimens but others were retained with my diaries of expeditions to the swamp-forest. The following concern, chiefly, the bark which to the practiced eye is the most important field-character. For a general account of bark I refer to the illustrated descriptions by Wyatt-Smith (1954) and for microscopic analysis to the papers by Whitmore $(1962,1963)$ who took up this subject for his doctoral thesis.

\section{Acanthaceae}

Gymnostachyum ?, SFN 29472, 29497.- herb -1 m high, nodes swollen; leaves not falling off on picking; corolla pale greenish yellow with the upper petal-lobe pink and with a pink stripe leading from it into the tube.

\section{Aizoaceae}

Sesuvium portulacastrum L.- I have entered this plant in my list because it needs to be checked. I have an emphatic note that I did not find it in the streams entering Jason Bay. According to the Flora Malesiana (ser, 1, 4, 1951, 272) it has not been reported from Borneo. The absence may be significant.

\section{Anacardiaceae}

For the identification of many specimens I am indebted to Dr. Ding Hou.

Campnosperma macrophylla (B1.) Hook.f.:- SFN 36625, Pengkalan Rajah, Pontian, Johore; tree $-40 \mathrm{~m}$, trunk $60 \mathrm{~cm}$ thick at $1.7 \mathrm{~m}$; crown wide but often lax and thin (resembling that of Jackia, but the leaves withering red); buttresses none; stilt-roots $-1.2 \mathrm{~m}$ high, subcylindric, spreading; pneumatophores as looproots $-45 \mathrm{~cm}$ high, not abundant; bark drab ochre to brownish, shallowly rugosefissured, not scaly; inner bark rich pinkish brown, very thick, with copious grey gummy sap.

This was a fairly common tree in the peat-swamp at Pontian, easily distinguished from the other two species of Camprosperma by the stilt-roots and the red old leaves.

Gluta velutina $\mathrm{Bl}$ : - inflorescence, pedicels and calyx green; petals pink, white at the base; stamens white; ovary pale greenish white; style white; young leaves reddish pink; fruit 7-8 cm wide, light brown, scurfy, with a few irregular pleats and ridges from the base, subglobose; sap thick, opalescent, slowly turning reddish then black on exposure, slightly irritant.- Plates 4, 6.

This characteristic riverside tree occurred from $\mathrm{Bt}$ Tiga upstream to Bagan Limau on the Sedili Besar between the putat and rassali-belts, with a maximum development about Mawai. It requires tidal mud with little tolerance of brackish water. The fact that the trees are seldom cut, on account of the poisonous sap, may favour their abundance. 
Mangifera foetida Lour.:- SFN 34909: trec - $33 \mathrm{~m}$, bole cylindric; bark light grey, shallowly rugose-fissured; young leaves violet; mature leaves stiff, flat, obtuse, rather shiny, yellow-green with yellow veins; wild, but ? identity.

M. griffithii Hook.f.: SFN 34948: leaves very coriaceous, bullate, dark shiny green; fruit 9-10 $\times 6-7 \mathrm{~cm}$, ovoid, not tipped, rounded in end-view, ripening dull green with white or pale yellowish, soft, fibreless flcsh, fragrant; stone slightly flattened or almost cylindric, pale yellowish, slightly grooved, very thick and strong, without fibres; flesh sweet, with a sour smack, like binjai; well-known locally as lekub.

M. aff. parvifolia Boerl. et Koord.:- SFN 26193, Jurong, Singapore; tree -27 m; crown dense, dark; young lcaves dull pinkish purple; flowers mostly on the twigs behind the leaves, very fragrant; petals cream-white; timber specimen taken.

This was a fairly common tree at Jurong, where it must now be extinct. It flowered gregariously in March 1933.

M. quadrifida Jack:- SFN 32203, 34946, 34947: tree -20 ni; said by Malays to have fruit like that of $M$. foetida but sweet, round, plump, ripening green with yellow fibrous flesh and round stone; flowcrs cream-white; well known locally as kolah.- SFN 32436: tree $-33 \mathrm{~m}$, bole cylindric; crown large, dome-shaped, heavy; bark fawn brown, slightly fissured with short shallow longitudinal lenticel-fissures, not scaly or rugose; inner bark brownish yellow, darkening on exposure, like yellow custard just below the dead bark; leaves vcry stiffly coriaceous, dark green, dark yellowish green beneath; inflorescence with pale grcen branches; calyx pale greenish; petals 4, cream-white, with 4-7 faint yellow rays, tipped reddish; disc and filaments white, anthers purple; flowers fragrant; called lekub (? in error).

Melanochyla sp.- s.n. 6.8 .39 (as Melanochyla A) Bt Tinjau Laut, c. $350 \mathrm{~m}$, on ridges in the kapur-forest: tree $-13 \mathrm{~m}$, bole cylindric; bark pale greyish buff, smooth, entire, with persistent leaf-scars; inner bark pinkish brown; field-note says "just like $M$. auriculata'; compare $M$. aff. auriculata SFN 29364.

Melanorrhoea wallichii Hook.f.:- tree -40 (-50) m, 60-70 cm thick at $2 \mathrm{~m}$, slightly buttressed or not; bark greyish brown to pale reddish grey, slightly fissured and ridged, thinly flaky in small oblong angular pieces, often black-spotted from exuding gum; inner bark light reddish brown to pinkish brown; sap scant, watery reddish, slowly blackcning on exposure; heart-wood deep red-brown; crown rather high and narrowly dome-shaped. the limbs often twisted and gnarled, for a long time monopodial.

I have often supposed that the black spots on the trunk mark cracks in the bark caused by the swaying of the trunk in the wind.

M. woodsiana Scort.:- s.n. 6.8 .39 (as rengas A), Bt Tinjau Laut, 300-400 m alt., fairly common in the upper kapur-forest: tree $-45 \mathrm{~m}$, fluted at the base; bark rich brown, narrowly and rather shallowly rugose-fissured, not scaly but bits breaking off and leaving black marks; inner bark pale pinkish with white opalescent latex; specimen sterile, ? identity.

Melanorrhoea sp.:- rengas A, Jurong, Singapore :tree $-33 \mathrm{~m}$, without buttresses; bark greyish brown, closely and regularly fissured and transversely cracked, with sniall oblong regular scales flaking off from below upwards.- Plate 34.

Pentaspadon officinalis Homes:- described in Wayside Trees of Malaya and the roots figured in my Life of Plants (plate 13b). The species flowered gregariously twice a year in the Sedili region, about April and October.

Swintonia penangiana King:- s.n. 6.8 .39 (trec B, tree C), Bt. Tinjau Laut, 250$400 \mathrm{~m}$ alt., common canopy-tree in the upper kapur-forest: tree $-40 \mathrm{~m}$, sharply buttressed $-1.2 \mathrm{~m}$; bark warm brown to orange-brown, dippled-scaly; inner bark 
pale pinkish brown, with a little ochre-brownish gum; wood pale pink; trunks like Pometia: det. Ding Hou.

\section{Annonaceae}

Sinclair (1955) records 38 genera and 198 wild species for the Malay Peninsula. Of these, 25 genera and 58 species occurred in the Sedili region, where four species or varieties appear to have been endemic, namely Alphonsea johorensis, Anaxagorea javanica var. dipetala, Enicosanthum praestigiosum, and Pseuduvaria galeata. Climbers number 17 species. Sinclair remarks that arborescent species do not occur in genera with climbing species, but Desmos seems to be an exception. Some species of Desmos are certainly climbers but I studied $D$. dasymaschala carefully and observed that it was a small spreading tree with flopping, not scandent, branches.

The family makes up a considerable part of the smaller trees of the swampforest where none seems to have a particular habitat except Polyalthia sclerophylla of the mempisang-belt and Xylopia fusca. Many of the small trees grew as well in the hillock-forest. They are recognisable from the monopodial habit, distichous leaves on the side-branches, smooth or lenticellate trunks not flaky or fissured, the sourly resinous smell of the crushed leaves or cut bark, and the way in which the branches of the main stem are set at right angles to the subtending leaf. Mezzettia leptopoda and Polyalthia hypoleuca may enter the canopy and in large trees their trunks may become fluted at the base. Generally, however, with the exception of Xylopia malayana, there are no buttresses. Stilt-roots occur in Goniothalainus malayanus (at lcast when growing in flood-regions), conspicuously in Xylopia fusca of the swamp-forest, and in X. ferruginea whether in the swamp or hillside forest. Pneumatophorcs are conspicuous as upright pegs or posts in Polyalthia sclerophylla, and in $P$. hypogaea which did not occur in the Sedili region, and as loop-roots in Xylopia fusca. X. malayana may have short stilt-roots.

Cyathocalyx ridleyi (King) J. Sinclair:- tree $-20 \mathrm{~m}$, cylindric from the base; bark light buff to greyish cream, smooth, becoming finely cracked, often faintly pustular with small lenticels 1-2 mm wide, more or less in longitudinal rows; inner bark pale yellowish ochraceous, dark green just below the surface and reddish below the green layer, faintly aromatic.- Plate 10 .

This was a striking monopodial tree. The crown was limited to the upper third or quarter of the trunk, vcry much as in saplings of Anthocephalus. The branches first ascended, almost vcrtically, then sagged as they lengthened, and finally hung downwards before abscission. Thus the crown was almost spherical and appeared to consist of enormous pinnate leaves, such as occur in Aglaia.

Enicosanthum praestigiosım J. Sinclair:- tree $-15 \mathrm{~m}$, without buttresses or stiltroots; bark fuscous grey, smooth then narrowly fissured from greyish white lenticels, leaf-scars persistent; inner bark pale straw-ochraceous, with fine wavy lines; cauliflorous with thick woody leafless twigs arising from swollen bosses $-15 \mathrm{~cm}$ wide on the trunk almost from the ground.

Goniothalanus malayanus Hook.f. et Th.: - tree $-6 \mathrm{~m}$, rarely as much as $17 \mathrm{~m}$, often tufted; stilt-roots $-2 \mathrm{~m}$ high, cylindric, congested, more or less perpendicular, no loop-roots; bark silvery grey or slightly buff, smooth, with faint leaf-scars, slightly pustulate with small lenticels $1 \mathrm{~mm}$ wide, more or less in short vertical rows; inner bark fawn-ochraceous or pinkish, with broad pallid white rays expanding into the cortcx, strongly radially striate.- Plate 21.

Mitrella kentii (Bl.) Miq.:- big climber, not uncommon in the swamp-forest, identifiable from the old twigs $(5-15 \mathrm{~mm}$ thick) becoming longitudinally striate from rows of elongate brown lenticels with tumid lips. 
Polyalthia cauliflora var. beccarii (King) J. Sinclair. I have noted that this is very like v. cauliflora but differs in having palc greyish lilac petals and anther-tops and cream-coloured stigmata. The young leaves are pale greenish white and develop in dangling tassels.

P. glauca (Hook.f.) Boerl.:- tree $20 \mathrm{~m}$, bole $-30 \mathrm{~cm}$ thick at $1.7 \mathrm{~m}$, without buttresses but with slight fluting extending up to $1.2 \mathrm{~m}$ and passing into horizontal roots rising occasionally as irregular loops $30-45 \mathrm{~cm}$ high, no copious pneumatophores; bark pale greyish white, often pinkish, very smooth, ultimately breaking into very thin small papery flakes, with faint leaf-scars; inner bark pale yellowish or pinkish, $-12 \mathrm{~mm}$ thick, not sclerotic; wood white.

P. hypoleuca Hook.f. et Th.:- SFN 36689, Pengkalan Rajah, Pontian, Johore: tree $-33 \mathrm{~m}$, monopodial; crown small, dense, shortly conical; branches curving shortly up, then gradually down and finally up again; bole rather slender, cylindric or slightly fluted at the base; without special roots; bark dull greyish drab, often brownish, slightly rough and pocked, not scaly; inner bark pale ochraceous or brownish, tough, laminate, easily separating into concentric layers; leaves glaucous beneath; flowers axillary; petals dull yellow; stamens green, falling off in the late afternoon; fruits 1-5 from a flower, 1-seeded.- Plate 37.

This tree was very abundant in the peat-swamp forest at Pontian where it entered into gaps in the canopy with its narrow crown. There was a general flowering in early 1939. The species was well known locally as tepis. At Jurong, Singapore, I did not see trees taller than $20 \mathrm{~m}$. In the Sedili region it occurred in hillock-forest and I had no record from the swamp-forest.

P. scleroplyylla Hook.f. et Th.:- tree $-15 \mathrm{~m}$, monopodial; crown conical; pneumatophores $-70 \mathrm{~cm}$ high, unbranclied, narrowly conical, peg-like, upright, copious; deciduous Feb.-April; new leaves pale olive buff (not scarlet as given by Sinclair); flowers March-May, with dull purple-brown petals; fruits ripening red to black, May-July.- Plate 11.

I am not satisfied with the identification of this very characteristic tree of the freshwater tidal riverside mud. Sinclair does not mention the pneumatophores, and he identified with it SFN 29588 (P. Duchong Laut, rocky coastal forest) which, at the time of collection. I thought was different. My notes on SFN 29588 are as follows:- tree $-13 \mathrm{~m}$ in rocky coastal forest, scarce; bark fuscous, finely and irregularly creviced; inner bark pale fawn-ochraccous; wood pale yellowish white; flowers 1ather fragrant; sepals green; petals yellowish with a dull pinkish crimson splash at the base; ovarics cream-white.

This may be $P$. lateriflora with short leaves on the rocky coast. I note that the tree of $P$. purptrea Ridley, that grew on a dry lawn near the Bandstand Hill in the Singapore Botanic Garden, scemed identical with mempisang of the Sedili rivers but, as would be expected, produced no pneumatophores.

Xylopia caudata Hook.f.- tree $-20 \mathrm{~m}$, with small-leafed graceful crown; bole cylindric, $23 \mathrm{~cm}$ thick at $2 \mathrm{~m}$, without stilt-roots and pneumatophores; bark light to dark grey, smooth, entire; inner bark and wood pallid yellowish, faintly aromatic; fruit flushed purple, splitting open with lurid pink interior and bluish seeds; well known locally, the wood splitting casily and making good firewood, even when green.

$X$. fusca Maingay:- tree $-35 \mathrm{~m}$; bole $-75 \mathrm{~cm}$ thick at $2-3 \mathrm{~m}$, lapering downwards and strongly stilted; stilt-roots up to $4 \mathrm{~m}$ high on the trunk, more or less flattened vertically near the trunk but cylindric for most of their length, passing steeply into the soil and rather crowded, branching freely beforc entering the soil with similar cylindric and fastigiate lateral roots; loop-roots forming semicircles or steep loops with perpendicular sides, up to $1 \mathrm{~m}$ high, $-7 \mathrm{~cm}$ thick, spreading round the bole 
for distances up to $20 \mathrm{~m}$, often very close as masses of hoops, soon developing from saplings, the loop formed by downgrowth of the root-apex, light yellow to pale fawn-buff, soon with prominent lenticels, the inner bark as on the trunk but not or scarcely sclerotic; bark light greyish yeilow to pale pinkish brown (? when wet), always pale, smooth, entire, with persistent leaf-scars half girdling the trunk, becoming slightly fissured and rather coarsely tuberculate with pustular brownish lenticels up to $2 \mathrm{~cm}$ wide, particularly conspicuous near the base of the trunk; inner bark pale yellowish, granular or gritty with many, very hard, small, irregular, pale yellowish sclerotic masses $-2 \mathrm{~mm}$ wide, stripping fairly easily, with a strong resinous-aromatic smell; wood rather soft, easily axed, pale yellowish throughout; crown monopodial and conical, then dome-shaped but rather open with a few wide-spreading limbs, often brownish from the young leaves; mature leaves pointing forward along the twig; young leaves densely brown silky beneath.Plates 24, 35, 36: Figure 7.

This was a common and very characteristic tree of the freshwater swampforest in Singapore and the Sedili region. It grew with Palaquilum xanthochymum, often co-dominant along muddy channels though never so big. It seemed to prefer the stream-swamps above the tidal effect. Some trees had massive trunks and low stilt-roots, possibly in the less flooded places, and others had the high stilt-roots attached to the trunk which tapered into the comparatively slender tap-root. The stiits and loop-roots rarely carried epiphytes. Systematists dealing with herbariumspecimens have missed the real nature of the tree.

SFN 32403 has been called var. sessiliflora Kochummen et Whitmore (Fed. Mus. J. 13, 1968, 135) because of the shortly pedicellate flowers.

$X$. malayana Hook.f. et Th.:- tree $-27 \mathrm{~m}$; bole $30 \mathrm{~cm}$ thick at $2 \mathrm{~m}$; buttresses $1-3,-1.2 \mathrm{~m}$ high, low, thin, spreading, simple; stilt-roots rare, occasionally 1-3 small cylindric roots from heights up to $40 \mathrm{~cm}$ on the trunk; pneumatophores none; bark light greyish yellow to yellowish buff, often tinged pinkish brown, entire, with persistent leaf-scars, becoming rough with small erumpent lenticels; inner bark pale yellowish, with slight sclerotic masses (not gritty as in $X$. fusca), very aromatic; crown conical, monopodial; flowers white, without scent; young leaves not brown silky. Compare $X$. subdehiscens as a juvenile state.

Xylopia sp. ?:- s.n. 13.4.35, S. Sedili; tree $-20 \mathrm{~m}$; bole $20 \mathrm{~cm}$. thick at $2 \mathrm{~m}$; stilt-roots $-1.3 \mathrm{~m}$ high, cylindric to more or less arcuate, striding but rather crowded; bark dull rufous brown, slightly and shortly longitudinally cracked, not fissured, smooth; inner bark pale pinkish, rather coarsely veined with rays, minutely granular-sclerotic, thick, resinous-aromatic.

I have not traced this specimen in Sinclair's works; it was sterile.

\section{Apocynaceae}

Cerbera manghas L.:- coastal species with pink eye to the corolla and smaller glossier leaves than $C$. odollam; persisting for a long time in Eugenia grandis forest and growing up to $14 \mathrm{~m}$, but without seedlings in this forest.

Kopsia singapurensis Ridley:- shrub or small tree $-7 \mathrm{~m}$; crown more or less conical; stilt-roots and pneumatophores absent; bark greyish buff, rather silvery, entire but rather uneven and bumpy or subtuberculate, becoming slightly flaky in small pieces; inner bark pale yellowish, thin, with small ochraceous sclerotic particles; wood white; corolla $3.5-4 \mathrm{~cm}$ wide across the open limb, white with crimson eye; 6-7.5 cm wide in SFN 28731; with pink eye in SFN 28680; flowering gregariously Jan.-Feb. throughout the swamp-forest, and again Sept.-Oct. 
Though occasionally cultivated, this plant would repay more attention. The large-flowered specimen (SFN 28731) was exceptionally handsome but I found only one specimen (near S. Kayu, Jemaluang Rd) and never obtained seeds. SFN 28680 (mile 12, Jemaluang Rd) seemed to me a different species or variety distinguished by the smaller leaves, longer and more slender petioles, more slender inflorescences, different venation, and pink eye to the corolla. It has been classified by Markgraf (1972) as K. singapurensis, though queried by Timmerman (1959).

Tabernaemontana corymbosa var. kelsalli King et Gamble:- young twigs and petioles dark green, old twigs silvery greyish; leaves rather deep green, yellowish green beneath, slightly bullate, vertical pairs of leaves tending to be unequal; inflorescence pseudoterminal or axillary; peduncle dark green, forked once, with a median flower-cluster ( $1-4$ flowers) or without, the lateral clusters with 3-6 flowers; flowers facing down, scarcely fragrant; pedicels pale green; sepals yellowgreen with recurved tips; corolla $35-45 \mathrm{~mm}$ wide, white with very faint, narrow, yellow eye, the tube $-25 \mathrm{~mm}$ long and pale yellowish white.

\section{Aquifoliaceae}

Ilex cymosa $\mathrm{Bl}$ : - - tree $-27 \mathrm{~m}$; bole $35 \mathrm{~cm}$ thick at $2 \mathrm{~m}$, without buttresses or stiltroots; bark greyish white to white, more or less tuberculate with lenticels, not scaly or fissured; inner bark ochre-brownish, c.10 mm thick, coarsely granularsclerotic; wood white, with large vessels; flowers white; berries reddish purple then black.

This common and characteristic tree of Tristania-banks, well known as mensirau, was especially abundant as a small tree $-13 \mathrm{~m}$ high between Lubok Besar and Danau in a very swampy stretch of the Sedili Besar. I was surprised to find later that it grew to a much larger tree abundantly in Eugenia grandis forest where, in wetter places, it was co-dominant.

\section{Araceae}

My list is probably incomplete because many specimens were collected without number and I have been unable to consult them. I use the names given by Dr. C. X. Furtado, but have followed Nicolson (1969) for Aglaonema.

Cryptocoryne cordata Griff.:- growing in the mud by the Sedili Besar in the freshwater region, often along the foot of Tristania-banks, generally submerged $30-200 \mathrm{~cm}$ at low water, rarely exposed at low tide; leaves purplish beneath: limb of spathe bright ochre-yellow. deeper round the mouth of the tube; tube $-45 \mathrm{~cm}$ long, white; ? flowers not reaching the surface of the water.

\section{Asclepiadaceae}

\section{Dischidia aff. complexa Griff.: -Jurong, Singapore; S. Kayu, Jemaluang Rd.}

This was not infrequent as a slender climbing epiphyte at Jurong. It has not been found elsewhere in Singapore and is now extinct. Holttum collected it at S. Kayu, but I never saw it myself in the Sedili region. In 1933 I brought living plants of this very rare species to the Royal Botanic Gardens at Kew, but they aroused no interest and in 1938 I learnt that they no longer existed. There is a dried specimen from Jurong in the Singapore Herbarium and, perhaps, the material that $I$ put in alcohol. The species resembles $D$. rafflesiana in having pitchers but they were smaller and the whole plant was much more delicate. 
Hoya ? diversifolia B1.:- s.n. 2.2.36: climbing on Saraca; leaves green; pedicels pale pink, deep rose-red at the apex; sepals pale pink; corolla and corona pale cream, the corona-lobes with a narrow pink edge; anthers pale cream: this plant grown in the Singapore Botanic Garden.

Hoya ? ridleyi King et Gamble:-S.n. June 1934; common climber low down in Eugenia grandis forest, forming aerial root-balls of masses of tufted roots; leaves narrow, rather small and thin.

Hoya sp.:- s.n. 27.7.39, S. Sedili; leaves pale green without any red or purple; flower pinkish white, fragrant; pedicels and outside of sepals with pinkish purple spots; corona white, with purple inner points.

\section{Bombacaceae}

Coelostegia griffithii Benth.- buttresses to $4 \mathrm{~m}$ high, branching at $0.5-2 \mathrm{~m}$ above ground; bark greyish rufous to dull rufous brown, entire, then slightly lenticellatefissured, not flaky; inner bark pale pinkish yellow, white in the buttresses, stripping.

This canopy-tree is strictly monopodial; the leader persists until the tree begins to die back from the top. The main branches are numerous but rather short and at a wide angle from the trunk; thus the crown is rather narrowly domeshaped. It occurred in the swamp-forest at the rate of 2 large trees per hectare, but might be locally gregarious.

Durio singapurensis Ridley:- bark fuscous rufous, nearly smooth; inner bark pink, with a reddish layer under the dead bark (as in Neesia); leaves coppery beneath; ramiflorous, the flowers with white petals and smelling of sour milk; flowering March-April, fruiting July-Oct.

This is a very distinct species with round, narrowly spinous fruit and no aril to the seed. I followed Bakhuizen v.d. Brink in reducing it to $D$. oblongus Mast. (Corner 1939, 305; Wayside Trees of Malaya), but this seems to have been a mistake. Wyatt-Smith (1954) distinguishes $D$. oblongus by the hairy petals, in contrast with the scaly outside of those of $D$. singapurensis, and by the arillate seed. Kostermans (1958) also keeps them apart, though next to each other in his key, and he emphasizes the ovate petals, which I had also emphasized for $D$. singapurensis. The question still seems open, as there is still doubt also with several species of Durio. Whether there are two species or varieties, it is clear that the aril has been lost in $D$. singapurensis; the elaborate aril, as a generic feature, could not have been evolved independently and de novo in $D$. oblongus.

Kostermansia malayana Soegeng, Reinwardtia 5 (1959) 2.- This magnificent tree, which is probably still preserved in the Mersing-Jemaluang forest and on Gunong Panti, used to be frequent in the swamp-forest of the Sedili, Johore and Tiram rivers. Soegeng has given a full description. It comes between Durio and Coelostegia and, in my opinion, the three genera could be reduced to Durio. The trees were well knoivn as krepal or krepau. They resembled Coelostegia in the very prominent buttresses which in hillside forest might reach up to $7 \mathrm{~mm}$ high but were generally not more than 4-5 $\mathrm{m}$ in the swamp-forest. The tree flowered rarely. There was a group of several trees on a hillock to the east of the Jemaluang Road shortly after it left the Mawai Road, and I used to examine these trees several times a year from 1932 onwards. I saw no flowers or fruits until there was a general flowering of the species in March 1940 when, with the aid of a monkey which climbed up the stem of a creeper, I obtained the first flowering specimens. I had noted a general fruiting in September 1932 when I first found the species at Ulu Tiram (Wayside Trees of Malaya p. 437). The thorny fruits are at once recognised by their splitting almost to the base in a star-like manner and their persistence for a long time after the seeds have fallen at the ends of the copious 
twigs; hence the manuscript name $C$. ramealis which I wrote on the herbarium specimens. The white petals $(5$, occasionally $6-7)$ have a few yellow spots which turn brown; the flowers have scarcely any scent; the seeds have no aril. Kostermans misidentified the fruiting specimen SFN 26060 as D. singapurensis, which differs in every detail.

Kostermansia was dominant on a small hill covered with original forest in Ulu Tiram Estate (Plates 8, 36). From the fruits on the twigs, I counted c. 30 big tree, 40-50 $\mathrm{m}$ high, in c. 2 hectares, with many smaller trees and saplings. There were several uprooted trees in this forest. They had no tap-roots, but many slender roots, up to $5 \mathrm{~cm}$ thick, passed from the base of the trunk and the undersides of the main lateral roots vertically into the ground.

Neesia malayana Bakh.- tree $-33 \mathrm{~m}, 23 \mathrm{~m}$ to the first branch; bole $60-70 \mathrm{~cm}$ thick at $3 \mathrm{~m}$, some cylindric from the base, others fluted or with slight buttresses $-2 \mathrm{~m}$ high; no stilt- or loop-roots; bark greyish brown to dark red-brown on the mature bole, darker and almost blackish brown higher on the trunk and on the main branches, faintly tuberculate with paler brown lenticels $2-4 \mathrm{~mm}$ wide often in longitudinal rows up to $3 \mathrm{~m}$ along the bole, then the bark becoming rather flaky and tessellately cracked (especially on the branches); inner bark 10-15 mm thick, deep pink-brown to bright purple-red, the outer bark flaking off on cutting: scattered in the swamp-forest along with many trees with stilts and pneumatophores, solitary, occasionally entering the canopy; bark-photograph, see my Life of Plants plate 15.

\section{Burseraceae}

Canarium apertum H. J. Lam:- tree $-27 \mathrm{~m}$, buttressed $-1.7 \mathrm{~m}$, without stilts or loop-roots; bark light fawn-grey or pinkish, slightly flaky; inner bark with light yellow gum and very penetrating resinous smell; leaves stifly coriaceous.

C. littorale B1.- tree $-20 \mathrm{~m}$, not or slightly buttressed; bark pale pinkish grey, pustulate with lenticels 1-3 mm wide; gum greyish, scant; fruit edible, mesocarp sour and stringent but sweetening on chewing, kernel nutty; very variable in size of tree when flowering and in leaf-character (Leenhouts 1959).

C. pilosum Benn.- tree $-30 \mathrm{~m}$; bole $30 \mathrm{~cm}$ thick at $2 \mathrm{~m}$, cylindric from the base; bark pale greyish white, rather copiously flaky in thin, papery, irregular, and rather large pieces, not fissured, with small scattered pustular lcnticels 1-2 mm wide; inner bark pale pinkish brown, not stripping, with dark greyish resinous-aromatic gum; wood pale yellowish white; leaflets withering scarlet.

The trunk resembled that of Santiria laevigata but seemed not to become buttressed and it had more flaky bark, more deeply coloured inner bark, and gum which flowed readily.

Dacryodes macrocarpa H. J. Lam:-tree $-35 \mathrm{~m}$, with spreading flattened arcuate stilt-roots $-2.5 \mathrm{~m}$ high, giving off numerous smaller subcylindric stilt-roots; looproots apparently none; bark fawn brown, somewhat fissured and flaky with thin elongate angular pieces, slightly pustulate with lenticels $2-4 \mathrm{~mm}$ wide; inner bark yellowish, with strong resinous smell and scant clear gum; wood yellowish white, hard; flowering Oct. 1936; photo in Flora Malesiana ser. 1, 5, 227, f.11.

Santiria apiculata Benn.- tree $-20 \mathrm{~m}$, often fertile at heights from $4 \mathrm{~m}$, not buttressed; bark pale grey, slightly flaky in small pieces, slightly pustulate; inner bark pinkish, with scant colourlcss gum; leaves oftcn trifoliate; fruits cream-white then pink to purple, commonly empty or with insects; leaflets withering scarlet.

S. conferta Benn.- tree $-20 \mathrm{~m}$, not buttressed; bark pale greyish fuscous, finely creviced and fissured, not flaky; inner bark pinkish, with scant grey gum, faintly resinous-aromatic; leaf-stalks rusty scurfy. 
S. laevigata $\mathrm{Bl}$. - tree $-40 \mathrm{~m}$, with spreading branches and large crown; buttresses -2 m high; without loop-roots; bark pale greyish, rather flaky in angular pieces; inner bark pinkish, slightly resinous-aromatic, with scant gum; leaflets withering scarlet; often as a smali tree without buttresses.

S. rubiginosa $\mathrm{Bl}$ - - tree $-40 \mathrm{~m}$, becoming fluted at the base $-2 \mathrm{~m}$ high, occasionally with low buttresses spreading as narrow flanges over the ground, old trees becoming knobbed and bossed on the trunk: loop-roots $-60 \mathrm{~cm}$ high, $8 \mathrm{~cm}$ thick, tuberculate with numerous lentice's, the bark rather lurid greanish yellow, with gum, not numerous; bark greyish or brownish yellow, thinly flaky in small irregular pieces, with numerous tumid lenticels 2-6 $\mathrm{mm}$ wide; inner bark pale yellowish, with greyish white gum slowly darkening on exposure, slightly resinous-aromatic; crowl large, rounded, compact.

S. tomentosa Bl. - tree $-40 \mathrm{~m}$, buttressed or fluted to $2 \mathrm{~m}$ high; loop-roots $-30 \mathrm{~cm}$ high, scattered, often indistinct; bark fawn buff, flaky in irregular oblong pieces, slightly lenticellate-pustulate; inner bark pinkish, with white sticky latex, scarcely resinous-aromatic; twigs, buds, rachis, and undersides of the veins fawn hairy; leaves not resinous-aromatic when crushed.

\section{Celastraceae}

Euonymus javanicus Bl.- small tree $-13 \mathrm{~m}$, flowering and fruiting as a shrub 1-2 m high; bark greyish buff or silvery grey, flaking in small oblong pieces with curling edges, tuberculate with thick, corky, tumid, yellowish buff lenticels more or less longitudinally elongate or in rows, the outer bark papery-tough and easily stripping off to show the vivid orange-yellow inside; inner bark pink, purplish pink next the outer bark; wood pale brownish yellow; leaves greenish brown beneath; petals greenish red with white fimbriate edges, purple-brown at the base; capsules pink, pyriform-angled.

This little tree or shrub can soon be recognised in the forest from the opposite leaves with brownish undersides and from the outer bark with vivid orange-yellow inner layer. Glyptopetalum quadrangulare has a similar yellow inner bark but 4angled twigs and leaves not brownish beneath.

Lophopetalum multinervium Ridley:- tree $-30 \mathrm{~m}$, not or slightly buttressed $-1.3 \mathrm{~m}$ high: crown monopodial, rather straggling and open; pneumatophores developing as broad flattened conical pegs from the uppersides of the widely spreading lateral roots, becoming upright planks $-2 \mathrm{~m}$ high with blunt apex and thickened sides, often very densely crowded in the more tidal or flooded regions, bark as on the trunk but more lenticellate; bark greyish brown, for a long time smooth, with persistent leaf-scars, developing elongate lenticel-fissures, the intervals entire or creviced and with scattered pustular lenticels eventually confluent into new fissures; inner bark pale pinkish brown, fairly thick, soft, easily stripping; wood pale yellowish; leaves often eaten by insects; sepals and petals green: disc dull rose-pink or purplish; fruits not found; buds often galled.- Plates 14, 16, 17.

This was one of the striking trees of the freshwater tidal forest. The tall planklike pneumatophores might be set so closely that it was impossible to edge between them. In dryer parts of the swamp-forest they were much shorter, $-20 \mathrm{~cm}$ high.

\section{Clusiaceae}

Calophyllum L.- My collections have been identified by Henderson and WyattSmith (1956), who have incorporated my field-notes in their descriptions. They say that Calophyllum is the dominant genus of big trees in east Johore. They rccord 19 species, out of c. 50 in Malaya, for the Sedili region but give several more for 
the regions of Rompin, Mersing and Jemaluang, and these may well occur in the Sedili region. Shorea, with 18 species in the region seemed to me to be the really dominant genus. Most species have fissured bark and lack buttresses. In the fieldchart given by Henderson and Wyatt-Smith, at the end of their paper, 3 species are given with buttresses, 3 with stilt-roots, and 4 with pneumatophores as loopor knee-roots. They seem to have omitted my field-note on $C$. curtisii with steep buttresses (SFN 30865) and my records of knee-roots for $C$. soulattri (s.n. 10.6.34) and their Calophyllum sp. 44 with both stilt- and knee-roots (s.n. 30.4.34). Flooding certainly affects the development of these roots but it is also clear that the property of developing them is possessed only by a small number of species. $C$. inophylloides and $C$. sclerophyllum are striking examples. The pneumatophores are $\lambda$-roots except in C. kunstleri for which I noted true loop-roots as in Xylopia fusca; the root-apex first ascends, then descends without degenerating into the abortive tip of the $\lambda$-root. The pneumatophores are highly lenticellate and air can easily be blown through them.

C. retusum Wall. - tree $-40 \mathrm{~m}$; bole cylindric from the base, $70 \mathrm{~cm}$ thick at $2 \mathrm{~m}$; loop-roots $-45 \mathrm{~cm}$ high, $-2 \mathrm{~cm}$ thick, copious, dull brown, with prominent, transversely elongate, lenticels; bark dull brown, tinged purplish to vinaceous fuscous, lenticellate-fissured with tumid and deep purplish lenticels on the bole, not rugose; inner bark pale brown to pinkish brown, darkening on exposure, rather thick, soft, easily stripping, slowly oozing a greyish or yellowish gum; no loop-roots observed on the trees at Jurong, Singapore.

C. rupicolum var. elatum Whitmore, Gdns' Bull. Singapore 26 (1973) 270.- This variety is said to be distinguished by the greater stature of the trees $-18 \mathrm{~m}$ high, and by the larger leaves. In citing the Sedili collections, Whitmore has overlooked the fact that the trees were small, $-10 \mathrm{~m}$ high, and grew on the river-banks.

C. sclerophyllum Vesque.-- for a comparable case of stilt-roots in this species, see Ashton (1964, pl. 32).- Plates 10, 13, 22.

Garcinia L.- Identification of Malaysian specimens has been handicapped since the thirties because much of the herbarium-material at Singapore has been on loan in the Bogor Herbarium, waiting revision. In this uncertainty I have had to use several names as current at Singapore without knowing if they are correct.

Species of Garcinia are common in the undergrowth of the swamp-forest, contrary to the remark in the Tree Flora of Malaya vol. 2. Several are conspicuous from their stilt-roots and one, which I call $G$.? rostrata, for its stilts and pneumatophores. For correct identification, male and female flowers and fruits are necessary, though the trees are more often sterile, but this implies that they can be identified from leafy twigs. I studied the barks and found that they were useful in distinguishing several of the small-leafed species. I prepared this key:-

Latex white; inner bark yellowish white. Trees without stilts.

Bark yellowish fuscous, finely fissured G. ? eugeniaefolia

Bark yellowish brown, tuberculate Garcinia sp.

(SFN 28087, 28094)

Latex yellow. Trees often with stilts.

Bark dull yellowish, often brownish or pinkish, more or less smooth; pneumatophores often present G. ? rostrata

Bark dark fuscous brown or chocolate brown, becoming finely fissured and flaky in small subcircular pieces or in oblong pieces;

pneumatophores absent. G. bancana, G. forbesii, G. nigrolineata 
G. bancana Miq. - collections from Jurong, Singapore; tree $-20 \mathrm{~m}$, bole $25 \mathrm{~cm}$ thick at $1.5 \mathrm{~m}$; stilt-roots arising at heights up to $60 \mathrm{~cm}$, slender, spreading; pneumatophores none; bark dark greyish brown, brittle, with longitudinal and transverse fissures, breaking up into square or oblong, rather thick scales; inner bark dark red-brown, not stripping; latex yellow, fairly copious; wood pallid ochraceous.

About the three collections from Pontian, Johore, I am not sure, but Henderson's notes on SFN 36618 (det. G. cf. hombroniana) agree, thus:- slender tree $-17 \mathrm{~m}$; bark dark chocolate brown, lightly cracked with small oblong pieces; inner bark deep rich red-pink; latex yellow.

G. ? engeniaefolia:-s.n. 11.6 .34 (as Garcinia A); tree $-13 \mathrm{~m}$, without stilts or buttresses; bark yellowish fuscous, rather finely fissured; inner bark pale yellowish; latex white, scant; leaves caudate-acuminate.

G. forbesii King:- I have notes that this may also be stilted in the montane forest at Cameron Highlands.

G. maingayi Hook.f.- tree $-20 \mathrm{~m}$; stilt-roots $-1.2 \mathrm{~m}$ high, rounded, congested; bark rufous brown, entire, with persistent leaf-scars, slightly pimply with small lenticels 2-4 mm wide; inner bark deep ferruginous brown, thick, not stripping; latex dull ochre-yellow, semi-opaque, fairly copious.

A similar tree, collected by me in swamp-forest at Ulu Tiram, Johore, SFN 28667, as a $5 \mathrm{~m}$ treelet, is called Garcinia 3 in the Tree Flora of Malaya vol. 2. SFN 36829 is given as Garcinia $A 2$ in the Tree Flora. I have noted that G. maingayi may be stilted in montane forest away from streams (SFN 33240, Fraser's Hill, Pahang).

G. nigrolineata Planch.- tree $-17 \mathrm{~m}$; bole $20 \mathrm{~cm}$ thick at $1.7 \mathrm{~m}$; stilt-roots $-1.2 \mathrm{~m}$ high, slender, scarcely flattened, very numerous, but absent from trees in dryer parts of the sivamp-forest; bark dark fuscous brown to dark reddish brown, becoming finely fissured and slightly flaky with small subcircular scales, not rugose or tuberculate; inner bark pale yellowish to pinkish buff, thin, easily stripping; latex yellow, rather watery; twigs often with 1-2 pairs of scale-leaves $(-5 \mathrm{~mm}$ long) at the outset.

I refer here the collection Corner s.n. 15.4 .34 (Mandai Road, Singapore), which had this typical bark except that the inner bark was light red-brown. The fruits were those of $G$. nigrolineata, thus:- fruit 25-35 $\times$ 20-27 mm, ellipsoid, shortly and truncately rostrate with papillate stigma immersed, ripening pale dull watery apricot-orange, never globose. It was a tree $13 \mathrm{~m}$ high without stilts.

I refer here, also, the collection Corner s.n. 13.5.34 (Mawai), which represented a frequent tree in the swamp-forest. Fertile specimens were not obtained, but it seemed identical with SFN 26198 (Jurong) and SFN 28098 (Mandai Road). My notes were:- tree $-20 \mathrm{~m}, 23 \mathrm{~cm}$ thick above the stilts; stilt-roots up to $4 \mathrm{~m}$ high, the larger arcuate-flattened, not crowded; bark dark fuscous brown, even, entire, then slightly flaky with small rounded irregular pieces; latex yellow; kedundong.

I am not certain, now, if $G$. nigrolineata differs in bark from $G$. parvifolia (Corner 1939a).

G. ? penangiana:- tree $-23 \mathrm{~m}$; bole $50 \mathrm{~cm}$ thick at $2 \mathrm{~m}$, becoming fluted at the base, without buttresses or stilts; crown very dense; bark chocolate or purple brown, blackish when moist, becoming flaky with rather large, oblong, angular pieces displaying the light fawn new bark and thus mottled; inner bark reddish pink or rich orange-brown, thick, soft, not stripping; latex white, oozing in small drops; wood yellow-bown; flowers fragrant; sepals pale cream; petals light primrose yellow; stamens and ovary cream; fruit crimson-red, with 1-2 large seeds $3.8 \times 3 \mathrm{~cm}$ 
surrounded by transparent, white or yellowish, thin jelly, fruit-wall smelling resinous; flowering Dec.- Feb., fruiting sparsely April-May, but also fruiting in Oct. 1936.

This tree, with striking mottled bark recalling Ochanostachys, has been referred in the Singapore Herbarium to $G$. hombroniana by Whitmore, but for me it was certainly not that well-known coastal species. The collection H. M. Burkill 1854 (new road to K. Sedili) appears to be this species, also, though identified in the Singapore Herbarium as $G$. opaca by Whitmore.

G. ? rostrata:- tree $-25 \mathrm{~m},-33 \mathrm{~m}$ in the peat swamp-forest at Pontian, Johore, monopodial; stilt-roots $-1.5 \mathrm{~m}$ high, subcylindric to flattened and arcuate, rather wide-spreading, often branched; pneumatophores $-60 \mathrm{~cm}$ high, $1 \mathrm{~cm}$ thick, $\lambda$-shaped, with greyish yellow lenticellate bark, often forming a dense 'forest' round the base of the trunk; bark light fawn brown, pinkish fawn, or fawn-ochraceous, always with a distinct clay-yellow tone, with persistent leaf-scars, entire, smooth, then creviced and slightly elongate-lenticellate or not; inner bark pinkish white to pinkish brown, usually deeper rufous brown near the outside, (pale yellow, SFN 28541), rather thin, rather gritty from sclerotic particles; latex deep bright yellow (SFN 26097, 28665,36687 ), yellow (SFN 36613, 36615), opaque, gummy; sepals and reflexed petals greenish yellow, the petals cream-white in SFN 26097, 36629, 36687; stigma becoming dull red to purple (? after pollination).- Plates 34, 39: Figure 6.

This was one of the typical trees in the swamp-forest of Singapore and south Johore, recognisable from the smooth bark with dull yellowish cast, the stilts and the pneumatophores. It was very conmon in the peat-swamp at Pontian, where it was large enough to become a canopy-tree. There was a general flowering at Pontian in early July 1939, where the name kachang kachang was in use for it among the wood-cutters.

The collection Corner s.n. 31.12 .34 may bclong to $G$. ? eugeniaefolia; it had white latex which turned yellowish very slowly after some hours of exposure.

The pneumatophores of the trec; at Jurong, Singapore (SFN 26097), were of two kinds. Mostly they were stecp $\lambda$-shaped roots arising from the main lateral roots travelling horizontally in the humus. They produced 1-3 descending laterals which ramified in the humus. Some ascending roots, however, had no such descending laterals but produced a cluster of 3-6 ascending roots some of which had short ascending branches.

Garcinia sp.- SFN 28087, 28094. Mandai Road, Singapore; tree -7 m; bole $10 \mathrm{~cm}$ thick at $1.7 \mathrm{~m}$. without stilt-roots; bark light vellowish fawn or yellowish rufous brown, tuberculate with rather tumid-corky lenticels 1-3 mm wide and elongating longitudinally 4-6 mm, often in confluent vertical series $2-3 \mathrm{~cm}$ long, not or scarcely fissured, entire or slightly flaky; inner bark pale yellowish white, stripping with difficulty; latex white, watery, scant, sticky; male flowers with large convex yellow-orange sticky stigma, fragrant, somewhat of vanilla; female stigma large, yellow.

Garcinia sp.- s.n. 25.11.34, Tg Tebar, near Tg Sedili Besar; tree $-10 \mathrm{~m}$; bole $18 \mathrm{~cm}$ thick at $2 \mathrm{~m}$, without stilts or buttresses; bark light grey-buff to smoky grey, finely and irregularly fissured, flaky in thin, narrow, elongate, and irregular pieces, often with a darker line separating the dead bark from the new; inner bark reddish pink with narrow white rays; latex white, thick, fairly copious; fruit ripening dull ochraceous; in muddy ground among rocks with Terminalia catappa, at the foot of cliffs.

Bark and habitat suggest $G$. hombroniana, but not the fruit. The latex of $G$. hombroniana is given as white or yellow in the Tree Flora of Malaya vol. 2, but I never saw a tree with yellow latex. 
Mesua ferruginea Pierre.- This common small tree or bush with white bark and irregular habit grew on the freshwater tidal mud with rassau or at the front of the mempisang-belt; it was impossible, except at low water, to trace its origin. On the Sedili Besar it occurred from Bt Tiga upstream to Bagan Limau and was most abundant below Mawai. On the Sedili Kechil it was even commoner and I frequently noticed that low branches, spread over the water and exposed to swift floods, had narrower, almost lanceolate, leaves as happens with so many riparian plants. With pale green youing leaves and the old leaves silvery, glancing, and pointing almost vertically down, it was easy to recognise. Some collections which I made have been referred by Whitmore (Gdns' Bull. Singapore 26, 1973, 279) to Mesua aff. assamica, without apparently consulting my field-notes, but I can hardly believe that they are the same as this inland tree of hill-forest. Strangely this common species had no Malay name; indeed, it was not recognised by Malays on either of the Sedili rivers.

M. kochummeniana Whitmore:- My field-notes on the type of this species, quoted in part by Whitmore, seem to be missing.

M. lepidota Anderson:- tree $-20 \mathrm{~m}$, without stilts or buttresses; bark dull greyish brownish, somewhat dippled-scaly with short oblong flakes, not fissured or rugose; inner bark pinkish brownish, giving out a scant, watery, pale yellowish brownish gum; wood pale pinkish brownish; pedicels pale greenish yellow; sepals greenish white; petals, filaments, and ovary white (no pink colour); flowering at the end of January 1937.
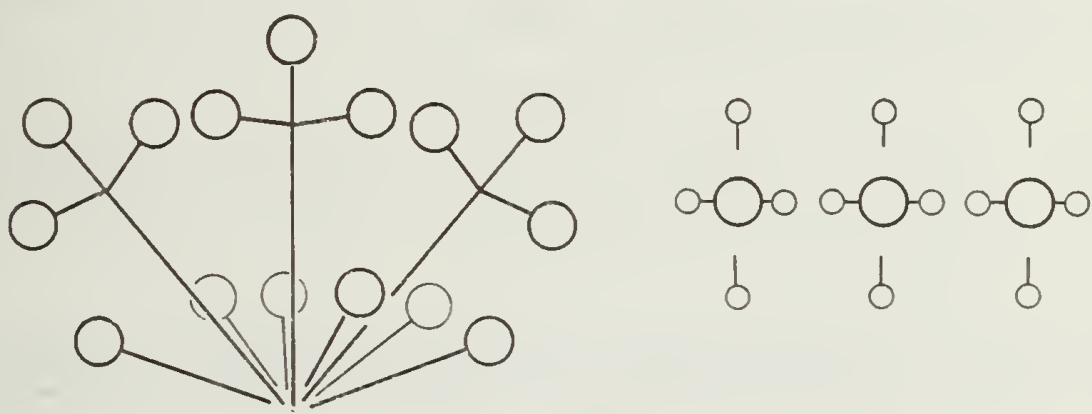

Figure 18. Mesua lepidota; diagram of the construction of the terminal inflorescence. 
These notes refer to SFN 32243. My second collection (s.n. 20.1.35) was from a tree with sparse stilt-roots up to $1 \mathrm{~m}$ high and loop-roots $25-40 \mathrm{~cm}$ high. Possibly this species flowers only once a year.

I was greatly struck by the terminal inflorescences of SFN 32243 which had 15 flowers in 3 sets. Each set had 5 flowers of which two were single and lateral at the base of the set, and three were in a pedunculate trichasium (Figure 18). The three trichasia were erect and set in the same plane, like the three crucifixes, surrounded by the ring of six basal flowers. My field-note says 'Tree of Calvary'. On some twigs the terminal inflorescence was reduced to 6-9 flowers in an umbel; that is to say, the trichasia were reduced to the terminal flower of each, or they were not formed; when present, these terminal flowers had longer pedicels. Below the terminal inflorescences there were axillary clusters of 5 flowers.

M. rosea (Ridley) Kosterm.- This was a common tree in the freshwater swampforest of the Sedili Besar. It had rather long leaves and pink flower-pedicels, though the flower was white in all parts. I noted for SFN 29273 that several trees were flowering in the middle of April 1935 and for SFN 32122, collected on 19 Oct. 1936, that several trees were in flower-bud. Possibly this species has a double flowering every year. I did not notice stilts or loop-roots.

\section{Commelinaceae}

Cyanotis vaga (Lour.) J. A. et J. H. Schultes:- According to R. Seshagiri Rao (1964), this is the correct name for C. barbata.

\section{Compositae}

Spilanthes urens Jacq. - sand-dune creeper with superficial horizontal stem, or rhizome, with fleshy leaves; flowers pallid white or cream, in small heads; creeping among Ischaemum muticum, Canavalia, and Ipomoea, and on the open dune as a pioneer.- Plate 37.

This is the only Malayan record of this peculiar species, and I found it only on the sand-spits between the mouth of S. Tuensel and that of S. Semandan on Jason Bay. It is known also from north Borneo (v. Steenis in Gdns' Bull. Singapore $17,1958,273)$.

\section{Cornaceae}

Aralidium pinnatifidum Miq.- bark yellowish grey, entire, with faint leaf-scars, becoming uneven with light brown pustular lenticels $2-4 \mathrm{~mm}$ wide; inner bark pale yellowish, with ochraceous sclcrotic rays; wood with long wide rays; occupying a variety of habitats from nibong-forest behind the mangrove to inland kapur-forest.

Alangium ebenaceum (Clarke) Harms var. tutela (Ridley) Kochummen. Fed. Mus. J. 13 (1968) 133.- tree $-20 \mathrm{~m}$; buttresses $-70 \mathrm{~cm}$ high, sharp, spreading; bark pale fawn buff, eventually thinly and slightly flaky in subcircular, angular, scaling pieces; inner bark fawn brownish, green just below the surface, fairly thick; wood yellowish drab throughout, hard; flowers white, with heavy sickly scent. [A. javanicum (Bl.) Wang.]

Mastixia ? trichotoma Bl.- tree $-14 \mathrm{~m}$; bole $20 \mathrm{~cm}$ thick at $2 \mathrm{~m}$, cylindric; bark greyish buff to light grey, slightly fissured, slightly dippled scaly with small pieces; inner bark pale yellowish, green just below thc surface, slightly sclerotic-gritty; wood yellowish white throughout. 


\section{Cyperaceae}

Every Malesian botanist is indebted to the late J. H. Kern for his meticulous revision of this family for the Flora Malesiana (ser. 1, vol. 7). The genera of importance in the swamp-forest are Hypolytrum, Mapania, Scirpodendron, and Thoracostachyum. The monotypic Scirpodendron and some species of Mapania are so like Pandanus in outward appearance that it is impossible to distinguish them in the forest without inflorescences (lateral in Mapania, terminal in Scirpodendron and Pandanus). I remark that I never saw in Malaya such robust spccimens of Scirpodendron as I later cncountered in the Solomon Islands near the eastern end of its distribution between Ceylon and Samoa. The local name for Scirpodendron and similar Cyperaceas was selengsen.

Cyperus pedunculatus (R.Br.) Kern:- Concerning this characteristic pioneer of sand-dunes, which used to be known as Remirea maritima, Kern has discussed its systematic position and the strangc construction of the 'nut' (Acta Botanica 7, 1958, 795).

Mapania cuspidata (Miq.) Uitt. - This is the common species with broad petiolate leaf; var. petiolata has a relatively longer lamina, stouter petiole, and narrower leaf-sheath. The plants are erect, never decumbent. The old part of the stem dies away and the leafy upper part comcs to stand, lik a small pandan, on slender stiltroots up to $45 \mathrm{~cm}$ high. To add to the resemblance, the inflorescences are often more or less hidden in the leaf-shcaths.

M. micropandanus Holtt.- This is just like a miniature pandan. It grows to $45 \mathrm{~cm}$ high. The older part of the stem (5-10 mm thick) dies away and leaves the upper part standing on the slender adventitious roots. The stem commonly becomes more or less horizontal with the leafy bud upturned; thus, it appears to creep on stilts $20-30 \mathrm{~cm}$ high. It has been found, also, on P. Tioman and, according to Kern its nearest ally may be $M$. graminea Uitt. of east Borneo.

\section{Dilleniaceae}

Wormia with dehiscent fruit and arillate secds is no longer distinguished from Dillenia, chiefly because the nature of the fruits is not known in several species (Hoogland 1952). In this respect it is the primitive element, however, and among the species of Wormia the inflorescence appears to be most complicated and, perhaps, least reduced.

Dillenia albiflos Ridley.- tree $-17 \mathrm{~m}$, without buttresses, occasionally with 1-3 stiltroots $-1 \mathrm{~m}$ high; bark rufous brown, uneven and dippled; inner bark pinkish brown, thick; wood deep pink brown to reddish brown throughout, hissing on cutting; inflorescenccs terminal, hanging, gradually elongating $-50 \mathrm{~cm}$, with $1-3(-4)$ branches and up to 30 flowers in all; pcduncle (to the first flower) $7-18 \mathrm{~cm}$ long; pedicels 5-30 mm long, shortening distally, distichous; bracts 3-35 $\mathrm{mm}$ long, shortening distally; open flowers $4-5 \mathrm{~cm}$ wide, opening one at a time along the branches in the carly morning; sepals cream-white internally; petals white, falling off c. $1 \mathrm{pm}$; stamens cream-colour; styles white; fruit developed from every flower, white, dehiscent; aril white (?).

This species calls for investigation. Its exact distribution in Malaya, where it is endemic, needs determination because, like Pandanus epiphyticus, Dipterocarpus lowii or Ficus cucurbitina, it ties with the flora of Sarawak and shows the penetration of this element into that of Malaya. So far as known, it occurs in the swampand hillock-forest from Ayer Hitam and Kluang to Endau, Mersing, and the Sedili region. I recall no collections south wcst of Kota Tinggi or from G. Panti itself; it was certainly not in Singapore. It was sufficiently common at Rengam to have been 
enumerated by Cousens (Malayan Forester 14, 1951, 131, as Wormia beccariana). It is easily recognised from the trunk as Dillenia and, specifically, by the winged petiole distinct from the lamiria. I have noted that, unlike most trees, taller trees bear larger leaves, but there must be a limit, and old trees have not been studied. Its nearest ally is $D$. beccariana of Sarawak to which, on a report from C. E. C. Fischer at Kew, I had reduced D. albiflos (Corner 1939). Hoogland distinguishes $D$. beccariana by the unbranched inflorescence (which occurs also in $D$. albiflos), by the larger flower $(6 \mathrm{~cm}$ wide), the yellow petals, and the longer rigid hairs on the carpels. However, P. S. Ashton looked into the colour of the flowers for me in Sarawak and reported in litt. that the petals were white. Hence I am still uncertain of the specific distinction.

D. grandifolia Wall.- see Whitmore, Gdns' Bull. Singapore 24, 1969, 3.

D. pulchella (Jack) Gilg:- tree $-33 \mathrm{~m}, 23 \mathrm{~m}$ to the first branch; bole $80 \mathrm{~cm}$ thick at $1.7 \mathrm{~m}$, without buttresses or stilts; bark greyish brown to pinkish grey, finely fissured and breaking ofl in small subrectangular pieces.

This tree was scarce at Jurong, Singapore, and I saw but one specimen which showed, however, the size that it could attain, given the opportunity. At Pontian, Johore, it was rather frequent in the peat-swamp but not more than $23 \mathrm{~m}$ high.

Dillenia sp. ?: - s.n. 11.6 .34 (as simpoh A), Jason Bay, S. Rhu Reba; tree -17 m, without stilts or buttresses; bark reddish brown, somewhat papery-flaky in small curling pieces; inner bark pink, coarsely veined; wood pale ochre; blaze hissing on cutting; leaves elliptic-obovate, with 8-9 pairs of lateral veins; scattered in wet parts of the Eugenia grandis forest. (? D. pulchella).

\section{Dipterocarpaceae}

The names which I use are those given me by my lamented friend C. F. Symington. The sterile specimens were named more or less to his satisfaction. The Malay names which I give were used consistently on the Sedili River, though they do not all agree with those advocated by Symington.

Dipterocarpus? hasseltii Bl.- The damar of this tree was extracted for caulking. In a bole $20-25 \mathrm{~cm}$ thick a cut would be made $8-14 \mathrm{~cm}$ deep and up to $20 \mathrm{~cm}$ high and the bottom of the cut would be scooped out to make a basin. Then a fire was lit in the hollow for 15 minutes. In 24 hours there would be a puddle of greyish gum that remained liquid for two weeks. If left for a week, the hollow would fill with gum.

D. lowii Hook.f.- trunk becoming slightly fluted-buttressed; bark pale greyish buff, somewhat lenticellate, rather shaggy-flaky with oblong fibrous pieces; leaves stiffly coriaceous with upcurled sides.

Dipterocarpus sp. (9.9.34). - Tree -30 nı, not buttressed; bark grey, with rather deep hoop-marks, pustulate with lenticels $3-5 \mathrm{~mm}$ wide, not scaly; leaves not matched by Symington.

Hopea mengarawan Miq.- tree - $30 \mathrm{~m}$, with a few buttress-like stilt-roots $-1.5 \mathrm{~m}$ high, or without stilts in dry forest; bark fuscous brown, fissured, rather roughly flaky; inner bark pallid wood-white to yellowish, easily stripping, separated from the hard outer bark by a characteristic wavy brown line.

H. ? Inengarawan (30988). - tree $-50 \mathrm{~m}$, with rounded buttresses $-2 \mathrm{~m}$ high; bark dark grey, deeply and narrowly rugose-fissured (as in Fagraea fragrans); wood pale yellowish throughout; crown like that of kapur; leaves resinous aromatic when crushed. 
H. polyalthoides Symington.-small tree-5 m; bark fawn-brown, slightly creviced, smooth; inner bark pinkish, thin, flaking off on cutting in thin pieces with the outer bark breaking away.

$H$. resinosa Symington.- tree $8-20 \mathrm{~m}$, with flattened arcuate stilt-roots $-3 \mathrm{~m}$ high, copious, sometimes with tufts of small cylindric stilt-roots, but no stilt-roots in dry soil; no loop-roots; bark dark fuscous or blackish, ertire, then somewhat fissured with narrow subtumid lenticels more or less in longitudinal rows; inner bark pale pinkish buff, stripping; wood yellowish.

Shorea acuminata Dyer.- tree $-47 \mathrm{~m}$, with buttresses $-2 \mathrm{~m}$ high; bark dark fuscous to dull pinkish brown, inconspicuously roughened and scaly with irregular angular pieces, not or slightly fissured; inner bark deep purplish brown, thick; heart-wood dark pinkish brown; buds and large subpersistent stipules inhabited by ants.

S. bracteolata Dyer.- tree $-30 \mathrm{~m}$, buttressed $-3 \mathrm{~m}$ or scarcely at all; bark fuscous, irregularly and shallowly fissured-flaky, scarcely rugose, not pustulate, or with lenticels 1-2 mm wide; inner bark cream-whitc, laminated with concentric ochraceous sclerotic zones.

S. exelliptica Meijer.- tree $-57 \mathrm{~m}$, trunk $75 \mathrm{~cm}$ thick at $2.5 \mathrm{~m}$ high, buttressed to $2.3 \mathrm{~m}$; bark greyish rufous, becoming rather irregularly flaky and subrugose; inner bark pale pinkish, yellowish next the sap-wood; leaves brownish slivery shite beneath.

This is S. ? elliptica Burck of Symington (see Ashton 1964).

S. foxworthii Symington.- tree $-47 \mathrm{~m}, 65 \mathrm{~cm}$ thick at $5 \mathrm{~m}$ high, buttresses $-4 \mathrm{~m}$ high, sharp and scarcely spreading; bark dull fawn brown, thinly flaky with oblong angular pieces (especially over the buttresses), sometimes more or less rugosefissured at first and scaling off when mature; inner bark pallid yellowish, fairly thick; sap-wood yellowish tan, narrow; heart-wood dull rich brown, hard; leaves silvery beneath.

This was a common canopy-tree in the kapur-forest. It differed from the other species of balau, $S$. exelliptica, in the yellowish, not pink, inner bark.

S. lepidota (Korth.) Bl.- tree $-40 \mathrm{~m}$, slightly buttressed; bark fuscous fawn, becoming rather coarsely rugose-fissured; inner bark dark reddish fuscous; heartwood pinkish brown; fallen leaves coppery beneath.

S. leprosula Miq. - tree $-50 \mathrm{~m}$, buttressed $-3 \mathrm{~m}$; bark light brown, rather distantly rugose-fissured; inner bark deep pink.

S. ovalis (Korth.) B1.- tree $-47 \mathrm{~m}$, with very thick buttresses $-2.7 \mathrm{~m}$ high, or slight or none (? immature trees); bark greyish fuscous to chocolate brown, smooth, entire, with hoop-marks, then rather finely rugose-fissured; inner bark brown, deep pinkish brown to blood-red just below the surface, blaze with bacony streaks.

One tree that I measured at mile $5 \frac{1}{2}$ on the Kota Tinggi-Mawai Road was $47 \mathrm{~m}$ high and the trunk above the buttresses was $165 \mathrm{~cm}$ thick; possibly this was the stoutest trunk that I saw in the Sedili region, but compare Mesua kochummeniana. There was a general flowering of S. ovalis in May 1935.

S. palembanica Miq.- tree $-35 \mathrm{~m}$, buttressed 1-2 $\mathrm{m}$ high; bark light fawn buff or greyish buff, becoming irregularly fissured flaky, not rugose, pustulate with small lenticels 1-4 mm wide; inner bark pink to pinkish brown; heart-wood dark brown.

For this species Symington gives the vernacular names sengkawang or tengkawang but, on the Sedili rivers, these names were used for $S$. singkaw'ang or, possibly by confusion, for $S$. lepidota. 
S. parvifolia Dyer.- tree $-35 \mathrm{~m}$, with low buttresses; bark with elongate lenticelfissures, not flaky; inner bark pinkish brown, dull blood-red just below the dead outer bark, blaze with bacony streaks.

S. pauciflora King.- tree $-20 \mathrm{~m}$, not buttressed (? immature); bark rufous greyish, flaky with thin rectangular picces, somewhat fissured, not rugose; inner bark thick, soft, deep brown-pink, blood-red just below the dead outer bark.

$S$. platycarpa Heim.- tree $-35 \mathrm{~m}$, buttressed; bark grey-brown, fissured; inner bark pinkish to purplish brown, reddish near the outside, blaze with bacony streaks.

S. resina-nigra Foxw.- tree $-55 \mathrm{~m}, 35 \mathrm{~m}$, to the first branch, buttresses $3-4 \mathrm{~m}$ high; bark greyish fawn, rather flaky and fissured, not rugose; inner bark pallid yellowish; damar blackening on exposure- Plate 8.

S. singkawang (Miq.) Burck.- tree $-45 \mathrm{~m}$, fluted at the base or with buttresses $-2 \mathrm{~m}$ high; bark rufous grey to fuscous grey, rugose-fissured, not or slightly flaky; inner bark pinkish white or pallid buff-white.

When growing by the Sedili Besar this tree recalled neram (Dipterocarpus oblongifolius) with flattened and twisted trunk leaning over the rivcr and the branches laden with epiphytes. I think that it was confused by Malays with S. lepidota.

S. sumatrana (V.Sl.) Symington.- I used to recognise this tree from a characteristic small toadstool that grew on the fallen leaves.

Vatica wallichii Dyer.- tree $-23 \mathrm{~m}$, often short and crooked, without buttresses or stilt-roots; bark fuscous brown to pale grey, often white from a distance, smooth, with leaf-scars; inner bark yellowish, dark fuscous below the outer dead bark (flaking off on cutting), slightly resinous-aromatic (distinctly so in 28982); wood yellowish white; both flowering and fruiting specimens found in March 1932.

\section{Ebenaceae}

Diospyros L. - A dozen or more species of Diospyros occur in the swamp-forest, as trees up to $20 \mathrm{~m}$, treelets and, almost, shrubs. The smaller are generally known as segun. The botanist recognises them from the dark grey or black bark which, in the blaze, gives a brittle and coal-like outer layer; the inner bark varies in colour and these differences scem to bc important. Thus, I drew up the following key:-

Inner bark pink to dcep red; D. apiculata, D. argentea, D. maingayi, Diospyros sp. (6.8.39), D. sp. (1.7.39), (also D. dictyoneura and $D$. helferi, not in the Sedili region).

Inner bark white to yellowish or pale ochre.

Inner bark quickly turning deeper yellow on exposure; D. lanceifolia,

D. siamang, Diospyros sp. (7.10.34).

Inner bark not deepening on exposure; $D$. confertiflora, $D$. nutans,

D. wallichii.

Buttresses are seldom and but slightly developed as in D. maingayi. Stilt-roots occur in $D$. lanceifolia and $D$. siamang which also has loop-roots as pneumatophores, but it does not appear to have been found in the Sedili region.

D. apiculata Hiern:- SFN 29359; tree $-10 \mathrm{~m}$; trunk $5 \mathrm{~cm}$ thick, no stilt-roots; bark dull black, shortly and shallowly longitudinally creviced, subtuberculate, with faint leaf-scars; inner bark pinkish brown beneath the coal-black dead bark; wood pinkish white; corolla white. 
D. argentea Griff.- bark greyish black, carbonaceous, rather distantly fissured and subrugose; inner bark pinkish buff, not changing colour on exposure; wood white.

D. confertiflora (Hiern) Bakh.- treelet 3-4 m; twigs drooping, phyllomorphic, with small leaves; bark greyish brownish, rather finely and shallowly fissured; inner bark pallid whitish, thin; sepal 3-4, green; petals pinkish; fruit orange when ripe.

D. lanceifolia Roxb.-SFN 29373; tree $-17 \mathrm{~m}$; bole $10 \mathrm{~cm}$ thick at $2 \mathrm{~m}$; stilt-roots $-45 \mathrm{~cm}$ high, the lower stout and flattened, the upper narrow and cylindric, not spreading; bark coal-black, finely, closely, and shortly fissured or creviced, somewhat rugose-fissured towards the base of the trunk, not tuberculate or scaly; inner bark pallid whitish, quickly turning deep yellow on exposure, stripping, coal-black and brittle at the surface; wood pallid whitish, quickly turning deep yellow on exposure; flowers mostly on the twigs behind the leaves, occasionally in the leafaxils, not on the trunk; compare SFN 26167 (Jurong, Singapore).

In the collection s.n. 10.6.34 (as segun B, S, Tuenseh, Jason Bay) the inner bark was light brownish and, apparently, did not change colour on exposure. This tree, which may not be $D$. lanceifolia, was scattered in Eugenia grandis forest where it grew to a height of $20 \mathrm{~m}$.

D. maingayi (Hiern) Bakh.- tree $-20 \mathrm{~m}$; bole $20 \mathrm{~cm}$ thick at $2 \mathrm{~m}$; buttresses $-60 \mathrm{~cm}$ high, often low and inconspicuous; crown often narrow and irregular; bark greyish black or coal-black, rather coarsely rugose, eventually flaking in long narrow brittle strips; inner bark $-5 \mathrm{~mm}$ thick, deep blood-red beneath the brittle coal-black outer bark, very fibrous, stripping, with red sap; wood pallid yellow, then deeper yellow on exposure; fruit ochraceous yellow when ripe.

D. nutans King:- SFN 29339, 29442; tree -10 m; bole cylindric, slender; bark black, slightly and narrowly rugose-fissured, not scaly or fibrous, somewhat knobbly; inner bark pallid yellowish beneath the coal-black outer layer, not deepening on exposure; wood pallid yellowish, not deepening on exposure; fruits in the axils of old leaves or just behind on the bare twigs, not on the branches or trunk.

I am not certain about the identity of all the numbers that I give under this name. SFN 29442 has been determined as D. pauciflora. In SFN 21312, 32304, and 32365 the twigs became strongly and irregularly angular with corky outgrowths.

D. siamang Bakh.- SFN 26167 and s.n. 15.1 .33 (Jurong, Singapore), SFN 36623 (Pontian, Johore); tree $-33 \mathrm{~m}$; bole $40 \mathrm{~cm}$ thick at $1.5 \mathrm{~m}$, cylindric or slightly fluted at the base; stilt-roots few, at the base of the bole; pneumatophores as loops $-45 \mathrm{~cm}$ high, or as knee-roots, rather congested, $-6 \mathrm{~cm}$ thick, with bark as on the trunk but the coal-black outer bark very thin and not fissured, strongly tuberculate-rugose with lenticels 1-2 cm long; bark dark blackish grey, finely, closely, and shallowly fissured, with faint large transverse lenticels; inner bark light yellowish brown, with a thin brittle coal-black outer layer; wood pallid white, quickly turning light yellow on exposure to the air as the inner bark; crown narrow, thin, poorly and irregularly developed.

This remarkable species, which I may have found once in the Sedili region, though not at the Mandai Road in Singapore, occurred at Jurong (Singapore) at the rate of one large tree, or two small ones, per acre. It was cauliflorous but, instead of inflorescences, there were often very dense bunches of galled twigs.

Diospyros sp.:- s.n. 6.8 .39 (as Diospyros A, Bt. Tinjau Laut); tree $-25 \mathrm{~m}$, monopodial, without buttresses; bark coal-black, closely rugose-fissured; inner bark dull drab pink; wood pale yellow, not deepening on exposure.

Diospyros sp.:- s.n. 1.7.39, in peat-swamp, Pengkalan Raja, Pontian, Johore; tree $-20 \mathrm{~m}$, with a few stilt-roots $-70 \mathrm{~cm}$ high, not buttressed; bark coal-black, 
slightly fissured; inner bark reddish; common locally but all trees sterile at the time of collection.

Diospyros sp.-S.n. 7.10 .34 (Mawai, Johore); tree $-13 \mathrm{~m}$; bole $30 \mathrm{~cm}$ thick at $2 \mathrm{~m}$, slightly fluted at the base; no stilts or loop-roots; bark fuscous brown, nearly black, rather finely longitudinally flaky with narrow fissured pieces and shreds, sparsely pustulate with lenticels 3-5 mm wide; inner bark pale yellow, coal-black and brittle at the surface, not stripping; wood pallid white; inner bark and wood quickly turning deep yellow on exposure.

\section{Elaeocarpaceae}

Elaeocarpus macrocerus (Turcz.) Merr.- tree $-25 \mathrm{~m}$, buttressed and with numerous stilt-roots $-2 \mathrm{~m}$ high; pneumatophores $-1.7 \mathrm{~m}$ high, as loop-roots or $\lambda$-shaped, the tops often capitate or knobbed; bark pinkish brown, smooth; prostrate trunks proliferating new stems eventually established as independent trees; flowers fragrant, April-June.- Plate 12.

The name of this striking and characteristic tree of the freshwater tidal swampforest has been changed from E. obtusus to $E$. littoralis and, now, to E. macrocerus; let us hope that it is final, but for the record in botanical research these earlier names must be remembered.

\section{Erythroxylaceae}

Ixonanthes reticulata Jack. - tree $-33 \mathrm{~m}$; buttresses $-2.7 \mathrm{~m}$ high, not spreading widely, the bole sometimes merely fluted at the base; bark light grey to pinkish brownish, smooth, entire, with faint hoop-marks; inner bark deep blood-red or blackish red, rather thick, very astringent, not stripping, much paler on the buttresses.

The fallen leaves of a peculiar ochre-brown and the intense colour of the inner bark identify this tree. Some trees have a slight tendency to form stilt-roots.

\section{Euphorbiaceae}

The importance of this family is shown by the large number of species, c.110, reported so far from the Sedili region. For Malaya and Singapore, the Tree Flora of Malaya vol. 2 gives 371 spp. and the odd remark that 'only a few species are common in permanent swamps'. About sixty species occurred in the swamp-forest round the Sedili rivers, where they made a considerable part of the undergrowth. The family has been badly in need of taxonomic repair which in recent years has been undertaken by Airy Shaw whose numerous papers, unfortunately almost without illustration, are cited in the Tree Flora; one must consult, also, his Euphorbiaceae of Borneo (Airy Shaw 1975). From these I have gleaned many namechanges and new species, and I add many field-notes which had not been consulted. The family is bedevilled with microgenera and it seems that the wood cannot yet be seen for the trees.

Aporosa lunata (Miq.) Kurz: - tree $-7 \mathrm{~m}$; bark dark grey, entire, slightly pustulate with irregular and somewhat elongate lenticels; inner bark pinkish brown, thin; leaves large, coriaceous, with sunken veins; twigs and lower sides of the leaves brown hairy; styles ochre-yellow; fruit pink.

A. nigricans Hook.f.- tree $-10 \mathrm{~m}$, without stilts; bark greyish white, finely longitudinally creviced, slightly flaky in small oblong pieces, not truly fissured or scaly; inner bark pale brownish, very thin; wood pallid tan, very dense; racemes on the twigs behind the leaves, not on the trunk. 
A. pseudoficifolia Pax:- tree $-5 \mathrm{~m}$, without stilts; bark pale greyish brown, slightly fibrous and fissured; inner bark pale brownish, very thin; wood pale yellowish brownish throughout; flowers in sessile clusters on the branches behind the leaves; bark and wood recalling Baccaurea.

Austrobuxus Miq.- The identity of this genus, hidden for over a century in Buxaceae, has been discovered by v. Steenis (Blumea 12, 1964, 362). A. nitidus Miq. is the tree so long and well known as Longetia malayana. An effort to conserve Longetia failed; so Austrobuxus perpetuates distastefully the error, or folly, of Miquel. Of the type v. Steenis wrote "though it is sterile but for a single flower bud, this brought to light the surprising fact that it is no Buxacea, but manifestly a common Euphorbiaceous Malaysian tree'.

A. nitidus Miq.- collection from Jurong, Singapore; tree $-22 \mathrm{~m}$; bole $25 \mathrm{~cm}$ thick at $1.7 \mathrm{~m}$ without buttresses, but narrowly fluted up to $1 \mathrm{~m}$ high; bark greyish brown, slightly rugose-fissured, slightly flaky; inner bark pale pinkish brown, c. $6 \mathrm{~mm}$ thick, not stripping; latex none; wood rather deep pinkish brown, with a narrow outer ring of whitish sap-wood c. $6 \mathrm{~mm}$ wide.

Baccaurea Lour.- The bark is given as 'red to orange brown' in the Tree Flora of Malaya vol. 2 p. 63. I never saw truly red bark in any species, though this colour comes in spuriously through red corticolous algae or lichens, as on coconuttrunks; in a few species it is orange brown but in the majority it is fawn brown to greyish brown.

B. hookeri Gage:- tree $-13 \mathrm{~m}$; bark light fawn, fibrous-scaly in small pieces; fruit on the twigs behind the leaves.

B. ? javanica (Bl.) M.A.- tree $-13 \mathrm{~m}$, fluted at the base; bark light fawn, very thinly dippled-flaky; fruit in racemes from the twigs behind the leaves; seeds 1-2 per fruit, with bluish lilac pulp.

B. lanceolata (Miq.) M.A.-SFN 36976; small tree $-7 \mathrm{~m}$; bark pale grey, slightly fibrous, almost smooth; inner bark pale ochraceous, thick; fruits borne only on the trunk from ground-level up to $3 \mathrm{~m}$ high, 1-seeded, pale green ripening dull creamwhite; seeds with white pulp.

B. racemosa (Reinw.) M.A.- tree $-13 \mathrm{~m}$; bark pale buff, greyish when old, finely creviced and flaky in small picces; inner bark pale yellowish, very thin; wood pale yellowish tan, hard, finc-grained; flowers pale yellow, sour-scented; fruit 1-3-seeded, cherry red, fruiting racemes green and hanging from the twigs behind the leaves; seeds with purple-blue pulp.

This frequent small tree much resembles $B$. motleyana in general appearance. The collection s.n. 15.7.40 (Danau, Sedili Besar), if it belongs here, represented a very common under-storey tree of the swamp-forest, which had a general and heavy fruiting at that time.

B. scortechinii Hook.f.- In Wayside Trees of Malaya I carefully distinguished this species from B. parviflora to which it has been reduced by Airy Shaw (Kew Bull. $26,1972,220$ ) and so-called in the Tree Flora of Malaya. There is surely some mistake here.

B. sumatrana (Miq.) M.A.- tree $-15 \mathrm{~m}$; bark rufous fawn, finely fissured-flaky; fruits on the leafy twigs, 2 -seeded; seeds with rich orange-red pulp.

Blumeodendron tokbrai (Bl.) J. J. Sm.- tree $-23 \mathrm{~m}$, without buttresses; stilt-roots $-2.5 \mathrm{~m}$ high, spreading; pneumatophores none; bark grey to pale pinkish brown, rather smooth, slightly longitudinally fissured; inner bark deep pinkish brown; latex none; leaf-blade jointed with a slight clongate swelling to the large thick 
petiole, leaves usually in alternating whorls of 3 ; fruits $2.8-3.6 \mathrm{~cm}$ long, slightly broader, depressed globose with 3 slightly depressed sutures, rounded triangular in end-view, with a vestige of the style, glabrous, ripening pale yellow; exocarp $1.5 \mathrm{~mm}$ thick, rather dry; endocarp $3 \mathrm{~mm}$ thick, woody, dehiscent on the tree; seeds 1-3 per fruit, covered with thin, pale yellow pulp, with a beery smell.- Plate 19.

Bridelia ? cinnamomea Hook.f.- tree $-17 \mathrm{~m}$; bole $15 \mathrm{~cm}$ thick at $2 \mathrm{~m}$, rather copiously branched above, without stilts; bark pale pinkish fawn, inclining to silvery buff, slightly flaky with inconspicuous angular scales, faintly pustulate with small, rather scattered lenticels; inner bark pinkish fawn; sap-wood narrow, yellow; heart-wood rich pink-brown; twigs and petioles light brown hairy; flowers pale cream-yellow, the sepals greenish yellow; wood very handsome.

B. pustulata $\mathrm{Bl}$ - - treelet $-5 \mathrm{~m}$, trunk $7.5 \mathrm{~cm}$ thick at $2 \mathrm{~m}$; stilt-roots few, low, spreading, up to $20 \mathrm{~cm}$ high on the trunk; thorns $-5 \mathrm{~cm}$ long, simple or 2-3-fid, set along the trunk up to $3.5 \mathrm{~m}$ high (? abortive roots); bark light grey, silvery, smooth; inner bark reddish, thin.

Cephalornappa lepidotula Airy Shaw:- tree $-20 \mathrm{~m}$; bole $30 \mathrm{~cm}$ thick at $2 \mathrm{~m}$, without stilts; bark fuscous fawn or dull greyish brown, closely pimply with small lenticels 1-3 mm wide, entire; inner bark pale brown, fairly thick, rather hard and dry; crown dense, dark, brownish from the brown scurfy undersides of the leaves; petiole geniculate; lamina serrulate, with a gland on each side of the base of the midrib underneath.

With these field-characters I had no difficulty in recognising this tree.

Cleistanthus maingayi Hook.f.- tree $-8 \mathrm{~m}$; bark greyish green becoming chocolatebrown, scaling in irregular pieces with pale new bark; inner dark pallid greenish white; wood pinkish; leaves rather glaucous beneath; young leaves pale green; twigs and petioles brown hairy; several trees gctting new leaves and flowers in Feb. 1935, but others with mature fruit.

Croton laevifolius B1. - This common shrub was always obscrved to flower gregariously about February and to fruit about May. I did not record a second flowering in the year. The inner bark smells faintly of eucalyptus. The species has been called $\mathcal{C}$. oblongus Burm.f., but I have seen no proof (Corner 1939).

Dimorphocalyx murinus Elm.- SFN 29295, 29296; tree $-13 \mathrm{~m}$, without stilts or buttresses; bark light greyish fawn, rather silvery, slightly but closely pimply with small lenticels, somewhat dippled or pocked, very thin (paper-thick); inner bark pale orange to deep orange-brown in young tree, reddish orange in old trees, rather thick, not sclerotic; wood pale yellowish tan. See notes under Ostodes.

Endospermum diadenum (Miq.) Airy Shaw.- This is the species so long known as $E$. malaccense; it is another of Miquel's coups de grace. Large trees were common in the hillock-forest along the Jemaluang Road but many were felled because the wood was used for match-sticks.

Galearia Zoll. et Mor.- This genus is referred to Pandaceae by Forman (Kew Bull. 26, 1971, 153). I have noted that treelets of Galearia have scale-leaves on the main stem and foliage leaves only on the branches, as in Glochidion.

Glochidion glomerulatum (Miq.) Boerl. - This was recorded by Polak (1933, as G. palustre) as common with Elaeocarpus macrocerus (as E. littoralis) in the swampforests of Sumatra. I did not find this association in the Sedili region where the Elaeocarpus grew near the tidal river-banks and the Glochidion round the periphery of the swamp-forest.

Hymenocardia sp.- SFN 26100, Jurong, Singapore; tree $-13 \mathrm{~m}$; bole $10 \mathrm{~cm}$ thick at $1.2 \mathrm{~m}$, without buttresses or special roots; bark dull greyish, slightly brownish, 
finely and shallowly fissured, flaking with small thin elongate pieces (much as in Jackia ornata); inner bark rich brown or reddish brown, thin; wood whitish; latex none.

Under this name I filed provisionally specimens of a small tree that was scattered in the undergrowth at Jurong, but which I never saw elsewhere.

Macaranga baccaureifolia Airy Shaw:- The many species of Macaranga in Malaya are evergreen and, perhaps, ever-leafing. This species of the freshwater tidal swampforest is therefore exceptional. In February, when the river was subsiding after the monsoon rains, there becane noticeable in the flat swamp-forest behind the mempisang-beit many undergrowth trees completely bare of leaves which lay beneath them as a fresh brown litter. From the bare twigs green male catkins began to hang down, recalling the hazel (Corylus) of Europe. Then the new leaves came out in March and fruits began to ripen in May and June. The identity of the tree puzzled me for many years until, at the Singapore Herbarium in 1972, I found that it had been named by Airy Shaw. Deciduousness is often associated with cold or dry seasons. Here is a truly deciduous tree in the undergrowth of tropical swamp-forest where the climatic effect is a slight improvement in drainage. What of its allies? The species has been found also in Borneo.

M. griffithiana M.A.- This species built dense stands of secondary forest up to $23 \mathrm{~m}$ high on old logging sites by the Sedili Besar. It is given as a small bushy tree in the Tree Flora of Malaya vol. 2, which applies to its early growth. It has been reduced to a subspecies of the Bornean $M$. motleyana M.A. (Whitmore, Kew Bull. 29, 1974, 448).

M. javanica Hook.f.- I refer to the plant described in Wayside Trees of Malaya., for which I spent much time in ascertaining the botanical name. It is called $M$. heynei by Whitmore $(1967,1969)$, which differs merely in details of the bracteoles of the male flowers. I considered, and still consider. the difference too trivial for specific distinction if, indeed, it is so reliable. Similarly $M$. lacinata is a northern variation of $M$. iavanica.

M. quadricornis Ridley:- According to Whitmore (1969), this has a disjunct distribution in Malaya, for it is known from the mountains of the main range and from south east Johore. He suggests in explanation that it has evolved from the complex of $M$. triloba independently in both places. In the same year, however, Cockburn (1969) reported $M$. quadricornis from G. Mandi Angin in Trengganu. This proves that knowledge of the distribution of common plants in Malaya is still insufficient for theorising. I have noted many other examples of apparent disjunction such as Lithocarpus maingayi and, in varying degree, $L$. kingianus, $L$. kunstleri, $L$. perakensis, and $L$. urceolaris, for which a double origin is so unlikely that it can be ruled out. And there are the instances of Antidesma brachybotrys, $A$. pahangense, Castanopsis fulva, Ficus urnigera, Garcinia maingayi, Homalium dasyanthum, Vatica stipulata, and Zingiber wrayi. Such are relics of the past history of the Sedili region where Bt. Tinjau Laut and G. Panti are opposing markers. Indeed, the distribution of Dryobalanops aromatica must be part of the problem. In the case of the montane plants that occur also on the seashore, without intervention, such as Baeckia frutescens, Styplielia (Leucopogon) malayana, and Vaccinium bracteatum ( $V$. malaccense), ecological factors may enter as well as historical.

Neoscortechinia forbesii (Hook.f.) C. T. White:- tree $-7 \mathrm{~m}$, without stilt-roots; bark pinkish grey to brownish, entire, pustulate with numerous small, light brown lenticels 1-2 mm wide, more or less in longitudinal rows; inner bark pale yellowish brown, reddish below the outer bark.

$N$. sumatrensis S. Moore:- tree $-20 \mathrm{~m}$; bole $20 \mathrm{~cm}$ thick at $2 \mathrm{~m}$, slightly fluted at the base, without stilts or pneumatophores; bark fuscous brown to grey, entire or 
creviced, with faint leaf-scars, often closely pustulate with small, round, dirty white lenticels; inner bark light brownish ochraceous, somewhat gritty, breaking off without stripping; wood yellowish throughout; fruit grey-hairy.

Ostodes pendula (Hassk.) A. Meeuse:- This species, which has usually been known as $O$. macrophylla, is called Fahrenheitia pendula in the Tree Flora of Malaya vol. 2. The differences between Fahrenheitia, Ostodes, and Dimorphocalyx have been set out by Airy Shaw (Kew Bull. 20, 1966-67, 409), but they do not seem to me more than sections of a genus such as Streblus, Ficus, or, indeed, Tacca.

Pimeleodendron macrocarpum J. J. Sm.- tree c. $30 \mathrm{~m}$ high; bole $40 \mathrm{~cm}$ thick at $2 \mathrm{~m}$, cylindric from the base; bark fuscous fawn, uneven and rather rough, with short shallow anastomosing fissures, slightly flaky with small, rather thin, irregular pieces, (trunk uniformly fissured, rough, and flaky); inner bark pallid fawnochraceous with numerous fine darker fibres, pallid reddish brown near the surface; latex white, rather watery, not copious; fruits set in 2's and 3's on the twigs behind the leaves, facing downwards, green turning yellow (? orange when ripe).

I found two trees, one at mile 5-6 on the Kota Tinggi Mawai Rd, the other in the swamp-forest at S. Dohol. Local forest-guards called it perah, doubtless from the resemblance to Elateriospermuin.

Sapium indicum Willd. - There were a few trees behind the police-station at Mawai. Thence, downstream to the nipa-belt, there were scattered trees, mainly along the tributaries of the main river. The species has been transferred to Excoecaria by Airy Shaw (1975), who gives the trunk as thorny, though I never noticed this.

Suregada Roxb.- Gelonitum is reduced to this genus. The Tree Flora of Malaya vol. 2 treats $S$. glomerulata as a synonym of $S$. multiflora but it seemed to me that there were two species in the Sedili region and I have retained them.

Trigonostemon rufescens Jabl. - shrub or small tree $-8 \mathrm{~m}$ high; trunk $-15 \mathrm{~cm}$ thick at the base; branches few, straggling, more or less erect with the leaves clustered spirally at the ends, often in rosettes; bark fuscous greyish or yellowish, finely fissured or creviced, often pustulate with rather large transverse lenticels; inner bark pinkish brownish, with a hard, almost carbonaceous, blackish layer near the surface; wood cream-white, rather hard and dense; sap blood-red, fluid (not gummy), scant in the bark of old stcms, copious in younger stems and twigs (reminiscent of Myristicaceous sap); monoecious with bisexual racemose inflorescences, at first axillary with female flowers then becoming male in the lower part of the raceme, the distal part fruiting and breaking off, then the racemes persisting on the branches and trunk as scattered male inflorescences $-5 \mathrm{~cm}$ long though some cauline inflorcscences (even only $12 \mathrm{~cm}$ above the ground) with a terminal female flower; female flowers 1-4 per raceme, one always terminal, 1-2 flowers open at a time, the corolla twice as big as in the male flowers; male flowers axillary from bracts in the lower part of the inflorescence, developing after most or all of the female flowers set fruit, also on the short cauline inflorescences; sepals green; petals blood-red to deep crimson in male and female flowers; filaments and anthers pale greenish yellow, then pinkish; ovary and styles pale greenish yellow; disc pallid yellow; fruiting sepals becoming reddish, much enlarged and enclosing the capsule.

$T$. sumatranus Pax et Hoffm.- tree 8-20 $\mathrm{m}$ high (small tree in Tree Flora of Malaya vol. 2); bark pinkish grey to silvery, entire except for more or less longitudinally elongate lenticels; inner bark rather thin, deep pink to purplish pink, with faint bacony streaks; wood soft, pinkish white; flower-pedicels pale pink to rose-red; sepals greenish; petals deep orange, reddening on the outside; stamens and styles yellow; glands pale pink. 
T. viliosus Hook.f.- treelet $-5 \mathrm{~m}$, laxly branched; bark greyish black, carbonaceous, with fine anastomosing rugose fissures; inner bark reddish, with copious blood-red sap; corolla dull crimson; stamens creamy yellow.

\section{Fagaceae}

With the help of Soepadmo's revision of this family in the Flora Malesiana and his citation of collections (1971), I record from the Sedili region 5 species of Castanopsis, 14 of Lithocarpus, and 7 of uncertain identification as listed below. The absence of Quercus s.str. may be significant. They were frequent trees, rarely exceeding $25 \mathrm{~m}$ high, but often sterile, in which case field-characters of habit, bark, and fallen leaves were useful in identification. I note the following points:-

Buttressed; L. bennetti, L. urceolaris, L. ? cyclophorus (7.2.35),

L. ? javensis, Pasania A (18.2.37); in most species the bole was cylindric from the base.

Stilted; L. hystrix, L. leptogyne (also pneumatophores), L. urceolaris.

Inner bark deep pink, red, or purple; L bennettii, L. ? cantleyana,

L. ? ewyckii, L. ? javanica; most species with pale brownish inner bark.

Oaks can be recognised from the very wide medullary rays and, generally, the ease with which the bark breaks off the wood in cutting the blaze. The species which seemed most readily to withstand flooding was the riverside $L$. elegans. The occurrence of the mountain $L$. maingayi is remarkable.

Lithocarpus bennettii (Miq.) Rehd. - tree $-30 \mathrm{~m}$; buttresses $-1 \mathrm{~m}$ high. spreading; no stilt-roots; crown with rather steeply ascending limbs; bark greyish white, pustulate with numerous small lenticels; inner bark deep wine-red to dull mangosteen-purple, $-15 \mathrm{~mm}$ thick, stripping easily; wood pallid brownish, with very wide rays and vessels.

L. eichleri (Wenzig) A. Cam.- tree $-17 \mathrm{~m}$, not buttressed; bark greyish to brownish, pustulate with pallid lenticels $2-4 \mathrm{~mm}$ wide, scattered or in vertical rows, becoming finely creviced, with persistent leaf-scars; inner bark pale brownish, rather hard and sclerotic; wood pallid drab.

L. hystrix (Korth.) Rehd- - tree $-20 \mathrm{~m}$; bole $25 \mathrm{~cm}$ thick at $2 \mathrm{~m}$; stilt-roots $-1 \mathrm{~m}$ high, spreading, subarcuate; buttresses none; bark greyish white, with persistent leaf-scars, slightly pustulate with scattered lenticels 2-3 mm wide; inner bark pallid yellowish tan; wood soft; twigs and undersides of the leaves brown hairy.

L. kunstleri (King) A. Cam. - tree $-13 \mathrm{~m}$, with poor and malformed crown, no stilt-roots; bark greyish fawn, with faint leaf-scars, somewhat pustulate with small whitish lenticels 1-2 $\mathrm{mm}$ wide, the lenticels elongating transversely; inner bark pale brownish drab, thin; twigs olivaceous hairy.

L. leptogyne (Korth.) Soepadmo:- tree $-23 \mathrm{~m}$; bole $35 \mathrm{~cm}$ thick at $4 \mathrm{~m}$; stiltroots $-4 \mathrm{~m}$ high, the main stilts flattened and arcuate, the smaller subcylindric, often fastigiate, forming a dense thicket round the trunk; penumatophores as slender unbranched erect roots or $\lambda$-shaped, abundant in very swampy places; bark chocolate brown to paler fuscous fawn, closely pustulate with tubercular lenticels $2-5 \mathrm{~mm}$ wide, more or less in vertical rows, with faint leaf-scars, becoming slightly fissured and flaky; inner bark brown, fairly thick; wood yellowish buff throughout; leaves silvery beneath; flowering in February.

This remarkable tree, which in its thicket of stilt-roots resembles species of Calophyllum, is figured in Flora Malesiana ser. 1, 7, fig. 29, p. 378 (representing SFN 28959). The collections SFN 28968 and 28986 were made on the following 
day in the same place and from identical trees, but 28968 is referred by Soepadmo (1971) to L. sundaicus and 28986 has been omitted; both were tentatively named Pasania ? sundaica-lamponga in the Singapore Herbarium.

L. urceolaris (Jack) Merr.- tree $-25 \mathrm{~m}$; buttresses $-1 \mathrm{~m}$ high, rather low, spreading, tending to form tufts of cylindrical stilt-roots; bark brownish grey, dull, coarsely tuberculate with rather tumid lenticels $3-5 \mathrm{~mm}$ wide, leaf-scars faint; inner bark pale fawn tan, fairly thick; wood pallid tan-buff throughout; leaves greyish green on both sides or silvery beneath; flowering and at the same time with nearly mature fruits in February.

A tree of this which I planted from seed in the Singapore Botanic Garden still stands near the library.

L. ? cantleyana:-s.n. 15.4 .36 (7); tree $-27 \mathrm{~m}$, fluted at the base; bark as in $L$. eichleri but the inner bark deep pink with bacony streaks in the blaze; in sivamp-forest.

L. ? cyclophorus: - s.n. 7.2.35 (S. Berassau near the Jemaluang Road, as Pasania 1); tree $-30 \mathrm{~m}$; bole $50 \mathrm{~cm}$ thick at $2 \mathrm{~m}$; buttresses $-2.5 \mathrm{~m}$ high, spreading, rather sharp; bark light fawn brown, inclining to pale rufous, irregularly flaky with small, rather fibrous, longitudinal pieces, subpustulate with small lenticels, without leafscars; inner bark pallid tan; tending to sucker from the base; several big trees locally in the swamp-forest, but sterile.- The herbarium specimen was taken from a sucker-shoot, but I noted that the leaves on the crown were the same.

L. ? cyclophorus:- s.n. 3.2 .35 (mile 17, Jemaluang Road, as Pasania 1); tree - $30 \mathrm{~m}$; bole $40 \mathrm{~cm}$ thick at $2 \mathrm{~m}$, cylindric from the base; bark greyish white, leaf-scars faint, rather closely tuberculate with small lenticels; apparently merely 2-4 fruits per inflorescence.

L. ? ewyckii:-S.n. 16.634 (S. Semandan, Jason Bay, as Pasania 1); tree -23 m; bole $35 \mathrm{~cm}$ thick at $2 \mathrm{~m}$; buttresses slight; bark pinkish grey, faintly rugose-fissured, not flaky or lenticellate; inner bark pinkish brown, thick, lurid reddish immediately below the dead outer layer, easily breaking off; leaves subglaucous beneath; berangan babi.

This tree was frequent in old Eugenia grandis forest along the coast and the only oak that I saw in that forest.

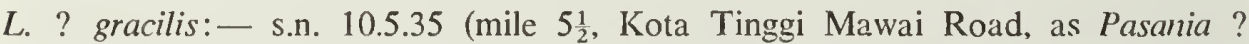
omalakos, ? cytorrhyncha); tree $-23 \mathrm{~m}$, cylindric from the base; bark light grey, somewhat pustulate, entire; in dryer parts of the swamp-forest.

L. ? javensis: - s.n. date ? (3 miles below Mawai, as Pasania costata); tree $-23 \mathrm{~m}$; bole $45 \mathrm{~cm}$ thick at $2 \mathrm{~m}$; buttresses few, sharp, $-\frac{1}{2} \mathrm{~m}$ high; bark light greyish fawn, faintly lenticellate-fissured, nearly smooth, with persistent leaf-scars; inner bark deep red-brown, thick; berangan babi; frequent in hillock-forest.

Pasania A :- s.n. 18.2.37 (S. Kayu, in swamp-forest); tree $-40 \mathrm{~m}$ with big spreading crown; buttresses $-1.2 \mathrm{~m}$ high, some as broad flat stilts; bark light brown, slightly pustulate with elongate lenticels; inner bark brownish bistre, darkening on exposure, very thick; leaves rather yellow-green beneath, not silvery.

\section{Flacourtiaceae}

Casearia grewiaefolia Vent. var. deglabrata K. et V.- tree $-23 \mathrm{~m}$, cylindric from the base; bark light grey or greyish buff, smooth, then slightly pustulate with small lenticels more or less in vertical rows, finally slightly lenticellate-fisured; leaf-scars persistent; inner bark pale pink, not or hardly stripping, $-4 \mathrm{~mm}$ thick; wood pale ochre throughout, fairly hard. 
Casearia sp.- SFN 32517 (Mandai Road, Singapore); shrub -2 m; young leaves pale pinkish fawn; fruits brilliant orange; seeds white, aril red.

Homalium dasyanthum (Turcz.) Warb.- tree $.13 \mathrm{~m}$; bole $20 \mathrm{~cm}$ thick at $2 \mathrm{~m}$, cylindric from the base; bark light brownish drab to drab white, strongly marked with transversely elongate, tumid, white, crowded lenticels $3-12 \times 3-4 \mathrm{~mm}$, sometimes united in bands, the outer bark thin and stripping like cherry-bark; inner bark pale ochraceous, greenish under the outer bark, thin; wood yellowish tan throughout; calyx and corolla pale green; filaments greenish white, often becoming rose-pink at the ends; anthers dull orange; glands dull yellow; ovary greenish.

This tree, easily recognised from the whitish, pustulate and banded bark, was not uncommon along the S. Kayu Ara. According to Sleumer (Flora Malesiana ser. $1,5,1954,56)$ the species is known otherwise from limestone hills. In the Tree Flora of Malaya it is given as coastal, sometimes on limestone, and common in the north west of Malaya.

Hydnocarpus curtisii King:- tree $-7 \mathrm{~m}$, scraggily branched; bark pale drab fawngrey, with fairly numerous, small, transversely elongate lenticels; inner bark pale ochraceous tan, thin; wood pinkish brown; inflorescences male (with small ovary) or female (with staminodes) on the same tree; sepals pallid white, or green (male); petals and filaments cream-white; anthers yellow, vibrating; ovary cream-white.

Of the 7 species of Hydnocarpus in Malaya, 6 occur in the Sedili region.

Ryparosa scortechinii King:- tree $4-13 \mathrm{~m}$; bole $3-13 \mathrm{~cm}$ thick at $2 \mathrm{~m}$, cylindric from the base, cauliflorous; bark greyish rufous fawn, smooth, then somewhat fissured with clongate, pustular, longitudinal lenticels; inner bark yellowish, with ochraceous sclerotic particles, rather thick; wood pallid white; racemes 1-3 on small knobs on the trunk (not from the branches), from $15 \mathrm{~cm}$ above the ground upwards, hanging, $-14 \mathrm{~cm}$ long, the rachis black-hairy; petals, stamens, and ovary pale greenish yellow, becoming orange-ochraceous; ovary becoming black-hairy on fertilisation; sepals black-hairy; flowers with a faint musty smell.

According to Sleumer the sepals and ovary are rusty hairy but in the living state the hairs are black (? very dark purple from anthocyanin), and the blackhairy young fruit is characteristic.

\section{Flagellariaceae}

Hanguana malayana (Jack) Merr.- By this name I mean the common lily-like plant of the forest, that we used to call Susum malayanum. In the Flora Malesiana (ser. 1, 4, p. 249) it is equated with the aquatic Susum anthelminthicum to which the description largely refers. I am not convinced that they should be made into one species, though structural differences may be slight. I have seen hundreds of plants of the forest $S$. malayanum in the swamp-forest, where they vary in numerous ways, but I never saw in the Sedili region the aquatic $S$. anthelminthicum, though there were abundant opportunities for it in the muddy open back-waters and sluggish streams, where I saw it later in Trengganu and Sarawak. In such places, even at the brink of the water, $S$. malayanum never ventured to become $S$. anthelminthicum.

In the forest $S$. malayanum was solitary or with short, inconspicuous stolons it built small colonies. Some plants were big, with long leaves, and they sometimes developed a second rosette above the first on a distinct stem; yet this was not necessarily the habit of old plants. Some of these were distinguished by the long petioles. In some plants the leaves were deep purple beneath, in others pale green; and in some places all the leaves were longitudinally silvered in blurred stripes. Some plants had tall spreading panicles; others had them so compact as almost 
to be capitate. The bigger plants occurred in the deep humus of wet forest, the smaller on hill-sides; yet I was not convinced that they were merely ecological diversifications. I recommend the species for cultivation and autecological research.

\section{Gesneriaceae}

Cyrtandra suffruticosa Ridley: - Epiphytic bush at heights up to $10 \mathrm{~m}$ in shady places in the swamp-forest; leafy stems freely hanging up to $120 \mathrm{~cm}$ long, arising from a congested rhizome creeping on the support; roots rarely reaching the ground; leaves hanging vertically down; bracts pale green, more or less suffused dull purple on the inner side; pedicel and calyx pale pink; corolla $40-45 \times 25 \mathrm{~mm}$, white, with 2 longitudinal brown patches at the base of the three corolla-lobes next the stamens, a brown patch at the base of the stamens, and a large pinkish purple patch on each of the other two petal-lobes (these patches often confluent).

Cyrtandrornoea Zoll. - This genus has been transferred to Scrophulariaceae by B. L. Burtt (Bull. bot. Surv. India 7, 1965, 73).

Didissandra johorica Ridley:- s.n. 23.4 .38 (mile 14, Jemaluang Road); herb $-75 \mathrm{~cm}$ high; stem purplish; leaves dark green, whitish beneath, fleshy; flowers axillary; peduncles purple; corolla dingy white, suffused brownish purple on the upperside, the lower side of the throat bright yellow with two brown longitudinal bars.

Paraboea densifolia (Ridley) Henderson:- This herb grows in thick tufts on rocks in Saraca-streams and it is strongly attached by fibrous roots. It marks the change from swamp-forest, where it does not occur, to the swifter Saraca-streams that are the upper tributaries of the Sedili Besar. It can also be found on boulders in the forest, possibly as relics of former stream-beds.

\section{Gonystylaceae}

Gonystylus bancanus (Miq.) Kurz:- SFN 36657; tree $-40 \mathrm{~m}$; bole cylindric, no stilts or pneumatophores; crown compact, dark; bark dark tawny brown to rich brown, fissured, cracking transversely into oblong flakes, becoming shaggy-scaly (like old trees of Cratoxylon arborescens); inner bark pinkish, thick, dry; wood pale yellow throughout; leaves dark glossy green, coriaceous, spirally arranged, upstanding, with upcurled sides.

This was a common tree in the peat-swamp at Pontian, Johore, and known locally as kayu gatal. When the bark dries and the outer layer is broken away, the surface of the inner bark becomes finely hairy from minute and irritating fibres. Young trunks suggest Eugenia, old ones $C$. arborescens. In the Sedili region it was remarkably uncommon.

\section{Gramineae}

Panicum repens L.- This is one of the few real dune-binders on the Malayan coasts. The rhizome lies up to $60 \mathrm{~cm}$ deep and sends up the more superficial branches which end in inflorescences. The deep rhizome develops swollen internodes and becomes artichoke-like. Most herbarium-specimens do not show this feature.

Paspalum vaginatum Sw.- This is another coastal grass with deep rhizome. Round Jason Bay it grew in the wet hollows of sand-spits and, especially, by streams in the forest where it formed close swards, up to $60 \mathrm{~cm}$ high, under Avicennia, and Sonneratia near the mouths of streams. The inflorescence has $2(-3)$ short deflexed branches.- Plate 28. 
Sphaerocaryum malaccense (Trin.) Pilger: - small grass on the riverside mud in the freshwater zone, submerged at high tide and, in places, at low tide, often in masses round the bases of putat and rassau; leaves pinkish purple beneath; panicle very small, with solitary florets.

This was also a common grass of forest-paths. Perhaps the putat-belt was its original habitat.

\section{Gymnospermae}

Podocarpus motleyi Dumm.- tree $-27 \mathrm{~m}$; bole $35 \mathrm{~cm}$ thick at $2 \mathrm{in}$, cylindric from the base; bark fuscous, slightly and distantly fissured, slightly fibrous-flaky, inclined to become dippled; inner bark reddish brown, rather thick.

This tree was scattered through the swamp-forest and occasionally entered the canopy. At S. Kayu I saw three large trees in a distance of c. $150 \mathrm{~m}$. Saplings were more frequent.

\section{Hypericaceae}

Cratoxylon arborescens (Vahl) Bl.- This tree was gregariously dominant in parts of the swamp-forest, though for what reason I never discovered. Seedlings and saplings were often abundant. With monopodial growth they penetrate to the canopy and develop large, heavy, rounded crowns which, in age, lose the monopodial character. Unlike so many swamp-forest trees, this species lacks buttresses, stilt-roots, and pneumatophores. The bark of saplings is rather coarsely rugosefissured but this bark is scaled off from below upwards and the mature trunk develops the shaggy-flaky bark. Besides being a typical swamp-forest tree, this species occurs in lowland and montane forest.

C. formosum (Jack) Dyer:- The trees on the Sedili Besar were all of the larger variety, as mentioned in Wayside Trees of Malaya. The point is overlooked in the Tree Flora of Malaya vol. 2, where the bark is given, not as fissured, but as paperyflaky which seems wrong.

C. ligustrinum (Spach) Bl.- This species is reduced to C. cochinchinense (Lour.) Bl. in the Flora Malesiana ser. 1, 8, 1974, 7. This may satisfy the herbarium but not the student of living trees. It does not resolve the ecological, geographical, and structural differences so apparent to the field-botanist. The mistake is perpetuated in the Tree Flora of Malaya vol. 2, where the bark of $C$. ligustrinum is ascribed to $C$. cochinchinense and my account of $C$. cochinchinense is omitted.

\section{Hypoxidaceae}

Curculigo latifolia Dryand.- This common herb with plicate leaves is either very variable or has distinct forms. Particularly noticeable in the swamp-forest of the Sedili region was a form with long-petiolate leaves reaching $2 \mathrm{~m}$ high. The genus would repay critical study by means of transplants and the raising of seedlings.

\section{Icacinaceae}

Cantleya corniculata (Becc.) Howard:- trees at Jurong, Singapore; tree $-23 \mathrm{~m}$ high; bole $30 \mathrm{~cm}$ thick at $1.5 \mathrm{~m}$, without buttresses but occasionally slightly thickened over the main lateral roots; without pneumatophores; branches ascending, then outcurving; bark dark grey, entire, nearly smooth, then somewhat longitudinally fissured wtih elongate lenticels (as in Calophyllum), not scaly; inner bark pale ochraceous, rather soft, $-12 \mathrm{~mm}$ thick, not stripping; wood pale yellowish throughout, with a faint sweet smell; leaves subcoriaceous, the veins more or less invisible. 
This is illustrated in the Flora Malesiana (ser. 1, 7, 1971, 51-53) as a lofty tree with strong blunt buttresses. I did not find the tree in the Sedili region, though there is the record from $\mathrm{S}$. Gembut which is a tributary of the Sedili Besar. It was frequent, however, at Jurong though not so large as recorded in the Flora Malesiana.

Platea excelsa Bl. var riedeliana (Becc.) Sleumer:- SFN 36686, Pontian, Johore; tree $-33 \mathrm{~m}$; stilt-roots $-2.3 \mathrm{~m}$ high, flattened, arcuate; loop-roots $-45 \mathrm{~cm}$ high, abundant round the base of the trunk; bark warm brown, smooth, entire, then with fine faint transverse wrinkles closely set; inner bark ochraceous sclerotic; crown small; leaves spirally arranged, upstanding; buds brown scurfy, petioles and midribs slightly so.- Plate 18.

$P$. latifolia $\mathrm{Bl}$. - tree $-30 \mathrm{~m}$; stilt-roots $-2.3 \mathrm{~m}$ high, rather congested, the larger arcuate-flattened, the smaller subcylindric; bark fuscous brown, slightly fissured, slightly pustulate with small scattered lenticels, with persistent leaf-scars, for the most part smooth; inner bark pallid brownish tan, without smell or latex; leaves rather distant, with upcurled sides; fruit solitary, axillary, shortly pedicellate, ripening purple to black.- Plate 18.

Stemonurus malaccensis (Mast.) Sleumer:- tree $-17 \mathrm{~m}$; bole $20 \mathrm{~cm}$ thick at $2 \mathrm{~m}$, cylindric from the base; bark greyish fawn tinged pinkish, smooth, entire except for rather distant lenticels $2-3 \mathrm{~mm}$ wide, tending to be in vertical rows, with faint leaf-scars; inner bark yellowish, with abundant ochraceous sclerotic particles or strands; wood yellowish throughout; leaves coriaceous, dark green, veins almost invisible; fruit shiny green but the distal third dull grey-green.

S. scorpioides Becc.- tree $-27 \mathrm{~m}$, flowering as a sapling at $4 \mathrm{~m}$; bole $45 \mathrm{~cm}$ thick at $2 \mathrm{~m}$, cylindric from the base; pneumatophores $-45 \mathrm{~cm}$ high, $1-2.5 \mathrm{~cm}$ thick, peg-like, cylindric, obtuse, fleshy, as the ends of $\lambda$-roots branched below ground, abundant in swamp-forest; bark light brownish buff to light greyish brown, rather finely and closely pustulate with whitish lenticels $2-3 \mathrm{~mm}$ wide, more or less in vertical rows, with faint leaf-scars and irregular hoop-marks; inner bark $-20 \mathrm{~mm}$ thick, yellowish, green below the surface (even on old trunks), with coarse ochraceous sclerotic strands and zones; wood yellowish throughout, fairly hard; leaves thick, fleshy, glossy, with faint oblique veins; buds thickly covered with hard brownish yellow resin breaking into dust on the opening leaves; twigs rather thick, green, hoary from the resinous bloom; fruit with green proximal half and pale greenish white conical distal half.

The presence of this frequent tree was told by the resin-capped buds, green twigs, and fleshy leaves of saplings, as well as by the distinctive pneumatophores; it is a xeromorph of swamp-forest.

\section{Lauraceae}

For a general account of this family and its genera I refer to Kostermans (1957). Many of my notes, attached to herbarium-specimens long on loan, have not been available to me. The only instances of stilt-roots that I met were in Litsea gracilipes and Notaphoebe coriacea. Strong buttresses occurred in Lindera sp. (SFN 28520) which was a dominant tree, with strangely swollen trunk, in Eugenia grandis forest.

Hexapora curtissi ?:- SFN 26196, 4.3.33, Jurong, Singapore: tree -23 m; bole $30 \mathrm{~cm}$ thick at $1.7 \mathrm{~m}$, cylindric from the base; bark greyish white (white from a distance), apparently smooth but cracking into small thin irregular pieces; inner bark deep vinous brown, c. $12 \mathrm{~mm}$ thick. with numerous pale brown sclerotic granules or masses, not stripping; wood pale yellowish brown.

Notaphoebe coriacea Kosterm.- shrub or tree $-10 \mathrm{~m}$; trunk conically thickened downwards; stilt-roots present or not; some plants with small leaves, others with large; see my Life of Plants pl. 13a.- Plate 21. 
This common and characteristic small tree, that often developed thickets in the tidal muddy creeks of the Sedili Besar, I had identified as $N$. kingiana var. glabrescens Gamble, but it appears to be this species of Kostermans. I was puzzled by its variability and, hence, the number of collections which I made; it needs fuller enquiry.

\section{Lecythidaceae}

\section{Barringtonia Forst.}

The collections in the Singapore Herbarium have been named by the recent monographer Payens (1967). Of the eight species recorded from the Sedili region, $B$. asiatica, $B$. conoidea, $B$. macrostachya, and $B$. racemosa have special habitats; the others appear to occur indiscriminately in the swamp-forest where only $B$. filirachis is commor. The ecology of the genus deserves study, how it infiltrates from coast to montane forest. Several species have the stems or trunks thickened conically at the base, e.g. $B$. conoidea, $B$. acutangula, and $B$. racemosa.

B. filirachis Payens.- Small tree $-13 \mathrm{~m}$, trunk $15 \mathrm{~cm}$ thick at $2 \mathrm{~m}$; branches gnarled, crooked, looping, with slender twigs; no buttresses, stilt-roots, or pneumatophores; bark fawn brown, or tinged orange or rufous, entire, then slightly fissured-flaky, not or slightly pustulate, without leaf-scars; inner bark pale yellowish to pinkish brown, stripping easily, fairly thick; inflorescence very slender, hanging; petals and stamens crimson pink; calyx bifid, greenish white; fruit 4-angled; flowering mainly April-May. Johore, Sumatra.

B. macrostachya (Jack) Kurz.- Tree $-7 \mathrm{~m}$, sparsely branched with no compact crown; bark brownish grey, smooth; inflorescence hanging; flowers rose-red; fruit rose-purple.

B. racemosa (L.) Spreng.- Small tree $-10 \mathrm{~m}$, trunks often thickened conically at the base; leaves of many plants yellow-veined on the upperside; flowers fragrant, nocturnal; petals white, the fallen corollas floating downstream; restricted to small openings, or niches, in the riverside vegetation in the freshwater or somewhat brackish tidal reaches, with many old and moribund specimens along the edge of the encroaching forest.

\section{Leguminosae}

Crudia Schreb.- Pollen of this genus has been recorded from Tertiary deposits in Borneo (Muller 1972). In the discussion which followed the delivery of this paper, there was doubt of the identification. Both $C$. caudata and $C$. wrayi, however, were locally abundant on the Sedili region, and it is not unlikely that, during the Tertiary extension of these and neighbouring rivers, Crudia might have been better represented than its present, almost relict, occurrence.

C. caudata Prain:- always a small tree $-8 \mathrm{~m}$ high; twigs and fruit brown villous; bark dark fuscous, smooth; inner bark pinkish brown, thin; wood pinkish yellowish; seen only on the Sedili Kechil, but locally abundant.

Dalbergia parviflora Roxb.- This stout climber, rooted in the soft freshwater tidal mud by the river, developed into large impenetrable thickets. It threw up several stems on which massive, woody, and conical thorns developed up to $5 \mathrm{~cm}$ long, generally set in 2's and 3's. Old stems, trailing on the mud, were often the only passage over its treachersous surface, for a foot could usually be inserted between the clusters of thorns. This climber certainly needs ecological study.

Dialium kingii ? :- s.n. 5.5.35, S. Kayu Ara, in kapur-forest; tree $33 \mathrm{~m}$ high; bole $30 \mathrm{~cm}$ thick at $2 \mathrm{~m}$; buttresses $-1.2 \mathrm{~m}$ high, sharp, spreading; bark pinkish grey, drab, smooth, entire, but here and there pimply with small, irregular, very crowded 
lenticels; inner bark pinkish brownish, with copious thin red sap soon clotting into thick reddish black sticky masses; wood pale tan; leaves brown hairy beneath (not golden hairy).

D. patens Baker:- tree $-27 \mathrm{~m}$; bole $30 \mathrm{~cm}$ thick at $2 \mathrm{~m}$; buttresses $-1.7 \mathrm{~m}$ high, sharp, not branched; bark pale to dark fawn brown, drying to pinkish fawn, closely pimply with 1-2 mm lenticels, with persistent leaf-scars, in old trees scaling off in small pieces (as in Koompassia malaccensis); inner bark pinkish fawn, rather thin, with thin blood-red sap darkening on exposure; wood as hard as iron.

Inocarpus fagiferus (Parkinson) Fosberg:- For the occurrence of this plant in Malaya I refer to my early account under the name I. edulis (Corner 1939, p. 269).

Ormosia macrodisca Baker:- s.n. 4.3.33, Jurong, Singapore; tree -17 m; bole $25 \mathrm{~cm}$ thick at $1.7 \mathrm{~m}$, cylindric from the base; bark with a thin papery grey-brown superficial layer, easily peeling off in places to show the green under-bark, smooth, then shallowly fissured; inner bark pale yellowish brown, stripping easily, smelling of raw potato; wood pale yellowish.

A single tree was found, which may have been the last on Singapore Island.

Pterocarpus indicus Willd.- At S. Sebong, on Jason Bay, there were many, strongly buttressed, big trees of this species, well over $30 \mathrm{~m}$ high, growing along the riverbank in the region of nipa, Sonneratia, and Bruguiera, just where the bank sloped on to the muddy flat. The trees were well known locally as sena and that they were wild within the memory of man was confirmed by the local record given to me by Harun bin Awang Kechil. I did not record the tree from other rivers leading into Jason Bay.

Sympetalandra hildebrandii v. Steenis:- This was described recently with SFN 31984 as the type (Blumea 22, 1975, 166). I collected, also, a fallen fruit on G. Panti at c. $300 \mathrm{~m}$ alt. (Oct.1935), which was referred to $S$. borneensis in the Tree Flora of Malaya vol. 1, 1972, 274.

\section{Liliaceae}

Dracaena granulata Hook.f.- tree 8-13 m high; trunk $45 \mathrm{~cm}$ thick at $2 \mathrm{~m}$, dividing at a height of 2-3 m into sevcral branches; stilk-roots as cylindric adventitious roots $-30 \mathrm{~cm}$ high at the base of the trunk; branches more or less pendent, like sprays of Freycinetia; bark greyish buff, finely creviced to narrowly and shortly fissured, not scaly but somewhat scrobiculate; inner bark greenish white, very thin; wood white, soft; fruit $28 \mathrm{~mm}$ wide, subglobose, succulent, carrot-red, solitary or paired on the lax terminal inflorescence.- Plate 25.

Looking at the feet of trunks, I was astonished to come upon this arborescent monocotyledon.

Smilax L.- I refer to the monograph by Koyama (1960).

\section{Linaceae}

Ctenolophon parvifolius Oliver:- tree $-33 \mathrm{~m}$, buttressed; pneumatophores as knee-roots (as in Ganua); bark grey-brown, more or less scaly; inner bark red, very thick, dry, fibrous.

These are Henderson's field-notes on SFN 36607. The tree was fairly common in the peat-swamp at Pontian, Johore, but scarce in the Sedili region, and absent, apparently, from the swamp-forest of Jurong and the Mandai Road in Singapore. The twigs evidently resemble those of Gynotroches, under which the specimens were doubtfully placed in the Singapore Herbarium. 


\section{Loganiaceae}

Fagraea crenulata Maingay:- I note the absence of this tree from the regions of Pontian, Singapore and the Sedili rivers. I note also the absence of $F$. fragrans from the Sedili region; it occurs further north in the coastal swamp-forest of Pahang.

Norrisia major Soler.- tree $-17 \mathrm{~m}$, monopodial, usually laden with epiphytes; bark rather orange-rufous, inclining to fuscous, rather cracked and fissured, rugged; inner bark pale yellowish white; twigs annulate at the nodes; leaves dark green, glossy, with upcurled sides; young leaves pale green, old leaves withering yellow, set in two rows by petiolar twisting.

It was on a tree of this species that so many epiphytes were counted (p. 27).

\section{Lythraceae}

Lagerstroemia ovalifolia var. exapiculata Furtado et Montien:- I noticed in this tree that the living cambium showed as a characteristic fuscous purple line on cutting the blaze, not the result of oxidation on exposure.

\section{Magnoliaceae}

Aromadendron nutans Dandy:- SFN 36626, Pontian, Johore; tree -17 m, monopodial; bole cylindric from the base, no special roots; bark ochre-buff, slightly cracked, otherwise smooth; inner bark light brownish ochre, thick, rather scleroticgritty; wood yellowish white.- Plate 9.

\section{Marantaceae}

The Malayan species have been monographed by Holttum (1951).

Phacelophrynium maximum (Bl.) K. Schum.- This appears to be common in the intermittent swamps along the Saraca-streams on the east of the main range. Its southern limit seems to be set at S. Kayu on the Jemaluang Road and at Bt. Tinjau Laut. It did not occur in the main area of swamp-forest round the Sedili rivers and I did not find it round the foot of G. Panti. See Phrynium basiflorum.

Phrynium basiflorum Ridley:- This beautiful plant, which we called 'Tiger Stripes' because of the dark green stripes on the leaves, was common by Saraca-streams and on muddy banks in the forest (? stream-remains) round the foot of G. Panti. It did not occur in the main swamp of the Sedili region and I did not find it on Bt. Tinjau Laut. Thus it impinges on Phacelophrynium maximum without intermixing. According to Holttum it is closely allied with Phrynium hirtum of much wider distribution.

\section{Melastomataceae}

Memecylon L.- This genus was in much confusion in the Singapore Herbarium. Furtado (1963) has disentangled several problems, but further study is needed into the habit of the trees and the colour of flowers and fruits. The genus made up a great deal of the undergrowth of the swamp-forest. With very thin bark, that seemed to avoid the need for pustular lenticels, and hard wood, the species gave the appearance of slow growth, but of this I have seen no proof.

M. garcinioides Bl.- tree $-17 \mathrm{~m}$; bole $20 \mathrm{~cm}$ thick at $2 \mathrm{~m}$, cylindric from the base; bark fuscous, paler with age, closely and narrowly rugose-fissured, becoming flaky with thin narrow fibrous strips and losing the rugose appearance; inner bark 
very thin, pinkish; wood fuscous drab throughout, hard as iron; fruit grey-green then yellow.

M. paniculatum Jack:- trec $-10 \mathrm{~m}$; bark fuscous, finely rugosc-fissured, not flaky; inner bark pinkish fawn, very thin; wood very hard; fruit ripening mauve-purple; leaves rather fleshy (as in Fagraea racernosa).

\section{Meliaceae} family.

I have been unable to find most of the copious notes which I made on this

Amoora rubiginosa Hiern:- tree $-25 \mathrm{~m}$; bole $40 \mathrm{~cm}$ thick at $2 \mathrm{~m}$, cylindric from the base or shortly buttressed, main lateral roots often protruding strongly, but no stilts or loop-roots; crown open, with wide-spread limbs leafy only at the ends; leaves coppery beneath; bark light pinkish brown to greyish brown, flaky in rounded-angular pieces $2-3 \mathrm{~cm}$ wide; inner bark pale pinkish brown, $10-12 \mathrm{~mm}$ thick, stripping easily; latex copious, white; wood pallid yellowish.- Plate 36.

Chisocheton Bl.- The collections have been named by Dr. D. J. Mabberley in the course of his revision of the genus. I am indebted to him also for the following notes. C. antabilis, which was the commonest species by the Sedili rivers, is restricted to the swamp-forests of Malaya, Sumatra, and Borneo; in the Sedili region it seemed restricted to the mempisang-belt. $C$. erythrocarpus is a more or less coastal species of Malaya and Borneo. C. pauciflorus is a Malayan endemic and is the widespread leptocaul ally of $C$. perakensis (Maxwell's Hill). C. paucijugus, of Malaya, Sumatra, and Borneo, is to be regarded as a subspecies of $C$. pentandrus which belongs typically to the more monsoon climate of the Philipines, Moluccas, and Java. In Malaya, typical $C$. pentandrus has been found only in the coastal forest of Jason Bay. C. patens is spread from Burma to the Moluccas. C. penduliflorus is a pachycaul treelet of Malaya and south Thailand. C. princeps is a Malayan pachycaul with sarcotestal seed and is close to the Bornean $C$. polyandrus Merr. with arillate seed. C. sarawakensis is widc-spread in Malaya and Borneo. On the whole, these collections from the Sedili region seem to me to indicate the derivation of its flora from the China sea rivers of the glacial period.

C. amabilis (Miq.) C.DC.- tree $-10 \mathrm{~m}$, no special roots; bark dark fuscous grey, finely cracked, slightly pustulate; inner bark pinkish reddish below the thin black superficial layer; fruit pink then rose-red, splitting into 3 parts, flesh white; seeds chestnut-brown, with a rich orange-yellow aril on the side about the hilum.

\section{Monimiaceae}

Kibara chartacea Bl.- treelet $-4 \mathrm{~m}$, without stilts; bark light grey, shallowly creviced-fissured, scarcely rugose, not scaly or tuberculate; inner bark pale greenish white, very thin; wood white, soft, with wide primary rays, easily fracturing longitudinally; ripe receptacles yellowish pink, lobed; 'seeds' black, slightly shiny.

\section{Moraceae}

No species of Artocarpus, seven of which are recorded for the Sedili region, seems peculiar to the swamp-forest. With Ficus (46 species recorded and the doubtfully wild $F$. elastica) there are certainly riverine species but such characteristic examples as $F$. ischnopoda, $F$. oligodon, and $F$. racemosa did not occur in the Sedili region. Among the strangling figs, $F$. calophylla, $F$. consociata, $F$. crassiramea, $F$. delosyce, $F$. retusa, $F$. sundaica, and $F$. microcarpa arc certainly common in the swamp-forest but not limited to it. The root-climbers $F$. apiocarpa, $F$. excavata, 
and $F$. uncinulata appear to be restricted to the swamp-forest, and the small tree $F$. obpyramidata is strictly riparian. No species of Ficus was endemic to the region but $F$. uncinulata has not been collected elsewhere in Malaya, though known from Borneo and the Natuna Islands. F. cucurbitina, described originally from Borneo, has been collected also near Kuantan. That Ficus should have so many species in the region is a taxonomic device; Ficus is treated as one big genus whereas the genera of many other families such as Annonaceae, Euphorbiacease, Lauraceae, or Rubiaceae correspond rather with sections of Ficus. The largest and most impressive element of Ficus by the river and in the swamp-forest was the subgen. Urostigma with the strangling figs. Biologically they provide an immense amount of food; ecologicaliy by destroying big trees they hasten the turn-over of the forest. It was the custom of Chinese wood-cutters to leave many large strangling figs in the belief that they were haunted or spiritual, though it is true that they may be difficult and dangerous to fell. At the foot of many left in clearings there would be a little altar with places for joss-sticks. I did not meet this reverence among Malays, though it is known in Borneo.

Artocarpus gomezianus Wall.- tree $-20 \mathrm{~m}$, not or slightly buttressed; bark fuscous blackish, rather flaky and fissured; inner bark pinkish, thick; wood very tough, used for axe-handles etc.; (flowering in Oct., Trengganu).

A. kernando Miq.- tree $-30 \mathrm{~m}$; bole $35-45 \mathrm{~cm}$ thick at $1.5 \mathrm{~m}$, cylindric or with slight spreading buttresses $-30 \mathrm{~cm}$ high; bark dark greyish brown to dark grey, finely creviced, then rough with rather short, shallow, elongate, lenticel-fissures 5-15 mm long, not pustular or flaky; inner bark dark brown-ochre, fairly thick, easily stripping; latex white, copious, thick, quickly coagulating; wood pallid white; scattered in the swamp-forest, nowhere abundant, apparently not a canopy-tree.

A. nitidus Trec. ssp. griffithii (King) Jarrett:- This species has been known in Malaya, where it is a familiar tree, as $A$. gomezianus var. griffithii. That this is a mistake was shown by Jarrett (1960) who transferred it to $A$. nitidus but, as the fruit of this species ripens brown, often brown velvety, with yellow flesh, I doubt if this disposition is final. I have seen living fruits of $A$. nitidus ssp borneensis (Merr.) Jarrett and they are certainly not those of the Malayan tree. The fruits of A. nitidus ssp. lingnanensis (Merr.) Jarrett have, however, the pink flesh of the Malayan tree; possibly ssp. lingnanensis and ssp. griffithii are a separate species for which the name $A$. parvus Gagnep. may be correct, if inappropriate.

Ficus microcarpa Linn. f.- For this common and much cultivated tree with pointed leaves the name $F$. retusa $\mathrm{L}$. has been employed wrongly for over 150 years (Corner 1960). Puzzled with this point of the leaf, I found the type and I confess that I was so disturbed that the Devil tapped my shoulder and said 'Destroy it' for no one seemed to know of its existence; it is still, however, in the rooms of the Linnean Society of London.

I did not understand the natural occurrence of $F$. microcarpa until I had explored the Sedili river. There used to be, before roads were widened and rustic tenements eliminated, large trees of jejawi in most coastal villages. They stood by muddy creeks, often where tongkangs unloaded timber, and there they spread with such pillar-roots as they were allowed, for the young aerial roots were commonly cut off for tooth-brushes. Beneath them often stood the simple altar with joss-sticks, and I fancied they were planted by wood-cutters, who had risen to timber-merchants, in propitiation of the spirits of the forest. Now I know that they were relics of the primeval swamp-forest, conserved in unwritten veneration. They were not the recent invasions of young trees such as infest, for instance, Fort Canning in Singapore.

Jejawi had a particular habitat in the tidal reaches of the Sedili Besar. It coincided with putat (Barringtonia conoidea) in longitudinal distribution though it developed in the rassau-belt immediately behind that of putat. It formed a 
straggling bush or small tree composed of obliquely ascending limbs, loosely and widely ramified with drooping ends. There was no trunk because, as a strangler, it started epiphytically in the heads of rassau and slowly developed the limbs from which the copious aerial roots descended. These roots could develop into pillar-roots to support the extension of the plant in the mempisang-belt, but they did not succeed where the lower part of the plant was inundated at high tide; at such times the branches appeared to rise from the water.

Jejawi occurred along the Sedili Besar from Tanjong Besar, near the upper limit of the mangrove, upstream to Bagan Limau where the belts of putat and rassau began to fail and the river-side steepened into Tristania-banks. Its main development lay between Bt. Tiga and Bt. Prah, especially in the long straight stretch of the river just above $\mathrm{Bt}$ Tiga. Here its branches ascended to $10 \mathrm{~m}$ and the loose crowns had a span of $20-30 \mathrm{~m}$. It was smothering rassau, which was here deteriorating near the downstream limit of its occurrence, and it was arching over the water and shading the bushes of putat. Above Mawai it developed no great size and, at its upper limit at Bagan Limau, it was merely a sprawling and insinuating bush with thick gnarled branches of considerable age, clearly not a newcomer. Yet, except for a large tree under which the river-boats were tied just below the jetty at Mawai, there were no large trees on the river-front. They developed, apparently, only inside the swamp-forest in the nibong-berembang region (Oncospernia and Sonneratia) along tributaries and small coastal rivers where, perhaps, there was firmer and less inundated soil for the pillar-roots to take hold and support the extending crown. Such was the exceptionally large tree that I found by S. Rhu Reba at Jason Bay, as mentioned in Wayside Trees of Malaya. In 1972, when this coastal forest had been more or less cleared or decimated, I saw numerous large trees of jejawi beside the creeks, not a few with improvised altar and joss-sticks. The big tree at Mawai seems to have been a relic.

I conclude that $F$. microcarpa of the swamp-forest is a species of tidal riverbanks, mainly in the brackish region. It has, however, other habitats. It grows in the rocky coastal forest where it may be dwarfed on the sea-ward rocks into a sprawling bush, and it occurs on limestone hills where brackishness cannot be a factor. In Ceylon, F. microcarpa occurs in forest far inland to an altitude of $2000 \mathrm{~m}$. In Malaya it has never been found in inland or montane forest, except on the limestone hills. The species is widely distributed from India and south China to Australia, New Caledonia, the Solomon Islands, and Micronesia, mainly as a coastal plant, but as var. naumannii it extends inland to heights of $1000 \mathrm{~m}$ in the Solomon Islands. Structural differences are slight; yet it seems that there must be ecological varieties. In this connection I note an account of $F$. microcarpa (as F. nitida Bl.) by Hickson (1889). A rock called Batu Kapal lay at the north end of Limbe Island off the north east extremity of Celebes. The rock stood about $100 \mathrm{ft}$ high in the sea with precipitous basalt sides and the top more or less covered with guano from frigate-birds and boobies. The only plant on the rock was F. nitida which Hickson said was Urostigna microcarpa Miq.

Parartocarpus venenosus (Zoll. et Mor.) Becc. ssp. forbesii (King) Jarrett; This is a striking, yet hardly common, tree of both swamp-forest and that of Eugenia grandis. It was easily recognised from the pale greyish or yellowish white, strongly lenticellate, bark, the wide-spreading roots with similar bark, the absence of stiltroots and pneumatophores, and by the copious white latex. The spiny syncarps resemble small durians, but have abundant latex when unripe. The stout and superficial main roots sent many small crowded lateral roots perpendicularly for 2-3 $\mathrm{m}$ into the soil, without a strong tap-root (Plate 33). Thus from bark and roots, stumps of this tree could be recognised in recently deforested areas and, from a study of these in Singapore and south Johore, I estimated that there were 
2-4 large trees per hectare. Saplings did not seem to be commoner. Adult trees developed a large, dense, rather uneven, dark crown. Though reduced to $P$. venenosus by Jarrett, I think this is a distinct species.

\section{Myristicaceae}

The Malayan species have been revised by Sinclair (1958) who incorporated my field-notes in the descriptions. From the collections which he lists it can be seen that most numbers (c.180) were made by King's collector Kunstler, then by Ridley (c. 150), and thirdly by myself (c. 135), but I must have examined in the forest several hundred trees in the course of checking my notes. Sinclair (1958a) gives many useful photographs of barks.

For the family in Asia and Australasia Sinclair describes c. 155 species, namely Gymnacranthera 6, Horsfieldia c. 40, Knema 37, and Myristica 72. For the Malay peninsula the numbers are as follows, with those of the Sedili region in brackets:Gymnacranthera 4 (3), Horsfieldia c. 19 (10), Knema 20 (9), and Myristica 11 (8). Of 54 species, that is, 30 occurred in the Sedili region.

Horsfieldia irya (Gaertn.) Warb. - tree $-20 \mathrm{~m}$ (-27 m on the Sedili Kechil), monopodial with the slightly drooping branches only in the upper part of the trunk, often conspicuous from the rusty orange male inflorescences on the bare branches behind the leaves; pneumatophores as gyrose knee-roots; flowering April-June; fruits ripening in $2 \frac{1}{2}$ months; common in the mernpisang-belt; on the Sedili Besar from some distance below $\mathrm{Bt}$ Tiga upstream to $\mathrm{K}$. Dohol and a few scattered trees up to Lubok Pusing, with the maximum development from a mile or two below Mawai to a mile or two above.- Tall trees were cut for poles, masts, and so on, which might have accounted for the smaller size of the trees on the Sedili Besar.

Horsfieldia sp.- s.n. 28.4.35, S. Berassau, Jemaluang Road; tree $-13 \mathrm{~m}$; stilt-roots $-1.3 \mathrm{~m}$ high, subcylindric, rather congested; loop-roots $-60 \mathrm{~cm}$ high, as long arcs or as $\lambda$-shaped pneumatophores, clustered round the tree-base; bark yellowish grey, somewhat pustulate with slightly transverse lenticels becoming creviced, not rugose or flaky; inner bark pale pinkish brown; sap watery pink; leaves slightly fleshy, glaucous beneath; standing in a marshy stream; not cited by Sinclair but identified by him as $H$. brachiata var. brachiata.

Knema intermedia (Bl.) Warb. - tree $-20 \mathrm{~m}$; bole $30 \mathrm{~cm}$ thick at $2 \mathrm{~m}$, commonly with rather slender stilt-roots $-2.3 \mathrm{~m}$ high, usually from the underside of leaning trees; loop-roots as simple loops or branched once, $-60 \mathrm{~cm}$ high, $3 \mathrm{~cm}$ thick, abundant round some trees, scarce or absent from others; bark dull madder brown, entire, nearly smooth but subtuberculate with abundant lenticels $2-4 \mathrm{~mm}$ wide; inner bark light pinkish brown, rather thin, stripping; sap watery reddish brown, issuing from the medullary rays; wood pallid yellowish throughout; leaves more or less glaucous beneath.

I noted that trees with and without stilt-roots occurred side by side, and that others in the same swamp-forest had but slightly developed stilts. Thus it is not clear that their development is merely facultative.

Myristica elliptica Hook.f. et Th.- This was generally a rather small tree $-15 \mathrm{~m}$ high in the mernpisang-belt but bigger trees $-30 \mathrm{~m}$ occurred in the swamp-forest to suggest that those of the mempisang-belt persisted through this stage in the development of the swamp-forest. Many of the larger trees developed wide loop-roots (Plate 14).

M. lowiana King:- This developed into one of the large, if uncommon, trees of the swamp-forest, easily recognisable from the black rugose-fissured bark and, in most cases, from the wide-spreading stilt-roots up to $2.5 \mathrm{~m}$ high. As usual, in dryer parts of the swamp, the stilts were shorter, even absent.- Plates 24, 38. 


\section{Myrsinaceae}

Ardisia Sw.- Several species have been described or re-defiined by Furtado (Gdns' Bull. Singapore 17, 1959, 279-311). I have taken the names that are on the specimens in the Singapore Herbarium, but several collections remain unidentified.

A. andamanica Kurz - tree $-10 \mathrm{~m}$, monopodial; branches slightly swollen at the base; pedicels and calyx bright pink; petals paler pink.

A. ? wrayi :- herb or shrub $-2 \mathrm{~m}$, unbranched, the leaves only at the top of the stem, rather succulent, especially the stem and pedicels; leaf-edge crenulate; petals pale mauve.

Ardisia sp.- SFN 29012, mile 14, Jemaluang Road; tree $-13 \mathrm{~m}$; trunk $13 \mathrm{~cm}$ thick at $1.7 \mathrm{~m}$, cylindric from the base; branches vertically dilated at their junction with the stem, unbranched; bark light greyish drab, rather pustulate with small, crowded or scattered, rounded lenticels; inner bark deep reddish fawn, thick, with prominent rays forked centripetally; wood pale brownish; inflorescences terminal on the branches.

Ardisia sp.- SFN 36609, Pontian, Johore; shrub $-2 \mathrm{~m}$; peduncle and pedicels pale pink; flower-buds cream-yellow; frequent by stream-sides.

\section{Myrtaceae}

Eugenia L.- In the wide sense of this genus, which is thus comparable with Ficus, Elaeocarpus and Macaranga, it becomes the largest genus of trees in Malaya. Henderson (1949) in his invaluable revision of the Malayan collections gives 138 species, of which some 55 occur in the Sedili region. They makc up a great deal of the smaller trees 3-30 m high in the forest, and there are no parts of the freshwater swamp-forest where they are not conspicuous. Henderson managed to identify most of the sterile material, for which I am indebted, because with so many species identification in the forest is often uncertain and fertile material is often not available. Concerning the distinction between Eugenia and Syzygium, which I retain as one genus, I refer to the recent analysis by Schmid (1972), who favours their separation; the difficulty then is that they cannot be enumerated from sterile material unless the actual species are known. A point which needs more thorough investigation is the character of the bark.

Bark-colour is more vivid after rain. Dry weather evaporates capillary water, admits air, and dulls, pales, or silvers the brighter hues. After rain white, grey, brown, black, pink, orange, and reddish trunks are conspicuous. In the swampforest various orange-brown trunks then stand out. For instance, the sharply buttressed trunks of Pometia with pinnate leaves, the stilt-rooted trunks of Dillenia with large dentate leaves, the hard trees of Tristania with scrolls of peeling bark, and the papery-flaky barks of certain species of Eugenia. Thus I was led to study the colour, scaling, fissuring, and ridging of barks and thc obvious features of the inner bark shown by the blaze. I have felt for many years that specific alliances in Eugenia cannot be determined without the bark-characters which need, of course, microscopic study for understanding. Henderson has included in his specific descriptions these gross bark-characters for nearly 80 species which I collected in Malaya. I give now a tentative grouping of these species, but I must warn against errors that can arise, particularly with the smooth barks of trees in the open, when the bark is coloured by lichens; they may be habitual infections but, when present, one should search for the uninfected bark in the forest. I distinguish 5 categories of bark, thus:-

1. Bark orange, orange-brown, or rufous brown (varying greyish, especially in young trees), papery-flaky with the flakes separable into translucent pieces (? 
one or a few cells thick); kelat gelam (kelat from the astringent bark, gelam from the resemblance with Melaleuca and the use of such bark for caulking and as a styptic).

$E$. attenuata (E. penangiana), E. cerina (E. punctulata), E. grata, E. kunstleri, E. oleina, E. papillosa, E. pauper, E. polita, E. subhorizontalis, E. spicata.

The species are widely separate in Henderson's account, as in those of others, but the question is whether this very remarkable bark is not more indicative of affinity than the floral marks.

Possibly there should come in this list, though placed in the next group 2, $E$. curtisii, E. ? pseudoformosa and Pseudoeugenia. I notice that species of group 1 often have stilt-roots.

2. Bark intensely pink-brown, red-brown, reddish, or rich grey-brown, in some cases fissured or scaly, not papery-flaky.

$E$. atronervia, $E$. castanea, $E$. chlorantha, $E$. conglomerata, $E$. curtisii, $E$. duthieana, $E$. dyeriana, $E$. filiformis, $E$. glauca, $E$. napiformis, $E$. nemestrina, $E$. oblongifolia (see group 3), E. palembanica, E. pseudocrenulata, E. pustulata (? group 3), E. ? pseudoformosa, E. rugosa, E. syzygioides (E. cymosa).

In this manifold group the species with grey-brown or rufous brown bark should be distinguished.

3. Bark pale pinkish, greyish pinkish, brownish pinkish, or brownish.

$E$. caudata, $E$. cumingiana, $E$. densiflora, $E$. fastigiata, $E$. grandis (see group 4), $E$. griffithii (see group 4 ), E. helferi, E. hemsleyana, E. leptostemon (see group 5), $E$. linocieroides, $E$. longiflora, $E$. microcalyx (see group 5), E. millsii, E. ngadimaniana, E. nigricans (see group 5), E. oblongifolia (see group 2), E. pachyphylla, E. pahangensis (? group 5), E. pearsoniana, E. polyantha (see group 5). E. pseudosubtilis (see group 5), E. ridleyi, E. salictoides, $E$. stapfiana, $E$. subdecussata, $E$. tahanensis (? group 5), E. tumida, E. virens, Eugenia sp. (SFN 30315).

I note that strongly stilt-rooted trees of $E$. longiflora in swamp-forest have rich orange-brown bark, though not papery-flaky, possibly the result of growth in deep shade.

4. Bark pale buff or greyish buff (distinctly yellowish as in Vitex pubescens).

E. flosculifera, E. garciniifolia, E. griffithii (see group 3), E. grandis (see group $3), E$. oblata, E. valdevenosa (see group 5), E. verecunda.

With the exception of $E$. flosculifera and $E$. griffithii, the inner bark of these species is dark purple-brown.

5. Bark pale grey, silvery, or whitish (not yellowish, pinkish, or brownish).

E. claviflora, E. cumini, E. kemamanensis, ? E. kiahii, E. leptostemon (see group 3), E. leucoxylon, ? E. microcalyx (see group 3), E. muelleri, E. nigricans (see group 3), E. perakensis, $E$. polyantha (see group 3 ), $E$. pseudoformosa (see group 2), E. pseudosubtilis (see group 2), E. pseudosyzygioides, $E$. valdevenosa (see group 4), Eugenia sp. (SFN 28995, 29319), Eugenia sp. (SFN 30300).

I note, in addition to these 5 groups the following features:-

a. Inner bark intense pink-brown, red-brown, purple, or vinaceous:-

E. atronervia, ? E. claviflora, E. duthieana, ? E. garciniifolia, E. glauca, E. grandis, E. hemsleyana, E. linocieroides, E. nemestrina, E. ngadimaniana, E. nigricans, $E$. oblongifolia, E. pahangensis var. fraseri, E. palembanica, E. pseudocrenulata, E. rugosa, $E$. valdevenosa, $E$. verecunda.

b. Inner bark or wood changing colour on exposure:-

i. Inner bark turning mauve or purple; E. kunstleri, E. polyantha, E. rugosa. 
ii. Inner bark and, usually, the sap-wood darkening to drab brown or fuliginous; $E$. curtisii, $E$. filiformis, $E$. microcalyx, E. pseudosyzygioides, $E$. pustulata.

In Table 1, there are listed species with buttresses (6), with stilt-roots (15), and with loop-roots (3).

As canopy-trees, over $30 \mathrm{~m}$ high, I noted in the Sedili region $E$. conglomerata and $E$. glauca of kapur-forest, and $E$. grandis, $E$. rugosa, and $E$. syzygioides of coastal forest. The swamp-forest of Singapore adds $E$. nemestrina, that of the Sedili E. garciniifolia.

E. cerina Henders. - tree $-23 \mathrm{~m}$, slightly fluted-buttressed or, in swamp-forest, with flattened arcuate stilt-roots $-1.7 \mathrm{~m}$ high and then with loop-roots $-45 \mathrm{~cm}$ high; bark orange to reddish brown, papery-flaky; inner bark pallid fawn to pale pinkish brown; as $E$. punctulata in Wayside Trees of Malaya.

This common riverside tree, known from its blunt ovate leaves, occurred on the Sedili Besar mainly from Lubok Pusing upstream; none occurred below K. Dohol. Yet it occurred also inside the main swamp-forest. Possibly it cannot tolerate much tidal influence.

E. cumingiana Vidal. - tree $-17 \mathrm{~m}$; in swamp-forest with slender stilt-roots $-1 \mathrm{~m}$ high, no buttresses; bark pinkish brown, slightly flaky and ridged; inner bark pale pinkish; heart-wood pinkish brown.

E. curtisii King.- tree $-17 \mathrm{~m}$, fluted at the base, bole $35 \mathrm{~cm}$ thick at $2 \mathrm{~m}$; bark pinkish fawn to pale rufous, very slightly papery-flaky, appearing smooth, with persistent leaf-scars; inner bark pale brownish, turning fuliginous on exposure; wood yellowish, fuliginous on exposure; frequent along the Sedili Kechil, not seen by the Sedili Besar.

E. garciniifolia King.- This large tree has great similarity with $E$. grandis. In my field-notes I wrote "? inland ancestor or derivative'. It flowered June-July in 1936.

$E$. grandis Wight:- I give here some notes which concern the thesis that trees without buttresses have, generally, tap-roots which are absent from buttressed trees. In October 1936 many big trees of this species were cut down and the stumps extracted along the Serangoon Road in Singapore. I examined thirty. The bases of the trees were $70-170 \mathrm{~cm}$ in diameter. As usual, they were slightly fluted over the main lateral roots which were very numerous; the flutings projected up to $30 \mathrm{~cm}$ from the trunk, and there were no true buttresses. None of the trees had a tap-root, even a vestige of one. The ground where the trees grew was raised on a slight hillside and was not stony or swampy; hence a tap-root could easily have developed. I conclude that $E$. grandis lacks both tap-root and buttresses. Compare $E$. garciniifolia with sharp spreading buttresses -2.7 high in the swamp-forest.

E. kunstleri King:- tree $-20 \mathrm{~m}$; bole $35 \mathrm{~cm}$ thick at $2 \mathrm{~m}$, often fluted at the base; crown much branched, bushy; bark pale rufous to orange-rufous, thinly and later rather thickly papery-flaky, slightly pustulate; inner bark pale pinkish or brownish buff, turning mauve or brown-ochraceous on exposure; wood pallid yellowish buff.

E. leptostemon (Korth.) Miq. - tree $-20 \mathrm{~m}$; bole $20 \mathrm{~cm}$ thick at $2 \mathrm{~m}$, often slightly buttressed; bark light grey to slightly pinkish fawn, slightly pustulate, smooth; inner bark pale pinkish fawn.

E. leucoxylon Miq.- tree $-17 \mathrm{~m}$; bole $26 \mathrm{~cm}$ thick at $2 \mathrm{~m}$, slightly fluted at the base, without stilts or loop-roots; bark light grey, smooth, entire, with persistent leaf-scars, eventually slightly fissured-flaky; inner bark fawn-drab.

E. longiflora (Presl) F.-Vill.- in swamp-forest with conspicuous, flattened, arcuate stilt-roots $-2.7 \mathrm{~m}$ high, but no loop-roots; flowering gregariously in March 1932. 
E. nigricans King:- tree $-23 \mathrm{~m}$; bole $40 \mathrm{~cm}$ thick at $2 \mathrm{~m}$, narrowly buttressed or fluted, occasionally with short stilt-roots; bark pale pinkish grey, very smooth, then slightly fissured flaky; inner bark deep purple-brown, thick, easily stripping, very astringent; heart-wood red-brown; like $E$. palembanica in bark, signified by the Malay name, often growing together.

E. papillosa Duthie:- This species, described in Wayside Trees of Malaya, was easily recognised from the reddish-orange bark and the large leaves. The arcuateflattened stilt-roots were usually up to $1.7 \mathrm{~m}$ high but in the swamps of Saracastreams in Kemaman I met trees with stilts up to $4 \mathrm{~m}$ high. Round the base of the tree there were abundant loop-roots $-45 \mathrm{~cm}$ high.

E. ? pseudoformosa King:- tree $-7 \mathrm{~m}$, with open sympodial crown; trunk $10 \mathrm{~cm}$ thick at $1.5 \mathrm{~m}$, without stilts or buttresses; bark fuscous rufous to orange-brown, scaly-flaky (not papery-flaky); inner bark pale pinkish fawn; leaves lanceolate, subsessile, with cordate base, rather large.

E. spicata Lamk:- tree $-10 \mathrm{~m}$, often less; bole $15-20 \mathrm{~cm}$ thick, often more or less horizontal, twisted and gnarled, subtriangular in cross-section; branches low and spreading; bark rufous orange, thinly papery-flaky; inner bark pale fawn, very thin.

This was a characteristic small tree of the river-side, with spreading and insinuating habit that led to its falling over. On the Sedili Besar it occurred from $\mathrm{Bt}$ Tiga upstream to Bagan Limau. Between Bt Tiga and Mawai it grew mostly where the Tristania-banks dipped into the mempisang-belt, whence it projected horizontally over the water. Between Lubok Pusing and Bagan Limau it grew in the rassau-belt and resembled in habit the scraggy specimens of $F$. microcarpa. It was a fire-fly tree and, with Gluta velutina, marked the river-banks at night. Concerning papers by Dr. and Mrs. Buck (1966, 1968), Haneda (1966) for New Guinea, and Bassot and Polunin (1967).

E. valdevenosa Duthie:- tree $-13 \mathrm{~m}$, without buttresses or stilt-roots; bark pale grey, often tinged yellowish or pinkish, smooth or very finely fissured; inner bark deep pink-brown, red-brown, or blood-red, not stripping; heart-wood pink-brown, very hard, not eaten by insects, rotting very slowly, valued locally for houses; common with Cratoxylon arborescens and Melanorrhoea wallichii in the swampforest, recognised from the pale bark with deeply coloured inner bark.

Eugenia sp.- SFN 37730, Pontian, Johore; tree $-27 \mathrm{~m}, 13 \mathrm{~m}$ to the first branch, very like $E$. grandis in shape, bark, and leaves; buttressed shortly $-70 \mathrm{~cm}$ high; bark brownish buff, flaky with thin, angular, rather large pieces, not fissured; inner bark pale brown.

Eugenia sp.-s.n. 6.8 .39 (as Eugenia A) Bt. Tinjau Laut, in kapur-forest, frequent at $250 \mathrm{~m}$ alt.; tree $-27 \mathrm{~m}$; buttresses $-70 \mathrm{~cm}$ high, sharp; bark warm brown (reddish brown from a distance), slightly creviced, barely scaly, appearing very smooth and even from a distance; inner bark intensely purple-brown.

Eugenia sp.- s.n. 7.8 .39 (as Eugenia A), Bt. Tinjau Laut, in kapur-forest, frequent at $250 \mathrm{~m}$ alt.; tree $-27 \mathrm{~m}$; buttresses slight; bark bright fawn-brown, slightly purplelenticellate, appearing smooth; inner bark pale pinkish brownish; wood yellowbrown.

Eugenia sp.- s.n. 6.8 .39 (as Eugenia B), Bt Tinjau Laut, in kapur-forest, frequent at $250 \mathrm{~m}$ alt.; tree $-27 \mathrm{~m}$ or more; buttresses very slight; bark fawn-brown, shallowly fissured, scaly with rather thin, oblong flakes, not ridged; inner bark pale pinkish brown; wood pinkish brown.

Pseudoeugenia singaporensis King:- tree $-13 \mathrm{~m}$; bole $20-25 \mathrm{~cm}$ thick at $2 \mathrm{~m}$, sometimes buttressed $-45 \mathrm{~cm}$ high; stilt-roots $-1 \mathrm{~m}$ high, slender, subarcuate, formed 
in very swampy ground; bark reddish brown, or rufous tawny, smooth then somewhat rugose-fissured and slightly flaky (not papery-flaky); inner bark pinkish fawn to deep purple-brown; wood pale pinkish fawn, very hard.

Tristania ? merguensis Griff.- tree $-30 \mathrm{~m}$; bole $30 \mathrm{~cm}$ thick at $1.5 \mathrm{~m}$, without buttresses or special roots; bark light greyish or brownish, fibrous-flaky, scaling off in small oblong pieces or in large scrolls, exposing the smooth, dark brown, new bark (deep red to almost blood-red on the twigs and branches); inner bark thin, pale yellowish; wood pallid yellowish; young leaves and twigs thinly tomentose with caducous ferruginous down. soon glabrous; leaves on saplings ( $-3 \mathrm{~m}$ high) and on coppice-shoots large, subsessile, auricled (as in $T$. subauriculata). - Plates 24,34 .

Though common at Jurong, Singapore, I never found fertile specimens and have not satisfactorily identified this tree. It did not occur in the forest on the Mandai Road and I saw only one sapling in the Sedili region and that was in the swamp-forest near Jason Bay. Thus it indicates for the Jurong forest a distinct phytogeographical position, emphasized by the occurrence of Mangifera aff. parvifolia, Alseodaphne? pendulifolia, and the tree tentatively referred to Hymenocardia. I have seen saplings of $T$. Inaingayi on Penang Hill which appeared to be identical with the Jurong plant. Compare, however, $T$. pontianensis, which I took to be the same as the Jurong plant.

The trees at Jurong were mostly up to $20 \mathrm{~m}$ high, with many saplings of all sizes, but occasionally there were big trees entering the canopy at a rate of $1(-2)$ per hectare. Trees of all sizes were spindly, the trunk dividing into a few, steeply ascending, repeatedly dividing, and almost fastigiate branches, giving a broken and rather flat-topped crown of distinctive appearance. It was the form of a tree that could just penetrate into the canopy but was unable to make a commanding dome. The trunks of old trees could be mistaken for those of Cratoxylon arborescens (smaller opposite leaves, red gum in the bark).

T. pontianensis Henders. - tree $-23 \mathrm{~m}$, without buttresses; bark buff yellowish to greyish, rather scaly and fissured, seldom peeling in scrolls except on the twigs with orange-brown new bark; old leaves withering red; calyx dull rusty reddish tomentose; petals yellowish white; stamens and ovary pale yellow; flowers faintly fragrant of vanilla.

This was, perhaps, the commonest tree in the peat-swamp forest at Pontian, Johore. There was a general flowering in early July 1939. On seeing this plant at Pontian, I took it to be the same as T. ? merguiensis at Jurong, though the bark of the Pontian trees did not peel in such obvious scrolls and the twigs were not deep red-brown. If not identical, the two must be very close.

T. ? pontianensis Henders.- SFN 31939, mile 15 Jemaluang Road; tree - 35 m; bole $60 \mathrm{~cm}$ thick at $2 \mathrm{~m}$. cylindric from the base or very slightly buttressed; bark pale greyish white with oblong pinkish streaks and patches of new bark, very smooth and soft like soft leather, the old greyish white or greyish buff bark peeling in thin scrolls $30-120 \mathrm{~cm}$ long, collecting round the base of the trunk; crown sympodial with a few large ascending limbs and heavy, dark green foliage of leathery and more or less erect leaves; pedicels and calyx green; petals white; stamens yellow; disc pale yellowish; style green; flowers with a slight scent of honey.

This collection was referred to $T$. pontianensis by Henderson but it differed in the bark and in the green calyx. It may be the same as Tristania sp. (Corner s.n. 31.12.34); both were trees of hillock-forest, not of the peat-swamp.

$T$. sumatrana Miq.-This is the characteristic tree of the raised river-banks along the Sedili rivers; it is described in Wayside Trees of Malaya. The orange trunks curving over the river collect at the base the scrolls of old bark. Young trees have 
silvery grey bark before it peels off to reveal the orange mature bark. The yellowish green crown was always flecked with scarlet from the withering leaves. The tree did not occur in the flat swamp-forest. It flowered twice a year, June-August and November-January or February.

Tristania sp.- s.n. 31.12.34, mile 13 Jemaluang Road, scattered canopy-tree in hillock-forest on laterite soil; tree $-40 \mathrm{~m}$; bole $60 \mathrm{~cm}$ thick at $2 \mathrm{~m}$, cylindric from the base; trunk forking into two, rather flattened and twisted, equal branches at $20 \mathrm{~m}$ above ground (as in $T$. sumatrana); crown with rather open and candelabraappearance (as in $T$. ? merguiensis); bark pale pinkish white to pale pinkish fawn (not orange), very smooth, entire, then the old bark peeling in long scrolls collecting at the base of the trunk, the new bark appearing as a piece of naked wood; inner bark thin, pallid yellowish white, green just below the surface (even at the base of old trees); heart-wood pinkish brown.

This handsome tree must be near to $T$. pontianensis but is distinguished by the smooth pink bark. My notes say 'cf. SFN 24967', the notes on which I have been unable to trace.

\section{Ochnaceae}

Brackenridgea hookeri (Pl.) A. Gray:- tree $-20 \mathrm{~m}$; bole $22.25 \mathrm{~cm}$ thick at $2 \mathrm{~m}$, often twisted and flanged at the base of leaning trees, not truly buttressed; bark rufous fawn, shallowly and closely rugose-fissured, becoming slightly flaky in small oblong pieces; inner bark rich pinkish brown; sap-wood yellow, thin; heartwood pinkish brown.

\section{Olacaceae}

Strombosia maingayi (Masters) Whitmore:- tree $-23 \mathrm{~m}$; bole $18-35 \mathrm{~cm}$ thick at $2 \mathrm{~m}$, rather slender, cylindric from the base, no pneumatophores; bark very thin (paper-thick), dull greyish brown to dull chocolate brown, entire then flaking in rather large roundish pieces leaving faint flattened scars (as in Ochanostachys but not so flaky), slightly roughened with small scattered lenticels 1-2 mm wide; inner bark light brownish, $-6 \mathrm{~mm}$ thick, green just below the surface (even in old trees), stripping easily; wood pale yellow, heart-wood grey brown to pinkish brown, very hard but splitting easily, the trunk splitting on felling.

SFN 29264 differed in the dull reddish brown, slightly tuberculate, and entire bark with the inner bark pinkish brown and dull reddish (not green) below the surface. The tree was $10 \mathrm{~m}$ high and probably immature.

\section{Orchidaceae}

The Sedili list of c. 115 species is certainly incomplete because I seldom had time to search for orchids. I gathered merely what I came across in flower or, if of unusual growth. I brought living plants to the Singapore Botanic Garden where my lamented friend C. E. Carr had initiated the alcohol-collection as he did also at Kew with Mr. Summerhayes. Few dried specimens were made. I stayed twice with Carr at his bungalow at Tembeling in Pahang and made expeditions with him to S. Cheka, S. Teku, Fraser's Hill and Brastagi in Sumatra. Thus I learnt much about Malayan orchids, and he made several trips with me to the Sedili river, Gunong Panti, and Jurong. I did not collect fully the orchids at Mandai Road in Singapore. The poor orchid-flora at Pontian, Johore, was real because both Henderson and I collected all that we could find.

The Malayan orchids have been revised by Holttum $(1953,1957)$, and I have followed his nomenclature. 


\section{Oxalidaceae}

Sarcotheca laxa (Ridley) Knuth var. hirsuta Veldk.- spindly shrub or tree $-5 \mathrm{~m}$; stem 6-7 $\mathrm{cm}$ thick at $1.2 \mathrm{~m}$, cylindric from the base; bark rufous fawn, finely creviced, with persistent leaf-scars, otherwise smooth and entire; inner bark pinkish fawn, rich red-brown below the dead bark; wood pinkish white; leaves subglaucous beneath, young leaves pink; sepals pink; petals rose-red; filaments and ovary pale greenish, anthers yellow; fruit $18 \times 14 \mathrm{~mm}$ (living), ellipsoid, pulpy, rose-red to purple, then black.

$S$. laxa appears to be endemic to the Malay peninsula and this variety to the Sedili region. Var. laxa is said to reach $23 \mathrm{~m}$ but var, hirsuta, of which I saw many specimens, is very much smaller. It was a graceful little tree, tolerant of shade, that I raised from seed in the Singapore Botanic Garden but with many others it was lost after the war.

\section{Palmae}

Except for nipa, with its counterpart in rassau, palms were not as conspicuous in the swamp-forest as pandans. I have no accurate assessment and I do not know of a satisfactory method. I certainly did not pay sufficient attention to the thickets of rotans and asarn paya (Salacca) for which I record but one species. The main palms were nipa, nibong, bayas, serdang, palas, rotan, asain paya, and Pinanga. Concerning nibong I note the remark by Vincent (1962) that it 'occurs in pure stands covering considerable areas, e.g. Kuala Sedili F.R.'. As observed by Polak (1933), nibong occurs with nipa in the boundary between mangrove and freshwater swamp. Concerning Cornera, if this genus is distinct from Calamus, I note that it has been misconstrued by Whitmore in his Palms of Malaya (p. 50) for he gives two, not three, species in Malaya; see Furtado (Gdns' Bull. Singapore 14, 1955, 518).

\section{Pandanaceae}

For the identifications in this family I am indebted to Dr. B. C. Stone (19671971, especially his papers in the Malayan Nature Journal vol. 19 and 21). It was soon evident on my excursions to the Sedili Besar that Pandanus was important because there was no part of the swamp-forest where its species did not occur. Collection of these massive plants is difficult and identification is hampered by the fragments suitable for herbarium-sheets, though I had no difficulty in recognising most species in the forest from their habits of growth. Hence I devoted much time to their study, with copious field-notes and photographs. My material was studied, apparently, by Holttum and St. John, whose works I know only through the references in Stone's papers; if I had been informed, my notes would have been made available.

Freycinetia angustifolia Bl.- flowering March-April, fruiting June, on the Sedili Kechil; syncarps $2-2.5 \times 0.6-0.8 \mathrm{~cm}$, pink to dull orange red, soft and mucilaginous when ripe.

Pandanus Stickm.- Stone records c. 55 species from the Malay peninsula, many of very local occurrence. For the Sedili region I record 16 species which fall vegetatively into the following 5 categories:-

1. with stout branching trunks; $P$. atrocarpus (swamp-forest), and $P$. dubius and $P$. odoratissimus of the sea-coast.

2. with thinner, or slender, of ten sparingly branched trunks; $P$. helicopus, $P$. affinis, $P$. malayanus, $P$. recurvatus, $P$. scortechinii, and $P$. yvanii.

3. apparently stemless, tufted, with long leaves; $P$. kaniii (freshwater swampforest), $P$. corneri (in the mangrove and nipa stretches of the river). 
4. short tufted species in dwarf thickets; $P$. echinodermops, $P$. parvus, $P$. pentodon.

5. epiphytes; $P$. alticolus, $P$. epiphyticus.

To judge from the occurrence of $P$. corneri, $P$. dubius, $P$. echinodermops, $P$. epiphyticus, $P$. kamii, $P$. pentodon and $P$. scortechinii, the affinity of the pandanflora is with that of Borneo, though many Bornean species are absent, just as many species of west and north Malaya. Pandans are not exterminated during timbercutting and the Sedili region still offers the opportunity for their ecological study, particularly in regard to the establishment of seedlings and the development of thickets by branching in a sort of soboliferous manner. Ripe fruits seemed generally to occur in the drier periods from June to August. Pollination may be by beetles which frequent the fragrant male inflorescences (? the female) or by wind, as in the case of $P$. helicopus in which the pollen detaches in clouds. There is, therefore, the possibility of hybridisation and the need to examine sterile specimens in the forest. Pandanus illustrates well the evolution of leptocaul species both in the forest undergrowth and as epiphytes such as $P$. alticola.

$P$. atrocarpus Griff.- This common species of greater size than any other Malayan pandan seems not to occur in Borneo where $P$. gibbsianus and $P$. obovoideus are allied (Stone 1968b).

$P$. corneri Kanehira:- This is easily recognised from the tufts of erect sword-like leaves without the broken pendent tip of so many others and its habitat in brackish tidal swamps. It is known from south Malaya, Singapore, Sarawak, and north Borneo (Stone 1971).

$P$. dubius Spreng.- solitary, $-13 \mathrm{~m}$ high; trunk much branched, rather thorny, sappy, soft; stilt-roots $-2 \mathrm{~m}$ high, stout; leaves $1.2-2 \mathrm{~m} \times 14-18 \mathrm{~cm}$; bracts yellow; female head solitary, fragrant, full of beetles.

Scattered trees occurred in the coastal forest south of $\mathrm{Tg}$ Sedili Kechil and they seem to be the only instance of the species on the mainland. It is known from P. Tioman, P. Tulai, P. Chibeh, and P. Tenggol (off Dungun). This small arc appears to be the western limit of the species which extends castwards in increasing abundance and becomes the commonest sea-shore pandan in the Solomon Islands (Stone 1968). The roots are figured in my Life of Plants plate 12c.

$P$. echinodermops Holtt. et St. John:- short pandan forming thickets of low flopping stems becoming leafless for heights of $1-1.7 \mathrm{~m}$; leaves $70-130 \mathrm{~cm}$ long, not broken, not glaucous beneath, with obtuse tip; syncarps solitary or 3-4 on an erect stalk, red; more or less immersed at high tide, submerged in floods.

$P$. epiphyticus Martelli:- This pandan used to be the most remarkable sight on the road from Kluang to Mersing. It stood erect on the branches of most large trees, obliquely or variously hanging and upcurving, as if a contortionist. The forest has now been felled or extracted and one must travel far off the road to see it. It did not occur in the main region of the Sedili or on G. Panti, but at the bridge at the 17th mile on the Jemaluang Road it was abundant; this appears to have been its southern limit in Malaya. It is common in Sarawak where it grows also on coastal rocks and cliffs, but I never saw it on any part of the east coast of Malaya or on the islands off Mersing, Pahang and Trengganu (Stone 1971). When I spoke of its distribution to the late F. N. Chasen, curator of Raffles Museum, he drew my attention to the similar distribution of the squirrel Sciurus nigrovittatus johorensis and that of some tree-rats, which may distribute the seeds.

Young plants begin with a creeping stem, fixed by adventitious roots to the branch or trunk of the host, and then later the erect free stems develop. Some become top-heavy and lean over, even fall off (to judge from the débris in the 
forest), but those which manage to hold on curve up and re-establish themselves with more roots.

$P$. helicopus Kurz:- This species likes the low muddy flats by tidal rivers or flooded areas (as at Tasek Bera) and seems intolerant of brackish water. Above Danau, on the Sedili Besar, it was restricted to scattered thickets. I never saw such large specimens as occur in Sarawak where the stems grew to $17 \mathrm{~m}$ high.

P. kamii B. C. Stone:- tufted in dense thickets, apparently stemless, with very long leaves; stems $-50 \times 8-11 \mathrm{~cm}$, decumbent, much branched, silvery white; leaves 5-8 $\mathrm{m}$ long, $8-10 \mathrm{~cm}$ wide (when flattened), unbroken or the old leaves broken about $\frac{1}{4}$ of their length from the tip, not glaucous, the leaf-base orange brown; syncarp solitary, massive, trigonous-cylindric, more or less pendent, ripening red.Plate 5.

This is the common pandan that forms massive thickets in the freshwater swamp-forest. I had assumed that it was $P$. immersus Ridley, though immersed only in exceptional floods, but Stone (1971) distinguishes the two species.

P. malayanus B. C. Stone:- short pandan with slender stems $-5 \mathrm{~m}$ high, sparsely branched, not in thickets; leaves $35-45 \mathrm{~cm}$ long on young stems, up to $90 \mathrm{~cm}$ on mature stems, rarely broken, subglaucous beneath, the midrib smooth; fruits solitary, pendent: (now treated as a variety of $P$. militaris).

On the river-front there is the stout $P$. helicopus. Within the swamp-forest, by the small streams and in the muddy hollows, there is this slender species which I took to be $P$. militaris. According to Stone (1968b), P. malayanus is a problematic species in need of further study.

$P$. odoratissimus Linn.f.- The name of this common coastal pandan has at last been settled (Stone 1967a); it has been called $P$. fascicularis and P. tectorius. It has a thornless variety, occasional on sea-coasts, which may have been the origin of plants cultivated in villages for mat and basket work; it is P. spurius Miq. (Stone 1968a). I am doubtful of SFN 32763 which occured in the forest far inland in the Sedili region.

$P$. parvus Ridley:- dwarf pandan; leaves $40-70 \times 7-10 \mathrm{~cm}$, short, broad, with wavy edges and down-pointing tip, glaucous beneath or not (SFN 32477).

$P$. pentodon Ridley:- short pandan forming thickets; stems $-2 \mathrm{~m}$ long, $2-3 \mathrm{~cm}$ thick, decumbent, mostly prostrate on the mud, the ends more or less erect for 30-60 cm, whitish, scarcely thorny, concealed by the leaves; leaves c. $120 \times$ $1.7-2 \mathrm{~cm}$ (when flattened), more or less glaucous beneath, midrib smooth, not broken but drooping; syncarp solitary, erect, swathed in bracts.

This resembles in habit Scirpodendron, which does not grow in these upper and swifter streams. I noted for SFN 29391 that it had simple, bifid, or quadrifid stigmata.

P. scortechinii Martelli:- stem -2 m high, $1.5 \mathrm{~cm}$ thick, weakly erect, often flopping and uncurving, sparingly branched, with slender stilt-roots at the base; leaves not glaucous beneath; syncarps $1-3$ on a spike, frequent; male plants never encountered.

This was a common plant in the freshwater swamp-forest. Young stilted specimens resembled the stouter pandans in miniature. Stone referred here SFN 29238 , but I am not at all certain. Though frequent in the swamp-forest it rarely fruited, unlike typical $P$. scortechinii. It resembled more $P$. helicopus with the more slender habit of $P$. yvanii; I thought it might have been one or other of these two species developed in shade. My notes on SFN 29238 are as follows:- stems $-7 \mathrm{~m}$ high, gregarious, appearing solitary but probably soboliferous, not developing 
thickets, unbranched or the older stems sparingly branched near the top; leaves $-150 \mathrm{~cm}$ long, eventually broken; syncarp solitary, pendulous.

P. yvanii Solms:- stems $-5 \mathrm{n}$ high, $2 \mathrm{~cm}$ thick, light ochre-yellow then chocolate brown in the leafless part, frequently branched with straggling and often drooping branches, rather stoutly spiny in the lower part of the trunk; aerial roots $2-2.5 \mathrm{~cm}$ thick, rather stout, with very shaggy root-cap, very spiny, descending perpendicularly; leaves $70-120 \times 1.8-2 \mathrm{~cm}$ (when flattened), not broken, not glaucous, midrib with few spines in the basal half of the leaf; syncarps solitary, pendent, ripening orange-brown.

This species occurred in small inlets of the rasau-belt, especially on the Sedili Kechil, and by streams and pools in the forest with $P$. pentodon. It is clearly less light-demanding than $P$. helicopus.

\section{Polygalaceae}

Xanthophyllum Roxb.- I have noted that the young leaves are pale green on emergence in $X$. affine, $X$. curtisii, and $X$. maingayi, but purplish pink in $X$. obscurum.

$X$. affine Korth.- tree 4-13 m; bole cylindric from the base; bark fuscous grey, entire, slightly pustulate with small round lenticels, with faint leaf-scars; inner bark dull ochraceous straw-colour, stripping; leaves subglaucous beneath, with a gland at the base of the lamina on each side of the midrib; flowers pale yellow; fruit ochre.

This little tree was very common on the banks of the Sedili Kechil. On the Sedili Besar it occurred on the Tristania-banks and inside the swamp-forest. There was always a gregarious flowering in June, but some trees flowered in October.

$X$. ? ellipticum:- Jurong, Singapore; tree $-17 \mathrm{~m}$; bole $23 \mathrm{~cm}$ thick at $1.7 \mathrm{~m}$, fluted at the base, with large superficial roots spreading horizontally for some distance and tending to become loop-roots; bark dull pinkish brown, with a very thin greyish superficial layer cracking into very small irregular flakes, not tuberculate, with faint leaf-scars; inner bark pale pinkish brown, not very thick, not stripping; wood dull ochraceous fawn with pinkish brown heart-wood; roots with the same thin greyish superficial flaky layer, but with vivid reddish pink inner bark; crown thin, scant, composed of a few erect subfastigiate branches; rare, merely two specimens seen side by side.

X. pulchrum King:- SFN 29321; treelet $-4 \mathrm{~m}$, with a few cylindric stilt-roots $-45 \mathrm{~cm}$ high; bark light greyish, finely creviced longitudinally, with scattered, white, scarcely prominent, lenticels; inner bark and wood pale yellowish.

$X$. wrayi King:- treelet $-4 \mathrm{~m}$; sepals cream-buff, the two lateral sepals pale lilac; petals white, the two upper with yellow spots near the base; flowering in February.

\section{Rhizophoraceae}

For a modern and excellent account of mangrove trees, see Flora Malesiana ser. 1, vol. 5, 1958, 429-493. Apart from noting the occurrence of the species, I did not pay detailed attention to the mangrove in the Sedili region. The Rhizophoraforest near Kuala Sedili Besar stood over $35 \mathrm{~m}$ high and was practically uncut in 1939.

Anisophyllea R. Br.- This genus has been placed in Lecythidaceae, Rhizophoraceae, and in its own family. It has the one-seeded fruit with hypocotylar embryo of Barringtonia and from this tendency the viviparous embryo of Rhizophora may have originated. 
A. corneri Ding Hou:- Tree $-10 \mathrm{~m}$, without buttresses or stilts; bark fawn-brown, smooth, entire; inner bark brownish yellow, reddish below the dead outer bark, thin; wood yellowish tan, hard.

The trees on the Sedili were small, but Ding Hou records them up to $23 \mathrm{~m}$ high from other parts of Malaya, where the species is endemic. It is Aniosophyllea sp. in Wayside Trees of Malaya, p. 125.

Carallia brachiata (Lour.) Merr.- tree $-23 \mathrm{~m}$; bole cylindric from the base, without stilts; bark rather rufous brown, uneven from the lighter brown, corky-tumid lenticels 3-6 mm wide, often in longitudinal rows; inner bark brownish, thin; wood somewhat rufous brown, with well-marked, wide and long medullary rays.

This is $C$. lucida of Wayside Trees of Malaya. Ding Hou describes the species as a large tree occasionally with stilt-roots (Flora Malesiana ser. 1, 5, 1958, 485, f. 31.32). I never saw such trees in the Sedili region where the species was frequent in the wetter parts of the swamp-forest. However, smaller trees $-13 \mathrm{~m}$ high were common in the peat-forest at Pontian, Johore, and they frequently had stilt-roots up to $30 \mathrm{~cm}$ high. SFN 28677 and 28678 are referred to Pellacalyx saccardianus in the identification List 4 (Flora Malesiana), but to judge from my field-notes this cannot be so. I did not record this species of Pellacalyx from the Sedili region.

Pellacalyx axillaris Korth.- This small tree has no stilt-roots or buttresses, but it develops small loop-roots ( $\lambda$-roots) up to $25 \mathrm{~cm}$ high, as pneumatophores in the swamp-forest.

\section{Rosaceae}

Parinari corymbosa Bl-- tree $-33 \mathrm{~m}$; bole $55 \mathrm{~cm}$ thick at $2 \mathrm{~m}$, slightly flutedbuttressed; bark greyish white, flaking in fairly large, irregular, angular pieces separating from below upwards, eventually almost smooth and becoming pustulate with minute scattered lenticels; inner bark pink-brown to red-brown, persistently green just below the dead outer bark, not stripping; wood very hard.

This was one of the big dominant trees in Eugenia grandis forest. There was a general flowering in June-July 1934. The species is also called Maranthes corymbosa (Kostermans 1965b).

$P$. costata (Korth.) Bl. - trce $-30 \mathrm{~m}$; bole $35 \mathrm{~cm}$ thick at $2 \mathrm{~m}$, scarcely buttressed; bark silvery drab white to greyish, slightly pimply with small lenticels $1 \mathrm{~mm}$ wide, becoming irregularly cracked and slightly flaky; inner bark orange-brown, thick, rather fibrous-sclerotic, with a strong smell of milk (as durian-flowers), not stripping; wood pallid yellowish, with large vessels, very hard.

$P$. nannodes Kosterm. - tree $-20 \mathrm{~m}$; bole $25 \mathrm{~cm}$ thick at $2 \mathrm{~m}$, cylindric from the base; bark greyish fuscous, finely and closely tesselately cracked, not rugose or pustulate or scaly; inner bark dark reddish brown, rather thick, with a smell of bugs, the outer bark brittle; wood pallid dull reddish brown throughout, very hard and heavy; petals white; filaments pinkish lilac; anthers yellow.

This species had been known as $P$. asperulum until the new identification by Kostermans (1965a); it was altered in the same year into Cyclandrophora nannodes (Kosterm.) Kosterm. et Prance as a split from Parinari (Kostermans 1965b). He refers SFN 34712 (not 37412) to C. excelsa (Jack) Kosterm.

Pygeum Gaertn. - This genus has been reduced to Prunus by Kalkman (1965). The microscopic structure of fruit and seed should be studied for this step will be a considerable simplification. I have retained Pygeum for the specimcns are thus filed in the Singapore Herbarium. 
P. lainpongum Miq.- tree $-10 \mathrm{~m}$; bark fuscous, smooth, entire, with persistent leaf-scars; inner bark pallid pinkish white, very thin, stripping; fruit green when ripe, in Feb. 1935.

\section{Rubiaceae}

Aulacodiscus premnoides Hook.f. - tree $-8 \mathrm{~m}$; bole $8 \mathrm{~cm}$ thick at $2 \mathrm{~m}$, cylindric, without stilts; bark fawn-drab, entire, slightly roughened and uneven; inner bark pale pinkish fawn, fairly thick; wood pale tan brownish.

This tree resembles saplings of Anthocephalus cadamba. The long spreading branches, which are themselves unbranched or but sparingly, occur only in the upper metre of the stem. The inflorescences are in the axils of the old leaves and on the bare parts of the branches.

Canthium didymum Gaertn.- SFN 32258 (Scudai, Johore); tree -7 m; primary branches decussate; secondary branches regularly alternate, one at a node, along the applanate leafy sprays; flowers $8 \mathrm{~mm}$ wide, green with yellow anthers, many galled; leaves dull dark green; bark pale to dark grey, slightly creviced, not scaly; inner bark pale yellowish white; wood pale yellowish tan.

Ixora L.- I refer to my detailed account of this genus in Malaya (Corner 1941) and to the descriptions in Wayside Trees of Malaya. The species flowered gregariously in the Sedili region February-March and again September-October.

I. concinna Hook.f.- tree $-12 \mathrm{~m}$; bark fuscous brown, pustulate with tumid brown lenticels $2-3 \mathrm{~mm}$ wide, becoming finely rugulose, transversely creviced, and rather tesselately scaly; inner bark pale pinkish tan; wood pale buff.

I. grandifolia Zoll. et Mor.- This common small tree was especially abundant by the river between Mawai and S. Dohol. It flowered in February and about July. I have a record of gregarious fruiting in October.

I. lobbii King et Gamble:- My collections represented forms 7 and 8 of my notes on Ixora (Corner 1941), with the large flowers. The bark was chocolatebrown and cracked.

Morinda rigida Miq.- SFN 26111, Jurong, Singapore; lofty climber -25 m long; twigs leafy for a considerable length, the leaves not bunched; wholly glabrous; bud-scales thinly waxy, often with 1-2 small orange-waxy secretions at their tips; lamina $7-12 \times 2.6-5 \mathrm{~cm}$, elliptic, shortly and obtusely acuminate, gradually attenuate to the narrowly cuneate base, thinly coriaceous; lateral veins 7-11 pairs, more or less invisible in the living leaf, or faintly on the upperside; midrib pale pinkish on both sides of the young leaves, yellowish in mature leaves, raised on the upperside; petiole 10-18 $\times 2-3 \mathrm{~mm}$; umbels terminal, composed of (1-) 3-4 heads, 1-2 fruiting; heads 16-22 mm wide, composed of 7-9 flowers; peduncles of heads $10-20 \times 2-2.5 \mathrm{~mm}$; calyx-tubes projecting $2-5 \mathrm{~mm}$; fruit-heads yellowish white with dark green sutures.

Mussaendopsis beccariana Baill.- tree $-27 \mathrm{~m}$; bole fluted-buttressed 1.5-3.5 m high, the buttresses $-35 \mathrm{~cm}$ wide and spreading over the lateral roots, with many small roots descending into the soil from the main laterals; without tap-root, stilt-roots, or pneumatophores; crown open, often irregular and ill-formed, the trunk dividing into 2-3 main, ascending, often twisted and flattened, branches, rarely with monopodial trunk; bark light greyish brownish, smooth, then thinly flaky in small rectangular pieces; inner bark pale yellow, rapidly fuliginous on exposure, $-12 \mathrm{~mm}$ thick, rather soft; wood pale brown.- Plates 25,34 .

This distinctive tree of the freshwater swamp-forest is distributed from Perak to Singapore, Riouw, Sumatra and Borneo. 
Nauclea maingayi Hook.f. - tree $-20 \mathrm{~m}$; bole cylindric from the base; bark fuscous grey to blackish, slightly transversely fissured, pustulate with subelongate lenticels more or less in rows; inner bark light pinkish, turning reddish on exposure.

N. subdita (Miq.) Merr.- This grew into a small upright tree 3-4 m high, but in places up to $7 \mathrm{~m}$, with spreading horizontal branches. On the Sedili Besar a few specimens occurred just above K. Dohol, but it was an upstream sun-loving plant. It became very abundant from Bagan Limau up to the bifurcation of the river into S. Ampang and S. Sedili. It was conspicuous where the banks shallowed into the water and it developed, apparently as a first coloniser, where mud was accreting. Thus it took the place of Barringtonia conoidea (putat) above the tidal limit. It was profuse in shallow open back-waters, and was well known as gedemba, though apt to be confused with Neonauclea.

Neonauclea sp.- SFN 32985, S. Dohol. frequent on the river-banks; shrub or treelet $-5 \mathrm{~m}$; leaves withering scarlet; often confused by Malays with $N$. subdita.

Petunga roxburghii DC. - tree $-20 \mathrm{~m}$; bole $25 \mathrm{~cm}$ thick at $2 \mathrm{~m}$, without buttresses or stilts; bark greyish brown, finely longitudinally fissured, slightly flaky, easily stripping; inner bark pale brownish; common under Eugenia grandis in the sandy forest behind Casuarina, the leafy branches appearing as pinnate leaves, well known as membras. - Plate 26 .

P. venulosa Hook.f.- bush or small tree $-7 \mathrm{~m}$; stem $7 \mathrm{~cm}$ thick at $1.5 \mathrm{~m}$; bark fuscous brown to pallid greyish, narrowly fissured-flaky in thin, elongate, rather shaggy pieces; inner bark pale yellowish brownish, thin; wood pale yellowish brownish.

Randia sp.-SFN 28954, S. Berassau near the Jemaluang Road, 6.2.35; epiphytic bush at c. $10 \mathrm{~m}$ high on a small tree in the swamp-forest; stem short, c. $30 \mathrm{~cm}$ long, clasping the host-trunk with lateral roots and sending one long root perpendicularly to the ground (as in an incipient strangling fig); branches 5-6, more or less horizontal, up to $4 \mathrm{~m}$ long, spreading freely, 1-3 basal nodes often with scaleleaves, the leaves subtending the inflorescences also as scale-leaves or much reduced in size; inflorescences axillary, singly at every second node and only from the upperside of the branch; flowers white, turning dull cream to pale ochraceous yellow, lasting several days, opening one or two at a time but eventually all the flowers of the inflorescence open together.

I met the one specimen of this remarkable plant, which I took at first sight to be an epiphytic fig such as $F$. obscura. In the position of the inflorescence it resembled $R$. anisophylla and $R$. scortechinii.

Tarenna Gaertn.- I refer to my notes on this genus (Corner 1939).

T. mollis Wall.- bark rich chestnut-brown, peeling in very small pieces; inner bark pale greenish, deeper green just below the surface; wood white; surprisingly abundant in parts of the swamp-forest, especially along muddy streams.

Timonius wrayi King et Gamble:- tree $-17 \mathrm{~m}$; bark fawn-yellowish, rather closely rugose- fissured and transversely rugulose, pustulate with rather prominent lenticels more or less in vertical rows; inner bark pallid pinkish ochraceous tinged brownish; wood fawn ochraceous throughout.

\section{Rutaceae}

Tetractomia tetrandra (Roxb.) Craib:- tree $-30 \mathrm{~m}$; bole $35 \mathrm{~cm}$ thick at $2 \mathrm{~m}$, cylindric from the base or very slightly buttressed; main lateral roots superficial, forming irregular loops, pustulate with lenticels, and developing knee-roots as pneumatophores $-45 \mathrm{~cm}$ high; crown narrow, interrupted, often very small, ? monopodial; bark cream-buff or buff-white, inclining to greyish buff, even, entire, 
becoming slightly pimply with lenticels, with faint leaf-scars; inner bark creamy or ochraceous buff, thick, homogenous, green just below the surface, sourly aromatic; wood yellowish, hollow; leaves more or less opposite, with geniculate petiole.Plates 7, 36.

This tall slender tree was not difficult to recognise from the meagre crown, the pale bark with sourly aromatic smell, and the leaves. It had been known as $T$. holttumii Ridley. At Pontian, Johore, it was frequent in the peat-forest and all the trees had the pneumatophores.

\section{Sabiaceae}

Meliosma Bl.- This genus has been revised in great detail by Beusekom (1971). M. pinnata (Roxb.) Walp. ssp. ridleyi (King) Beus. - tree $-17 \mathrm{~m}$, fluted-buttressed at the base; bark pinkish brownish grey, slightly creviced-fissured, with persistent leaf-scars and short transverse rows of more or less transversely elongate lenticels; inner bark pinkish brown; wood pinkish brown; twigs and petioles fulvous hairy; petals white; anthers orange; ovary with rose-red hairs towards the apex; apparently $\mathrm{K} 4 \mathrm{C} 3 \mathrm{~A} 2 \mathrm{G} 1$ in falling phyllotaxis at the floral apex.

M. sumatrana (Jack) Walp.- treelet $-5 \mathrm{~m}$; leaves erect, very oblique to the stem; leaflets fleshy-coriaceous, pale green; fruits ripening yellow.

\section{Sapindaceae}

Allophylus L.- See Corner (1939a) and Leenhouts (1967) for this intricate and wide-spread species.

Dimocarpus Lour.- Leenhouts (1971) has revised the conception of this genus as distinct from Nephelium, and includes in it the Malayan mata kuching $(N$. malaiense) with the longan as one large species $D$. longan Lour. Yet I venture to say that no Malay would mistake the mata kuching for the longan, and no one would pay the same price. My own impression of the living trees in Malaya was that specifically they were distinct, but I have not studied their complexity in Thailand, Indochina, and China.

Lepisanthes Bl.- This genus has been revised by Leenhouts (1969) and enlarged to cover Aphania, Erioglossum, and Otophora. Thus it embraces 24 species of the Old World tropics. The common little L. tetraphylla can often be recognised from its limp white new leaves.

Pometia Forst.-In his treatment of this genus, Jacobs (1962) makes $P$. alnifolia of the swamp-forest a forma alnifolia of the river-side and wide-spread $P$. pinnata. I am not sure of the reduction to the status of forma, and the matter should be investigated in the field. The following are my notes on $f$. alnifolia.

Big trees reach $35 \mathrm{~m}$ high in the canopy of the swamp-forest and they have sharp, spreading and undivided buttresses $-2.3 \mathrm{~m}$ high; occasionally they may have slight stilt-roots. The trunk and branches have characteristic thickened arcs which encircle a third or less of the stem and give an annulate appearance. These arcs are present in the wood as bands with a knobbly surface against the bark. They may correspond with leaf-scars. The trunk divides into two or three main branches which build a fairly dense sympodial crown. Smaller trees with slender trunks are commoner in the forest and may be the ascendent saplings. The Chinese woodcutters said that the timber was hard but would not split.- Plates 9, 36.

Xerospermum sp.- s.n. 13.4.35, Sedili Besar; tree $-20 \mathrm{~m}$; bole $20 \mathrm{~cm}$ thick at $2 \mathrm{~m}$, cylindric from the base; bark dark fuscous brown, smooth, entire, or slightly tuberculate from lenticels; inner bark reddish brown. 


\section{Sapotaceae}

There have been so many changes in generic concepts in this family that it is becoming difficult to follow specific nomenclature. No two specialists seems to agree, and I begin to wonder if there is not a single genus Sapota.

Ganua motleyana (de Vr.) Pierre- tree $-47 \mathrm{~m}$, generally not more than $35 \mathrm{~m}$; bole cylindric, dividing into 2-3 main ascending limbs, with rather open, sympodial crown; knee-roots as in Bruguiera, generally copious, lenticellate, with thick white latex; bark pale grey to greyish white, pustulate with brown lenticels $2-4 \mathrm{~mm}$ wide, with hoop-marks, not fissured or scaly.- Plates 7, 34 .

I may have confused more than one species under this name. Thus SFN 26158 (Jurong, Singapore), which I took to be G. motleyana, is named Madhuca sp. by F. S. P. Ng in the Singapore Herbarium. If there is a complex of two or three species, it is not clear how they differ ecologically.

Madhuca hirtiflora H. J. Lam:- tree $-13 \mathrm{~m}$; bole $13 \mathrm{~cm}$ thick at $2 \mathrm{~m}$, slightly fluted at the base; bark greyish fuscous, rather pallid, slightly tuberculate with tumid, shortly elongate, lenticels, otherwise entire; inner bark pinkish, with fairly thick, white latex; wood pale pinkish yellowish; crown compact, dense, regular, with Terminalia-branching; general flowering in January-February 1935; referred to Ganua in the Tree Flora of Malaya 1 (1972) 398.

M. sessiliflora v. Royen:- small tree 2-7 m, flowering almost as a shrub; bark dark chocolate-brown to dull rufous fawn, slightly tuberculate with small lenticels, otherwise entire, with persistent leaf-scars; inner bark pinkish brown; latex white, rather watery; wood pallid yellowish; young leaves and twigs woolly with fulvous caducous hairy down; corolla white; calyx fulvous hairy; common locally; general flowering May-June 1935.

M. tomentosa $\mathrm{H}$. J. Lam:- small tree 3-12 m, flowering almost as a shrub; bark light grey, slightly pustulate with rather large, brown lenticels 3-5 mm wide; inner bark pinkish fawn; leaves glabrous, chartaceous; corolla white; flowering in February.-SFN 21330 as the type of $\boldsymbol{M}$. paludosa v. Royen.

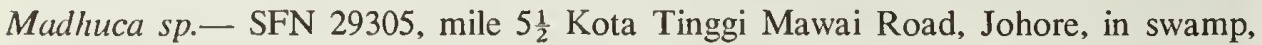
10. 5. 35 ; tree $-20 \mathrm{~m}$; bole $28 \mathrm{~cm}$ thick at $2 \mathrm{~m}$, slightly buttressed $-45 \mathrm{~cm}$ high; bark fuscous, rather uneven and rough, somewhat fissured, not pustulate; inner bark pinkish brownish; latex white, rather thin; heart-wood pale fuscous brown; fruits green (ripe), rather large.

Palaquium hexandrum (Griff.) Engl. - tree $-50 \mathrm{~m}$, sharply and steeply buttressed $-2 \mathrm{~m}$ high; bark light brown, becoming light grey and dippled-flaky with rather large scales (as in Intsia); latex white.

I mistook the trunk of this tree at first sight for that of merbau. A tree in the swamp-forest at Mandai Road, Singapore, had a few cylindrical stilt-roots, but I did not meet with the species in the swamp-forest of the Sedili region.

P. ridleyi King et Gamble:- SFN 36699, Pontian, Johore; tree $-40 \mathrm{~m}$; buttresses $-1 \mathrm{~m}$ high, thin, prominent, spreading; trunk slotted with hollows (as in Adina); crown dense, dark green; bark fuscous brown, smooth, then slightly cracked longitudinally and breaking into small inconspicuous oblong scales; inner bark pale pink, thick; latex white; pedicels and sepals green; corolla white; flowers faintly fragrant of vanilla, often galled.

The peculiarity of the trunk is not mentioned in the Tree Flora of Malaya vol. 1,; yet I saw it in several trees in the peat-swamp at Pontian where it was not common. 
P. xanthochymum Pierre:- tree $-35 \mathrm{~m}$, occasionally $-45 \mathrm{~m}$; bole $70-80 \mathrm{~cm}$ thick at $2 \mathrm{~m}$; trunk dividing into several large ascending limbs, with small spires of foliage on the copious twigs; crown convex, even, fairly compact; stilt-roots $1-7 \mathrm{~m}$ high, much flattened vertically, widely arching, branching copiously near the ground, often producing bundles or mats of small roots lying on the mud and floating on the water, without loop-roots or distinctive pneumatophores; bark dark grey to greyish brown, slightly to distinctly fissured, flaky; inner bark pink or reddish, fairly thick, stripping; latex white, copious, very sticky.- Plates 13, 17, 35.

This common tree of the freshwater swamp-forest took two forms. In the mempisang-belt it developed copiously the bundles or mats of small roots over the mud and to a certain extent the stilt-roots. Then, in the swamp-forest with seasonal flooding, the stilt-roots were much more evident, reaching even to $7 \mathrm{~m}$ high while the root-bundles were often not formed. I have illustrated the manner of development of the stilt-roots in my Life of Plants pl. $12 \mathrm{~b}$.

Palaquium sp.- s.n. 9.9.34, mile 11, Jemaluang Road, Johore; tree $-23 \mathrm{~m}$; bole $30 \mathrm{~cm}$ thick at $3 \mathrm{~m}$; stilt-roots $-3 \mathrm{~m}$ high, flattened, arcuate then descending almost vertically, rather fastigiate; bark fuscous fawn, lenticellate-fissured; inner bark pallid yellowish; latex white, in drops from the blaze, smeary, opaque, not copious.- Plate 20.

One sterile tree was found by a stream at the base of a hillock about $7 \mathrm{~m}$ from where the stream dilated in to the swamp-forest. The leaves were rather large and resembled those of Dillenia to which genus Mohamad Nur was convinced that it belonged. The specimen was placed at the end of Sapotaceae as "? Pouteria malaccensis'.

\section{Simaroubaceae}

Quassia indica (Gaertn.) Nooteboom:- This is a characteristic little tree of freshwater and brackish creeks from Madagascar through Indo-Malesia to the Solomon Islands, but in the Malay peninsula it seems to be known merely from the east coast of Johore and south Pahang. It can be mistaken for Inocarpus, which has red sap in the bark. The species has been known for 170 years as Samadera indica until this genus was reduced to Quassia by Nooteboom (1962).

\section{Staphyleaceae}

Turpinia sphaerocarpa Hassk. - tree $-20 \mathrm{~m}$; bole $35 \mathrm{~cm}$ thick at $2 \mathrm{~m}$; buttresses -1.7 m high, short, sharp, steep; no special roots; bark light grey, becoming closely and deeply rugose-fissured, not flaking; inner bark pale yellow, with abundant ochraceous sclerotic particles, fairly thick; wood yellowish white; flowers pale creamy yellow; leaves opposite with 3-5 leaflets.

The Sedili specimens were identified as $T$. laxiflora Ridley by v.d. Linden but are not mentioned as such in the Flora Malesiana ser. 1, vol. 6, 1960, 57. Whitmore has annotated them as $T$. sphaerocarpa with which I agree for they were originally identified as $T$. latifolia Ridley, now reduced to $T$. sphaerocarpa.

\section{Sterculiaceae}

Heritiera Ait.- Kostermans (1959) has reduced Tarrietia to Heritiera.

H. simplicifolia (Mast.) Kosterm. - tree $-30 \mathrm{~m}$; bole $85 \mathrm{~cm}$ thick at $2 \mathrm{~m}$; buttresses $-2.7 \mathrm{~m}$ high, wide-spreading, thin; bark reddish brown to light rufous, rugosefissured, the dead greyish bark flaking off in oblong pieces; inner bark pinkish to rich orange-brown, rather closely and finely laminate, dry, hard, $-8 \mathrm{~mm}$ thick, 
stripping; heart-wood pale rufous brown; leaflets $3-5$, even on trees $-23 \mathrm{~m}$ high, or solitary; crown dense.

H. sumatrana (Miq.) Kosterm.- similar to $H$. simplicifolia but leaflets 5-7, twigs and petioles brown hairy; seen only in the swamp-forest.

Leptonychia Turcz.- The position of this genus in Sterculiaceae is doubtful because the seeds have the construction of Elacocarpaceae or Tiliaceae (Corner, Seeds of Dicotyledons, 1976). Compare Paragrewia in Tiliaceae (R. Seshagiri Rao, J. Bombay Nat. Hist. Soc. 51, 1953, 671).

L. glabra has greenish flowers and green capsules dehiscing to show the two black seeds with red arils.

Pterospermum javanicum Jungh.- This large tree can be recognised among the strongly buttressed by the brownish undersides of the leaves and the vivid magentapink bacony streaks in the blaze. It becomes one of the dominant trees in Eugenia grandis forest. It flowered generally about April and again about October.

Scaphium macropodum (Miq.) Beumée:- tree $-40 \mathrm{~m}$; bole $50-70 \mathrm{~cm}$ thick at $2 \mathrm{~m}$; buttresses 1-3 m high, 1-2 m wide, spreading; no special roots; bark fuscous rufous, shallowly rugose-fissured, slightly flaky, often with abundant, brown, rather tumid lenticels $2-4 \mathrm{~mm}$ wide, the bark on the upper part of the trunk and on the main branches often more deeply coloured; inner bark pinkish with broad brownish rays, up to $18 \mathrm{~mm}$ thick, deep blood red beneath the dead outer bark, but this colour disappearing from old trunks, the inner bark stripping and the outer breaking ofl; flowering February-June, ? mostly in May, ? not yearly; leafchange in August 1939 on Bt. Tinjau Laut.

A tree over $30 \mathrm{~m}$ high was blown down and uprooted in the swamp-forest near the Kota Tinggi Mawai road. Besides buttresses up to $1.5 \mathrm{~m}$ high, it had two tap-roots, one barely $1.7 \mathrm{~m}$ long, stout and with a few lateral roots, and the other much longer, stouter, and penetrating deeply into the soil with many lateral roots. Thus this tree of the swamp-forest has buttresses and not one, but two, tap-roots in defiance of the thesis that buttressed trees lack tap-roots. Moreover in this wet habitat it is deciduous.

Sterculia bicolor Mast.- tree $-27 \mathrm{~m}$, deciduous, without buttresses; bark greyish buff, slightly flaky in round patches showing the brownish new bark, tuberculatelenticellate; inner bark rich pink-brown, with hard rays.

This species shed its leaves about March-April when the fruits had ripened. It occurred on the Sedili Besar from c. 2 miles above Bt Tiga upstream and chiefly just behind the mempisang-belt.

S. macrophylla Vent.- tree $15-23 \mathrm{~m}$; bole $30-40 \mathrm{~cm}$ thick at $5 \mathrm{~m}$; buttresses 1-2.2 m high, branched; crown rather flat, with wide-spread limbs; bark pinkish grey to pale rufous, silvery grey in old trees, slightly fissured, with rather tumid lenticels, with persistent leaf-scars; intuer bark pinkish brown, with bacony streaks in the blaze, $-15 \mathrm{~mm}$ thick, green just below the surface, stripping; wood yellowish white.

This tree is deciduous. In the forest on the Mandai Road, Singapore, where it was not infrequent, trees shed their leaves 12-17 April 1933 and developed pinkish new leaves from 24 April onwards. I illustrated this species in my Life of Plants plate 24.

$S$. cf. scortechinii King:- tree $-13 \mathrm{~m}$; bole $18 \mathrm{~cm}$ thick at $1.3 \mathrm{~m}$, cylindric from the base; bark silvery buff, pustulate with scarcely crowded, brownish lenticels 2-3 mm wide, with faint leaf-scars; inner bark reddish brown, thick, blaze without bacony streaks; leaves brownish beneath; calyx pale pink, internally rose-red. 


\section{Styracaceae}

Styrax crotonoides Clarke:- tree $-13 \mathrm{~m}$, bole cylindric; bark greyish pinkish fawn, very smooth and even, then slightly creviced, with faint leaf-scars; inner bark rufous fawn, thick, firm; leaves pale rusty scurfy beneath.

\section{Symplocaceae}

For the identification of specimens of Symplocos I am indebeted to H. P. Nooteboom, and refer with pleasure to his monograph (1975).

Symplocos barringtoniifolia Brand:- tree $-17 \mathrm{~m}, 18 \mathrm{~cm}$ thick at $2 \mathrm{~m}$, bole cylindric; bark dull grey-brown, often pale, smooth, then closely and finely dotted with small, dark brown, lenticels 1-2 mm wide, leaf-scars faint; inner bark pale pinkish or brownish; wood yellowish throughout; fruits greenish white (nearly ripe), slightly pulpy; leaves rather fleshy, coriaceous, not glaucous.

S. rubiginosa Wall.- tree $-10 \mathrm{~m}$, with cylindric bole; bark light greyish buff, smooth, even or slightly pustulate with very small lenticels; inner bark pallid yellowish white.

Symplocos sp.- s.n. 3.2 .35 (as tree A); tree $-23 \mathrm{~m}$; bole $35 \mathrm{~cm}$ thick at $2 \mathrm{~m}$, cylindric; bark greyish to light brownish grey, rather faintly and coarsely tuberculate with lenticels, without leaf-scars; inner bark pallid wood-tan, rather thick, smelling of coconut-milk; wood cream-white throughout; branches subverticillate in threes; leaves pale green.

The specimen was sterile. The trunk resembled that of Lithocarpus but lacked the hoop-marks or leaf-scars.

\section{Taccaceae}

I refer to the monograph by Drenth (1972). The Malayan species are mostly common and easily recognised, but have been little collected.

Tacca leontopetaloides (L.) O.K.- This has usually rather yellowish green leaves, stem, and flowers. A variety at Jason Bay, near S. Diman, had the stem and petioles closely striped blackish purple with similar mottling between the stripes; the flowers were green with purple filaments to the stamens; the dissection of the leaf was also different.- Plate 31 .

\section{Theaceae}

Adinandra Jack: - I rely on the monograph by Kobuski (1947).

A. corneriana Kob.- tree $-10 \mathrm{~m}$, without buttresses or stilts; bark dull greyish fawn, closely tuberculate with scarcely prominent lenticels 2-4 mm wide; inner bark pinkish brown: wood drab yellowish throughout; leaves hairy, serrate; pedicels and sepals pale brownish cream; petals cream-white; apparently endemic to the Sedili region.

A. sarosanthera Miq. - tree $-27 \mathrm{~m}$; bole $35-50 \mathrm{~cm}$ thick at $2.5 \mathrm{~m}$; buttresses $-1.7 \mathrm{~m}$ high in swampy ground, sharp, but absent from trees in drier ground; bark fuscous chocolate, finely and shortly fissured-creviced, with persistent leaf-scars, slightly pustulate with small lenticels towards the base of the trunk; inner bark pinkish fawn, rather gritty; wood white, rather soft, splitting; twigs rather strongly 4-angled, in some cases almost winged, rather flattened; crown rather dense, dark, irregular, the leaves more or less upturned; flowers pendent, solitary, axillary; petals creamwhite, the corolla dropping off with the stamens; fruit $18-25 \mathrm{~mm}$ wide, ripening brown.- Plate 20. 
It is not clear from my field-notes if this tree flowers seasonally or is more or less in continuous flower and fruit. I collected both flower and fruit from the same trees in February 1935 and noted that there were three rather large trees in flower, scattered along a distance of half a mile. This is A. macrantha and, as in Wayside Trees of Malaya, A. larnponga.

Gordonia singaporeana Wall.- tree $-27 \mathrm{~m}$; bole $25-30 \mathrm{~cm}$ thick at $2 \mathrm{~m}$, cylindric from the base or slightly fluted-buttressed, without stilts; crown usually scraggy with more or less erect branches; bark greyish buff, then tesselate with blackish fibrous pieces peeling off to show the pale new bark, becoming slightly fissured; inner bark deep red-brown, rather fibrous, thick.- This bark seems characteristic of the genus.

Ploiarium alternifolium (Vahl) Melchior:- This is called Archytaea vahlii in Wayside Trees of Malaya; it is no more alternifoliate than a mango-tree. In the Sedili region it was a frequent small tree of the mempisang-belt with copious slender stilt-roots set as in a besom, up to $2.7 \mathrm{~m}$ high. I never saw by the Sedili the large trees, up to $25 \mathrm{~m}$ high, as occurred in the peat-forest at Pontian, Johore. There these large trees much resembled Tetramerista, which lacks stilt-roots and has much thicker bark.- Plates 11, 40.

A short article by Wyatt-Smith (1951) records a study of a natural and almost pure stand of $A$. vahlii in Ayer Panas Forest Reserve, Malacca. It was swampforest with Alstonia spathulata and Cratoxylon arborescens. The trees of $A$. vahlii were $10-13 \mathrm{~m}$ high. In the course of 16 years, and in spite of thinning, many of these trees died. He concludes that the trees reached generally a maximum girth of $30-45 \mathrm{~cm}$, and that they represented a seral stage from swamp-forest.

Ternstroemia bancana Miq.- tree $-20 \mathrm{~m}$; bole $25 \mathrm{~cm}$ thick at $2 \mathrm{~m}$, cylindric from the base; bark silvery greyish buff, or slightly pinkish, tuberculate with fairly crowded, tumid, brown lenticels $3-5 \mathrm{~mm}$ wide, more or less in vertical rows, without leaf-scars; inner bark lurid rufous ochraceous, fairly thick; wood white; sepals green; petals cream-white then pinkish distally; filaments and ovary creamwhite; pollen brilliant orange.*

Tetramerista glabra Miq.- SFN 36696, Pontian, Johore; tree -33 m; bole cylindric; loop-roots $-45 \mathrm{~cm}$ high, not copious; crown rather narrow, with Terminaliabranching; bark fawn-brown, fissured, slightly scaly in small pieces, the bark of old trunks deeply rugose-fissured (as in Ploiarium but with broader ridges); inner bark pale pinkish white, thick, dry, spongy, soft, fibrous; inflorescences green; flower-buds dull brownish crimson; sepals and petals green, tinged crimson on the outside; frequent at Pontian but not found in the Sedili region or in Singapore.

\section{Thymelaeaceae}

Aquilaria beccariana v. Tiegh.- The Sedili specimens are cited by Ding Hou in the Flora Malesiana ser. 1, vol. 6, 1960, 13. A. beccariana is there given as a tree -20 m high but the Sedili trees, of which I saw many and cultivated two in my garden in Singapore, were sparingly branched and spindly little trees. I figured the fruits in my account of the durian theory under the name of Gyrinopsis $s p$. (Ann. Bot. Lond. n.s. 13, 1949, 367).

A. malaccensis Lamk:- The Sedili collections are A. malaccensis, not A. microcarpa which differs in flower, fruit and seed, such as are usually not available in the forest. For $A$. inicrocarpa, Ding Hou cites only Singapore for the Malay peninsula. I note here that, as an experiment, I stripped the bark off a tree of A. ? microcarpa in the forest on the Mandai Road, Singapore, from almost groundlevel up to a height of $10 \mathrm{~m}$, thus exposing all the wood in the lower half of the

* All these collections from the Sedili region have now been transferred to a new species T. corneri H. Keng, Gdns' Bull., Singapore, 29 (1977) 143. 
trunk. In a few weeks new bark began to grow in countless spots all over the bared wood, apparently from the ends of the medullary rays, and after 7-8 months the bark was wholly renewed and sealed without any evident damage to the tree, which had remained in full leaf throughout the period.

Phaleria capitata Jack:- small tree $-5 \mathrm{~m}$; bark dark greyish brown, smooth, very tough, stringy, stripping; inner bark white; wood white, fibrous; flowers white, fragrant, in masses on small tubercles on the trunk and branches, almost from ground-level.

This was wild round Jason Bay in the swamp-forest and in the Eugenia grandis forest, though I never saw it in the forest up either of the Sedili rivers. It illuminates a point in phytogeography. The distribution of the species is given by Ding Hou (Flora Malesiana ser. 1, vol. 6, 1960, 21, f. 7); it is roughly a parabola opening north west with Luzon, Waigeo Island, Celebes, Java, the west coast of Sumatra, and Ceylon as the periphery, and Jason Bay as an eccentric focus. Thus it bears on the problem of the Riouw pocket from a south easterly direction. When I found the species at Jason Bay, I was aware of its importance for I was familiar with the genus from a plant cultivated on the Bandstand Hill in the Singapore Botanic Garden. Ding Hou suggested that the collections from Jason Bay might have come from plants escaped from cultivation, but the species was not cultivated in the Malay peninsula, for which reason it was omitted from my Wayside Trees of Malaya; there were none in the villages round Jason Bay. The mistake has been copied and extended in the Tree Flora of Malaya (vol. 2. 384) with the remark "known in Malaya from only two collections'. There are four in the Singapore Herbarium and, of course, the number of collections is not a measure of natural abundance. I saw many specimens of $\boldsymbol{P}$. capitata in the forest, as I could have informed the author of this mistake when he was working at Cambridge. I grew plants of $P$. capitata from seed collected at Jason Bay, but whether they have survived in the Botanic Garden I do not know. Compare the distribution of Aquilaria beccariana, Inocarpus, and Quassia indica.

\section{Tiliaceae}

Brownlowia Roxb.- Kostermans (1961) has revised the genus and discovered the name-change for $B$. lanceolata.

Grewia L.- I still use this genus in the wide sense, which Hutchinson employed in his Genera of Flowering Plants vol. 2 (1967). Others prefer to split off Microcos L. on floral grounds which to me are subgeneric. I think that seed-structure will be critical.

G. blattaefolia Corner:- bark dark rufous brown, rather pustulate with lenticels in more or less vertical rows, with persistent leaf-scars, eventually slightly creviced; inner bark pale pinkish; wood pinkish white, soft.

G. hirsuta (Korth.) Kochummen:- tree $-17 \mathrm{~m}$, without buttresses or stilts; bark fuscous brown, slightly uneven and bumpy, entire; inner bark pinkish brownish, thick; wood white, turning brownish on exposure.

Pentace Hassk. - The genus has been revised by Kostermans (1964).

$P$. corneri Kosterm.- tree $-57 \mathrm{~m}$; bole $70 \mathrm{~cm}$ thick at $3 \mathrm{~m}$; buttresses $-1.2 \mathrm{~m}$ high, rather slight and low, none in some trees over $30 \mathrm{~m}$ high; bark fuscous rufous, narrowly and rather distantly lenticellate-fissured, the lenticels often discrete and rounded, eventually rugose-fissured in the lower part of the trunk and slightly scaly with small oblong pieces; inner bark bright pink-red, the dead outer bark pink-brown; wood pallid brown, sap-wood yellowish; leaves very glaucous beneath.

Several huge trees of this species were found in the kapur-forest on a hillock just south of S. Kayu Ara on the Jemaluang Road. They were sterile and the specimen was collected from a branch knocked off in felling kapur; I fear that all 
this forest has been destroyed, but the species has been collected also in Borneo; there is no other collection from the Malay peninsula. Three of the four Bornean collections were sterile but fruiting material was obtained in Sarawak in the month of March (? year). It seems that the species may flower as rarely as $P$. triptera, and that it is a relic of the land-connection between Borneo and Malaya.

P. triptera Mast. - tree $-47 \mathrm{~m}$; buttresses $-1.7 \mathrm{~m}$ high, prominent; bark rich orangebrown, fissured-flaky; inner bark bright pinkish red; fruiting in July 1939, 1940, but no fruits seen in previous years from 1930; the crown entirely pink from the 3-winged fruits.

Pentace sp.- s.n. 8.2.35, mile $13 \frac{1}{2}$ Jemaluang Road, by stream in hillock-forest; tree $-17 \mathrm{~m}$; bole $15 \mathrm{~cm}$ thick at $2 \mathrm{~m}$, cylindric from the base; bark chocolate-brown, smooth, entire, scarcely pustulate, with persistent leaf-scars; inner bark pinkish fawn, with numerous narrow white bacony streaks in the blaze, closely concentrically laminate near the cambium; leaves glaucous beneath, 3-veined, few lateral veins, rather diamond-shaped, with geniculate petiole; not mentioned in Kosterman's monograph, ? not Pentace.

Schoutenia accrescens var.- SFN 28681, 29006; tree $-17 \mathrm{~m}$; bole $18 \mathrm{~cm}$ thick at $2 \mathrm{~m}$, cylindric from the base or slightly fluted; bark rufous brown, slightly tuberculate with scattered and rather longitudinally elongate lenticels $2-4 \mathrm{~mm}$ wide, slightly flaky, not or scarcely fissured; inner bark deep pinkish brown, fairly thick, stripping; heart-wood pinkish brown, hard; leaves powdery white beneath at first, then glabrescent and pale green (not brown); flowers with light yellow perianth turning pinkish; ovary and stamens cream-yellow; disc dull ochre; fruiting calyx greenish white, 5 -lobed, $2.5-3 \mathrm{~cm}$ wide.

This tree, distinguished by the leaves not being coppery brown beneath but powdery white when young, was common about mile 12 on the Jemaluang Road. I did not see it elsewhere. In February 1935 several trees were changing leaf with pale green (not pink) new leaves and they were flowering at the same time. I had collected fruit from these trees in January 1935. SFN 28681 is labelled S. mastersii var. glabra Henders. ms. The variety was not understood by Roekmowati-Hartono (1965).

S. glomerata King:- bark fuscous rufous, faintly and closely pimply, otherwise entire; inner bark pinkish brown, rather thick, reddish beneath the dead outer layer.

\section{Urticaceae}

Poikilospermum suaveolens (Bl.) Merr.- The stems of this robust climber, and probably those of $P$. cordifolium, were used on the Sedili Besar for the purpose of keeping fire. The stems were chopped into lengths of c. $50 \mathrm{~cm}$, decorticated by hitting with a piece of wood or the back of a parang, sun-dried, tied into bundles with the slender stem of a climber, and stored in the floating houses on the river. Such a dried piece of stem, when lit at one end and placed with the other slightly elevated, would smoulder slowly until it had completely burnt up; when the smouldering end was blown upon it would glow brightly and ignite paper, straw or chaff. This means was more reliable than matches in the damp situation of these houses. The vessels in the wood are large and long and must serve as air-passages for the continuous smouldering. Thus, upstrearn from Mawai, this climber was not so abundant by the river.

\section{Verbenaceae}

Avicennia L.- I did no: study the genus in any detail. For an account of the structure and seedlings of four Malayan species I refer to Tan and Hsuan Keng (1969). 
Clerodendron ? brevifolium Ridley:- finely villous; leaves elliptic, crenulate, longstalked; inflorescence as a long racemose panicle.

C. buchanani Roxb.- shrub - $2 \mathrm{~m}$ high, thick and woody at the base, all parts with a foetid smell (like Premna); lower leaves with the lamina $-30 \times 25.5 \mathrm{~cm}$ and petioles $-23 \times 0.5 \mathrm{~cm}$; inflorescence terminal, as a corymbose panicle with immersed growing point, flowering above, fruiting below, with green axis and dull red branches and pedicels; calyx dull red, becoming fleshy, pinkish purple, and reflexed in fruit, but only slightly enlarged; corolla rose-red, fading pale pink, the petals turned up and the stamens turned down; filaments pink, anthers dull purplish; style dark rose-red, with darker stigma; fruit vivid blue-green.

Vitex clarkeana Gamble:- shrub or small tree $-8 \mathrm{~m}$ high, often more or less horizontal over the water's edge; corolla white with mauve lip; fruit often covered with green powder (as if Pleurococcus).

This small tree occurred on the muddy banks behind the nipa-belt and then upstream in the mempisang- belt to the limit of normal tides at Lubok Pusing on the Sedili Besar. Occasionally it occurred with Tristania, possibly on banks that had slipped into the river, but it was also abundant by the muddy stream S. Kayu in the swamp-forest. It would flower gregariously about July.

$V$. ovata Thunb.- Concerning this common and highly characteristic pioneer of coastal dunes, I argued that it was not V.trifolia L. (Corner 1939b). More recently v. Steenis has argued that it should be called $V$. trifolia ssp. littoralis (Blumea 8, 1957, 516). What we need to know is whether the two will hybridise and whether such hybrids occur naturally.

\section{Zingiberaceae}

I have followed the account of the Malayan species by Holttum (1950), though name-changes must, alas, follow as genera are more critically reviewed (Burtt and Smith 1972). For Globba I have followed the work of Lim 1972).

\section{Unidentified trees}

Corner s.n. $31.12 .34(5)$; tree $-7 \mathrm{~m}$; bole $10 \mathrm{~cm}$ thick at $1.7 \mathrm{~m}$; bark rather warm brown, finely shallowly and irregularly fissured, with fine short transverse crevices, faintly and distantly tuberculate; inner bark pallid pinkish; no latex or gum; leaves excentrically peltate; in hillock-forest. ? Euphorbiaceae, ? sapling.

Corner s.n. 21.1 .35 (7, near Mawai, as Tree A); $22 \mathrm{~m}$ high; bole $25 \mathrm{~cm}$ thick at $2 \mathrm{~m}$, cylindric from the base; bark fuscous to dark greyish brown, flaky in small oblong pieces $2-5 \times 1.5 \mathrm{~cm}$, slightly rugose-fissured, slightly shaggy; inner bark pale brown, stripping easily, rather fibrous and thin; wood yellowish, soft and coarsely fibrous; flowers greenish in terminal panicles on the bare twigs; in swampforest near the river.

Corner s.n. 8.2.35 (5, in kapur-forest, as Tree A); $20 \mathrm{~m}$ high; bole $25 \mathrm{~cm}$ thick at $2 \mathrm{~m}$; stilt-roots $-1.2 \mathrm{~m}$ high, flattened, arcuate, with dark madder-brown bark; bark rather chocolate-brown, drab, faintly and sparsely pustulate with small lenticels 1-2 mm wide, more or less in rows, slightly flaky in thin angular pieces, not fissured; inner bark pallid ochraceous, rather sclerotic; would yellowish throughout; leaves simple; kedondong.

Corner s.n. 15.4 .35 (1, in swamp-froest, as Tree A); $30 \mathrm{~m}$ high; leaves small dark green, opposite. ? Cratoxylon. 
Corner s.n. 12.5 .35 (1, in swamp-forest, as medang 1): $20 \mathrm{~m}$ high, bole cylindric from the base; bark fuscous grey, narrowly and irregularly rugose-fissured, rough, subtuberculate, rather rugged, not scaly or lenticellate; inner bark ochraceous, closely granular with small sclerotic particles; wood yellowish, hard; leaves opposite; inflorescence as terminal panicles; fruit ripening blue.

Corner s.n. 6.8 .39 (as Tree A, Bt Tinjau Laut); $20 \mathrm{~m}$, bole cylindric from the base; bark light greyish brownish, slightly dippled scaly, pustulate; inner bark thick, intensely rich pink; wood yellowish, hard; crown with a complete leaf-change, the new leaves appearing before all the old had fallen, veins impressed on the upper side of the leaf.

\section{Pteridophyta}

My list of c. 70 species is incomplete. My collections were named by Holttum but the names in critical genera were provisional, and I have had no opportunity to consult my specimens, if any were kept. I have perused Holttum's monograph on Malayan ferns (1954) and extracted what was germane but few details of collections or particular localities are given for the lowlands. I have followed his nomenclature but it is clear from recent papers that much of this will change for the Flora Malesiana; and in the welter of synonymy arising from the splitting and re-arrangement of genera, the ecologist will be bewildered. Unfortunately there are very few Malay names to serve as a stand-by. The late Mr Alston prepared a list of species of Selaginella which I have not been able to consult and no species is recorded, in consequence, for the Sedili region.

One fact emerges. It is that the swamp-forest is not a prime place for pteridophytes; primitive species or genera are lacking or poorly represented; most are advanced and particulate. The fact makes one wonder what became of the palaeozoic fern-flora in the swamps. Did it become epiphytic on the primitive flowering plants or, with pteridosperms, was it exterminated? Nipa and piai raya are still dumb. 


\section{Part VII. Malay names in the Sedili region}

akar china Loeseneriella macrantha

a. kait kait, a. kekait Roucheria, Uncaria

a. laka Dalbergia parviflora

a. letop Grewia umbellata

a. lundong Poikilospermum suaveolens

a. mempening Pericampylus incanus

a. setahun Poikilospermum suaveolens

a. subong 'che minah Lucinaea morinda akit Rhizophora apiculata

antoi Cyathocalyx see also bunga antoi apa apa Neesia

api api Aeschynanthus, Loranthaceae, Avicennia

ara Ficus (especially stranglers)

a. jantong Ficus annulata

a. lumut Premna trichostoma asam damat Grewia fibrocarpa

a. garam Garcinia nervosa

a. gelugor Garcinia atroviridis

a. kelugi, a. paya Salacca

bachang utan see machang utan

bakau Rhizophora

b. laut Rhizophora mucronata

bakong Crinum asiaticum

b. ulu Hanguana

balek adap Mussaenda glabra

balau Shorea exelliptica, S. foxworthyi, S. materialis

baru baru laut Thespesia

baru baru (bebaru) sungei Hibiscus tiliaceus

batai Peltophorum pterocarpum

batang buring Iguanura

batu Parinari corymbosa

bayas Oncosperma horridum

bebuas Premna obtusifolia

bebulan Endospermum

bebuloh Pellacalyx

bebuta Cerbera, Excoecaria beki Neoscortechinia

belukap Rhizophora mucronata

beluntas Pluchea

bernban Donax

bengka, bengku Ganua motleyana, (Palaquium xanthochymum)

bengkai, bengkal Nauclea maingayi

bengkulang Heritiera simplicifolia

b. daun tujoh $\mathrm{H}$. sumatrana

bengong Parishia? insignis

berangan Castanopsis inermis

b. babi Lithocarpus

berembang Sonneratia caseolaris

beremi, beremiu Herpestis

b. laut Sesuvium

bereh, beri Lithocarpus bennettii,

L. elegans

beringin Ficus binnendijkii

bertam Eugeissona tristis

bintangor Calophyllum

b. batu C. sclerophyllum

b. bunut C. macrocarpum

b. jangkang $\mathrm{C}$. sclerophyllum

b. sempang $\mathrm{C}$. soulattri

bruas Garcinia hombroniana

buah pelir kambing Sarcolobus, ?

Finlaysoniana obovata

b. saminyak Sapium indicum

b. saputeh Gomphandra quadrifida

b. ulat Lophopetalum multinervium

buas buas Premna obtusifolia

bulan bulan Endospermum

buloh Schizostachyum

buloh buloh Pellacalyx

bunga antoi Cyathocalyx pahangensis

b. ekor mera Asclepias curassavica

bungor Lagerstroemia ovalis

bunot Parishia pubescens

busing Bruguiera sexangula 
buta buta Cerbera, Excoecaria butun Barringtonia asiatica

chekri Dianella

chempedak, c. utan Artocarpus integer

c. ayer Artocarpus dadah, A. kemando chenderai Grewia tomentosa

chengai, chengal Balanocarpus heimii chengpok Aralidium pinnatifidum chenkri Cassytha filiformis cheperai Gnetum gnemon var. brunonianum

chepura Garcinia bancana cheret budak Garcinia bancana, Stemonurus scorpioides chingam Scyphiphora

dalu api Aeschynanthus, Loranthaceae damar hitain Shorea resina-nigra $d$, mata kuching S. sumatrana daun payong $\mathbf{J}$. Teysmannia d. tapah kudah Ipomoea pes-caprae dedahruang Anaxagorea delek Memecylon demundi Vitex ovata dendulang Eugenia cerina dulang dulang Eugenia cerina dungun Brownlowia, Heritiera littoralis durian daun Durio singapurensis

ekor gajah Grammatophyllum

e. kuching Limnophila erecta

e. mera Asclepias curassavica

e. tikus Lycopodium (epiphytic)

gaharu Aguilaria malaccensis gapis Saraca gedernbah Nauclea subdita gegeli Rhaphidophora minor gelugor Garcinia atroviridis geringgong Nephelium rubescens, Xerospermum spp.

geronggang, geronggong Cratoxylon arborescens

getah taban Palaquium gutta geylang Sesuvium gorek Caesalpinia bonduc guri Dalbergia ferruginea ha ha Neesia hati hati Barclaya

hujan panas Breynia, Dalbergia beccarii, Rourea mimosoides

inai inai Erythroxylon cuneatum inggi burong Alstonia angustifolia, Evodia roxburghiana, Ixonanthes reticulata

ipil Intsia bijuga

jada Millettia hemsleyana jambu Eugenia

j. ayer E. densiflora

j. laut E. grandis

jangka tinggi Palaquium xanthochymum jangkang Xylopia ferruginea, X. fusca jarum jarum Pavetta

jawi jawi, jejawi Ficus microcarpa jelawai Terminalia phellocarpa jelunut Goniothalamus jelutong Dyera costulata jenjarum Pavetta jerujoh Acanthus ilicifolius jiremong Elaeocarpus griffithii j. babi Cryptocarya kurzii

kachang belurok Entada phaseoloides $k$. laut Canavalia rosea, Vigna marina kadoh Piper miniatum kait kait Roucheria, Uncaria kampar Guettarda kandis Garcinia forbesii, G. nigrolineata, G. parvifolia

k. gajah G. griffithii kangkong pasir Ipomoea gracilis kapau Livistona kingiana, Pholidocarpus kapur Dryobalanops aromatica kasai Aglaia, Pometia katong Crudia havilandii $k$. laut Cynometra ramiflora kayu baki Diplospora

k. gah Vitex peralata

k. gaharu Aquilaria malaccensis

$k$. gatal Gonystylis bancanus 
k. manis Cinnamomum iners kedi Engelhardtia serrata kedongdong Canarium, various Meliaceae kedundong Garcinia sp. kekait see akar kait $k$. keladan Dryobalanops oblongifolia keladi utan Hanguana kelat Eugenia

k. gelam, $k$. nasi nasi, $k$. nenasi E. oleina,

E. papillosa, E. spicata,

E. subhorizontalis

k. jambu E. valdevenosa

$k$. puteh E. leucoxylon

k. samak E. nigricans, E. palembanica kelentek nyamok Grewia fibrocarpa

kelubu Caesalpinia bonduc

kembang samangkok Scaphium

kempas Koompassia malaccensis

kemunting Rhodomyrtus

$k$. akar, $k$. semut Marumia nemorosa

kemuyang Alocasia denudata

kenanga utan Goniothalamus malayanus kentut kentut Saprosma

kepala berok Hydnophytum

kepau Livistona kingiana, Pholidocarpus

kepayang ayer Crateva religiosa

kerbau jalang Melanorrhoea pubescens

kerepit Inocarpus

keropoh Macaranga baccaureifolia

kertah udang Buchanania

ketaling Strombosia

ketapang Terminalia catappa

ketumbit Leucas zeylanica

kikir buntal Xerospermum muricatum

kobing Macaranga

kolah Mangifera quadrifida

kopi utan Canthium, Diplospora,

Fagraea racemosa

kopit Inocarpus

kranji Dialium

k. papan Crudia caudata

krepal, krepau Kostermansia

kruing, kuing Dipterocarpus $k$ gombang Dipterocarpus apterus

$k$. sol Dipterocarpus lowii

$k u k u$ bujang Schefflera venulosa

$k$. lang Randia longiflora, Zizyphus

kulim Scorodocarpus

kuran Dialium patens

kuras Dryobalanops oblongifolia

langkap Arenga westerhoutii

leban Vitex pubescens

lekub Mangifera griffithii

lemak berok Xanthophyllum

l. ketam Aegiceras, Desmodium umbellatum

lembah Calanthe, Curculigo

lempoyang various Zingiberaceae

lenggadai Bruguiera parviflora

lenggadi Vitex ovata

letop letop Pterospermum javanicum

lidah katak Pternandra coerulescens

limau lilang Merope angulata

linau Cyrtostachys lakka

lingtak Terminalia catappa

linjuang utan Dracaena granulata

longgundi Sophora tomentosa

machang utan Mangifera foetida

mahang Macaranga

malbera Mussaendopsis

mali mali Leea indica

mampat Cratoxylon formosum

mangas Memecylon levigatum,

M.paniculatum

mata ayam Ardisia crispa

m. keli Gynotroches

m. kuching Dimocarpus longan

m. pelandok Ardisia elliptica

medang Elaeocarpus spp., Kopsia,

Lauraceae, Platea, Styrax

crotonoides, Tetractomia

$m$. jangkang Elaeocarpus macrocerus

m. ketanah Phoebe cuneata

mernali Leea indica

membatu, m. laut Parinari corymbosa

membras Petunga roxburghii 
membulan Endospermum, Macaranga populifolia

membuloh Pellacalyx

mempadi Eurya acuminata

mempari Pongamia

mempelam babi Terminalia phellocarpa

mempelas Tetracera indica

$m$. asah Tetracera arborescens

$m$. gajah Tetracera sarmentosa

mempenai Ardisia elliptica

mempening Lithocarpus

mempisang Polyalthia, P. sclerophylla

mempoyan Rhodamnia

mempoyang various $Z$ ingiberaceae

mendarong Trema orientalis

mengkedi Hopea resinosa

mengkuang Pandanus atrocarpus

mengkudu Morinda citrifolia

m. rimba Rennellia

menjarum Pavetta

menkadai Kandelia

menkirai Commersonia

mensirau Ilex cymosa

mentigi Pemphis

merambong Scaevola

meranti Shorea spp.

m. gajah S. singkawang

m. kepong $\mathrm{S}$. ovalis

m. pa'ang S. bracteolata

m. paya S. platycarpa

$m$. pinang baik S. palembanica

m. rambai daun $\mathrm{S}$. acuminata, S. lepidota

m.samak S. pauciflora

m. sarang punai S. parvifolia

m. tembaga S. leprosula

merawan Hopea mengarawan

merbatu Parinari

merbau Intsia bakeri

merlimau Atalantia, Streblus taxoides

mertajam Lepisanthes rubiginosa

mesepat Macaranga javanica

misi Planchonella obovata

muring Nenga, Pinanga nasi nasi, nenasi Eugenia spicata nenulang Eugenia cerina ngjulong Agrostistachys nibong Oncosperma filamentosum n. palai Grammatophyllum nipa Nipa fruticans nipis kulit, Memecylon, M. myrsinoides nyaru Vitis gracilis nyatoh Madhuca, Palaquium nyireh Carapa granatum n. batu C. moluccense pakai panggil Clerodendron villosum pakan heran Gardenia tubifera paku laut Cycas rumphii palas Licuala pandan Pandanus, P. kamii pasah Aglaia, Santiria rubiginosa passu petri Platycerium pechah periok Ixora pedaru Dimocarpus longan pedendang Trichosanthes wallichiana pelali urat Tacca integrifolia, T. vespertilio pelawan Tristania pelawai Terminalia phellocarpa pelir kambing Finlaysonia, Sarcolobus penaga Calophyllum, Mesua p. darat Calophyllum sclerophyllum p. laut $\mathrm{C}$. inophyllum penalt Balanocarpus heimii penara, penarahan, Myristicaceae penawa pahit Eurycoma peradun Dillenia indica perah Elateriospermum, Pimeleodendron perepat Sonneratia alba perupoh Lophopetalum multinervium petai Parkia speciosa

p. belalang Pithecellobium clypearia petaling Ochanostachys, Strombosia piai raya Acrostichum aureum piandong Quassia indica pianggu Horsfieldia irya 
pinang buring Iguanura

p. punai Elaeocarpus

pokok gegli Raphidophora minor

p. teh Acalypha siamensis

pong pong Cerbera manghas

pudu Artocarpus kemando

pulai Alstonia spathulata

punggai Coelostegia

purun tikus Scleria, S. poaeformis

putat Barringtonia, $\mathrm{B}$. conoidea

p. ayain $\mathrm{B}$. racemosa

p. ayer $\mathrm{B}$. conoidea

p. laut $\mathrm{B}$. asiatica

p. ulu Helicia robusta

rambai Baccaurea motleyana

r. tikus B. brevipes, B. scortechinii

rassau Pandanus helicopus

r. tikus Pandanus spp.

redan Nephelium glabrum

rengas Gluta, Melanochyla,

Melanorrhoea

r. ayam Melanorrhoea sp.

r. ayer Gluta velutina

r. kerbau jalang Melanorrhoea

repat Mangifera cf. quadrifida

reriang Ploiarium

resak r. laru Vatica wallichii

$r$ rambai Hopea polyalthioides

rhu Casuarina equisetifolia

riang riang Ploiarium

rotan Calamus, Daemonorops

r. batu Calamus paspalanthus

r. dini Flagellaria

r. lilin Calamus exilis

r. manau lilin Calamus tumidus

r. tawar Daemonorops angustifolius

rumput dawai Panicum repens, Paspalum vaginatum

r. ekor kuching Limnophila erecta

$r$. sesuroh Lycopodium cernuum

r. tai babi Leptaspis urceolata

sakat epiphytes in general

sakit rastong Paramignya scandens saminyak Sapium indicum

sawi nggang Erechtites valerianifolia

segun Alphonsea, Diospyros, Polyalthia,

Pseuduvaria, Trivalvaria; this name

given to small trees with slender

whippy stems and black bark, that served as fishing rods.

sekentut Saprosma

sekunyit Fibraurea ochroleuca

selaseh pasir Heliotropium indicum

selengsar Glochidion littorale

selengsen Mapania, Scirpodendron

(? Pandanus echinodermops)

s. akar Freycinetia

selimbu Cyperus malaccensis

seluma, selumba Jackia

selunjut Derris heptaphylla

sernaram Palaquium semaram

sembong Didymocarpus

sena Pterocarpus indicus

senambun Baccaurea parviflora

sendok sendok Endospermum

sendudoh ayer Ochthocharis borneensis

sengkawang Shorea lepidota, S.

palembanica, S. singkawang

senkam Glochidion leiostylum, lutescens

sepetir Sindora

sepungga Fagraea ceilanica

seranta tangga Castanopsis megacarpa

serdang Livistona seribus, Pholidocarpus

serentang tikus Buchanania sessiliflora

serta tangga Castanopsis megacarpa

serunai laut Wedelia biflora

sesuroh Lycopodium cernuum

setabul Bryophyllum calycinum

setada Podocarpus neriifolius,

P. polystachyus

setambun Baccaurea parviflora

setawar Dracaena granulata

setudong Macaranga puncticulata

siakum Pandanus echinodermops

sial menaung Pternandra

simpoh Dillenia

s. ayer D. suffruticosa

s. jangkang D. grandifolia, D. reticulata 
sireh murai Piper pedicellosum sol Dipterocarpus lowii sundek Palaquium semaram suntai Palaquium xanthochymum suroh suroh Lycopodium cernuum susop Lumnitzera littorea

tabah Myristica elliptca taban Palaquium gutta tajam penggali Myristica elliptica tampal Baccaurea scortechinii tampang Artocarpus nitidus ssp. griffithii, A. dadah tampoi Baccaurea motleyana tangisong burong Chisocheton, Dysoxylon, Trigonachras, (Ficus apiocarpa, F. ruginervia). tebrau Saccharum arundinaceum teh Acalypha siamensis telingga gajah Macaranga gigantea telisai Terminalia phellocarpa tempulut Artocarpus gomezianus tempunai Xylopia caudata tengar Ceriops tegal tengayun Parartocarpus venenosus ssp. forbesii

tengkawang see sengkawang tengkok biawa Fagraea racemosa tepis Polyalthia hypoleuca tepus Achasma macrocheilos terap Artocarpus elasticus terentang, teruntang Campnosperma

t. jantan C. squamata teruntuin Lumnitzera tetimah Glochidion leiostylum tetiup, tiup tiup Adinandra, Gordonia toyok Tacca leontopetaloides tuba Derris malaccensis tukas Caryota mitis tulang dain Garcinia ? rostrata, G. eugeniaefolia

tumu Bruguiera

ubah Eugenia grandis

urat kurus Beilschmiedia tonkinensis 


\section{References}

Airy Shaw, H. K. 1975 The Euphorbiaceae of Borneo. Kew Bull. Additional Series IV.

Aleva, G. J. J. 1973 Aspects of the historical and physical geology of the Sunda Shelf essential to the exploration of submarine tin placers. Geol. Mijnb. 52, 79-91.

Anderson, J. A. R. 1958 Observations on the ecology of the peat-swamp forests of Sarawak and Brunei. Proc. Symp. Humid Tropics Vegetation, Tjiawi (Indonesia), UNESCO Science Co-operation Office, S. E. Asia, 141-148.

Anderson, J. A. R. 1963 The flora of the peat swamp forest of Sarawak and Brunei, including a catalogue of all recorded species of flowering plants, ferns and fern-allies. Gdns' Bull. Singapore 20, 131-228.

Anderson, J. A. R. 1964 The structure and development of the peat swamps of Sarawak and Brunei. J. Trop. Geogr. 18, 7-16.

Ashton, P. S. 1964a Manual of the dipterocarp trees of Brunei State. Oxford University Press.

Ashton, P. S. 1964 b Ecological studies in the mixed dipterocarp forests of Brunei State. Oxford Forestry Memoirs n. 25, 1-75.

Ashton, P. S. 1968 Manual of the dipterocarp trees of Brunei State and Sarawak Supplement). Borneo Literature Bureau, Kuching.

Ashton, P. S. 1972 The Quaternary geomorphological history of Western Malaysia and lowland forest phytogeography. Trans. 2nd Aberdeen-Hull Symposium on Malesian ecology (1971); Department of Geography, University of Hull; 35-62.

Bassot, J-M. and I.V. Polunin 1967 Synchronous flashing of fireflies in the Malay Peninsula. Sci. Rep. Yokosuka City Mus. 13, 18-22.

Beusekom, C. F. van 1971 Revision of Meliosma (Sabiaceae). Blumea 19, 355-529.

Beveridge, A. E. 1953 The Menchali forest reserve. Malay. Forest. 16, 87-93.

Biswas, B. 1973 Quaternary changes in sea-level in the South China Sea. Geol. Soc. Malaysia Bull. 6, 229-256.

Buck, J. and E. Buck 1966 Biology of the synchronous flashing of fireflies. Nature $211,562-564$.

Buck, J. and E. Buck 1968 Mechanism of rhythmic synchronous flashing of fireflies. Science 159, 1319-1327.

Burgess, P. F. 1969 Preliminary observations on the autecology of Shorea curtisii Dyer ex King in the Malay Peninsula. Malay Forest. 32, 438.

Burkill, I. H. 1927 Botanical collectors, collections and collecting places in the Malay Peninsula. Gdns' Bull. S. S. 4, 113-202.

Burtt, B. L. and R. M. Smith 1972 Key species in the taxonomic history of Zingiberaceae. Notes R. Bot. Gdn Edinburgh 31, 177-227.

"Cactus" 1954 Water, water everywhere. Malay. Forest. 17, 184-194.

Chew Wee Lek 1963 Florae Malesianae Precursores, XXXIV. A revision of the genus Poikilospermum (Urticaceae). Gdns' Bull. Singapore 20, 1-104.

Cockburn, P. F. 1969 Gunong Mandi Angin, Trengganu; a botanical visit. Malay. Nat. J. 22, 164-170.

Corner, E. J. H. 1935 The seasonal fruiting of agarics in Malaya. Gdns' Bull. S. S. 9, 79-88.

Corner, E. J. H. 1938 The sytematic value of the colour of withering leaves. Chronica Botanic 4, 119-121. 
Corner, E. J. H. 1939a Notes on the systematy and distribution of Malayan phanerogams, 1. Gdns' Bull. S. S. 10, 1-55.

Corner. E. J. H. $1939 \mathrm{~b}$ Notes on the systematy and distribution of Malayan phanerogams, III. Gdns' Bull. S. S. 10, 239-329.

Corner, E. J. H. 1940 Wayside Trees of Malaya. (2nd ed. 1952). Government Printing Office, Singapore.

Corner, E. J. H. 1941 Notes on the systematy and distribution of Malayan phanerogams, IV; Ixora. Gdns' Bull. S. S. 11, 177-235.

Corner, E. J. H. 1958 An introduction to the distribution of Ficus. Reinwardtia $4,15-45$.

Corner, E. J. H. 1960 Taxonomic notes on Ficus Linn., Asia and Australasia. Gdns' Bull. Singapore 17, 368-404.

Corner, E. J. H. 1964 The life of plants. Weidenfeld and Nicolson, London.

Corner, E. J. H. 1968 A monograph of Thelephora. Nova Hedwigia Beih. 27, 1-110.

Corner, E. J. H. 1969 The complex of Ficus deltoidea; a recent invasion of the Sunda Shelf. Phil. Trans. Roy. Soc. London B 256, 281-317.

Drenth, E. 1972 A revision of the family Taccaceae. Blumea 20, 367-406.

Fitch, F. H. 1949 Evidence for recent emergence of the land in east Pahang. J. Malay. Br. R. As. Soc. 22, 115-122.

Furtado, C. X. 1963 Notes on some Malaysian Melastomaceae. Gdns' Bull. Singapore 20, 105-122.

Gibson Hill, C. A. 1952 Tongkang and lighter matters. J. Malay. Br. R. As. Soc. $25,84-110$.

Gilliland, H. B. 1971 Grasses of Malaya. Revised Flora of Malaya, vol. III. Government Printing Office, Singapore.

Gobbett, D. J. and C. S. Hutchison 1973 Geology of the Malay Peninsula. WileyInterscience, New York, London.

Haile, N. S. 1971 Quaternary shore lines in West Malaysia and adjacent parts of the Sunda Self. INQUA, special volume.

Haile, N. S. 1971 Quaternary deposits and geomorphology of the Sunda Shelf off Malaysian shores. INQUA, special volume.

Haneda, Y. 1966 Synchronous flashing of fireflies in New Guinea. Sci. Rep. Yokusuka City Mus. 22, 1-8.

Henderson, M. R. 1949 The genus Eugenia (Myrtaceae) in Malaya. Gdns' Bull. Singapore 12, 1-293.

Henderson, M. R. and J. Wyatt-Smith 1956 Calophyllum L. Gdns' Bull. Singapore $15,285-376$.

Hewitt, B. R. 1967 The occurrence, origin and vegetation of lowland peat in Malaya. Proc. Linn. Soc. N.S.W. 92, 58-66.

Hickson, S. 1889 A naturalist in North Celebes.

Hill, R. D. 1966 Changes in beach form at Sri Pantai, north east Johore, Malaysia. J. Trop. Geogr. 23, 19-27.

Holttum, R. E. 1950 The Zingiberaceae of the Malay Peninsula. Gdns' Bull. Singapore $13,1-249$.

Holttum, R. E. 1951 The Marantaceae of Malaya. Gdns' Bull. Singapore 13, 254-296.

Holttum, R. E. 1954 Ferns of Malaya. Revised Flora of Malaya, vol. II. GovernPrinting Office, Singapore. 
Holttum, R. E. 1957 Orchids of Malaya. Revised Flora of Malaya, vol. I. (1st ed. 1953). Government Printing Office, Singapore.

Hoogland, R. D. 1952 A revision of the genus Dillenia. Blumea 7, 1-145.

Jacobs, M. 1962 Pometia (Sapindaceae), a study in variability. Reinwardtia 6, $109-144$.

Jarrett, F. M. 1959 Studies in Artocarpus and allied genera, III. J. Arn. Arb. 40, 113-368.

Jarrett, F. M. 1960a idem, IV. J. Arn. Arb. 41, 73-140.

Jarrett, F. M. 1960b idem, V. J. Arn. Arb. 41, 320-340.

Jenik, J. 1967 Root adaptations in West African trees. J. Linn. Soc. (Bot.) 60, 25-29.

Kalkman, C. 1965 The Old World species of Prunus subgen. Laurocerasus including those formerly referred to Pygaeum. Blumea 13, 1-115.

Kobuski, C E. 1947 Studies in Theaceae XV. A review of the genus Adinandra. J. Arn. Arb. 28, 1-98.

Kostermans, A. J. G. H. 1957 Lauraceae. Reinwardtia 4, 193-256.

Kostermans, A. J. G. H. 1958 A monograph of the genus Durio Adans. (Bombacaceae). Part II. Species of Burma, Malaya, Sumatra. Comm. Forest Res. Inst. Indonesia n. 62.

Kostermans, A. J. G. H. 1959a The genus Durio Adans. (Bombac.). Reinwardtia $4,47-153$.

Kostermans, A. J. G. H. 1959b A monograph of the genus Heritiera Aiton (Stercul.) Reinwardtia 4, 465-583.

Kostermans, A. J. G. H. 1961 A monograph of the genus Brownlowia Roxb. (Tiliaceae). Forest Res. Inst. Bogor n. 73.

Kostermans, A. J. G. H. 1964 A monograph of the genus Pentace Hassk. (Tiliaceae). Forest Res. Inst. Bogor n. 87.

Kostermans, A. J. G. H. 1965a New species of Parinari Aubl. (RosaceaeChrysobalanoideae). Reinwardtia 7, 47-61.

Kostermans, A. J. G. H. 1965b A monograph of Maranthes Bl. and Cyclandroprora Hassk. (Chrysobalanaceae) of the Asiatic and Pacific area. Candollea 20, 103-142.

Koyama, T. 1960 Materials towards a monograph of the genus Smilax. Quart. J. Taiwan Mus. 13, 1-61.

Kunkel, G. 1965 Der Standort: Kompetenzfactor in der Stelzwurzelbildung. Biol. Centralbl. 84, 641-651.

Leenhouts, P. W. 1956 Florae Malesianae Praecursores XII. Dichapetalum. Reinwardtia 4, 75-87.

Leenhouts, P. W. 1959 A monograph of the genus Canarium (Burseraceae). Blumea 9, 275-475.

Leenhouts, P. W. 1967 A conspectus of the genus Allophylus (Sapindaceae). Blumea 15, 301-358.

Leenhouts, P. W. 1969 A revision of Lepisanthes (Sapindaceae). Blumea 17, 33-91.

Leenhouts, P. W. 1971 A revision of Dimocarpus (Sapindaceae). Blumea 19, 113-131.

Lim Siew-Ngo 1972 Cytogenetics and taxonomy of the genus Globba L. (Zingiberaceae) in Malaya, I: Taxonomy. Notes R. Bot. Gdn Ediburgh 31, 241-269. 
Lowe, R. 1963 The height of buttresses in relation to size of stem and crown. J. W. Afr. Sci. Ass. 8, 6-17.

Markgraf, F. 1972 Identification lists of Malaysian specimens, n. 42. Flora Malesiana, Leiden.

Medway, Lord 1972 Phenology of a tropical rain-forest in Malaya. Biol. J. Linn. Soc. 4, 117-146.

Muller, J. 1972 Palynological evidence for change of geomorphology, climate, and vegetation in the Mio-Pliocene of Malesia. Trans. 2nd Aberdeen-Hull Symposium on Malesian ecology, 1971; University of Hull; 6-34.

Nicolson, D. H. 1969 A. revision of the genus Aglaonema (Araceae). Smithsonian Contr. Bot. n. 1.

Nooteboom, H. P. 1962 Generic delimitation in Simaroubaceae tribus Simaroubeae and a conspectus of the genus Quassia L. Blumea 11, 509-528.

Nooteboom, H. P. 1975 Revision of the Symplocaceae of the Old World (New Caledonia excepted). Universitaire Pers, Leiden.

Oldeman, R. A. A. 1970 L'architecture de la vegetation forestière des fleuves et criques Guyanais. Centre ORSTOM Cayenne, Cote B 46, 1-14.

Payens, J. P. D. W. 1967 A monograph of the genus Barringtonia (Lecythidaceae). Blumea 15, 157-263.

Polak, E. 1933 Ueber Torf und Moor in Niederlandische Indien. Verh. K. Akad. Wet. Amsterdam 30, n.3, 1-85.

Roekmowati-Hartono 1965 A monograph of the genus Schoutenia Korth. (Tiliaceae). Reinwardtia 7, 91-138.

Schmid, R. 1972 A resolution of the Eugenia-Syzygium controversy (Myrtaceae). Am. J. Bot. 59, 423-436.

Seshagiri Rao, R. 1964 Indian species of Commelinaceae. - Miscellaneous notes. Notes R. Bot. Gdn Edinburgh 25, 179-189.

Sewandono, M. 1938 Het Veengebied van Bengkalis. Tectona 31, 99-135.

Sinclair, J. 1955 A revision of the Malayan Annonaceae. Gdns' Bull. Singapore 14, $149-516$.

Sinclair, J. 1958a A revision of the Malayan Myristicaceae. Gdns' Bull. Singapore $16,205-472$.

Sinclair, J. 1958b Florae Malesianae Precursores XX. The genus Gymnacranthera (Myristicaceae) in Malaysia. Gdns’ Bull. Singapore 17, 96-120.

Sinclair, J. 1961 Florae Malesianae Precursores XXXI. The genus Knema (Myristicaceae) in Malaysia and outside Malaysia. Gdns' Bull. Singapore 18, $102-327$.

Sinclair, J. 1968 Florae Malesianae Precursores XLII. The genus Myristica in Malesia and outside Malesia. Gdns' Bull. Singapore 23, 1-536.

Sinclair, J. 1974 The genus Horsfieldia (Myristicaceae) in and outside Malesia, I. Gdns' Bull. Singapore 27, 133-141.

Sinclair, J. 1975 idem II. Gdns' Bull. Singapore 28, 1-181.

Soepadmo, E. 1971 Identification lists of Malaysian specimens. Fagaceae, n. 41. Flora Malesiana, Leiden.

Stone, B. C. 1967a Studies of Malesian Pandanaceae I. Gdns' Bull. Singapore 22, 231-257.

Stone, B. C. $1967 \mathrm{~b}$ idem II. Fed. Mus. J. 12, 105-110. 
Stone, B. C. 1968a Pandanus Stickm. in the Malay Peninsula, Singapore and Lower Thailand, Part 3. Mal. Nat. J. 21, 1-16.

Stone, B. C. 1968b idem, Part 4. Mal. Nat. J. 21, 125-141.

Stone, B. C. 1970a Malayan climbing pandans - the genus Freycinetia in Malaya. Mal. Nat. J. 23, 84-91.

Stone, B. C. 1970b Studies in Malesian Pandanaceae, XI. Fed. Mus. J. 15, 199-202.

Stone, B. C. 1971 Studies in Malesian Pandanaceae, VIII, IX. Fed. Mus. J. 13, $138-154$.

Swan, S. B. St. C. 1967 Maps of two indices of terrain, Johor, Malaya. J. Trop. Geogr. 25, 48-57.

Swan, S. B. St. C. 1974 A raised beach at Kahang, Johor, Peninsular Malaysia. J. Trop. Geogr. 38, 55-60.

Symington, C. F. 1943 Foresters' manual of dipterocarps. Malayan For. Rec. n. 16.

Tan Ah See and Hsuan Keng 1969 Comparative morphological studies of four species of Avicennia (Verbenaceae) in Singapore. J. Singapore Nat. Acad. Sci. 1, 8-29.

Tay, T. H. 1969 The distribution, characteristics, uses, and potential of peat in West Malaysia. J. Trop. Geogr. 29, 58-63.

Timmerman, E. H. L. 1959 Identification lists of Malaysian specimens, n. 5, Kopsia. Flora Malesiana, Leiden.

Tjia, H. D. 1970a Monsoon-control of the eastern shore-line of Malaya. Geol. Soc. Malaysia Bull. 3, 9-15.

Tjia, H. D. 1970b Quaternary shorelines of the Sunda land, South East Asia. Geol. Mijnb. 49, 135-144.

Torrey, J. G. and D. T. Clarkson 1975 The development and function of roots. Academic Press Inc. (London) Ltd.

Vincent, A. J. 1962 A note on Oncosperma filamentosa Bl. (nibong). Malay. Forest. $25,150-154$.

Whitmore, T. C. 1962 Studies in systematic bark morphology, I. New phytol. 61, 191.- idem, II. New Phytol. 61, 208.- idem, III. Gdns' Bull. Singapore 19, 321.

Whitmore, T. C. 1963 Studies in systematic bark morphology, IV. New Phytol. $62,161$.

Whitmore, T. C. 1967 Studies in Macaranga. Malay. Nat. J. 20, 89-99.

Whitmore, T. C. 1969 First thoughts on species evolution in Malayan Macaranga. (Studies in Macaranga III). Biol. J. Linn. Soc. 1, 223-231.

Whitmore, T. C. 1973 Palms of Malaya. Oxford University Press.

Wyatt-Smith, J. 1951 Archytaea vahlii Choisy (riang riang). Malay. Forest. $14,36-38$.

Wyatt-Smith, J. 1954 Suggested definitions of field-characters. Malay. Forest. $17,170-183$.

Wyatt-Smith, J. 1959 Peat swamp forest in Malaya. Malay. Forest. 22, 5-32.

Wyatt-Smith, J. 1961 A note on the freshwater swamp, lowland and hill forest types of Malaya. Malay. Forest. 24, 110-121.

Wyatt-Smith, J. 1964 A preliminary vegetation map of Malaya with descriptions of the vegetation types. J. Trop. Geogr. 18, 200-213. 
Wycherley, P. R. 1967 Rainfall probability tables for Malaysia. R. R. I. M. Planting Manual n. 12.

Zuijderhoudt, G. F. P. 1967 A revision of the genus Saraca (Legum.-Caes.) Blumea $15,413-425$.

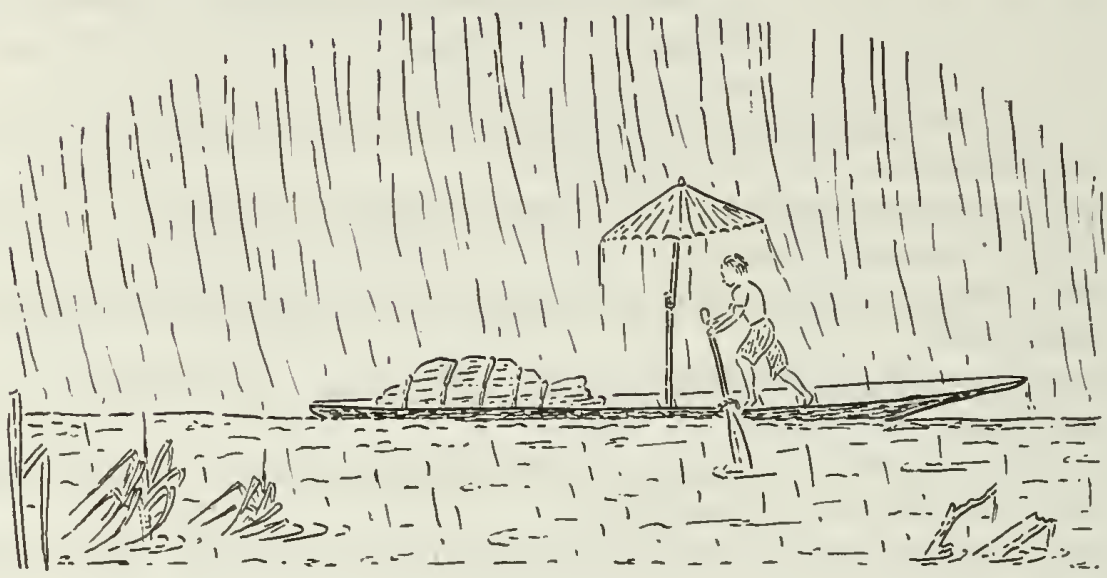




\section{INDEX}

Abacopteris triphylla 161

Acalypha siamensis 114

Acanthus ilicifolius 95

Achasma macrocheilos 35, 160 megalocheilos 160

pauciflorum 160

sphaerocephalum var. petiolatum 160

Achyranthes aspera 95

Acriopsis javanica 141

Acronychia porteri 152

Acrostichum 52

aureum 14, 42, 161, 224

stands of 32

Acrotrema costata 74

costatum 110

Actinodaphne sp. 76, 123

areolata 123

corneri 123

glomerata 123

maingayi 76,123

malaccensis 123

sesquipedalis 123

var. venosa 76

Adenanthera pavonina 58, 126

Adenia macrophylla var. singaporeana see A. singaporeana

singaporeana 146

Adenoncos sumatrana 79, 86

Adina 216

Adinandra 64, 87, 219

sp. 157

acuminata 32,157

lamponga 157

corneriana 32, 157, 219

dumosa 53

lamponga (see also A. sarosanthera) 220

macrantha 220

sarosanthera $18,21,27,157,219$, pl. 20

Adinobotrys erianthus 76

Aegiceras corniculatum 137

Aerides odoratum 141
Aeschynanthus obconica 120

parvifolius 27, 75, 120

purpurascens 120

radicans 120

wallichii 75,120

Agelaea borneensis 74, 107

macrophylla 107

Aglaia 45, 64, 70, 92, 167

spp. 131

angustifolia 37,131

argentea 131

hernii 131

lanuginosa 131

meliosnoides 131

odoratissima 131

palembanica 131

salicifolia 44

cf. trichostemon 35, 131

Aglaodorum griffithii 14, 32, 100

Aglaonema 60, 170

nebulosum 100

nitidum 73, 100

pictum 73, 86

simplex 35,100

Agrostistachys 53

gaudichaudii 114

sessilifolia 75,114

Agrostophyllum bicuspidatum 79, 141

Agyneia bacciformis see Synostemon bacciformis

Alangium ebenaceum 26 var. tutela $26,74,108,178$

havilandii 24

javanicum see A. ebenaceum var. tutela

Alchornea javensis see A. rugosa

rugosa 114

villosa 75

Allophylus 215

cobbe 58

var. velutina 152

Alocasia denudata 73, 100

Alphonsea elliptica 96

johorensis $32,96,167$ 
Alpinia javanica 160

Alseodaphne 123

sp. 123

bancana 123

coriacea 123

corneri 123

obovata 32,123

paludosa 123

? penduliflora $62,64,67,68,69,76$

? pendulifolia 206

Alsomitra sp. 108

Alstonia 61

angustifolia $68,69,72,99$

angustiloba 99

spathulata $20,23,24,25,60,62,72$, 99,220

Amomum hastilabium 82, 160

uliginosum 160

Xanthophlebium 82, 160

Amoora 70

spp. 131

rubiginosa $21,22,26,63,67,70,77$, 131,198 , pl. 36

Amorphophallus bufo 100

Amyema beccarii 128

Anadendrum? latifolium 100 microstachyum 100

montanum 73

Anaectochilus geniculatus 79, 141

Anaxagorea 39

javanica var. dipetala 96, 167

var. javanica 96

Aneilema vaginatum 106

Angiopteris evecta 161

Anisophyllea 211

sp. 212

corneri 32, 147, 212

disticha 80,147

Anisoptera marginata $64,74,85,86,88$, 89,90

Anodendron candolleanum 72, 99

Anplectrella anomala 129

Anplectrum viminale 77

Anthocephalus 167

cadamba 27, 148, 213

Anthocleistus 24

Antidesma 45

sp. 114

alatum see $A$. neurocarpum brachybotrys 114, 187

cuspidatum 114

leucopodum 114

? montanum 75

neurocarpum 114

pachystachys var. palustre 114

pahangense $34,35,37,114,187$

salicinum 44

stipulare see A. brachybotrys

tomentosum see A. pachystachys

Antrophyum callifolium 161

ants, keringa 130

ants/termites 59, 123, 181

Aphanamixis rohituka 77,131

Aphania 215

Apocynaceae 70

Aporosa spp. 115

falcifera 114

frutescens 40,114

lunata $32,114,184$

nigricans 114,184

prainiana 114

pseudoficifolia 114, 185

symplocoides 114

Appendicula sp. 79

cornuta 141

densifolia 141

lucida 79,141

pendula 141

Apostasia nuda 100

Aquilaria beccariana 157, 220, 221

malaccensis $22,35,82,157,220$

microcarpa 220

? microcarpa 220

Aralidium pinnatifidum $32,108,178$

Archytaea vahlii see Ploiarium alternifolium

Ardisia 64, 92

sp./spp. 78, 137, 202

andamanica 137, 202

colorata 137

crispa 58,137

elliptica 51, 58, 137

foliosa 137

lanceolata 137

miqueliana 137

ngadimanii 137

odontophylla 137

pachysandra 32,137

? solanacea 32,137

teysmanniana 137

tuberculata $17,68,78,137$

? wrayi 35, 137, 202 
Areca latiloba 143 montana $31,32,143$

Arenga hastata 143 westerhoutii $34,35,143$

Argostemma johorensis 148

Argyreia ridleyi 74, 107

Aromadendron elegans 35, 129 nutans $22,70,77,86,87,197$, pl. 9

Artabotrys suaveolens 97 venustus 97 wrayi 97

Arthrophyllum sp. 101 ovalifolium 73, 101

Artocarpus 70, 88, 198 anisophyllus 132 dadah 132

elasticus $21,26,32,35,58,63,77,87$, 132

gomezianus $58,88,132,199$ var. griffithii 199

integer var. silvestris 35,132

kemando $21,26,40,58,63,67,68$, $77,87,89,132,199$

maingayi 26,132

nitidus 199

ssp. borneensis 199

ssp. griffithii 77, 133, 199

ssp. lingnanensis 199

parvus 199

rigidus 133

scortechinii 63,77

Asclepias curassavica 101

Asplenium borneense 34, 35, 161 glaucophyllum 82,161

macrophyllum 161

nidus $28,82,161,162$

tenerum 82

Atalantia monophylla 58, 152 spinosa see A. monophylla

Athyrium esculentum 161

Aulacodiscus premnoides 148, 213

Austrobuxus 70, 185

nitidus $68,75,115,185$

Avicennia 11, 24, 52, 108, 159, 192, 222

Baccaurea $64,70,92,185$

sp. 75

bracteata 26,115

? bracteata 75

Baccaurea brevipes 115

hookeri 115,185
? javanica 115,185

kunstleri 75

lanceolata 115,185

macrophylla 115

motleyana 115,185

parviflora $32,115,185$

racemosa 115,185

scortechinii 115,185

sumatrana 115,185

? velutina 115

Baeckia frutescens 187

Balanocarpus heimii 32, 35, 89, 110

balau 6

Barathranthus axanthus 128

Barclaya 13, 19, 87, 121

flowering 30

motleyana 79

motleyi 140

Barringtonia 58, 64, 70, 194, 211

acutangula 14, 195 ssp. spicata 42

asiatica $51,58,125,195$

conoidea (see also putat) 6, 11, 14, $32,42,45,46,125,195,199,214$

filirachis $18,125,195$

flowering 30

macrocarpa 125

macrostachya 125,195

racemosa $14,17,18,45,125,195$ ever-flowering 31

reticulata 40,125

scortechinii 125

spicata 42

sumatrana see $B$. reticulata

- Terminalia formation 1

composition of flora 58

rocky shore 58

sea-front 53,54

Batrachospermum 40

Bauhinia audax 125

bidentata 18,125

flammifera see B. integrifolia

finlaysoniana 125

integrifolia 35,125

kockiana 125

Begonia sinuata 45

Beilschmiedia spp. 123

glabra 18, 123

kunstleri $18,76,123$

lumutensis $34,35,123$

tonkinensis $50,52,58,123$, pl. 26 , pl. 27 , pl. 31 
Belvisia callifolia 37,161

berok 8

Bhesa paniculata 73, 103 flowering 30

Blastus caudatus 129

Blechnum 45 finlaysonianum 161 orientale $45,82,161$

Blumeodendron calophyllum 37 kurzii 115 tokbrai $21,26,62,67,68,70,75,89$, 115,185 , pl. 19

Boesenbergia plicata 160 praineana 35,160

Borreria articularis see $\mathrm{B}$. hispida hispida 57, 148

Botryophora geniculata 115

Brachylophon curtisii 129

Brackenridgea hookeri 79, 140, 207

Breynia coronata 115 rhamnoides see B. vitis-idaea vitis-idaea 115

Bridelia cinnamomea 75 ? cinnamomea 115,186 griffithii 75 pustulata $26,115,186$ stipularis 115

Bromheadia alticola 141 aporoides 141 finlaysoniana 79

Brownlowia 221 argentata 14,157 lanceolata (see also B. tersa) 221 tersa 157

Brucea amarissima see B. javanica javanica 155

Bruguiera 24, 54, 99, 127, 196, 216 special localities 32 caryophylloides see B. cylindrica cylindrica 147 eriopetala see B. sexangula gymnorrhiza 147 parviflora 147 sexangula 54,147

- Sonneratia forest 71

Bryophyllum calycinum 108

Buchanania 42 fruiting 31 lucida $18,20,30,31,58,95$ flowering 29 flowering and fruiting 31 sessilifolia 18, 20,29, 39, 95, pl. 1 flowering 29

Bulbophyllum 92

Bulbophyllum Sp. (Sect. Aphanobulbum) 79

acuminatum 79,141

adenopetalum 141

alcicorne 141

apodum 79,141

botryophorum 79,141

carunculaelabrum 141

cleistogamum 141

concinnum 141

cuspidipetalum 37

epicrianthes 141

lasianthum 141

limbatum 141

macranthum 141

membranifolium 37

pileatum 79,141

pulchellum 27, 79, 141

purpurascens $28,79,141$

restrepia 79,141

rugosum 141

sessile $28,79,141$

singapurianum 141

stella 141

subumbellatum 141

tenuifolium 141

vaginatum $28,79,141$

Bulbostylis barbata 108

buttresses, account 23 et seq.

Buxus sempervirens 22

Byttneria brevipes 155 maingayi 155

Caesalpinia bonduc 125

crista 125

tortuosa 125

nuga see $\mathrm{C}$. crista

Calamus (see also rotan) 64, 92, 208

spp. 80

exilis 143

flabellatus 143

flabelloides 143

giganteus 143

holttumii 37

javensis var. peninsularis 143

mawaiensis 143

paspalanthus 143

ramosissimus 143

riparius 143

tumidus 143 
Calanthe johorensis 37

pulchra 79,141

veratrifolia 141

Callicarpa farinosa 82,159

Calophyllum 6, 10, 22, 23, 24, 40, 64, $92,104,165,173,189,193$

flowering 29,31

sp. 105,174

austrocoriaceum 36

canum 104

curtisii 26, 104, 174

depressinervium 104

floribundum 63, 67, 70, 73, 104

fragrans 24

gracillimum 104

incrassatum $21,32,63,73,104$

inophylloide 26,174

inophylloides var. singapurense 21 , 73, 104

inophyllum 51, 58, 104

kunstleri 26, 104, 174

macrocarpum 18, 21, 104

molle 73

pulcherrimum 18, 104

retusum $21,26,63,67,68,70,73$,

104,174

rubiginosum 104

rufigemmatum see $C$. wallichianum

rupicolum 18

var. elatum 104, 174

sclerophyllum 21, 26, 31, 105, 174, pl. 10, pl. 13, pl. 22

leafing 30,31

scriblifolium 85

soulattri $21,26,105,174$

tenuivenium 105

wallichianum $21,32,67,68,70,74$, 105

Camarotis adnata 79,141

Campnosperma 6, 165

flowering 30

auriculata $40,63,67,68,70,72,86$, 95

macrophylla $25,70,72,85,165$

minus see $C$. squamata

squamata $20,51,63,64,70,72,86$, 95

Camptandra parvula 160

Canarium apertum 103, 172

littorale 20,32, 35, 103, 172

odontophyllum 73

patentinervium 103

pilosum $63,67,68,70,73,103,172$
Canavalia 50, 54, 178

maritima see C. rosea

obtusifolia see C. rosea

rosea 57,126

Canthium sp. 148

confertum 58, 148

didymum 148, 213

glabrum 148

hirtellum 148

horridum 148

Cantleya corniculata $64,67,68,76,89$, 122,193

Carallia brachiata $18,64,70,80,147$, 212

lucida see C. brachiata

Carapa 11

granatum 131

moluccensis 14, 32, 39, 131

Caryota 64

mitis 54,143

Casearia sp. 75, 191

grewiaefolia var. deglabrata 119, 190

lobbiana 75

velutinosa 119

Cassytha filiformis 123

Castanopsis 189

spp., flowering 30

fulva 118,187

inermis $26,75,118$

johorensis 118

malaccensis 118

megacarpa 26, 118

Casuarina $6,50-54,56,57,85,102,106$, $108,115,117,120-122,138,153,156$, 158,214 , pl. 26 , pl. 27 , pl. 28

felled for firewood 53

saplings 54

seedlings 50,53

foreshore 54

forest 49, 50, 52, 54, 107, pl. 26, pl. 27

fringe 53

stand 54

\& sand-spit 51

-strips 55

equisetifolia 50,103

Centotheca lappacea 120

Cephaelis griffithii 148

singapurensis 148

Cephalomappa lepidotula 115, 186

Ceratopteris 42

thalictroides 162 
Ceratostylis subulata 142

Cerbera 17

odollam $3,14,16,17,18,99,125$

flowering 30

manghas 51, 58, 99, 169

Ceriops candolleana see C. tagal tagal 147

Chamaeanthus laciniatus 79, 142

Champereia manillana 141

Chasalia curviflora 148

Cheirorchis filiformis 79 major 142

Cheiropleuria 36 bicuspis 37

chengal 34

Chilocarpus cantleyi 99 costatus 99

decipiens 99

obstusifolius 99

Chisocheton 64, 70, 198

spp. 131

amabilis 17, 131, 198

flowering 30

erythrocarpus 131,198

patens 131,198

pauciflorus 131

paucijugus 131, 198

penduliflorus 131,198

pentandrus $58,89,131,198$

perakensis 198

princeps 131, 198

polyandrus 198

Sarawakensis 131,198

Chrysophyllum lanceolatum 32, 153

Chrysopogon aciculatus 120

orientalis 120

Cibotium barometz 36, 37

Cinnamomum iners 123

mollisimum 32,123

rhynchophyllum 123

Claderia viridiflora 79, 142

Clausena excavata 152

Claoxylon indicum 115

Cleistanthus? contractus 115 aff. glaber 115

hirsutipetalus 115

macrophyllus 115

maingayi 115,186

myrianthus 115

podocarpus 115

praetermissus 32,116

pseudopodocarpus 116
Clerodendron ? brevifolium 159, 223

buchanani 159,223

deflexum 82,159

inerme 159

myrmecophilum 159

? paniculatum 159

villosum 82, 159

climbers, woody 69

Cnestis palala 32,74

ssp. diffusa 107

Cocculus ovalifolius 132

Coelodiscus subcuneatus see Mallotus dispar

Coelogyne cumingii 142

testacea 142

rochussenii 79

Coelorachis glandulosa 44, 120

Coelospermum scandens 81

Coelostegia 51, 64, 70, 87, 171 griffithii $20,25,63,73,86,102,171$ ramealis 172

Colubrina asiatica 147

Combretum squamosum 106 sundaicum 35,106 tetralophum 17, 106

Commersonia bartramia 155

Connaraceae 70

Connarus 18 grand is 18,107

flowering 30

monocarpus 18

ssp. malayensis 74, 107

paniculatus 18,107

semidecandrus $18,74,107$

Copaifera palustris 24

Coptophyllum capitatum 148

Cornera 208 lobbiana 143

Corybas mucronatus 37

Costus speciosus 160

Cotylelobium burckii 89 malayanum $88,89,90$

Crateva membranifolia see C. religiosa religiosa 103 flowering 30

? Cratoylon 223

Cratoxylon 19, 22, 23, 40, 52, 71, 113 arborescens $6,20,21,58,61,62,66$, $67,68,70,76,89,103,104,115$, $122,144,192,193,205,206,220$, pl. 34 
flowering 30

special localities 31

cochinchinense 193

formosum $18,21,52,58,62,76,87$, 122,193

deciduous 31

flowering and leafing 30

pioneer seedlings 52

glaucum 89

ligustrinum $34,35,76,122,193$

Crinum asiaticum 95

Croton? erythrostachys 116

heterocarpus 116

laevifolius 35, 75, 116, 186

flowering and fruiting 30

oblongus 186

Crudia 195

caudata $76,125,195$

havilandii 40

wrayi $51,125,195$

Cryptocarya 123

sp./spp. 76,123

cinnamoniifolia 123

crassinervia 123

ferrea 123

griffithiana $32,76,123$

impressa 123

kurzii $13,18,123$

nitens 123

Cryptocoryne sp./spp. 100

flowering 30

special localities 32

cordata 100,170

griffithii 100

Ctenolophon 23, 87

parvifolius $26,70,77,128,196$

Ctenopteris moultoni 37

Curculigo latifolia 122, 193

villosa 122

Cyanotis barbata 178

vaga $57,106,178$

Cyathea glabra 82,86

latebrosa 82,162

obscura $34,35,162$

squamulata 162

Cyathocalyx pahangensis 32,97

ramuliflorus 67,72

ridleyi $22,32,97,167$, pl. 10

Cyathostemma viridiflorum 72,97

Cycas rumphii 50, 58, 161

Cyclandrophora excelsa 212 nannodes 212
Cyclophorus acrostichoides 28

Cymbidium finlaysonianum 28, 142

Cynometra ramiflora 58, 125

Cyperus cyperinus 108

cyperoides 108

Cyperus haspan 31

javanicus 57, 108

malaccensis 54,108 , pl. 28

pedunculatus $51,108,179$

polystachyos 57,108

radians 57,108

sphacelatus 74

stoloniferus 57,108

tenuiculmis 108

Cyrtandra spp. 120

lanceolata 120

pilosa 120

suffruticosa 120, 192

Cyrtandromoea 155, 192 grandis 120

Cyrtostachys $36,54,65,67,68,70$ lakka $37,54,70,80,89,143$

Dacrydium 85

Dacryodes incurvata 73

laxa 103

macrocarpa $20,25,89,103,172$ flowering 31

rostrata $20,73,103$

Dactylocladus 85 stenostachys 24

Dactyloctaenium aegyptiacum 57, 121

Daemonorops (see also rotan) 65, 92 spp. 80

angustifolius 18, 143

geniculatus 143

kunstleri 143

lasiospathus 144

leptopus $68,80,144$

longipes 144

periacanthus 144

var. macrocarpus 144

sabut 144

verticillaris 144

Dalbergia sp. 127

beccarii 16,126

leafing 30

ferruginea 58, 126

forbesii 126

havilandii 76

parviflora 16, 17, 18, 126, 195

stercoracea 127 
Dapania 68

racemosa $35,80,143$

Davallia denticulata 162 solida 28, 162

Decaspermum fruticosum 78, 137

Delima sarmentosa 110

Dendrobium 92

acerosum 28, 142

aloifolium 28, 79, 142

bifarium 79

callibotrys 142

calycopsis 79

carnosum 79, 142

comatum 79, 142

crocatum 142

crumenatum 58, 79, 142

fugax 142

indivisum 142

indragiriense 142

kelsallii 142

leonis 79,142

lonchophyllum 79, 142

pandenate 142

plicatile 79,142

prostratum 79,142 ,

salaccense 142

secundum 58, 142

spurium 28, 79, 142

Dendrochilum album 142

longifolium 79

spathulatum 142

Dendrophthoe lanosa 128

pentandra 128

Dendrotrophe buxifolia 81

Deplanchea bancana 36, 73, 102

Derris 6

amoena 127

heptaphylla 16, 42, 127

malaccensis 18,127

sinuata 127

uliginosa $14,17,127$

Desmodium umbellatum 58, 127

Desmos 167

dasymaschala 97, 167

var. dasymaschala see var. wallichii

var. wallichii 97

dumosa 72, 97

Dialium spp. 26

? kingii 33, 125, 195

maingayi 125
196

patens $21,51,67,68,70,76,89,125$,

platycepalum $21,70,76,89,125$

wallichii $21,70,76,125$

Dianella ensifolia 76, 127

Dichapetalum griffithii 109

Didissandra johorica 120, 192

Didymocarpus platypus 120

Didymoplexis ornata 142

Digitaria dispar 57 (see also D. heteranthera)

heteranthera 121

? longiflora 57, 121

Dillenia 40, 70, 110, 179, 180, 202, 217

sp. 180

albiflos 26, 33, 35, 37, 110, 179, 180

beccariana 180

excelsa $18,21,31,110$

flowering 30

fruiting 31

var. tomentella 110

eximia see D. grandifolia

grandiflora 24

187

grandifolia 21, 26, 37, 74, 110, 180 ,

deciduous 31

indica 110

pulchella $21,67,70,74,110$

? pulchella 180

reticulata $21,26,37,87,110$

deciduous 31

suffruticosa $18,51,53,64,110$ ever-flowering 31

Dimocarpus 215

longan 215

ssp. malesianus 152

Dimorphocalyx 188

murinus 116,186

Dioscorea sp. 110

lamprocaula 110

pyrifolia 110

Diospyros 92, 182

sp. $35,70,74,113,182,183,184$

apiculata 112,182

argentea $112,182,183$

confertiflora $33,112,182,183$

coriacea 74

dictyoneura 182

ferrea 113

? ferrea 58

? graciliflora 35,113

helferi 182

lanceifolia 26, 33, 74, 113, 182, 183 
latisepala 113

oblonga 74,113

maingayi $26,37,74,113,182,183$

? malayana 113

nutans $33,113,182,183$

? pahangensis 113

pauciflora 183

siamang $26,37,63,67-70,74,182$, 183

styraciformis 113

sumatrana 113

wallichii 182

Diplospora malaccensis 148

Dipodium pictum 37, 86

Dipteris conjugata 37 lobbiana 45

Dipterocarpus 23

sp./spp. $21,35,111,180$

apterus, 89,111

coriaceus $88,89,90$

cornutus 89,111

grandiflorus $26,58,88,111$

? hasseltii $52,58,111,180$

lowii $21,87,88,89,111,179,180$

oblongifolius (see also neram) 14, 40, $42,44,182$

sublamellatus 26, 87, 89, 111

? sublamellatus 111

Dischidia sp. 101

benghalensis 101

coccinea 73,101

collyris 73, 101

aff. complex 64, 73, 101, 170

gaudichaudii see D. nummularia

hirsuta 73

aff. hirsuta 101

nummularia 27, 73, 101

rafflesiana 58, 73, 101, 170

Disepalum anomalum 36, 86

Dissochaeta gracilis 129

johorensis 130

punctulata 33,130

Dodonaea viscosa 50, 153

Donax grandis 35, 129

Dracaena sp. 76

congesta? 127

elliptica 127

graminifolia 127

granulata $26,127,196$, pl. 25

maingayi 58,127

paludosa 128

porteri 127

singapurensis 128
Drymoglossum piloselloides 28, 162

Drynaria quercifolia 28, 82, 162

Dryobalanops aromatica (see also kapur) 7, 32, 33, $35,88,89,90,110,187$

oblongifolia $6,18,21,23,26,39,86$,

$87,89,90,111$, pl. 7

flowering 31

special localities 31

rappa 89

Dryopteris crassifolia 35

Drypetes 45

sp. 116

curtisii 116

pendula 75

riparia 44

Duabanga 46

grandiflora 46

moluccana 45

sonneratioides 46

Durio 171

carinatus 85,89

graveolens 73

? graveolens 102

griffithii 102

oblongus 171

singapurensis $3,35,73,102,171,172$

Dyera costulata 99

cauliflorum 33, 131

costulatum $17,18,132$

dumosum 132

euphlebium 132

? excelsum 132

flavescens 132

sericeum 33,131

lowii 24,45

Dysoxylon 45, 70, 92 ,

spp. 132

angustifolium 44

cauliflorum (see also D. sericeum) 33

macrothyrsum 21, 132

flowering 31

sericeum 131

Ehretia sp. 102

Elaeocarpus 23, 92, 186, 202

sp./spp. 75

flowering 30

acmossepalus see E. floribundus

floribundus 113

griffithii 18, 26, 39, 40, 64, 70, 75, 113

littoralis see $\mathrm{E}$. macrocerus

macrocerus $11,17,20,21,24,26,39$, $42,87,91,113,184,186$, pl. 12 flowering 30 
(E. macrocerus) fruiting 31

special localities 31 mastersii 75,86

nitidus 113

obtusus see E. macrocerus

paniculatus 18, 26, 113

petiolatus 19,113

polystachyus 75,113

robustus $13,19,113$

salicifolius 113

sphaericus 21,113

stipularis 26,113

Elateriospermum 188 tapos 33, 116

Elatostema sp. 158

elephants and sand hollows 53

Elettarriopsis curtisii 33, 160

Ellipanthus tomentosus 36

tomentosus var. gibbosus 35, 107

Elytranthe albida 128

Embelia 68

amentacea 137

? amentacea 78

canescens 137

coriacea $19,78,137$

dasythyrsa 137

garciniaefolia 137

Endiandra 123

holttumii 124

? macrophylla 124

maingayi 123

Endospermum pl. 15

diadenum 33, 75, 116, 186

malaccense see E. diadenum

Engelhardtia 86

nudiflora 76,86

serrata $70,76,86$

Enicosanthus praestigiosum 33, 97, 167

Entada phaseoloides 19, 126

flowering 30

spiralis 126

Epigynum ridleyi 99

Epipremnopsis media 100

Eragrostis atrovirens 57, 121 unioloides 44

Erechtites hieracifolia 106 valerianifolia 106

Eria floribunda 79, 142 gracilis 142 neglecta 79,142

nutans 79,142

pannea 79,142

pudica 28, 142

pulchella 79,86

teysmannii 142

velutina 79,142

vestita 28,142

Erioglossum 215

rubiginosum see Lepisanthes rubiginosa

Erycibe aenea 107

albida 107

griffithii 74

maingayi 33,107

princei see $\mathrm{E}$. maingayi

tomentosa var. hirsuta 107

Erythroxylon cuneatum 58, 114, pl. 27

Eugeissona 34 tristis 33,144

Eugenia 42, 64, 66, 67, 92, 165, 193 bark characters 202

coastal species 52

flowering 30

sp./spp. 27, 33, 58, 62, 63, 64, 78, $140,203,205$, pl. 36

A, B, 140, 205

anisosepala 137

atronervia 27, 137, 203

attenuata 203

brantiana 78

castanea 138, 203

caudata 203

cerina $13,19,21,27,37,40,42,51$, $68,70,78,138,203,204$

flowering 30

var. turbinata 67,138

chlorantha 138, 203

chloroleuca 138

? claviflora 203

var. maingayi 138

conglomerata 27, 33, 203, 204

var. paniculata 138

cumingiana 27, 78, 137, 203, 204

cumini 203

curtisii 138, 203, 204

cymosa see $\mathrm{E}$. syzygioides

densiflora 42, 43, 44, 58, 138, 203

duthieana 203

cf. duthieana 33, 138

dyeriana 33, 138, 203

fastigiata $19,42,138,203$

filiformis 138, 203, 204

flosculifera 203 
garciniifolia 27, 138, 203, 204

glauca 203, 204

grandis $24,49-53,58,96-100,102-106$,

$108,111,112,114-118,121,123$,

$124,127,129,131,132,137-139$,

$141,159,160,161,169,180,203$ -

205,214 , pl. 27

base of trees 204

forest 50, 52-56, 58, 141, 144-146, $148-150,152-154,156-158,169-$ $171,183,190,194,200,212,218$, 221, pl. 26, pl. 27, pl. 32 coastal, relics of 50 composition 58

seedlings 50

grata $27,138,203$

griffithii 138, 203

helferi 203

hemsleyana 203

kemamanensis 203

kiahii 27, 70, 138, 203

var. angustifolia 78, 138

kunstleri 78, 138, 203, 204

leptostemon 21, 27, 138, 203, 204

leucoxylon 138, 203, 204

linocieroides 203

longiflora $19,27,78,138,139,203$, 204 , pl. 23

microcalyx 78, 203, 204

millsii 203

muelleri 17, 19, 27, 42, 64, 67, 78 .

138,203

napiformis 139, 203

nemestrina $24,78,86,203,204$

ngadimaniana 139,203

nigricans $21,23,27,58,139,203,205$

oblata $27,43,139,203$

oblongifolia 203

oleina $23,27,78,139,203$

pachyphylla $78,138,203$

pahangensis 203

var. fraseri 203

palembanica $53,58,139,203,205$

papillosa $21,27,37.78,87,138,203$, 205

pauper $27,139,203$

pearsoniana 203

penangiana see $\mathrm{E}$. attenuata

perakensis 203

polita 203

polyantha 139

var. sessilis 139

pseudocrenulata $27,78,203$

pseudoformosa 203

? pseudoformosa 139, 203, 205

pseudosubtilis $21,33,40,42,139,203$ pseudosyzygioides 203, 204

punctulata see E. cerina

pustulata 203, 204

quadribracteata 139

ridleyi 139,203

rugosa $34,35,58,70,78,139,203$, 204

salictoides 203

scortechinii 19, 139

spicata $16,19,37,42,139,203,205$ flowering 30

stapfiana 203

subdecussata 139, 203

subhorizontalis $27,139,203$, pl. 15

syzygioides $58,139,203,204$, pl. 32

tahanensis 203

tetraptera var. pseudotetraptera 139

tumida $27,35,78,139,203$

valdevenosa $42,140,203,205$

venulosa see $\mathrm{E}$. muelleri

verecunda 203

virens 203

Eulophia graminea 57, 79

squalida 79,142

Euonymus javanicus 70, 73, 103, 173

Euphorbia atoto 57, 116

Eurya 64

acuminata 157

Eurycoma longifolia 155

Euthemis leucocarpa 79.86, 140

Evodia glabra 152

roxburghiana 152

Evolvulus alsinoides 57, 107

Excoecaria 188

agallocha 116

Fagraea auriculata 77

ceilanica $33,77,128$

crenulata 197

fragrans $88,180,197$

racemosa $19,64,77,128$

flowering 30

Fahrenheitia 188

pendula 188

Fibraurea ochroleuca 132

Ficus 8, 70, 88, 92, 188, 198, 199, 202

Subgen. Ficus sect. Ficus 134

sect. Calosyce 134

sect. Rhizocladus 134

sect. Sycidium 134

sect. Sycocarpus 135

Subgen. Pharmacosycea 134

Subgen. Urostigma 133

? acamptophylla 89 


\section{(Ficus)}

alba see F. grossularioides

albipila 64,77

annulata 133

apiocarpa $77,89,134,198$

aurata var. longipilosa 134

beccarii 88,135

benjamina 133

binnendijkii $19,77,133$

var. coriacea 133

bracteata $19,77,89,133$

callicarpides 89

calophylla $19,21,40,42,58,70,77$, 133,198

var. malayana 133

chrysocarpa see F. aurata var. longipilosa

consociata $19,21,58,77,198$

var. murtoni 133

crassiramea $19,21,40,42,58,133$, 198

cucurbitina $88,89,133,179,199$, pl. 8

delosyce $21,58,89,133,198$

deltoidea var. borneensis 89

var. deltoidea 27,89, 134

var. kunstleri 44

var. motleyana 89

depressa 88

diversifolia see F. deltoidea var.

deltoidea

dubia $58,89,133$

elastica 133,198

excavata $77,89,134,198$

fistulosa 77,135

var. angustifolia 135

geocarpa see $\mathrm{F}$. uncinata var. strigosa

glaberrima 88

glandulifera 134

globosa 16, 17, 19. 77, 133

grossularioides 77,134

heteropleura var. hirta 89

indica see F. sundaica

ischnopoda 45, 198

kerkhovenii 133

lepicarpa 11,135

microcarpa (see also jejawl) 3, 11, 17, $18,42,43,46,58,77,89,133,198$. $199,200,205$

var. naumannii 200

microsyce $77,89,133$

miquelii see F. schwarzii

nitida 200

obpyramidata $19,43,44,88,89,199$

obscura 214 var. borneensis $19,77,134$

oligodon 198

obpyramidata 135

parietalis 135

pendens 36,37

pellucido-punctata 77

pisocarpa 19,133

racemosa 198

recurva 27

var. bridelioides 134

var. ribesioides 77

retusa L. 18, 19, 77, 89, 133, 198, 199

retusa auctt. (see $F$. microcarpa)

ruginervia $77,89,134$

sagittata 134

var. minor 77

schwarzii 135

scortechinii 135

sinuata 135

var. oblonga 135

spathulifolia 86,88

stricta $58,70,77,89,133$

stupenda 88,89

var. minor 133

subgelderi 89

var. rigida 134

sumatrana 21

var. circumscissa 134

var. microsyee 134

sundaica $19,21,40,42,134,58,77$, 198

var. beccariana 88

supperforata 89

trichocarpa 77, 134

tristaniifolia $70,77,86,87,88,89$

truncata 133

uncinata 88

var. strigosa 135

uncinulata 88,134

uniglandulosa 135

urnigera 134, 187, 199

vasculosa var, acuminata 134

villosa 77

virens var. glabella 40,134

xylophylla $58,77,134$

Fimbristylis cymosa 57, 108

Fimbristylis dichotoma 57, 108

dura 44

ferruginea 54, 109

Fimbristylis pauciflora 74, 109

polytrichoides 54, 109

scricea 51, 57, 109

Finlaysonia obovata 101

fire-fly plants 14, 16, 205 
Fissistigma fulgens 97

$$
\text { kingii } 97
$$

lanuginosum 97

latifolium 97

manubriatum 97

Flacourtia rukam 75,119

Flagellaria, flowering 30

indica $68,75,120$

flora

estuaries, structure and zonation 54,55

ravine cliffs 54

shelving rocks 54

flowering and printing period 28 et seq.

Fomes lamaoensis 3 pectinatus 37

Fordia sp. 127 johorensis $34,35,127$ ngii 127

Forrestia gracilis 106 marginata 106 mollis 106

Freycinetia 196 anqustifolia 80, 145, 208

confusa 80,145

corneri $37,80,145$

imbricata 145

javanica 80,145

rigidifolia 145

Fuirena umbellata 109

fungi and Casuarina 50

Gaertnera 128, 81

sp.

obesa 33,148

schizocalyx 148

Gahnia tristis 109

Galearis 186

sp. 116

fulva 75,116

Galeola kuhlii 79, 142

Ganua 70, 216

sp. 81

kingiana $34,35,37,153$

motleyana $20,21,22,24,24,27,40$, $61,63,66,67,68,69,71,81,153$, 216 , pl. 7 , pl. 32, pl. 34

Garcinia 22, 24, 45, 60, 92, 105, 174

Garcinia A2, 3, 175

Garcinia A see G. ? eugeniaefolia sp./spp. 58, 74, 106, 174, 176 atroviridis 105 bancana $17,19,26,68,70,74,105$, 174,175

flowering 30

var. curtisii 105

cataractalis 44

? eugeniaefolia $105,174,175,176$

forbesii $26,67,74,105,174,175$

gaudichaudii 67,74

Garcinia griffithii 105

havilandii 24

hombroniana 58, 105, 176

hombroniana 74,175

maingayi $26,105,175,187$, pl. 23

nervosa $17,19,105$

nigrolineata $26,40,70,74,105,174$, 175

opaca 176

var. dumosa 105

parvifolia 74, 105, 175

? penangiona $33,175,105$ fruiting 31

? rostrata $26,67,68,70,74,105,174$, 170 , pl. 34 , pl. 39

scortechinii 74

uniflora 45

urophylla 106

Gardenia 45

griffihii 148

tentaculata $18,19,44,148$ special localities 32

tubifera $19,31,42,148$ flowering 30 fruiting 31

Gardeniopsis longifolia 33, 148

Gastrodia javanica 142

Gelonium 188

Geocharis aurantiaca 160

Geodorum citrinum 142

Gironniera nervosa 33,158 parvifolia 82,158

Gleichenia 64

laevigata 162

linearis 162

var. altissima 162

Globba 223

aurantiaca see G. patens

leucantha 160

marantina 160

patens 160

pendula 160

variabilis 35,160

ssp. pusilla 160 
Glochidion 186

glomerulatum 116, 186

laevigatum see $\mathrm{G}$. lutescens

leiostylum 75, 116

littorale 116

lutescens 75,116

palustre 186

rubrum 116

sericeum 75, 116

superbum 116

Gluta malayana $20,25,35,95$

renghas 14,41

flowering 29

tavoyana $33,35,95$

velutina (see also rengas) $11,14,39$, $43,45,95,165$, pl. 4

fireflies 205

flowering 30

Gluta wallichii 95, pl. 22

Glycosmis Chlorosperma 152

decipiens 152

pentaphylla see $\mathrm{C}$. chlorosperma

Glyptopetalum quadrangulare 103, 173

Gnetum 68

gnemon 161

var. brunonianum 161

flowering 30

gnemonoides $19,82,161$

latifolium var. funiculare 82,161

microcarpum 161

forma silvestre 82

Gomphandra sp. 122

quadrifida 122

var. ovalifolia 33,122

Gomphia serrata 19, 140

Goniothalamus spp.

flowering 30

macrophyllus 97

malayanus $22,25,40,72,97,167$,

pl. 21

ridleyi 72,97

tapis 33,97

Gonocaryum gracile 122

Gonystylus $71,85,87$

bancanus $26,70,75,85,120,192$

confusus 75,120

macrophyllus 120

Gordonia 87

? multinervia 35,157

singaporeana $21,157,220$

Grammatophyllum speciosum 142
Grewia 221

sp. 158

acuminata see G. umbellata

antidesmifolia 19, 40, 157

fruiting 31

blattaefolia $82,157,221$

fibrocarpa 40,158

hirsuta 158, 221

omphocarpa see G. hirsuta

tomentosa 42,158

umbellata 82,158

Guettarda 51, 115, 132

speciosa 58,149

Guioa bijuga 153

pleuropteris 58,153

Gymnacranthera 64, 87, 201

bancana $33,78,135$

eugeniifolia $26,70,85,89,135$ var. griffithii $21,37,78,135$ forbesii 21, 135

Gymnostachyum 95, 165

Gynochthodes lanceolata 81 sublanceolata 149

Gynotroches 70 axillaris $19,80,147$

Gyrinopsis sp. 220

Habenaria singapurensis 142 sumatrana 35,142

Hanguana 68 anthelminthica 45 malayana $75,120,191$

Hedyotis auricularia 44 capitellata 149 pinifolia 149

Hedychium longicornutum 160

Helicia attenuata 147 petiolaris 19,147 robusta $13,17,147$ rufescens 147

Heliciopsis velutina 147

Heliotropium indicum 102

Helixanthera cylindrica 128

Heritiera 217

elata $21,27,81,87,155$

littoralis 58,155

simplicifolia 21, 27, 155, 217, 218

deciduous tree 31

sumatrana $27,155,218$

Hernandra nymphaeifolia 58, 121

ovigera see $\mathrm{H}$. nymphaeifolia 
Herpestis monniera 32, 155

Heteropogon contortus 121

Hexapora ? curtisii 64, 68, 76, 194

Hibiscus 17, pl. 26

tiliaceus $14,43,44,51,58,129,153$ ever flowering 31 special localities 32

Histiopteris incisa 82

Hodgsonia capniocarpa 108

Homalium dasyanthum 119, 187, 191 longifolium 119

Homalomena 45, 60, 101 angustifolia 44 confusa 44

deltoidea 36

griffithii 44 forma kingiana 101

kiahii forma maculata 101

pendula 101

rostrata 101

rubra see $\mathrm{H}$. pendula

sagitifolia 73

var. angustifolia 73, 101

Homonoia 45

riparia 44

Hopea 89

? dyeriana 111

mengarawan $21,26,33,64,67,74$, $86,87,89,111,180$

? mengarawan 180

nutans 88

pachycarpa 163

pentanervia 89

polyalthioides $33,89,111,181$

resinosa $26,89,111,163,181$, pl. 15

Hornstedtia leonurus 82,160

phaeochoana 160

scyphiophora 82

Horsfieldia 67, 68, 70, 92, 201

sp. 26, 136, 201

brachiata 135 var. sumatrana 135

bracteosa 78,135

crassifolia $26,78,136$

flocculosa 136

grandis 78,136

irya $6,11,16,17,23,24,26,39,45$, 136, 201

flowering 30

macrocoma 64

var. canarioides 78,136

polyspherula $26,33,63,68,69,78$, 136 subglobosa 78

superba 78,136

wallichii 136

Hoya 102

spp. $58,73,102,171$

coronaria 102

diversifolia 102

? diversifolia 171

lacunosa 73,102

latifolia 102

parasitica 102

? ridleyi 102,171

Humata heterophylla 162

repens 28,162

Hydnocarpus 191

castanea 33, 119

curtisii 119,191

filipes 119

kunstleri var. tomentosa 119

nana 119

scortechinii 119

Hydnophytum 28

formicarum 81, 149

Hygrophila 45

saxatilis 44

Hylophila mollis 79, 142

Hymenocardia 206

Hymenocardia? 69

sp./sp.? 64, 69, 75, 186

Hymenophyllum denticulatum 162

neesii 28

penangianum 37

polyanthos 28,162

serrulatum 28, 162

Hypolytrum 179

nemorum 17, 18, 19, 109

var. proliferum 109

Hypserpa cuspidata 132

Iguanura geonomaeformis 144

polymorpha 144

wallichiana 144

ikan parang 8

Ilex 64

sp. 72

cymosa $13,19,39,43,51,72,100$, 156,170

macrophylla 72

maingayi 100

malaccensis 100

Illicium 36

peninsulare 37 
Imperata cylindrica 121 see also lalang

Inocarpus 89, 217, 221

edulis 196

fagiferus $50,127,196$

Inocybe 50

Intsia 216

spp. 26

bijuga 58,126

palembanica 21,126

Iodes ovalis 122

Ipomoea 50, 54, 178

carnosa see I. stolonifera

gracilis 57, 107

littoralis see I. gracilis

pescaprae 57, 107

stolonifera 57, 107

Irvingia malayana 81

Isachne globosa 121

Ischaemum 53

muticum 54, 57, 121, 178

Isoloma divergens 37,162 ovatum 37

Ixonanthes 17

reticulata $17,21,26,87,114,184$

Ixora 45, 213

flowering 29, 31, 213

concinna 149,213

congesta 81,149

flowering 30

grandifolia 17, 29, 149, 213

flowering 29

var. Iancifolia 149

javanica $18,19,43,149$

var. retinervia 33,149

lobbii 149,213

flowering 30

var. stenophylla 43,44

pendula 149

umbellata 149

J. Teysmannia 34

altifrons 33, 144

Jackia 165

flowering 30

ornata $63,68,69,70,81,149,187$

Jada 44, 45, patches 41

Jasminum ? maingayi 141

jejawi $3,11,12,16-18,32,39,104,106$, $131,199,200$, pl. 5 special localities 32

banks 39 stretches 32

-belt 11, 12, 17, 133, 151

Justicia sp. 95

johorensis 95

uber 95

Johore fig see Ficus kerkhovenii

Kadsura cauliflora 154

Kalanchoe pinnata see Bryophyllum calycinum

Kandelia 32

candel 147

rheedii see $\mathrm{K}$. candel

kapur 180

dominance 35

-forest 32, 34, 36, 95-98, 101-102, 104-109, 111-119, 122-123, 126-128, $130-132,135-140,143,144,147-$ $151,154-158,160,166,178,181$, $195,204,205,221-223$

flora 32, 33

-trees 7

keralt 9, 10

Kibara chartacea 132, 198

Knema 16, 67, 68, 70, 201

cantleyi see $\mathrm{K}$. plumulosa

conferta 78,136

curtisii 68

var. paludosa 78

furfuracea 136

glaucescens 17, 26, 136

forma rubens 136

var. cordata 136

var. patentinervia $35,78,136$

intermedia $17,26,63,68,69,78,136$, 201

latericia 136

laurina $35,37,136$

malayana 78,136

mandaharan 136

plumulosa 26, 136

Kokoona ochracea 104

Koompassia 22, 70

excelsa 90

malaccensis $22,24,26,33,40,51,62$, $67,70,76,89,126$, pl. 34

leafing 30

flowering 30

Kopsia singapurensis $35,72,99,169,170$ flowering 29, 30, 31

Korthalsia paludosa 144

Kostermansia 24, 87, 172, pl. 8, pl. 36 fruiting and flowering 29

malayana $20,25,102,171$ 
Kunstleria 127

corneri 127

curtisii 76

ridleyi 76

Kurrimia paniculata see Bhesa paniculata

Labisia 68

pothoina see L. punctata

punctata 78, 137

Lagerstroemia ovalifolia 21, 42, 43

var. exapiculata 129, 197

speciosa 42,43

lalang 53, 121

Languas melanocarpa 160

Lasianthus sp. 149

chryseus 149

ellipticus 33,149

griffithii 81,149

maingayi 149

stipularis 149

Lecananthus erubescens 81,149

Leea 45

gigantea 45

indica 159

Leersia hexandra 121

Lepidagathis longifolia 95

Lepidogyne longifolia 79

Lepionurus sylvestris 19, 141

Lepisanthes 153, 215

fruticosa 81

rubiginosa 153

senegalensis 153

tetraphylla 33, 153, 215

Leptaspis urceolata 76, 121

Leptonychia 218

glabra $33,156,218$

heteroclita 156

Leptospermum 36

forest 29

flavescens 37

Lepturus repens 121

Leucas zeylanica 122

Leucopogon malayanus see Styphelia malayana

Licuala 34, 208

ferruginea 144

kiahii 144

lanuginosa 35,144

longecalycata 144

spinosa $17,18,19,110,144$

triphylla 35,144
Limacia velutina 130

Limnophila 42

erecta 155

Lindera 92

sp. 26, 124, 194

lucida 76, 124

malaccensis 33, 76, 124

Lindsaea 45

borneensis 37

ensifolia see Schizoloma ensifolium

lucida 45

parasitica see L. scandens

scandens 83, 162

Linociera insignis 141

? insignis 79

paludosa 141

pauciflora 79, 141

Liparis gibbosa 79, 142

tricallosa 37

wrayi 79,142

Lithocarpus 64, 70, 92, 189, 219

sp. 26

andersonii 24

bennettii $21,26,61,63,67,68,75,87$, 118,189

? cantleyana 189,190

? cyclophorus 26, 189, 190

eichleri $118,189,190$

elegans 17, 19, 75, 118, 189

encleisacarpus 75,118

ewyckii 118

? ewyckii 189, 190

? gracilis 190

hystrix 26, 118189

? javanica 189

? javensis 26, 189, 190

kingianus 119, 144, 187

kunstleri 119, 187, 189

leptogyne $21,26,87,119,189$

lucidus 119

maingayi $119,187,189$

perakensis 119,187

sundaicus $19,119,190$

urceolaris $21,23,26,87,119,187$, 189,190

wenzigianus 24

wrayi 36,37

Litsea sp. 76

costalis 124

? costata 124 


\section{(Litsea)}

ellipticibacca see L. sessilis

ferruginea 76

firma 76,124

? kunstleri 124

lanceifolia 124

lanceolata 124

gracilipes $26,64,70,76,124,194$

grandis 76,124

johorensis 124

machilifolia 76

maingayi 124

megacarpa see L. costalis

perakensis 124

sarawakensis see L. lanceolata

sessilis 124

teysmannii 124

umbellata 124

Livistona kingiana 144

saribus 144, 208

Loeseneriella macrantha 16, 104

Lomariopsis cochinchinensis 162

Longetia 185

malayana see Autrobuxus nitidus

Lonicera 6

Lophathrum gracile 44

Lophopetalum 3, 62, 70

javanicum 104

multinervium $20,21,24,26,39,60$, $61,63,67,73,104,173$, pl. 14, pl. 16 , pl. 17

flowering 30

Loxocarpus holttumii 37

Lucinaea membranacea 149

morinda 81,149

Lucuma maingayi see Planchonella maingayi

malaccensis see Pouteria malaccensis

Lumnitzera 11

littorea 54, 58, 106

racemosa 58,106, pl. 29, pl. 30

Luvunga scandens 152

Lycopodium cernuum 64, 162

laxum 28, 162

nummularifolium 162

phlegmaria 83,162

scabrum 83

squarrosum 83,162

Lygodium 64

borneense 162 circinnatum 162

flexuosum 162

Macaranga 64, 92, 117, 187, 202

amissa 26, 116

baccaureifolia $31,116,187$

deciduous 31

flowering and fruiting 29, 30

leafing 30

caladiifolia 117

conifera 75

gigantea 75,116

griffithiana $21,75,116,187$

heynei 187

hosei 116

hypoleuca 75,117

javanica 117,187

laciniata 187

maingayi see $\mathrm{M}$. pruinosa

motleyana 187

aff. populifolia see M. amissa

pruinosa $70,75,117$

puncticulata $26,63,68,70,75,113$, 117, pl. 15

guadricornis 117,187

recurvata 75,117

tanarius 117

? tenuifolia see M. quadricornis

trichocarpa 75,117

triloba $75,86,117$

triloba complex 187

Macrolenes nemorosa see Marumia nemorosa

Macrosolen formosus 281

Madhuca sp. 154, 216

hirtiflora 154, 216

paludosa 216

sericea 153

sessiliflora 33, 154, 216

tomentosa 35, 154, 216

tubulosa 154

utilis 154

Maesa ramentacea 78, 137

Magnolia maingayi 129

Malaxis micrantha 80

Mallotus sp. 117

dispar 117

floribundus 42,43

? korthalsii 117

oblongifolius 117

porterianus see $\mathrm{M}$. oblongifolius

tiliifolius 58, 117

Mangifera 19, 23

sp. 72,96 
foetida 96

? foetida 58,166, pl. 32

griffithii 96,166

lagenifera, flowering 29, 96

longipetiolata see M. quadrifida

microphylla see $\mathrm{M}$. griffithii

aff. parvifolia $62,64,67,68,69,72$, 166,206

quadrifida $72,96,166$

cf. quadrifida 33

mangrove 11,45

reaches 32,39

relics 54

-belt 11,13

Mapania 53, 179

sp. 31,74

cuspidata 109179

var. petiolata 109,179

enodis 74,109

graminea 179

kurzii 33, 109

lorea $33,35,74,109$

micropandanus 33, 109, 179

palustris $35,37,109$

squamata 109

Maranthes corymbosa 212

Mariscus

albescens see Cyperus javanicus

cyperinus see C. cyperinus

sieberianus see $\mathrm{C}$. cyperoides

Marumia nemorosa 19, 130

rhodocarpa 77

Marsypopetalum pallidum 97

Mastixia trichotoma 74

? trichotoma 108, 178

Medinilla sp. 130

hasseltii (see also M. rubicunda var. hasseltii) 27

maingayi 27,130

pendens 130

rubicunda var. hasseltii $37,77,130$

scandens 130

Medusanthera gracilis 122

Meiogyne virgata 97

Melaleuca 203

Melanochyla 70

sp. $25,34,96,166$

auriculata $72,96,166$, pl. 39

aff. auriculata $33,96,166$

bracteata 96, pl. 21

densiffora 96 kunstleri 72

nitida 95,96

Melanorrhoea 70, 71

sp. $64,72,96,166$, pl. 34

aptera 25

deciduous 31

leafing 31

? aptera 96

pubescens 31

wallichii $20,22,40,61.63,66-69$, $71,72,86,87,96,166,205$, pl. 33 , pl. 34 , pl. 35

flowering 29

wallichii forest 62

transition 66

woodsiana $35,96,166$

forest, phase leading to lowland dipterocarp 71

Melastoma molle 130

Meliosma 215

lanceolata 152

pinnata ssp. ridleyi $33,152,215$

sumatrana $45,152,215$

Melodinus orientalis 99

Memecylon 22, 64, 70, 92, 197

sp. 77,130

amplexicaule 130

campanulatum 130

garcinioides 130, 197

hepaticum 130

heteropleurum 130

hullettii 130

laevigatum 19, 130

maingayi $33,35,130$

myrsinoides 19,130

paniculatum 40, 130, 198

subtrinervium 130

wallichii see $\mathrm{M}$. maingayi

Mempisang 6, 11, 109, 168

leaf-fall \& inflorescences 29

special localities 32

-belts 11-13, 16-18, 24, 29, 32, 39, $42,66,99,101,104-106,109$, $112-114,118,124-127,130-133,136$, $138,139,149,154,177,187,198$, $201,205,217,218,220,223$, pl. 4 , pl. 11

habitual members 17

Merope angulata 152

Merremia tridentata ssp. hastata 107

Mesophlebion chlamydophorum see Thelypteris chlamydophora motleyanum see $\mathrm{T}$. motleyana 
Mesua 106

aff. assamica 177

ferrea 33, 106

(Kayea) ferruginea 13, 19, 39, 42, $106,112,177$

fruiting 30

kochummeniana $33,106,177,181$

lepidota $26,106,177$

rosea $29,106,178$

flowering 29

Metroxylon 45

Mezzettia leptopoda 20, 72, 86, 89, 97, 167

Micrococca johorica 117

Microcos 221

Microsorium punctatum 28, 162

Microstemon curtisii see Pentospadon motleyi

Microtropis valida 104

Millettia atropurpurea 34, 35, 127 hemsleyana (see also jada) 41, 42, 43

Mischocarpus sumatranus 19, 153

Mitragyne 24

Mitrella kentii 68, 72, 97, 167

Mitrephora maingayi 97

Monocarpia marginalis 98

Morinda citrifolia 149

ridleyi 81,149

rigida $68,81,213$

? rigida 40

umbellata 149

Musa gracilis 135

violascens 135

Mussaenda glabra 19, 149

mutabilis 149

Mussaendopsis 22, 24, 70, 71

flowering 30,31

beccariana $21,27,63,66,67,68,69$, $81,89,150,213$, pl. 25, pl. 34

Myristica 22, 201

cinnamomea 78, 136

crassa $21,26,87,136$

elliptica $17,24,26,78,136,201$, pl. 14 flowering 30

guattariifolia 58, 89, 136

indica, fruiting 30

iners $21,23,26,63,78,87,136$, pl. 36 lowiana $21,23,26,36,37,51,62,67$, $68,69,78,89,136,201$, pl. 24 , pl. 38 maingayi 26,136

maxima 136

-Horsfieldia spp. 63

-Horsfieldia group 60

Myrmecodia 28

armata 150

tuberosa 81

Myxopyrum nervosum 141

Nauclea maingayi 19, 21, 86, 150, 214 subdita $39,43,44,150,214$

Naucoria 50

Neckia serrata 140

Neesia 64, 70, 86, 171

flowering 30

malayana $20,73,102,172$

Nenga $34,60,68,70,144$ macrocarpa $33,35,144$ pumila 80

Neolitsea $c f$. dealbata 124

Neonauclea 214

sp. 150, 214

Neoscortechinia 85 forbesii 117,187

fruiting 30

nicobarica 26,117 , pl. 20

paniculata see $\mathrm{N}$. forbesii sumatrensis 117,187

Nepenthes ampullaria $37,78,140$

gracilis $37,78,140$

rafflesiana $37,78,140$

Nephelium 215

flowering 29

eriopetalum 153

glabrum $19,21,51,81,153$

fruiting 30

cf. herveyi 153

malaiense 215

rubescens $19,21,30,81,153$

Nephrolepis biserrata 83, 162

neram 41-45, 182

\& pelawan, transition 41

streams 40

-rivers $14,40,42-45$

\& Saracca-streams, transition 41

Nipa fruticans (see also nipa) 144

Nervillia punctata 80,142

nibong

- berembang region 200

-forest 108, 154, 178

-swamps 101 
Nieuwiedia griffithii 72, 100

nipa $3,6,13,14,16,18,19,39,40$, $42-44,46,47,52,54,88,100,144$, $155,161,208,224$

forest 19

stretches 32

reaches 39

-belt $11,13,14,16,17,32,39,44$, $45,99,129,131,133,145,157,162$, 188,223

special localities 31

-swamps 129, 145

-zone 42

Norrisia 28

major 19, 27, 128, 197

Notaphoebe 123

coriacea 17, 26, 45, 124, 194, pl. 21 special localities 31

kingiana var. glabrescens 195

nitidissima 124

panduriformis 19,123124

reticulata 123,124

Oberonia sp. 80

flabellata 142

miniata 142

rhizophoreti 142

Ochanostachys 176, 207

amentacea 21,141

Ochrosia borbonica 58 oppositifolia 100

Ochthocharis borneensis 17,130 sylvestris 35,130

Omphalea bracteata 117

Oncodistigma monosperma 98

Oncosperma 20, 70, 200

filamentosum (see also nibong) 14, 144, 208, pl. 27

horridum $60,62,80,144,208$

Ophioglossum pendulum 28, 162 simplex 37

Ophiorrhiza singapurensis 150

Oplismenus compositus 121

Orchidantha fimbriata 128

Ormosia macrodisca 64, 76, 196

Orophaea enterocarpa 98

Oryza minuta 121

ridleyi 121

Osbeckia ? 130

sp. 33
Osmelia maingayi 75

Ostodes 118, 186, 188

Ostodes ? 117

macrophylla 188

pendula 117,188

Otophora 215

Oxymitra affinis 98

biglandulosa 72

borneensis var. sumatrana 72

filipes 98

glauca 98,172

latifolia 98

Pachycentria tuberosa 27, 37, 78, 130

padang-terrace 56

Paederia verticillata 150

Palaquium sp. 10, 27, 154, 217, pl. 20 burckii 70,81

clarkeanum 33, 154

confertum $21,27,154$

gutta 154

hexandrum 27, 34, 35, 81, 154, 216

leiocarpum 81,154

macrocarpum $21,27,154$

obovatum 21,154

ridleyi $70,81,85,86,216$

rostratum 27,81

semaram $21,27,58,70,81,154$

sukoei 33,154

xanthochymum 16, 20, 21-23, 27, 31, $39,50,60,61,62,66.68,70,71,81$, $86,87,154,169,217$, pl. 13, pl. 17, pl. 35

flowering 30

special localities 31

var. sessiliflora 169

xanthochymum forest 62 transition 66

Pancratium maritimum 95

Pandanus 6, 22, 24, 64, 92, 179, 208, 209 affinis $14,39,45,145$

alticola 80, 145, 209

atrocarpus 19, 27, 37, 62, 65, 67-70, $80,145,208,209$, pl. 38

aurantiacus see $\mathrm{P}$. affinis

corneri 45, 145, 208, 209, see also P. rostratus

corneri ? 89

dubius 50, 58, 89, 145, 208, 209

echinodermops 145, 209

epiphyticus $7,145,179,208$

distribution 209

fascicularis 210 


\section{(Pandanus)}

gibbsianus 209

helicopus (see also rassau) 3, 11, 13, $15,16,27,31,43,45,46,89,101$, $145,146,201,209,211$, pl. 1, pl. 4 flowering 30

fruiting 31

? helicopus 80

immersus 210

kamii 37, 60, 80, 145, 208, 209, 210, pl. 5

malayanus $13,16,27,39,145,208$, 210 , see also $\mathrm{P}$. militaris

militaris and variety 210

obovoideus 209

odoratissimus $45,50,58,80,145,208$, 210, pl. 30

ornatus see $\mathrm{P}$. recurvatus

parvus 145, 209, 210

pentodon $145,208-211$

recurvatus $34,37,54,148,208$

rostratus 145

scortechinii 146, 208, 210

spurius 210

tectorius 210

yvanii 13, 16, 27, 146, 208, 210, 211

Panicum brevifolium 44, 45

repens $57,121,192$

Paphiopedilum bullenianum 37

Paraboea sp. 120

densifolia 120, 192

pyrrhaeflora 120

Paragrewia 218

Paramapania parvibracteata 37

Parameria polyneura 72,100

Paramignya angulata see Merope angulata

lobata 152

scandens 152

Parartocarpus 22, 24, 36, 51, 69, 70

venenosus 201

ssp. forbesii $21,37,68,77,89,135$ 200, pl. 33

Parastemon urophyllum $19,70,80,87$, 89,148

Parinari 87, 212

asperulum see $\mathrm{P}$. nannodes

corymbosa 148,212

costata $21,80,148,212$

nannodes $21,33,148,212$

oblongifolia $21,80,148$

Parinarium corymbosum 58
Parishia sp/spp. 25, 63, 72

insignis 86

? insignis 96

? pubescens 19, 96

Parkia speciosa 21, 26, 31, 35, 76, 126 deciduous 31

Pasania A, 189, 190

costata 190

? cytorrhyncha 190

? omalakos 190

? sundaica-lamponga 190

Paspalum 54

cartilagineum 57,121

conjugatum 44,45

orbiculare 57,121

vaginatum 51, 54, 57, 121, 192, pl. 28

Pavetta spp. 150

indica 81,150

naucleiflora 150

tomentosa 150

Pelawan 41

-reach 43

Peliosanthes sp. 76

violacea 128

viridis 128

Pellacalyx 212 axillaris $19,27,80,147,212$ saccardianus 212

Peltophorum pterocarpum 58, 126

Pemphis acidula 54, 58, 129

Pentace 221, 222

sp. 158, 222

corneri 29, 158, 221

strychnoides, flowering 29

triptera $22,27,62,82,87,158,222$, pl. 35

flowering 29

Pentaspadon 87

motleyi 96

officinalis $11,20,25,96,166$

deciduous 31

flowering 29-31

pepper 5

Pericampylus incanus 132

Peristrophe sp. 95

Peronema canescens 159

Perotis indica 121

Petunga roxburghii 52, 214 venulosa 214

Phacelophrynium 35 maximum 34, 35, 129, 197 
Phaeanthus ophthalmicus 98

Phaeomeria maingayi 160 venusta 160

Phaius tankervillae 37

Phalaenopsis fuscata 142

Phaleria capitata 157, 221

Phellinus (Fomes) rimosus 50

Phoebe spp. 124

cuneata 19,124

declinata 85

Phoenicimon rubiginosum 152

Pholidocarpus 20

macrocarpus 144

Photinopteris speciosa 162

Phragmites 6

Phreatia secunda 142

Phrynium basiflorum 129, 197 capitatum 35, 129

gracile 129

hirtum 37, 129, 197

Phyllanthus sp. 117

frondosus see P. oxyphyllus gomphocarpus 33, 117 oxyphyllus 33,117

Phyllochlamys wallichii see streblus taxoides

Phymatodes crustacea 162 scolopendria 162

sinosum 28

sinuata 83,162

Physostelma wallichii 73

Phytocrene bracteata 76 oblonga 122

Pimeleodendron griffithianum 75, 117 macrocarpum 118,188

Pinanga 64, 144, 208

sp. 144

disticha 144

limosa 144

malaiana 144

pectinata 144

symplicifrons 144

Pinus 6

Piper spp. 146

? boehmeriaefolium 146

caninum 146

flavimarginatum 80

miniatum 80,146

? muricatum 146 nigrum 80

pedicellosum 146

porphyrophyelum 146

ramipilum 146

stylosum 37, 146

Piptospatha ridleyi 35, 101

Pithecellobium bubalinum 35, 126

clypearia 126

confertum 76

contortum 126

ellipticum 76

jiringa 126

kunstleri 126

Pittosporum ferrugineum 58, 146

Plagiostachys albiflora 35, 160

Planchonella maingayi 21, 27, 81, 154 obovata 58,154

Platea excelsa 70,86 var. riedeliana $26,76,194$, pl. 18 latifolia $21,26,76,122,194$, pl. 18

Platycerium coronarium 28, 83, 162 ridleyi 27,162

Plectocomia griffithii 144

Plethiandra sessiliflora 130

Pleurococcus 223

Plocoglottis sp. 37

gigantea 35,142

javanica 80,142

Ploiarium 17, 70, 220

alternifolium 17, 27, 82, 157, 220, pl. 11, pl. 40

Pluchea indica 106

pneumatophores 23 et seq.

Podocarpus 6

blumei see $\mathrm{P}$. wallichianus

motleyi 22, 193, 161

neriifolius 19, 22, 58, 161

leafing 30

polystachyus 58,161

wallichianus $22,70,82,161$

Podochilus lucescens 142 microphyllus 142

Podolasia stipitata 40, 101, pl. 40

Pogonanthera pulverulenta 130

Pogonatherum paniceum 44

Poikilospermum spp, flowering 30

amoenum 19

cordifolium 158, 222

microstachys 158 
(Poikilospermum)

scortechinii 82,158

suaveolens 158, 222

Polyalthia 92

angustissima 72,98

brunneifolia 33,98

bullata 98

cauliflora var. beccarii $35,98,168$

var. cauliflora 168

var. desmantha 98

glauca $63,67-69,72,85,98,168$

hookeriana 98

hypoleuca $20,68,70,72,85,89,98$, 167,168 , pl. 37

lateriflora $72,98,168$

macropoda 36,98

purpurea 168

sumatrana 33,98

sclerophylla (see also mempisang) 6,

$11,16,17,24,39,42,45,62,72$,

$98,167,168$, pl. 11, pl. 13

Polystichopsis hasseltii 37

Pomatocalpa latifolium 142

Pometia 22, 34, 60, 61, 62, 66, 167, 202 alnifolia 215

pinnata $45,86,215$

forma alnifolia $21,27,62,67,68$, $70,81,153,215$, pl. 9, pl. 36

Pongamia pinnata $42,58,127$

var. xerocarpa $17,19,127$ leafing 30

Popowia hirta 72

pisocarpa 98

Pothos latifolia 68,73

macrocephalus 101

scandens 101

Pouteria malaccensis 27, 33, 154 paucinervia 154

Pouzolzia indica 158

Premna 223

corymbosa see P. obtusifolia

divaricata 159

obtusifolia 159

trichostoma 16, 159

flowering 30

Prismatomeris 18

sp. 150

tetrandra 19,150

Procris sp. 158

Pronephrium triphyllum see Abacopteris triphylla
Prunus 212

arborea see Pygaeum griffithii

grisea see Pyg. lanceolatum

Pseuderanthemum sp. 95 crenulatum 95

Pseudoeugenia 70, 203 perakensis 140 singaporensis $27,78,140,205$

Pseuduvaria galeata 33, 98, 167 macrophylla 33,98

Psilotum sp. 162

Psychotria 92

sp./spp. 150

angulata 150

griffithii 150

helferiana 35,150

maingayi 81,150

obovata ? 81,150

ridleyi 150

rostrata 150

sarmentosa 150

? stipulacea 150

Ptelaeocarpa malaccensis 102

Pteridium aquilinum 37

Pteris asperula 37

ensiformis 162

tripartita 83

Pterisanthes coriacea 82, 159

Pterocarpus indicus 26, 56, 127, 196

Pterospermum 52, 87 javanicum $21,27,58,156,218$ flowering 29-31

Pternandra capitellata 45 coerulescens $19,40,77,131$ echinata 77

Ptunga roxburghii 58, 150, pl. 26 venulosa 150

Ptychopyxis kingii 118

Ptychoraphis singaporensis 33, 144

putat $9,12,13,14,16,39,40,41,43$, $104,107,125,193,199,200,214$, pl. 4 , pl. 6

-belt 11, 13, 14, 16, 121, 125, 126, 193, 199 , pl. 5 -rassau belts 40

Pycreus polystachyos see Cyperus polystachyos

Pygaeum 212 griffithii $37,80,86$

lampongum 148, 213

lanceolatum 80 
Pyramidanthe prismatica 72

Pyrenaria acuminata 157 kunstleri 157

Pyrrosia adnascens 162 angustata 83,162 longifolia 28,162 nummularifolia 162

Quassia 217 indica $155,217,221$

? indica 89

Quercus 189 craterophora see Lithocarpus urceolaris spicata see L. elegans

Quisqualis indica 106

Radermachera lobbii 102

Randia sp. 214 anisophylla 214 auriculata 81,150

binata 150

clarkei 81

fragranatissima 150

kuchingensis 150

longiflora 14,150

macrophylla 81

? oppositifolia 150

penangiana 33

? penangiana 150 scortechinii $35,151,214$

Raphidophora beccarii 101 minor 16, 101

sylvestris 33,73

forma crassifolia 101

rassau $3,6,9,11,13,14,16,18,39$, $40,41,43,104,107,147,193,200$, 208, pl. 4

special localities 32

stand 42

-banks 16

-belt 15, 16, 18, 32, 105, 106, 118, $121,126,133,139,151,165,199$,

205,211, pl. 4 , pl. 5

-thickets $12,18,39$

Remirea maritima see Cyperus pedunculatus

rengas $12,14,15,16,39,43$, pl. 4 , pl. 6 flowering 29

Rennellia elongata $33,35,151$ speciosa 151

Rhizophora $13,54,211$, pl. 28 apiculata 54,147

conjugata see R. apiculata mucronata 54,147

occurrence 32

Rhizophora-forest 211

Rhodamnia cinerea 140

trinervia see $\mathrm{R}$. cinerea

Rhodomyrtus 53

tomentosa 140

Rhynchospora corymbosa 17, 109

Rinorea anguifera 31, 159

horneri 159

javanica 159

lanceolata 159

river-mouths, new siting 51

Robiquetia spathulata 142

roots, role in swamp-forest 46

stilt,- 22 et seq.

rotans 9, 10, 52, 208

Roucheria griffithiana 77, 128

Rourea 18

mimosoides $16,17,19,107$

minor $19,74,107$

Roureopsis 18

asplenifolia 19, 107

rubber 5

Ryparosa hullettii 119 scortechinii 119, 191

Saccharum arundinaceum 43, 121

Salacca 13, 20, 52, 60, 62, 65, 67, 68, 70, 121,208 conferta $80,89,144$

Salacca-swamps 113

Salacia chinensis 104 korthalsiana 104 macrophylla 104 oblongifolia 104

Salix 6

Salomonia cantoniensis 45

Samadera indica see Quassia indica

Sandoricum sp. 33, 132

? emarginatum $77,86,89$

Santiria apiculata 70, 73, 103, 172

conferta 103,172

griffithii 73

laevigata $19,21,25,67,68,69,70,73$, $89,103,172,173$, pl. 34 , pl. 37

rubiginosa $21,25,63,67,68,70,73$, $89,103,173$, pl. 34 
(Santiria)

tomentosa $21,25,70,73,103,173$

Sapium baccatum 34, 35, 118

discolor 75

indicum 45, 118, 188

Sapota 216

Saprosma glomerulatum 33, 151 quadrifidum var. ? 33

Saraca 6,171

bijuga (see also Saraca-streams) 11, 45,126

indica 126

-streans 6, 11, 13, 16, 40, 42, 45, 91, $101,110,120,129,131,135,138$, $139,148,149,152,154,158-160$, $192,197,205$

Sarcanthus halophilus 142 machadonis 142

Sarcochilus berkeleyi 37 johorensis 142

Sarcolobus 101 globosus 14, 102

Sarcostoma javanicum 28, 80, 142

Sarcotheca laxa 208 var. hirsuta 143, 208 var. laxa 208

Saurauia tristyla 35,154

Scaevola 51, 91, pl. 26 frutescens see $\mathrm{S}$. taccada sericea see S. taccada taccada 58,120

Scaphium affine see S. macropodum linearicarpum 35,156 macropodum $21,24,27,30,31,35$, 156,218

deciduous 31

Scaphocalyx spathacea 119

Scaphochlamys erecta 160

klossii 161 var. minor 35,161

Schefflera cephalotes 64,73 , pl. 34, pl. 37 farinosa see $\mathrm{S}$. tomentosa lanceolata 101 subulata $17,19,73,101$ tomentosa 19, 101 venulosa 101

Schismatoglottis brevicuspis 35, 100 wallichii var. oblongata 101
Schizaea dichotoma 162 digitata 162

Schizoloma ensifolium 162

Schizostachyum chilianthum 19 gracile 121 zollingeri 121

Schoenorchis secundiffora 80,142

Schoutenia accrescens 31, 35, 158, 222 corneri 158

glomerata $11,45,158,222$

mastersii var. glabra see $\mathrm{S}$. accrescens

Scirpodendron 14, 17, 52, 54, 109, 179, 210 ghaeri 109

Sciurus nigrovittatus johorensis see squirrels

Scleria 109

lithosperma 109

multifoliata 44

poaeformis 109

? purpuracens 44,45

Scleroglossum debile 37

Scleropyrum ridleyi 152

Scolopia spinosa 119

Scorodocarpus borneensis 21, 33, 141

Scyphiphora hydrophyllacea 151, pl. 30

Sebastiana chamaelea 57, 118

Securinega virosa $42,43,44$

Selaginella 224

Selliguea heterocarpa 28, 162

Semecarpus velutina 96

Serianthes dilmyi 58, 126 grandiflorum 126

Sesuvium 51

portulacastrum 51, 95, 165

Shorea 22, 92, 142, 174

flowering 30

forest 62

leafing 30

spp. 39

acuminata $33,89,111,181$

albida $85,89,90$

bracteolata $19,87,89,90,111,181$

collina $24,88,89,111$

curtisii, fruiting 29

? elliptica 181

exelliptica $21,33,87,88,89,111,181$

? eximia 74

foxworthyi $33,35,88,89,90,111,181$ 
gratissima 74

inaequilateralis 89

lepidota $14,19,21,89,91,111,181$, 182

leprosula $89,112,181$

longiflora 89

longisperma 163

macrantha $88,89,90$

macroptera $61,63,74,89,112$

materialis $88,89,112$

ovalis $89,112,181$

pachyphylla 89

palembanica $19,21,33,87,89,112$, 181

parvifolia 112,182

pauciflora 112,182

platycarpa $21,40,51,61,63,67,68$, $70,74,86,88,89,112,182$

resina-nigra $88,89,112,163,182$, pl. 8

rugosa 89

var. uliginosa 85

scabrida 89

seminis 88,90

singkawang $14,21,39,87,88,89,91$, $111,112,181,182$

sumatrana $19,21,39,87,88,89,90$, 112,182

teysmanniana $85,89,90$

Sida cordifolia 129

Sindora 19, 23

coriacea $21,31,89,126$, pl. 7

deciduous 31

leafing 30

wallichii $21,76,89,126$

Sloanea javanica 59

Smilax 196

barbata see S. setosa

calophylla 37,128

leucophylla 128

myosotiflora 128

setosa 128

Solanum parasiticum 27, 155

Sonerila sp. 131

caesia 131

costulata 35

picta 131

Sonneratia $17,24,52,54,192,196,200$ forest 19

-belt 24

acida see $\mathrm{S}$. caseolaris

alba 54, 129, pl. 28

caseolaris 14, 32, 40, 44, 56, 129

stands 32 griffithii see $\mathrm{S}$. alba

and fire-flies 205

Sophora tomentosa 127

South Johore, seasons 28-30

Spatholobus sp. 76

Sphaerocaryum malaccense 14, 121, 193

Sphagnum 85, 87

Spilanthes 51

urens 57, 107, 178, pl. 37

Spinifex 51

littoreus 121

Sporobolus virginicus 57, 121

squirrels \& tree-rats

distributional pattern 209

Stachyphrynium griffithii 129

Staurogyne griffithiana 35,95 kingiana 95

Stemonurus 23

malaccensis 122,194

scorpioides $21,26,76,89,122,194$

secundiflorus $21,70,76,89,122$

Stenochlaena palustris 83,162

Stephania ? 132

Sterculia bicolor $81,156,218$

deciduous 31

flowering 30

brachycarpa 156

coccinea $33,64,68,81,156$

laevis see $\mathrm{S}$. coccinea

macrophylla $21,27,31,63,81,156$, 218

deciduous 31

cf. rostrata 156

rubiginosa $33,81,156$

cf. scortechinii $33,156,218$

Stephania sp. ? 33

Stichoneuron caudatum 35, 155

Streblosa pubescens 151

Streblus 188

elongatus 77

taxoides $33,35,135$

Strombosia 23, 40, 70, 87

maingayi $21,60,67,79,141,207$

Strychnos axillaris 128

ignatii 33,128

villosa 128

Styphelia (Leucopogon) malayana 187

Styrax crotonoides 35, 156, 219 
Suregada 188 glomerulata $58,118,188$ multiflora 118,188

Susum anthelminthicum 191 malayanum 191

Swintonia penangiana $33,34,35,96,166$ schenkii, flowering 29

Sympetalandra 36

borneensis 196

hildebrandii 37,126 var. steenis 196

Symplocos 40, 219

sp. 156, 219

barringtoniifolia $33,82,156,219$

celastrifolia 40,156

odoratissima var. odoratissima 156

rubiginosa 156, 219

Syngramma alismifolium 37, 162 borneensis 37 minima 37

Synostemon bacciformis 57,118

Syzygium 202

Tabernaemontana corymbosa 72,100 var. kelsalli 100,170

? cylindrica 100

? malaccensis 100

? pauciflora 100

sphaerocarpa 100

Tacca 188

chantrieri 156

cristata see $\mathrm{T}$. integrifolia

integrifolia 82,156

leontopetaloides 100, 156, 219, pl. 31

palmata 52, 156, pl. 31

vespertilio see $T$. chantrieri

Taeniophyllum sp. 28

culiciferum 143

filiforme 80,143

obtusum 80, 143

Taenitis blechnoides 83, 162 interrupta 162

Talauma 64

lanuginosa 77

singapurensis $60,62,77,129$

Tarenna 214

appressa 81,151

costata 151

fragrans 19,151

longifolia 81,151

mollis 151,214

stellulata 151
Tarrietia 217

Tectaria barberi 163

grandidentata 37

semibipinnata 163

singaporeana 163

Teratophyllum aculeatum 163

ludens 83

rotundifoliatum 163

Terminalia catappa 51, 58, 106, 114, 176 citrina 106

phellocarpa 20,21, 22, 74, 87, 106 -zone 161

Ternstroemia bancana 157, 220

corneri 220

elongata 33,157

Tetracera 42 akara $42,44,74$

arborescens 19, 74, 110

fagifolia 110

indica $19,42,44,110$

scandens 110

sylvestris see $\mathrm{T}$. akara

Tetractomia 22, 24, pl. 7 holttumii see $\mathrm{T}$. tetranda major $70,81,152$ tetrandra $27,70,81,152,214, \mathrm{pl} .36$

Tetramerista 70, 85, 87, 220 glabra $27,82,85,196,220$

Tetrardisia corneri 137

Teysmannia 34 altifrons 33,144

Thecostele secunda 37

Thelasis carinata 143 micrantha 80,143 triptera 80,143

Thelephora ramarioides 50

Thelypteris chlamydophora 83,163 crassifolia 28,163 motleyana 34,163

Thespesia populnea 58,129

Thoracostachyum 179 bancanum 74, 109 sumatranum 109

Thrixspermum acuminatissimum 143 amplexicaule 16, 143

arachnites 58, 143

carinatifolium 143

corneri 143

recurvatum 143

Thuarea involuta 57, 121 
Timonius 60

flavescens $37,51,68,70,81,151$

wallichianus 81

wrayi $33,151,214$

Toxocarpus glaborescens 73,102 griffithii 73

Trema amboinensis 82 orientalis 158 tomentosa 82

Trichoglottis lanceolaria 37

Trichomanes aphlebioides 37, 163 motleyi 83 obscurum 83, 163

Trichosanthes ? tricuspidata 108 wallichiana 108

Tridax procumbens 107

Trigonachras acuta 39,153

Trigoniastrum hypoleucum 146

Trigonostemon 34

borneensis 118

longifolius 33,118

rufescens $33,118,188$

sumatranus 118,188

villosus $33,118,189$

Tristania 6, 41, 71, 86, 96, 202, 223, pl. 3

sp. 140, 206, 207

grandifolia 86

maingayi 206

aff. maingayi 86

? merguensis $22,62,64,67,68,70,78$,

$86,140,206,207$, pl. 24 , pl. 34 obovata 86,140

pontianensis $70,78,86,206,207$

? pontianensis 33, 140, 206

spathulata 37

subauriculata 206

sumatrana (see also pelawan) 6, 11, $18,19,30,37,39,41,44,46,86$, $140,206,207$, pl. 14

flowering 29

-bank $7,11,13,16,18,32,39,40$, $57,87,99,100,103,104,107,111$. $113,118,121-128,130,131,133$, $134,138-141,143-151,153,156-$ $159,161,170,200,205,211$, pl. 1 , pl. 3 , pl. 14

flora $18-19$

Tristellateia australasiae 129

Triumfetta repens 158
Trivalvaria nervosa 35,99

Turpinia latifolia 217

laxiflora 217

sphaerocarpa 27, 155, 217

Tylophora asthmatica 102

Uncaria 8, 68, 151

attenuata 16,151

glabrata 151

ovalifolia 81,151

pedicellata 151

pteropoda 151

scleroptera 16,151

Urceola brachysepala 100 torulosa 72

Urnularia flavescens 72

Urophyllum 60

sp. 151

corymbosum 151

glabra 81,151

hirsutum 151

? macrophyllum 151

streptopodium $35,81,151$

trifurcum 151

Urostigma 199

microcarpa 200

Utricularia flexuosa 127

Uvaria cordata 99

leptopoda 72, 99

pauciovulata 99

Vaccinium acuminatissimum 114

bracteatum 37, 58, 114, 187

malaccense see $\mathrm{V}$. bracteatum

Vandellia crustacea 45

Vanilla griffithii 58, 80, 143

Vatica 70

hullettii 163

maingayi 89,112

mengachapoi 88

pauciflora 163

stapfiana 89,112

stipularis 34

stipulata $35,89,112,163,187$

wallichii $13,19,21,42,63,68,69,74$,

$85-87,89,112,163,182$

fruiting 30

Ventilago malaccensis 147

Vetiveria nemoralis 44

Vigna marina 57,127

Viscum orientale 128 wrayi 128 
Vitex clarkeana 14, 17, 19, 31, 159, 223 ovata $57,159,223$

peralata $19,27,159$

flowering 30

pubescens 27,159

trifolia see V. ovata

ssp. littoralis 223

Vitis glaberrima 82

furcata 159

gracilis 159

hastata 82

japonica 82,159

? lawsonii 160

mollissima 82,160

novemfolia 82

pyrrhodasys 160

? trifolia 160

Vittaria ensiformis 28, 83, 163

Wedelia biflora 51, 57, 107

Willughbeia coriacea 72,100

glaucina 86 grandiflora 86

Wormia 179

beccariana see Dillenia albiflos

Xanthophyllum 92, 211

affine $19,80,146,211$ flowering 31

fruiting 31

bullatum 146

curtisii 146, 211

ellipticum 146

? ellipticum 80,211 kingii 19

maingayi 146, 211

malayanum 146

obscurum 147, 211

pulchrum 27, 147, 211

stipitatum 147

wrayi 147, 211

Xerospermum, flowering 29

sp. 153,215

muricatum 21, 153

Xylopia 70

sp. 99,169

caudata $68,72,89,99,128,168$

ceriifolia 24

elliptica 99

ferruginea 24, 25, 99, 167

var. oxyantha 99

fusca $6,20,24,25,39,60,61,62,67$, $68,71,72,99,167-169,174$, pl. 24, pl. 35 , pl. 36

forest 66

special localities 31

maingayi 89

malayana $99,167,169$

staudtii $24,25,61,63,67,68$

subdehiscens 99, 169

Zingiber puberulum 82, 161

var. chryseum 161

wrayi $34,35,161,187$

Zizyphus calophylla 16, 17, 19, 147 elegans 80

Zoysia matrella 121 


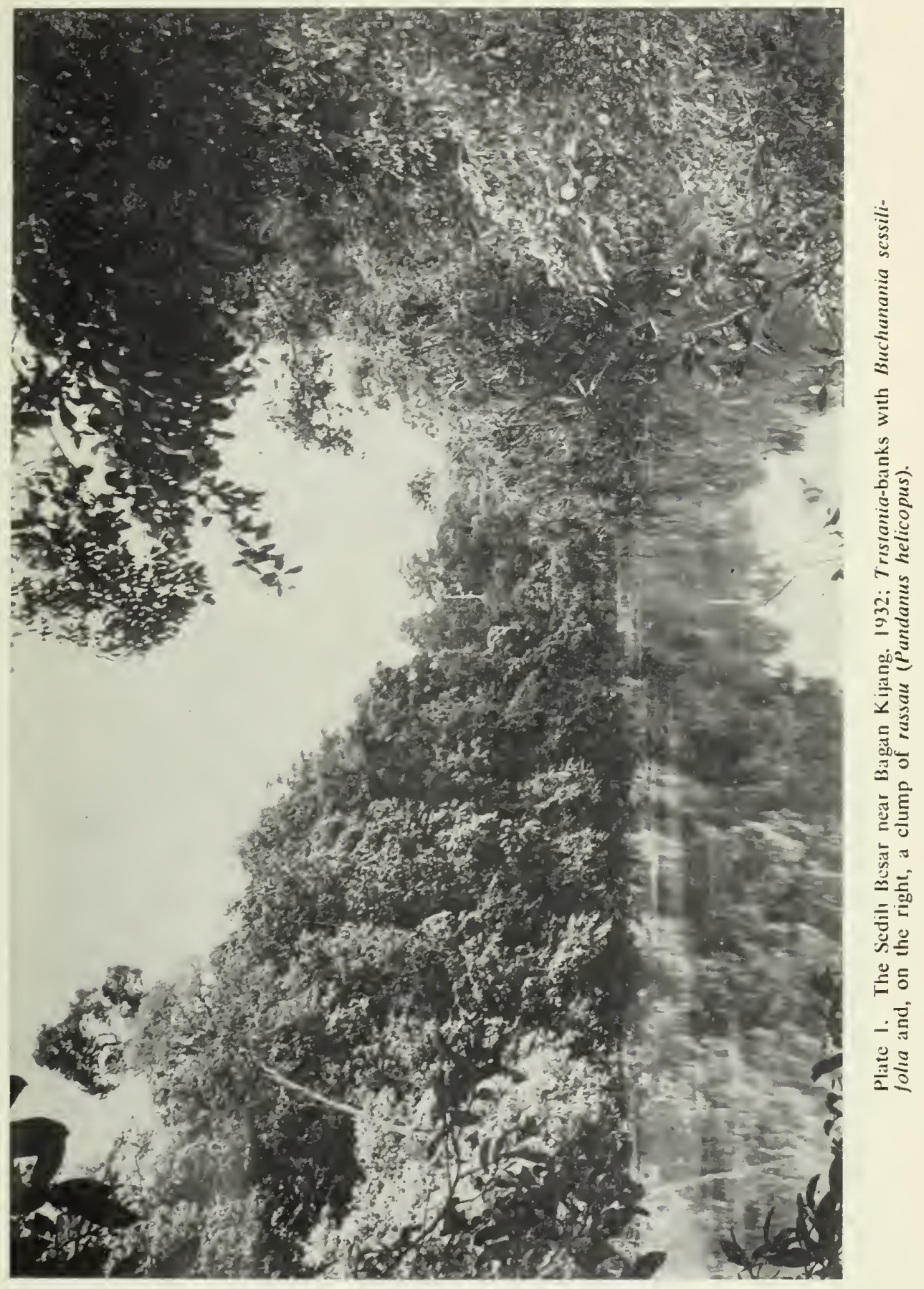



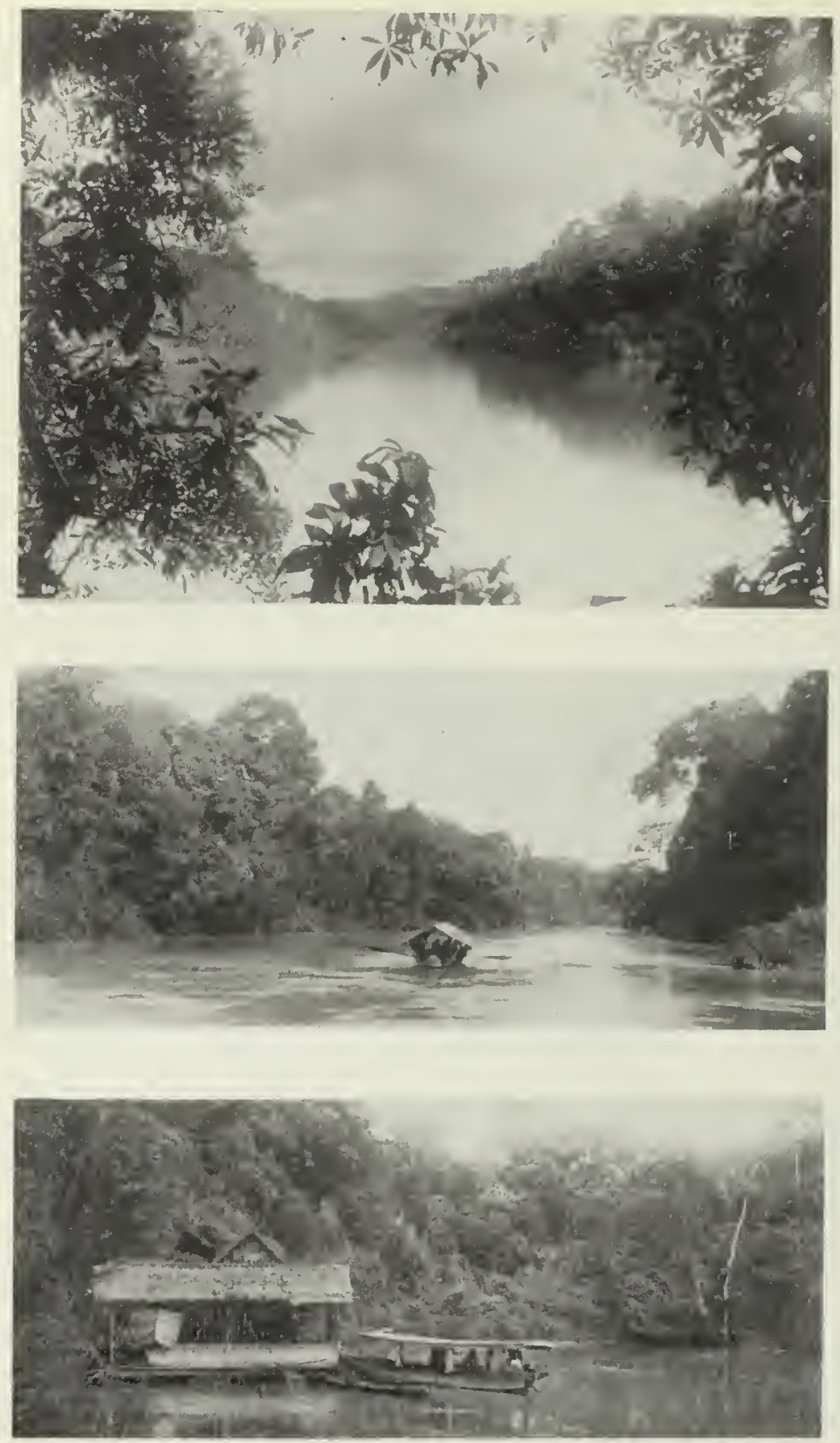

Plate 2. Sedili Besar, 1932. Upper, between Bt Perah and Bt Tiga with Bt Tinjau Laut in the distance.- Centre, Tg Rambutan.- Lower, floating house at Danau. 

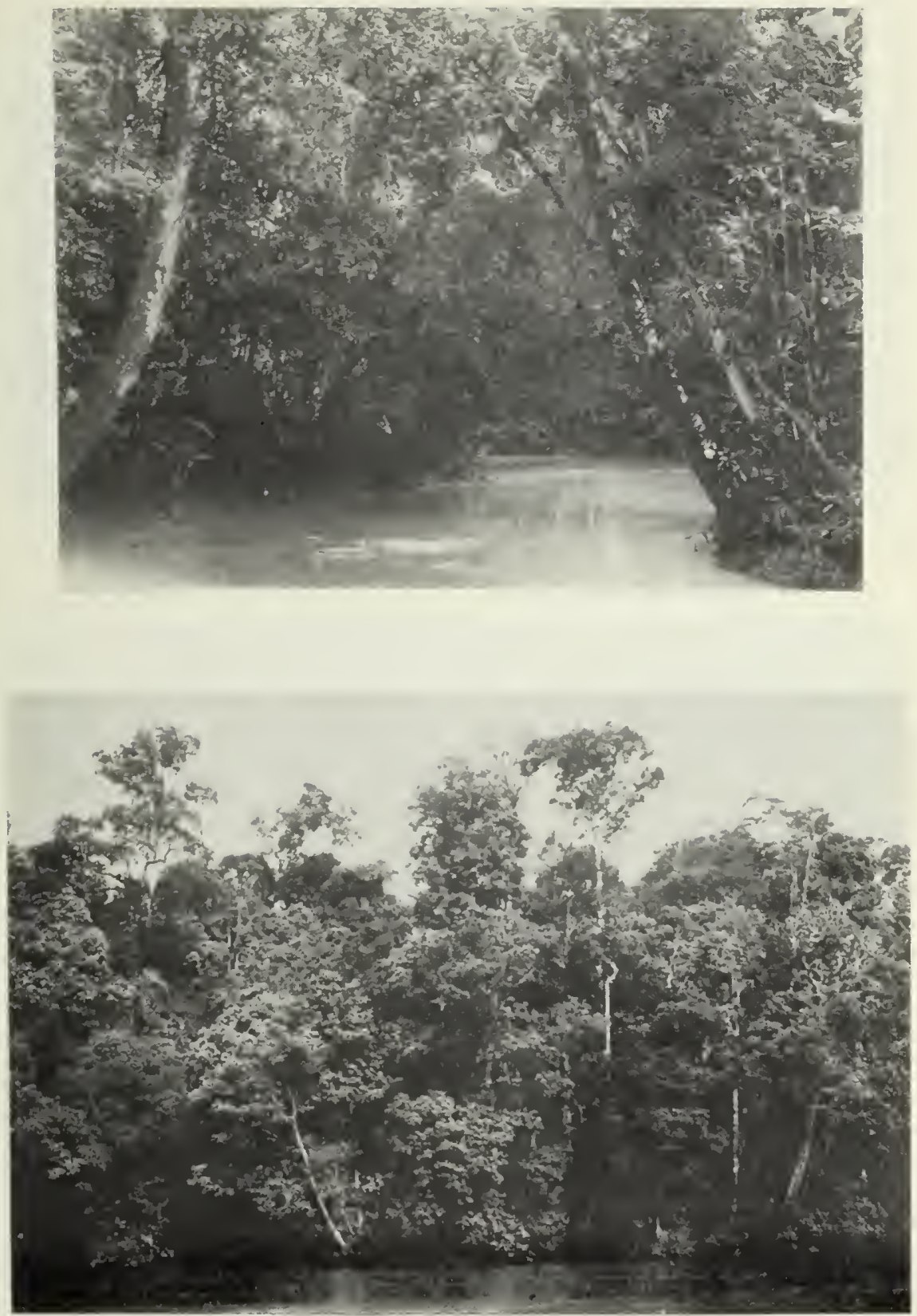

Plate 3. Upper, S. Dohol near the Jemaluang Road, with Tristania (left).- Lower, a Tristania-bank on the Sedili Besar, 3 miles below Mawai. 

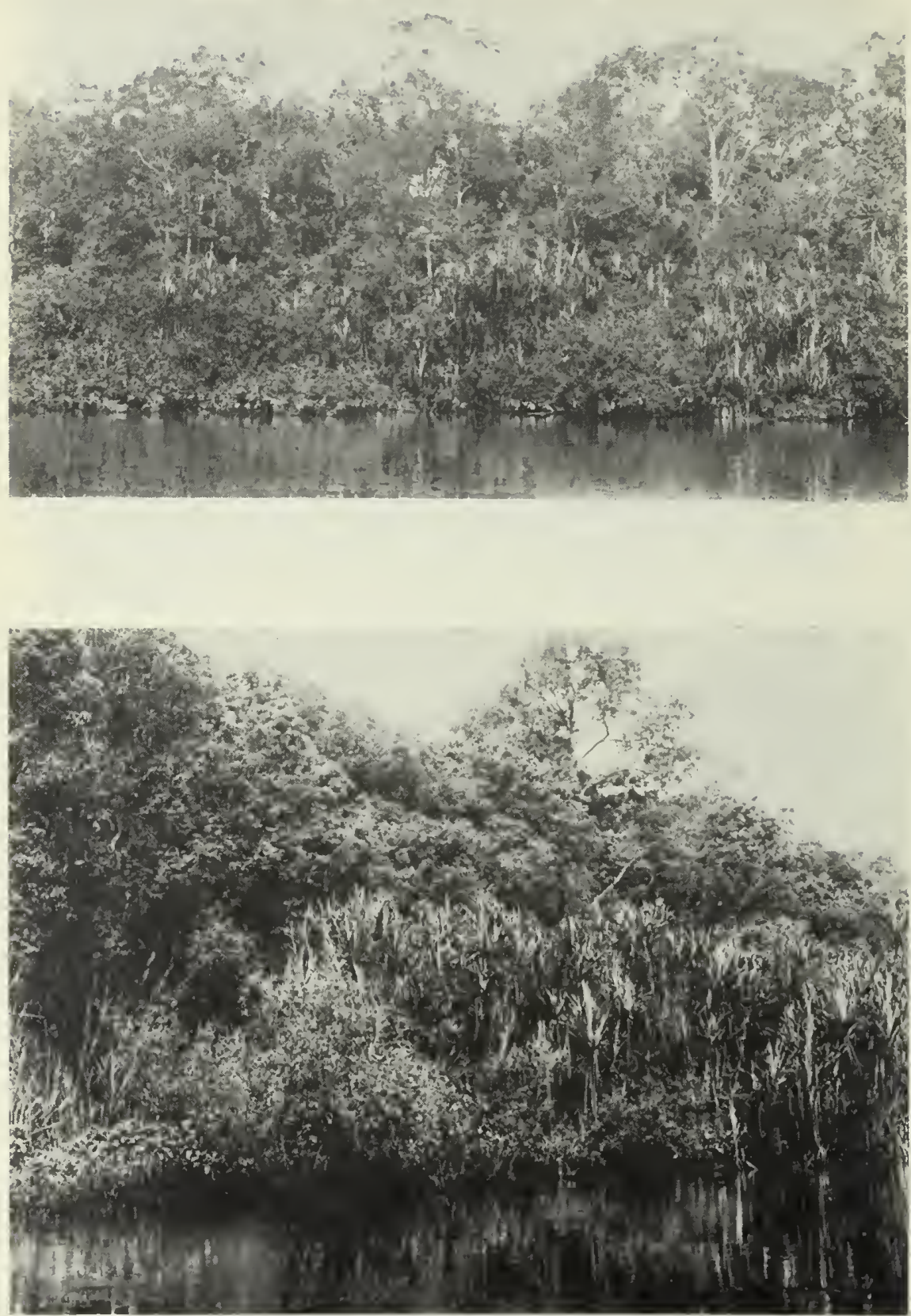

B

G

G

Plate 4. The Sedili Besar near Bt Perah. 1932. Upper, rassau-belt with putat (Barringtonia conoidea) at the water-front. Pandanus helicopus behind, and rengas (Gluta velutina) between.- Lower, rassau, putat (B), and rengas (G), with the mempisang-belt behind. 

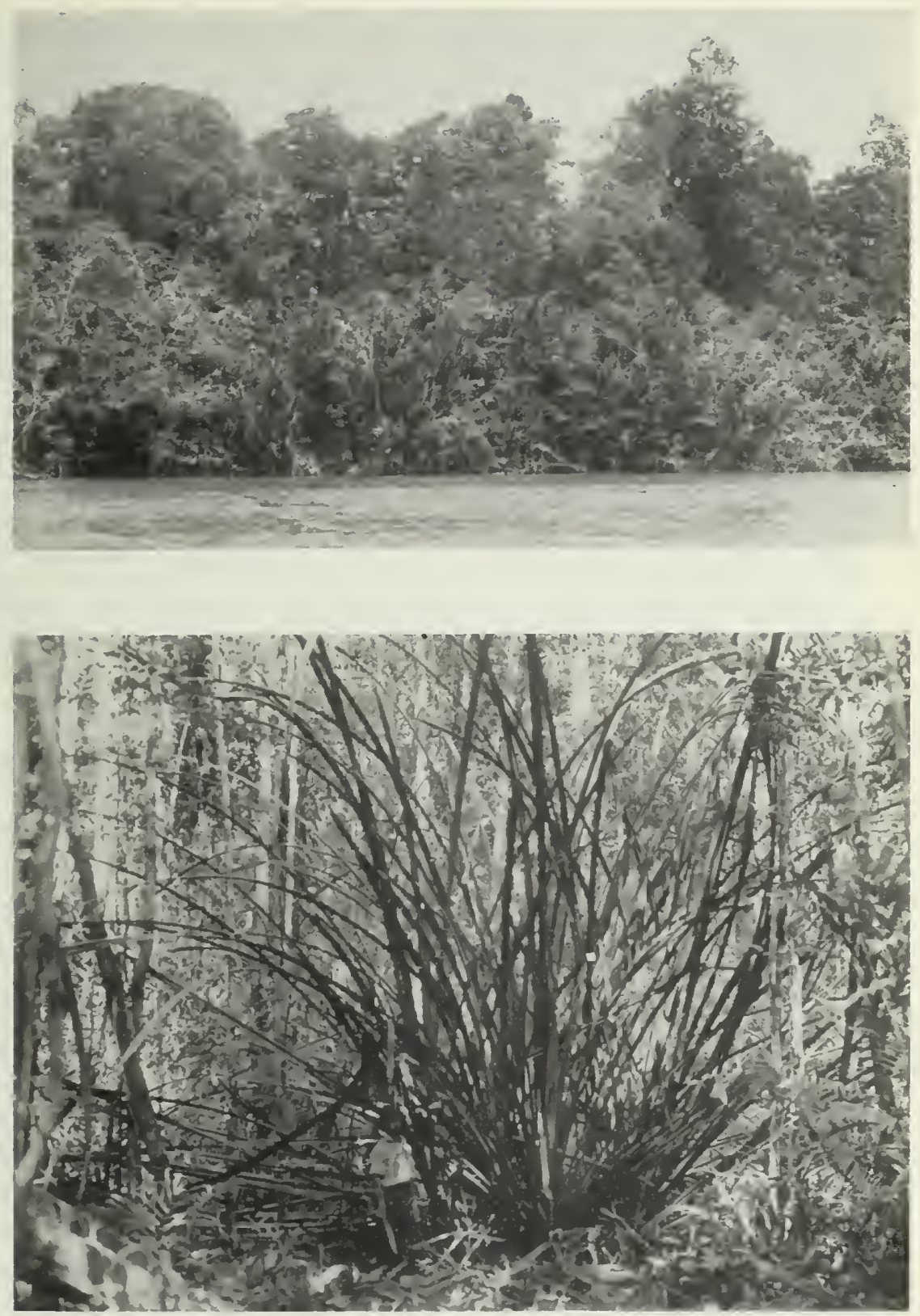

Plate 5. Upper, the Scdili Besar near Bt Tiga with jejawi (Ficus microcarpa) smothering the belts of putat and rassau. - Lower, Pandanus kamii in the freshwater swamp-forest. 



Plate 6. Upper, an old tree of rengas (Gluta velutina) in the slime, at low water below Mawai.- Lower, putat (Barringtonia conoidea) at half tide. 


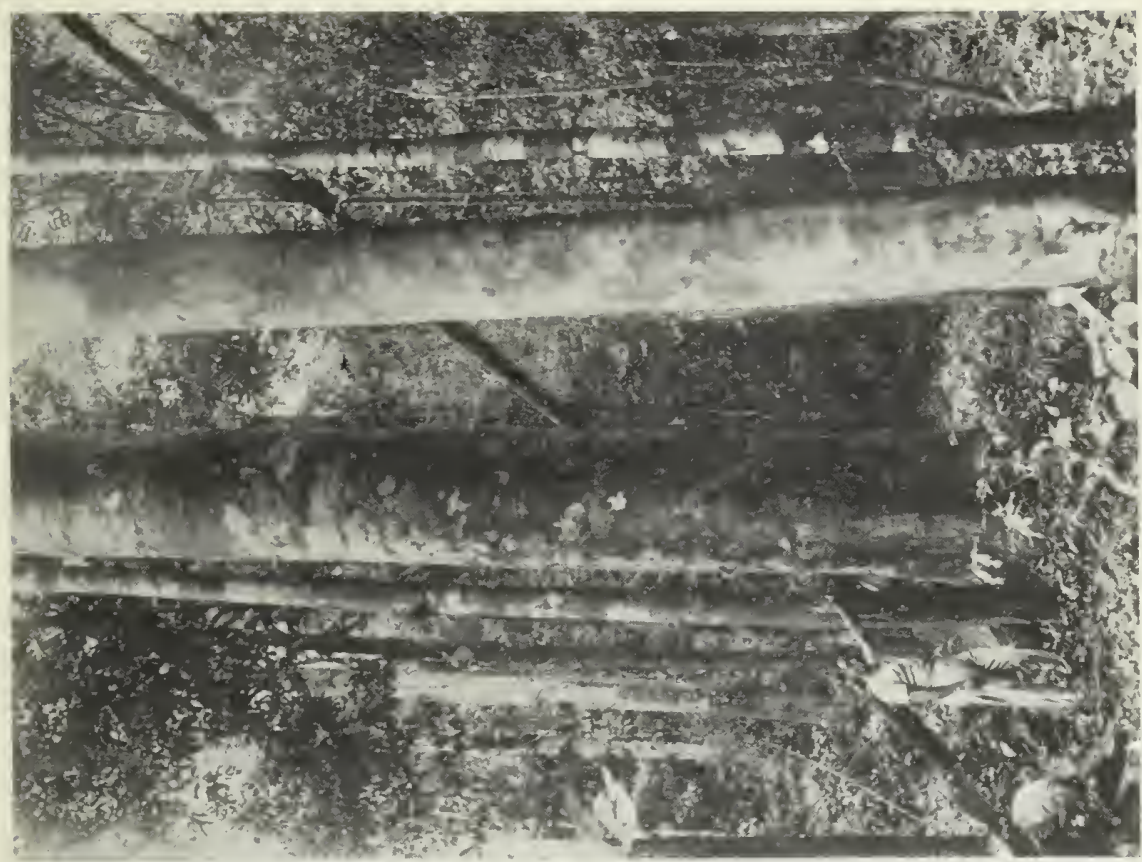

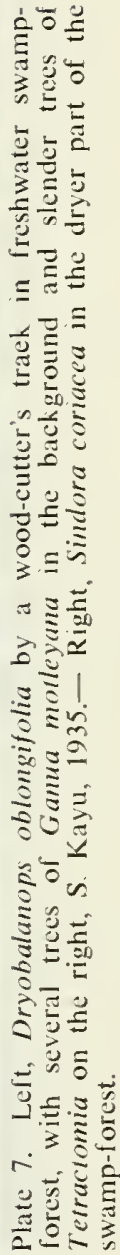

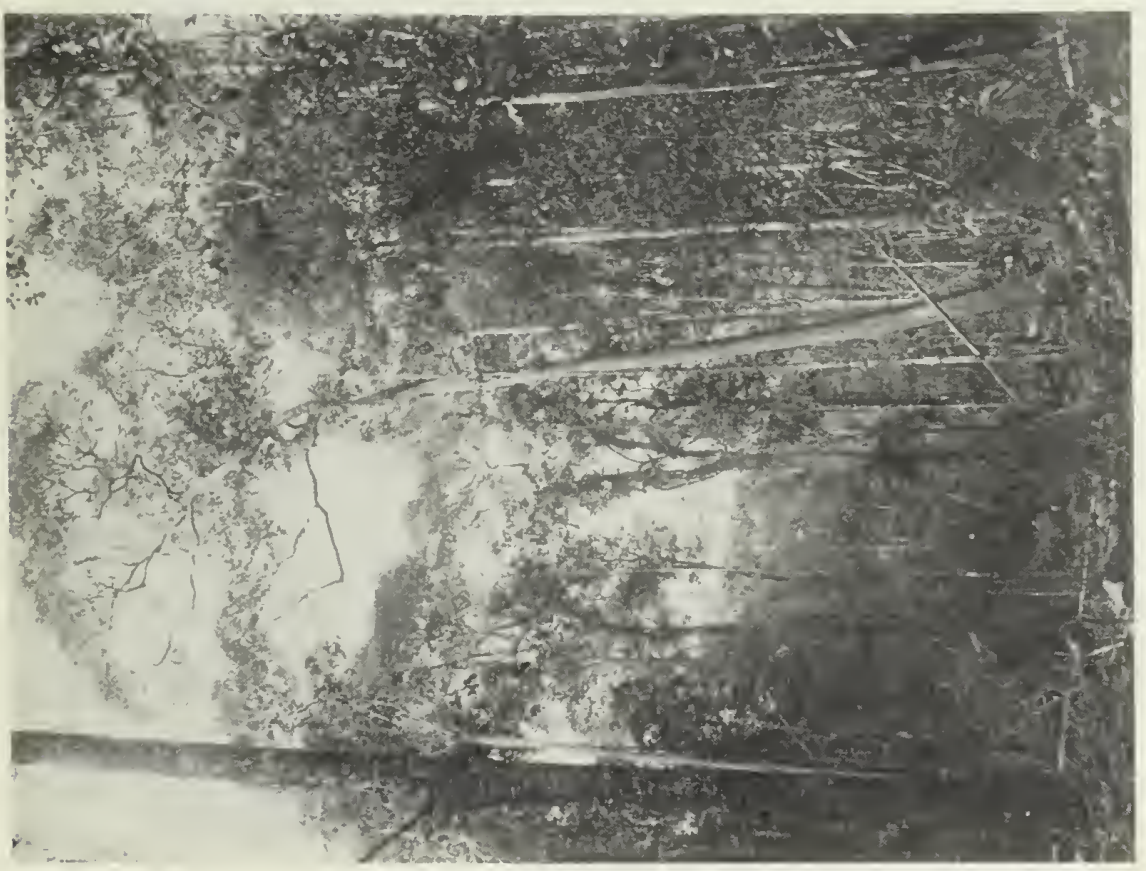




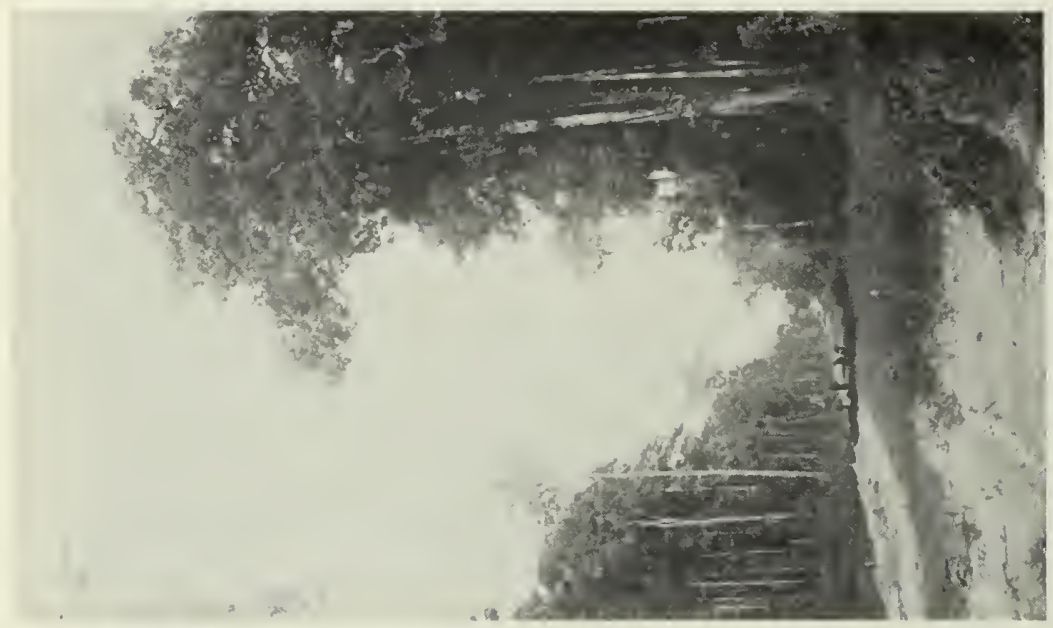

气

ㄱํำ

ปิํํ

政

듬

릉

政

药

ษ

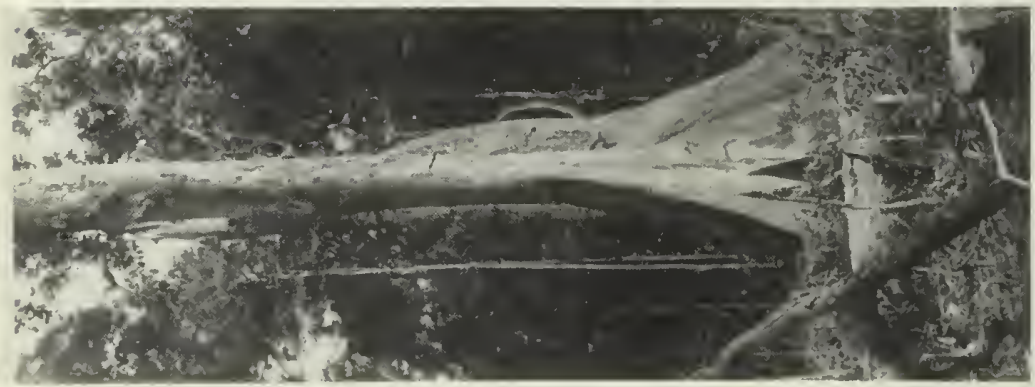

ฐ

Ð

$\vdots \frac{\pi}{2}$

।

ป

这

产弯

क्ष

동

ธิ

है।

ต

ปับ

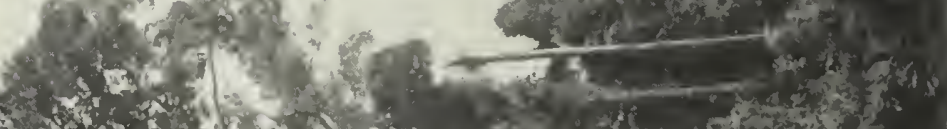

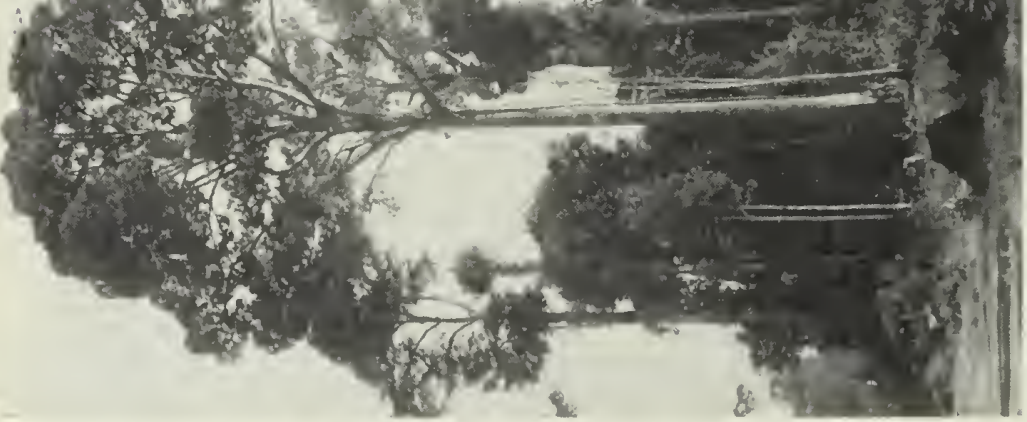

تृ

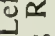

sor

$\infty$ ฮิก

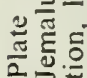



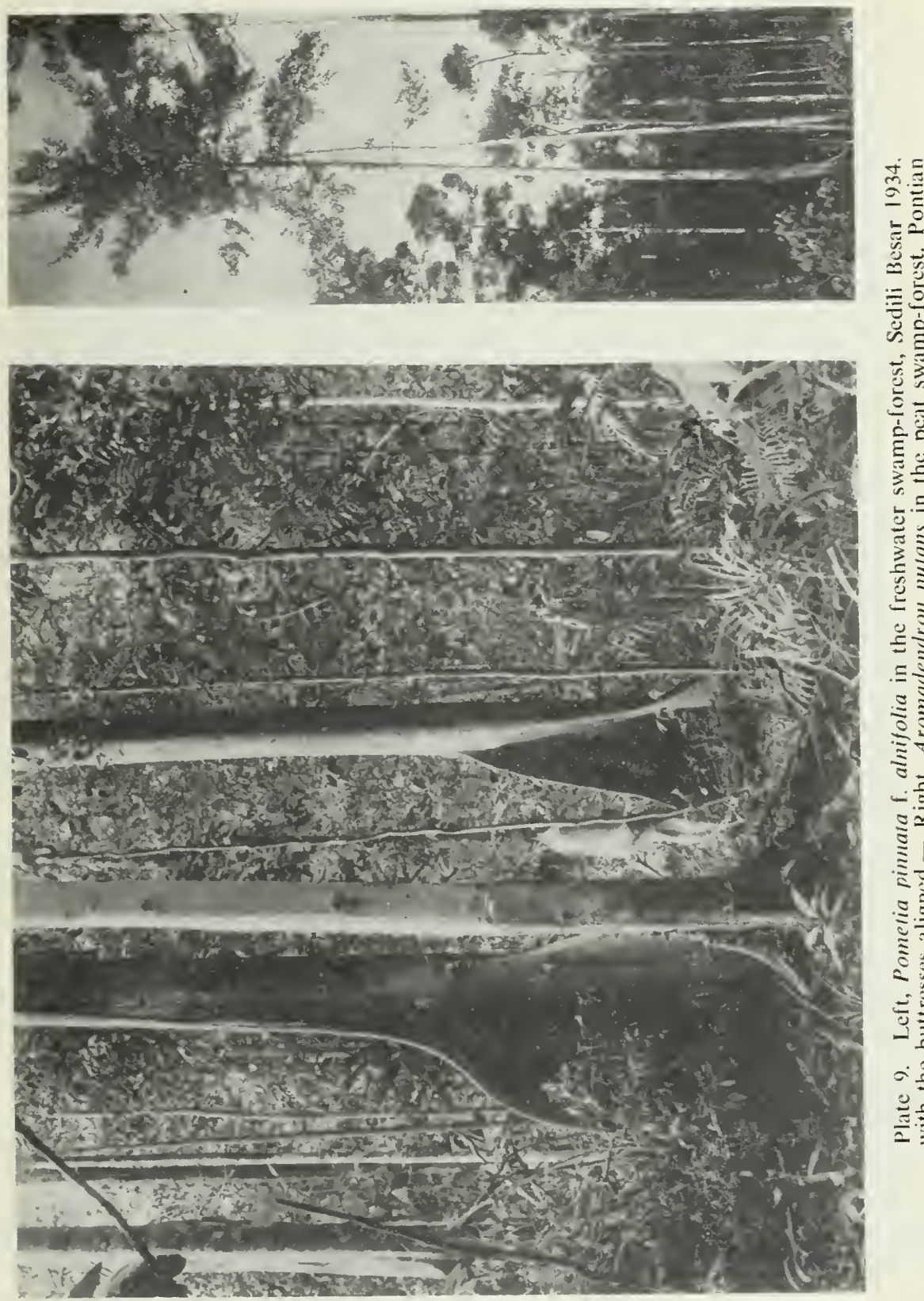

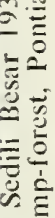

范

柯

ธ่อ

焉

.

栗

ํำ

记

$\Xi$

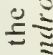

$\Xi \Xi$

으

군

ธิ

므

छ

ㄴ.

.

츤

충

$\therefore$

ป气

$-5$

号

톨 

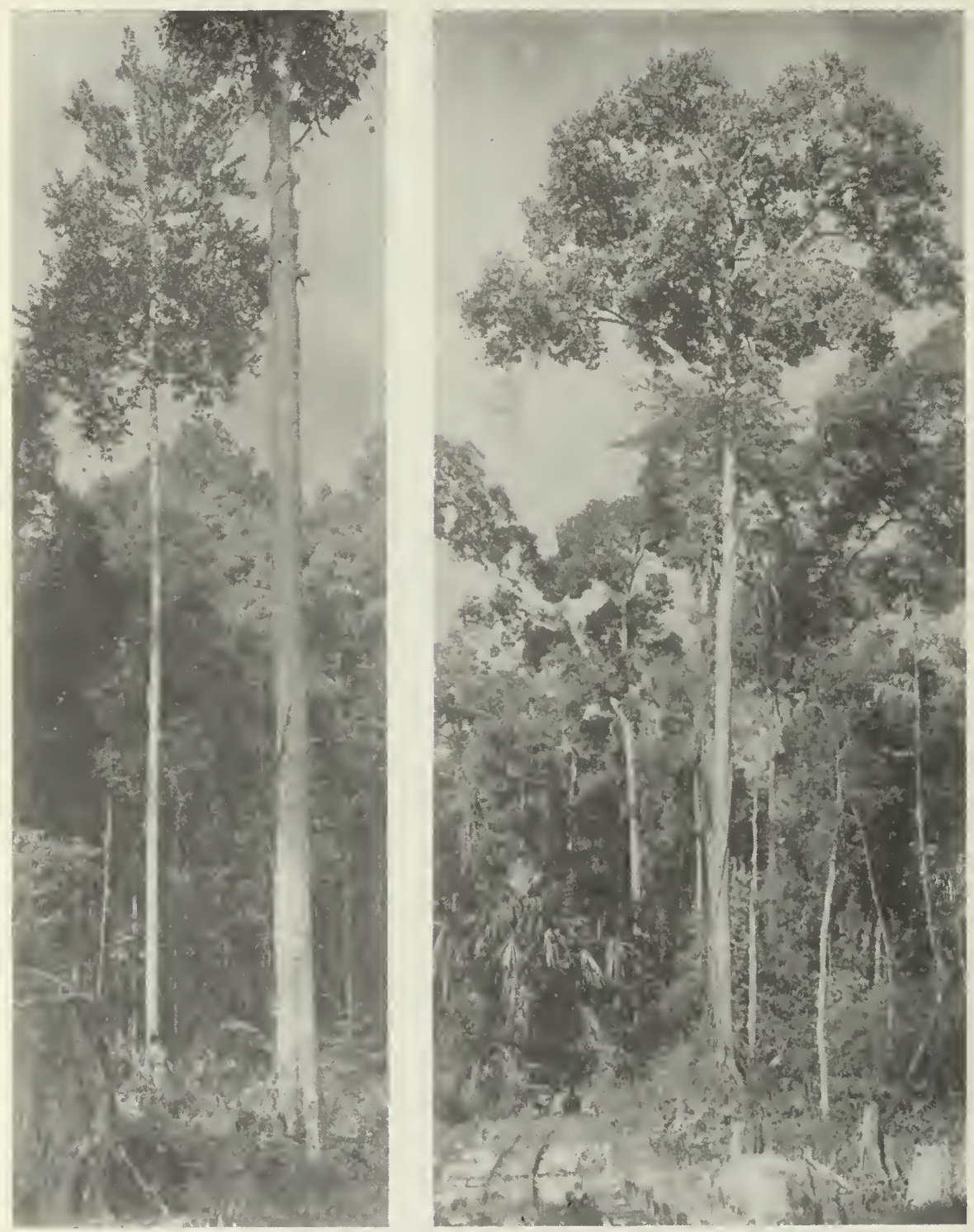

Plate 10. Left, Cyathocalyx ridleyi with monopodial crown, in hillock-forest, Jemaluang Road

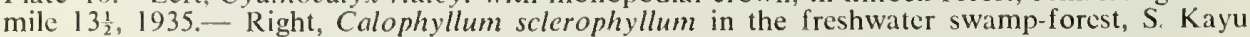
1935. 

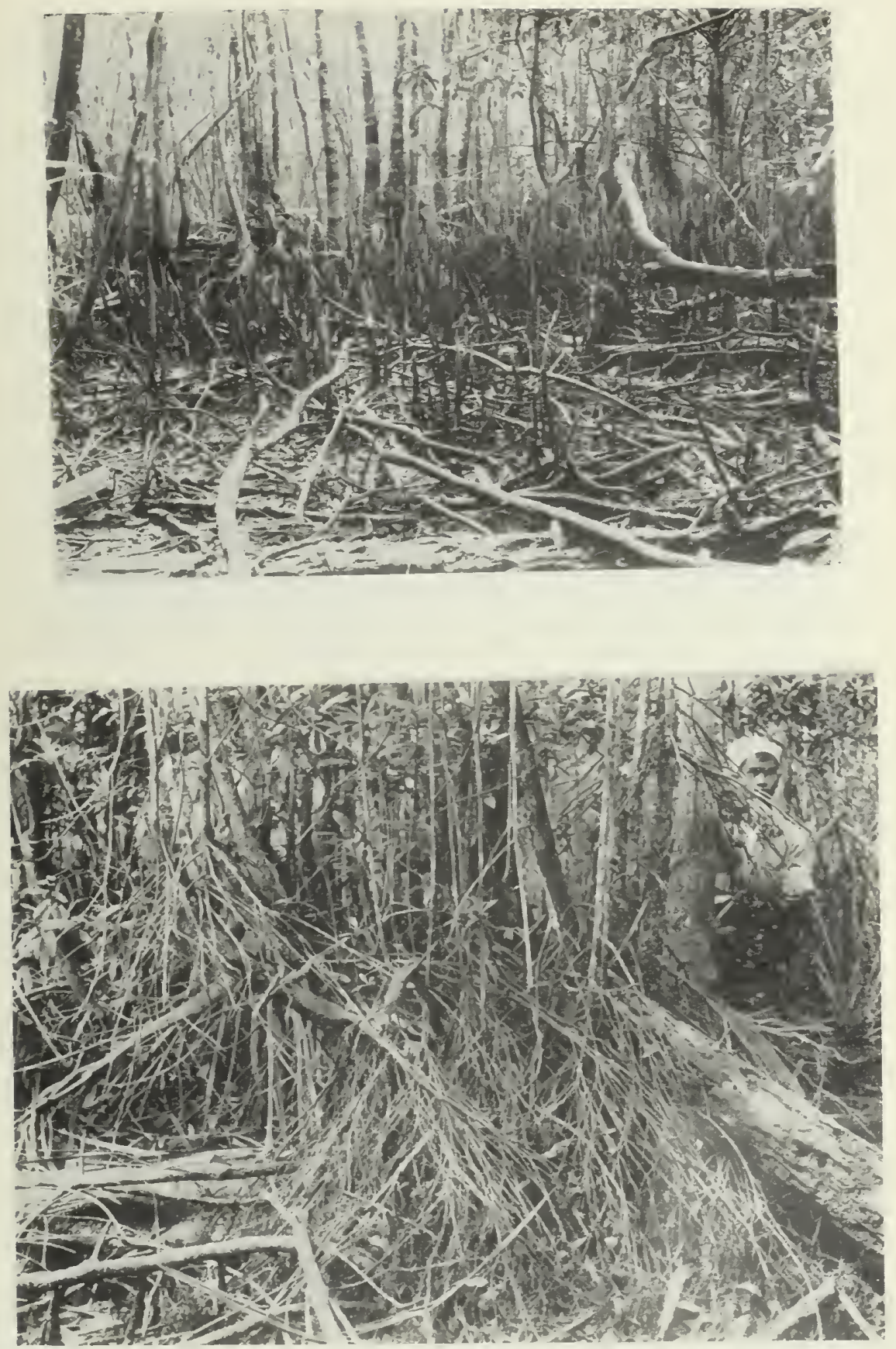

Plate 11. Upper, pneumatophores and trunks of Polyalthia sclerophylla at low tide near Mawai.- Lower stilt-roots of Ploiarium alternifolium in the mempisang-belt, with Hassan, near Mawai. 

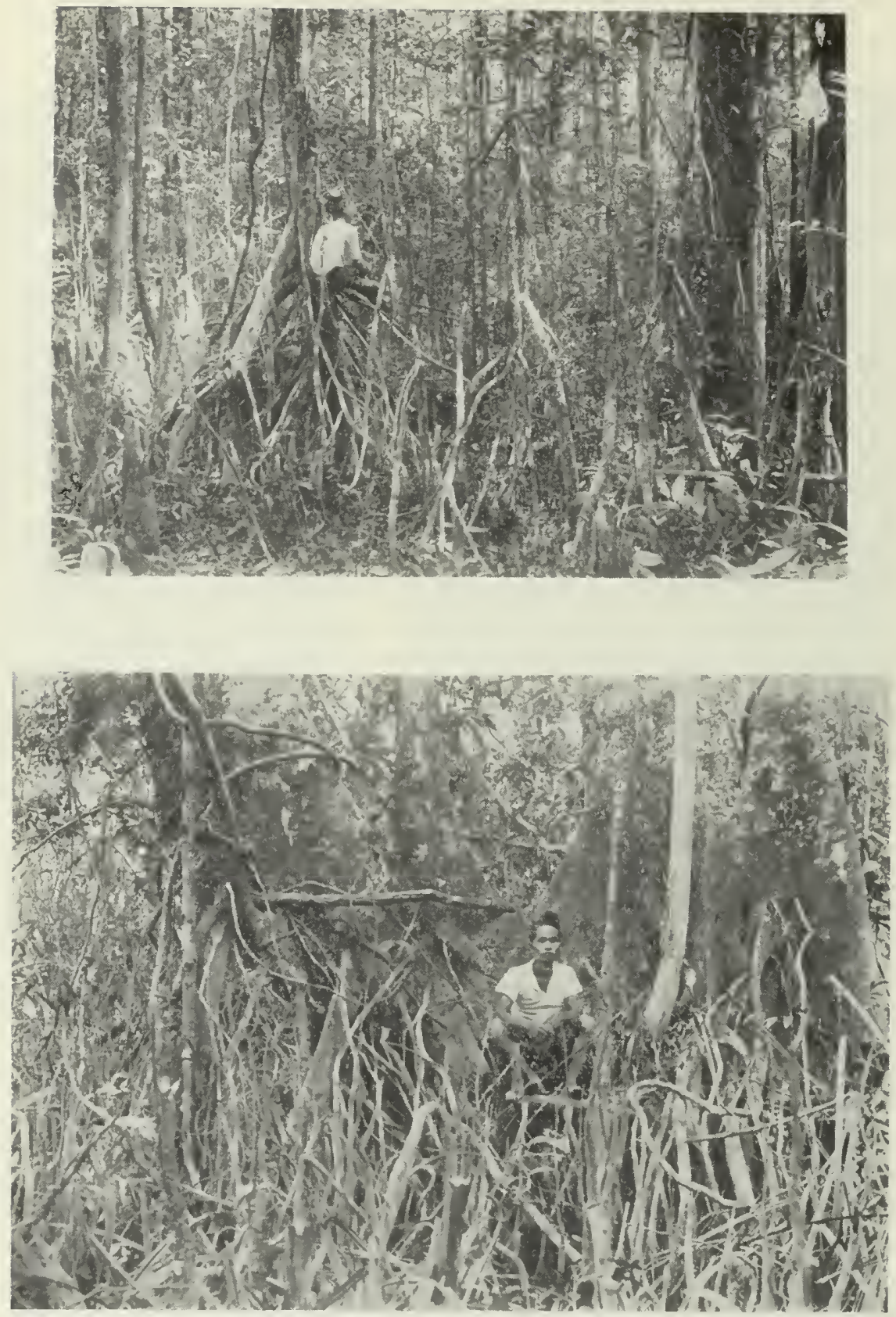

Plate 12. Elaeocarpus macrocerus, stilt-roots and pneumatophores in the freshwater swampforest, with Hassan, near Mawai; the lower figure showing four (actually five) buttressed trunks arisen from one prostrate trunk. 

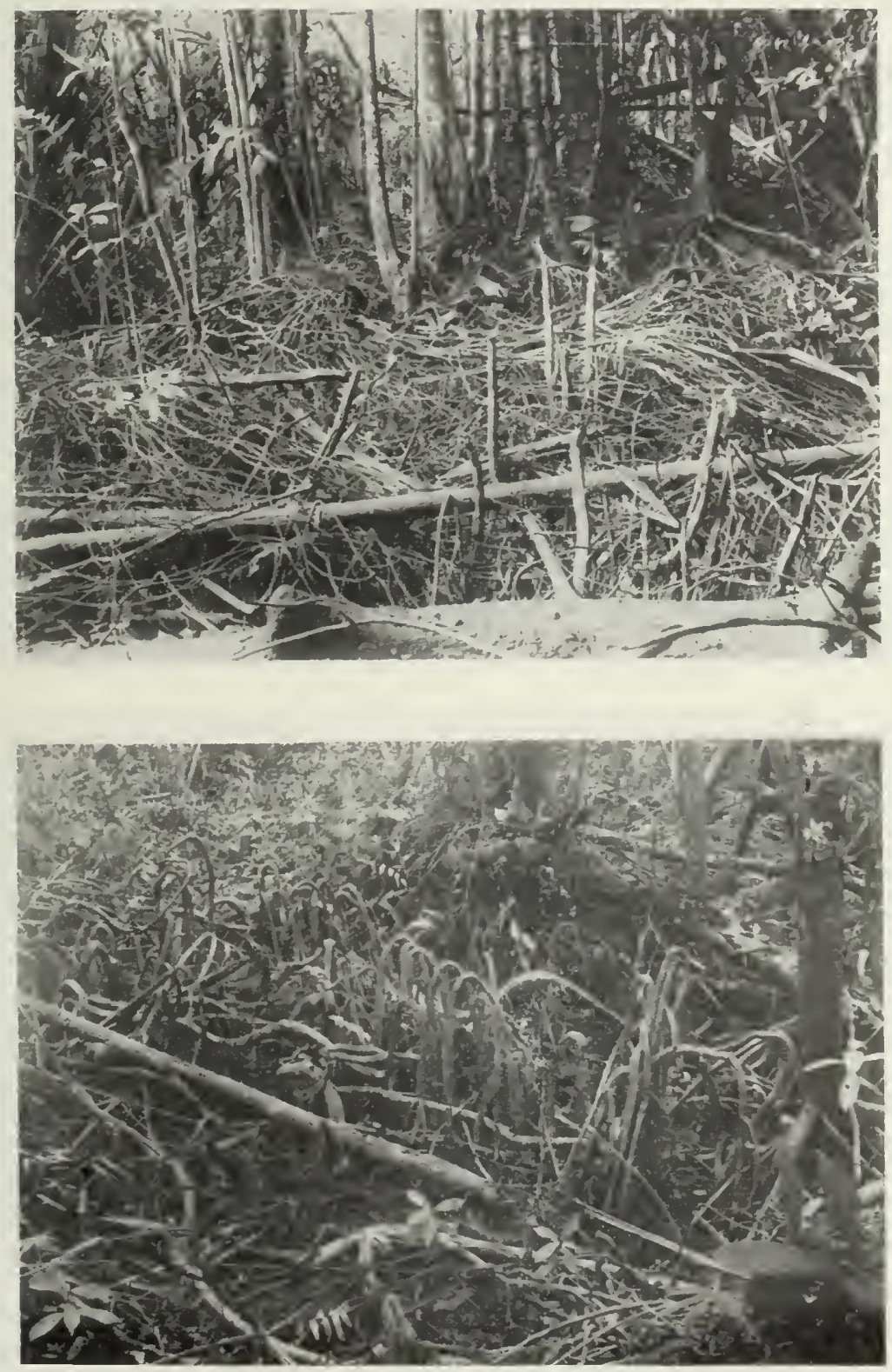

Plate 13. Upper, mat of acrial roots of Palaquium xanthochymum, with erect pneumatophores of Polyalthia sclerophylla, by the Sedili Besar.- Lower, loop-root pneumatophores of Calophyllum sclerophyllum in the freshwater swamp-forest. 

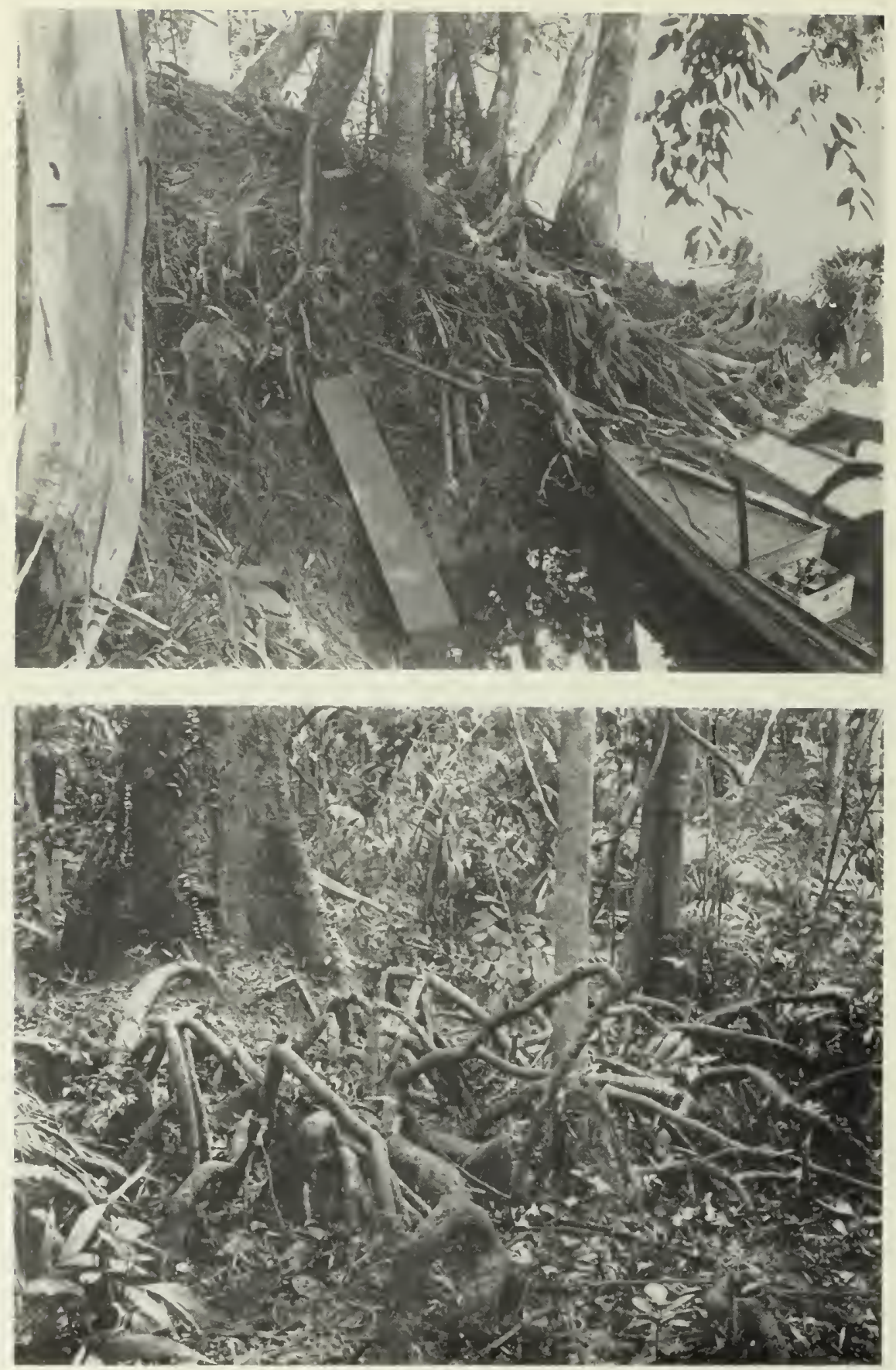

Plate 14. Upper, a Trisınia-bank on the Sedili Besar at low water, with Tristania sumatrana (left) and Lophopetalum multinervium (centre).- Lower, Myristica elliptica, base of trunk (left) and loop-roots, in the freshwater swamp-forest. 

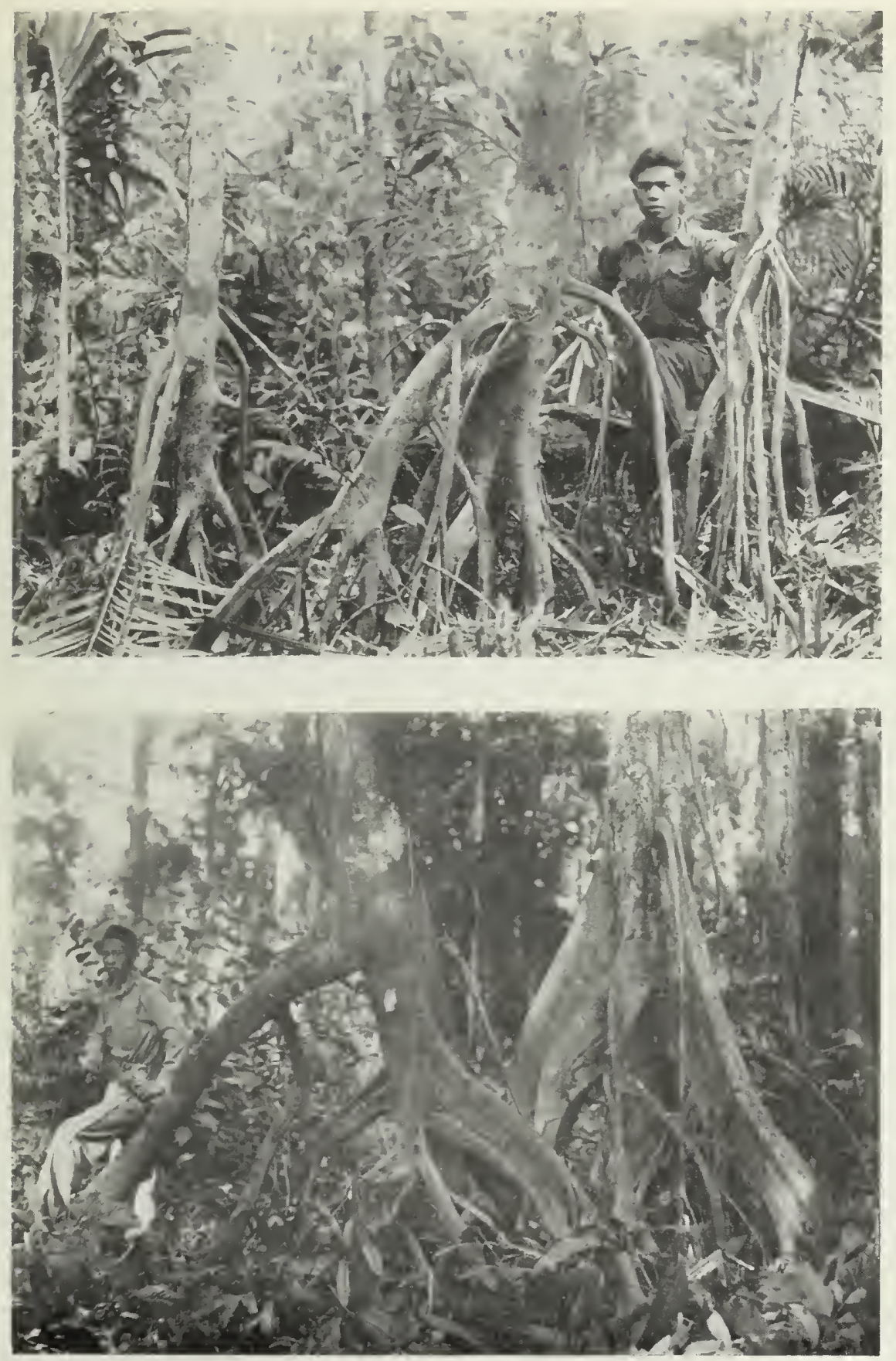

Plate 15. Upper, stilt-roots of Macaranga puncticulata (centre) and Endospcrmum (on each side). Mawai 1934.- Lower, stilt-roots of Hopea resinosa (left) and Eugenia subhorizontalis (right), with the forest-guard Ibrahım, S. Berassau 1935. 


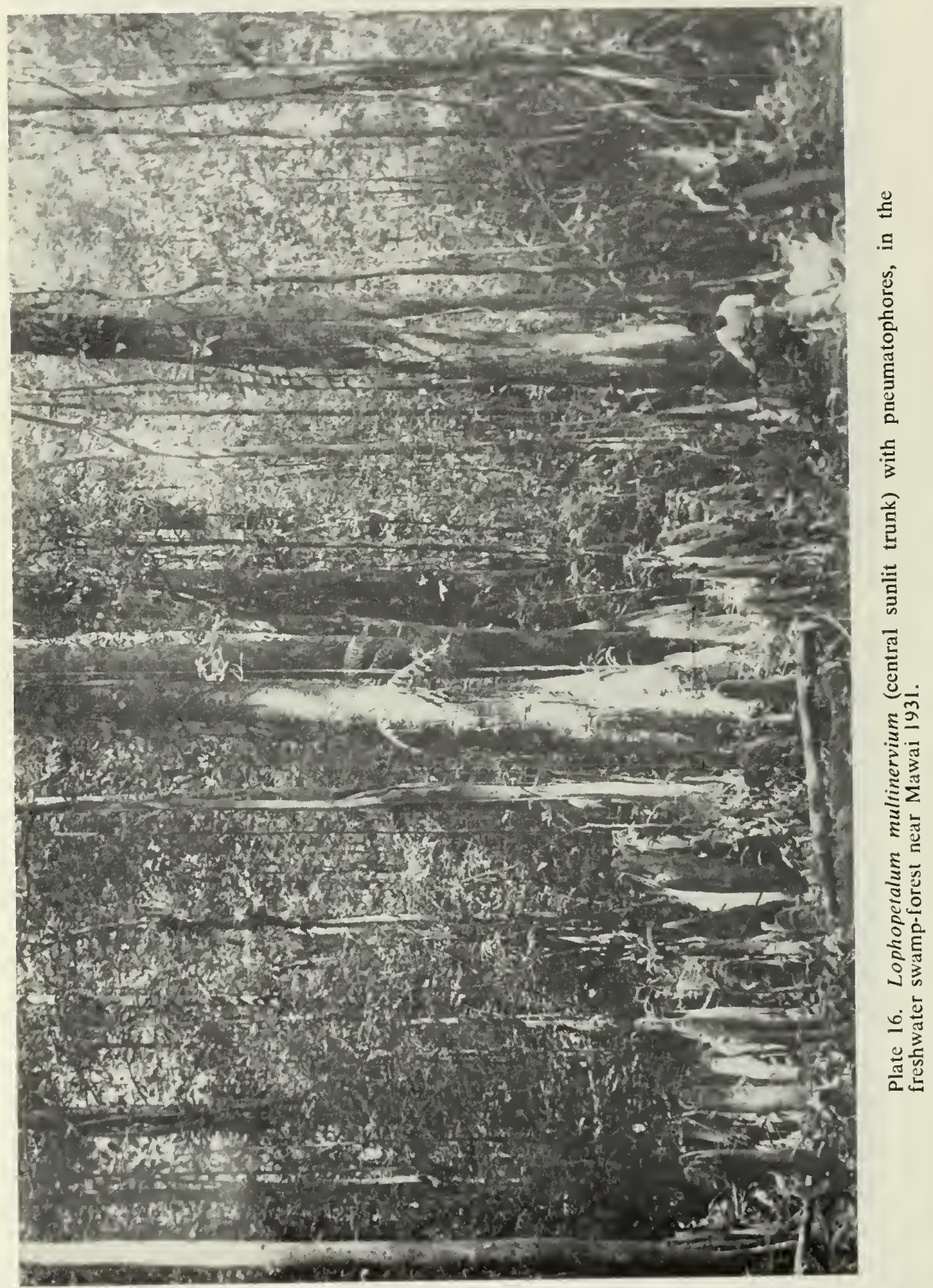



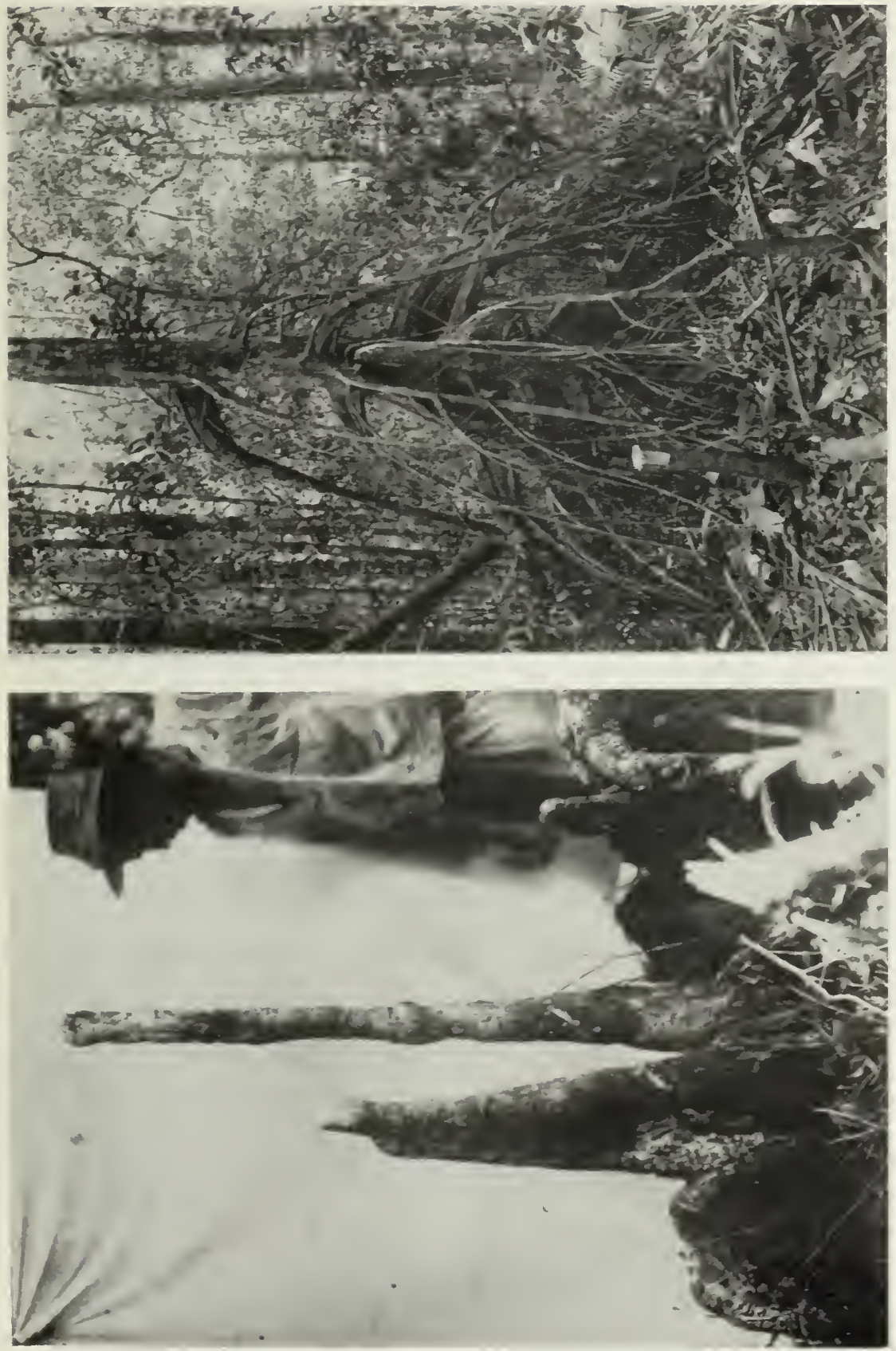

主

踏

$=$

콜

란

E

$\stackrel{?}{=}$

$=$

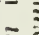

$\equiv$

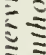

$\equiv$

इ

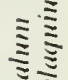

ㄴ.

亏

s.

3

言

药

至

.

ह

는

竞高

$=$

可

들

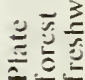




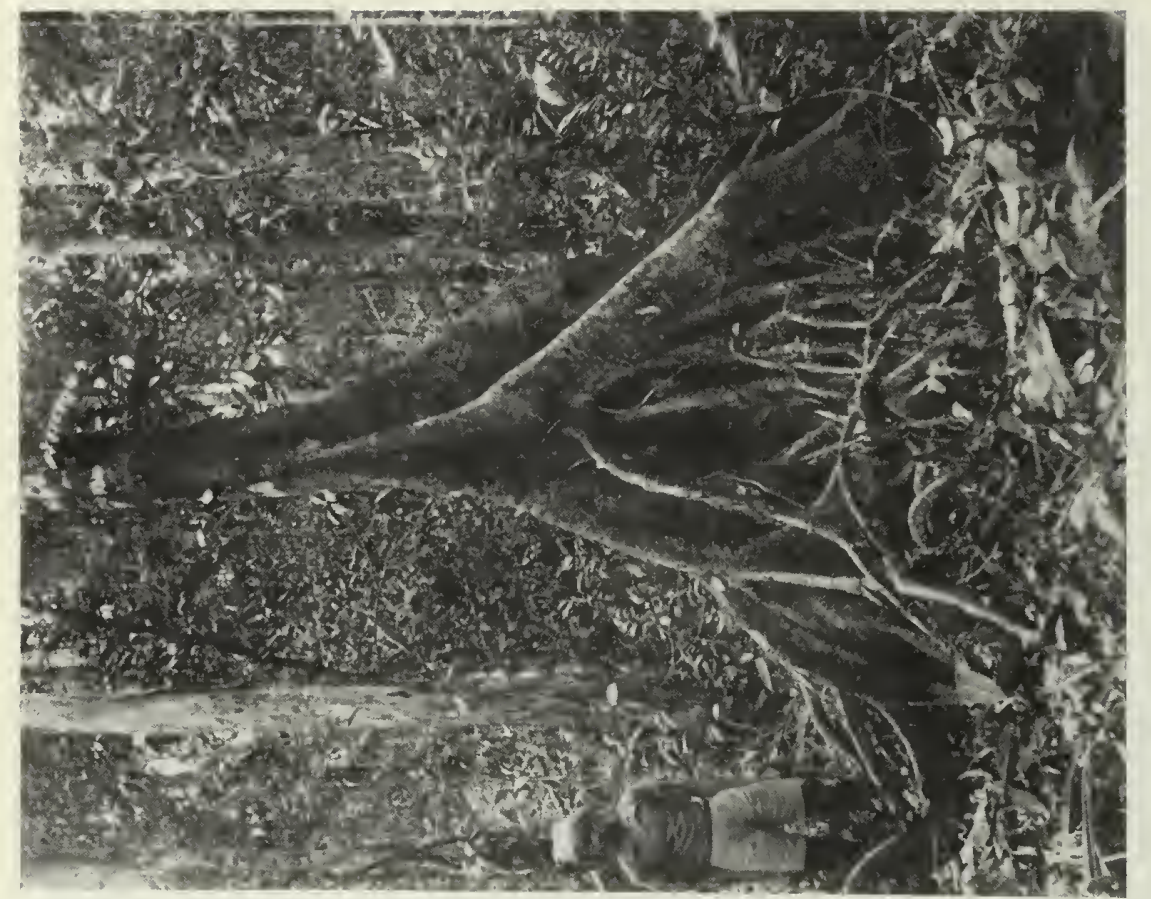

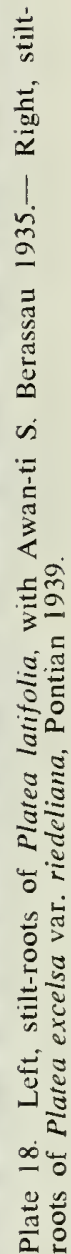

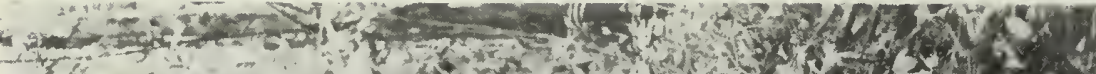

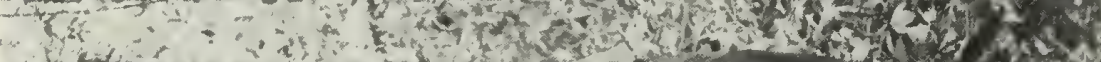

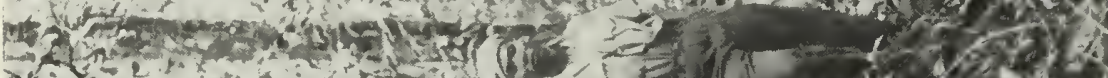

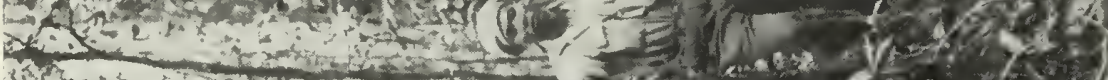

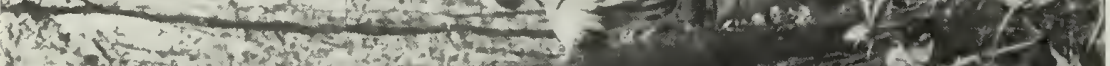

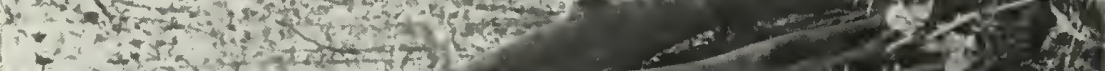

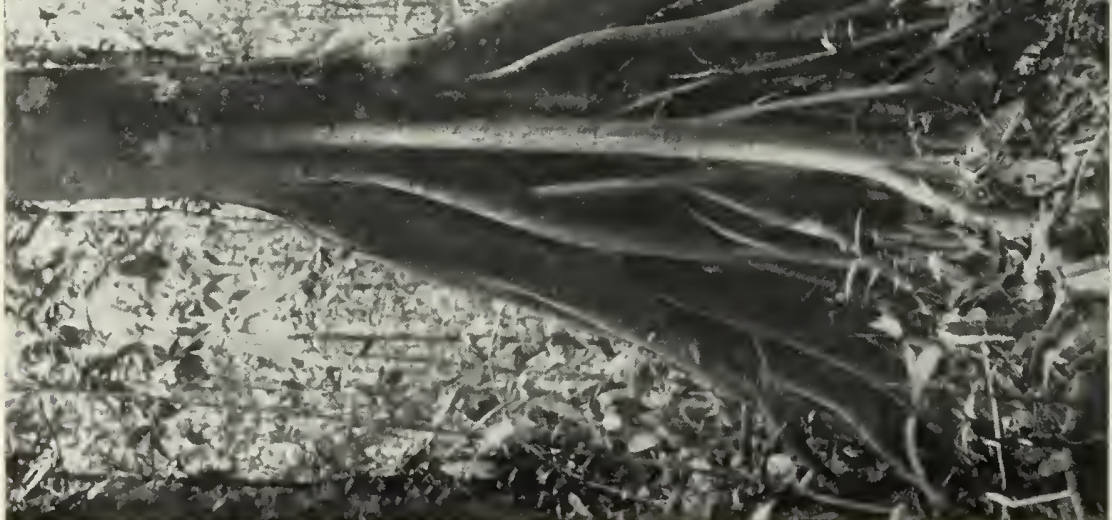




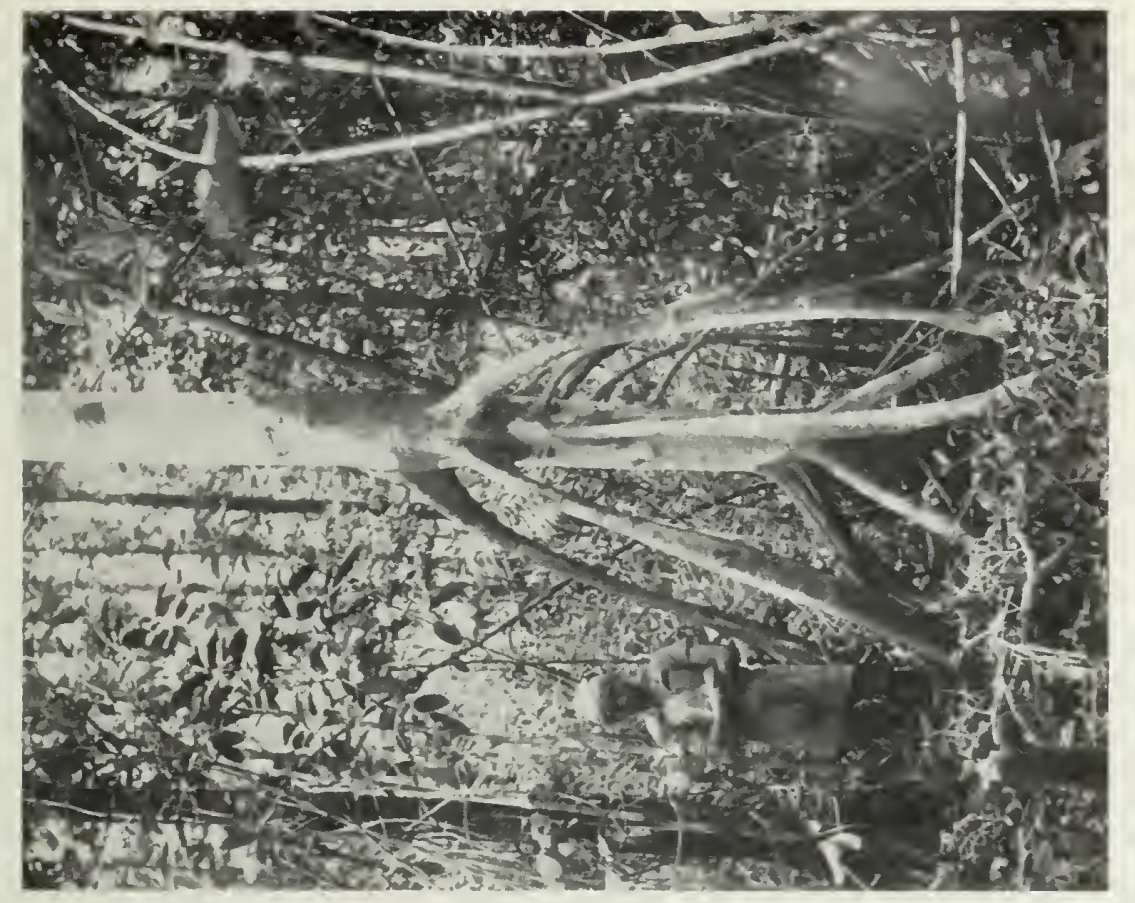

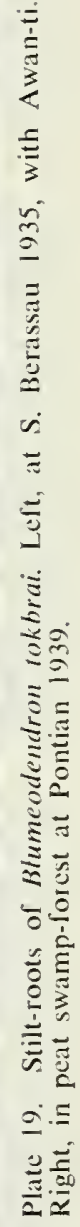

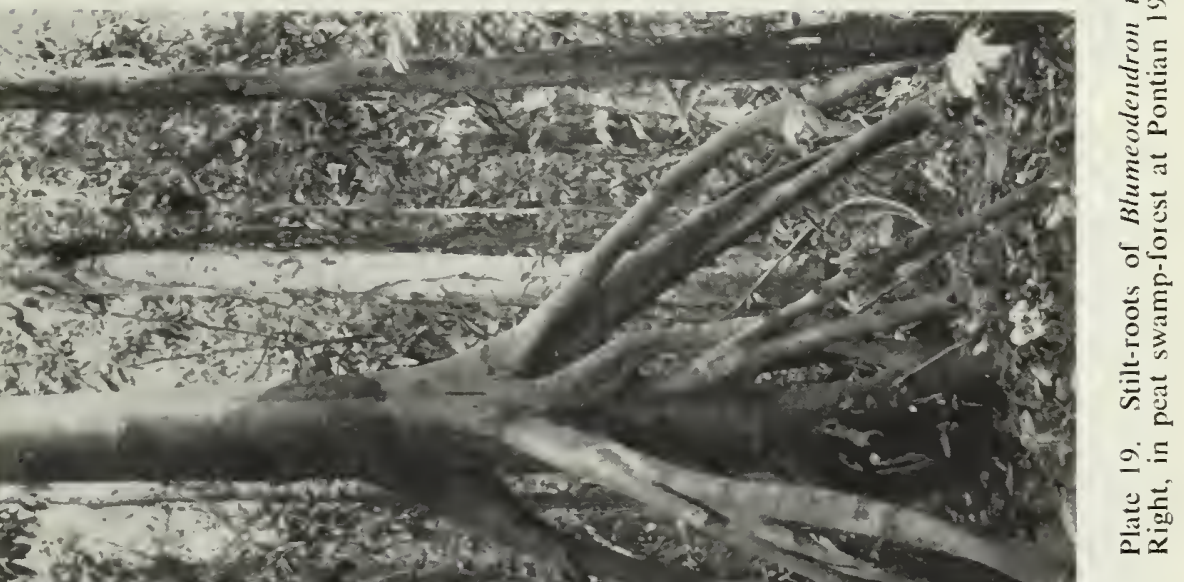



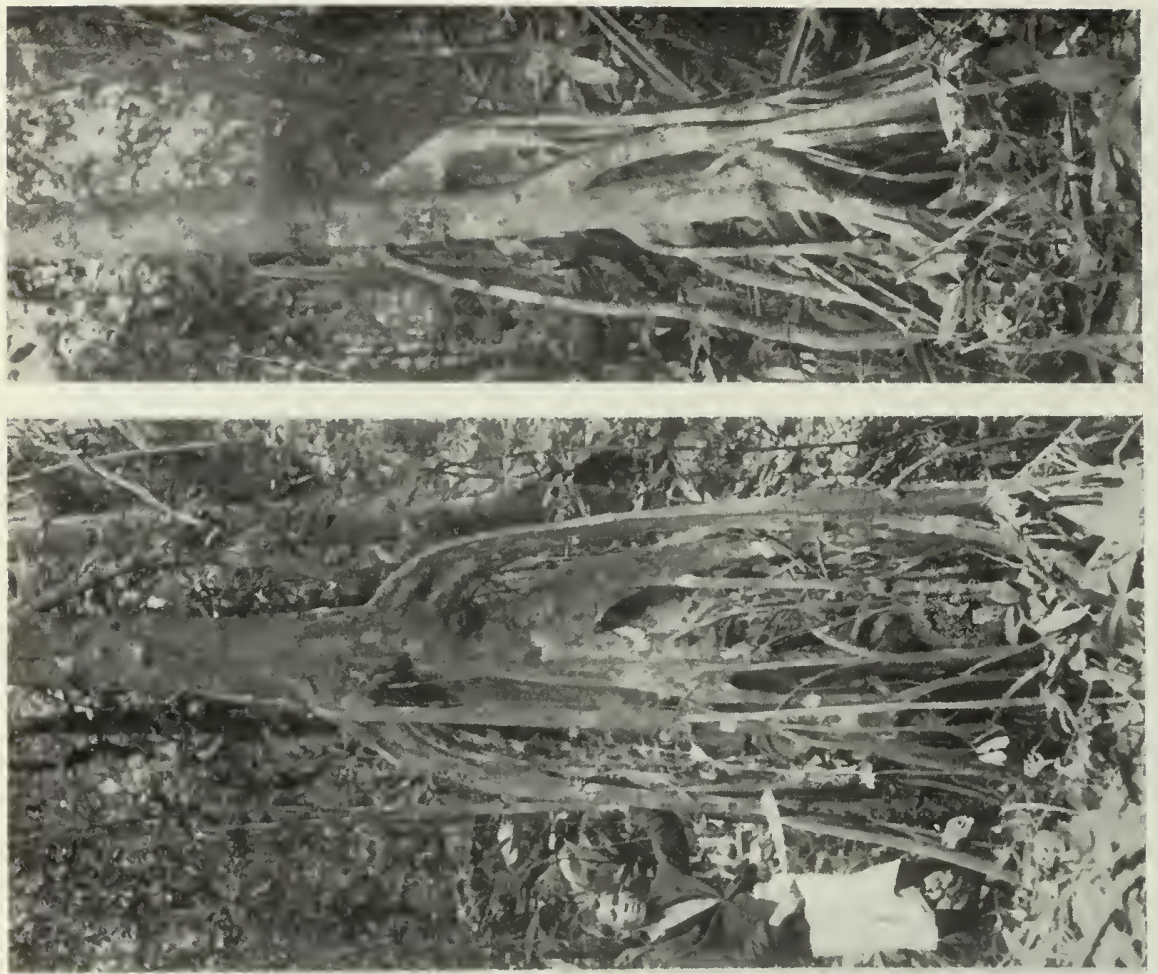

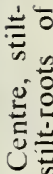

i.

间

무

키

ชิธิ

$\dot{\sim} \propto$

s

祀

츤

S है

है은

व

डू ह

气.

इ

₹

प大a

兰它

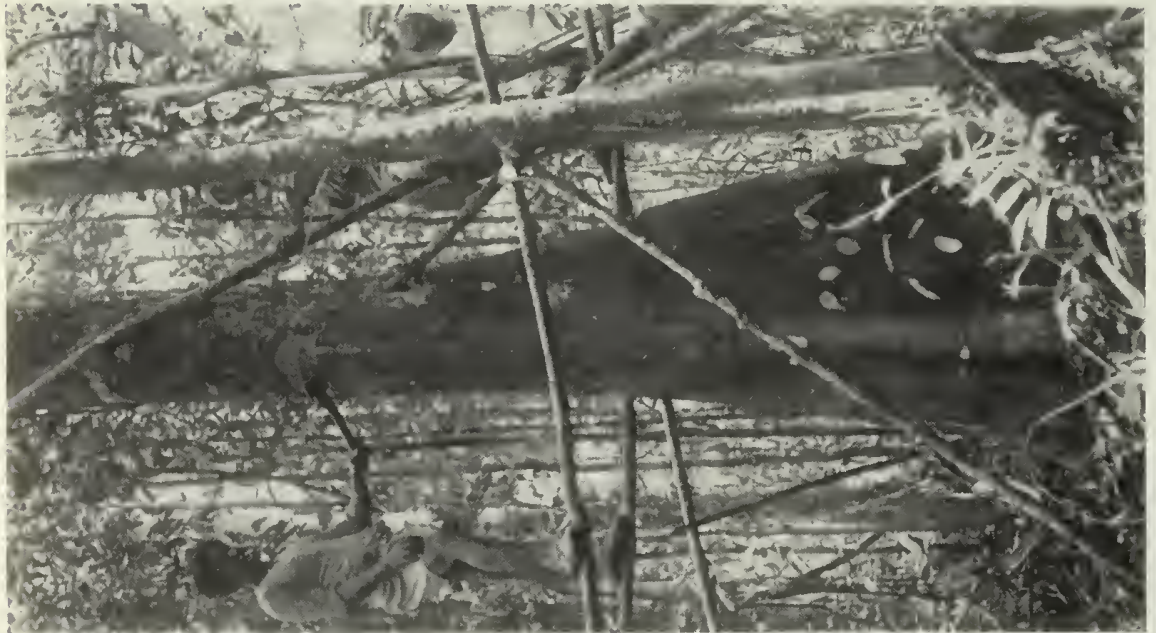

已.

万 0

ऊิ

ㅇํㄹ

อ.

웡

人与

तें

๑ $气$

준 

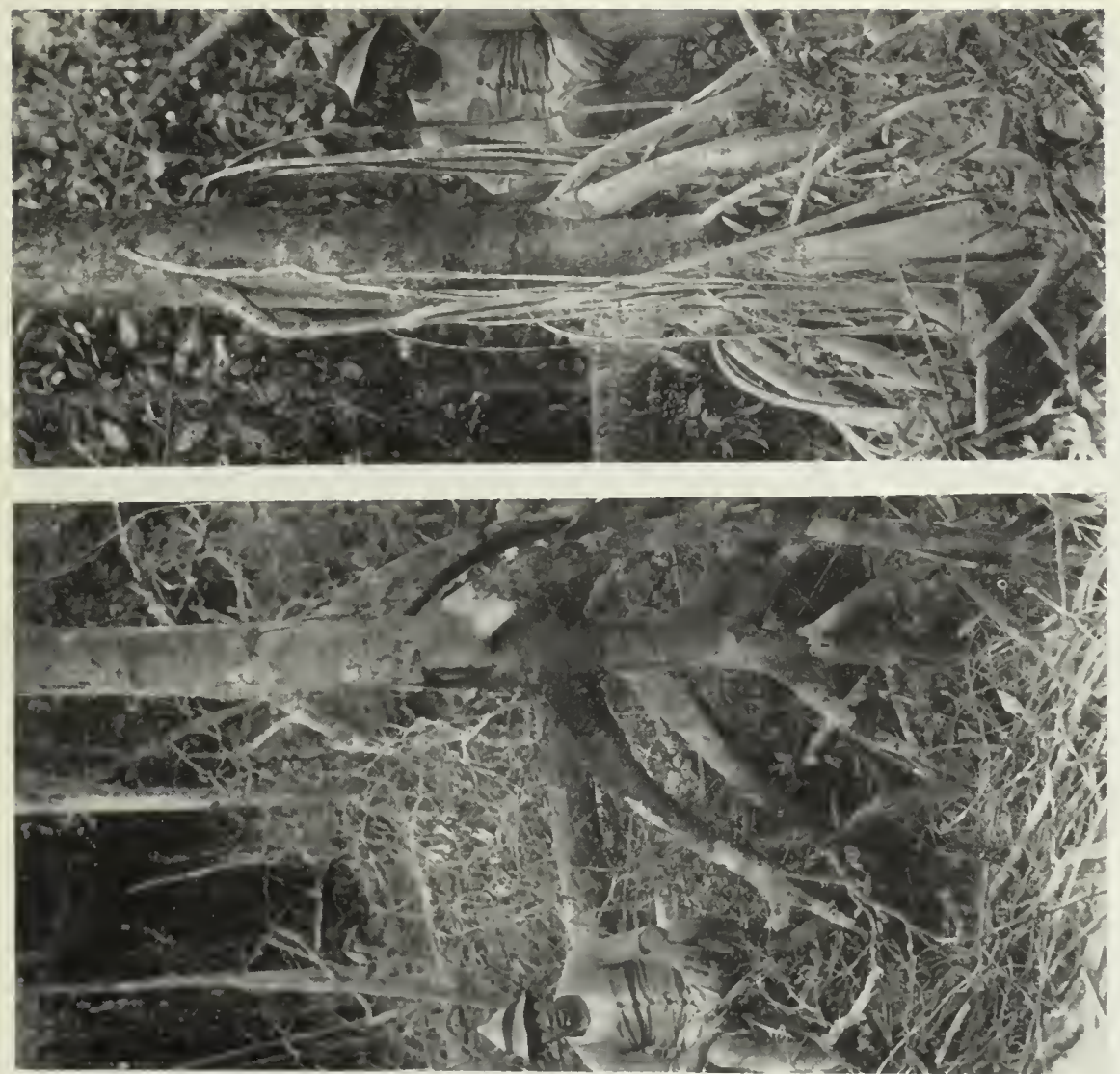

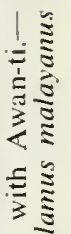

ใิ

क

Zن

至

․․․

产।

5.

$\Xi \stackrel{n}{3}$

ธัँ

压

政

zo

ज़्ले

viz

2.

引

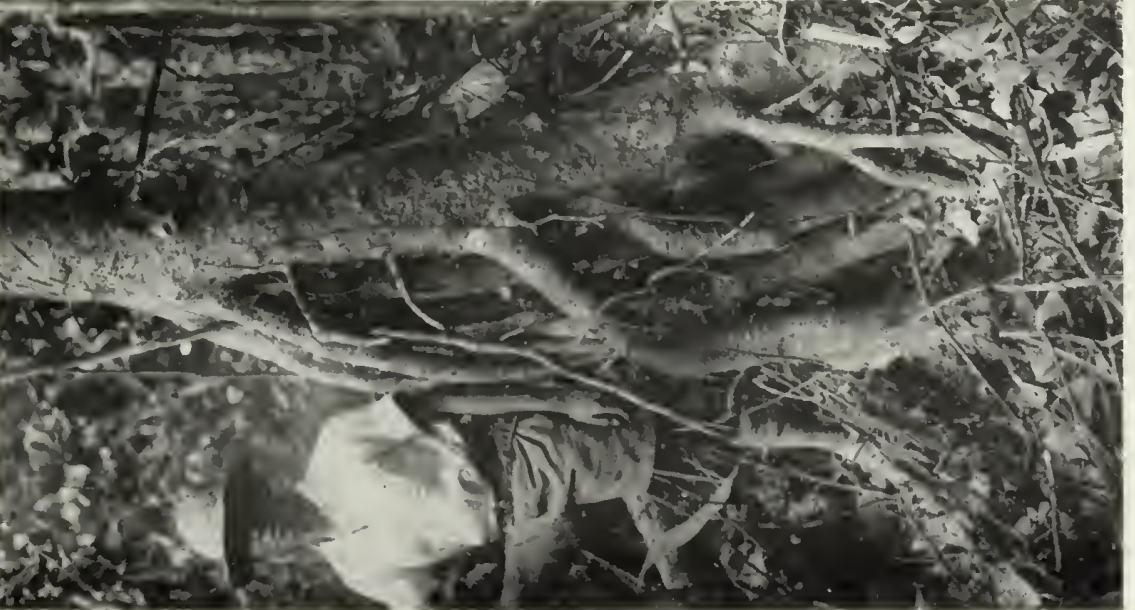

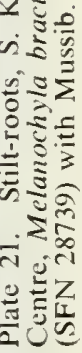



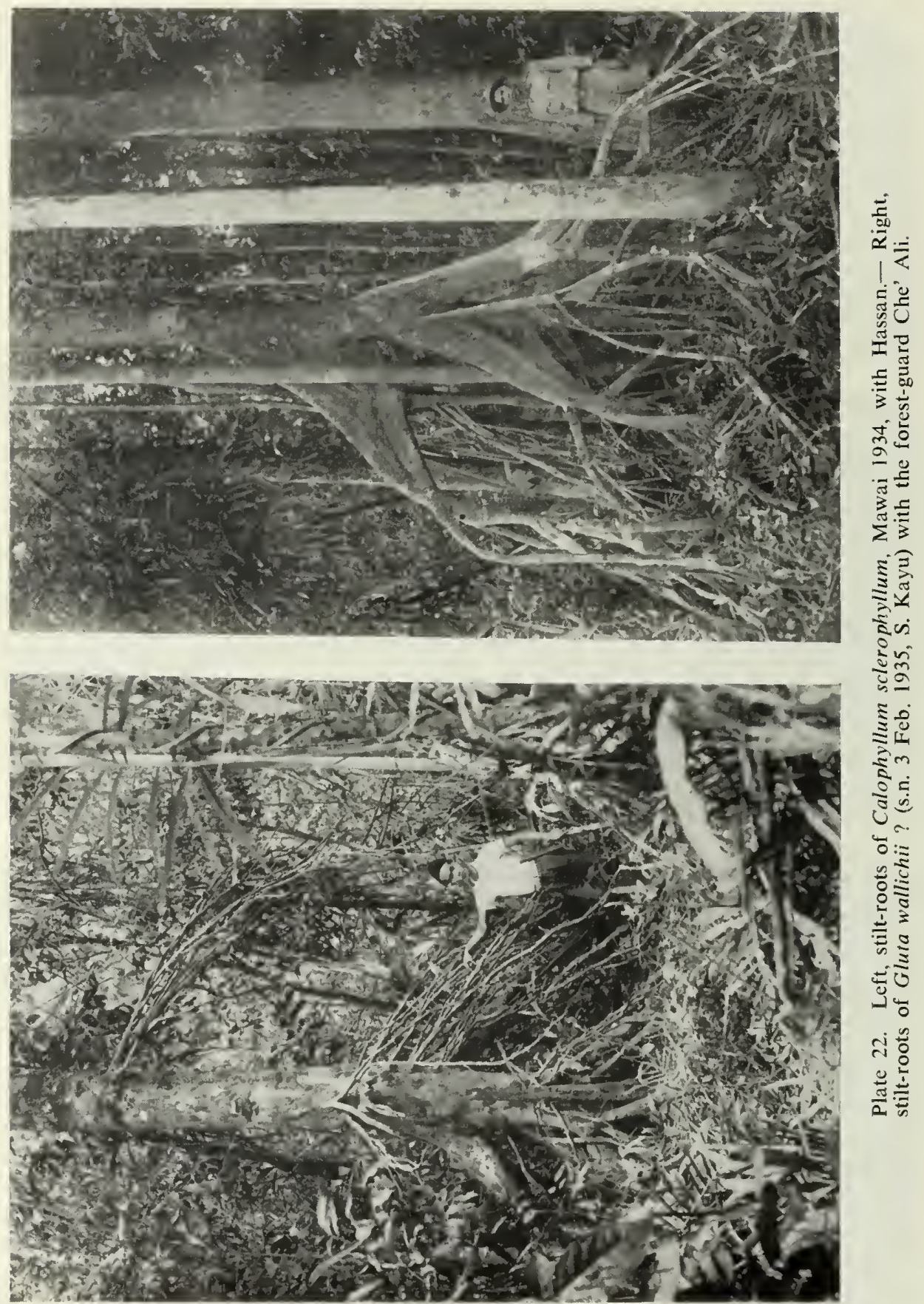


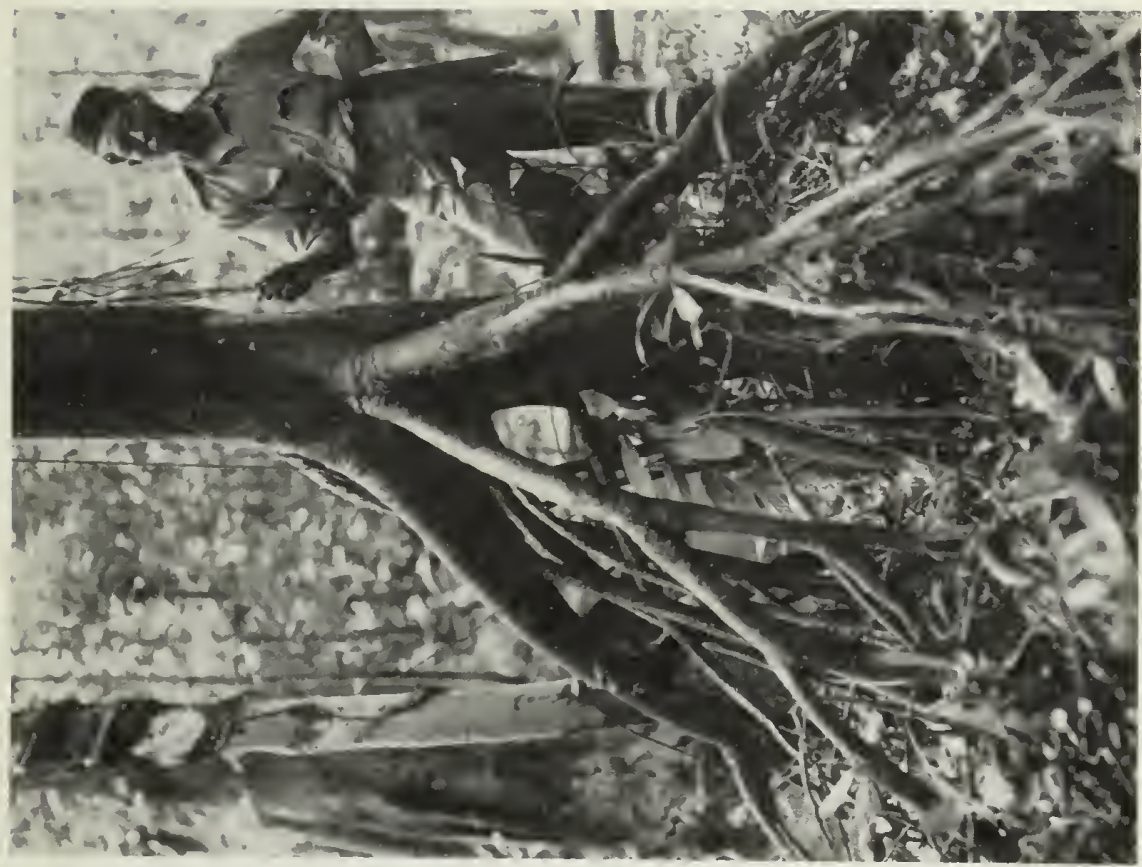

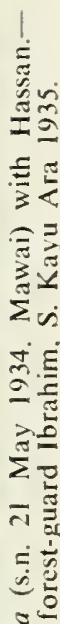

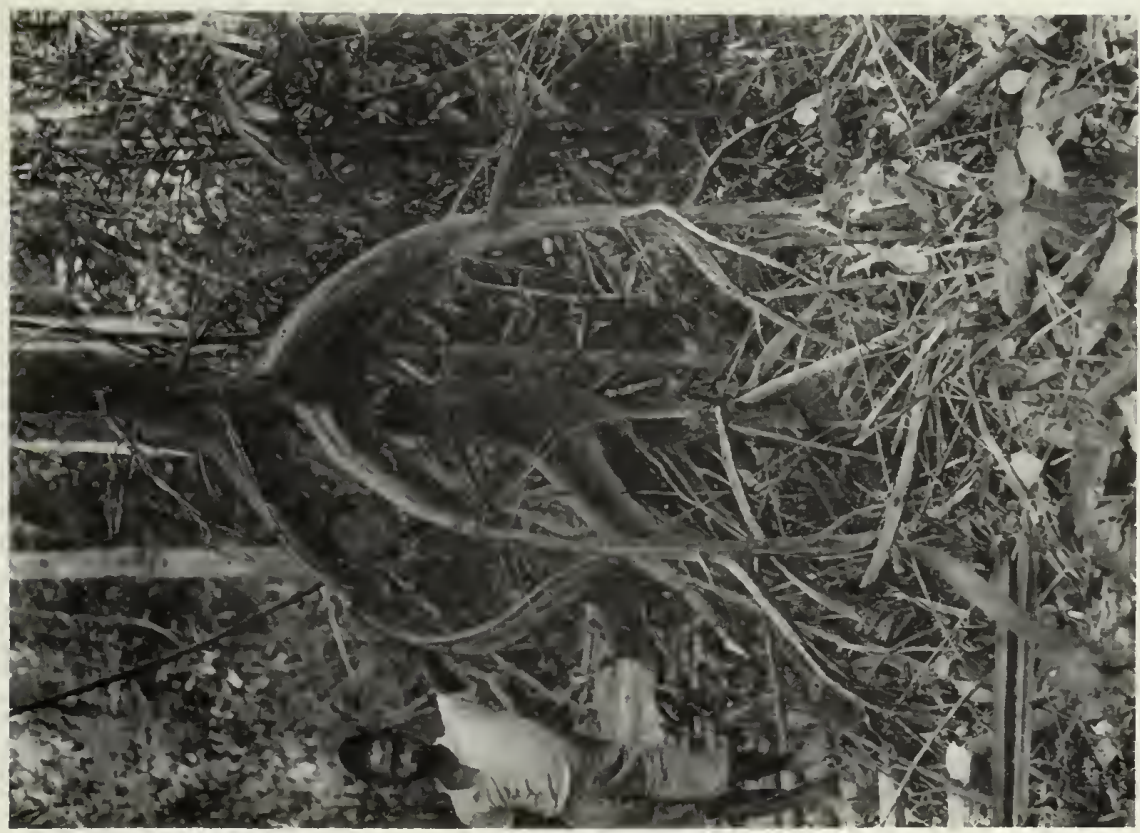

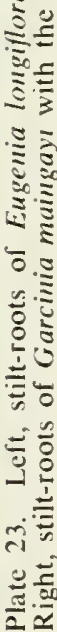



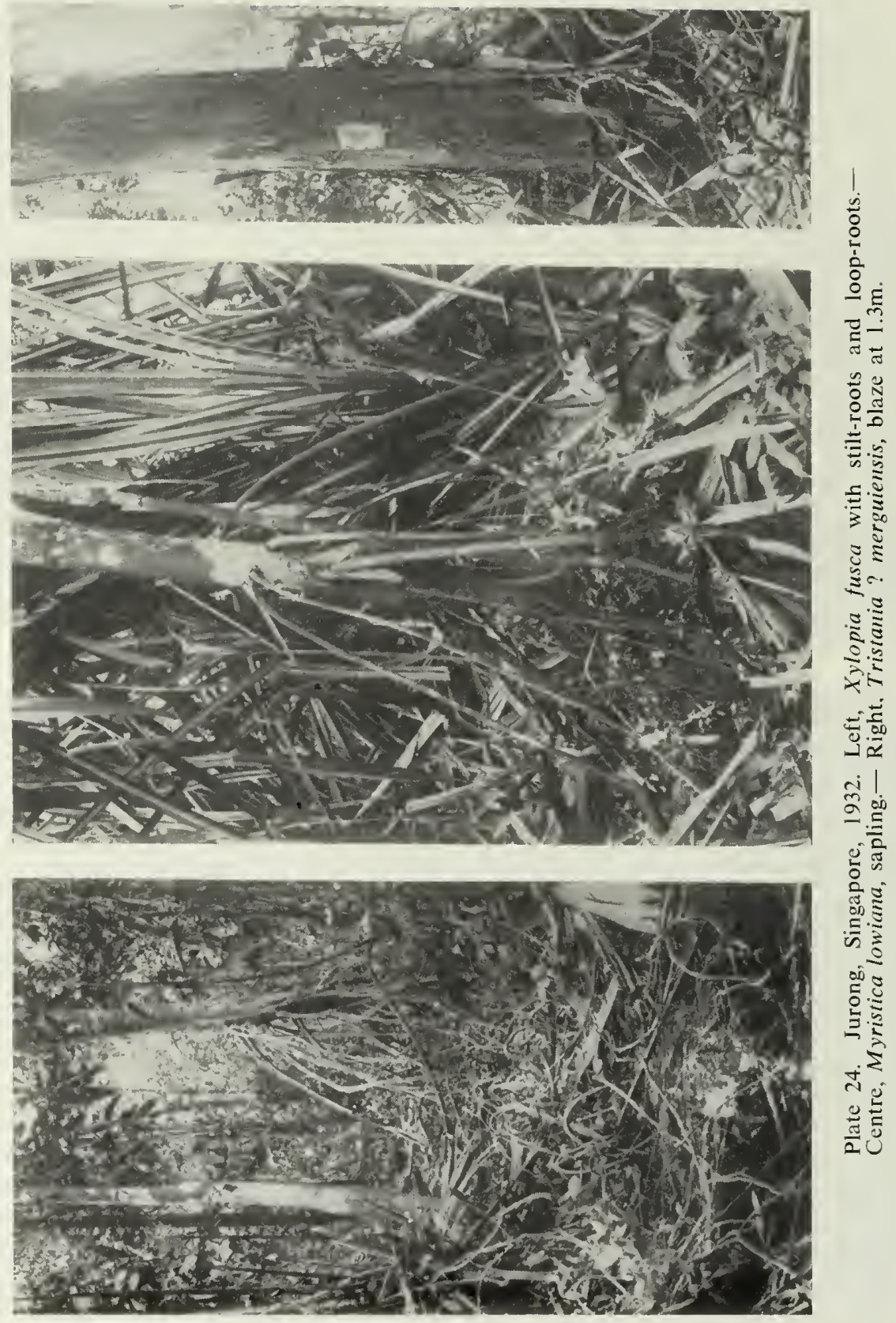

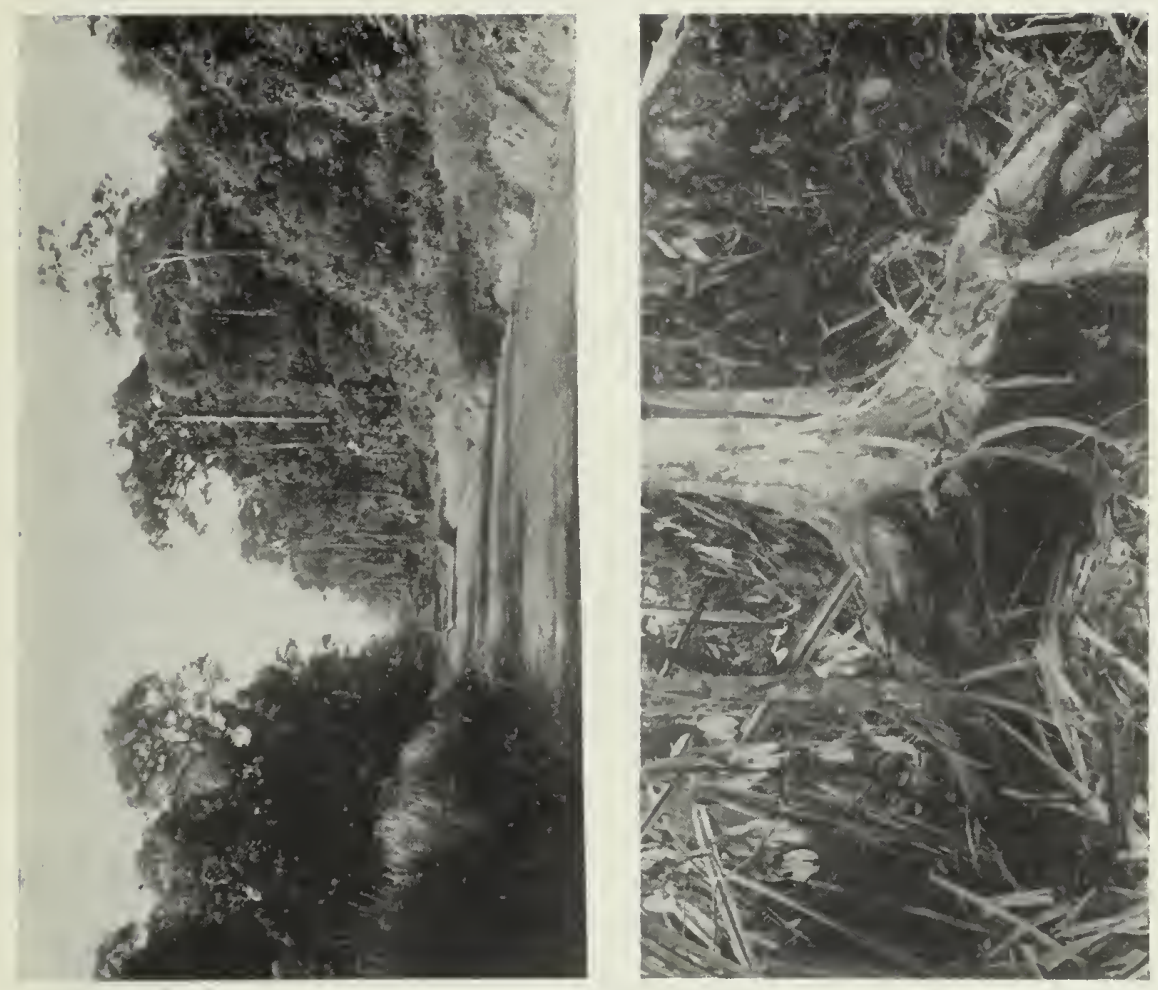

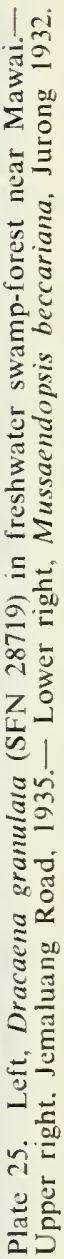

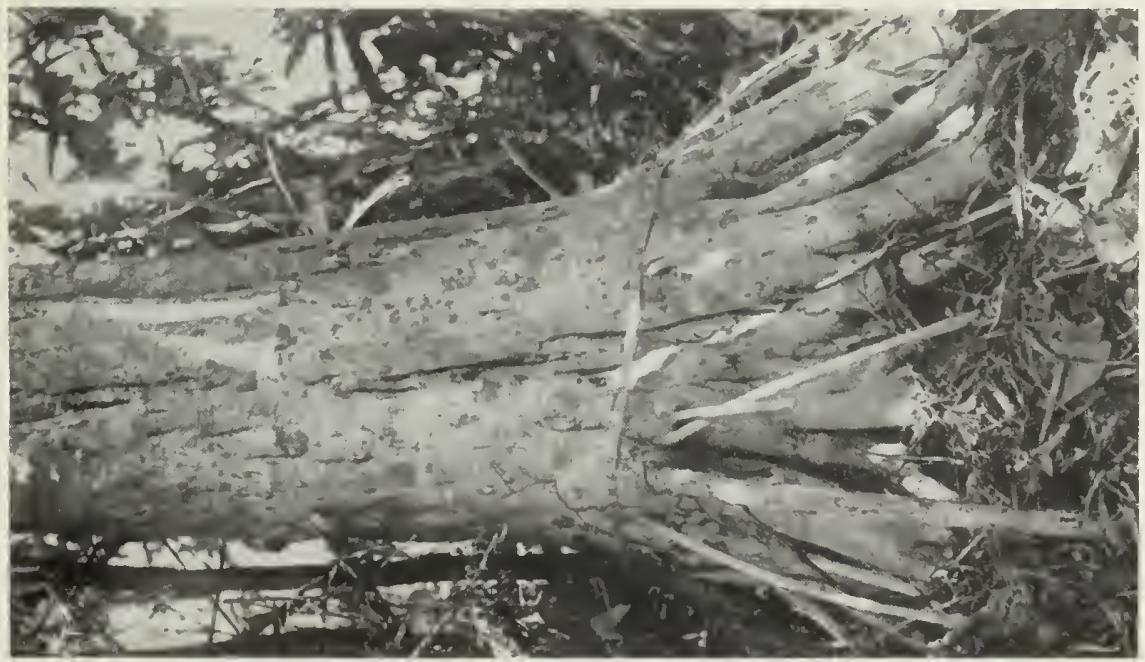



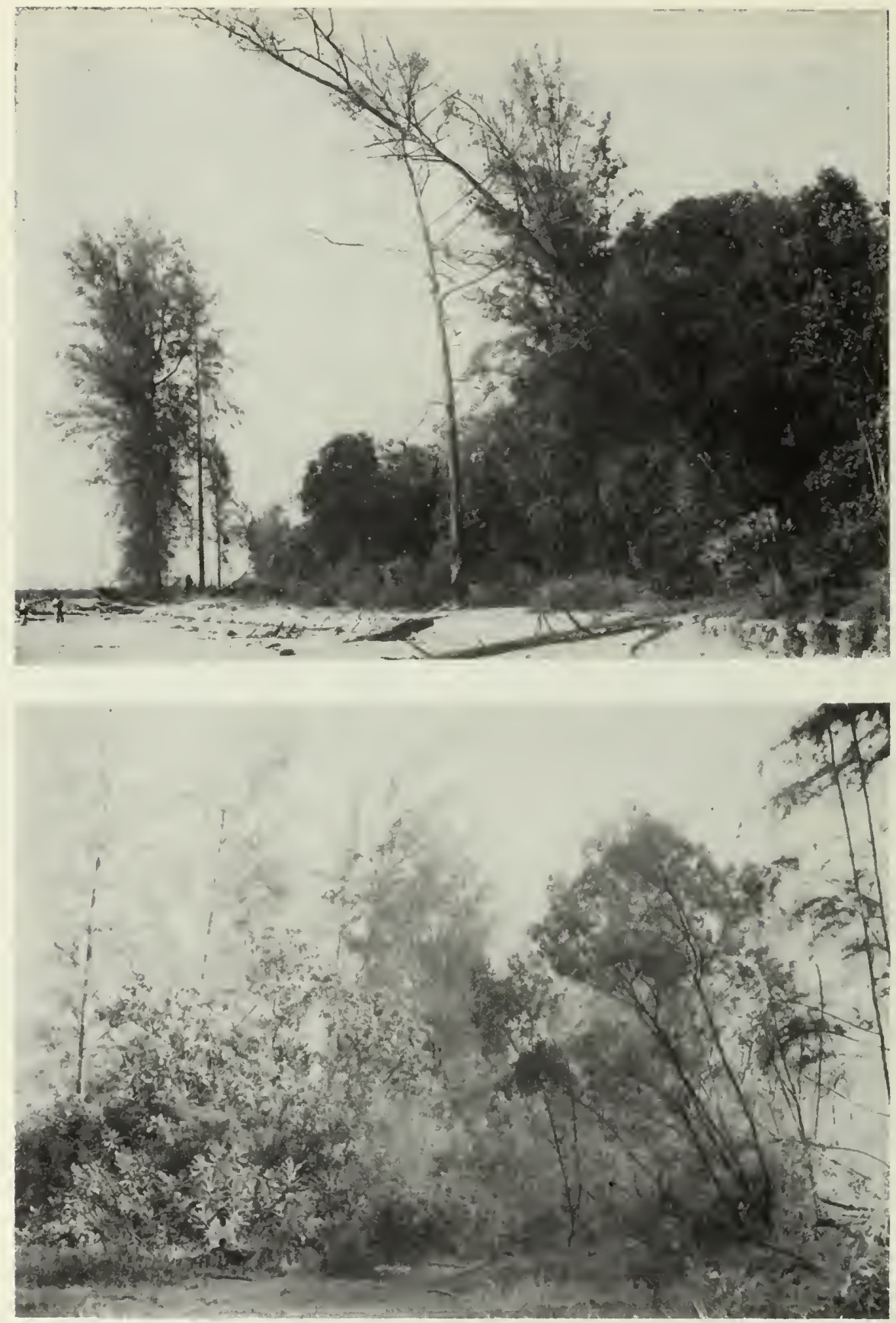

Plate 26. Jason Bay 1934. Upper, coastal abrasion at S. Rhu Reba with the Casuarina-forest cut back to a single file against Eugenia grandis forest (on the right); Beilschmiedia tonkinensis as the dark crown in the distanee between the Casuarina-trees. - Lower, Petunga roxburghii (on the right) in young Casuarina-forest, with Hibiscus and Scaevola on the left, S. Tuensch. 

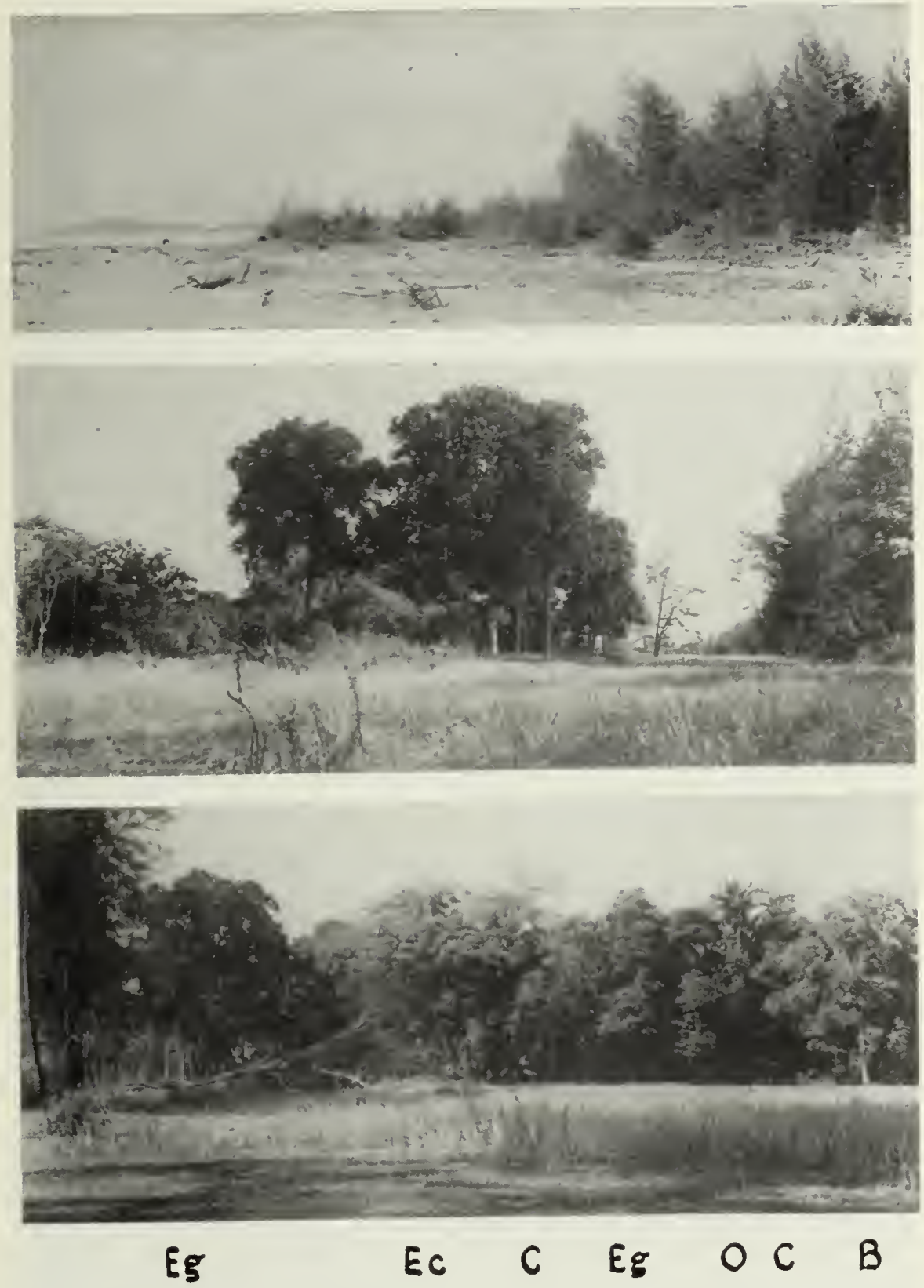

Plate 27. Jason Bay 1934. Upper, Casuarına-forest developing just south of S. Tuenseh.Centre, clearing at S. Rhu Reba with remains of Eugenia grandis forest (in the centre) and Casuarina on the right.- Lower, clearing at S. Rhu Reba with intact transect of Eugenia grandis forest, the sea on the left, two old Casuarina-trees embedded in the forest: B, Beilschmiedia tonkinensis: C. Casuarina; Ec, Erythroxylon cunearum; Eg, Eugenia grandis: $\mathrm{O}$, Oncosperma filamentosum. 

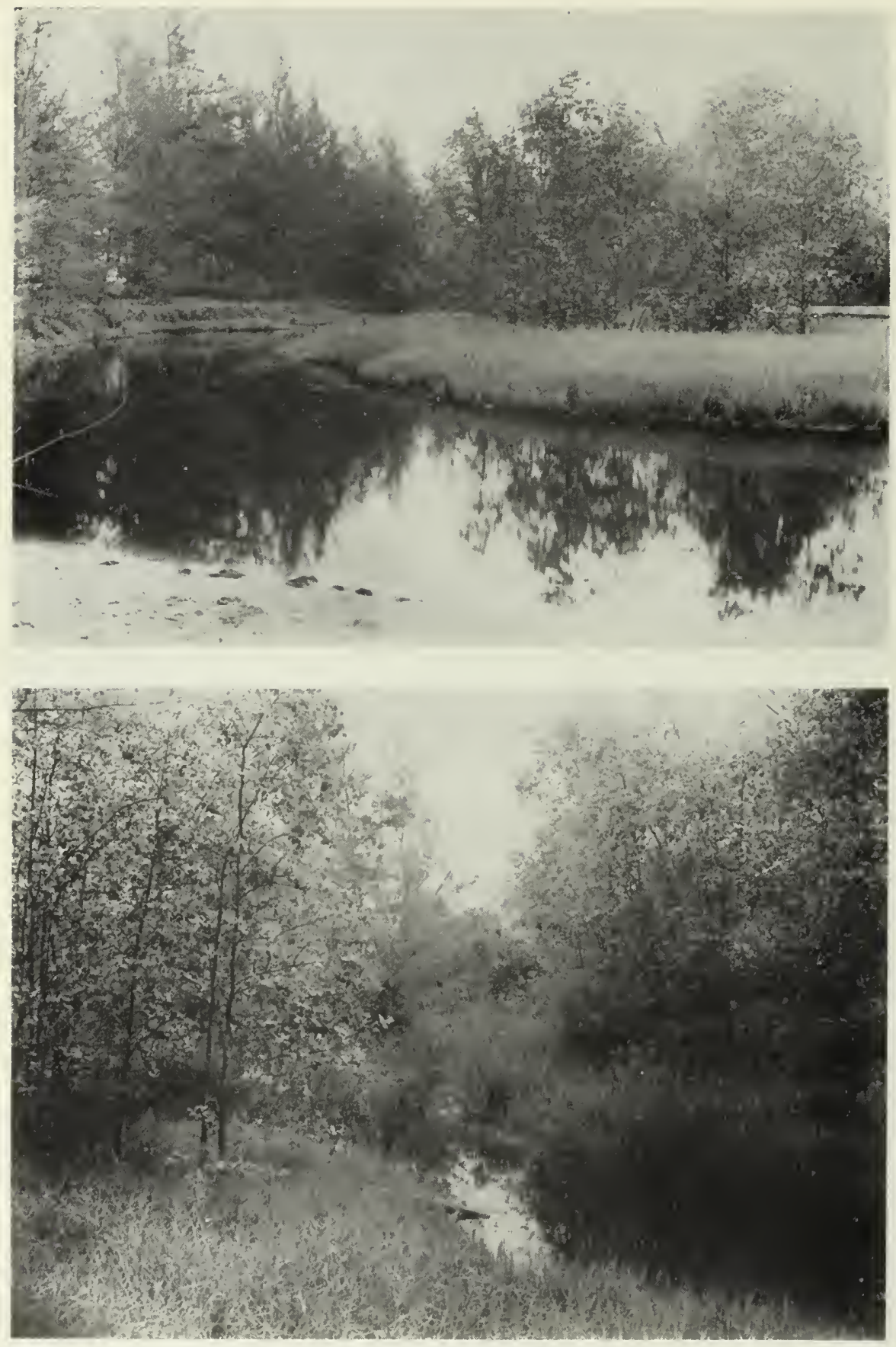

Plate 28. Jason Bay, S. Diman 1934, with young forest of Somneratia alba. Upper, near the river-mouth with Casuarina, a sward of Paspalum vaginalum, and seedlings of Rhizophora.Lower, further inland with $P$. vaginatum in the foreground and Cyperus malaccensis behind. 

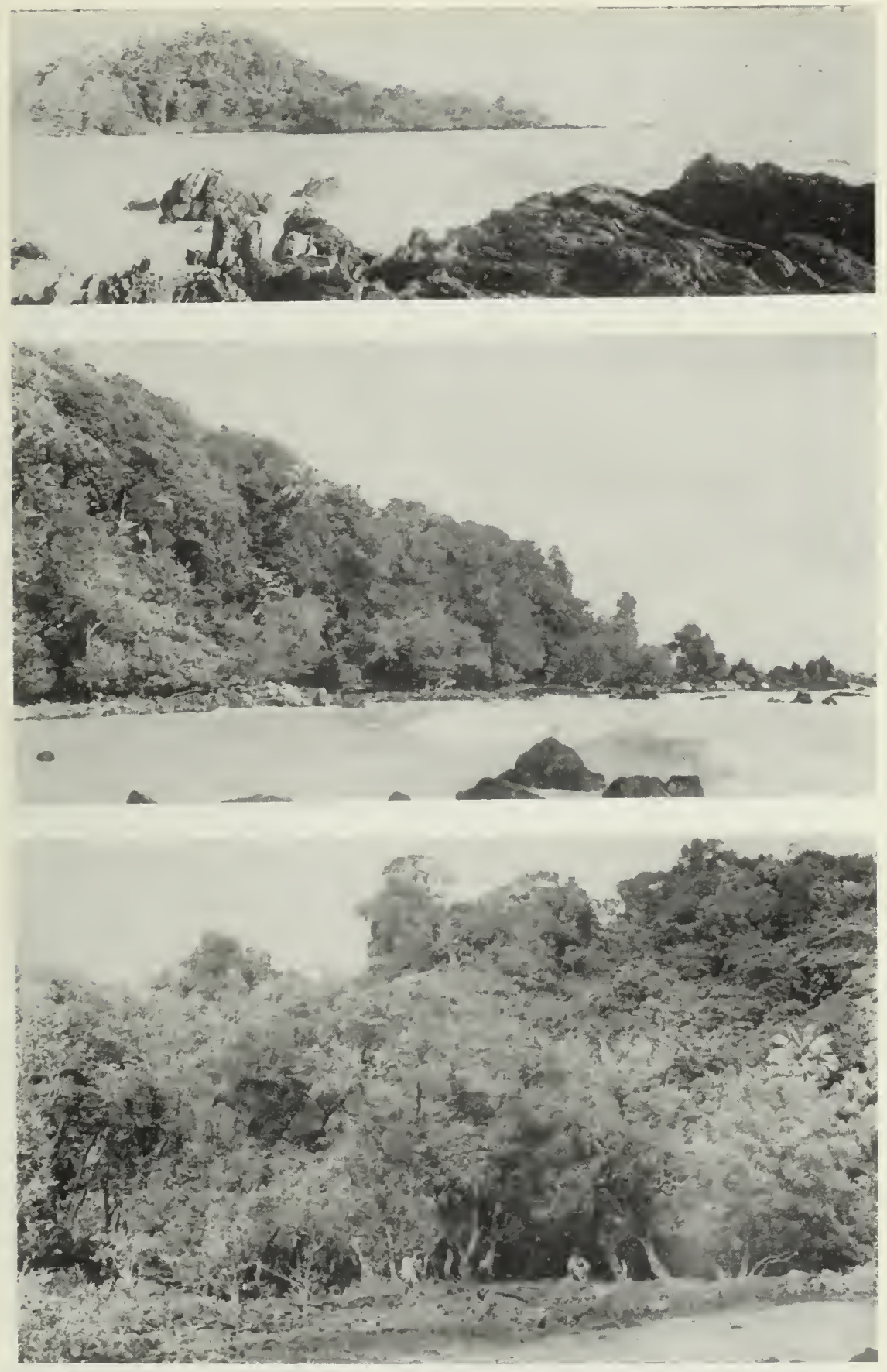

Plate 29. Upper, Tg Temalah across Teloh Temalah.- Centre, the coast near Tg Gemoh.Lower, the coast between $\mathrm{Tg}$ Temalak and $\mathrm{Tg}$ Tebar with Lumnitzera racemosa at the stream-mouth, 1934. 

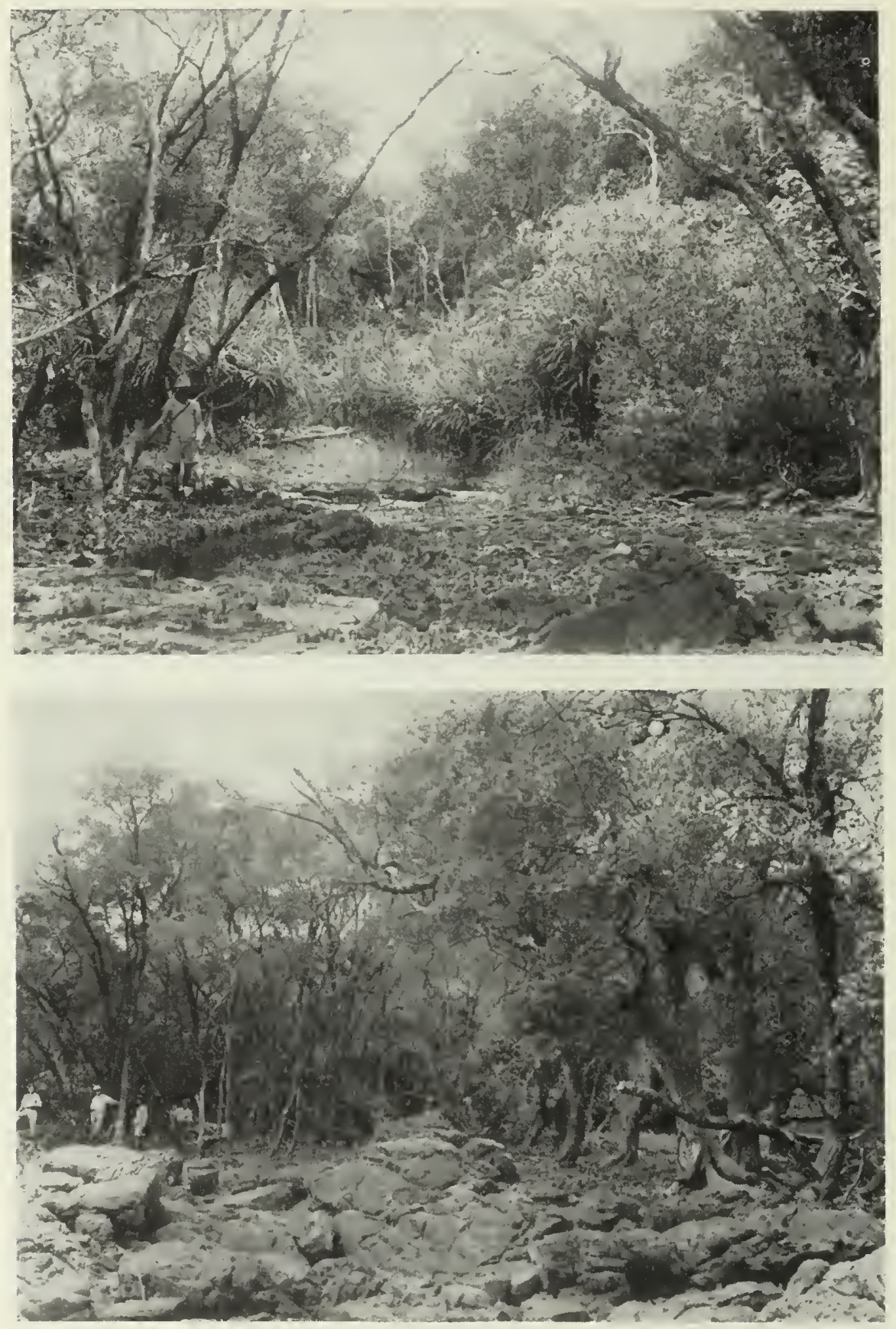

Plate 30. Upper, the stream as in Plate 29, with Lumnitzera racemosa on both sides, Pandanus odoratissimus (centre), and a bush of Scyphiphora (right). - Lower, the coastal frontage of $L$, racemosa, as in Plate 29. 

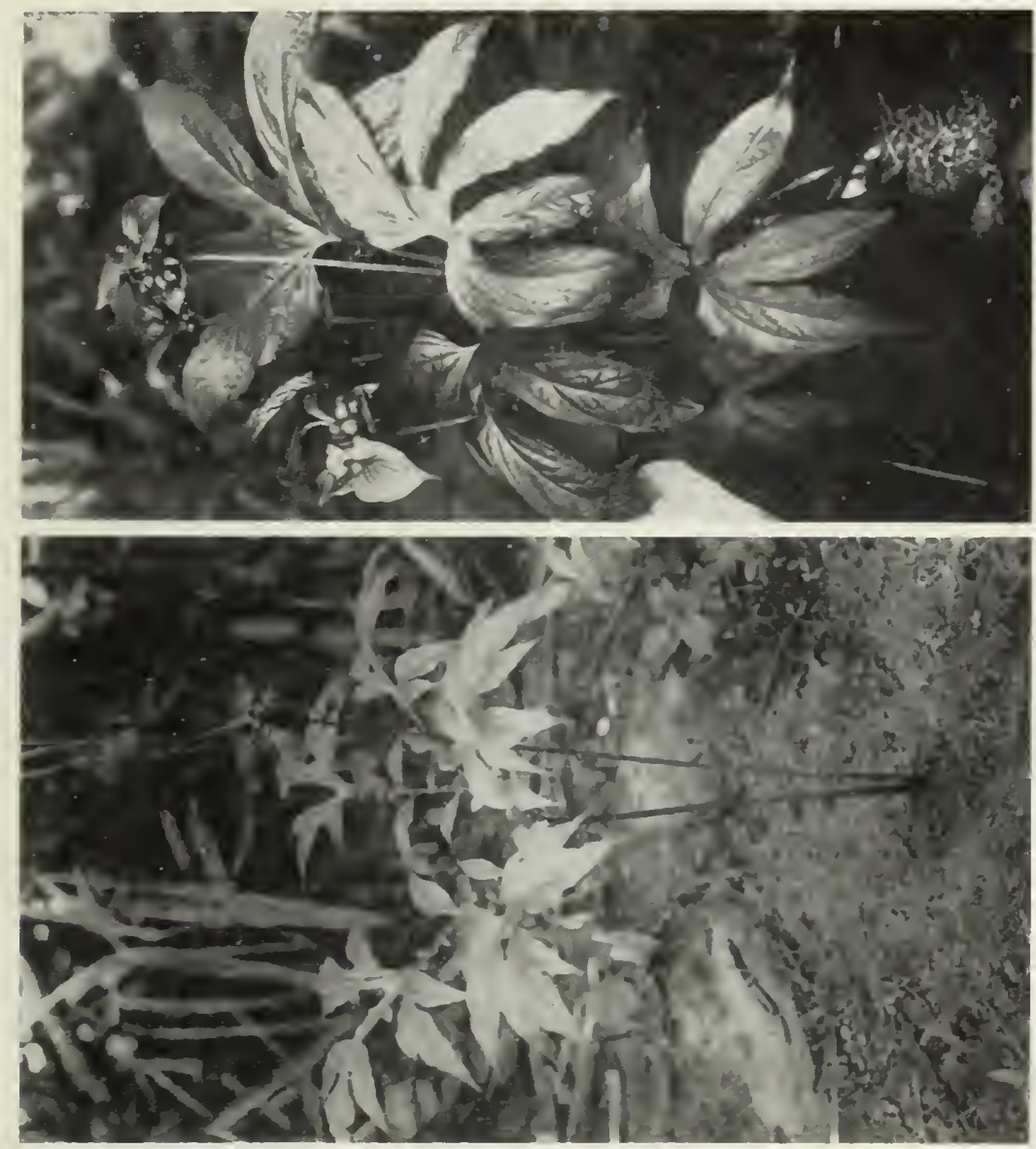

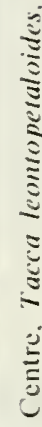

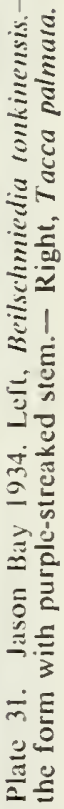

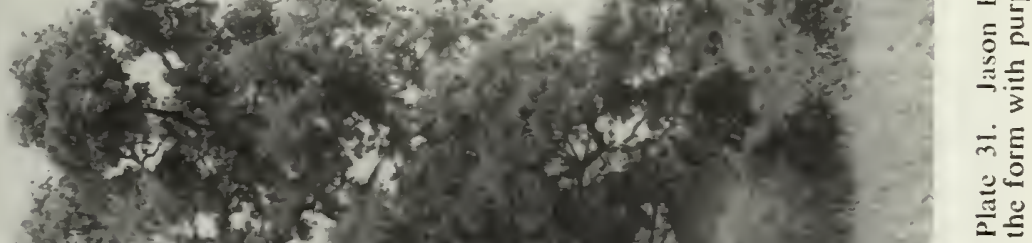




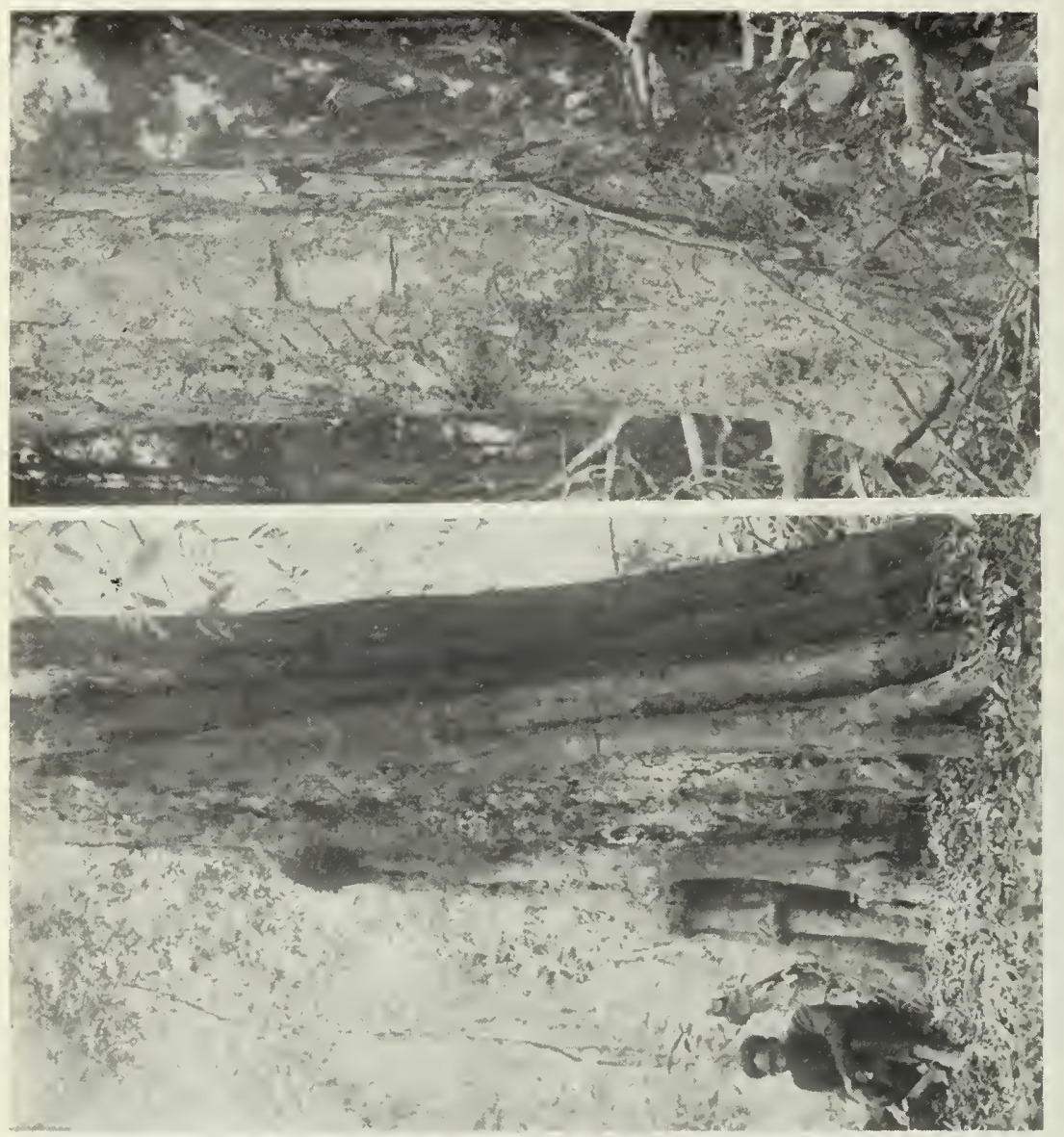

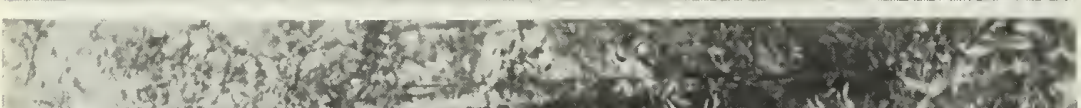

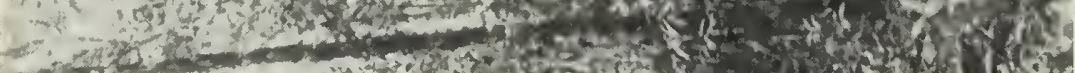

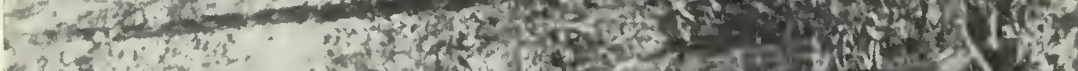

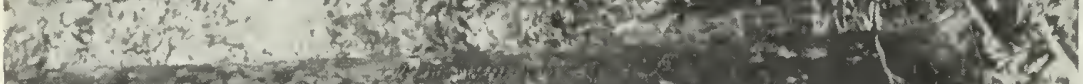

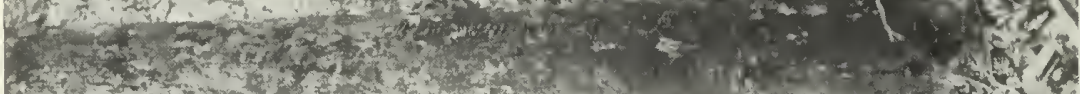

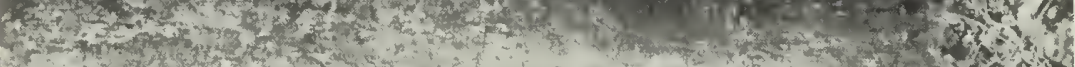

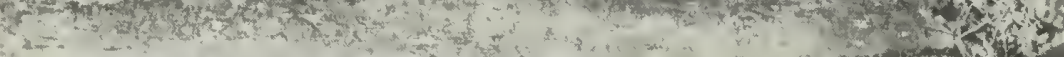

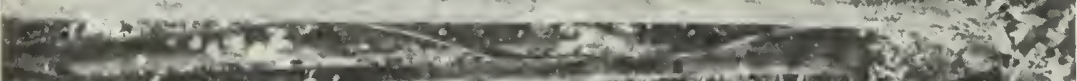

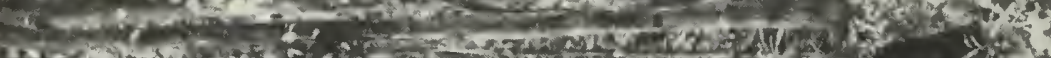

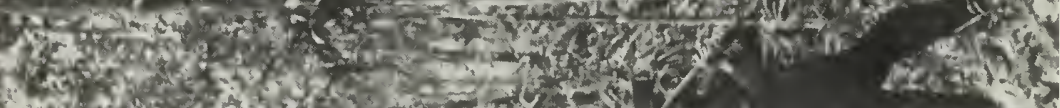
5. 

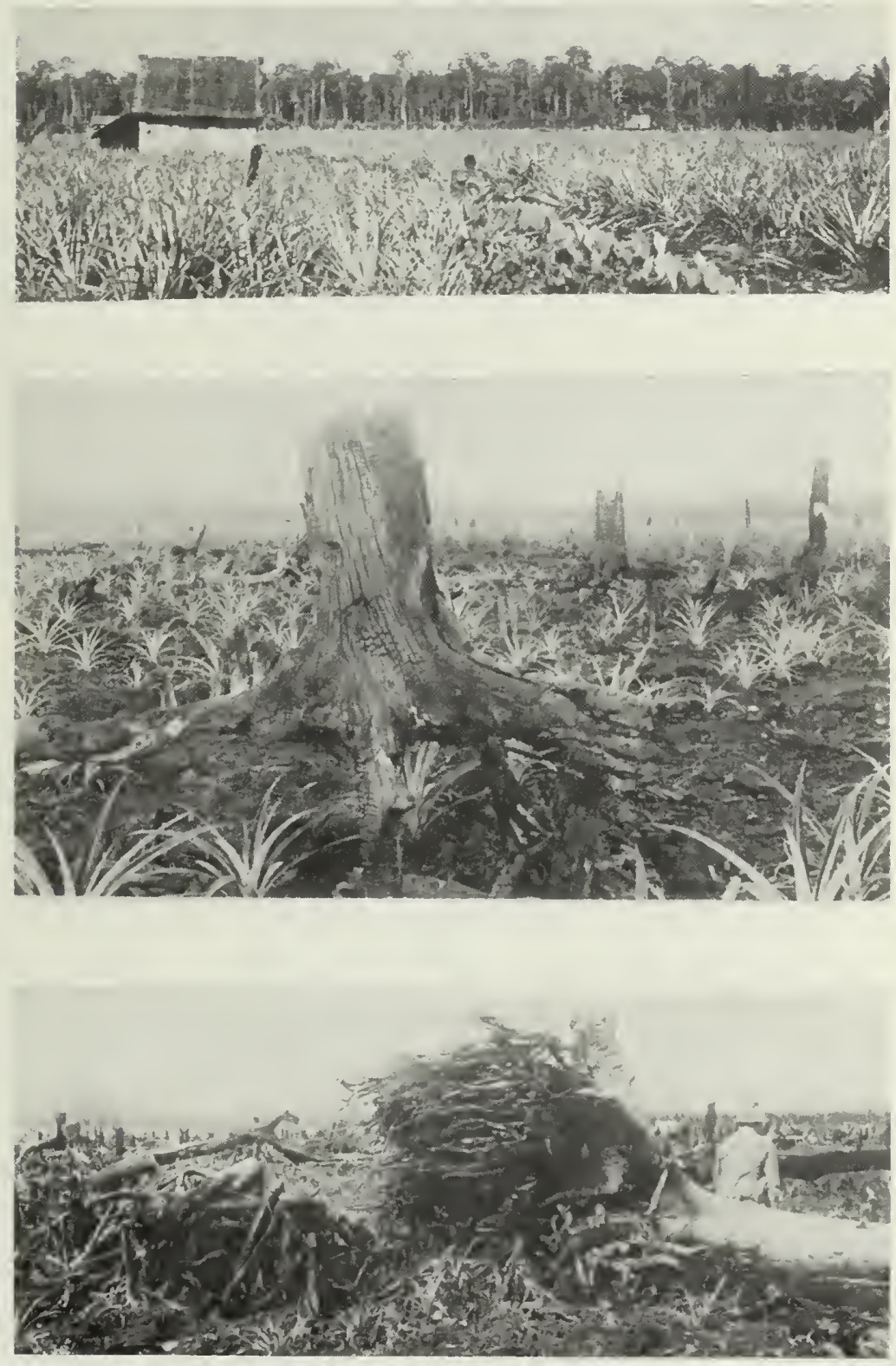

Plate 33. Upper, the relic of the peat swamp-forest at Pengkalan Rajah, Johore, 1939.Centre, stump of Melanorrhoea wallichii at Jurong, 1933. - Lower, an uprooted tree of Parartocarpus venenosus ssp. forbesii at Jurong, 1933. 


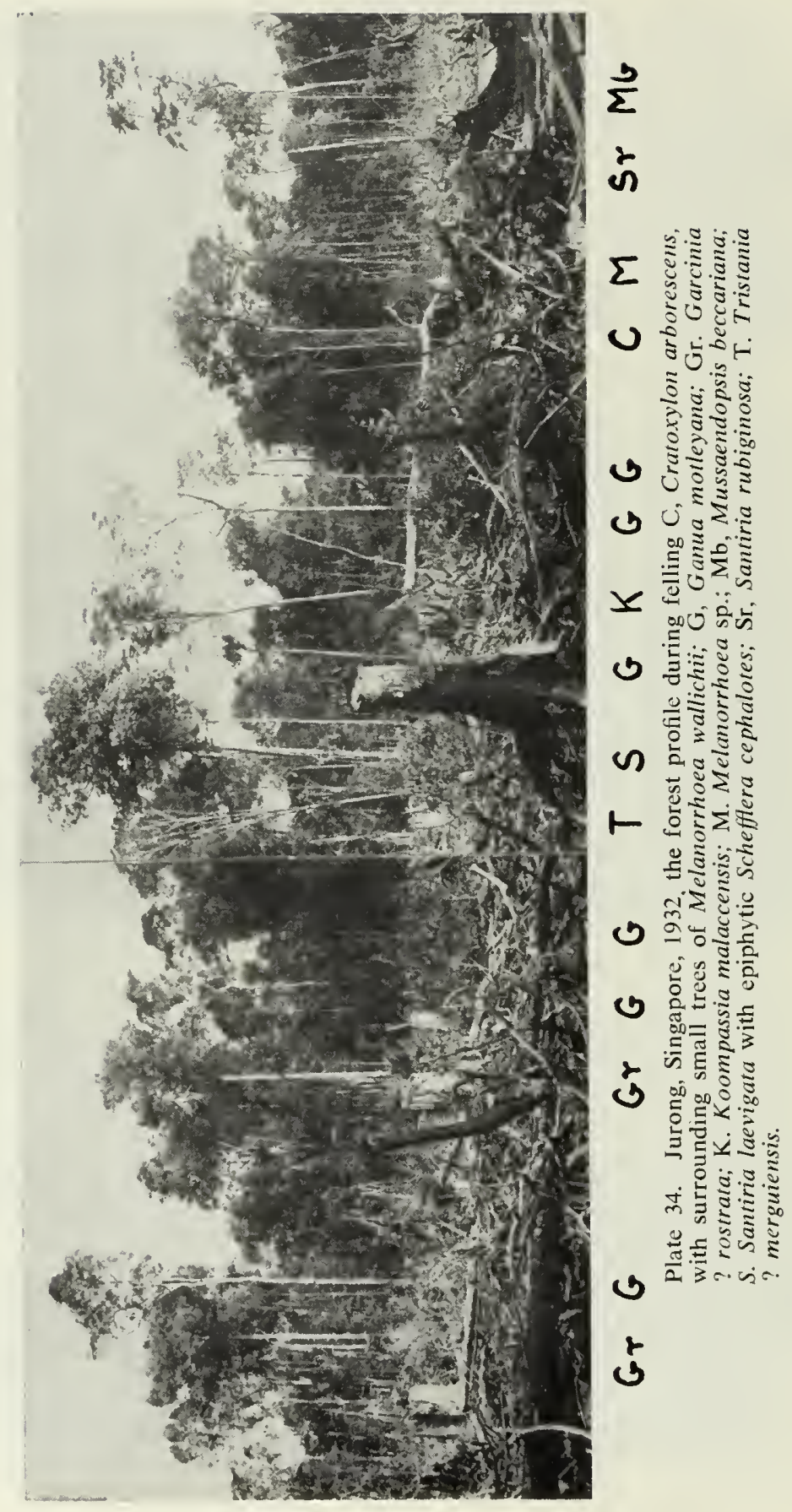





Plate 35. Mandai Road, Singaporc, the forest in process of felling in 1940. M. Melanorrhoea wallichii; P, Palaquium xanthochymum; Pt, Pentace inptera; $X, X$ ylopia fusca. 

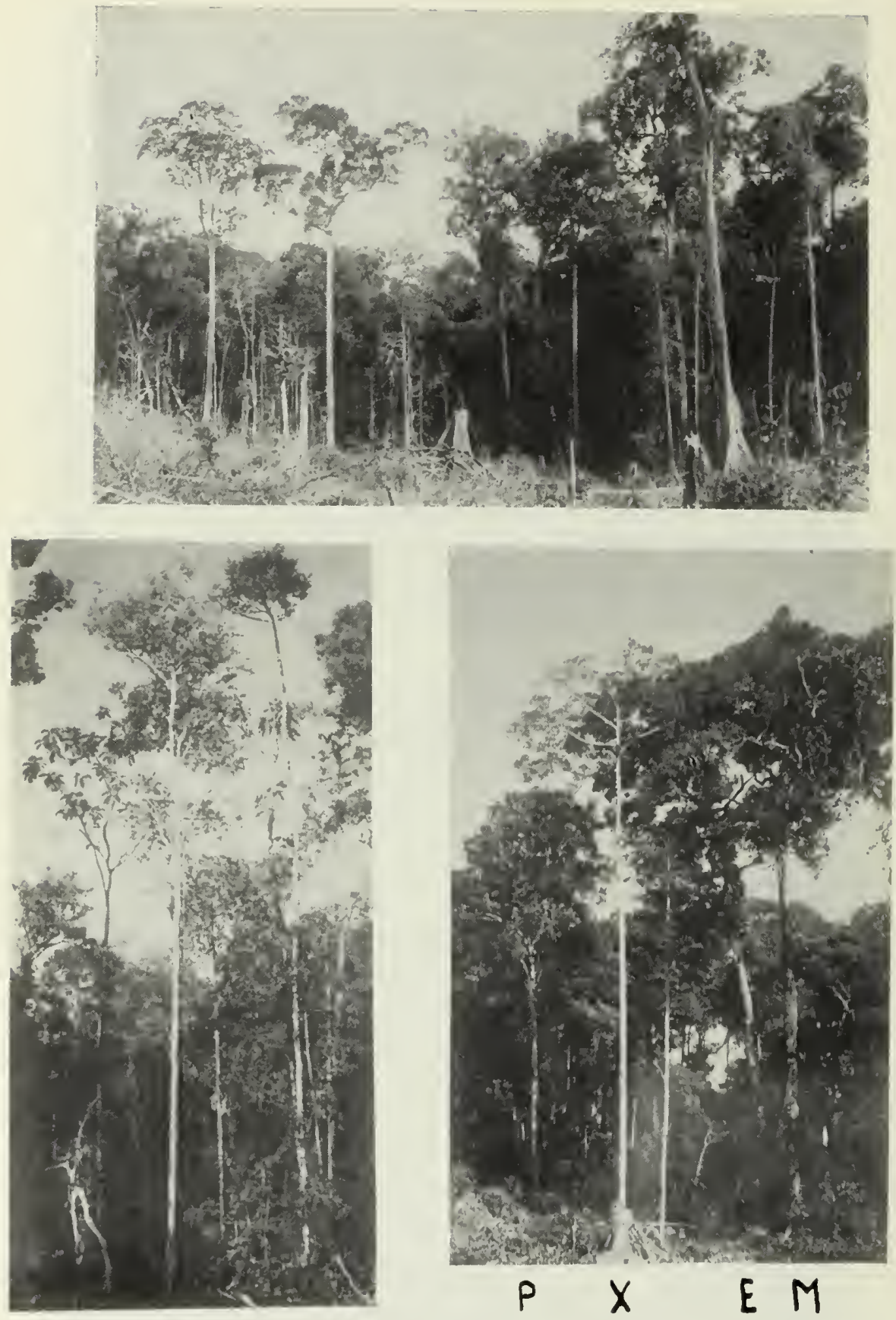

Plate 36. Upper, forest of Kostermansia with nine eanopy trees, Ulu Tiram, Johore 1932.Lower left, peat swamp-forest at Pontian 1939; Amoora rubiginosa with pinnate leaves (on the left) and Tetractomia tetrandra with small dense crown on the top of the tall slender trunk (on the right). - Lower right, freshwater swamp-forest, Mandai Road 1940; E, Eugenia sp. (SFN 37133); M, Myristica tners; P, Pometia pinnata f. alnifolia; X, Xylopia fusca. 

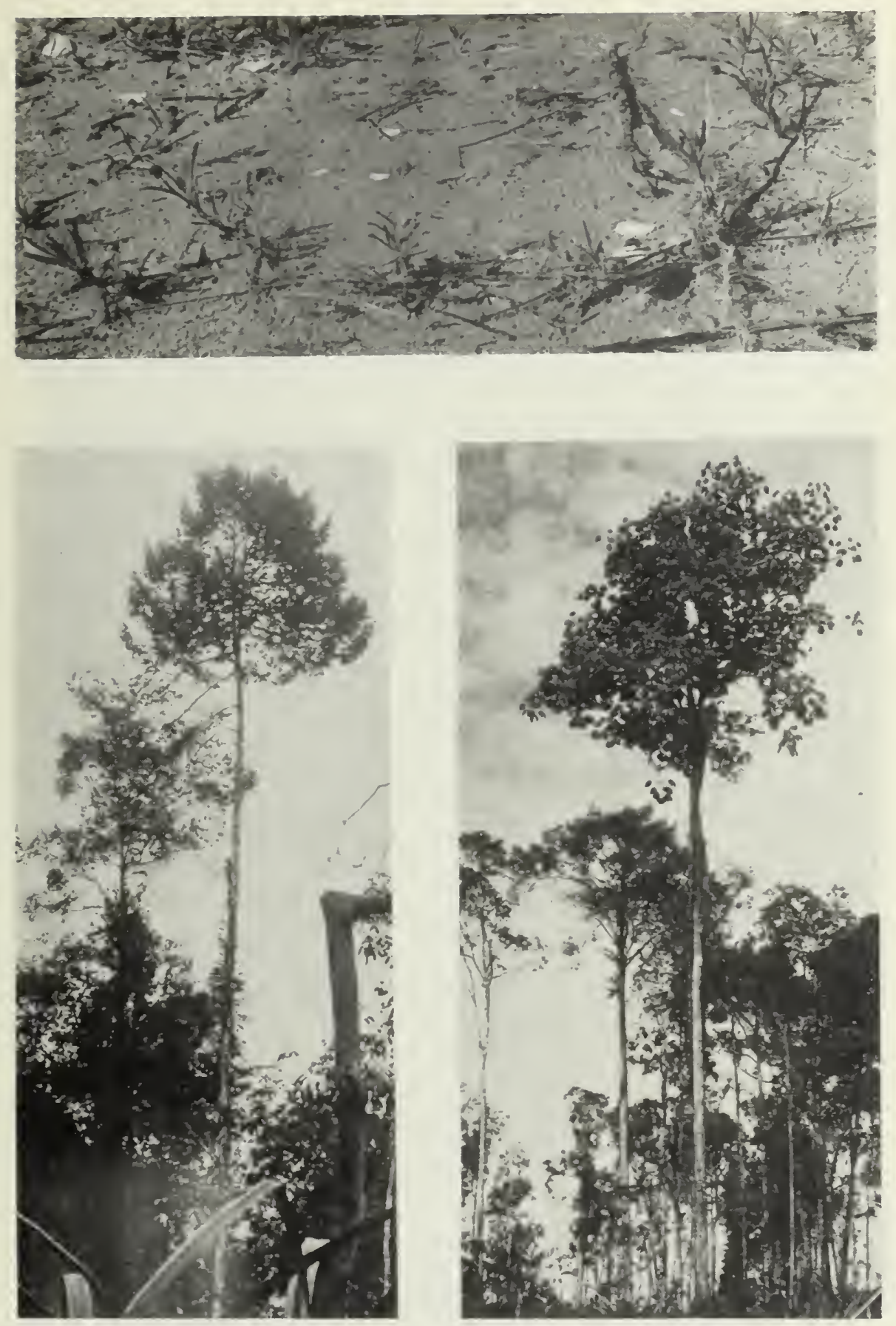

Plate 37. Upper, Spilanthes urens at S. Tuenseh, Jason Bay 1934.- Lower Left, Polyalthia hypoleuca at Pontian. 1939. - Lower right. Schefflera cephalotes, epiphytic on the trunk of Santiria laevigata and supplanting the crown, at Jurong 1932. 


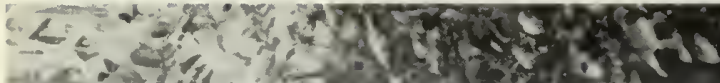

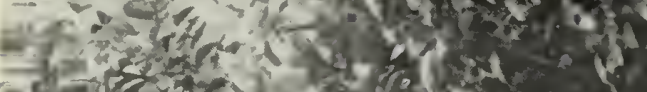
It

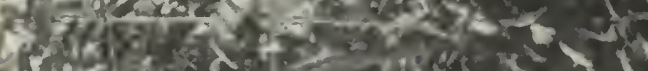

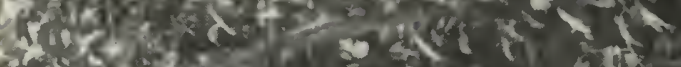

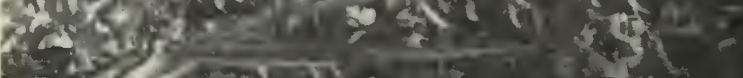

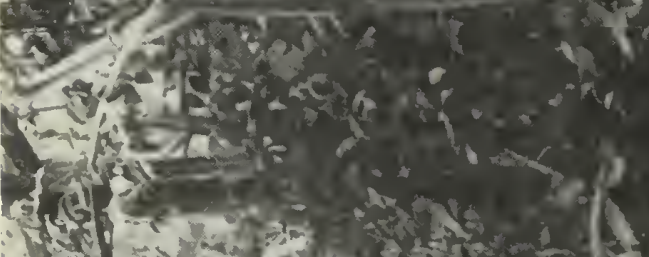
I.

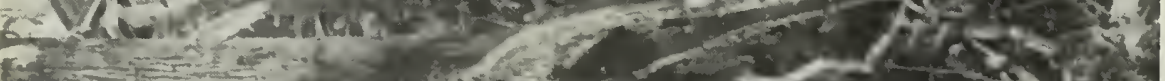

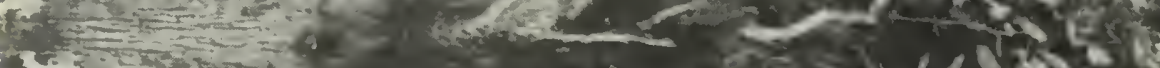

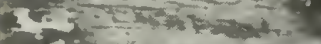

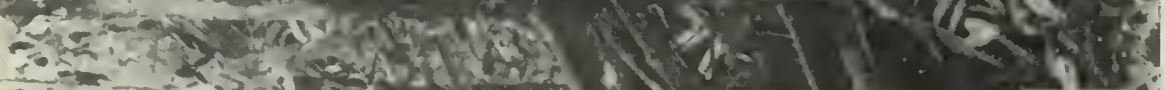

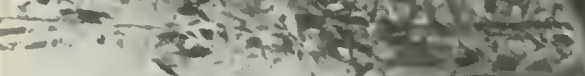
A.t.

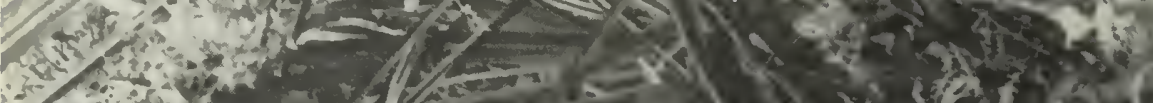

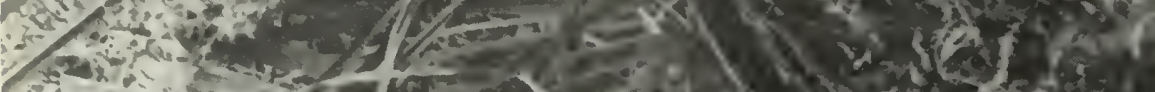

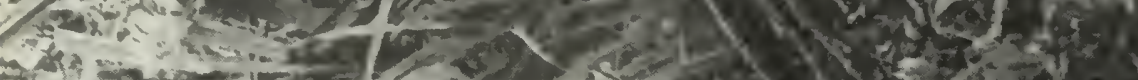

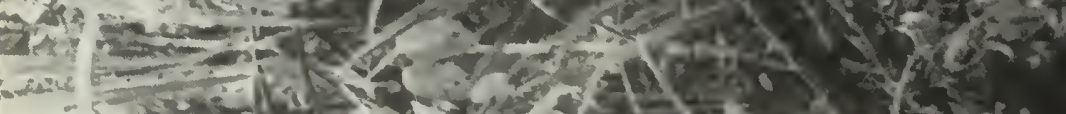

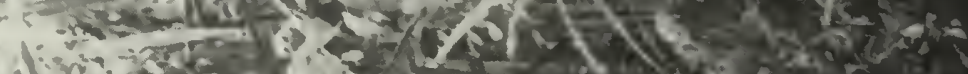

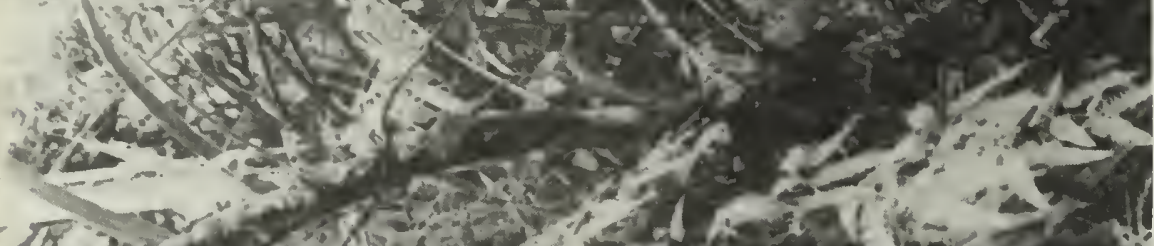

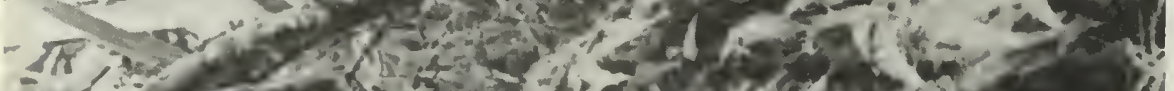

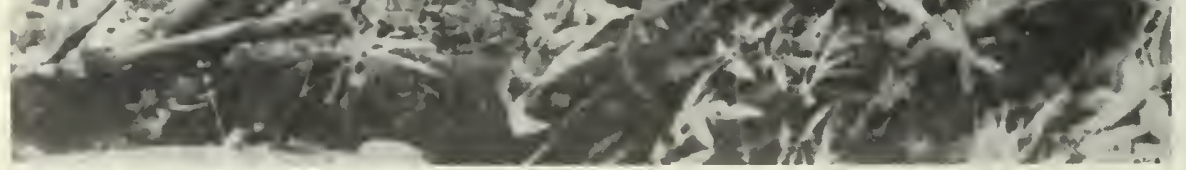



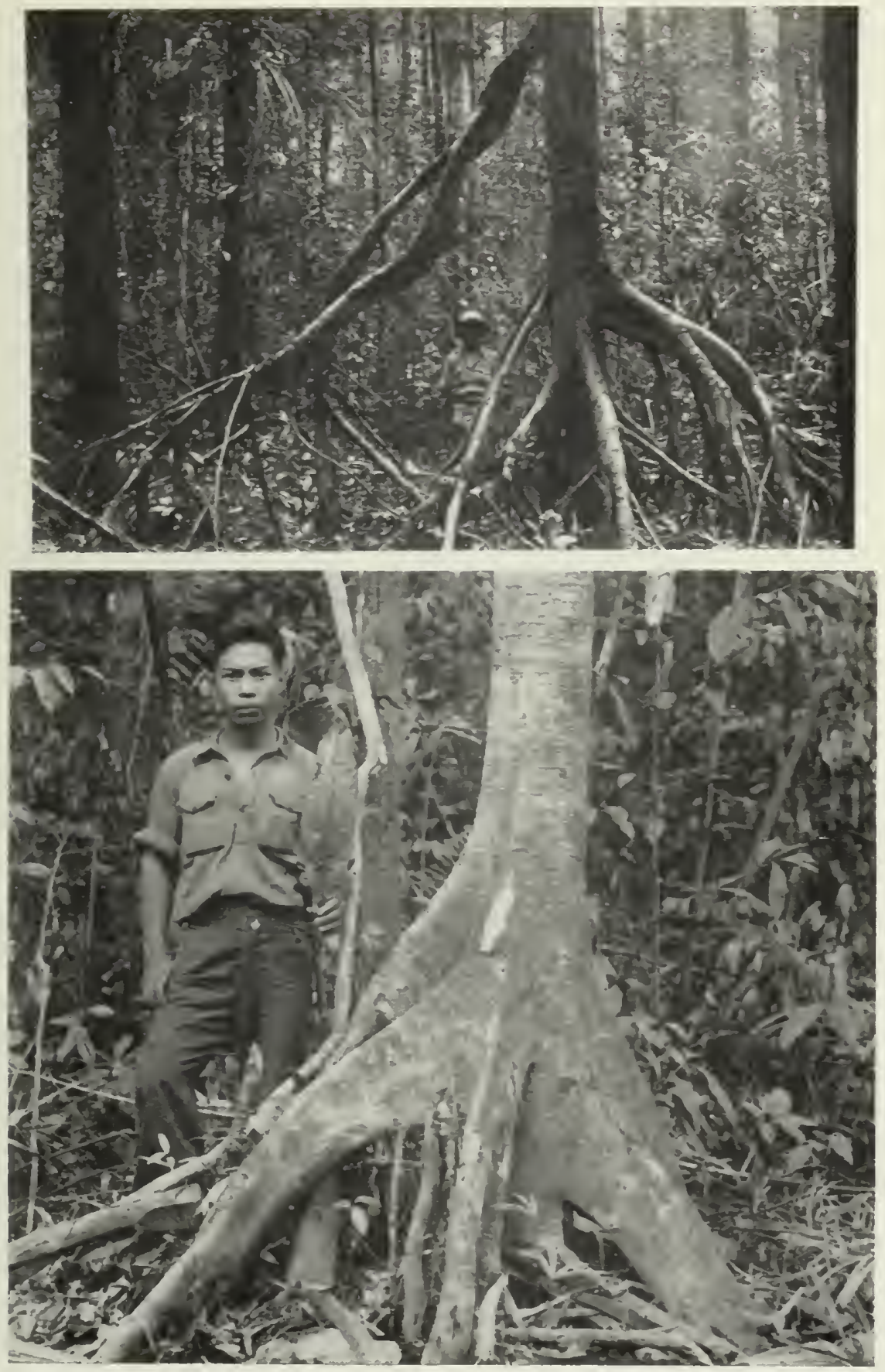

Plate 39. Upper, Garcinia ? rostrata at Pontian 1939.- Lower. Melanochyla auriculata in freshwater swamp-forest near Mawai 1934. 

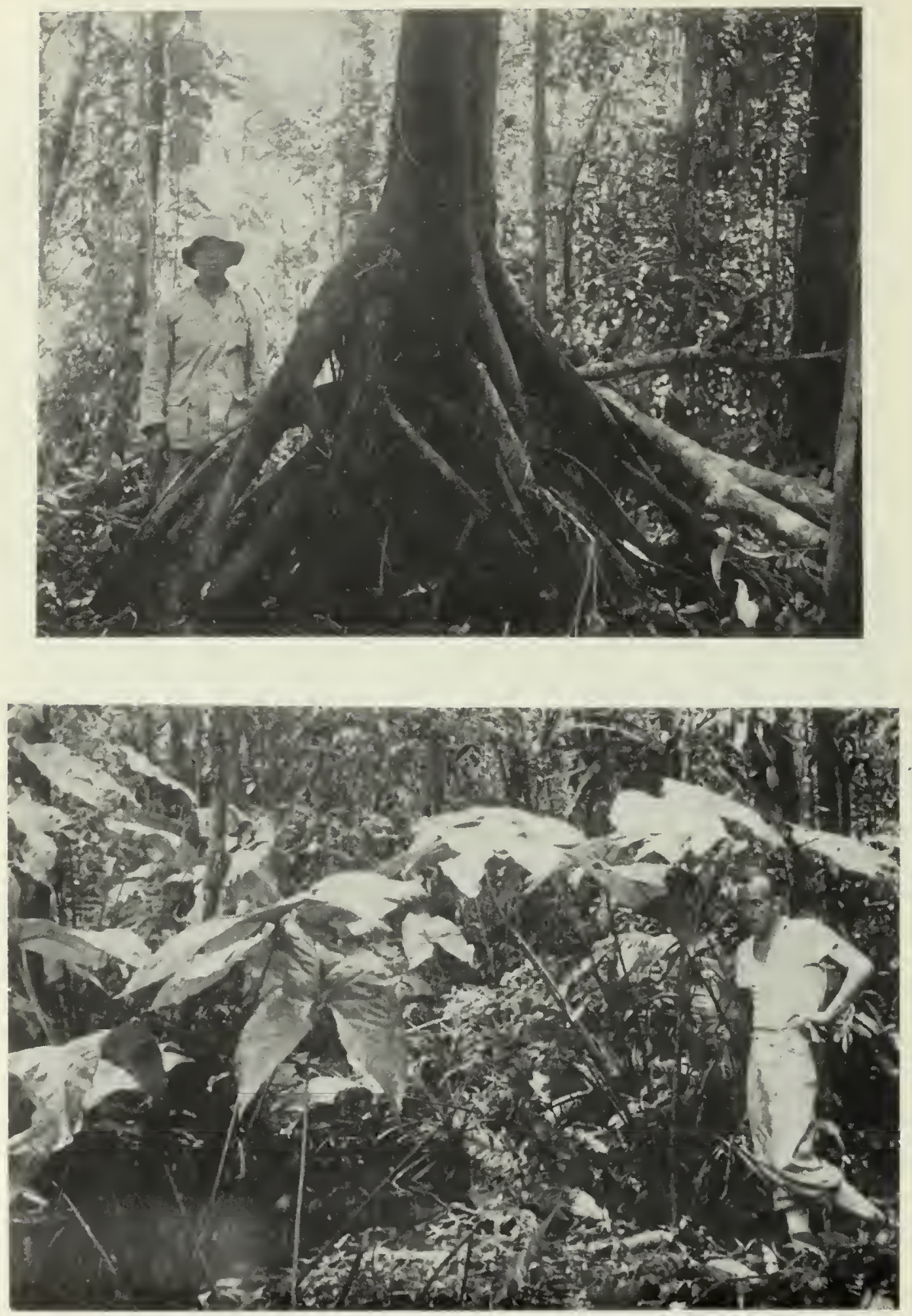

Plate 40. Upper. Ploiarium alternifolium in incipient peat swamp-forest at Pontian 1939.Lower, Podolasia stipitata near Mawai 1937, with L. Moysey. 





Bookbinding $\mathrm{Co}_{0}$, Inc. 300 Summer Street

Boston, Mass. 02210 
Fl58/C81f

Corner, E. J. H.

AUTHOR

The Freshwater Swamp-forest of

TITLE

Sunth Tnhnre and Singanore 
8 